\title{
Estudios estratigráficos, de procedencia sedimentaria y ambiente tectónico del Paleozoico Inferior del extremo norte del Terreno Precordillera.
}

\author{
Lic. Paula Verónica Frigerio \\ - Tesis Doctoral -
}

Director: Dr. Carlos Alberto Cingolani

Co-Director: Dr. Udo Zimmermann

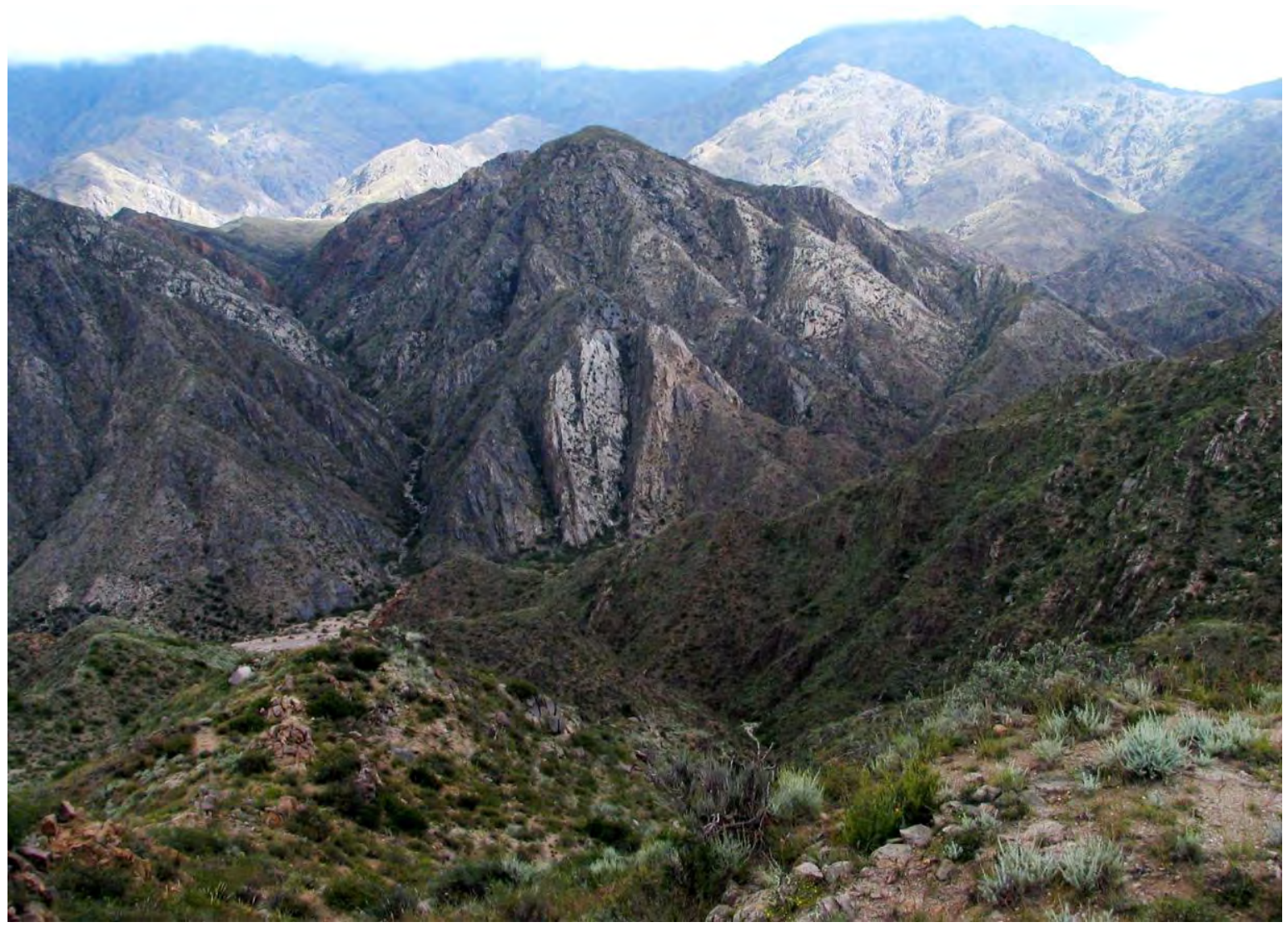

UNIVERSIDAD NACIONAL DE LA PLATA

- FACULTAD DE CIENCIAS NATURALES Y MUSEO 2013 
A mis padres, Erich e Irene, a mi hermano Marcos, y a la Oma. 


\section{ÍNDICE}

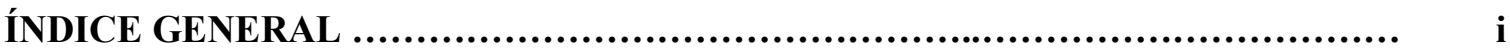

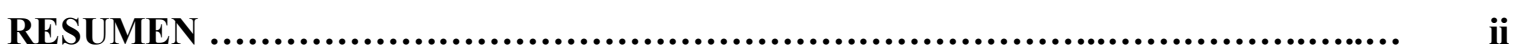

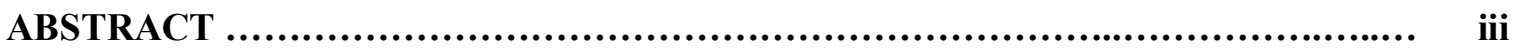

Capítulo 1: INTRODUCCIÓN .......................................................... 1

1.1- Ubicación del área de estudio .................................................. 1

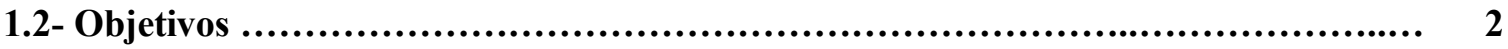

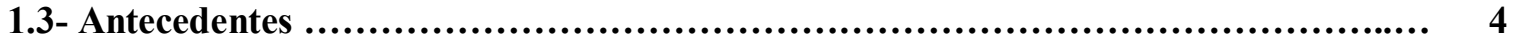

1.3.1- Cartografía de base ...................................................... 4

1.3.2- Marco Geológico Regional .................................................. 5

Capítulo 2: METODOLOGÍAS .................................................... 18

2.1- Introducción ...................................................................... 18

2.2- Metodologías empleadas ................................................... 19

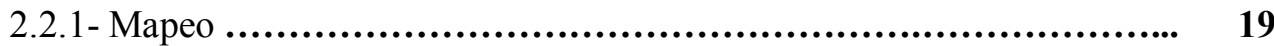

2.2.2- Métodos petrográficos . ......................................... 19

2.2.3- Búsqueda de material fosilífero .................................. 21

2.2.4- Métodos geoquímicos e isotópicos .................................. 22

2.2.5- Análisis de minerales pesados ..................................... 28

2.2.6- Estudios de procedencia y ambiente tectónico.......................... 29

2.2.7- Laboratorios e intrumental utilizados ................................. 31

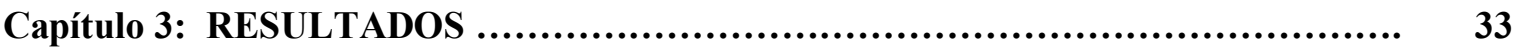

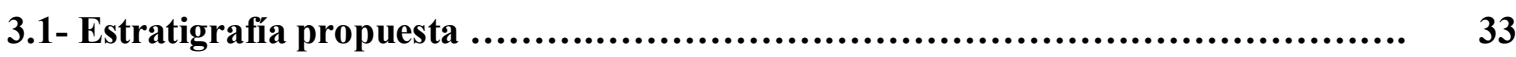

3.1.1- Introducción ................................................................. 33

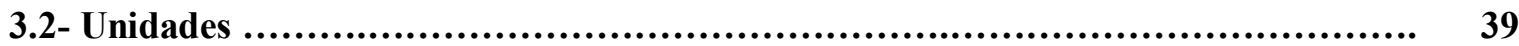

3.2.1- Formación Espinal (Turner, 1964) ............................................. 39

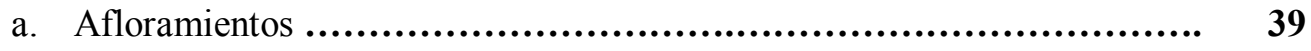

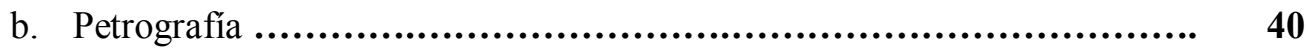

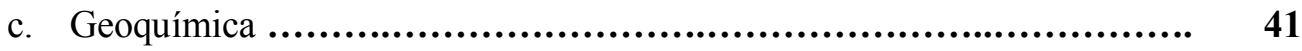

d. Geocronología ...................................................... 44

3.2.2- Formación Río Bonete (Aceñolaza, 1969; Aceñolaza et al., 1971; parcialmente Complejo Metamórfico Río Bonete, Martina y Astini, 2009). Faja de deformación de Jagüé: Primera parte.

a. Afloramientos

> Miembro Mármol Las Damas (Martina y Astini, 2009; Miembro Calizas Las Damas, Aceñolaza et al., 1971)

> Miembro Esquistos Cerro Cóndor (Aceñolaza et al., 1971) 
> La faja de deformación de Jagüé (Martino y Astini, 1998; parcialmente Complejo Metamórfico Río Bonete, Martina y Astini, 2009)

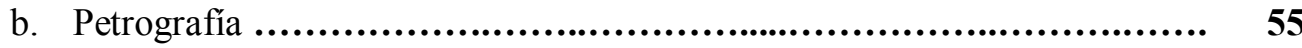

- Esquistos calcáreos y mármoles .......................................... $\quad 56$

- Esquistos cuarzo-muscovíticos (blanquecinos) …....................... 58

- Esquistos micáceos ......................................................... $\quad \mathbf{5 8}$

- Esquistos verdes ....................................................... 61

- Otros litotipos de esquistos ............................................... 63

3.2.3- Formación Del Salto (emend.) ('Lutitas Del Salto’ de Aceñolaza y Bernasconi (1969) más Formación Chuscho de Fauqué y Villar (2003) más afloramientos del Mb. $\mathrm{C}^{\circ}$ Cóndor del norte del Granito Potrerillos (Aceñolaza et al 1971); equivalente a Formación Chuscho de Martina y Astini, 2009).

3.2.3.1- Rocas metasedimentarias estratificadas ('Lutitas Del Salto' de Aceñolaza y Bernasconi (1969), más afloramientos sedimentarios al norte del granito Potrerillos)..
a. Afloramientos 69
b. Petrografía 73
c. Registro fosilífero 80
d. Geoquímica 82
e. Geología isotópica 90
f. Análisis de la Procedencia y ambiente tectónico. 95

3.2.4- Rocas básicas (Formación Chuscho, Toselli y Durand, 1996; Fauqué y Villar, 2003; parte de la Andesita Cerro Chuscho, Aceñolaza et al., 1971. Diques)

3.2.4.2- La Formación Chuscho ................................................... 108

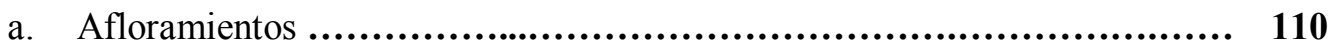
b. Petrografía ........................................................... 110
c. Geoquímica........................................................... 115
d. Geología isotópica ..................................................... 117

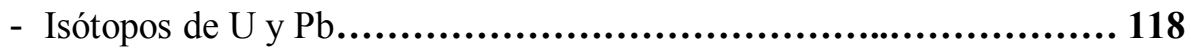
- Isótopos de Sm y Nd................................................... 120
e. Ambiente geotectónico .............................................. 121

3.2.5- Formación Quebrada Seca (Cravero et al., 1984) y Formación Jagüel (González y Bossi, 1986. Equivalentes a Formación Punilla, Furque, 1956)............................... 130
a. Afloramientos ....................................................... 130
b. Petrografía ................................................................. 132
c. Geoquímica ........................................................... 135
d. Fósiles ............................................................. 136
e. Correlación estratigráfica ................................................ 139 
3.2.6- Granito Potrerillos (Aceñolaza y Bernasconi, 1969a) o Formación Potrerillos

(Maisonave, 1979)

a. Afloramientos ........................................................................... 144

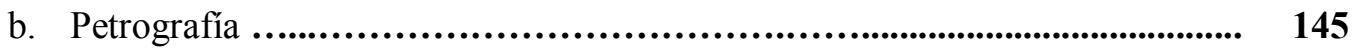

c. Geoquímica ........................................................................ 150

d. Implicancias sobre el ambiente geotectónico ................................. 157

e. Geología isotópica y edad .................................................................. 157

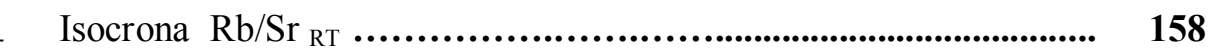

- Isótopos de $\mathrm{U}$ y $\mathrm{Pb}$............................................................. 159

- $\quad$ Isótopos de Sm y Nd ................................................................ 164

f. Consideraciones finales ....................................................................... 165

3.2.7- La faja de deformación de Jagüé: Segunda parte (esquistos miloníticos) ............ $\quad \mathbf{1 6 7}$

a. Geoquímica ............................................................................................................... 167

b. Geología isotópica y edad ........................................................................................ 169

c. Correlaciones ....................................................................................................... 175

d. Apuntes sobre metamorfismo y variedades de esquistos ......................... 175

3.2.8- Conglomerados de Jagüé (Paleozoico Superior) ........................................................ 179

Formación Cerro Tres Cóndores (Conglomerados castaños) …………..................... 179

Otros conglomerados .......................................................................................... 181

Estructura del Paleozoico Superior y correlación regional ....................................... 184

Capítulo 4: DISCUSIÓN ............................................................................................. 186

4.1- Consideraciones sobre la estratigrafía ...................................................................... 186

4.2- Deformación ................................................................................................... 197

4.3- La Precordillera de Jagüé en el marco geológico regional. Correlaciones ..... 200

4.4- Implicancias tectónicas ............................................................................................. 202

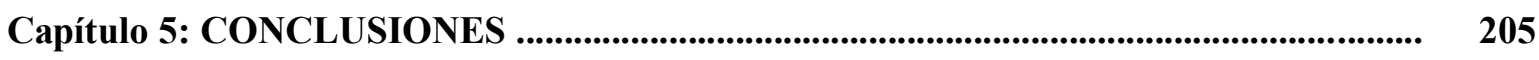

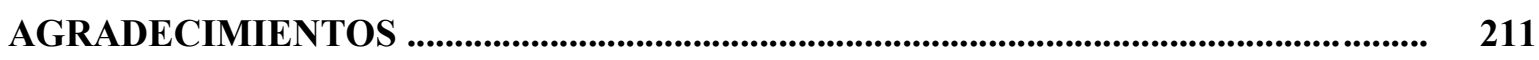

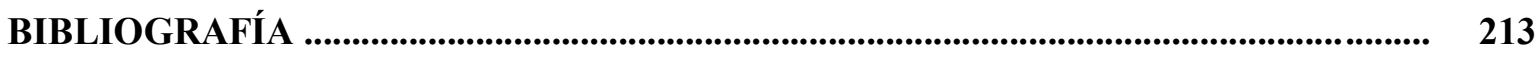

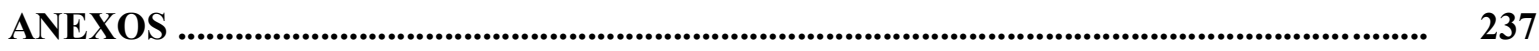

Mapas y perfiles geológicos ...................................................................................... A1

Muestras analizadas ........................................................................................................... A2

Estereogramas ............................................................................................................. A3

Descripciones Petrográficas ...................................................................................................... A4

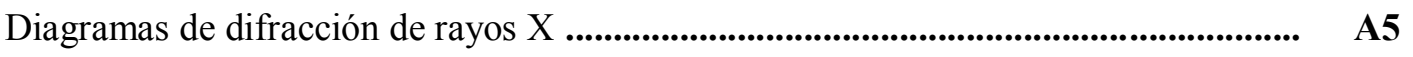

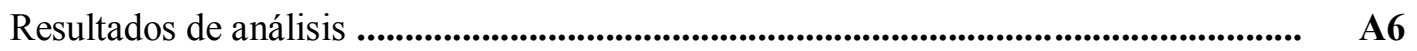

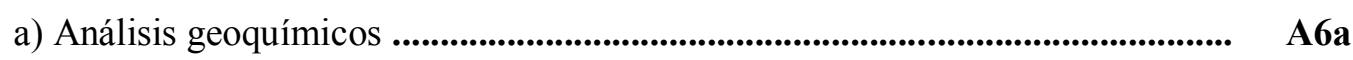

b) Análisis isotópicos ................................................................................................. A6b

c) Valores de referencia y fórmulas ................................................................... A6c 


\section{Capítulo 2:}

RESUMEN

El propósito de este estudio es caracterizar los afloramientos que conforman el Paleozoico Inferior de la denominada Precordillera de Jagüé, conformando los afloramientos mas septentrionales del Terreno Precordillera o Cuyania. En el marco regional este sector constituye el nexo con las provincias geológicas aledañas de Sierras Pampeanas Occidentales, Cordillera Frontal y la Puna Austral. Las rocas que allí afloran se encuentran deformadas, principalmente sobre el río Bonete, por donde pasa una faja de cizalla importante conocida como faja de deformación de Jagüé (Martino y Astini, 1998), que genera milonitización e intercalación tectónica de litologías de distinto origen y edad. Los afloramientos involucrados fueron definidos por Aceñolaza et al. (1971) como Formación Río Bonete y comprendía un conjunto de rocas calcáreas, sedimentitas y esquistos verdes que afloran al noroeste de la localidad de Jagüé, provincia de La Rioja, y de la cual existe escasa información antecedente ya que es una zona de difícil acceso. Se definió como una intercalación de origen incierto (primario o tectónico) de bancos de calizas y esquistos que integran los Miembros Caliza Las Damas y Esquistos Cerro Cóndor (Aceñolaza et al., 1971). La correlación con los afloramientos de la Precordillera se hizo en base a la presencia de fósiles ordovícicos de características similares en las sedimentitas halladas en las quebradas del Chuscho, del Salto y de Los Árboles las cuales se correlacionaron con el Miembro Cerro Cóndor y se denominaron informalmente como 'Lutitas del Salto'. El área tipo para la Formación se determinó en los afloramientos de calizas y esquistos que aparecen intercalados en el tramo medio del río Bonete, mientras que el área tipo para cada Miembro se situó mas al oeste, en la zona de Los Llantenes, en el Cerro Las Damas y Cerro Cóndor, respectivamente para calizas y esquistos.

Se estudiaron y mapearon los cuatro afloramientos principales en los que afloran estas rocas: quebrada de Potrerillos, quebradas del Río Bonete-Ciénaga Grande, quebradas del Chuscho-del Salto y área de Los Llantenes (quebrada Seca-cerros Las Damas). Para comprender la geología local y aspectos regionales se aportan datos de otras unidades íntimamente relacionadas con las rocas de interés y cuyo estudio ha contribuido a la resolución de aspectos de la estratigrafía de la zona. Para el estudio se han utilizado en conjunto una serie de metodologías, especialmente análisis petrográficos, geoquímicos, isotópicos, estudios de minerales pesados e interpretación de imágenes. La observación y relevamiento de campo fue muy importante. Como complemento de los estudios regionales presentan datos geocronológicos del plutón que intruye a la Formación Del Salto (Granito Potrerillos), del basamento que aflora inmediatamente al este de la Precordillera de Jagüe (Formación Espinal) y de las lavas-almohadilladas y autobrechas (Formación Chuscho, Fauqué y Villar, 2003).

A raíz de los resultados obtenidos, principalmente en base a las asociaciones litológicas, grado metamórfico y características de la deformación, así como al aporte de nuevos datos isotópicos y edades $\mathrm{U}-\mathrm{Pb}$ en circones, se ha modificado la estratigrafía de la zona, especialmente para los 
'esquistos' de la Formación Río Bonete. Se han diferenciado varias asociaciones litológicas que sobre la quebrada del río Bonete han quedado reunidas por la faja de cizalla y que originalmente se agruparon dentro de esta unidad: 1)- esquistos calcáreos asociados a esquistos verdes, 2)- esquistos blanquecinos cuarzo muscovíticos y esquistos biotíticos y 3)- metasedimentitas estratificadas asociadas a rocas básicas.

Los esquistos calcáreos y esquistos verdes se reúnen por el momento en la Formación Río Bonete s.s. ya que no son exactamente equivalentes a la Formación Río Bonete definida en sus orígenes. Ambos se encuentran intercalados e intensamente deformados, con estructuras miloníticas penetrativas, plegamiento apretado a escala de afloramiento, y afectados por metamorfismo en facies esquistos verdes, tanto en los alrededores de la quebrada del Bonete como en el área de Los Llanenes. Estos esquistos provienen de protolitos básicos en su mayoría, y también sedimentarios. En base a las edades U-Pb en circones detríticos obtenidas (una moda de mesoproterozoica $c a .1000 \mathrm{Ma}$, con edad máxima de sedimentación de $837 \pm 16 \mathrm{Ma}$ ) para los esquistos se reubicaron estratigráficamente y conformarían el basamento de la región. Los esquistos se correlacionan con bloques fragmentados del basamento del terreno Cuyania mientras que los mármoles se correlacionan con la plataforma carbonática de la Precordillera sanjuanina. Se interpreta que por las estructuras regionales y gran similitud observada serían la continuación de los afloramientos del oeste de la sierra de Umango.

Las sedimentitas con fósiles del Ordovícico Superior se encuentran siempre bien estratificadas y sin rocas calcareas o esquistos asociados, lo que permite diferenciar sus afloramientos. Se encuentran en el norte de la quebrada de Potrerillos, donde son intruidas por el Granito Potrerillos, y en los alrededores de la quebrada del Chuscho, donde se asocian e intercalan con lavas almohadilladas, autobrechas volcánicas y diques de la Formación Chuscho (Toselli y Durand, 1996). Las edades U-Pb obtenidas para las metasedimentitas dieron una edad máxima de sedimentación cerca del límite Ordovícico-Silúrico, coherente con la fauna hallada. Al separarse las sedimentas de la Formación Río Bonete, se propone redefinir la asociación litológica metasedimentitas - rocas básicas como Formación Del Salto (emend.), y denominar a las litologías asociadas como Miembro Metasedimentitas Estratificadas y Miembro Cerro Chuscho, respectivamente. Tienen un grado de deformación mucho menor al de los esquistos (pliegues abiertos) y un grado de metamorfismo incipiente (Epizona) lo que permitió la preservación de la estratificación y muchas texturas sedimentarias primarias, incluyendo los fósiles. Las rocas básicas originalmente fueron consideradas comagmáticas con otras volcanitas andesíticas carboníferas de la región, sin embargo su intercalación con las metasedimentitas ordovícicas permite constatar su reubicación en Ordovícico (Fauqué y Villar, 2003). Las lavas muestran signaturas relacionadas a un ambiente tectónico de arco de isla oceánico y no se descarta su vinculación con la Ofiolita Famatiniana (Kay et al., 1984). El análisis de los datos obtenidos para las metasedimentitas hace pensar en un ambiente de depositación relacionado a márgenes continentales activos con aporte de detritos procedentes del basamento mesoproterozoico y de un arco que para la época podría corresponder al de Famatina o Puna al oeste del Gondwana. 
En la boca y tramo inferior del río Bonete esquistos cuarzo-muscovíticos blanquecinos y esquistos biotíticos han quedado intercalados entre bloques de otras unidades y esquistos de variada composición (esquistos verdes cloríticos, anfibólicos y epidóticos, esquistos calcáreos, anfibolitas) por la faja de deformación de Jagüé. Aunque se mapeaban entre los esquistos 'ordovícicos' de la Formación Río Bonete, estos esquistos tienen su origen en la deformación por cizalla del Granito Potrerillos y de su roca de caja sedimentaria (Mb. Metasedimentitas Estratificadas de la Formación Del Salto), respectivamente. Además existen bloques de las rocas básicas del Mb. Cerro Chuscho que han quedado intercalados tectónicamente en la faja de deformación, y no se descarta que involucre a sedimentitas devonico-carboníferas que afloran en la region (Formaciones Jagüé-Quebrada Seca). La faja de cizalla involucra a litologías de variado origen y edad y en todo caso debería mapearse separadamente. Esta estructura se habría reactivado en varias ocasiones hasta el Carbonífero Inferior y luego es cubierta en discordancia por las unidades tipicas de las secuencias del Paleozoico Superior representada en la región especialmente por los conglomerados castaños de la Formación Cerro Tres Cóndores. Las unidades del Paleozoico Inferior y del basamento afloran en bloques limitados por fallas y se relacionan mediante discordancias con los afloramientos del Paleozoico Superior.

Se ha caracterizado al Granito Potrerillos, que intruye a las metasedimentitas de la Formación Del Salto y genera una aureola de contacto. Es un plutón superficial, elipsoidal, formado por una serie de facies de distinta composición. Se han detectado evidencias de mingling y asimilacion de bloques de la roca de caja. Geoquímicamente es un granitoide tipo I, metaaluminoso a peraluminoso, subalcalino con facies más alcalinas. Se obtuvieron edades U-Pb que junto a otras características observadas permiten diferenciarlo del magmatismo calcoalcalino carbonífero típico de Cordillera Frontal y vincularlo a estadíos tardío- a postorogénicos respecto del ciclo Famatiniano.

Entre los afloramientos mapeados como metasedimentitas ordovícicas sobre la quebrada del Chuscho se halló un bloque pequeño correspondiente a la Formación Jagüel (Devónico-Carbonífero Inferior) que aflora hacia el sur. En el área de Los Llantenes afloran rocas con características similares que han sido definidas por Cravero et al. (1984) como Formación Quebrada Seca, quienes las asignaron al Ordovícico. Sin embargo se encontraron fósiles de invertebrados y plantas mal preservados afines al Devónico-Carbonífero Inferior, por lo que la unidad sería equivalente a la Formación Jagüel. Estan constituidas por metapelitas verdosas concrecionales en las que se encuentran escasos estratos amarillentos arenosos, a veces canaliformes.

De acuerdo a las observaciones realizadas los afloramientos de esquistos verdes y rocas calcáreas conformarían bloques fragmentados que se correlacionarían con las unidades que forman el basamento en facies de esquistos verdes del sector occidental de la sierra de Umango (Sierras Pampeanas Occidentales) y plataforma carbonatica de Precordillera, mientras que las metasedimentitas estratificadas asociadas a lavas almohadilladas se correlacionarían con unidades que forman parte de la cubierta sedimentaria de la Precordillera Occidental. 


\section{Chapter 2:}

\section{ABSTRACT}

The purpose of this study is to characterize the outcrops that comprise the Lower Paleozoic of the so known Precordillera of Jagüé, forming the northernmost outcrops of the Precordillera or Cuyania Terrane. At the regional level, this sector constitutes the link between the surrounding geological provinces of Western Pampean Ranges, Frontal Cordillera and Southern Puna. The rocks that outcrop there are deformed, principally on the quebrada del rio Bonete, through which it crosses a major shear zone known as faja de deformación de Jagüé (Jagüé Deformation Belt, Martino and Astini, 1998). This belt produces mylonitization and tectonic intercalation of lithologies of different origin and age. The othcrops involved were named as Río Bonete Formation by Aceñolaza et al. (1971) and comprised a set of calcareous and sedimentary rocks and green-schists in the northwest of the town of Jagüé, La Rioja Province. There is little background information because it is an area of difficult access. The unit was defined as an intercalation of uncertain origin (primary or tectonic) of limestone beds and schists that comprise the Caliza Las Damas and Esquistos Cerro Cóndor Members (Aceñolaza et al., 1971). The correlation with outcrops in Precordillera was based on the presence of Ordovician fossils with similar characteristics in the sedimentary rocks of the quebrada del Chuscho, quebrada del Salto and quebrada de Los Árboles. These sediments were correlated with the Cerro Cóndor Member and informally named as 'Lutitas del Salto'. The type section of the Río Bonete Formation was defined in the outcrops of alternating limestones and schists of the middle stretch of the Bonete River, while the type section for each Member was defined to the west in the Las Damas Hills and Cóndor Hill respectivelly, in Los Llantenes area.

There were studied and mapped the four main outcrops wherw these rocks crop out: the quebrada de Potrerillos, the quebradas del Río Bonete-Ciénaga Grande, the quebradas del Cuschodel Salto and Los Llantenes area (quebrada Seca and cerros Las Damas). For the better understanding of the local geology and and regional aspects here there is a contribition of data from other units closely related with the rocks of interest, and whose study helped to the resolution of aspects of the stratigraphy of the area. A set of methodologies were used altogether, especially petrographyc, geochemical and isotopic analysis, heavy minerals studies and image interpretation. Field observation was very important. Geochronological complemetary data are presented for the pluton that intrudes the Del Salto Formation (Potrerillos Granite), the basement that outcrops inmediately to the east of the Precordillera of Jagüé (Espinal Formation) and the pillow-lavas and volcanic autobreccias (Chuscho Formation, Fauque and Villar, 2003).

Following the results, especially because of the lithologic associations, metamorphic grade and deformation style, and the contribution of new isotopic data and $\mathrm{U}-\mathrm{Pb}$ ages on zircon, the local stratigraphy was modified, particularily for the "schists" of the Río Bonete Formation. Various lithologic associations originally gathered in this unit on the quebrada del Rio Bonete coud be differentiated because they were mixed due to the shear zone: 1)- calcareous schists associated to 
green schists, 2)- quartz-muscovite whitish schists and micaceous schists, and 3)- stratified metasedimentary rocks associated to basic rocks.

By the moment, calcareous schists and green schists are grouped in the Río Bonete Formation s.s, because they are not exactly equivalent to the Río Bonete Formation originally defined. Both are intensely intercaled and deformed, showing penetrative mylonitic structures, large-scale tight folding, and affected by metamorphism in greenschist facies both around the quebrada del Bonete and Los Llantenes area. Most of these schists derive from basic protoliths, and also sediments. Because of the $\mathrm{U}-\mathrm{Pb}$ ages obtained on detrital zircons (mesoproterozoic mode $c a .1000 \mathrm{My}$; $837 \pm 16 \mathrm{My}$ maximum sedimentary input age) the schists were re-located in the stratigraphy conformming the basement of the area. The schists are correlated with fragmented blocks of the Cuyania basement while the marbles correlate with the carbonate platform of the Precordillera of San Juan. By the regional structures and great similarity observed it is interpreted that they would be the continuation from the outcrops of the Sierra de Umango.

The Upper Ordovician fossiliferous sedimentary rocks are always well stratified and lack calcareous rocks or associated schists, and those characteristics allow differenciate their outcrops. They appear to the north of the quebrada de Potrerillos, where they are intruded by the Potrerillos Granite, and in the surroundings of the quebrada del Chuscho, where they are associated and intercaled with pillow-lavas, volcanic autobreccias and dikes of the Chuscho Formation (Toselli y Durand, 1996). The U-Pb ages obtained for the metasedimentary rocks gave a maximum sedimentation age close to the Ordovician-Silurian limit, what is coherent with the fauna found. It is proposed to re-define the metasedimentary rocks-basic rocks lithologic association as Del Salto Formation (emend.) and to name the associated lithologies as Metasedimentitas Estratificadas Member and Cerro Chuscho Member, respectively. They have a much lower degree of deformation to the schists (open folds) and an incipient metamorphic grade (Epizone); these allowed preserveing the stratification and other primary sedimentary structures, including fossils. In the biginning the basic rocks were considered as co-magmatic with other Carboniferous andesites of the region, but the fact that they are intercales with the Ordovician metasediments confirm their relocation in the Ordovician (Fauque y Villar, 2003). The lavas show signatures related to an oceanic island arc tectonic setting and their vinculation with the Famatinian Ofiolite (Kay et al., 1984) can not be discarded. The analysis of the data obteined for the metasediments points to a depositional environment related to active continental margins with input of detritus from the Mesoproterozoic basement and from an arc that, for this time, can correspond to the Famatina or the Puna in the west of Gondwana.

Withish quartz- muscovitic schists and biotitic schists remained intercaled between other units blocks and schists of various composition in the mouth and lower section of the Bonete River due to the faja de deformacion de Jagüé (chloritic, anfibolic, asn epidotic green schist, calcareous schists and anfibolites). Although this rochs were mapped within the 'Ordovician schists of the Rio Bonete Formation, they are originated due to the shear deformation of the Potrerillos Granite and its sedimentary wall-rock (Metasedimentitas Estratificadas Member from the Del Salto Formation), 
respectively. There exist block of the basic rocks of the Cerro Chuscho Member also, that remained tectonically intercaled inside the shear zone. It can also involve Devonian-Carboniferous sedimentites that crops out in the region (Jagüel-Quebrada Seca Formations). The shear zone invove a variety of lithologies of diferent ages, so they may be mapped separately. This structure probably reactivated in differet moments until the Lower Carboniferous, and the is covered in discordande by the typical units from the Upper Paleozoic, represented in the area by the brownish conglomerates from the Cerro Tres Cóndores Formation. The Lower Paleozoic units and the basement crops out in faulted blocks and are related with the Upper Paleozoic units by discordance.

It is characterized the Potrerillos Granite, that intrudes the metasedimentary rocks of the Del Salto Formation producing a contact aureole. It is an elipsoidal, sub-surface pluton composed by a variety of facies of different composition. Mingling evidences and wall-rock assimilation processes were detected. Geochemically, it is a type-I granitoid, metaaluminous to peraluminous, subalcaline with some more alcaline facies. U-Pb ages were obtained, and with other characteristics observed allowed differenciating it from the Carboniferous calcoalcaline magmatism typical from the Frontal Cordillera, and link it to late to post-orogenic stages respect to the Famatinian Cicle.

Between the outcrops mapped as Ordovician metasediments on the quebrada del Chuscho, it was found a small block corresponding to the Jagüé Formation (Devonian-Lower Carboniferous) that crops out to the south. In the Los Llantenes area crops out rocks with similar characteristics defined by Cravero et al. (1984) as Quebrada Seca Formation assigned to the Ordovician. However, badly preserved fossils of invertebrates and plants were found that relate the rocks to the Devonian to Lower Carboniferous. So the unit is equivalent to the Jagüel Formation. They consist on greenish and cocrecional metapelites among which scarce beds of yellowish sandstones are found, sometimes channel-shaped.

According to the observations made the green-schists and calcareous rocks outcrops conform fragmented blocks that can be correlated to the units that forms the greenschists facies basement from the western side of the Sierra de Umango (Western Pampean Ranges) and carbonate platform of Precordillera, while the well stratified metasediments associated with pillow-lavas can be correlated with units that forms the sedimentary cover of the Wertern Precordillera. 


\section{Capítulo 1:}

\section{INTRODUCCIÓN}

\section{1- UBICACIÓN DEL ÁREA DE ESTUDIO.}

La denominada Formación Río Bonete por Aceñolaza et al. (1971) conforma los afloramientos ordovícicos más septentrionales del Terreno Cuyania (Ramos, 1982), en lo que se conoce localmente como Precordillera de Jagüé (Figura 1.1). Esta es una extensa estructura orográfica limitada por lineamientos regionales que la separan de la Cordillera Frontal (Sierra del Peñón) al oeste, y Sierras Pampeanas Occidentales (Sierra del Toro Negro) al este, mientras que hacia el norte es cubierta por el volcanismo propio de la Puna Riojana. A su vez constituye un nexo entre las provincias geológicas de Famatina y la Precordillera sanjuanina. Por el sur está cubierta por los sedimentos cuaternarios del Bolsón de Jagüé y valle del río del Peñón y luego es posible seguir los últimos afloramientos precordilleranos de la Sierra de la Punilla y alrededores.

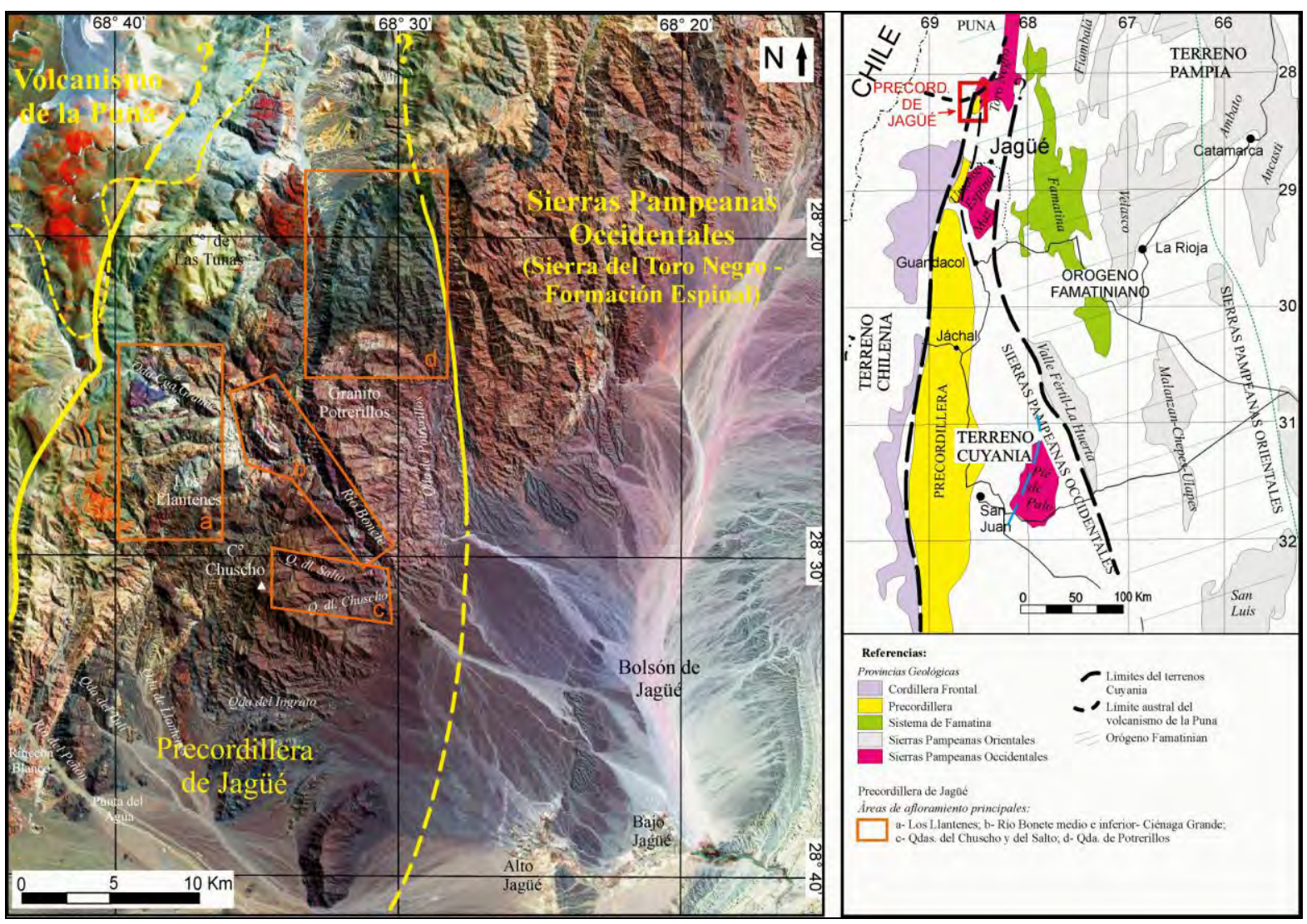

Figura 1.1: Ubicación de las áreas de estudio en la Precordillera de Jagüé y marco regional.

La zona de estudio queda comprendida entre los $28^{\circ} 18^{\prime}$ y $28^{\circ} 32^{\prime}$ de latitud sur y los $68^{\circ} 28^{\prime}$ y $68^{\circ} 40^{\prime}$ de longitud oeste. Regionalmente, se reconocieron cuatro áreas principales de afloramientos (Fig. 1) que de oeste a este son:

a)- la zona de Los Llantenes - $\mathrm{C}^{\circ}$ Las Damas y al norte de ésta (incluyendo el tramo medio de la Quebrada de Ciénaga Grande), comprendiendo dos bloques rodeados por fallas; 
b)- sobre los tramos medio e inferior de la quebrada del Río Bonete, incluyendo el tramo inferior de la quebrada Ciénaga Grande;

c)- en el área del Cerro Chuscho, sobre las quebradas del Chuscho y del Salto;

d)- al norte del Granito Potrerillos, sobre el tramo superior de la quebrada homónima, donde es intruida por éste cuerpo.

Maisonave (1979) describe otro afloramiento más al este, en discordancia angular sobre la Formación Espinal, pero estos afloramientos no pudieron ser estudiados en esta oportunidad por las complejidades logísticas.

\section{2- OBJETIVOS}

La importancia regional de la Precordillera de Jagüé radica en que constituye el nexo entre las provincias geológicas aledañas. Sin embargo, si bien ha contado con algunos trabajos y relevamientos regionales, es aún poco conocida en virtud de la dificultad de los accesos. Así, este trabajo pretende contribuir a mejorar su conocimiento, especialmente desde el punto de vista de la estratigrafía, de sus características sedimentológicas, procedencia y definición del ambiente tectónico. El objetivo principal es el estudio de la originalmente denominada Formación Río Bonete, única unidad definida dentro del Ordovícico de este sector. Por otro lado, se aportarán datos de las unidades relacionadas a sus afloramientos, en especial las ígneas (Granito Potrerillos y Formación Chuscho). Cabe destacar que la estratigrafía reconocida en este sector es diferente a la que se presenta en el Ordovícico del oeste y noroeste de Argentina, incluso respecto a otras unidades equivalentes de la Precordillera, especialmente en cuanto a la intensa deformación que presenta. Así es que los estudios que se llevaron a cabo apuntan principalmente a precisar la estratigrafía y establecer diferencias y correlaciones con unidades de la Precordillera sanjuanina, las cuencas del Famatina y del Noroeste argentino. De esta manera se aporta al conocimiento de la evolución tecto-sedimentaria del Paleozoico Inferior del área, y por ende de la evolución del borde occidental de Gondwana durante este período.

Los siguientes objetivos específicos se plantearon como punto de partida para establecer la estratigrafía de la zona:

- Reconocimiento estratigráfico de las unidades establecidas como ordovícicas en el área de la Precordillera Riojana o Precordillera de Jagüe (Formación Río Bonete y sus Miembros Esquistos Cerro Cóndor y Caliza Las Damas).

- Tratar de determinar la edad, extensión y características bioestratigráficas de la Formación Río Bonete, el paleoambiente que la caracteriza, el grado y edad del metamorfismo que la afecta. 
- Establecer el patrón de procedeniencia sedimentaria y áreas fuente de los sedimentos silicoclásticos.

- Llegar a establecer edades estratigráficas más precisas por medio de análisis isotópicos U-Pb.

- Establecer correlaciones y/o vinculaciones entre esta unidad y otras unidades/rocas equivalentes de Precordillera y comparación con áreas colindantes donde afloran sedimentitas del Ordovícico en el oeste y noroeste de Argentina. En éste sentido, una hipótesis de trabajo fue la de tratar de comprobar si el Miembro Las Damas forma parte o no de la plataforma carbonática de Precordillera.

- Llegar a establecer la relación estratigráfica que guardan las volcanitas del Cerro Chuscho, reubicada por varios autores en el Ordovícico, con la Formación Río Bonete y analizar si conforman una mezcla tectónica de ambiente oceánico.

- Intentar definir si el Granito Potrerillos que intruye a la Formación Río Bonete está relacionado al Arco Famatiniano o al Gondwánico y brindar una caracterización geoquímica del mismo.

Una parte importante de la tesis doctoral ha sido analizar la procedencia sedimentaria de los detritos silicoclásticos mediante el análisis petrográfico, geoquímico - isotópico y del patrón de minerales pesados. En este sentido se propuso: a- Evaluar los procesos secundarios (grado de alteración, retrabajo, meteorización, diagénesis) y/o metamórficos que pudieron afectar la composición de las rocas sedimentarias mediante el análisis petrográfico, geoquímico y de difracción de rayos X. b- Evaluar probables áreas fuente de los detritos. Para ello el estudio tipológico (con imágenes SEM, BSE, CL) de los minerales pesados más importantes (especialmente circones) y los análisis isotópicos sobre circones aportarán más datos acerca de la procedencia y los procesos de sedimentación y alteración de granos individuales. c- Modelar la procedencia de las rocas clásticas y origen de las ígneas mediante el análisis de datos geoquímicos. Los elementos mayoritarios se utilizaron principalmente para cuantificar el grado de alteración de las muestras, mientras que las tierras raras y algunos elementos traza característicos, debido a su inmovilidad, dan información más confiable para modelar la composición de las fuentes de aporte. d- Realizar como complemento análisis isotópicos de $\mathrm{Sm}-\mathrm{Nd}$ en roca total para obtener edades $\mathrm{T}_{\mathrm{DM}}$ ('edad modelo') de las rocas fuente, e información sobre residencia crustal del material detrítico. Los resultados serán combinados con edades de las diferentes fuentes obtenidas por medio de dataciones de circones detríticos por el método U-Pb (ICP-MS-LA).

Luego del mapeo, se analizaron petrográfica- y geoquímicamente las rocas ígneas básicas de la Formación Chuscho, para entender las relaciones que guardan con las demás unidades. A su vez podrían brindar información relacionada a la evolución tectónica de la cuenca.

Cabe señalar que los relevamientos de campo y estudios petrográficos detallados permitieron determinar una gran deformación y grado de recristalización en las capas de rocas calcáreas, por lo que ha sido necesario redireccionar en parte los objetivos planteados originalmente.

Teniendo en cuenta los estudios estratigráficos y de procedencia ya mencionados, se intentará constreñir el ambiente tectónico de formación de la cuenca ordovícica, y así aportar información 
acerca de los procesos de evolución crustal durante el Paleozoico Inferior en el extremo norte de Precordillera. Esto permitirá contrastar con los modelos paleogeográficos, de procedencia y ambiente tectónico existentes para el Ordovícico de regiones aledañas (NOA incluyendo la Puna, Famatina, Precordillera y Bloque de San Rafael), y eventualmente proponer nuevas líneas complementarias de interpretación.

\section{3- ANTECEDENTES}

\subsection{1- Cartografía de base.}

Para la planificación de los trabajos de campo y acceso a los afloramientos fueron de gran utilidad las hojas topográficas del área $(14 \mathrm{~b}, 14 \mathrm{c}, 15 \mathrm{~b}$ y 15c, Dirección Nacional de Geología y Minería - SEGEMAR) y fotointerpretaciones realizadas de las fotografías de las corridas 2969 - 210 14 a 22; 2969 - 211 - 11 a 20; 2969 - 212 - 12 a 22 (Departamento de Fotogrametría, SEGEMAR).

En cuanto a la cartografía geológica, se partió del análisis principalmente de la Hoja $14 \mathrm{c}$ a escala 1:200.000 (Maisonave, 1979), la Hoja Geológica 2969-II a escala 1:250.000 (Fauqué y Caminos 2004, preliminar), y la carta imagen Landsat TM 2969-II equivalente. Dado que las escalas son muy pequeñas, el relevamiento de detalle de la zona de afloramientos se ha completado con mapas y esquemas locales tomados de estudios mineros y artículos publicados de la bibliografía, haciéndose una síntesis de los distintos aspectos considerados en cada uno, sumado a datos y relevamientos propios. En este sentido Cravero et al. (1984) han realizado un mapeo geológico de las unidades que afloran en el área de Los Llantenes, aunque la interpretación estratigráfica sea diferente, se ha usado este mapa de base para ese sector, además los perfiles geológicos y mapeos parciales de Ramaccioni y Olsacher (1962) y Aceñolaza (1969). Para los afloramientos del área del río Bonete y Cerro Chuscho se han usado de referencia los perfiles geológicos y mapeos publicados por Aceñolaza y Bernasconi (1969b), Aceñolaza (1970), Toselli y Aceñolaza (1971), Fauqué y Villar (2003). También han sido de gran utilidad los perfiles geológicos regionales publicados en Caminos (1972) y Martina y Astini (2009), y la síntesis del área de Aceñolaza et al. (1971). Finalmente se ha consultado la Hoja Geológica 2969-II a escala 1:250.000 realizada por Caminos y Fauqué (2004) que se acompaña de perfiles geológicos, perfiles columnares y esquemas geológicos.

Con el programa Google Earth y recientemente mediante el uso de un Sistema de Información Geográfica (programa ArcGIS) se pudieron ubicar las muestras y puntos de interés ingresando las coordenadas tomadas con GPS, volcando luego estas en la imagen de base georeferenciada (Landsat ETM 232/80, realzada y normalizada). Con GIS además se pudo mapear y terminar de hacer una síntesis de la información abarcando el área de interés, luego mejorada para su presentación con el programa CorelDraw.

Las imágenes de base utilizadas ya sean para la planificación de los trabajos de campo como para el mapeo y labores de gabinete se resumen en la Tabla 1.1. 
Tabla 1.1: Hojas topográficas, geológicas e imágenes satelitales utilizadas como cartografía de base para la realización del trabajo de tesis.

\begin{tabular}{|c|c|c|c|c|}
\hline Cartografía / Imagen* & Título & Escala & Coordenadas & Fuente - Autor - Año \\
\hline \multicolumn{5}{|c|}{ HOJAS TOPOGRÁFICAS } \\
\hline \multirow[t]{4}{*}{$14 \mathrm{~b}$} & Laguna Brava & $1: 100.000$ & $69^{\circ} 15^{\prime}-68^{\circ} 30^{\prime} \mathrm{O}$ & O. L. Carnacini (topog.), N. G. Konisberg \\
\hline & & & $28^{\circ} 30^{\prime}-28^{\circ} 00^{\prime} \mathrm{S}$ & (fotointerp.), S. N. Pedalino (dibujo) \\
\hline & & & & 1943 (levant. DNGM) \\
\hline & & & & 1972 (fotointerpret.) \\
\hline \multirow[t]{2}{*}{$14 \mathrm{c}$} & Cerros & $1: 100.000$ & $67^{\circ} 45^{\prime}-68^{\circ} 30^{\prime} \mathrm{O}$ & C. Barbieri, E. Turco Greco. \\
\hline & Cuminchango & & $28^{\circ} 30^{\prime}-28^{\circ} 00^{\prime} \mathrm{S}$ & 1943-1949 (Relev. de la DGIM) \\
\hline \multirow[t]{2}{*}{$15 b$} & Cerro de & $1: 100.000$ & $68^{\circ} 30^{\prime}-69^{\circ} 15^{\prime} \mathrm{O}$ & Autor no especificado. SEGEMAR ${ }^{(1)}$ \\
\hline & Chaparro & & $28^{\circ} 30^{\prime}-29^{\circ} 00^{\prime} \mathrm{S}$ & \\
\hline \multirow[t]{3}{*}{$15 \mathrm{c}$} & Vinchina & $1: 100.000$ & $67^{\circ} 45^{\prime}-68^{\circ} 30^{\prime} \mathrm{O}$ & Autor no especificado. SEGEMAR \\
\hline & & & $28^{\circ} 30^{\prime}-29^{\circ} 00^{\prime} \mathrm{S}$ & (levant. 1943, 1944 y 1948, DNGM). \\
\hline & & & & 1950 (edición), 1961 (reedición) \\
\hline \multicolumn{5}{|c|}{ HOJAS GEOLÓGICAS } \\
\hline \multirow[t]{2}{*}{$14 \mathrm{c}$} & Cerros & $1: 200.000$ & $67^{\circ} 45^{\prime}-68^{\circ} 30^{\prime} \mathrm{O}$ & Maisonave, 1979 \\
\hline & Cuminchango & & $28^{\circ} 30^{\prime}-28^{\circ} 00^{\prime} \mathrm{S}$ & \\
\hline \multirow[t]{2}{*}{$15 \mathrm{c}$} & Vinchina & $1: 200.000$ & $67^{\circ} 45^{\prime}-68^{\circ} 30^{\prime} \mathrm{O}$ & Turner, 1964- Boletín Dirección Nacional de \\
\hline & & & $28^{\circ} 30^{\prime}-29^{\circ} 00^{\prime} \mathrm{S}$ & Geología y Minería \\
\hline \multirow[t]{2}{*}{ 2969-II } & Tinogasta & $1: 250.000$ & $67^{\circ} 30^{\prime}-69^{\circ} 00^{\prime} \mathrm{O}$ & Fauqué y Caminos, 2004 (preliminar), \\
\hline & & & $28^{\circ} 00^{\prime}-29^{\circ} 00^{\prime} \mathrm{S}$ & SEGEMAR \\
\hline \multicolumn{5}{|c|}{ IMÁGENES SATELITALES } \\
\hline Landsat TM 2969-II (Carta & Tinogasta & $1: 250.000$ & $28^{\circ} 0^{\prime} 29^{\circ} 0^{\prime} \mathrm{S}$ & IGM \\
\hline Imagen) & & & $67^{\circ} 30^{\prime}-69^{\circ} 0^{\prime} \mathrm{O}$ & \\
\hline Landsat 7 ETM-238-80 & Recorte & Resol. original: 15 & & CONAE $^{(2)}$ \\
\hline Combinación de bandas: & & Resol. final: $30 \mathrm{~m}$ & (re-muestreada con una & \\
\hline RGB 7-4-2 normalizado & & imagen pancromát & ica) & \\
\hline Capturas de pantalla del & - & Resolución hasta & - & Google Earth \\
\hline programa Google Earth & & $1-5 \mathrm{~m}$ & & \\
\hline
\end{tabular}

\subsection{2- Marco geológico regional}

Como fuera expresado, a nivel regional la Precordillera de Jagüé constituye un nexo entre las provincias geológicas aledañas. Por el oeste, en la Sierra del Peñón se imponen las alturas y el magmatismo gondwánico típico de la Cordillera Frontal; hacia el este aparece en contacto tectónico el basamento metamórfico de la Sierra de Toro Negro (Formación Espinal) y las estructuras características de las Sierras Pampeanas Occidentales, así como el arco magmático ordovícico del Sistema de Famatina; mientras que hacia el norte los afloramientos desaparecen bajo el vulcanismo de la Puna Riojana.

Los afloramientos vinculados directamente a esta investigación conforman bloques tectónicos de esquistos y mármoles de la Formación Río Bonete, así como metasedimentitas fosilíferas estratificadas asociadas a rocas básicas e intruidas por el Granito Potrerillos (ver estratigrafía en 
capítulo 3). Todo este conjunto está afectado por una faja de cizalla de importancia regional denominada 'faja de deformación de Jagüé' (Martino y Astini, 1998) que afecta y pone en contacto a litologías y unidades de diferente tipo y edad.

En el área de Los Llantenes y en el tramo medio del río Bonete aparecen mármoles intercalados con metabasitas y metamorfitas de bajo grado, con deformación milonítica característica, habiéndose diferenciado originalmente los miembros Caliza Las Damas y Esquistos Cerro Cóndor respectivamente. Estas rocas son las que originalmente fueron definidas en conjunto como Formación Río Bonete por Aceñolaza et al., (1971), quienes incluyeron además a metasedimentitas fosilíferas ordovícicas sobre la quebrada del Chuscho. En estos últimos afloramientos y en los que están sobre la quebrada de Potrerillos no afloran rocas carbonáticas y la deformación y metamorfismo son menores.

El área tipo de la Formación Río Bonete fue definida originalmente por Aceñolaza et al. (1971) en el tramo medio del río homónimo, donde es posible observar la intercalación regular de bancos de calizas grises y amarillentas con esquistos verdes y verde - azulados, dando un aspecto bandeado característico a la quebrada. Por otro lado, el área tipo de cada uno de los miembros se definieron en Los Llantenes, en los cerros Las Damas para las calizas y en el cerro Cóndor para los esquistos (Anexos A1: M1 y M6a-b). Allí aparece un bloque de rocas carbonáticas deformadas limitado por fallas y rodeado de esquistos verdes y metabasitas deformadas. En discordancia hacia el sureste aflora la Formación Quebrada Seca que fuera definida y mapeada por Cravero et al. (1984), quienes mencionan además que se hallan parcialmente cubiertas por lavas almohadilladas y cortadas por diques básicos asociados (feno-andesitas y basaltos) de la Formación Punta del Agua (González y Bossi, 1986). Este conjunto constituye el núcleo de un anticlinal cuyos flancos están formados por los conglomerados de la Formación Cerro Tres Cóndores, asignada al Carbonífero.

La ubicación de esta región dentro de la Precordillera se debe en primer lugar a la presencia de la Caliza Las Damas que se correlacionó con la plataforma carbonática cambro-ordovícica de la Precordillera. Por otro lado, el hallazgo de una fauna de graptolites y bivalvos ordovícicos en metasedimentitas silicoclásticas sobre las quebradas del Chuscho y de los Árboles (Aceñolaza y Bernasconi, 1969a) permitió correlacionarlas bioestratigráficamente con unidades principales de la Precordillera. Más tarde, Kay et al. (1984) sumaron otro argumento al incorporar las lavas almohadilladas del cerro Chuscho dentro de la faja ofiolítica famatiniana del oeste de la Precordillera (Haller y Ramos, 1984), asignándolas al Ordovícico, lo que sugiere también su ubicación en el límite occidental del terreno Cuyania.

A modo de síntesis, pueden citarse como antecedentes mas representativos de la geología y estratigrafía del Paleozoico Inferior de la Precordillera de Jagüe, los trabajos de Aceñolaza et al. (1971) para el área del río Bonete, Cravero et al. (1984) en el área de Los Llantenes, así como los recientes aportes estratigráficos de Martina y Astini (2009). A nivel regional son importantes los trabajos de Maisonave (1979), Caminos (1972), Caminos y Fauqué (2004, preliminar) y el trabajo mencionado de Martina y Astini (2009). 
A continuación se hace un desarrollo de los antecedentes que existen de la región. Las distintas interpretaciones estratigráficas para el área se resumen en el Cuadro 1.

Para la zona de Los Llantenes (Anexos A1: M6a-b) los primeros trabajos corresponden a los estudios llevados a cabo por Ramaccioni y Olsacher (1962), en relación con los yacimientos de minerales de mercurio y selenio de Cuesta de Los Llantenes. Dado el escaso conocimiento geológico de la región que por entonces se tenía, los datos de las unidades formacionales son imprecisos, así como sus edades. Sin embargo, se expresa la vinculación de las manifestaciones minerales con numerosos cuerpos intrusivos de poca extensión y gran variabilidad composicional y estructural que afectan a distintas unidades sedimentarias y metamórficas en diferentes localidades de la región. Estos yacimientos han sido explotados desde mediados hasta fines de 1800 por los minerales de plata contenidos en vetas portadoras de seleniuros, citándose entre ellos umanguita (seleniuro de cobre), eucairita (seleniuro de plata y cobre), tiemannita (seleniuro de mercurio) y cóndor - tiemannita (seleniuro de hierro y mercurio). Con el correr del tiempo, los laboreos fueron abandonados y las investigaciones de exploración se retomaron durante la década de 1960, dada la importancia económica de las mineralizaciones. Las unidades ordovícicas quedarían comprendidas dentro de lo que estos autores atribuyeron a los "Esquistos Precámbricos", que se encuentran en discordancia por debajo de conglomerados fluvio - glaciales carboníferos. En la zona de Los Llantenes predomina el mercurio y el plomo sobre la plata y según los autores la mineralización sigue el contacto tectónico Precámbrico - Carbonífero.

Por su parte, Aceñolaza y Castaño, (1968, en Aceñolaza y Bernasconi 1969) distinguen informalmente las unidades 'Caliza Las Damas' constituida por los miembros caliza magnesiana y dolomía, y 'Esquistos Cerro Cóndor' conformado por los miembros filítico, carbonoso y "alterado". Además expresan que las leptometamorfitas allí aflorantes son muy similares litológicamente a las metamorfitas y sedimentitas ordovícicas del sector sur de la Precordillera Riojana. Mas tarde, Aceñolaza (1969) presenta los principales caracteres estratigráficos y geológicos de la zona de Los Llantenes - Cerro Las Damas, paralelamente a una serie de estudios llevados a cabo por la Dirección Provincial de Minería de La Rioja, con el objetivo de esclarecer la importancia de la mineralización cupro - selenífera con mercurio. De los estudios realizados se desprende la estratigrafía citada en el Cuadro 1, en la que se define la Formación Río Bonete y aunque en ese momento no fue posible datar paleontológicamente a los esquistos y calizas, los atribuyó al Ordovícico por evidencias litológicas y geotectónicas que permitían correlacionarlos con otros sectores de Precordillera. A la unidad Caliza Las Damas se la correlacionó tentativamente con las rocas carbonáticas de la Formación San Juan (Llanvirniano) de los afloramientos de Guandacol, y a los Esquistos Cerro Cóndor se los relacionó con las metamorfitas de bajo grado que constituyen la Formación Río Blanco (ver Furque, 1972). Asimismo identificó dos ciclos intrusivos andesíticos, uno Tacónico - Caledónico (Ordovícico medio) y otro Varíscico (intra-Carbonífero), debido a que algunos intrusivos andesíticos afectan a metamorfitas con probables edades ordovícicas y otras también a niveles basales de la secuencia 
neopaleozoica. Se distinguen tres tipos de intrusivos andesíticos basándose en su color y desarrollo de los fenocristales. Uno gris verdoso con abundancia de fenocristales de plagioclasa, otro pardo amarillento con pequeños cristales de plagioclasa, y finalmente un pórfido gris oscuro con gran abundancia de fenocristales de plagioclasa y anfíbol. Los ubica dentro del Carbonífero porque afectan a los Esquistos Cerro Cóndor y a la Formación Guandacol.

Para la zona del Chuscho, Aceñolaza y Bernasconi (1969a) hacen referencia al hallazgo de fósiles ordovícicos sobre las quebradas del Chuscho y del Salto, afluentes del río Bonete a unos dos kilómetros al oeste - sudoeste de su desembocadura y a unos $20 \mathrm{Km}$ al norte de Jagüé, región que hasta entonces se consideraba precámbrica. Los fósiles se hallan en potentes bancos de lutitas pizarreñas carbonosas intercaladas con cuarcitas negras y verde grisáceas, a las que los autores denominaron informalmente 'Lutitas del Salto'. Entre los restos descriptos se hallan varios ejemplares de graptolites, la mayoría en deficiente estado de preservación y valvas de pelecípodos mejor preservadas, que corresponden a Glossograptus cf. ciliatus Emmons, Graptoliithina indet. y Pelecypoda gen. et sp. indet. Respectivamente. De acuerdo con el material paleontológico coleccionado, se concluyó que las lutitas y metamorfitas de bajo grado de la Quebrada del Chuscho son del Ordovícico superior y que estos afloramientos son equivalentes a niveles lutíticos que afloran en la zona de Huaco (San Juan). Los mismos constituirían un miembro poco metamorfizado de los "Esquistos Cerro Cóndor" de la zona de Los Llantenes mencionados por Aceñolaza y Castaño (1968). Las rocas ordovícicas aparecen afectadas por dos intrusivos: uno granítico Silúrico - Devónico y el intrusivo del cerro Chuscho, que atribuyen al Carbonífero. Mas tarde Aceñolaza (1970) describió un pelecípodo, Ctenodonta bonetensis, y una fauna de graptolites en las márgenes del Río Bonete, que permitió asignarle una edad llanvirniana para los estratos calcáreo - pelíticos y llandeiliana para los exclusivamente pelíticos (Ordovícico Medio).

Para el área del río Bonete, Aceñolaza y Bernasconi (1969b) describen los intrusivos que afloran en la quebrada de Potrerillos y cerro Chuscho, asignándoles edades provisorias: respectivamente, silúrica con dudas para el granito y carbonífera inferior a media para el intrusivo del Chuscho. Proponen el nombre de Granito Potrerillos, con área tipo en la quebrada homónima, para el cuerpo intruido entre las lutitas fosilíferas ordovícicas y los esquistos precámbricos, dando sus características petrográficas generales. El granito solo había sido mencionado antes por Arigós (1965) al suroeste de la Hoja 14c, como un 'granito aplítico' sobre el río Potrerillos al que considera Precámbrico. Además describen la composición petrográfica preliminar del intrusivo del Chuscho como un pórfido basandesítico.

Durante un estudio geológico económico del Distrito Minero Los Llantenes que realiza Guerrero (1969) a los $68^{\circ} 38^{\prime} 45^{\prime}$ ' longitud oeste y $28^{\circ} 27^{\prime} 50^{\prime \prime}$ latitud sur, reconoce las unidades Caliza Las Damas y Esquistos Cerro Cóndor y las asigna al Llandeiliano por similitud con los esquistos menos metamorfizados del cerro Chuscho, en los que se habían hallado graptolites.

Toselli y Aceñolaza (1971) establecen características petrológicas y estructurales principales que rigieron el emplazamiento de la Andesita del Cerro Chuscho que los autores asignan al 
Carbonífero inferior y concluyen que habría una relación estrecha entre el emplazamiento del intrusivo y las mineralizaciones cupro - seleníferas con mercurio halladas en la zona. Consideran a estas rocas como una auto - brecha de flujo que conforma un domo sub-volcánico, en contacto neto con pizarras pero sin evidencias de metamorfismo de contacto.

En la descripción que hace Faroux (1971) del mosaico 31B del mapa geológico económico de la Provincia de La Rioja (Plan La Rioja) menciona que la Caliza Las Damas constituye bancos intercalados concordantemente dentro de los Esquistos Cerro Cóndor y presenta una laminación de los componentes minerales. La base de la Formación Río Bonete no se conoce y en su techo apoya, en discordancia angular, la Formación Rincón Blanco (Carbonífero, Maisonave 1971). Las filitas que afloran al norte del granitoide del cerro Las Tunas, de posible edad devónica según Caminos (1970), son asignadas al Ordovícico, con dudas. La estructura de la región conforma bloques separados por fallas meridianas regionales, y fallas menores de rumbo este - oeste. La Formación Río Bonete se superpone por falla inversa al Carbonífero y lo mismo ocurre con el Precámbrico sobre el Ordovícico. Incluye dentro de la Formación Potrerillos al granito de la quebrada homónima y al del cerro de Las Tunas, considerándolo post-Ordovícico y pre-Carbonífero. Indica que la Formación Espinal equivale a la Formación Umango de Arigos (1956)

Por su parte Aceñolaza et al. (1971) hacen una síntesis de la geología de la región y dejan constancia que el sistema orográfico al que llaman Precordillera de Jagüé puede ser considerado como el engranaje entre tres importantes regiones morfo - estructurales argentinas: Cordillera Frontal, porque posee importante magmatismo carbonífero; Precordillera, por las sedimentitas del Paleozoico Inferior y Medio; y Sierras Pampeanas, porque posee basamento precámbrico. Además presentan un cuadro estratigráfico (Cuadro 1) de la región en el cual la Formación Río Bonete está conformada por sedimentitas marinas y metamorfitas de bajo grado que afloran en la quebrada del río homónimo y regiones aledañas, e involucra a dos miembros: Miembro Calizas Las Damas, y el Miembro Esquistos Cerro Cóndor. En este último se encuentra la franja de niveles argilíticos poco metamorfizada portadora de la fauna fósil ordovícica (Glossograptus ciliatus Emmons, Glossograptus ciliatus Emmons cf. var. douglasi (Lapw), Glossograptus sp., cf. Glossograptus sp., Ctenodonta bonetensis Aceñolaza). Se destaca que las lutitas fosilíferas se disponen inmediatamente por sobre las Calizas Las Damas, tentativamente ordovícicas. En su esquema estratigráfico los intrusivos andesíticos conocidos como "Andesita Cerro Chuscho" comprenderían tres cuerpos principales de la región, a los que consideran co-magmáticos: Andesita Punta del Agua y Andesita Las Casitas, que intruyen al Carbonífero, y Andesita cerro Chuscho, que solo se presenta intruyendo al Ordovícico. Se presentan edades K/Ar en el cerro Chuscho de $327 \pm 18$ Ma y $368 \pm 19$ Ma. Por último, estos autores consideraban a las volcanitas de la Andesita Cerro Chuscho como parte de un cono subvolcánico heterogéneo y calcoalcalino.

Posteriormente, Caminos (1972) presentó un perfil geológico de $120 \mathrm{Km}$ de longitud aproximadamente, en el noroeste de la provincia de La Rioja, entre $\operatorname{los} 28^{\circ}$ y $28^{\circ} 30^{\prime}$ latitud S, desde la sierra del Toro Negro hasta el límite argentino - chileno, describiendo los principales rasgos 
estratigráficos y tectónicos de la región. El trabajo se completa con cuatro dataciones radimétricas preliminares K/Ar en biotita para cuerpos graníticos que los ubica en el Paleozoico Superior: $324 \pm 5,8$ Ma. (Carbónico inferior) para el Granito Cerro de las Tunas; 306,5 \pm 16,6 Ma (actualizada de 313 Ma; Carbónico sup.) para el stock del río Potrerillos; y $224 \pm 12$ Ma y $233 \pm 12$ Ma (límite Permo-Triásico) para los granitos y pórfidos graníticos del cerro Comecaballos. Se sugiere que a pesar que los datos de $\mathrm{K}-\mathrm{Ar}$ en roca total a veces pueden mostrar "rejuvenecimientos" por efecto de algunos procesos geológicos, las edades muestran una cierta coherencia.

En la síntesis que escribe Furque (1972) para el Ordovícico de la Precordillera, menciona que los esquistos del cerro Cóndor, Lutitas del Salto, Formaciones Yerba Loca, Río Blanco, Calingasta y Alcaparrosa en el cerro Hilario, y el conjunto metamórfico que se presenta en Uspallata (Grupo Puntilla de Uspallata), "constituyen los elementos de un solo ambiente de depositación, representando las sedimentitas de la cuenca mas profunda del Caradociano". Sin embargo, menciona que las lutitas que afloran en la quebrada de Los Azules (Precordillera de San Juan), presentan una fauna de graptolites que permiten asignarlas al Llandeiliano compuesta por graptolitos y trilobites (Porterfeldia jachalensis Harrington y Leanza). Esta es la única fauna similar a la hallada en las Lutitas del Salto descripta para el Ordovícico en este trabajo. Además se menciona que el único magmatismo asociado estaría representado por las rocas básicas y ultrabásicas de las capas inferiores de la Precordillera occidental, por lo cual "el pico del volcanismo estaría en el Caradociano".

Mas tarde, Maisonave (1979) realiza la descripción de la Hoja 14c Geológica - Económica, denominada Cerros Cuminchango, a escala 1:200.000, que abarca la porción oriental de los afloramientos estudiados. En la misma, se detallan las características de las tres provincias geológicas que allí convergen: Sistema del Famatina, Sierras Pampeanas y Precordillera, presentándose el esquema estratigráfico y la evaluación de las posibilidades mineras de la región. Reconoce la presencia de afloramientos de la Formación Río Bonete (Aceñolaza et al., 1971) de edad llandeiliana, diferenciándolas de las sedimentitas de la Formación Suri, también ordovícica por sus características litológicas y totalmente diferentes en su aspecto metamórfico y tectónico. Estima un espesor de 1.000 m para la Formación Río Bonete, que estaría constituida casi exclusivamente por pelitas con calizas intercaladas, y por filitas, cuarcitas y esquistos clorítico - sericíticos que testimonian un avanzado leptometamorfismo. El autor reconoce dos sectores de afloramientos, uno al poniente del Cerro Chuscho y otro al sur del Cerro Champas o Toro, en las nacientes de la Quebrada del río Potrerillos. Describe además la presencia de filonaciones e inyecciones cuarzosas que provienen de un intrusivo cercano, como así también pórfidos, aglomerados, brechas y coladas andesíticas pertenecientes a la Formación Cerro Chuscho, a la que asigna una edad pérmica inferior. Cabe destacar que en este trabajo se menciona la base de la Formación Río Bonete, en las cercanías del cerro de la Escarcha, donde el autor describe esquistos y calizas apoyando en discordancia sobre el basamento de la Formación Espinal.

Dentro del marco del Plan La Rioja, Cravero y Ríos Gómez (1981-1982) realizan un levantamiento geológico detallado a escala 1:20.000 sobre base fotográfica a $40 \mathrm{Km}$ al noroeste de 
Jagüé (en los alrededores de Los Llantenes), efectuando perfiles y tomando muestras para análisis mineralógicos. Luego Cravero et al. (1984) estudiaron el área comprendida entre $28^{\circ} 27^{\prime}-28^{\circ} 33^{\prime}$ latitud S y $68^{\circ} 40^{\prime}$ longitud $\mathrm{O}$, considerando que la integración de los conocimientos estratigráficos y tectónicos "demostraría la continuidad hacia el norte de la provincia de La Rioja de la Precordillera". Se propone la denominación de Formación Quebrada Seca a una sucesión grano-decreciente de sedimentos marinos, cubiertos parcialmente por lavas almohadilladas basálticas 'espilitizadas' y cortados por diques asociados, que hasta entonces se consideraban dentro de los Esquistos Cerro Cóndor. Estos quedan ahora integrados sólo por las metamorfitas de bajo grado, pasando los componentes sedimentarios (principalmente pelitas) a formar parte de la Formación Quebrada Seca propuesta. Estas rocas no están plegadas ni metamorfizadas y apoyan en discordancia sobre los esquistos. La estratigrafía considerada se resume en el Cuadro 1. La Formación Quebrada Seca podría ser equivalente a las Lutitas del Salto de Aceñolaza y Bernasconi (1969), y por analogía con la Formación Yerba Loca (Furque, 1979) y la graptofauna hallada en el área del Chuscho por Aceñolaza (1970) y Aceñolaza et al. (1971) se considera a las unidades ordovícicas del Llandeillano inferior a Caradociano inferior. La secuencia del Paleozoico inferior constituye el núcleo de un anticlinal cuyos flancos están constituidos por las sedimentitas continentales carboníferas. Por último, se diferencian tres etapas de mineralización primaria.

Zimmermann y Van Staden (2002) estudiaron los afloramientos ordovícicos ubicado en coordenadas $68^{\circ} 29^{\prime} 45,9^{\prime \prime}$ longitud $\mathrm{O}$ y $28^{\circ} 31^{\prime}$ latitud $\mathrm{S}$, en el área de la Boca del río Bonete. Una falla importante hace que el sector sudoeste del afloramiento cabalgue sobre el sector noreste. En el sector norte del mismo se describe una sucesión de areniscas miloníticas cubiertas por carbonatos con probables matas algales, slumps, estilolitas, y otras estructuras. El contacto entre las areniscas miloníticas y los carbonatos "podría ser tectónico, pero las capas son todas concordantes en este sector"; sin embargo se menciona que en la base de los carbonatos aparece una zona con deformación frágil. Estos son seguidos por limolitas y areniscas grano-decrecientes con litoclastos sedimentarios y metamórficos, carbonatos laminados con porosidad fenestral y posibles matas algales, y finalmente calizas amarillas con alto contenido en dolomita, que pasan lateralmente a areniscas y esquistos. En el sector sur del valle la secuencia también comienza con areniscas miloníticas seguidas por esquistos con lentes carbonáticas e intercalados con cenizas epiclásticas, cubiertos por rocas volcánicas. Por último, más al sur no aparecen rocas sedimentarias sino un afloramiento masivo de rocas plutónicas máficas. Se hallaron fósiles “con afinidades de Tentaculites" en depósitos volcaniclásticos resedimentados que se intercalan entre las vulcanitas y las sedimentitas. Los tentaculitidos podrían datar la sucesión dentro del Ordovícico medio para las rocas epiclásticas y asociadas, lo que estaría de acuerdo con la estratigrafía propuesta por Aceñolaza et al. (1971). Se propone un modelo de facies preliminar en el que luego de la depositación de arenitas y pelitas se intruyeron y extruyeron rocas (sub-)volcánicas en un ambiente submarino. Lateralmente es probable que se hayan depositado calizas. Las rocas volcánicas se habrían depositado en forma sin-sedimentaria o poco tiempo después de las rocas clásticas de grano fino. No fue posible determinar si fue un evento intrusivo o extrusivo. 
Luego de un fallamiento asociado a milonitización (evidenciado por las areniscas miloníticas) toda la sucesión fue metamorfizada, probablemente en forma sin-tectónica. Las litofacies son parcialmente comparables con los Miembros Las Damas y Cerro Cóndor definidos por Aceñolaza (1969). La parte superior de la sucesión puede identificarse como Formación Río Bonete (Llanvirniano); si la zona de falla se interpreta como anterior a ésta Formación las unidades inferiores (milonitas, pelitas y volcaniclásticas) asociadas con el magmatismo básico son de edad Ordovícico inferior. Es difícil la correlación de estas rocas con la Formación San Juan ya que en éstas se hallaron bentonitas potásicas como evidencias de actividad volcánica con edades Arenigiano - Llanvirniano. Zimmermann y Van Staden (2002) proponen mantener la denominación de la sucesión como Formación Río Bonete y expandir la litología de lo antes mencionado, y definir la parte inferior asociada a rocas volcánicas básicas como de edad Ordovícico inferior a media.

En cuanto a la mineralización que se describe en esta región, Angelelli (1984) hace una síntesis, en la que destaca que el noroeste de La Rioja cuenta con los dos únicos yacimientos seleníferos del país, en el área de Los Llantenes al oeste de Jagüé y el cerro Cacho, al oeste de la sierra de Umango. "Se trata de relleno de fracturas en rocas de distinta naturaleza, conformando vetas delgadas y vetillas que encierran diversos seleniuros, explotados en el pasado por su contenido en cobre y plata, e incluso por mercurio hace algunos años". La mineralización selenífera se vincularía al Carbonífero, y se aloja en pequeñas fallas de poco rechazo de rumbo noreste - sudoeste a este - oeste principalmente, oblicuas o transversales a la estructura tectónica regional (norte - sur a noroeste sudeste). Ha sido depositada en dos etapas, una primera de sulfuros de temperatura media, y una segunda de carácter epitermal a la que se vinculan los seleniuros en ganga de calcita. La roca de caja son anfibolitas, calizas cristalinas, y esquistos alterados e invadidos por venillas y masas de calcita con seleniuros. Describen la estratigrafía siguiendo a Guerrero $(1968$ - 1969; 1969) para ambos sectores (ver Cuadro 1). En el área del cerro Cacho se describen para el Precámbrico rocas muy similares a las descriptas en el área de la Precordillera de Jagüé (calizas y esquistos de la Formación Río Bonete), dentro de la Formación Cerro Cacho. En el mapeo del área de Los Llantenes los esquistos verdes y las rocas asignadas a la Formación Quebrada Seca por Cravero et al. (1984) se mapean todos juntos dentro de los Esquistos Cerro Cóndor.

Las lavas almohadilladas del Cerro Chuscho han sido consideradas como parte de una "ofiolita" en el margen Occidental de la Precordillera por Kay et al. (1984), quienes analizaron muestras de vulcanitas ordovícicas con el fin de compararlas geoquímicamente y definir su ambiente tectónico. Son basaltos evolucionados (E-MORB), que pueden ser compatibles con basaltos de cuenca de retroarco, y por otro lado se considera que son semejantes a los segmentos de dorsal oceánica de tipo transicional y pluma. Hacen un análisis de los distintos ambientes tectónicos posibles basándose en consideraciones geoquímicas y de campo, y finalmente proponen un modelo posible de 'rift oceánico próximo a un margen continental en estado de desarrollo incipiente'; sin embargo desde el punto de vista geoquímico no excluyen que pueda tratarse de un 'ambiente de retroarco o dorsal 
oceánica en un estado avanzado o de tipo islándico'. Las rocas intrusivas y extrusivas no pueden interpretarse claramente dentro de un ambiente tectónico (Coira et al., 1982; Zimmermann et al. 1999; Bock et al., 2000; Coira et al., 2002). Sin embargo, varias rocas extrusivas de edad Arenigiano aflorantes en la Puna (Huaytiquina, Aguada de la Perdiz, quebrada Diablo) muestran relaciones geoquímicas e isotópicas (Sr-Nd-Pb) vinculadas a un arco volcánico continental (Hanning, 1986; Breitkreuz et al., 1989; Bock et al., 2000; Zimmermann \& Bahlburg, 2003) como las vulcanitas de la Sierra Famatina de edad Arenigiano hasta Llanvirniano (Acenolaza et al., 1996).

Toselli y Durand (1996) consideran los cuerpos que afloran en el cerro Chuscho y en el cerro Las Casitas, con notable autobrechamiento, dentro del volcanismo del ciclo magmático precordillerano. Estos cuerpos afectan al Ciclo Famatiniano, entre la Cordillera Frontal y las Sierras Pampeanas Occidentales, y son vinculados con eventos magmáticos similares en el área de Famatina, especialmente en el Cerro Negro de Rodríguez y Chaschuil. Por su posición estratigráfica es ubicado dentro del Carbónico inferior a medio, asociándolo con el magmatismo Meso-Varícico de la Cordillera Frontal.

Por su parte, Villar (2003) presenta datos geoquímicos de las lavas almohadilladas de cerro Chuscho y compara las características de estos afloramientos con otros de Precordillera Occidental: Rodeo, Calingasta, Uspallata, Los Gateados, concluyendo que se integra a la ofiolita de la Precordillera Occidental (Kay et al., 1984), llevando mas al norte el límite septentrional del terreno Cuyania.

El trabajo de Fauqué y Villar (2003) sintetizan las características de las lavas almohadilladas de la Formación Chuscho. En base a cortes petrográficos, análisis geoquímicos y geocronológicos los autores redefinen la Formación Chuscho como un complejo de volcanitas máficas intra-ordovícicas representado por diques y filones de diabasa que cortan a basaltos espilitizados almohadillados asociadas a sedimentitas ordovícicas que se hallan en la base, por lo que formarían parte de la Faja Ofiolítica Famatiniana de la Precordillera Occidental (según Ramos et al. 2000; Villar 2003; Haller y Ramos, 1984). Consideran que los nombres originales de Andesita Cerro Chuscho (Aceñolaza et al., 1971) y Andesita Punta del Agua (Aceñolaza, 1971) agrupan a rocas pertenecientes a distintos ciclos magmáticos, por lo que consideran mas apropiado utilizar las denominaciones de Formación Chuscho (siguiendo a Toselli y Durand, 1996) y Formación Punta del Agua (de González y Bossi, 1986). Presentan dataciones U/Pb (ID-TIMS) en circones primarios que dieron una edad ordovícica de 454 Ma que confirmarían la extensión hacia el norte de las ofiolitas ordovícicas (Haller y Ramos, 1984), mientras que xenocristales dieron edades grenvillianas de $1036 \mathrm{Ma}$. Así, los basaltos almohadillados de la Formación Chuscho se asocian a la apertura de un rift oceánico cambro-ordovícico de cuenca marginal durante la acreción de Chilenia (Kay et al, 1984; Ramos et al., 1984; Villar, 1998; Villar y Escayola, 1999), mientras que la Formación Punta del Agua son principalmente andesitas con características orogénicas asociadas a un arco volcánico Carbonífero superior - Pérmico inferior, que corresponden a un complejo volcánico-sedimentario emplazado en un ambiente continental. A lo largo del rift cambro-ordovícico las características tectono-magmáticas varían: de N-MORB en la Cordillera 
Frontal a E-MORB (P-MORB) en la Precordillera de San Juan y La Rioja, probablemente debido al cambio de elevación del rift respecto del manto (Wilson 1991). Geoquímicamente, las pillows de cerro Chuscho coinciden con los de Precordillera de San Juan y Mendoza y con los basaltos de Los Gateados en Cordillera Frontal (Villar, 1998). El Ordovícico consta entonces de dos unidades: las metasedimentitas de la Formación Río Bonete con sus dos miembros, y la Formación Chuscho conformada por ofiolitas asociadas a las metasedimentitas.

En la hoja geológica "Tinogasta", a escala 1:250.000, Fauqué y Caminos (2004, preliminar) mapean la región y distinguen dentro de las unidades ordovícicas vulcanitas y metamorfitas de bajo grado. Además se presenta un mapa tectónico y una columna estratigráfica del área en la que las vulcanitas y piroclastitas de la Formación Las Planchadas se consideran dentro del sistema precordillerano y no en el de Famatina. Las volcanitas del cerro Chuscho son mapeadas dentro del Ordovícico, siguiendo los resultados obtenidos previamente por Fauqué y Villar (2003).

Martina et al. (2005) presenta una edad U/Pb de $1.118 \pm 17$ Ma para un granito milonitizado incluido dentro de la faja de deformación de Jagüé, que entonces serían parte del basamento meso proterozoico.

Por su parte, Varela et al. (2011) hacen referencia a la región de Jagüé y se refieren al Complejo Metamórfico Río Bonete siguiendo a Martina y Astini (2009) y le asignan edad mesoproterozoica. En forma separada se ocupan de la Formación Espinal de la sierra de Toro Negro que consiste en gneises, migmatitas, mármoles y anfibolitas. Las edades U-Pb (TIMS) en titanita sería de $454 \pm 3$ Ma y $432 \pm 2$ Ma, correspondientes a la deformación principal y metamorfismo regional.

Estructura.

Considerada como unidad estructural, en el contexto regional la Precordillera se acuña en su extremo norte a medida que se extiende en forma oblicua al Frente de Facturación de Valle Fértil (Baldis et al., 1979). Baldis et al. (1981) concluyen que este acuñamiento estaría relacionado a la presencia de antiguas líneas tectónicas, (en particular el sistema de fallas de Valle Fértil), que ha controlado la evolución sedimentaria y estructural del área.

Como ya se mencionó, Martino y Astini (1998) consideran que la zona del río Bonete forma parte de una faja de deformación subvertical a la que denominan "Faja de deformación de Jagüé", de rumbo aproximado $\mathrm{N} 300^{\circ}$ con una foliación bien desarrollada, cuya continuidad es obliterada por grandes cabalgamientos con vergencia al este. Esta faja sería el resultado de una deformación por cizalla simple con movimiento sinestral y posee similitudes litológicas notables con la faja de Angaco - Cerro Salinas pero con desplazamiento opuesto (dextral). Integradas regionalmente se trataría de una faja de deformación única que representa un cabalgamiento regional del basamento sobre su cobertura, que se transforma a lo largo del rumbo en una transcurrencia sinestral, que hace de límite norte al 
Terreno de Precordillera, prolongándose hacia el noroeste, posiblemente en el lineamiento de Valle Ancho, Chile (Mpodozis et al,. 1997).

Mas recientemente Chernicoff y Vujovich (2004) realizaron un estudio geofísico en el sector sudoeste de La Rioja y norte de San Juan entre los $28^{\circ} 30^{\prime}$ y $30^{\circ} 00^{\prime}$ latitud sur y los $69^{\circ} 15^{\prime}$ y $67^{\circ} 15^{\prime}$ longitud oeste, donde el basamento metamórfico proterozoico está expuesto en los bloques sub-meridionales de Sierras Pampeanas Occidentales elevados durante el Cenozoico (sierras de Umango, Maz, Espinal y Las Ramaditas). Sin embargo los estudios revelaron la existencia de estructuras más antiguas (¿1000-1.200 Ma?) de rumbo oeste-noroeste que atraviesan las norte-sur y que representarían zonas de sutura al norte de Cuyania (Ramos et al., 1998), que habrían sido reactivadas luego del Paleozoico inferior. Distinguen en el área tres lineamientos principales de rumbo oeste-noroeste que la dividen en cuatro bloques: Lineamiento Guandacol, Lineamiento Vinchina y Lineamiento Valle Fértil (ver Fig. 2). La zona de Jagüé estaría dentro del bloque que se halla al norte del lineamiento Guandacol y aunque no se mapeó específicamente es probable que se vea afectado también por el Lineamiento de Valle Fértil.

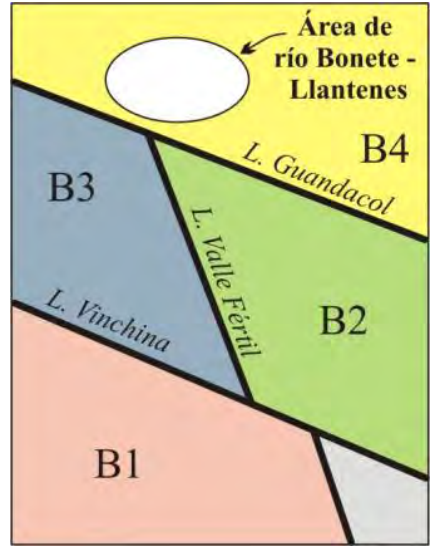

Figura 2: lineamientos definidos por Chernicoff y Vujovich (2004) en base a estudios geofísicos del basamento, y ubicación del área de estudio.

Recientemente Martina y Astini (2009) presentan una nueva síntesis de la geología de la región del río Bonete, en la que se expone un mapa y un perfil geológico. Se destaca una nueva interpretación de la estratigrafía, en la que se propone el reemplazo de Caliza Las Damas por el de Mármol Las Damas y de Formación Río Bonete por Complejo Metamórfico Río Bonete que incluye las unidades metamorfizadas e intensamente deformadas de la faja de deformación de Jagüé. Las lentes de mármol son considerados de edad Cámbrico medio a superior. Se hace un análisis estructural de la faja de deformación de Jagüé, a la que asocian a la orogenia Oclóyica, vinculándola con el emplazamiento del terreno Precordillera contra el margen occidental de Gondwana. La Formación Chuscho pasa a estar constituida por las lavas almohadilladas (Fm Chuscho de Fauqué y Villar, 2003) y por las metasedimentitas de bajo grado ('Lutitas del Salto' de Aceñolaza y Bernasconi, 1969a). Esta asociación estaría indicando el desarrollo de un depocentro marino profundo con profuso volcanismo basáltico vinculado a extensión en el terreno Precordillera durante el Ordovícico superior. "La asociación de rocas silicoclásticas marinas profundas con volcanismo básico, afectadas por metamorfismo de bajo grado y desarrollo de bandas kink es una característica común en toda la 
Cuadro 1: Síntesis comparativa de los antecedentes estratigráficos de la zona de Precordillera de Jagüé y alrededores, en la que se presentan las distintas interpretaciones que se hicieron para esta región por parte de diferentes autores.

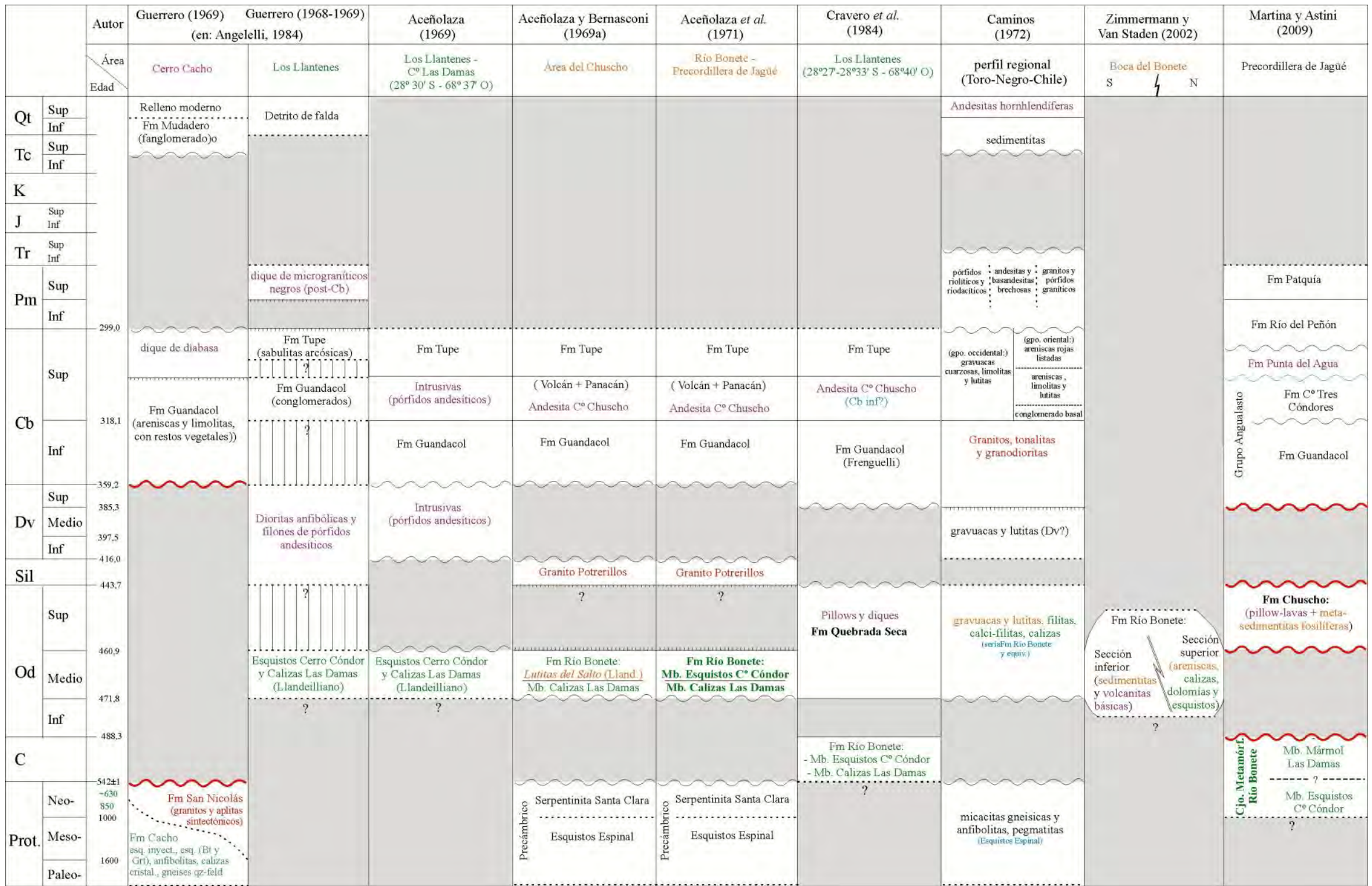


Precordillera Occidental y se vincula con un episodio de deformación devónico" (acreción de Chilenia). Por otro lado, consideran que la Formación Quebrada Seca (Cravero et al 1984) es parte de lo que Aceñolaza (1969) definió como Formación Guandacol en Los Llantenes. Entonces, dentro del Paleozoico superior reúnen a las formaciones Guandacol y Cerro Tres Cóndores dentro del Grupo Angualasto definido más al sur en Precordillera, y por encima a las formaciones Punta del Agua, Río del Peñón y Patquía. Indican la presencia de conglomerados dentro de la Formación Chuscho, con clastos calcáreos y de esquistos que los llevan a interpretar que 'con posterioridad al pico de deformación se habría producido la exhumación de la faja de deformación, que actuó como área fuente de los conglomerados incluidos en la Formación Chuscho'. Por último mencionan la posibilidad de que las sucesiones ordovícicas se vinculen con la separación de un fragmento cortical para-autóctono separado de la Precordillera y acrecionado más tarde como Chilenia? (Astini et al., 2000). La deformación asociada a la faja de deformación de Jagüé se considera oclóyica tentativamente y sería la responsable de la deformación del Complejo Metamórfico Río Bonete.

En resúmenes previos se describen nuevos aportes de material fosilífero sobre las quebradas del Chuscho y del Salto (Frigerio et al., 2005), se han presentado las características de los afloramientos del granito Potrerillos y de las metasedimentitas que afloran al norte de este cuerpo, y se aportan los primeros datos de edad U-Pb en circones para ambas unidades (Frigerio 2008a, b; Frigerio et al. 2009, 2010) y se discute sinteticamente la problemática estratigrafica (Frigerio, 2011). El granito es considerado como un cuerpo postorogénico respecto a la orogenia Famatiniana, asociado a estadios póstumos de la subducción durante el emplazamiento de la Precordillera, y no dentro del magmatismo gondwánico. Por otro lado, dado que no se han hallado fósiles en las metasedimentitas estratificadas aflorantes al norte del Granito Potrerillos, estas edades suman otro argumento, más allá de las características de campo observadas, para considerar la equivalencia con las metasedimentitas fosilíferas del área de la quebrada del Chuscho. 


\section{Capítulo 2: METODOLOGÍAS}

\section{1- Introducción.}

Teniendo en cuenta la variedad de unidades litoestratigráficas que se presentan en el área, las metodologías empleadas para la toma y estudio de muestras estuvieron relacionadas al tipo de roca y al objetivo con el que se las recogió. Lo primero que se hizo fue examinar la información antecedente e interpretación de imágenes de la zona (fotografías aéreas, imágenes satelitales, etc.) para planificar el trabajo de campo, teniendo en cuenta la geografía, disponibilidad de agua y otros recursos, estado de accesos y caminos, clima, etc.

Las metodologías de campo fueron especialmente referidas al relevamiento (mapeo) de lo que originalmente fue definido como Formación Río Bonete y de las distintas unidades con las que se asocian sus afloramientos, para aclarar la relación que guardan unas con otras, espacial- y temporalmente, y precisar la estratigrafía del área. Así, aparte de los mármoles y esquistos miloníticos que originalmente caracterizan a la Formación Río Bonete en su área tipo, se realizaron observaciones y recogieron muestras de las metasedimentitas que afloran en el área de las quebradas del Chuscho, del Salto y de Potrerillos, así como de las rocas básicas asociadas (basaltos, andesitas, lavas almohadilladas y diques), del Granito Potrerillos, y del basamento metamórfico que se encuentra en contacto tectónico hacia el este (Formación Espinal). Se levantaron perfiles esquemáticos, se mapearon las estructuras principales que las afectan, y se colectaron distintos tipos de muestras para varios objetivos:

- Análisis de la petrografía: muestras de mano de las distintas litologías (mármoles, esquistos, sedimentitas, granitoides y rocas básicas). Muestras orientadas con fines estructurales y microestructurales, y de areniscas para análisis de procedencia por conteo de puntos.

- Análisis geoquímicos e isotópicos: muestras pequeñas de las variedades litológicas, sin alteración, con especial atención en muestras de pelitas, areniscas y rocas ígneas.

- Búsqueda de minerales pesados: muestras de entre 5 y $10 \mathrm{Kg}$, de vaques y areniscas, esquistos, granitoides y rocas básicas, con fines geocronológicos, isotópicos, de procedencia etc.

A continuación se describen las técnicas de gabinete y laboratorio empleadas para cumplir con los diversos estudios. 


\section{2- Metodologías empleadas}

\subsection{1- Mapeo}

El mapeo de campo se realizó principalmente contando con imágenes satelitales y equipo GPS, para ubicar con precisión los afloramientos, contactos, estructuras importantes, planimetría, etc., y brújula tipo Brunton para la orientación en el espacio de estructuras presentes (fallas, foliaciones, ejes de pliegues, estratificación, contactos, etc.). Teniendo en cuenta toda la información disponible (observaciones de campo, datos de petrografía, geoquímica y antecedentes) se realizaron perfiles y mapas geológicos regionales y de detalle en los que se sintetizan las interpretaciones de la zona estudiada. Los mismos se presentan en los Anexos A1. El mapeo y ubicación de muestras por coordenadas se realizó usando el programa Arc-Gis y luego se dibujaron y completaron los mapas en Corel-Draw. Se usaron de base dos imágenes regionales de la zona, una raster y una tiff que al ser recortes poseen baja resolución; por ello ciertos detalles y ubicación precisa de algunas muestras fueron completados sobre la base de lo observado en imágenes más detalladas tomadas del programa Google Earth.

\subsection{2- Métodos petrográficos.}

Los objetivos fundamentales fueron los de clasificar las muestras, caracterizar su textura, microestructura y composición mineralógica. Luego determinar las composiciones modales de las psamitas y granitoides en los casos que la deformación y/o alteración de las mismas lo permita, para analizar la procedencia de las areniscas y clasificación de los granitoides. También se hicieron cortes orientados de muestras características para análisis de la deformación.

Para los estudios petrográficos convencionales se realizaron cortes delgados de 148 muestras de las distintas unidades (42 esquistos, 11 mármoles, 40 rocas sedimentarias, 14 granitoides, 34 rocas básicas, 7 del basamento; Anexos A4). Los mismos se realizaron en el laboratorio de cortes delgados del Centro de Investigaciones Geológicas (CIG) con una sierra circular Conrad D3392 ClausthalZellerfeld y una devastadora Petro-Thin. Para realizar cortes pulidos se utilizó una pasta diamantada de $0,25 \mu \mathrm{m}$ tipo P” para lubricación con $\mathrm{HC}$, y alúmina levigada de $0,3 \mu \mathrm{m}$.

El estudio microscópico de los cortes delgados se llevó a cabo en el Laboratorio de Petrografía del CIG, con un equipo de luz polarizada Zeiss Wetzlar y otro Nikon Eclipse E200 para mayor detalle, mientras que los conteos modales se llevaron a cabo con un contador de puntos Swift, mod. F, adosado a un microscopio Leitz Laborlux 12 Pol. Se tomaron micro-fotografías de algunos cortes con una cámara digital adosada al microscopio, para mostrar las características petrográficas y microestructurales descriptas.

Se realizó también una tinción con alizarina (A4: Tabla 4) en los cortes de las muestras carbonáticas para identificar calcita magnesiana (rosada) de calcita con alto contenido de hierro 
(azules) y dolomita (no se tiñe, igual que las fracciones silicoclásticas). Previamente a la realización de los conteos modales las muestras QP-G2 y QP-G6 fueron teñidas con cobaltinitrito de sodio (A4: Tabla 5), para identificación de los feldespatos, esencialmente plagioclasas (no se tiñen) de feldespato potásico (amarillo), de acuerdo a los procedimientos sugeridos por Hutchinson, (1973, Cap. 2).

La composición modal de las psamitas de grano medio con $<15 \%$ de matriz fue cuantificada en cortes delgados usando el método de conteo de puntos de Gazzi-Dickinson (Ingersoll et al., 1984; ver también Hutchinson, 1973, Cap. 3. A4: Tabla 6), contabilizando 300 a 400 puntos. Con el objetivo de evaluar la procedencia de las sedimentitas, los resultados fueron luego presentados en diagramas ternarios de discriminación tectónica Q-F-L, Qm-F-Lt, (Dickinson y Suczeck, 1979; Dickinson et al., 1983; Ingersoll et al., 1984). Los fragmentos líticos fueron contabilizados como líticos sedimentarios (Ls), metamórficos (Lm), volcánicos (Lv) y plutónicos (Lp, Zuffa, 1985), que contribuyen a las inferencias sobre las áreas de procedencia.

Para la clasificación modal de las rocas plutónicas se usó el diagrama QAPF, siguiendo la metodología aceptada por la IUGS descripta en Le Maitre (1989, 2002), contando 1000 puntos (A4: Tabla 7). Para las rocas volcánicas básicas la IUGS recomienda utilizar la clasificación geoquímica TAS.

El estudio de los restos fósiles hallados en las metasedimentitas, la identificación de minerales, caracteres texturales y estructurales de algunas muestras de mano y la separación manual de pesados se llevó a cabo bajo lupa binocular (Zeiss Stemi 2000-C y Nikon Type 102) en el CIG.

Asimismo, se realizaron análisis de difracción de rayos $\mathrm{X}$ (DRX) de 13 muestras sedimentarias con los objetivos de: a) identificar los minerales de grano fino, como los que conforman la matriz y/o el cemento de las sedimentitas, b) cuantificar la proporción relativa de los filosilicatos (Ill/Ms, Chl, caol) e interestratificados (I/S, C/S), c) determinar el grado de diagénesis o metamorfismo de bajo grado al que fueron sometidos las sedimentitas mediante el cálculo del índice de Kübler de cristalinidad de la Illita (IK; Kübler, 1968; Warr \& Rice, 1994), y d) comparación y mapeo de grados diagenéticos y anquimetamórficos presentes por los índices de cristalinidad. Para los análisis se utilizaron muestras en polvo molidas a mano en mortero de cerámica. Se usó un difractómetro Philips del Centro de Investigaciones Geológicas (CIG) con tubo de cobre operando a $18 \mathrm{~mA}, 36 \mathrm{kV}$, y con $\lambda=1,5414$. Se midió en forma continua en un rango de $3^{\circ}$ a $37^{\circ} \Delta 2 \theta$ para roca total (naturales), de $2^{\circ}$ a $27^{\circ} \Delta 2 \theta$ para muestras glicoladas y $3^{\circ}$ a $15^{\circ} \Delta 2 \theta$ para muestras calcinadas. Además se hicieron análisis de DRX en 7 esquistos verdes y 8 rocas ígneas básicas para analizar los filosilicatos presentes, especialmente los originados por alteración y diagénesis/metamorfismo. Los porcentajes relativos de los filosilicatos fueron determinadas en forma semicuantitativa basándose en la relación de las áreas de los picos correspondientes (A5: Tabla 1).

El índice de cristalinidad de la illita (Kübler, 1967, 1968, 1984; Kübler y Jaboyedoff, 2000, descripción en Warr \& Rice, 1994) permite cuantificar el grado de diagénesis o metamorfismo de bajo grado, se basa en el hecho de que el aumento de la cristalinidad de la illita se manifiesta en el difractograma de rayos X como un progresivo adelgazamiento del pico de $10 \AA$ [001] (Kübler, 1984), 
medido a la mitad de la altura del pico, en $\Delta^{\circ} 2 \theta$ para cátodo de $\mathrm{Cu} \mathrm{K} \alpha$. Sobre la base de la técnica de la cristalinidad de la illita se reconocen 3 zonas: diagénesis, anquizona y epizona (Weaver, 1960; Kübler, 1967; Kisch, 1991). De acuerdo a Kübler (1967) se distinguen:

- Zona de diagénesis IK $>3,0$

- Anquizona (metamorfismo de muy bajo grado): IK entre 3,0 y 1,5

- Epizona (metamorfismo de bajo grado, FEV) IK $<1,5$

Luego Kübler (1984) define límites ligeramente distintos, considerando valores de IK > 0,42 $2 \theta$ para la diagénesis, entre 0,42 y $0,252 \theta$ para el anquimetamorfismo (metamorfismo incipiente) y $<$ $0,252 \theta$ para el metamorfismo propiamente dicho.

Los minerales de difícil identificación al microscopio petrográfico y especialmente la identificación y caracterización de minerales pesados, se realizó a través de las imágenes tomadas con SEM, y análisis composicionales semicuantitativos con ayuda de un EDAX acoplado al SEM (ej.: Ttn, $\mathrm{Zr}$, Ap, Op, feldespatos, etc.). Los principales objetivos fueron la identificación de minerales, caracterización de los minerales pesados y análisis texturales de circones, registro de recristalizaciones, crecimientos secundarios y la composición de los feldespatos. Se trabajó sobre muestras de grano suelto con el SEM del Museo de Ciencias Naturales de La Plata, con SEM-EDS en el laboratorio SPECTRAU de la Universidad de Johannesburgh (Sudáfrica) y con SEM - EDAX en el Centro de Investigación y Desarrollo en Ciencias Aplicadas (CINDECA, La Plata). Los cristales separados se montaron en bases específicas, se cubrieron con películas conductoras de oro o carbono, y luego fueron analizados y caracterizados en términos de su forma, tamaño, inclusiones y otras características. En el SPECTRAU además se identificaron y caracterizaron minerales sobre cortes delgados, que fueron previamente pulidos y luego cubiertos con una película de carbono (BIORAD). Algunos minerales fueron identificados con microsonda electrónica (SPECTRAU), especialmente con el objetivo de cuantificar el grado de albitización de los feldespatos de las sedimentitas e identificación de mafitos de las rocas básicas y granitoides. Para la identificación de minerales pesados con EDAX, una vez separadas las distintas variedades de interés bajo lupa binocular, se montaron los minerales pesados no magnéticos de las muestras (BO27, LS1-9, QP-E9, y E-BO5) y todos los pesados (magneticos + no magnéticos) de la muestra QP-E20. Las fracciones de QP-E20 y LS1-9 fueron separadas con ioduro de metileno en Brasil). Una vez identificadas se ha podido comparar con granos con las mismas características encontradas en muestras similares.

\subsection{3- Búsqueda de material fosilífero}

a- en las rocas pelíticas:

En una de las campañas se ha encontrado material fósil en pelitas que afloran en las quebradas del Chuscho y del Salto y sobre la quebrada Seca. Se limpió el material hallado, y 
luego se revisó con lupa binocular con cámara clara, describiéndose todo lo que fue posible según el estado de preservación.

b- en las rocas calcáreas:

Para la búsqueda de microfósiles y análisis del residuo insoluble de las muestras calcáreas se seleccionaron las más oscuras (con mayor contenido de materia orgánica) y menos silicificadas y afectadas por la deformación. El proceso se llevó a cabo en el Instituto de Investigaciones Mineras de la Universidad Nacional de San Juan, con la guía y colaboración de la Dra. Susana Heredia (Universidad Nacional de San Juan). Por las características de las muestras se puso especial atención en la búsqueda de conodontes, más resistentes a la temperatura y deformación. Se disolvieron entre 300 y $500 \mathrm{~g}$ de muestra en solución al 10\% de ácido débil (un primer grupo de muestras fue disuelto en ácido clorhídrico y en una segunda etapa se trabajó con ácido fórmico. Se dejaron en recipientes durante un día y esto fue suficiente para disolver el material calcáreo y obtener un residuo insoluble. Como el residuo fue escaso no hubo necesidad de separar el material con bromoformo. Se lavó este residuo 5 veces dejándose secar bien, y luego se procedió a observar y separar el material por hand picking bajo lupa binocular.

\subsection{4- Métodos Geoquímicos e Isotópicos.}

La composición geoquímica de las rocas permite clasificarlas y caracterizarlas, así como contribuir a los estudios de procedencia de los distintos grupos litológicos. Es posible definir ciertas características de los ambientes tectónicos en los que se formaron los detritos que originaron las rocas sedimentarias y en los que se generaron los magmas. Para ello deben previamente analizarse los resultados en cuanto a la posible influencia que tuvieron factores tales como meteorización, diagénesis y metamorfismo.

Los análisis geoquímicos de roca total fueron realizados por fluorescencia de rayos X (FRX) en la Universidad de Johannesburgo, Sudáfrica, y mediante ICP-ES y ICP-MS en ACME Laboratories de Vancouver, Canadá (Anexos A6a). Los análisis isotópicos de $\mathrm{Sm}-\mathrm{Nd}, \mathrm{Pb}-\mathrm{Pb}$ y $\mathrm{Rb}-\mathrm{Sr}$ en roca total, y las dataciones U-Pb sobre circones por LA-ICP-MS y TIMS se realizaron en Brasil, en el Laboratorio de Geología Isotópica de la Universidade Federal do Rio Grande do Sul, Porto Alegre (LGI-UFRGS) y en el Centro de Pesquisas Geocronológicas de la Universidade de São Paulo, respectivamente. (Anexos A6b).

Los sistemas isotópicos más utilizados como geocronómetros se resumen en la Tabla 2.1. 
Tabla 2.1: Sistemas isotópicos. En negrita se resaltan los isótopos con los que se ha trabajado en ésta Tesis.

\begin{tabular}{|c|c|c|c|c|c|}
\hline $\begin{array}{l}\text { Isótopos } \\
\text { padres o } \\
\text { radioactivos }\end{array}$ & $\begin{array}{c}\text { Tipo de } \\
\text { decaimiento }\end{array}$ & $\lambda\left(\right.$ años $\left.^{-1}\right)$ & $\mathrm{t}^{1 / 2}$ (años) & $\begin{array}{l}\text { Isótopos } \\
\text { radigénicos }\end{array}$ & Relación \\
\hline${ }^{40} \mathrm{~K}$ & $\beta^{+} ; \beta^{-}$ & $5,54 \cdot 10^{-10}$ & $1,28.10^{9}$ & ${ }^{40} \mathrm{Ar} ;{ }^{40} \mathrm{Ca}$ & ${ }^{40} \mathrm{Ar} /{ }^{36} \mathrm{Ar}$ \\
\hline${ }^{87} \mathbf{R b}$ & $\beta^{-}$ & $1,42.10^{-11}$ & $4,8.10^{10}$ & ${ }^{87} \mathrm{Sr}$ & ${ }^{87} \mathrm{Sr} /{ }^{86} \mathrm{Sr}$ \\
\hline${ }^{138} \mathrm{La}$ & $\beta$ & $2,67 \cdot 10^{-12}$ & $2,59.10^{11}$ & ${ }^{138} \mathrm{Ce}$ & ${ }^{138} \mathrm{Ce} /{ }^{142} \mathrm{Ce} ;{ }^{138} \mathrm{Ce} /{ }^{136} \mathrm{Ce}$ \\
\hline${ }^{147} \mathrm{Sm}$ & $\alpha$ & $6,54.10^{-12}$ & $1,06.10^{11}$ & ${ }^{143} \mathrm{Nd}$ & ${ }^{143} \mathrm{Nd} /{ }^{144} \mathrm{Nd}$ \\
\hline${ }^{176} \mathrm{Lu}$ & $\beta^{-}$ & $1,94 \cdot 10^{-11}$ & $3,6.10^{10}$ & ${ }^{176} \mathrm{Hf}$ & ${ }^{176} \mathrm{Hf} /{ }^{177} \mathrm{Hf}$ \\
\hline${ }^{187} \mathrm{Re}$ & $\beta$ & $1,64 \cdot 10^{-11}$ & $4,23.10^{10}$ & ${ }^{187} \mathrm{Os}$ & ${ }^{187} \mathrm{Os} / /{ }^{186} \mathrm{Os} ;{ }^{187} \mathrm{Os} /{ }^{188} \mathrm{Os}$ \\
\hline${ }^{232} \mathrm{Th}$ & $\alpha$ & $4,948.10^{-11}$ & $1,4.10^{10}$ & ${ }^{208} \mathrm{~Pb} ;{ }^{4} \mathrm{He}$ & ${ }^{208} \mathrm{~Pb} /{ }^{204} \mathrm{~Pb} ;{ }^{3} \mathrm{He} /{ }^{4} \mathrm{He}$ \\
\hline${ }^{235} \mathbf{U}$ & $\alpha$ & $9,849.10^{-10}$ & $7,07.10^{8}$ & ${ }^{207} \mathrm{~Pb} ;{ }^{4} \mathrm{He}$ & ${ }^{207} \mathrm{~Pb} /{ }^{204} \mathrm{~Pb} ;{ }^{3} \mathrm{He} /{ }^{4} \mathrm{He}$ \\
\hline${ }^{238} \mathbf{U}$ & $\alpha$ & $1,551.10^{-10}$ & $4,47.10^{9}$ & ${ }^{206} \mathrm{~Pb} ;{ }^{4} \mathrm{He}$ & ${ }^{206} \mathrm{~Pb} /{ }^{204} \mathrm{~Pb} ;{ }^{3} \mathrm{He} /{ }^{4} \mathrm{He}$ \\
\hline
\end{tabular}

\section{Características de los métodos analíticos empleados.}

\section{a- Para análisis geoquímicos:}

XRF Fluorescencia de rayos X: Es un método simple y rápido. Permite determinar elementos mayoritarios y algunos minoritarios y traza, en muestras frescas y homogéneas previamente pulverizadas. El límite de detección para elementos mayoritarios está relacionado al número atómico (varía entre 1 y $10 \mu \mathrm{g}$ ); precisión $\pm 0,5(1 \sigma)$. Error del método $=0,5$ a 2\% Para calibrar el equipo según cada tipo de roca se utilizan estándares certificados internacionalmente. En este caso se usaron al menos 8 patrones de la Geological Society of America y Geological Survey of Japan, Geological Society of France y Geological Society of South Africa midiéndose dos veces cada muestra.

ICP $\boldsymbol{o}$ ICP-ES Espectrómetro de emisión atómica con plasma inductivamente acoplado: es un instrumento capaz de determinar las concentraciones de 40 a más de 70 elementos simultáneamente, mediante la medición de la intensidad de la luz emitidos por muestras aspiradas en un plasma de gas de argón calentado a mas de $10.000^{\circ} \mathrm{K}\left(9.727^{\circ} \mathrm{C}\right)$. Tiene muy bajos límites de detección (ppm o ppb).

ICP-MS Espectrómetro de masas con plasma inductivamente acoplado: permite determinar las concentraciones de más de 70 elementos simultáneamente midiendo la masa de los iones generados por un plasma de gas de argón calentado a más de $10.000{ }^{\circ} \mathrm{K}\left(9.727^{\circ} \mathrm{C}\right)$, y pasándolos por un cuadrupolo magnético hacia un detector. Tiene límites de detección ultra-bajos (ppb a ppt).

\section{b- Para análisis isotópicos y geocronológicos:}

Isotopía de rubidio y estroncio: el método ${ }^{87} \mathrm{Rb}^{87} \mathrm{Sr}$ se aplica al fechado de minerales y roca total (polvo) mediante la construcción de rectas isocronas. Se basa en el decaimiento $\beta-{ }^{87} \mathrm{Rb} \rightarrow{ }^{87} \mathrm{Sr}$ $\left(\mathrm{t}_{1 / 2}=48,8 \times 10^{9}\right.$ años) y su rango de aplicación es de $10 \mathrm{Ma}$ hasta 4,6 Ga. El Rb es un elemento alcalino con afinidad al K, altamente soluble en fluidos acuosos, y que se comporta como muy incompatible durante la fusión y la cristalización. El Sr es un elemento alcalinotérreo con afinidad al $\mathrm{Ca}$, bastante soluble en fluidos acuosos, y que se presenta como moderadamente incompatible durante la fusión y la cristalización de sistemas máficos, pero puede ser compatible en rocas félsicas. Por ello los procesos ígneos (fusión y cristalización) fraccionan fácilmente el $\mathrm{Rb}$ del $\mathrm{Sr}$, y es un método especialmente útil para rocas de composiciones intermedias a ácidas ya que concentran más estos 
elementos. Es un método flexible, aplicable a varios tipos de rocas y en varios procesos geológicos (magmatismo, metamorfismo, hidrotermalismo). Las desventajas pueden estar referidas al distinto comportamiento geoquímico entre $\mathrm{Rb}$ y $\mathrm{Sr}$ y cierta facilidad de apertura del sistema isotópico.

El método de la isocrona sólo es válido si: a) el sistema de interés estuvo en equilibrio isotópico en $\mathrm{t}=0$, o sea que la relación isotópica en ese momento (Ro) era uniforme y homogénea; $\mathrm{b}$ ) todo el sistema y cada una de sus partes ha permanecido cerrado desde $t=0$ a $t=t$. La pendiente de la recta es proporcional a la edad (t). Si los errores geológicos son mayores a los errores analíticos en vez de una isocrona se tiene una 'errorcrona'. El parámetro MSWD indica el error analítico, asociado al exceso de dispersión de los puntos. El sistema Rb-Sr se homogeiniza durante los procesos de fusión parcial, metamorfismo con desarrollo de fases minerales características, o durante la diagénesis de sedimentos finos (pelitas, filitas). Las edades $\mathrm{Rb} / \mathrm{Sr}$ obtenidas en roca total se interpretan en general como edades de cristalización ígnea o edades de recristalización metamórfica. Las edades obtenidas en minerales (micas, feldespatos) pueden interpretarse como de enfriamiento. Además, el análisis de las relaciones isotópicas iniciales $d{ }^{87} \mathrm{Sr} /{ }^{86} \mathrm{Sr}$ se vincula al origen de los magmas, resultando así de interés petrogenético.

Isotopía del samario y neodimio: el método ${ }^{147} \mathrm{Sm}-{ }^{143} \mathrm{Nd}$ se utiliza para datación de rocas ígneas, especialmente para rocas básicas que generalmente son pobres en circones como para utilizar el método U-Pb. Se utiliza para datación de minerales y rocas ígneas en muestras de roca total (polvo). Su rango de aplicación es de $120 \mathrm{Ma}$ hasta $4,6 \mathrm{Ga}$. Se basa en el decaimiento ${ }^{147} \mathrm{Sm} \rightarrow{ }^{143} \mathrm{Nd}+\alpha,\left(\mathrm{t}_{1 / 2}\right.$ $=10,6 \times 10^{10}$ años). Dada la gran inmovilidad de las tierras raras, la relación $\mathrm{Sm} / \mathrm{Nd}$ no es afectada por los procesos geológicos (alteración, metamorfismo, etc.), manteniéndose constante en el tiempo. Las edades obtenidas en rocas intermedias y básicas por el método de la isócrona, pueden interpretarse como de cristalización.

Por otro lado, los isótopos de $\mathrm{Nd}$ han sido ampliamente utilizados como indicadores de procedencia (e.g. McLennan et al, 1989, 1993) y su utilidad para este tipo de estudios se debe al comportamiento coherente de los elementos de las tierras raras durante los procesos sedimentarios. Las signaturas de isótopos de $\mathrm{Nd}$ de las rocas sedimentarias terrígenas representan un promedio de las fuentes a partir de las cuales derivan los sedimentos (McLennan et al., 1989). Dado que la relación $\mathrm{Sm} / \mathrm{Nd}$ es modificada durante los procesos de diferenciación corteza-manto, es posible estimar el momento en el cual el magma inicial se separó del manto superior, obteniendo lo que se denomina una Edad Modelo o $\mathrm{T}_{\mathrm{DM}}$ (De Paolo, 1981; Nelson and De Paolo, 1988). Estas representan edades de residencia en la corteza continental. Las edades modelo Sm-Nd tienen aplicación para los estudios de procedencia de sedimentos detríticos, asociado a otros métodos como isótopos de $\mathrm{Sr}$ y de $\mathrm{Pb}$ (ver más adelante). La edad se deduce de la siguiente fórmula: 


$$
\tau_{C H U R}=\frac{1}{\lambda} \operatorname{Ln}\left[\frac{\left(\frac{{ }^{143} N d}{{ }^{144} N d}\right)-\left(\frac{{ }^{143} N d}{{ }^{144} N d}\right)_{C H U R}}{\left(\frac{{ }^{147} S m}{{ }^{144} N d}\right)-\left(\frac{{ }^{147} S m}{{ }^{144} N d}\right)_{C H U R}}+1\right]
$$

Muchas veces lo que se utiliza es la 'función $\mathrm{Sm} / \mathrm{Nd}$ ' $\left(f_{(\mathrm{Sm} / \mathrm{Nd})}\right)$, que permite comparar la relación ${ }^{147} \mathrm{Sm} /{ }^{144} \mathrm{Nd}$ de la muestra con la del reservorio condrítico de referencia. Se calcula de la siguiente manera:

$$
\left.f_{(\mathrm{Sm} / \mathrm{Nd})}=\left({ }^{147} \mathrm{Sm} /{ }^{144} \mathrm{Nd}\right)_{\text {muestra }} /\left({ }^{147} \mathrm{Sm} /{ }^{144} \mathrm{Nd}\right)_{\text {Condrito }}\right)-1
$$

Existen dos modelos propuestos, uno en el que se asume un solo evento de diferenciación (De Paolo, 1981) y otro en el que se adjudican dos etapas de diferenciación y consecuente fraccionamiento del sistema isotópico Sm-Nd (De Paolo et al., 1991). Este modelo implica que el manto sufrió un fraccionamiento que dejó un reservorio residual enriquecido en la relación $\mathrm{Sm} / \mathrm{Nd}$ pero geoquímicamente empobrecido en los elementos litófilos de gran diámetro (LILE; De Paolo, 1981).

En el estudio de las rocas sedimentarias las edades modelo deben interpretarse como la 'edad modelo promedio' de las rocas que han contribuido en mayor proporción a la relación $\mathrm{Sm} / \mathrm{Nd}$ del sedimento. Uno de los puntos a favor de la aplicación del método de edades modelo Sm-Nd a los sistemas de roca total es que permite interpretar procesos tales como erosión, sedimentación, metamorfismo e incluso eventos de fusión cortical, que usualmente no registran otros métodos de datación (McLennan et al., 1989). Sin embargo, varios estudios han mencionado procesos que podrían alterar la signatura isotópica $\mathrm{Sm}-\mathrm{Nd}$ en las rocas sedimentarias. Estos incluyen la alteración de la relación $\mathrm{Sm} / \mathrm{Nd}$ y signaturas isotópicas de $\mathrm{Nd}$ durante la meteorización, diagénesis o selección (McDaniel et al., 1994; Bock et al., 1994). Dado que estos procesos pueden complicar la interpretación de las edades modelo, el énfasis se pone sobre los valores $\varepsilon_{\mathrm{Nd}}$ (i.e. McLennan et al., $1989 ; 1993)$. Mediante diagramas combinados de isotopía de $\mathrm{Nd}$ y $\mathrm{Sr}$ es posible interpretar cuestiones genéticas. El parámetro epsilon $\left(\varepsilon N d^{t}\right.$ o $\left.\varepsilon S r^{t}\right)$ expresa la diferencia entre la relación ${ }^{143} \mathrm{Nd} /{ }^{144} \mathrm{Nd}$ ó ${ }^{87} \mathrm{Sr} /{ }^{86} \mathrm{Sr}$ de la muestra para un tiempo $t$ con respecto al valor del reservorio de referencia en ese momento $t$ (en general CHUR -Chondritic Uniform Reservoir, De Paolo and Wasserburg, 1976-, o DM -Depleted Mantle, De Paolo, 1981). El cálculo y los valores de referencia son los siguientes:

$$
\varepsilon \mathrm{Nd}_{(\mathrm{t})}=\left\{\left[\left({ }^{143} \mathrm{Nd} /{ }^{144} \mathrm{Nd}\right)_{\text {muestra }} /\left({ }^{143} \mathrm{Nd} /{ }^{144} \mathrm{Nd}\right)_{\text {CHUR/DM }}\right]-1\right\} \times 10^{4}
$$

\begin{tabular}{|lcc|}
\hline & ${ }^{43} \mathbf{N d} /{ }^{144} \mathbf{N d}$ & ${ }^{143} \mathbf{S m} /{ }^{144} \mathbf{N d}$ \\
\hline CHUR & 0,512638 & 0,1966 \\
DM & 0,513144 & 0,222 \\
\hline
\end{tabular}

El $\varepsilon \mathrm{Nd}_{(0)}$ indica la derivación de la relación ${ }^{143} \mathrm{Nd} /{ }^{144} \mathrm{Nd}$ de la muestra respecto al valor de referencia (generalmente el CHUR), y se expresa como $\varepsilon_{\mathrm{Nd}} \mathrm{d}_{(0)}=\left\{\left[\left({ }^{143} \mathrm{Nd} /{ }^{144} \mathrm{Nd}\right)\right.\right.$ muestra (0) $/$ $\left.\left.\left({ }^{143} \mathrm{Nd} /{ }^{144} \mathrm{Nd}\right)_{\text {ChUR (0) }}\right]-1\right\} \times 10^{4}$. El $\varepsilon \mathrm{Nd}_{(\mathrm{t})}$ puede calcularse de la misma manera considerando $\mathrm{t}$ como 
la edad de la sedimentación. La relación $\mathrm{Sm} / \mathrm{Nd}$ no varía desde el momento (evento) en que se extrajo el material del manto. Así es que en los gráficos ( $\varepsilon N d$ versus $t$ por ejemplo) las rectas no cambian su pendiente. Si $\varepsilon N d<0$ ( $\varepsilon N d-)$ la fuente tiene mayor relación $\mathrm{Sm} / \mathrm{Nd}$ que el CHUR, mientras que si $\varepsilon N d>0(\varepsilon N d+)$ la fuente que originó el magma tiene menor relación $\mathrm{Sm} / \mathrm{Nd}$ que el CHUR. El $\mathrm{Nd}$ es más incompatible que el isótopo padre $\mathrm{Sm}$, entonces la relación ${ }^{143} \mathrm{Nd} /{ }^{144} \mathrm{Nd}$ es menor en la corteza $(\varepsilon \mathrm{Nd}-)$ y mayor en el manto deprimido $(\varepsilon \mathrm{Nd}+)$ porque el $\mathrm{Nd}$ se concentra en los diferenciados más que el Sm.

Isotopía de uranio y plomo en circones y roca total: el método $\mathrm{U}$ - $\mathrm{Pb}$ se usa para datación de minerales, con un rango de aplicación muy grande. Las edades obtenidas en minerales (circón, monacita, rutilo, etc.) pueden interpretarse como edades de cristalización y además permite detectar si hubo pérdidas de $\mathrm{Pb}$ (eventos metamórficos). Se basa en los decaimientos ${ }^{238} \mathrm{U}-{ }^{206} \mathrm{~Pb}\left(\mathrm{t}_{1 / 2}=4,47 \mathrm{x} 10\right.$ ${ }^{9}$ años) $\mathrm{y}^{235} \mathrm{U}-{ }^{207} \mathrm{~Pb}\left(\mathrm{t}_{1 / 2}=0,70 \times 10{ }^{9}\right.$ años$)$. Por el método de termo-ionización (TIMS) sobre circones se disuelven los cristales para obtener su edad U-Pb, mientras que por el método de ablación láser (LA- ICP-MS) se obtiene una o más edades puntuales in situ para distintos sectores de cada cristal, asociadas a su crecimiento. Los análisis por dilución isotópica con TIMS (ID-TIMS) son más lentos y trabajosos ( 1 análisis por hora) pero es el método analíticamente más preciso $( \pm 0,3 \%)$. Se realizaron con las siguientes especificaciones: Se separó la fracción magnética con un equipo Frantz a 1,5 amperes partiendo de una inclinación frontal de $15^{\circ}$ y $25^{\circ}$ de inclinación lateral. En las relaciones isotópicas ${ }^{207} \mathrm{~Pb} /{ }^{235} \mathrm{U},{ }^{206} \mathrm{~Pb} /{ }^{238} \mathrm{U},{ }^{207} \mathrm{~Pb} /{ }^{206} \mathrm{~Pb}$ el $\mathrm{Pb}$ radigénico fue corregido con un blanco y el $\mathrm{Pb}$ inicial, mientras que el $\mathrm{U}$ fue corregido mediante un blanco. Las concentraciones totales de $\mathrm{U}$ y $\mathrm{Pb}$ fueron corregidas con un blanco analítico. Las edades están dadas en millones de años (Ma), y fueron calculadas usando el programa Isoplot/Ex (Ludwig, 1998), con las constantes de decaimiento recomendadas por Steiger and Jäger (1977). El método de LA- ICP-MS es más rápido y simple de operar que con TIMS, ya que no es necesario preparar químicamente la muestra. Tiene una resolución espacial moderada a alta (diámetro del spot $=10-50 \mu \mathrm{m}, 12 \mu \mathrm{m}$ de profundidad) y una precisión analítica moderada a muy alta $( \pm 1 \%)$. Se aplica a superficies cristalinas lisas o rugosas. Las muestras fueron procesadas en la UFRGS (Porto Alegre). Los granos de circón fueron montados en resina epoxy, pulidos y analizados por microscopio óptica y electrónica de barrido. Luego se dataron con microsonda electrónica por ablación láser, utilizándose un tamaño de spot de $25 \mu \mathrm{m}$ excepto en muestras con bajo contenido de $\mathrm{Pb}$ o circones muy pequeños en los que se uso un spot de 15 y $10 \mu \mathrm{m}$ respectivamente. Las correcciones necesarias fueron realizadas en base al circón de referencia GJ-1 (Simon et al., 2004). Se ha tomado como valor representativo de la muestra el promedio de determinaciones ${ }^{207} \mathrm{~Pb} /{ }^{206} \mathrm{~Pb}$, mientras que para el ${ }^{206} \mathrm{~Pb} /{ }^{238} \mathrm{U}$ se asumió el valor extrapolado para $\mathrm{t}($ tiempo $)=0$. Los valores que no muestran un buen alineamiento son descartados. Para otras relaciones como ${ }^{206} \mathrm{~Pb} /{ }^{207} \mathrm{~Pb}$ y ${ }^{232} \mathrm{Th}^{238} \mathrm{U}$, cuando son aplicables o exhiben la misma tendencia de fraccionamiento, tambien se usan las relaciones extrapoladas. 
En el método $\mathrm{Pb}$ común $\left({ }^{207} \mathrm{~Pb}-{ }^{206} \mathrm{~Pb}\right)$ se utilizan las relaciones isotópicas de ${ }^{208} \mathrm{~Pb} /{ }^{204} \mathrm{~Pb}$, ${ }^{207} \mathrm{~Pb} /{ }^{204} \mathrm{~Pb}$ y ${ }^{206} \mathrm{~Pb} /{ }^{204} \mathrm{~Pb}$ para resolver cuestiones genéticas de las rocas y magmas de acuerdo a diagramas de evolución de $\mathrm{Pb}$. Se trabaja en forma comparativa contrastando los resultados obtenidos con los que caracterizan a otras regiones de posible vinculación o características similares.

\section{Preparación de las muestras.}

Las muestras seleccionadas para análisis de geoquímica fueron lavadas y secadas, descartándose los trozos alterados y con presencia de venas. Luego fueron reducidas de tamaño mediante trituración y molienda hasta producir una muestra pulverizada homogénea representativa de la roca original. Todas las muestras fueron procesadas en el Centro de Investigaciones Geológicas con trituradora de mandíbulas, mientras que la molienda fina se realizó con molino de widia, o se enviaron fragmentos de roca (rock chips) al laboratorio. Las muestras fueron primeramente analizadas en el laboratorio SPECTRAU (Universidad de Johannesburgh) por XRF y luego completadas en ACME Labs. (Canadá) por ICP-MS.

$\mathrm{El}$ análisis de óxidos de los elementos mayoritarios por FRX $\left(\mathrm{SiO}_{2}-\mathrm{Al}_{2} \mathrm{O}_{3}-\mathrm{Fe}_{2} \mathrm{O}_{3}-\mathrm{TiO}_{2}-\right.$ $\mathrm{MgO}-\mathrm{CaO}-\mathrm{MnO}-\mathrm{Na}_{2} \mathrm{O}-\mathrm{K}_{2} \mathrm{O}-\mathrm{P}_{2} \mathrm{O}_{5}$ ) se realizó en una muestra fundida (perla), lo cual permitió descomponer y homogeneizar la muestra totalmente antes de realizar el análisis elemental. Una porción de muestra en polvo se mezcló con un fundente como metaborato de litio $\left(\mathrm{LiBO}_{2}\right)$. La medición de los elementos minoritarios y traza $(\mathrm{Ba}-\mathrm{Nb}-\mathrm{Pb}-\mathrm{Rb}-\mathrm{Sr}-\mathrm{Th}-\mathrm{Zn}-\mathrm{Zr}-\mathrm{Cr}-\mathrm{Ni}-\mathrm{Y}-$ $\mathrm{Co}-\mathrm{Cu}-\mathrm{V}-\mathrm{Ga}-\mathrm{S}-(\mathrm{Hf})-(\mathrm{La})-(\mathrm{Ce})-(\mathrm{As})-(\mathrm{Sc})-(\mathrm{U}))$ se realizó sobre tabletas de presión. La muestra en polvo fue preparada y prensada a 20 toneladas en una prensa sosteniendo la presión durante 60 segundos. La pérdida de volátiles por calcinación ( $\mathrm{LOI}=$ loss on ignition) fue determinada por diferencia de peso luego de calentarse 1 gr de muestra seca a $1000^{\circ} \mathrm{C}$ durante 1 hora $\left(\mathrm{LOI}_{(\%)}=\right.$ [peso seco - peso calcinado] x 100).

En ACME Labs. se analizaron los elementos mayoritarios y algunos minoritarios por ICP-ES en roca total (grupo 4A: $\mathrm{SiO}_{2}-\mathrm{Al}_{2} \mathrm{O}_{3}-\mathrm{Fe}_{2} \mathrm{O}_{3}-\mathrm{MgO}-\mathrm{CaO}-\mathrm{Na}_{2} \mathrm{O}-\mathrm{K}_{2} \mathrm{O}-\mathrm{TiO}_{2}-\mathrm{P}_{2} \mathrm{O}_{5}-\mathrm{MnO}-$ $\mathrm{Cr}_{2} \mathrm{O}_{3}-\mathrm{Sc}$, LOI, TOT/C, TOT/S); los elementos minoritarios y tierras raras (grupo 4B: $\mathrm{Ba}-\mathrm{Be}-\mathrm{Co}$ $-\mathrm{Cs}-\mathrm{Ga}-\mathrm{Hf}-\mathrm{Nb}-\mathrm{Rb}-\mathrm{Sn}-\mathrm{Sr}-\mathrm{Ta}-\mathrm{Th}-\mathrm{U}-\mathrm{V}-\mathrm{W}-\mathrm{Zr}-\mathrm{Y}-\mathrm{La}-\mathrm{Ce}-\mathrm{Pr}-\mathrm{Nd}-\mathrm{Sm}-\mathrm{Eu}-$ $\mathrm{Gd}-\mathrm{Tb}-\mathrm{Yb}-\mathrm{Dy}-\mathrm{Ho}-\mathrm{Er}-\mathrm{Tm}-\mathrm{Yb}-\mathrm{Lu}$ ) fueron analizados por ICP-MS, y los elementos traza del grupo 1DX (Mo $-\mathrm{Cu}-\mathrm{Pb}-\mathrm{Zn}-\mathrm{Ni}-\mathrm{As}-\mathrm{Cd}-\mathrm{Sb}-\mathrm{Bi}-\mathrm{Ag}-\mathrm{Au}-\mathrm{Hg}-\mathrm{Tl}-\mathrm{Se})$ fueron digeridos en agua regia y luego analizados por ICP-MS. Además se realizó el análisis de carbono total (TOT/C) y azufre total (TOT/S, Grupo 2A C/S) por Leco sobre un mínimo de $2 \mathrm{~g}$ de muestra. El procedimiento para la determinación de los elementos mayoritarios, minoritarios refractarios y tierras raras implica la fusión de $0,2 \mathrm{~g}$ de muestra con $\mathrm{LiBO}_{2} / \mathrm{Li}_{2} \mathrm{~B}_{4} \mathrm{O}_{7}$ y digestión ácida nítrica, mientras que para el análisis de los metales preciosos, metales base y trazas se diluyó $0,5 \mathrm{~g}$ de muestra en $3 \mathrm{ml}$ de agua regia $\left(\mathrm{HCl}-\mathrm{HNO}_{3}-\mathrm{H}_{2} \mathrm{O}\right)$ en concentración 2:2:2 a $95{ }^{\circ} \mathrm{C}$ durante 1 hora, y fue diluida a $10 \mathrm{ml}$. 


\subsection{5- Análisis de Minerales Pesados.}

Los minerales pesados son aquellos que tienen una densidad mayor a $2,9 \mathrm{~g} / \mathrm{cm}^{3}$ y que se encuentran en escasa proporción (generalmente menor a 1\%), particularmente en las fracciones de arena muy fina y fina. Su concentración se debe a procesos selectivos, y en circunstancias especiales puede ser elevada formando placeres. Incluyen varios silicatos y óxidos (magnetita, turmalina, circón, rutilo, esfena, granate, epidoto, cromita, raramente olivino, etc.), que son encontrados en pequeñas cantidades $(<1 \%)$ en las areniscas. La preservación en las areniscas de los minerales pesados se debe a que presentan alta resistencia a la acción del clima, diagénesis y degradación, y como en general ocurren en condiciones particulares son útiles para la interpretación de las características de las áreas fuente.

Para la concentración de minerales pesados se recolectaron en el campo entre 5 y $10 \mathrm{~kg}$ de material por cada muestra (dependiendo de su litología y granulometría), lo más fresco posible. Luego se procesaron en el laboratorio de minerales pesados del CIG. Las muestras recolectadas consisten en rocas sedimentarias principalmente, ígneas y metamórficas. El objetivo es concentrar y separar los minerales pesados, especialmente circones (monacitas, apatitas y otros) para su caracterización morfológica para estudios de procedencia, y datación de granos de circón por el método U-Pb, ya que éstos minerales concentran isótopos de $\mathrm{U}, \mathrm{Pb}$ y $\mathrm{Th}$ en sus redes cristalinas y son resistentes al retrabajamiento sedimentario, alteración y metamorfismo. Una vez lavada, la muestra fue triturada y molida hasta reducirla lo necesario para disgregar los minerales que componen la roca sin romperlos o pulverizarlos. En este caso se utilizó una trituradora de mandíbulas y luego un molino de widia. A continuación se tamizó recuperando las fracciones mas finas que juntan los tamices $\# 100 \quad(\mu=150$ pasante), \#140 ( $\mu=106$ pasante) y el fondo.

\begin{tabular}{|c|c|c|}
\hline Malla tamiz (\#) & Apertura (pasante) & Retenido \\
\hline 35 & $500 \mu \mathrm{m}$ & $>500 \mu \mathrm{m}$ \\
60 & $250 \mu \mathrm{m}$ & $500-250 \mu \mathrm{m}$ \\
80 & $180 \mu \mathrm{m}$ & $250-180 \mu \mathrm{m}$ \\
100 & $150 \mu \mathrm{m}$ & $180-150 \mu \mathrm{m}$ \\
140 & $106 \mu \mathrm{m}$ & $150-106 \mu \mathrm{m}$ \\
fondo & - & $<106 \mu \mathrm{m}$ \\
\hline
\end{tabular}

Luego se hizo una primera separación densimétrica de las fracciones utilizando agua, para lo cual se pasaron por un elutriador, lavando antes la mayor cantidad de finos en un recipiente de vidrio para hacer más efectiva la separación. El caudal se reguló según la fracción granulométrica que se esté pasando (ver tabla).

\begin{tabular}{|c|c|}
\hline $\begin{array}{c}\text { Fracción } \\
\text { granulométrica }\end{array}$ & $\begin{array}{c}\text { Caudal aproximado } \\
\text { (Q, en } \mathrm{cm}^{3} / \text { min. }\end{array}$ \\
\hline Fondo & 2.100 \\
140 & $2.400-2.700$ \\
100 & 3.600 \\
\hline
\end{tabular}

Se hizo una separación magnética primero con imán de mano para eliminar la magnetita (que llega a ser muy abundante) y luego con el equipo Isodinámico Frantz para separar la fracción magnética (Bt, Hbl, Ep, etc.) de la no magnética de interés ( $\mathrm{Zr}$, Ap, Ttn entre otros). La intensidad 
magnética e inclinación del aparato se reguló en base a una tabla de susceptibilidad magnética de los minerales (ver Hutchinson, p.119), teniendo en cuenta la fracción granulométrica que se pasa y qué minerales se quieren rescatar. En este caso se hizo una primera separación en 0,5 (principalmente $\mathrm{Bt}$ ) y una segunda en 1,4. Por último se hizo una segunda separación gravimétrica mediante líquidos densos (Bromoformo: $\mathrm{CHBr}_{3}, \rho=2,89$ ) bajo campana de extracción, obteniendo un concentrado final de minerales pesados. La separación de minerales con líquidos pesados es un método que no se encuentra normalizado. Una buena descripción de la metodología de trabajo para la separación e identificación de minerales pesados se encuentra en Mange y Maurer (1992) y Hutchinson (1973: Cap. 5). Una vez concentrados los minerales pesados no magnéticos se procedió a la separación manual bajo lupa binocular (hand picking) de los minerales de interés, principalmente circones.

Para la caracterización de la población completa de minerales pesados se eligieron muestras características y se hizo la separación con bromoformo sin la separación magnética previa, es decir usando directamente los pre-concentrados obtenidos en el elutriador a los que se les retiró la magnetita con imán de mano. Algunas muestras fueron separadas en el Laboratorio de Geología Isotópica de la Universidade Federal de Rio Grande do Sul (UFRGS) con Ioduro de Metilo $\left(\mathrm{CH}_{3} \mathrm{I}, \rho=3,325\right)$, sin una previa separación magnética, recogiéndose entonces la población completa de minerales pesados.

\subsection{6- Estudios de Procedencia y Ambiente Tectónico.}

En el caso de las rocas ígneas el objetivo de este tipo de estudios es aportar información acerca de cuál es el origen del magma, si se produjo a partir de fusión de la corteza o del manto, y a qué ambiente tectónico está relacionado.

Los estudios de procedencia en las rocas sedimentarias apuntan a descifrar la composición y la evolución geológica de las áreas fuente de los detritos, y a caracterizar el ambiente tectónico de la cuenca de depositación de los sedimentos. La incidencia de efectos secundarios tales como selección, meteorización y metamorfismo, puede ocultar la información que brindan los distintos indicadores que se usan para evaluar las áreas de procedencia de las sedimentitas. Por ello es necesario un análisis combinado de metodologías teniendo en cuenta el trabajo de campo, petrografía, geoquímica y datos isotópicos (especialmente isótopos de $\mathrm{Pb}$ y $\mathrm{Nd}$ y datación de circones).

Los análisis petrográficos permitieron analizar la composición, texturas y microestructuras, presencia de minerales pesados y condiciones de diagénesis, para la confección de modas detríticas y elaboración de triángulos de procedencia.

El análisis de las signaturas geoquímicas permitió caracterizar los ambientes tectónicos de formación de las rocas ígneas y evaluar las relaciones entre áreas fuente y de depósito de los sedimentos mediante la confección e interpretación de diagramas geoquímicos de procedencia. Para ello previamente se monitorearon los procesos que pudieron afectar la composición de los sedimentos (meteorización, retrabajo y selección). Se trabajó principalmente con los elementos que son mas 
inmóviles y menos afectados por procesos secundarios, y que tienen un significado en los estudios de procedencia (especialmente Th, Sc, La, Y, Hf, Zr, Ti, V, Ni, Co, Cr, REE).

$\mathrm{La}$ determinación de isótopos de $\mathrm{Sm}-\mathrm{Nd}$ y $\mathrm{Pb}-\mathrm{Pb}$ permite la caracterización del material detrítico en cuanto a su historia cortical. Los isótopos de $\mathrm{Nd}$ aportan información valiosa sobre la procedencia, residencia cortical y el ambiente tectónico, mediante la determinación de parámetros como Epsilon $\mathrm{Nd}$ y edades modelo $\mathrm{T}_{\mathrm{DM}}$ (momento en que el magma inicial se separó del manto superior). En el caso de sedimentos se obtiene un promedio de edades modelo de todas las fuentes de aporte, entonces lo que importa son las variaciones de $\mathrm{T}_{\mathrm{DM}}$ en la secuencia sedimentaria y no su valor absoluto.

Además se ha identificado y caracterizado la población de minerales pesados (especialmente circones), por microscopio petrográfico, lupa, y microscopio electrónico de barrido SEM-BSE-EDS y SEM-EDAX, en especial aquellas fases que ocurren en paragénesis particulares. Los análisis geocronológicos, especialmente la datación de circones detríticos por U-Pb (ICP-MS-LA) y análisis de zonaciones y morfologías con SEM-BSE, permiten determinar tipo y edad de las probables rocas fuente de los detritos y llegar a obtener la edad máxima de sedimentación (circones más jóvenes). Para ellos es necesario realizar una cantidad de mediciones estadísticamente representativa.

Los isótopos de $\mathbf{P b}$ proveen una visión diferente de la procedencia sedimentaria en comparación con otros sistemas isotópicos. La relación entre la composición isotópica de $\mathrm{Pb}$ y el ambiente tectónico no es sencilla, pero es posible discriminar entre una corteza continental antigua y terrenos juveniles (especialmente en términos de ${ }^{207} \mathrm{~Pb} /{ }^{206} \mathrm{~Pb}$ ). El estudio de los isótopos de $\mathrm{Pb}$ en rocas sedimentarias (roca total) podría ser compleja debido el efecto que varios procesos pueden tener sobre el sistema del $\mathrm{Pb}$. El $\mathrm{Pb}$ uranogénico $\left({ }^{207} \mathrm{~Pb}\right.$ y $\left.{ }^{206} \mathrm{~Pb}\right)$ puede ser afectado por enriquecimiento de $\mathrm{U}$ durante los procesos sedimentarios que ocurren principalmente en las pelitas negras. Por otra parte, la meteorización podría lixiviar el $\mathrm{U}$ de la roca sedimentaria y entonces afectar los isótopos de $\mathrm{Pb}$ (Hemming and McLennan, 2001). La selección sedimentaria selectiva de fases minerales como circón, monacita, xenotima y feldespato podría fraccionar los isótopos de $\mathrm{Pb}$. Los efectos de la selección sedimentaria podrían ser complejos ya que aunque el U y Th están enriquecidos en los minerales pesados, sus relaciones son diferentes en los distintos minerales (Hemming and McLennan, 2001). Además, el $\mathrm{Pb}$ común $\left({ }^{204} \mathrm{~Pb}\right)$ no se encuentra en los mismos minerales que los otros tres isótopos de $\mathrm{Pb}$, pero se concentra en los feldespatos (particularmente $\mathrm{Fk}$ ). En general, areniscas con poca o ninguna matriz y no alteradas tenderán a preservar sus composiciones isotópicas de $\mathrm{Pb}$ (porque los minerales resistentes contendrán la mayor parte del $\mathrm{Pb}$ radigénico mientras que el no radigénico se hallará en los feldespatos), en tanto que las rocas de grano fino representarían una compleja mezcla características de la fuente, meteorización y diagénesis, más probablemente relacionada a la desintegración de los feldespatos, enriquecimiento o lixiviación de $\mathrm{U}$, etc. (Hemming and McLennan 2001).

La discriminación de componentes 'antiguos' usando datos de $\mathrm{Pb}$ reside en la observación de que la mayor parte del ${ }^{207} \mathrm{~Pb}$ fue producido en la historia temprana de la Tierra, debido a que el ${ }^{235} \mathrm{U}$ 
tiene un tiempo de vida media muy corta. Así, la relación ${ }^{207} \mathrm{~Pb} /{ }^{204} \mathrm{~Pb}$ es relativamente insensible a las variaciones $\mathrm{U} / \mathrm{Pb}$ Meso a Neoproterozoicas y más jóvenes (Asmeron and Jacobsen, 1993). El tiempo de vida media del $238 \mathrm{U}$ es similar al de la Tierra, así que la relación ${ }^{206} \mathrm{~Pb} /{ }^{204} \mathrm{~Pb}$ ha crecido en forma más linear a lo largo de la historia de la Tierra. En consecuencia, relaciones relativamente altas de ${ }^{207} \mathrm{~Pb} /{ }^{204} \mathrm{~Pb}$ de cualquier bloque cortical requiere la presencia de un componente antiguo (Asmeron and Jabobsen, 1993). Otras complicaciones pueden surgir de comparar los isótopos de $\mathrm{Pb}$ de una roca sedimentaria con los de la(s) probable(s) fuente(s), desde el momento en que las perturbaciones en el sistema de $\mathrm{Pb}$ durante la erosión y depositación, o debidas a procesos post-depositacionales pueden cambiar las relaciones de $\mathrm{Pb}$ dando valores muy distintos a aquellos de la roca fuente (e.g. McLennan et al., 2000). Por esto, las comparaciones entre sistemas de $\mathrm{Pb}$ de una roca sedimentaria con el de las fuentes no es sencilla y pueden obtenerse fácilmente resultados erróneos, particularmente cuando las interpretaciones basadas en isótopos de $\mathrm{Pb}$ no se comparan con otros indicadores de procedencia (e.g. McLennan et al., 2000).

\subsection{7- Laboratorios e intrumental utilizados.}

\section{CIG (Centro de Investigaciones Geológicas UNLP-CONICET):}

(Calle $1, \mathrm{~N}^{\circ} 644$, La Plata)

Laboratorio de cortes delgados:

Sierra circular Conrad D3392 Clausthal-Zellerfeld

Devastadora Petro-Thin

Laboratorios de molienda:

Trituradora y Molino Fritcsh

Tamizadora Lutz Ferrando y Cía. S.A.

Laboratorio de minerales pesados:

Separador magnético Isodinámico S.G.Frantz Co., Inc., mod. L-1, 115volts, 2,2 Amp.

Ultrasonido Decalab S.R.L., mod. TB-10.

Elutriador

Sala de Petrología:

Microscopios de luz polarizada: Leitz, Zeiss Wetzlar Laborlux 12 Pol, Nikon Eclipse E200

Contador de puntos: Swift, mod. F.

Lupa binocular: Nikon (Type 102), Zeiss Stemi 2000-C, con equipo fotográfico.

Laboratorios de geoquímica:

Campanas

Horno de alta temperatura $\left(1000^{\circ} \mathrm{C}\right.$, para LOI $)$

Balanzas de precisión

\section{MUSEO de La Plata (Facultad de Ciencias Naturales y Museo):}

(Paseo del Bosque s/n, La Plata)

Laboratorio de microscopía electrónica

SEM (Jeol modelo JSM-6360, procesado con el programa Jeol/EO, version 1.1, tamaño del spot entre 31 y $37 \mu \mathrm{m})$

Departamento Científico de Geología

Lupa binocular con cámara clara

Estereoscopio de espejos

University of Johannesburgh, Geology Department:

SPECTRAU Laboratory (The Central Analytical Facility of the Faculty of Science):

Microscopio petrográfico 
Microsonda electrónica

SEM (JOEL JSM-5600)-BSE-EDAX

FRX

Laboratorio de minerales pesados:

Frantz

Campanas-bromoformo

Laboratorio de molienda:

Molinos de acero (steel mill)

ACME Laboratories (Canadá):

Análisis de geoquímica de elementos mayoritarios - minoritarios - trazas - REE

IG-UFRGS (Laboratório de Geología Isotópica - Universidade Federal de Rio Grande do Sul, Porto Alegre, Brasil):

Análisis de isótopos de $\mathrm{Sm}-\mathrm{Nd}(\mathrm{RT})$

Análisis de isótopos de $\mathrm{U}-\mathrm{Pb}$ para datación de circones por LA-ICP-MS

IG-USP (Centro de Pesquisas Geocronológicas - Universidade de São Paulo, Brasil):

Análisis de isótopos de $\mathrm{Rb}-\mathrm{Sr}$ en roca total

Análisis de isótopos de $\mathrm{U}-\mathrm{Pb}$ sobre circones por ID-TIMS

CINDECA (Centro de Investigaciones en Catálisis UNLP-CONICET):

(Calle 47, No 257, La Plata)

SEM-EDAX

Microsonda electrónica 


\section{Capítulo 3: \\ RESULTADOS}

\section{1- ESTRATIGRAFÍA PROPUESTA.}

\subsection{1- Introducción.}

En este capítulo se presentan las descripciones detalladas de las unidades que conforman la Precordillera de Jagüé. Los resultados del mapeo y estudios realizados han llevado a redefinir en parte la estratigrafía para algunas de ellas. En los Cuadros 3.1 y 3.2 se muestran las unidades que afloran en los distintos sectores, y se hace una síntesis de la estratigrafía que se propone para la región.

Desde los primeros trabajos que realizaran Aceñolaza (1969; 1970), Aceñolaza y Bernasconi (1969a, b), Aceñolaza et al. (1971), Caminos (1972), Maisonave (1979), Cravero et al. (1984) y los realizados por el Plan La Rioja durante el fin de la década del '60 y comienzos de los '70, la estratigrafía de la zona, especialmente del Paleozoico Inferior, casi no ha sido objeto de nuevos estudios hasta la actualidad. La construcción y mejoramiento de los accesos y la reciente importancia que ha tomado este sector desde el punto de vista geotectónico y regional ha renovado la atención en su estudio.

A continuación se hace una breve discusión sobre los criterios usados para establecer este cuadro estratigráfico, y más adelante se describirán con mayor detalle las características de cada unidad.

El interés principal de esta tesis fue desde un comienzo la caracterización de la Formación Río Bonete y de las unidades ígneas asociadas a ella, debido a que el hallazgo de fósiles ordovícicos permitió integrarla al Paleozoico Inferior y así extender el límite norte de la Precordillera.

Sin embargo, los resultados obtenidos han llevado a separar la unidad en dos, cada una de las cuales reúne características litológicas, estructurales, grado metamórfico y edad distintivas. Asi, los esquistos verdes y mármoles de la Formación Río Bonete, se distinguen claramente de las metasedimentitas estratificadas fosilíferas a las que se propone denominar Formación Del Salto (emend.). Esta última corresponde a las 'Lutitas del Salto' originalmente definidas por Aceñolaza y Bernasconi (1969a) en el área de la quebrada del Chuscho, más los afloramientos similares que afloran al norte del Granito Potrerillos. A la vez se acuerda en reemplazar la terminología de Miembro Caliza Las Damas por el de Mármol Las Damas siguiendo la nomenclatura de Martina y Astini (2009), ya que se corresponde más con la composición litológica. Los esquistos verdes y mármoles están siempre asociados y presentan una deformación apretada y coherente entre ellas, pero distinta a los pliegues más abiertos de la metasedimentitas fosilíferas estratificadas, que además presentan un grado metamórfico más bajo que los esquistos y no se asocian a rocas calcáreas. Así, la Formación Río Bonete quedaría conformada sólo por los Miembros Esquistos Cerro Cóndor y Mármol Las Damas, 
Cuadro 3.1: Síntesis estratigráfica comparativa de los afloramientos de la Precordillera de Jagüé, ordenados de oeste (izq.) a este (der.).

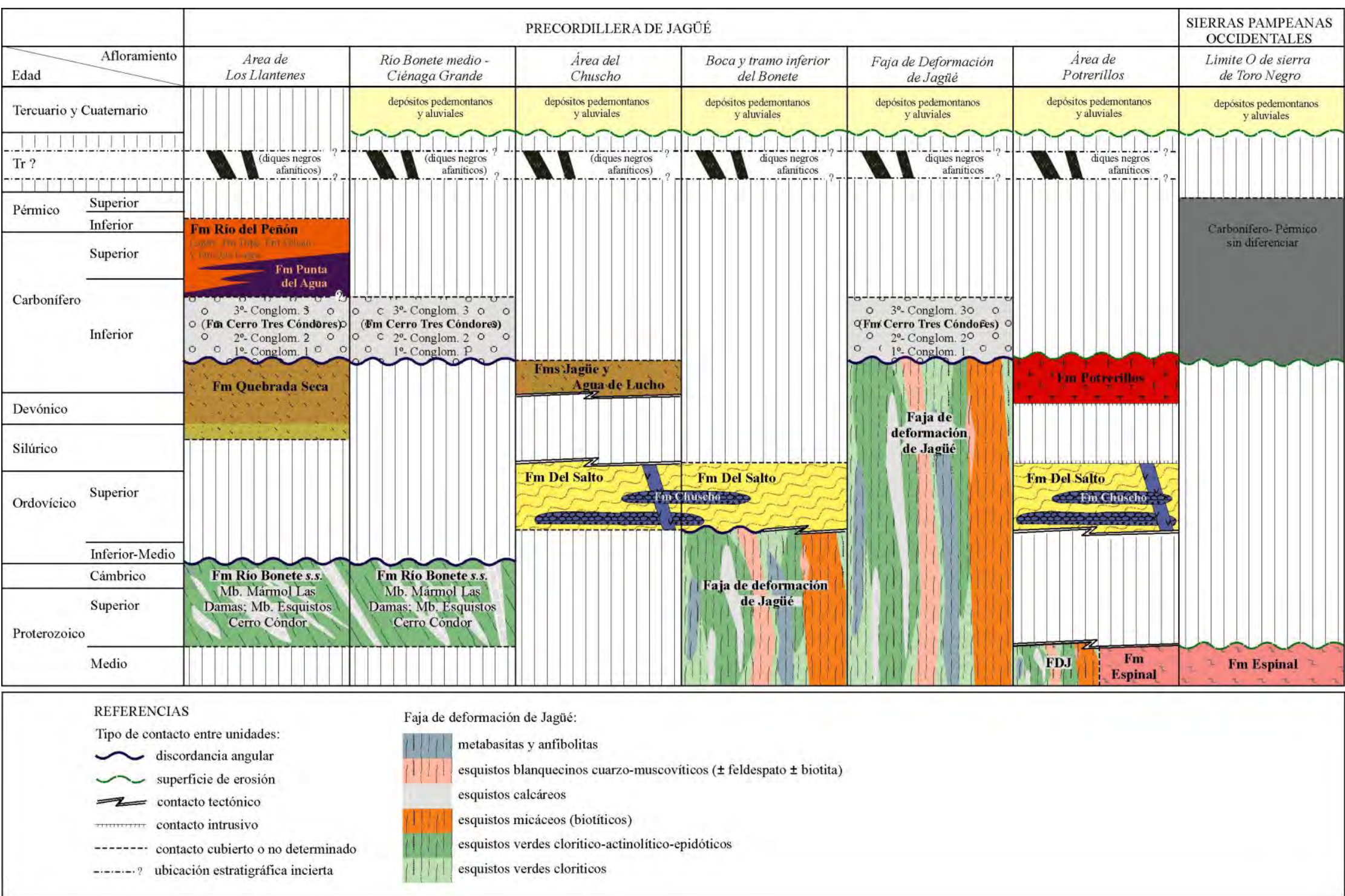


asignándose al Precámbrico Superior por las edades obtenidas en los esquistos en su área tipo y por similitudes con afloramientos de esquistos verdes y mármoles descriptos mas al sur en el basamento occidental de bajo grado de la Sierra de Umango (e.g. Sierra de Cacho, Zolezzi y Guerrero, 1981).

Las metasedimentitas de la Formación Del Salto están intercaladas con las lavas almohadilladas de la Formación Chuscho (Toselli y Durand, 1996; Fauqué y Villar, 2003). Recientemente, Martina y Astini (2009) proponen denominar a ambos tipos litológicos como Formación Chuscho, pero para no llevar a confusiones y por corresponder a rocas completamente diferentes, se prefiere conservar el criterio antecedente de Fauqué y Villar (2003) y Villar (2003), quienes hacen una descripción detallada de estas lavas. Por otro lado éste término ha sido aplicado a las rocas ígneas que constituyen el cerro Chuscho desde sus comienzos.

Cuadro 3.2: Cuadro de síntesis de la estratigrafía condensada propuesta para la Precordillera de Jagüé.

\begin{tabular}{|c|c|}
\hline Edad & Unidad \\
\hline Cuaternario & Depósitos pedemontanos y aluviales \\
\hline Terciario & $\therefore \quad$ Fms Vinchina y Toro Negr \\
\hline $\begin{array}{l}\text { Carbonífero Superior- } \\
\text {-Pérmico Inferior }\end{array}$ & $\begin{array}{ll}\text { Fm Río del Peñón } & \begin{array}{l}\text { Fm Punta } \\
\text { del Agua }\end{array}\end{array}$ \\
\hline Carbonífero inferior & 3 (castaño. Fm Cerro Tres Cóndores) $0^{\circ} \circ$ \\
\hline $\begin{array}{l}\text { Devónico - } \\
\text { Carbonífero inferior }\end{array}$ & $\begin{array}{r}\text { Fms. Quebrada Seca, Jagüel yAgua } \\
\text { de Lucho }\end{array}$ \\
\hline $\begin{array}{l}\text { Ordovícico tardío - } \\
\text { Silúrico temprano }\end{array}$ & \begin{tabular}{l||l} 
Granito \\
Potrerillos \\
(Cb inf. $)$
\end{tabular} \\
\hline $\begin{array}{l}\text { Proterozoico Medio } \\
\text { a Superior }\end{array}$ & 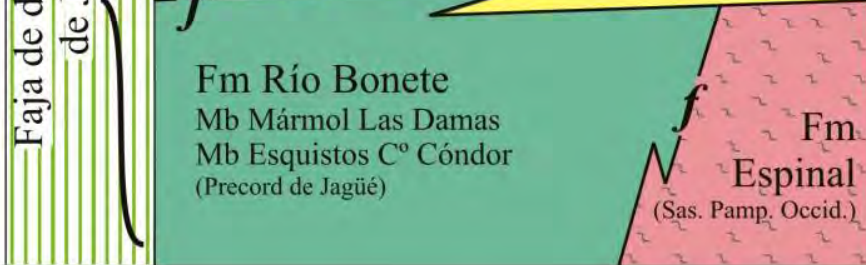 \\
\hline
\end{tabular}

Durante los trabajos realizados en el área de Los Llantenes se han hallado restos de plantas y fósiles marinos en la unidad denominada Formación Quebrada Seca por Cravero et al. (1984). Estos autores hicieron un mapeo detallado de los afloramientos y los consideraron ordovícicos por similitud 'litológica' con las lutitas fosilíferas descriptas por Aceñolaza y Bernasconi (1969a), considerrando a esquistos y calizas de la Formación Río Bonete en el Cámbrico con dudas. Pero la presencia de los restos hallados, especialmente los de plantas, han permitido reubicar a esta unidad en el intervalo Devónico-Carbonífero. Por otro lado, sobre el sector medio del tramo inferior de la quebrada del Chuscho se ha identificado un pequeño bloque de afloramientos con idénticas características a las 
halladas sobre la quebrada Seca, en contacto tectónico entre las metasedimentitas estratificadas de la Formación Del Salto. Este bloque correspondería a las unidades inferiores, predominantemente pelíticas, de la secuencia devónico-carbonífera inferior en la región, Formaciones Jagüel y Agua de Lucho (González y Bossi, 1987; sección 3.2.5). De esta manera, la Formación Quebrada Seca sería, al menos en parte, equivalente a las Formaciones Jagüé y/o Agua de Lucho en el área del Chuscho, y mas al sur a la Formación Punilla. En base a restos paleontológicos (polen, fósiles), la Formación Agua de Lucho sería equivalente a la Formación Malimán (Scalabrini Ortiz, 1973), miembro inferior del Grupo Angualasto (Limarino y Cesari, 1992, Azcuy et al., 2000) en la precordillera sanjuanina, y a la Formación Punilla (sección 3.2.8).

Cravero et al. (1984) mencionan la presencia de un complejo básico dentro del Ordovícico en Los Llantenes, formado por lavas almohadilladas y diques asociados y cubiertos por la Formación Guandacol (en la zona corresponde a la Formación Cerro Tres Cóndores). Como no se ha podido llegar a estos afloramientos, no se tiene más información que los antecedentes. Sin embargo, por su composición y estructura almohadillada, y teniendo en cuenta que en el perfil observado se encuentran entre los esquistos verdes y esquistos calcáreos de la Formación Río Bonete y por debajo de la Formación Quebrada Seca, por el momento se consideran estas lavas dentro del Ordovícico. Estos autores además las separan de otras rocas básicas mas jóvenes entre la Formación Guandacol y Tupe, a las que antes se consideraba dentro de la denominación de Andesita Cerro Chuscho (Aceñolaza et al., 1971), pero que probablemente correspondan a la Formación Punta del Agua (?) (González y Bossi, 1986).

El Granito Potrerillos (Aceñolaza y Bernasconi, 1969b) o Formación Potrerillos (Maisonave, 1979) está intruyendo y asimilando parte de las metasedimentitas estratificadas ordovícicas. Es un plutón principalmente monzonítico, pero compuesto por distintas facies, desde gabros y dioritas hasta granitos rosados. Por el momento se prefiere diferenciar del granito del cerro de Las Tunas, mas al oeste, ya que éste no se ha estudiado. Por los datos existentes de petrografía y edad, así como por su aspecto en las imágenes satelitales y fotografías aéreas, el granito del cerro Las Tunas se incluye dentro del magmatismo gondwánico mientras que el plutón de la quebrada de Potrerillos se incluye aquí dentro del magmatismo mas tardío del ciclo famatiniano (Frigerio et al., 2010).

En los afloramientos sobre la quebrada del río Bonete hay que tener presente que los distintos tipos litológicos de las unidades circundantes se encuentran asociadas y deformadas dentro de la importante faja de cizalla dúctil que se expone por allí ('faja de deformación de Jagüé', Martino y Astini, 1998). Esta faja involucra a esquistos, mármoles, metasedimentitas, rocas básicas y al granito, que debido a la deformación dúctil han sido transformadas en variedades de esquistos miloníticos, milonitas y filonitas: filitas y esquistos cloríticos y biotíticos (paraderivados), esquistos verdes clorítico - epidótico - actinolíticos, esquistos calcáreos, anfibolitas y metabasitas, y esquistos y milonitas blanquecinas cuarzo - feldespático - muscovíticos (ortoderivadas). 
Aunque Martina y Astini (2009) proponen utilizar el término Complejo Metamórfico Río Bonete "para la unidad con deformación dúctil" de la faja de cizalla, éste no es exactamente equivalente ni a la Formación Río Bonete ni a la faja de deformación de Jagüé tal como se consideran en este trabajo. Estos autores, a diferencia de lo aquí observado, consideran dentro de este Complejo Metamórfico sólo a las unidades pre-ordovícicas, dentro de las que describen "1- mámoles, 2milonitas y ultramilonitas graníticas (= ortogneises de Martino y Astini, 1998); y 3-anfibolitas (litología predominante)", y en el mapeo que se hace sobre la quebrada del río Bonete dentro de esta unidad se incluye a toda la faja de cizalla. Por esta misma razón tampoco es equivalente a la Formación Río Bonete ya que los autores homologan el Complejo Metamórfico con la faja de cizalla, cuando se trata de una de las unidades litoestratigráficas afectadas por la faja de cizalla. En todo caso convendría redefinir el Complejo Metamórfico Río Bonete como una unidad mapeable equivalente a la faja de cizalla y que involucra a la Formación Río Bonete y también a unidades más jóvenes (Formaciones Río Bonete, Del Salto, Chuscho, Jagüé? y Potrerillos), restringiéndola arealmente y ampliando la variedad de litologías y edad de las unidades a la que afecta. Hay que tener en cuenta que la faja de cizalla no constituye una unidad litoestratigráfica, y que su distribución areal se restringe a la faja de deformación que pasa por el río Bonete (Anexos A1: M1).

En conclusión, por las evidencias que se tienen, en este trabajo de tesis se considera que la faja de cizalla agrupa a rocas de distinta edad y origen, incluyendo con seguridad a la Formación Río Bonete, Formación Del Salto, Formación Chuscho y Granito Potrerillos (Figuras 3.1 y 3.2). Por ello aquí se prefiere hablar de faja de cizalla (o faja de deformación de Jagüé, Martino y Astini, 1998) para describir al conjunto de rocas involucradas por esta deformación que ha sido reactivada hasta incluso el Carbonífero Inferior, y continuar usando la denominación original de Aceñolaza (1969) para la Formación Río Bonete, compuesta sólo por los esquistos verdes y rocas calcáreas que se encuentran asociados en los afloramientos.

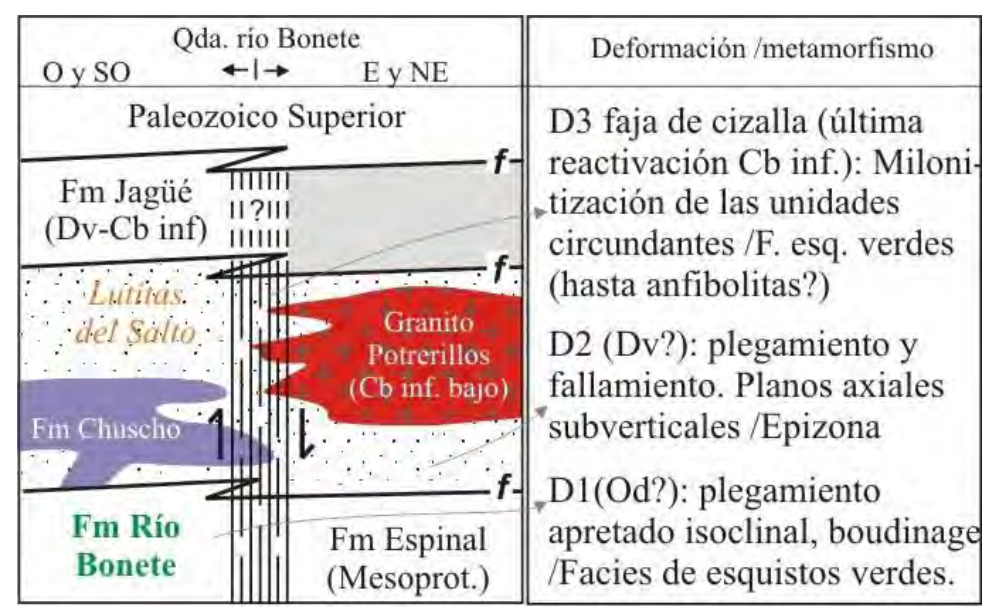

Figura 3.1: Síntesis estratigráfica de las unidades relacionadas con la deformación.

No ha sido posible distinguir si la faja de deformación involucra además a las unidades devónico-carboníferas inferiores (Formaciones Jagüé y Agua de Lucho). Pero con seguridad su última reactivación ocurrió en el Carbonífero Inferior, previamente al depósito de los conglomerados que inician la secuencia carbonífera que se superponen en discordancia angular a la faja de deformación en el tramo medio del río Bonete (sección 3.2.8), y con posterioridad al emplazamiento del granito Potrerillos. Esta discordancia angular es un carácter que se observa claramente en todo este sector de 
la Precordillera, y correspondería a la discordancia angular generada durante la fase Chánica (Cuadro $3.2)$.

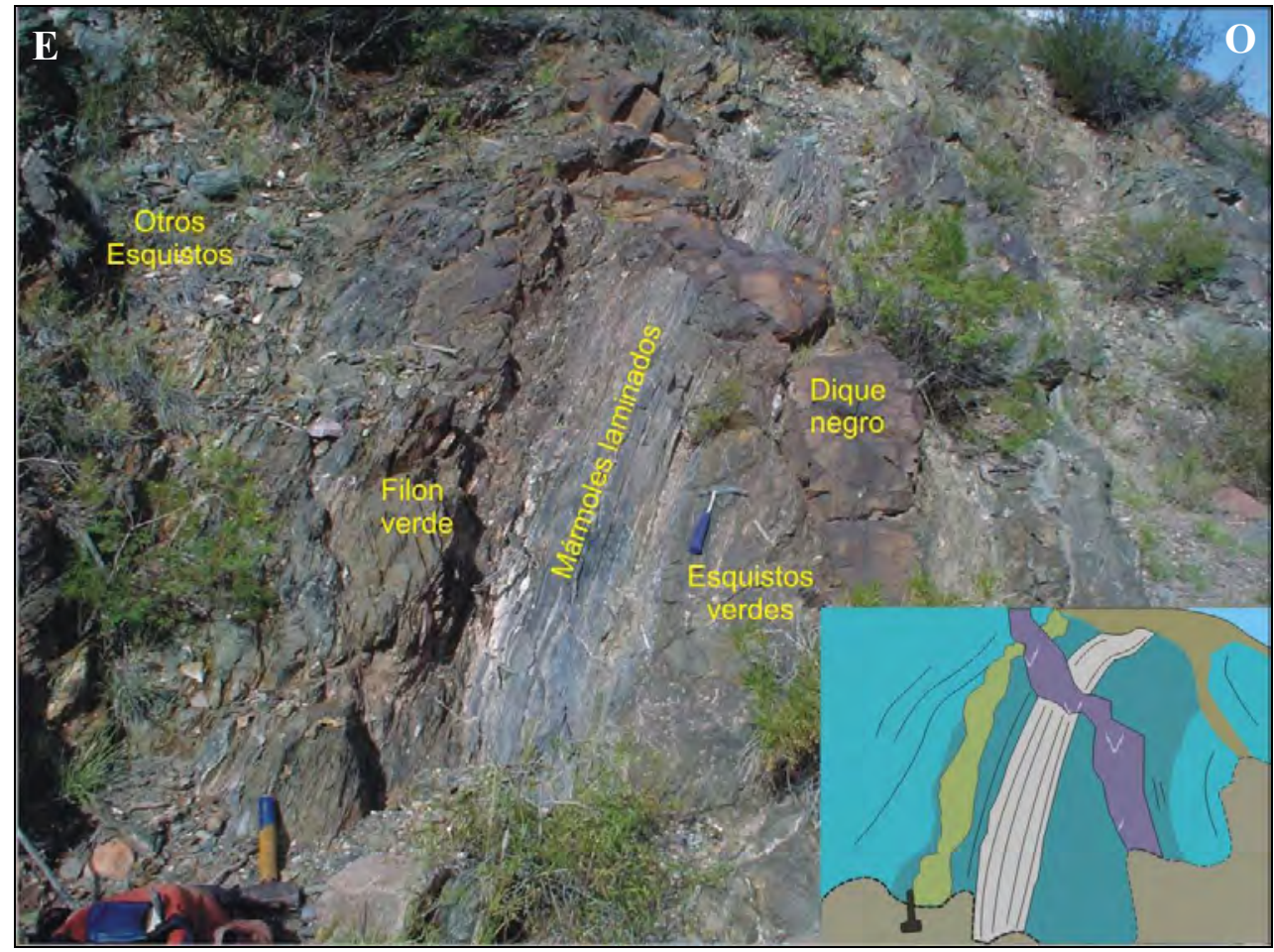

Figura 3.2: Algunas relaciones de corte entre unidades observadas en la boca del Bonete, dentro de la faja de cizalla. Una franja de esquistos calcáreos grises y verdosos asociados a esquistos verdes de la Formación Río Bonete s.s. se encuentran entre otras variedades de esquistos (esquistos biotíticos y cuarzo-feldespáticos, no se llega a apreciar en la fotografía). El conjunto es cortado por un filón verde deformado y abudinado apenas levemente discordante. Luego todas las rocas son cortadas por un dique negro afanítico sin deformar.

Con posterioridad a la depositación de la secuencia devónico carbonífera inferior y por encima de la faja de cizalla del río Bonete aparecen en fuerte discordancia angular las sucesiones clásticas del Paleozoico Superior. Estas se agrupan en dos secuencias (Fauqué y Limarino, 1991), una carbonífera que inicia con los conglomerados previamente mencionados (conglomerado castaño, Formación Cerro Tres Cóndores), y luego una secuencia carbonífera superior - pérmica inferior representada en este sector por la Formación Río del Peñón (González y Bossi, 1987). La discordancia entre ambas correspondería a la denominada discordancia intracarbonífera generada durante la fase diastrófica Río Blanco, de importancia en toda esta región (Cuadro 3.2).

En toda la región aparecen diques negros basálticos subverticales y sin deformar, cortando a todas las unidades, incluso a los conglomerados castaños. La orientación general de estos diques varía entre O - E y SO - NE, y coincide con la orientación de la faja de conglomerados que atraviesa la quebrada del Bonete por su tramo medio y con las estructuras compresivas (plegamientos suaves de gran escala) que afectan al Paleozoico Superior. La edad de estos diques se desconoce pero por las relaciones de corte y composición podrían ser Triásicos?, con dudas (capítulo 3.2.3.2).

El Terciario está representado en la región por depósitos clásticos aterrazados sinorogénicos de la Formación Toro Negro, asociados a la cuenca de antepaís de Vinchina (Ramos, 1999). Luego, hacia el noroeste, el complejo piroclástico - volcánico de la Formación Veladero (Pleistoceno 
Inferior; Marcos et al., 1971), forma un cordón montañoso con las mayores altitudes en el área, representadas por los cerros Bonete $(6.882 \mathrm{msnm})$, Bonete Chico $(6.850 \mathrm{msnm})$ y El Morado (5.300 msnm). Por último aparecen depósitos aluviales pedemontanos, depósitos fluviales, coluviales y evaporíticos cuaternarios como los que rellenan el Bolsón de Jagüé y salinas de la Laguna Brava.

\section{2- UNIDADES.}

\subsection{1- FORMACIÓN ESPINAL (Turner, 1964).}

La Formación Espinal es la unidad más antigua de la región. Fué definida por Turner (1964) en la Sierra del Espinal, extendiéndose hacia el norte por la Sierra de Toro Negro. Incluye esquistos, anfibolitas, gneises, metacuarcitas y mármoles; todo el conjunto está intruído por rocas ultrabásicas. Constituye parte del basamento metamórfico de medio y alto grado de las Sierras Pampeanas noroccidentales y posee una composición y estructura compleja. No hay casi información sobre estudios específicos de esta unidad en todos los afloramientos que se encuentran al oeste de la Sierra del Toro Negro. Puede citarse como principal referencia la descripción que hace Maisonave (1979) en la hoja geológica 14c Cerros Cuminchango. En la región de estudio, la Formación Espinal se pone en contacto a través de fracturas con unidades ordovícicas y del Paleozoico Superior al oeste (Precordillera de Jagüé), y con rocas terciarias y sedimentos cuaternarios del Bolsón de Jagüé al este (Aceñolaza et al., 1971).

A este basamento se lo incluye en diferentes terrenos alóctonos o paraautóctonos que habrían colisionado con el margen occidental de Gondwana durante el Paleozoico Inferior (Astini et al., 1995; Dalziel, 1997; Dalla Salda et al., 1993; Thomas y Astini, 1996, 1999; Ramos et al., 1986, 1993, 1998; Aceñolaza y Toselli, 1988, 2000, Aceñolaza et al., 2002; Rapela et al., 2010).

\section{a. Afloramientos.}

Se tomaron muestras de la Formación Espinal en el margen más occidental de los afloramientos sobre la quebrada del río Frío, al oeste de la quebrada del río Cuminchango, en coordenadas $28^{\circ} 27^{\prime} 10,1^{\prime \prime}$ latitud S y $68^{\circ} 22^{\prime} 56,1^{\prime}$ " longitud O (2230 msnm). Este sector está cerca del límite tectónico principal entre este basamento (Sierra del Toro Negro, Sierras Pampeanas Occidentales) y los afloramientos de la Precordillera de Jagüé, allí conformados por un bloque en que la Formación Del Salto es intruida por el Granito Potrerillos. El aspecto general del basamento en éste sector es heterogéneo, con predominio de un bandeamiento composicional y lineación mineral de inosilicatos (Figura 3.1.1). 

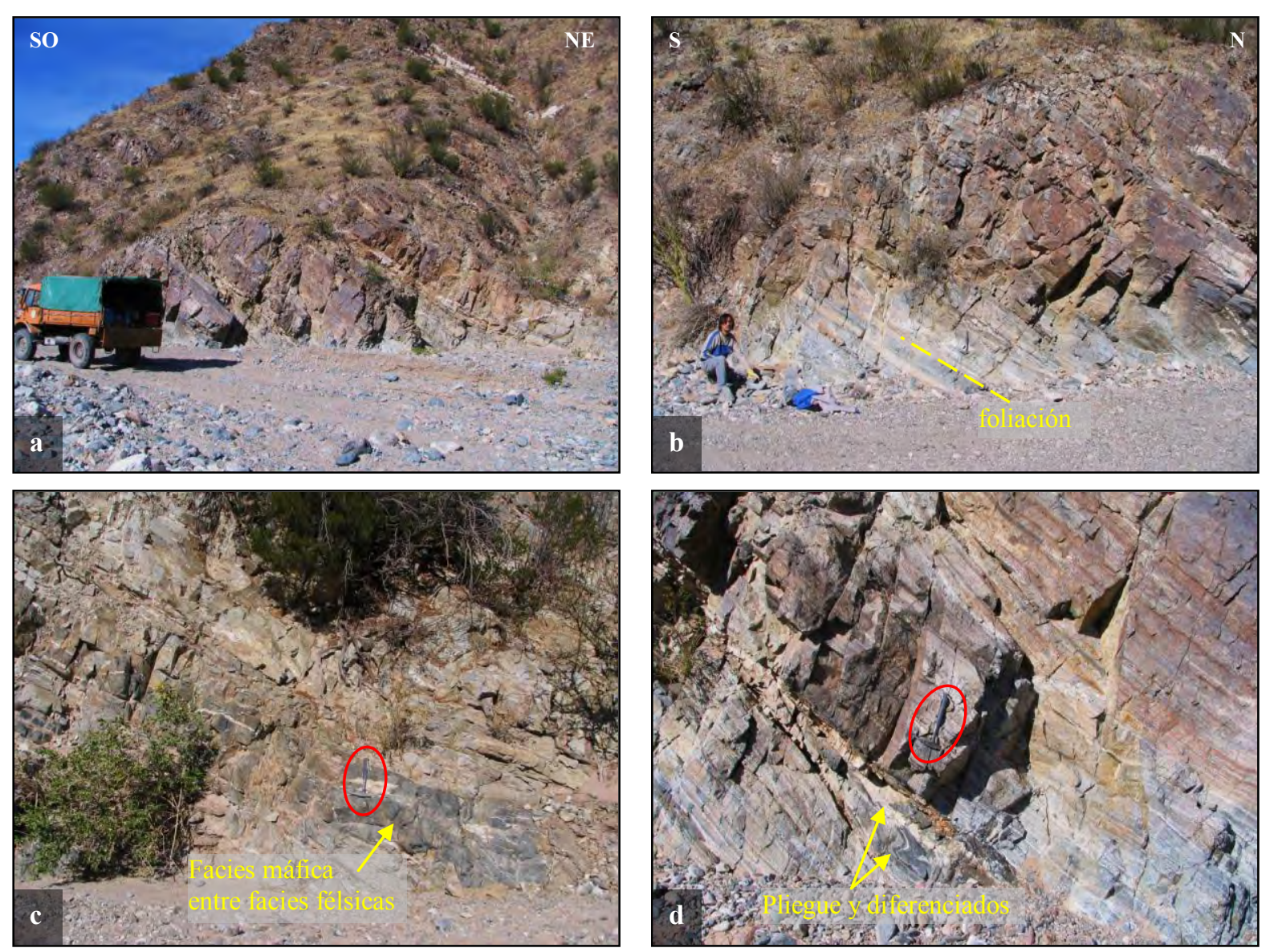

Figura 3.1.1: a, b)- Aspecto general de los afloramientos de la Formación Espinal, basamento metamórfico de Sierras Pampeanas Occidentales, sobre la desembocadura del Río Frío, al norte del Bolsón de Jagüé. Se observa la fuerte foliación, con plegamientos de distinta escala y variaciones litologicas. a, b)- Detalles. Los círculos marcan la ubicación de la piqueta geológica como escala.

En este sector del basamento aparecen rocas bien foliadas con coloraciones generalmente oscuras. Están compuestas por gneises y esquistos anfibólicos, granatíferos y biotíticos. Los minerales accesorios más comunes son la apatita, el circón y minerales opacos. Las rocas estan afectadas por un metamorfismo de medio a alto grado, y se genera una foliación composicional (bandeado gnéisico) y lineación mineral de inosilicatos negros (Anf/Cpx) y cuarzo. La foliación tiene una actitud $\mathrm{Az} \mathrm{N}$ $153^{\circ} / 33^{\circ} \mathrm{O}, \mathrm{Rbz} 230^{\circ} / 45^{\circ}$, Rbz $229^{\circ} / 44^{\circ}$, mientras que la lineación mineral sobre el plano de foliación tiene una actitud dominante $\mathrm{Rbz} 260^{\circ} / 41^{\circ}$ en este sector. La deformación está caracterizada por milonitización y plegamientos a escala mesoscópica (Figura 3.1.1d). Se distinguen filones compuestos por cuarzo, feldespato, anfibol y granate que en general son coherentes con la foliación, aunque algunos son discordantes.

\section{b. Petrografía.}

En líneas generales aparecen en este sector dos litologías: anfibolitas o gneisses anfibólicos y gneisses o esquistos biotíticos. Además se encuentran gneisses anfibólico-biotíticos (Lámina 3), que serían rocas transicionales entre ambos extremos. A continuación se describen. 
Anfibolitas o gneisses anfibólicos (Lámina 1), compuestos por anfíbol verde (Hbl), clinopiroxeno incoloro, plagioclasa, cuarzo y escaso feldespato potásico como microclino. Pueden aparecer además porfirocristales relícticos de clinopiroxeno incoloro con coronas y a veces parches de anfíbol al cual aparentemente se está transformando. También se presenta epidoto, calcita, biotita, y titanita, esta última generada comúnmente como coronas a expensas de opacos anedrales y generalmente intersticiales (ilmenita?). Localmente pueden observarse mirmequitas. La alteración principal es sericítica o saussuritización de las plagioclasas. El protolito correspondería a una roca básica con asociación Cpx $+($ Anf?) $+\mathrm{Pl}+$ Qtz (Muestras QRF-B1, J1, J2, J6). Sin embargo algunas de estas rocas derivarían de rocas sedimentarias (para-anfibolitas, ej, QRF-B1) como lo indican las observaciones petrográficas y geoquímicas. La muestra $\mathrm{J} 2$ presenta parches de un mineral incoloro y muy fibroso, producto de la retrogradacion de inosilicatos (tremolita?).

Gneises o esquistos biotíticos (Lámina 2), con granate (almandino). Compuestos principalmente por biotita, plagioclasa, cuarzo, a veces feldespato potásico, y granate. Además se pueden observar algunas plagioclasas mirmequíticas. El granate crece a partir de la biotita. Puede registrarse muscovita y clorita a partir de la biotita. El protolito correspondería a rocas sedimentarias principalmente, con asociación Qtz - feldespato - filosilicatos. - (Muestras J4, J5). En la muestra J4 existen escasas concentraciones de tremolita? incolora y muy fibrosa.

Gneises anfibólico - biotíticos (Lámina 3). Son sectores transicionales entre ambos extremos litológicos. Presentan una asociación mineral intermedia, con anfíbol y biotita, además de plagioclasa, cuarzo y microclino. - (Muestra J3).

Por la mineralogía presente en todas las rocas evidentemente hubo alta proporción de Ca y Ti en el ambiente en que se generaron (Cal, Ca-Pl, Ep, Ttn-Ilm). Por los datos de petrografía y geoquímica estas anfibolitas serían en su mayor parte para-derivadas (ver secciones siguientes).

Las características petrográficas detalladas observadas en las muestras de mano y al microscopio petrográfico se resumen en el Anexos A4: Cuadro I.

\section{c. Geoquímica.}

Se analizaron dos muestras del basamento correspondientes a los gneisses anfibólicos QRF-B1 (1 y 2; análisis en Anexos A6a: Tabla 1). Ambas muestras presentan composiciones similares tanto de elementos mayoritarios como minoritarios y trazas, con valores de LOI inferiores o iguales a $2 \%$. La composición geoquímica dominante es intermedia y presenta similitudes con la de una roca tipo vaque. El contenido de $\mathrm{SiO}_{2}$ varía entre 60,35 y $60,98 \%$, el de $\mathrm{Al}_{2} \mathrm{O}_{3}$ entre 14,68 y 14,79 \%, presentan altos tenores de $\mathrm{CaO}(7,35$ y $6,85 \%)$ y los porcentajes de $\mathrm{Fe}_{2} \mathrm{O}_{3}$ total $(6,16$ y $6,18 \%), \mathrm{MgO}(2,02 \%)$ y $\mathrm{TiO}_{2}$ (entre 0,8 y $0,9 \%$ ) son intermedios o un poco elevados. Los valores de $\mathrm{P}_{2} \mathrm{O}_{5}$ (alrededor de 0,2 \%), $\mathrm{Na}_{2} \mathrm{O}(3,07$ y $3,13 \%), \mathrm{K}_{2} \mathrm{O}(2,8$ y $2,9 \%)$ y $\mathrm{Cr}_{2} \mathrm{O}_{3}(0,007$ y $0,026 \%)$ son normales.

Entre los elementos minoritarios y trazas se destacan altos valores de Ba (alrededor de 800 ppm), Sr (entre 530 y 600 ppm), y en menor medida el Y (45,3 y 42,7 ppm). Los valores para 

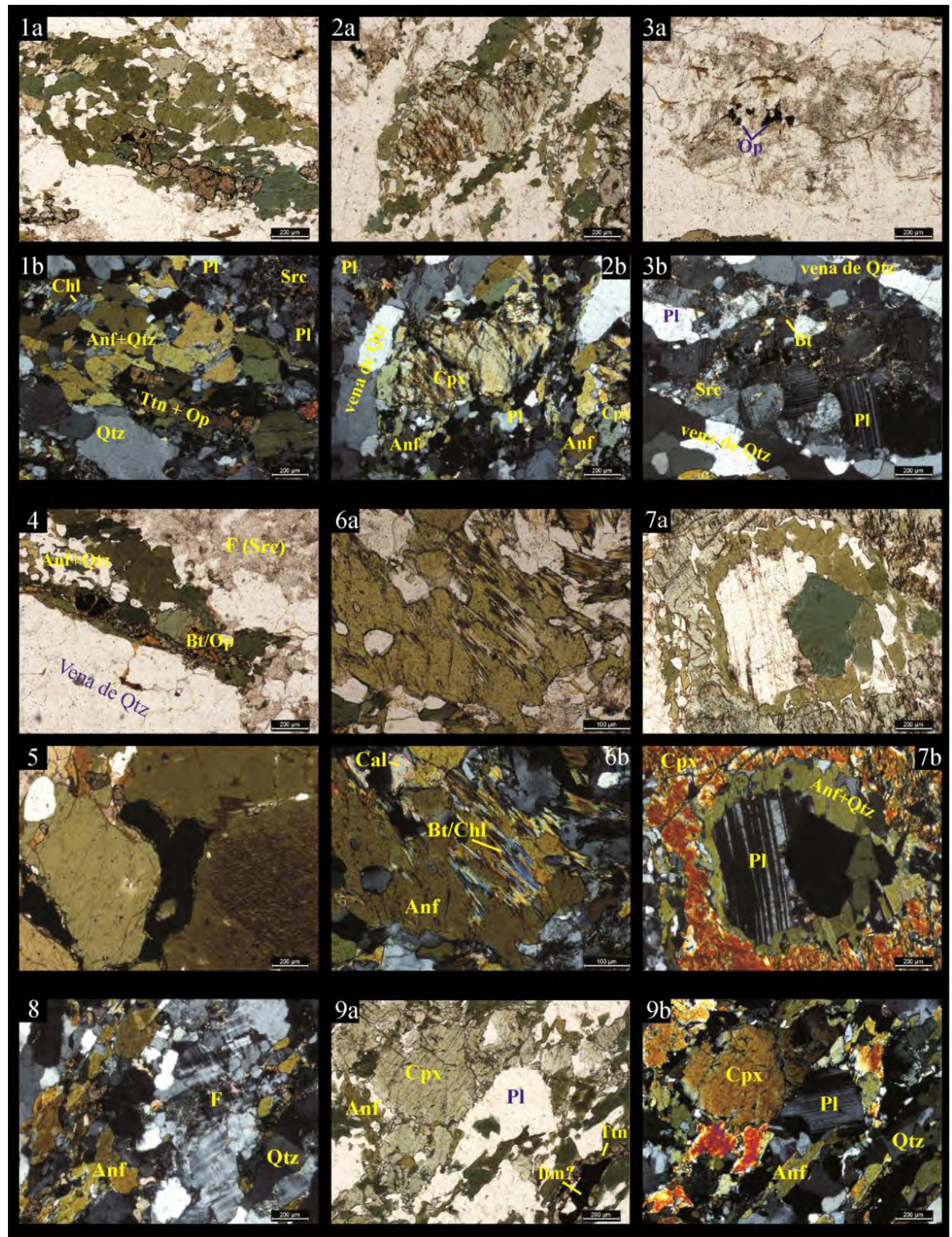

Lámina 1: Microfotografias de los cortes delgados correspondientes a anfibolitas y gneisses anfibólicos de la Formación Espinal. Fotos 1 a 4, 6: muestra QRF-B1(A); fotos 7a,b: muestra QRF-B1(B); foto 5: muestra J1; fotos 8 y 9: muestra J6. La escala se incluye en cada imagen. La composición y textura general de la roca puede apreciarse en las fotos 1, 2, 4 y 9

1a,b)- titanita asociada a opacos en una lente compuesta por anfibol y cuarzo. 2a,b)- núcleo de Cpx con manto y colas de anfíbol más cuarzo. 3a,b)- dominio rico en plagioclasas. 4)- asociación de biotita con opaco y titanita y anfibol con cuarzo en una lente de dominio máfico rodeado por venas de cuarzo; arriba a la derecha de ve un sector feldespático con abundante alteración sericítica. 5)- detalle: corona de titanita sobre un mineral opaco intersticial, probablemente ilmenita, entre anfiboles. 6a,b)- Anfibol con inclusiones de cuarzo y de biotita alterada a clorita. 7a,b)- desarrollo de un anillo de anfibol y cuarzo a partir de la retrogradación de un cristal de clinopiroxeno que engloba una plagioclasa. 8)-dominio rico en feldespato en un sector con predominio de microclino. 9a,b)-composición y orientación de los componentes principales de las rocas. 


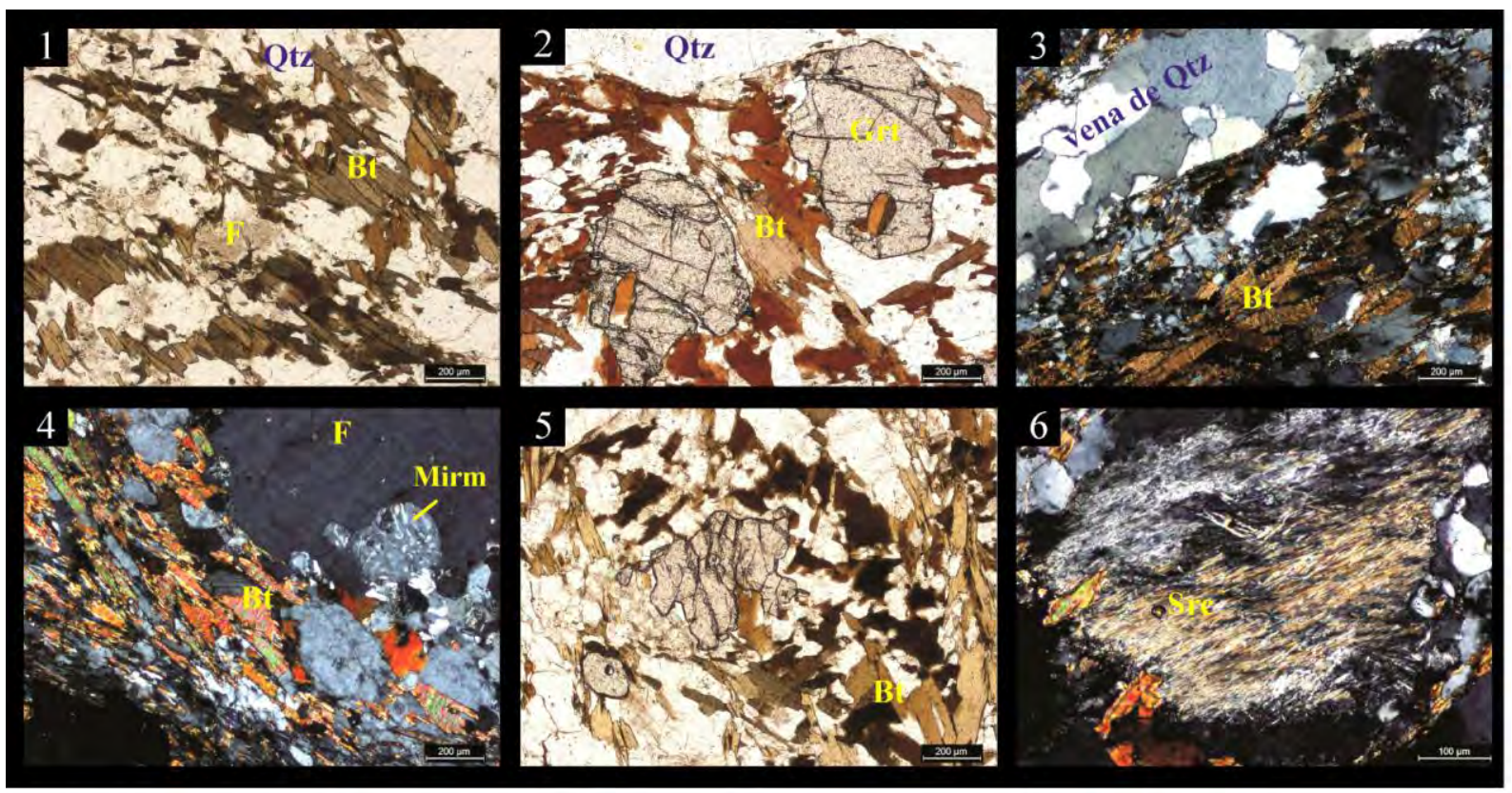

Lámina 2: Microfotografías de los cortes delgados correspondientes a gneisses y esquistos biotíticos de la Formación Espinal. La escala se incluye en cada imagen. Fotos 2,4 y 6: muestra J4; fotos 1,3 y 5 : muestra J5. Los componentes principales son biotita (Bt), feldespatos (especialmente $\mathrm{Pl}$ ) y cuarzo, con presencia común de granate (fotos 2 y 5 ) y segregación de venas de cuarzo (foto 3). Los feldespatos se encuentran comúnmente alterados a sericita (foto 6). Se ha observado el desarrollo de mirmequitas (foto 4 ).

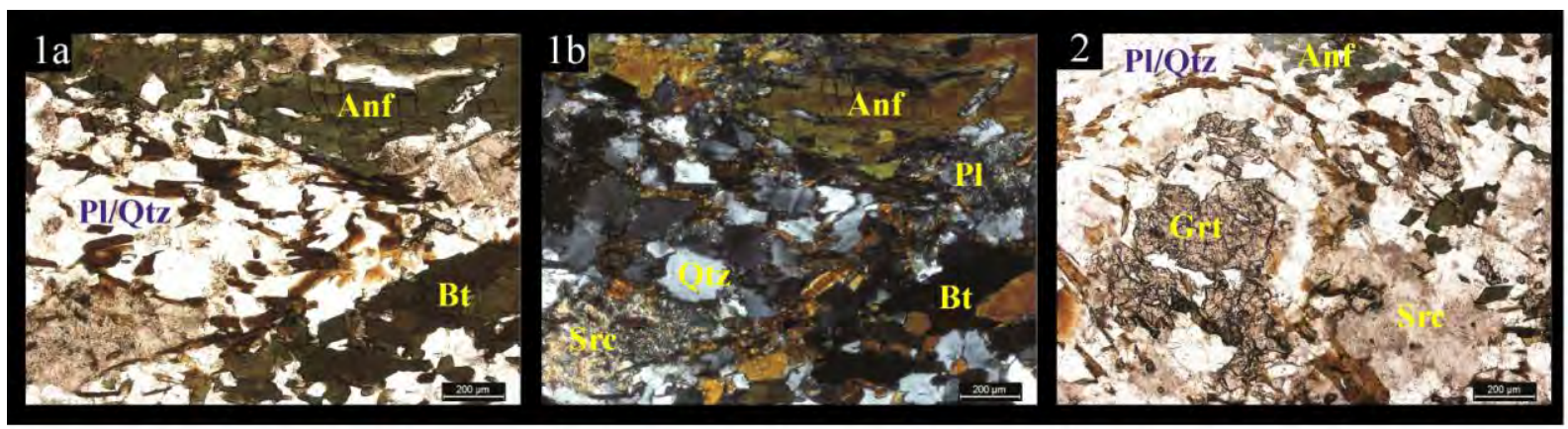

Lámina 3: Microfotografías de los cortes delgados correspondientes a gneisses anfibólico-biotíticos de la Formación Espinal (muestra J3).La escala se incluye en cada imagen. Se encuentran compuestos por biotita (Bt), anfibol (Anf), feldespato y cuarzo (Qtz), con presencia de granate (Grt, foto 2). Entre los feldespatos predomina la plagioclasa (Pl) y subordinado el microclino, comúnmente se encuentran parches de alteración sericítica $(\mathrm{Src})$.

elementos que usualmente se usan como trazadores de fuentes máficas ( $\mathrm{Co}, \mathrm{Ni}, \mathrm{Sc}, \mathrm{V})$ o félsicas (Hf,Th, Zr) son intermedios y similares a los que presentan las metasedimentitas de la Formación Del Salto y esquistos micáceos de la faja de cizalla (ver capítulos siguientes y Anexos A6a: Tabla 3).

\section{Tierras Raras:}

La movilidad de la REE en las rocas metamórficas es un tema de discusión en la literatura y no hay resultados concluyentes (Brod, 2004). Sin embargo, los diagramas de tierras raras normalizados al condrito C1 (Taylor y McLennan, 1985) presentan un patrón característico y valores similares a los de las rocas corticales, con un enriquecimiento en tierras raras livianas $\left(\mathrm{La}_{N} / \mathrm{Sm}_{N}=4,7\right.$ y 3), una rama subhorizontal de tierras raras medias y pesadas $\left(\mathrm{Gd}_{\mathrm{N}} / \mathrm{Yb}_{\mathrm{N}}=1,8\right.$ y 1,4$)$ y una anomalía de Eu negativa (Eu/Eu*) de 0,6 (Figura 3.1.2b). 


\begin{tabular}{|c|c|c|c|}
\cline { 2 - 4 } \multicolumn{1}{c|}{ a) } & $\begin{array}{c}\text { C1 } \\
\text { ppm }\end{array}$ & $\begin{array}{c}\text { QRF-B1(1) } \\
\text { /C1 }\end{array}$ & $\begin{array}{c}\text { QRF-B1(2) } \\
\text { /C1 }\end{array}$ \\
\hline La & 0,3670 & 107,90 & 112,26 \\
Ce & 0,6240 & 145,83 & 145,19 \\
Pr & 0,1370 & 81,46 & 81,17 \\
Nd & 0,7110 & 63,43 & 63,57 \\
Sm & 0,2310 & 39,35 & 37,66 \\
Eu & 0,0870 & 20,34 & 18,97 \\
Gd & 0,3060 & 27,42 & 25,98 \\
Tb & 0,0580 & 23,28 & 22,07 \\
Dy & 0,3810 & 19,74 & 19,66 \\
Ho & 0,0851 & 18,45 & 17,63 \\
Er & 0,2490 & 18,76 & 18,11 \\
Tm & 0,0356 & 20,22 & 18,54 \\
Yb & 0,2480 & 17,54 & 18,02 \\
Lu & 0,0381 & 17,59 & 16,80 \\
Y & 2,1000 & 21,57 & 20,33 \\
\hline$\sum \mathbf{R E E} *$ & & 226,96 & 226,97 \\
\hline
\end{tabular}

b)

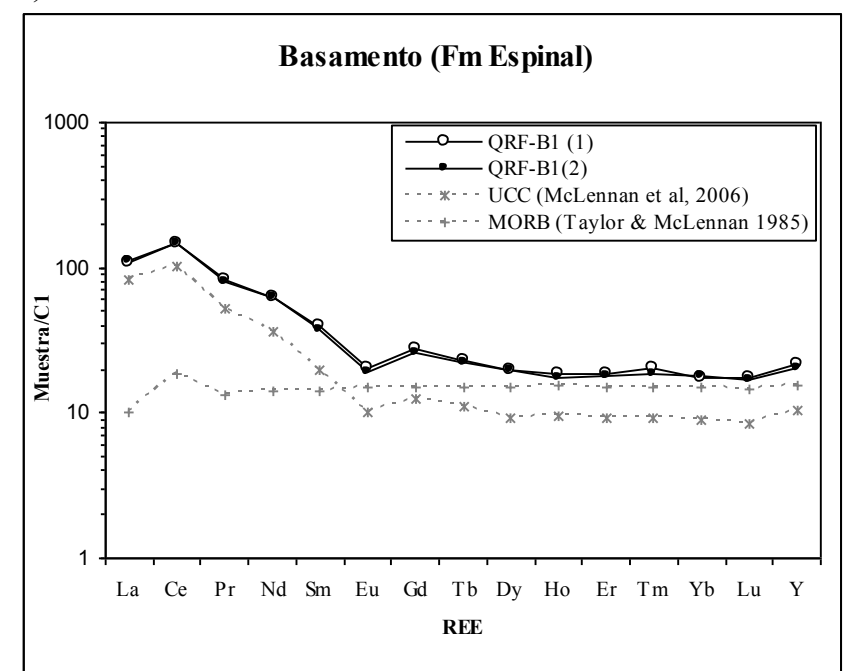

Figura 3.1.2: a- Tabla de datos y normalización de las tierras raras de la muestra QRF-B1 (1 y 2) al condrito C1 (Taylor \& McLennan, 1985); b- Diagrama de tierras raras normalizado a C1 para esta muestra. $(*)$ : en la sumatoria de REE no se incluye al Y.

La anomalía positiva de Ce observada puede tener más de una explicación. Generalmente en rocas sedimentarias se considera que esta anomalía puede deberse al efecto de la existencia de un ambiente oxidante en el que el $\mathrm{Ce}^{+3}$ cambia a $\mathrm{Ce}^{+4}$. Puede deberse a la presencia de carbonatos y rocas calcosilicáticas en el protolito, que comúnmente presentan esta característica. Este rasgo se ha observado en todas las muestras que se han analizado, independientemente de su litología, por lo que se asume que en este caso se debe al patrón que se usó para las mediciones en el laboratorio (ver capítulos siguientes).

\section{d. Geocronología.}

Se dató la anfibolita QRF-B1 por el método U/Pb ID-TIMS sobre 4 granos de circones detríticos (Anexos A6b: Tabla 1). Los circones observados en las muestras de la Formación Espinal en este sector son elongados pero subredondeados y bien redondeados (Figura 3.1.3b) Pueden presentar fracturas u superficies irregulares. Se obtuvo una discordia cuya intersección superior dio una edad de $905+14 /-13 \mathrm{Ma},(\mathrm{MSWD}=0,74)$.

\section{Correlaciones:}

La Formación Espinal constituye parte del basamento de medio a alto grado de las Sierras Pampeanas Occidentales de Toro Negro, Maz y Espinal. Por su edad mesoproterozoica (grenvilliana) a este basamento se lo incluye entre un conjunto de terrenos alóctonos - paraautóctonos que habrían colisionado con el margen occidental de Gondwana durante el Paleozoico inferior (Dalla Salda et al., 1992; Ramos et al., 1986, 1993; ver también la síntesis en Fauqué y Villar, 2003; Rapela et al., 2010; 


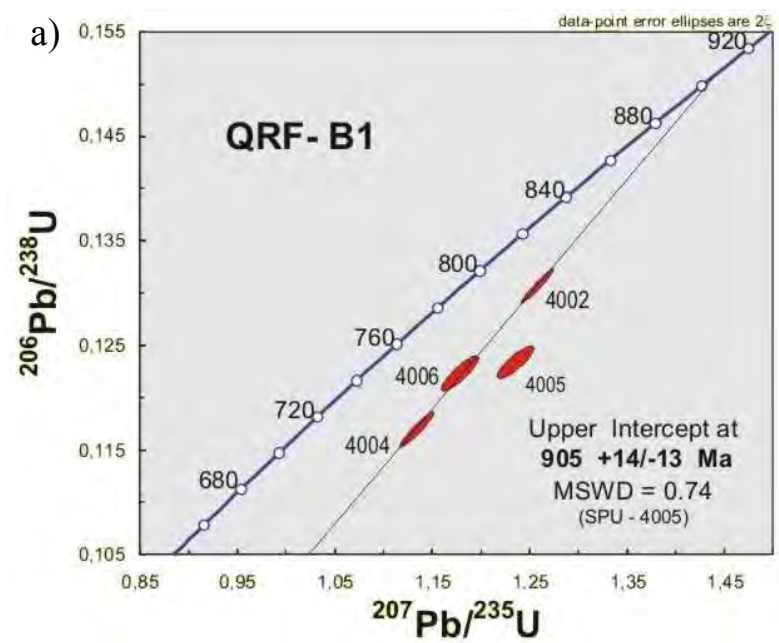

b)

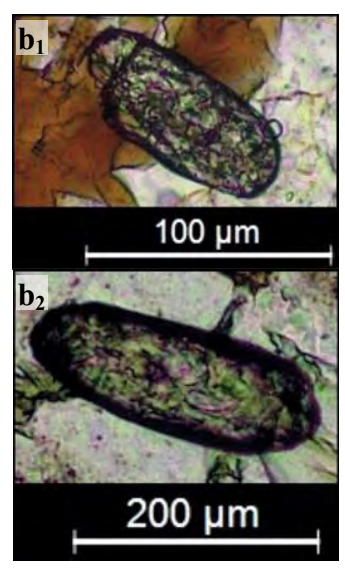

Figura 3.1.3: a- Diagrama discordia de U-Pb y edad obtenida para la muestra QRF-B1. b- Microfotografias con luz polarizada de dos granos de circones detríticos característicos de las muestras J4 $\left(b_{1}\right)$ y QRF-B1 $\left(b_{2}\right)$.

Varela et al., 2011) constituyendo los bloques más septentrionales del terreno Cuyania. Varela et al. (1996) obtuvieron una edad Rb-Sr de 1.030 \pm 30 Ma para rocas del basamento (Formación Espinal) en la Sierra de Umango, homologándolo con el ciclo orogénico Grenville Meso-Proterozoico. Luego se obtuvo una edad U-Pb de $1108 \pm 13 \mathrm{Ma}$ (Varela et al., 2003) para el mismo basamento confirmando la edad mesoproterozoica.

La Formación Umango (Arigós, 1956) se diferencia de la Formación Espinal porque reúne rocas de bajo grado metamórfico (Varela et al., 2003, 2011).

El basamento de la Precordillera s.s. no está expuesto y se conoce a través de xenolitos que arrastraron lavas miocenas en los Cerros Blanco y Ullún, en el este de la Precordillera oriental. Estos xenolitos son metamorfitas en facies granulita y anfibolita, deformados penetrativamente, que equivalen a rocas ígneas máficas y ácidas. Abruzzi et al. (1993) describen estas rocas y reportan una edad $\mathrm{U} / \mathrm{Pb}$ en circones de $1.188 \pm 122 \mathrm{Ma}$ en un xenolito silíceo, que interpretan como la edad a la que se formó el basamento. Consideran que el basamento de la Precordillera y su plataforma cambro ordovícica es derivada de Laurentia. Sin embargo, consideran que la continuación de éste basamento con el que se expone en las Sierras Pampeanas, al este, no está clara aun.

Existe más de una interpretación respecto a en qué ambiente geotectónico se habría generado el basamento del Terreno Cuyania (o Terreno Precordillera): Por un lado, los xenolitos que representarían el basamento de Precordillera fueron interpretados como formados en un ambiente de arco-trasarco oceánico, cerca del margen continental de Laurentia durante el Ciclo Grenvilliano (Kay et al., 1996). Por otro lado, el basamento de Sierras Pampeanas Occidentales está representado por el Complejo Pié de Palo, que aflora en la sierra de Pie de Palo y cerros Valdivia y Barboza. Las rocas meta-ígneas presentan afinidades con rocas de arco, trasarco, N-MORB y E-MORB; sería un complejo de supra-subducción que evolucionó cerca del margen de Laurentia (Vujovich y Porcher, 2008).

En Rapela et al., (2010) la Precordillera de Jagüé es considerada junto al basamento expuesto en la Sierra de Toro Negro dentro del Cinturón Famatiniano de las Sierras Pampeanas Occidentales 
(Rapela et al., 2010: Figura 1), que implica "una asociación de rocas proterozoicas, cámbricas (en parte basamento pampeano) y ordovícicas, con un metamorfismo ordovícico-silúrico sobreimpuesto e intruida por un magmatismo de arco ordovícico (484-463 Ma)". Estos autores estudian y comparan afloramientos de las sierras de Maz y Pie de Palo y xenolitos de la sierra de Ullún (representando el basamento de Precordillera). La sierra de Maz registraría la evolución de un arco desarrollado en margen continental, mientras que los otros dos sectores corresponden al desarrollo de una sucesión de arcos magmáticos oceánicos. Se expresa que "la historia geodinámica en ambas áreas estudiadas revelan una evolución orogénica compleja, dominada por una tectónica convergente $y$ acreción de arcos oceánicos juveniles al continente" (Rapela et al 2010).

En Varela et al (2011) los autores consideran la posibilidad de que el cinturon orogénico famatiniano (Cambrico tardío - Devónico tardío) esté formado por un par de cinturones móviles apareados ordovícicos, uno de alta $\mathrm{P} / \mathrm{T}$ al oeste y uno de mediana $\mathrm{P} / \mathrm{T}$ al hacia el este. La Precordillera de Jagüé, junto a las Sierras Pampeanas noroccidentales de Umango, Espinal, Maz y Toro Negro forman parte del cinturon occidental de alta $\mathrm{P} / \mathrm{T}$ en el segmento norte de este orogeno (Varela et al., 2011: Figura 10). El mismo sería el resultado de la colisión de los terrenos Cuyania y Chilenia, y consideran tres etapas del ciclo Famatiniano: una fase principal (480 - 450Ma), una fase tardía (440 420Ma), y por último la fase Chanica $(400-360 \mathrm{Ma})$.

3.2.2- FORMACIÓN RÍO BONETE (Aceñolaza, 1969; Aceñolaza et al., 1971; parcialmente Complejo Metamórfico Río Bonete, Martina y Astini, 2009)

La Formación Río Bonete es una compleja asociación de pizarras, filitas y esquistos verdes, metabasitas y mármoles, intensamente deformados, y metamorfizados en facies de esquistos verdes. Se encuentran intercalados con filones básicos (metabasitas) y cortados por diques feno-andesíticos y basálticos. Lo que originalmente fuera sintetizado por Aceñolaza et al., (1971) dentro de esta unidad aflora en una zona muy compleja tectónicamente y reúne rocas de distinto origen y/o edad. La presencia de rocas calcáreas y de fósiles ordovícicos en uno de estos afloramientos permitieron correlacionar estas unidades con la Precordillera, extendiendo así sus afloramientos hacia el norte, en la desde entonces denominada Precordillera de Jagüé. Sin embargo, el conjunto de características litológicas, estructurales, y aspecto en general (textura, color, etc.) que presentan los afloramientos luego de un mapeo de mayor detalle, así como los resultados de los análisis petrológicos, geoquímicos e isotópicos realizados, han permitido identificar y comparar distintos conjuntos de rocas, y separar a la Formación Río Bonete en dos asociaciones: esquistos verdes relacionados a mármoles por un lado, y rocas metasedimentarias estratificadas (intercaladas con lavas almohadilladas) por otro. Las lutitas 
intercaladas entre estas últimas son las portadoras de fósiles y por lo tanto lo único claramente documentado como Ordovícico.

Por otro lado, ya se ha mencionado que sobre la quebrada del Bonete, especialmente en su tramo inferior y en la zona de la Boca de la quebrada (antes del dique que deriva agua al pueblo de Jagüé), la importante faja de cizalla dúctil que pasa por allí provoca que estos esquistos se intercalen con esquistos biotíticos y cuarzo-muscovíticos, generados por la deformación de unidades adyacentes también involucradas en la faja de cizalla, afectando inclusive al Carbonífero Inferior más temprano (Granito Potrerillos, capítulo 3.2.6) en su última reactivación.

Dado que todos los esquistos se encuentran muy intercalados tectónicamente en los afloramientos, hasta el momento se han considerado dentro del Miembro Esquistos Cerro Cóndor de la Formación Río Bonete (Aceñolaza et al., 1971) y Complejo Metamórfico Río Bonete (Martina y Astini, 2009) a pesar de que parcialmente incluye a unidades más jóvenes deformadas. Por este motivo se describirán también a modo comparativo estas otras litologías. Como se explicó en capítulos previos, aqui se considerará dentro de la Formación Río Bonete a esquistos verdes y rocas calcáreas que se encuentran asociados, manteniendo el criterio original (Aceñolaza, 1969) y excluyendo a las metasedimentitas estratificadas de la Formación Del Salto y a los esquistos cuarzo-muscovíticos y biotíticos que aparecen intercalados en la faja de deformación de Jagüé (capítulo 3.1 y 3.2). Más allá de las edades obtenidas, la diferenciación entre las variedades de esquistos también puede hacerse a nivel de la estructura (plegamiento isoclinal apretado a escala de afloramiento e imágenes y foliación bien marcada y penetrativa en los esquistos, se contraponen con los plegamientos abiertos, estratificación preservada y caracteres sedimentarios reconocibles en las metasedimentitas), grado metamórfico alcanzado (facies esquistos verdes -en parte retrógrada- hasta anfibolitas epidóticas en los esquistos; anquimetamorfismo hasta facies esquistos verdes baja para los metasedimentos) y asociación litológica en los afloramientos (esquistos verdes y filitas asociados a mármoles y anfibolitas, versus metaarenitas intercaladas con pizarras y rocas básicas).

\section{a- Afloramientos}

Los esquistos verdes se encuentran siempre asociados a los mármoles laminados en los afloramientos. Aparecen en los siguientes sectores:

a- en el área de Los Llantenes, en los Cerros Las Damas y Cerro Cóndor. Aquí no se ve este bandeado sino que los mármoles constituyen dos grandes bloques que sobresalen del paisaje y son rodeados por los esquistos verdes y verde-azulados (Anexos A1: M6a-b).

b- En el tramo medio del Bonete y quebrada del Ciénaga Grande y otras menores que son afluentes desde el oeste, donde la intercalación de mármoles y esquistos es conspicua dando un aspecto bandeado a los márgenes de la quebrada (Anexos A1: M3) 
c- En el tramo inferior y boca del río Bonete, por donde pasa la faja de deformación haciendo que los esquistos verdes y mármoles se intercalen con esquistos cuarzo-muscovíticos y biotíticos, metabasitas y lentes graníticas foliadas (Anexos A1: M2).

Los primeros (Cerros Las Damas y Cerro Cóndor) constituyen los afloramientos tipo para cada miembro, mientras que el Area Tipo para la Formación Río Bonete tal y como fuera definida originalmente por Aceñolaza et al. (1971) se encuentra en el tramo medio del río Bonete (ítem b).

No se ha podido llegar a los afloramientos que se hallan al norte y noroeste de Las Damas, en la zona de El Pircado, al sur del granito del cerro Las Tunas y norte del tramo superior de la quebrada Ciénaga Grande, en donde también se han reportado y mapeado afloramientos de esta unidad (Aceñolaza et al., 1971; Caminos, 1972; Maisonave, 1979). Sin embargo por lo que se observa en las imágenes satelitales esos afloramientos conforman otro bloque con un 'bandeado' con orientación general E - O similar a lo que se observa en el tramo medio del Bonete donde el bandeado tiene rumbo predominante $\mathrm{N}-\mathrm{S}$ y responde a la intercalación y plegamiento apretado de mármoles y esquistos verdes.

Miembro Mármol Las Damas (Martina y Astini, 2009; Miembro Calizas Las Damas, Aceñolaza et al., 1971).

Las rocas calcáreas de la región se reúnen dentro de este Miembro, que consta de mármoles impuros deformados dando lugar a esquistos calcáreos laminados de grano fino y brechas calcáreas. Presentan coloraciones que varían entre negras y grises, y cuando son afectadas por dolomitización y silicificación toman coloraciones amarillentas y blanquecinas.

Los afloramientos más importantes son los mismos que para los esquistos del Miembro Cerro Cóndor, en especial los dos bloques que conforman los cerros Dama de Arriba y Dama de Abajo en el área de Los Llantenes (área tipo), y las capas intercaladas con los esquistos en el sector medio río Bonete y la quebrada del Ciénaga Grande. Los bancos además aparecen en la Cueva del Miquilo, boca del Bonete y alrededores dentro de la faja de cizalla. Favorecidos por el clima árido de la zona, estas rocas siempre sobresalen del relieve como rasgos positivos. La repetición de los bancos calcáreos y esquistos verdes responde al plegamiento isoclinal a gran escala, pero con la información disponible no es posible descartar que haya más de una capa de mármoles plegada. En el único sector en el que se han distinguido delgadas capas de esquistos calcáreos (de algunos centímetros a decímetros) intercalados entre esquistos verdes y filitas alteradas es sobre la Cueva del Miquilo. Aunque también se encuentran deformados dicha intercalación puede llegar a interpretarse como primaria.

En el tramo inferior y medio del río Bonete afloran bancos de mármoles, intercalados entre filitas verdes y esquistos, todos con foliación milonítica. La deformación es coherente con la de los esquistos colindantes. Los bancos calcáreos suelen estar parcialmente dolomitizados y silicificados, a partir de los bordes de los bancos y/o en fisuras, lo cual es más notorio en las capas que afloran sobre 
la quebrada del Bonete. Esto también se observa en los bancos que aparecen en la boca del Bonete y Cueva del Miquilo (Figura 3.2.1).
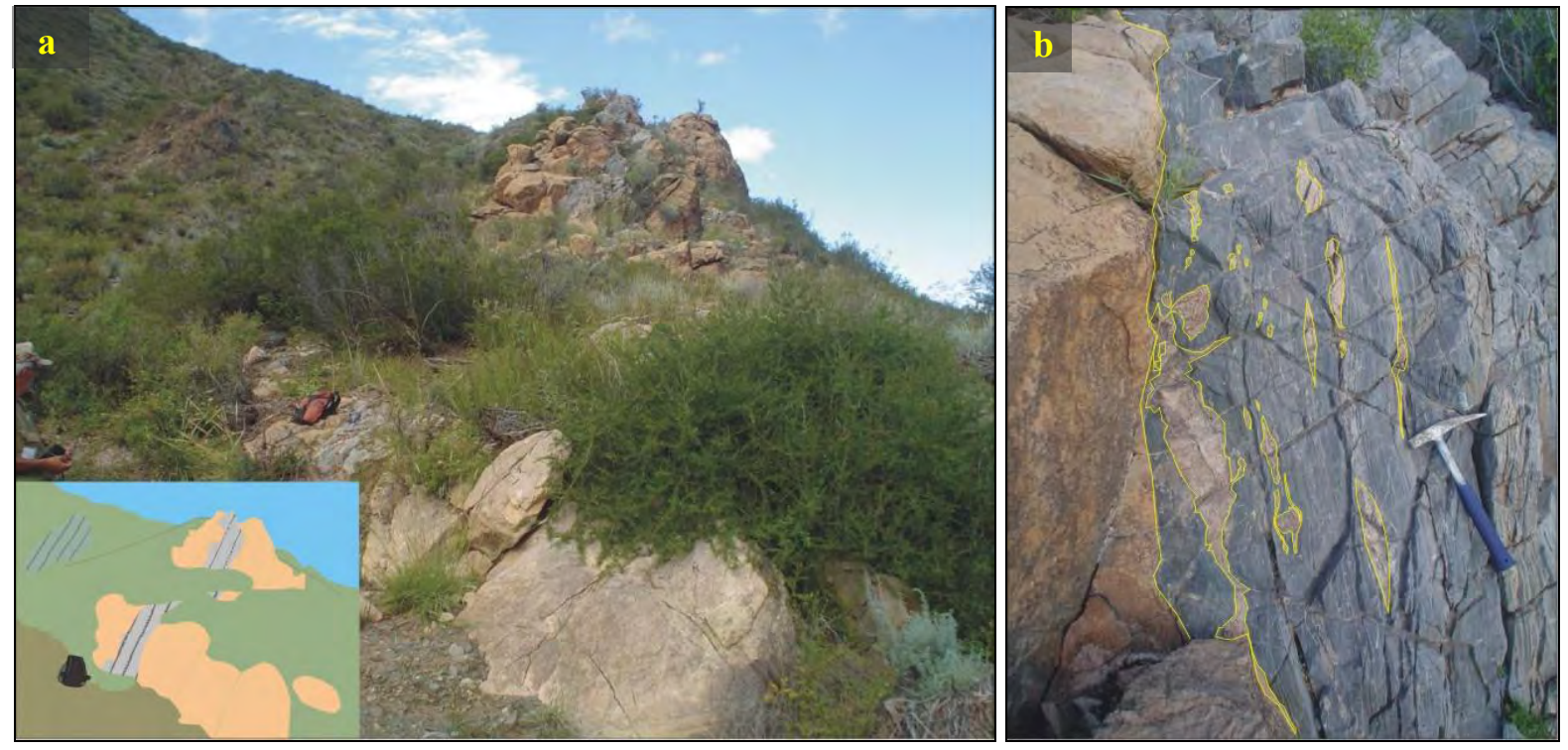

Figura 3.2.1: Aspecto de los afloramientos del Miembro Mármol Las Damas en el área de la Boca del Bonete. a)- Banco de mármoles entre esquistos verdes, margen oriental, vista hacia el SSE paralela al rumbo del banco; b)- detalle de los mármoles con laminación milonítica y parcialmente dolomitizados a partir del borde del banco calcáreo.

En el área de Los Llantenes los cerros Las Damas constituyen dos bloques de esquistos calcáreos, muy deformados por fallamiento y plegamiento, en los que la laminación milonítica se encuentra replegada en forma apretada, con pliegues disarmónicos e isoclinales, incluso a escala de muestra de mano (e.g. muestra C-LL15, Figura 3.2.2). En este área se observan atravesados por las vetas responsables de las manifestaciones minerales con seleniuros de cobre, plata y mercurio caracteristicas de la zona.

Figura 3.2.2: Fotografía de la muestra C-LL15 en la que se aprecia la deformación que presentan los esquistos calcáreos en el área de Los Llantenes, $\mathrm{C}^{\mathrm{o}}$ Dama de Abajo (plegamiento isoclinal y laminacion asociada

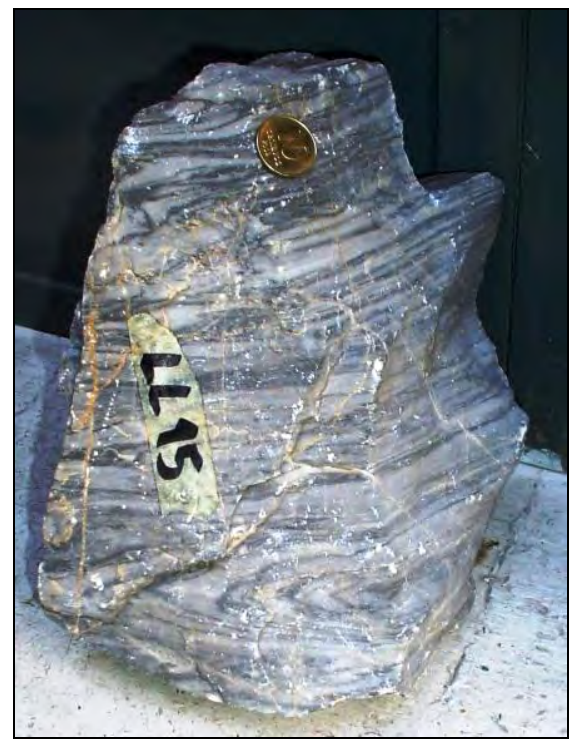
a foliación milonítica).

Miembro Esquistos Cerro Cóndor (Aceñolaza 1969; parcialmente Aceñolaza et al., 1971; parcialmente Martina y Astini, 2009).

Las mejores exposiciones del miembro Cerro Cóndor son aquellos de las zonas de Los Llantenes y sobre la quebrada de Ciénaga Grande y otras afluentes menores desde el oeste del tramo medio del río Bonete. Allí se puede observar bien la relación de éstos con los mármoles. 
Lo componen metamorfitas de bajo grado en facies esquistos verdes hasta subfacies de anfibolitas epidóticas, integradas por filitas y esquistos verdes y verde-azulados (metabasitas). La deformación característica es una foliación milonítica y/o cataclasis muy intensa y penetrativa que afecta tanto a esquistos como a mármoles. Presentan una foliación bien marcada, con desarrollo local de plegamientos tipo kink y kink-bands en las facies más finas y laminación milonítica delgada de 1-2 $\mathrm{mm}$ en los esquistos. A mayor escala es posible observar el plegamiento apretado a isoclinal de calizas y esquistos, especialmente en los alrededores de la quebrada del río Ciénaga Grande (Figura 3.2.3).

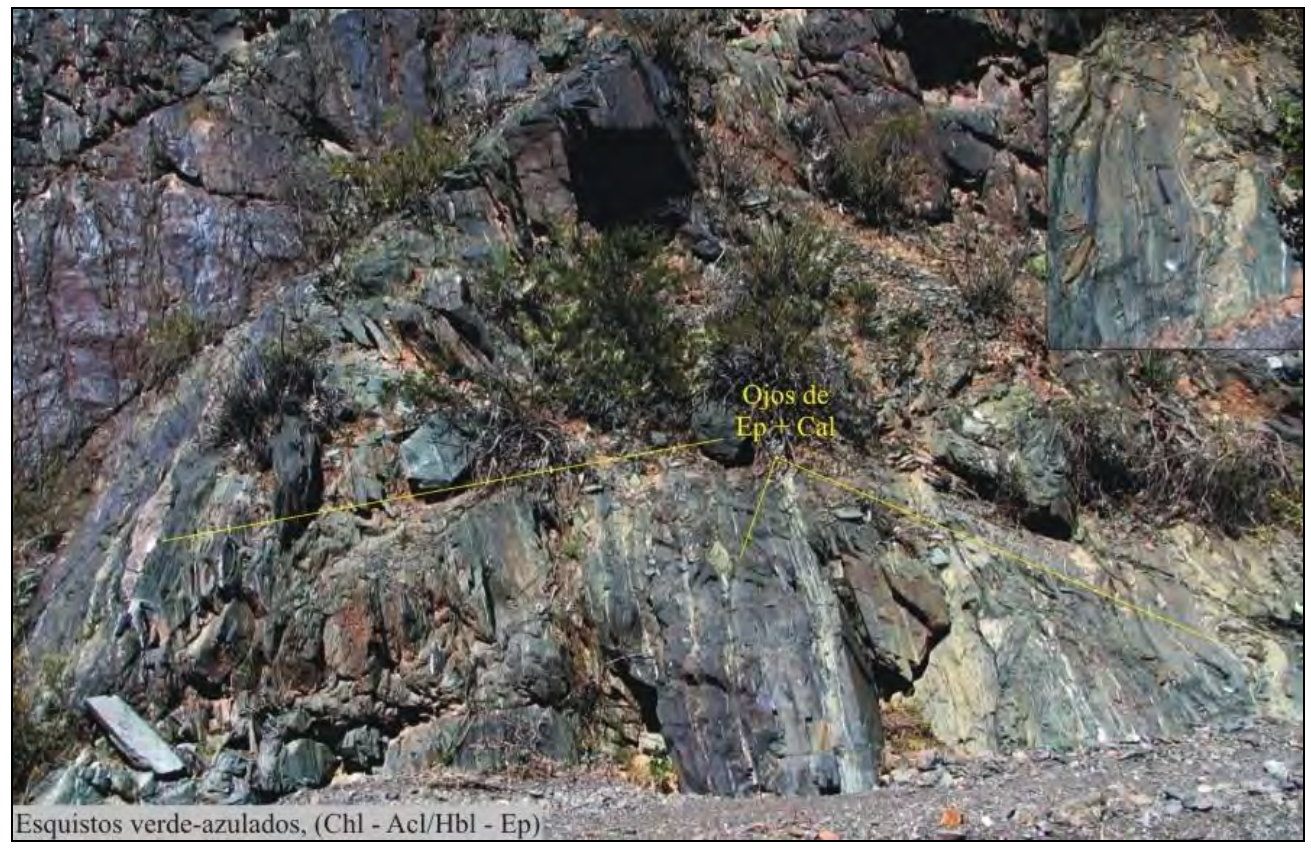

Figura 3.2.3: Afloramientos típicos de los esquistos del Miembro Cerro Cóndor sobre la quebrada Ciénaga Grande. Esquistos verdes y verde azulados miloníticos con ojos y cintas de epidoto y venas de calcita. Están intercalados con bancos de calizas en todo el tramo medio del río bonete y quebradas afluentes desde el oeste.

En los afloramientos del área de Los Llantenes el bloque de la Dorsal de la Orilla constituye el núcleo de un gran anticlinal cuyos flancos están formados por conglomerados castaños de la Formación Cerro Tres Cóndores. En el extremo norte de esta Dorsal aparecen filitas, esquistos y metabasitas rodeando a los cerros Las Damas compuestos por dos bloques calcáreos. Estos afloramientos son los que corresponden a la Formación Río Bonete (Anexos A1: M6a-b). Si hacemos un perfil que cruce la dorsal desde la Quebrada Seca, al este, hacia la Mina La Ramada (también llamada mina Las Damas) en la quebrada de Los Llantenes al oeste, se encuentra la siguiente secuencia (Anexos A1: P1):

A continuación de las metapelitas verdes concrecionales de la Formación Quebrada Seca (sección 3.2.5) aparecen esquistos verdes y verde-azulados algunas veces talcosos y/o serpentiníticos (metabasitas), con fuerte foliación milonítica. Entre los planos de foliación se dejan entrever algunos lentes de feno-andesitas de colores violáceos y con abundantes cristales de plagioclasa blanca, que probablemente correspondan a diques desmembrados más jóvenes. En un pequeño afloramiento menos deformado, hacia el contacto superior de la Formación Río Bonete con la base de la Formación Quebrada Seca, fue posible identificar bochones deformados y alterados entre metabasitas 
intensamente foliadas (esquistos verde azulados). Allí fue posible determinar que corresponden a lavas almohadilladas deformadas, con aspecto talcoso, serpentinizadas y cloritizadas. Luego el conjunto de esquistos y metabasitas es cortado por diques subverticales, negros o castaños en superficie, que presentan texturas afaníticas a microporfíricas con pequeños cristales aciculares de plagioclasa. Estos diques toman orientaciones transversales a la foliación y están desplazados por fallas menores de un evento posterior (¿Formación Punta del Agua?). Las metabasitas corresponderían a los afloramientos de lavas almohadilladas que predominan en el sector sur de la Dorsal de la Orilla y que han sido mencionados como parte de la Formación Punta del Agua o de la Formación Chuscho. Por la ubicación estratigráfica de sus afloramientos y porque son cortados por los diques andesíticos y basálticos mas jóvenes se asume aqui que corresponden a la Formación Chuscho (Ordovícico). Luego aparecen esquistos y filitas verdes y grises del Miembro Esquistos Cerro Cóndor, en su mayoría metasedimentarios (e.g. LL13, LL16), con plegamientos tipo kink y kink-bands (Figura 3.2.4). Más adelante los esquistos se ponen en contacto tectónico con los carbonatos del Miembro Mármol Las Damas, grises oscuros a blanquecinos, con foliación milonítica subvertical y replegada (e.g. muestras C-LL10, C-LL15). Todos los contactos caliza-esquistos son tectónicos y subverticales. Hacia el contacto de mármoles con esquistos las rocas calcáreas están brechadas y a veces mineralizadas y/o impregnadas por óxidos (muestras C-LL6 y C-LL7, con coloraciones ocres y rojizas), especialmente en el cerro Dama de Arriba. Los mármoles son atravesados por fallas, y vetas mineralizadas que fueron explotadas por piques y galerías en la mina Las Damas (también conocida como Mina La Ramada).

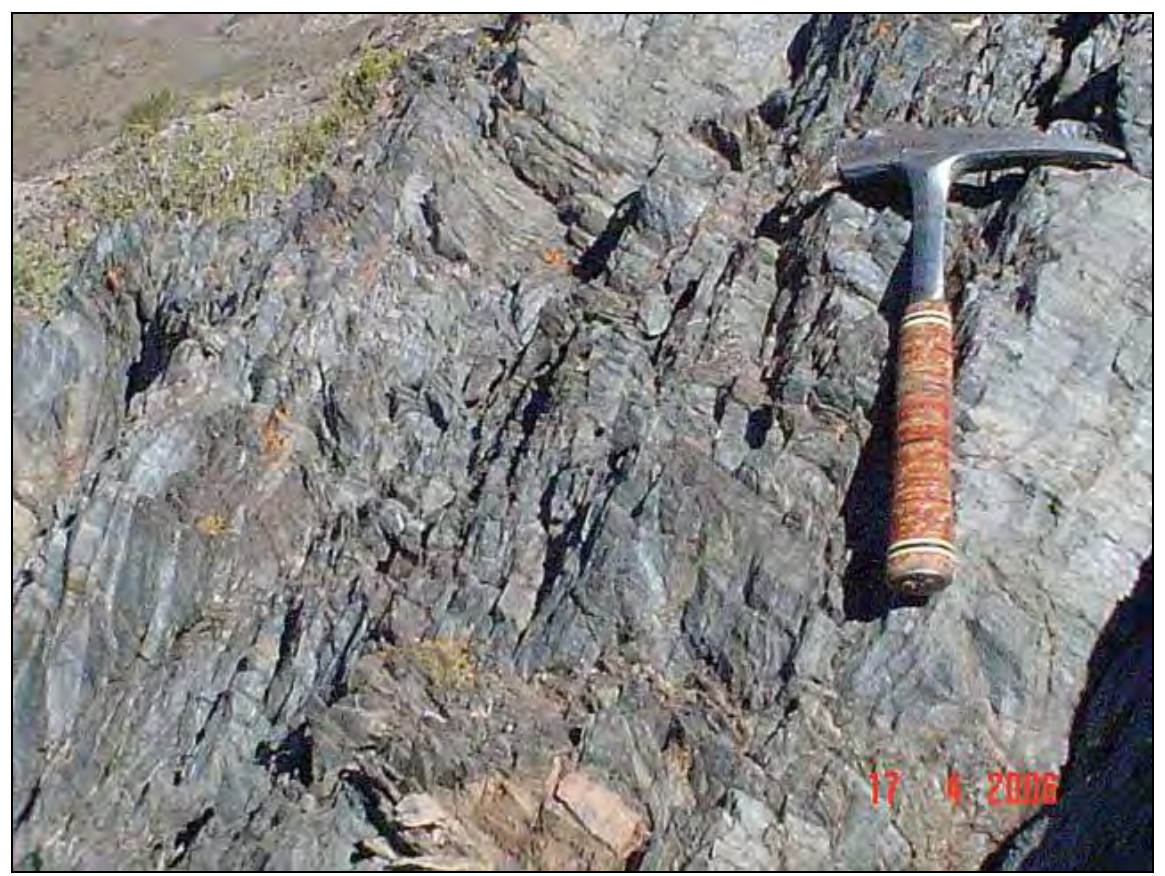

Figura 3.2.4: Aspecto de los esquistos verdes y filitas del Miembro Cerro Cóndor en el área de Los Llantenes, donde se encuentran rodeando los bloques de esquistos calcáreos de los cerros Las Damas. Puede observarse la foliación afectada por bandas kink.

Los esquistos verdes y metabasitas con foliación milonítica han sido tradicionalmente incluidos dentro de la Formación Río Bonete. Sin embargo, la intensa deformación que poseen las 
rocas en este sector respondería a otra faja de cizalla de menor magnitud que la que pasa por el río Bonete, desarrollada a lo largo de la Dorsal entre los afloramientos de la Formación Río Bonete y las lutitas de la Formación Quebrada Seca (Anexos A1: M6a-b), y que está afectando básicamente a la Formación Río Bonete y a las lavas almohadilladas.

Finalmente, al oeste aparecen nuevamente los conglomerados carboníferos de la Formación Cerro Tres Cóndores (flanco noroccidental del anticlinal) cubriendo en discordancia angular a los esquistos verdes y rocas calcáreas de la Formación Río Bonete.

\section{La faja de deformación de Jagüé (Martino y Astini, 1998) y variedades de esquistos:}

La faja de deformación que pasa por el río Bonete esta afectando tanto a la Formación Río Bonete como al Granito Potrerillos, Formación Del Salto y rocas básicas de la zona (especialmente Formación Chuscho y diques y filones verdes). Los diques basálticos negros no son afectados por la faja de deformación y cortan la foliación con rumbos NE-SO a E-O (capítulo 3.1). La fábrica original de las rocas se ve trasformada por el metamorfismo dinámico. La intercalación tectónica de las diversas litologías sumada al metamorfismo y alteración, impide un mapeo preciso de las unidades dentro de la faja de deformación, al menos en la escala en que se está trabajando. Si se observa con detalle, pueden distinguirse allí esquistos de tres composiciones distintas: esquistos verdes, esquistos blanquecinos y esquistos micáceos. (Los esquistos calcáreos se encuentran intercalados entre los esquistos verdes).

i) Esquistos verdes (Figura 3.2.5). En su mayoría de granulometrías muy finas, correspondientes

al Miembro Cerro Cóndor. Resultan de la deformación de protolitos sedimentarios o básicos. Los primeros son pizarras, filitas y esquistos cloríticos y clorítico-sericíticos con aspecto sedoso y coloraciones mas claras. Las metabasitas son en su mayoría esquistos cloróticoepidóticos, localmente talcosos, tremolíticos o actinolíticos, que se originan por la deformación y metamorfismo en facies de esquistos verdes (hasta facies de anfibolitas

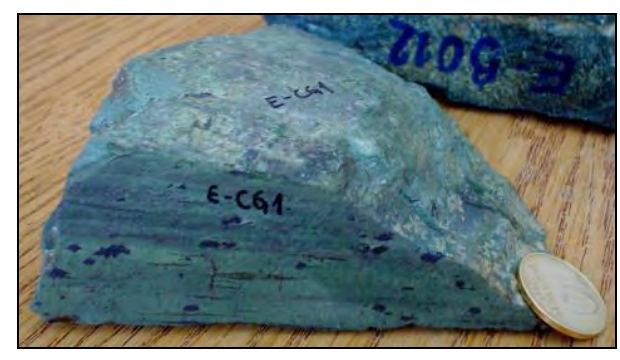

Figura 3.2.5: Aspecto típico de los esquistos verdes del tramo medio del río Bonete y quebrada Cienaga Grande. epidóticas) de rocas básicas. Se caracterizan y distinguen porque tienen un aspecto más cohesivo y por coloraciones más oscuras y/o azuladas en los afloramientos que los esquistos verdes metasedimentarios, pero no siempre es fácil distinguirlos. El color se debe a una composición dominada por la presencia de clorita y epidoto, con variable proporción de anfíbol verde pálido (actinolita); otros componentes son plagioclasa, cuarzo, hornblenda, calcita y opacos. En el tramo inferior del Bonete estos esquistos se ven bien intercalados con los esquistos blanquecinos (Figura 3.2.6). 

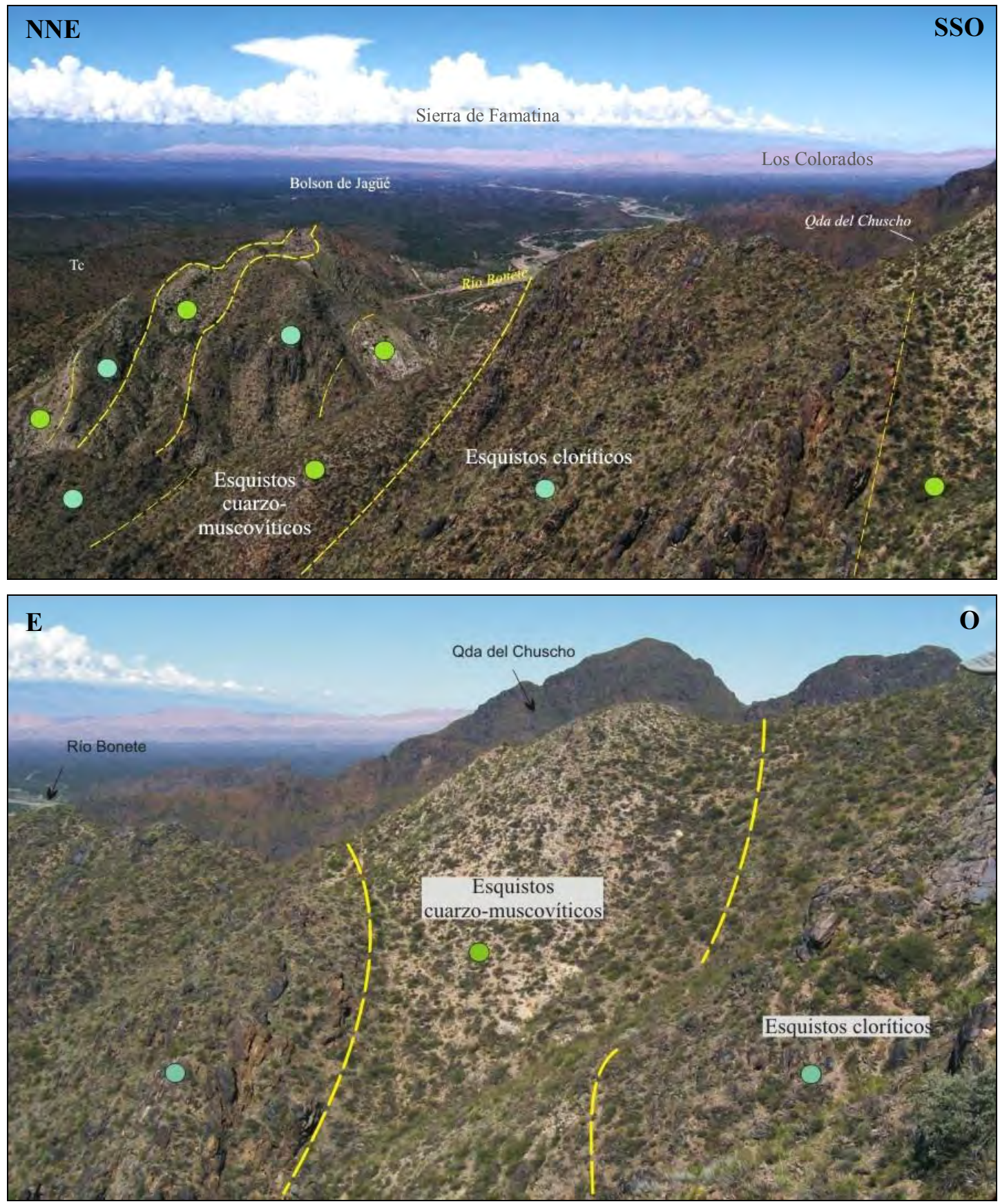

Figura 3.2.6: Aspecto de los afloramientos sobre el margen occidental del tramo inferior de la quebrada del río Bonete, dentro de la faja de cizalla. Se observa la intercalación de esquistos blanquecinos cuarzo-muscovíticos con metabasitas y esquistos verdes cloríticos. Además se observa la foliación en la faja de deformación, sub-paralela al trazado de la quebrada. Vista hacia el sudeste (arriba) y sur (abajo).

ii) Esquistos blanquecinos (Figura 3.2.7). Son el resultado de la deformación del Granito Potrerillos en el tramo inferior y boca del río Bonete. En las imágenes puede observarse claramente que el extremo sudoeste del plutón es truncado por la faja de deformación. La composición de estos esquistos es predominantemente cuarzosa o cuarzo-feldespática, con mayor o menor proporción de filosilicatos, especialmente muscovita. Son de granulometrías más gruesas y es posible ver en muestra 


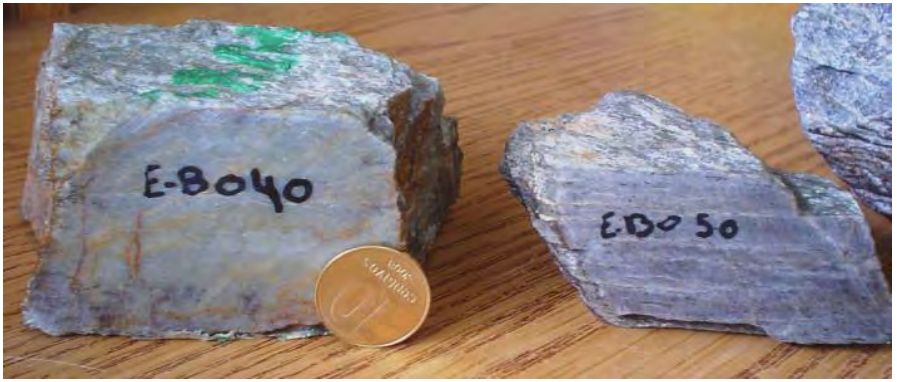

Figura 3.2.7: Aspecto de los esquistos blanquecinos que afloran en el tramo inferior del río Bonete. de mano ojos de cuarzo y feldespato estirados y deformados por la cizalla. La mayor o menor proporción de biotita esta condicionada por el grado de asimilación de bloques de la roca de caja del protolito granítico. En general se encuentra desferrizada y/o alterada a clorita y opacos.

iii) Esquistos micáceos (Figura 3.2.8). Se originan por la deformación de las metasedimentitas de la roca de caja del Granito Potrerillos, o de los bloques de roca de caja parcialmente asimilados por este (enclaves). Presentan tonalidades oscuras por la abundancia de biotita que ha crecido en la aureola de contacto del granito o durante la asimilación de los enclaves antes de la deformación. Los esquistos micáceos predominan en el margen oriental de la quebrada del Bonete, especialmente hacia el sector medio. Al alejarnos de la zona de deformación más intensa suelen preservar parcialmente la estratificación (So). Al subir por el margen oriental del tramo inferior de la quebrada se han observado franjas gnéisicas (gneises biotíticos) que no se relacionan a la faja de cizalla sino a la inyección de filones del granito entre los esquistos. Además se encontraron zonas (1-3 m) en las que los esquistos biotíticos (ej.: E-BO54) se intercalan y mezclan con delgadas capas de mármoles amarillentos silicificados. Por la manera en que se relacionan y la deformación coherente, estos sectores corresponderían a zonas en los que la faja de cizalla ha mezclado ambas litologías. Al alejarnos de la zona de deformación los esquistos muestran nuevamente la estratificación original (So).
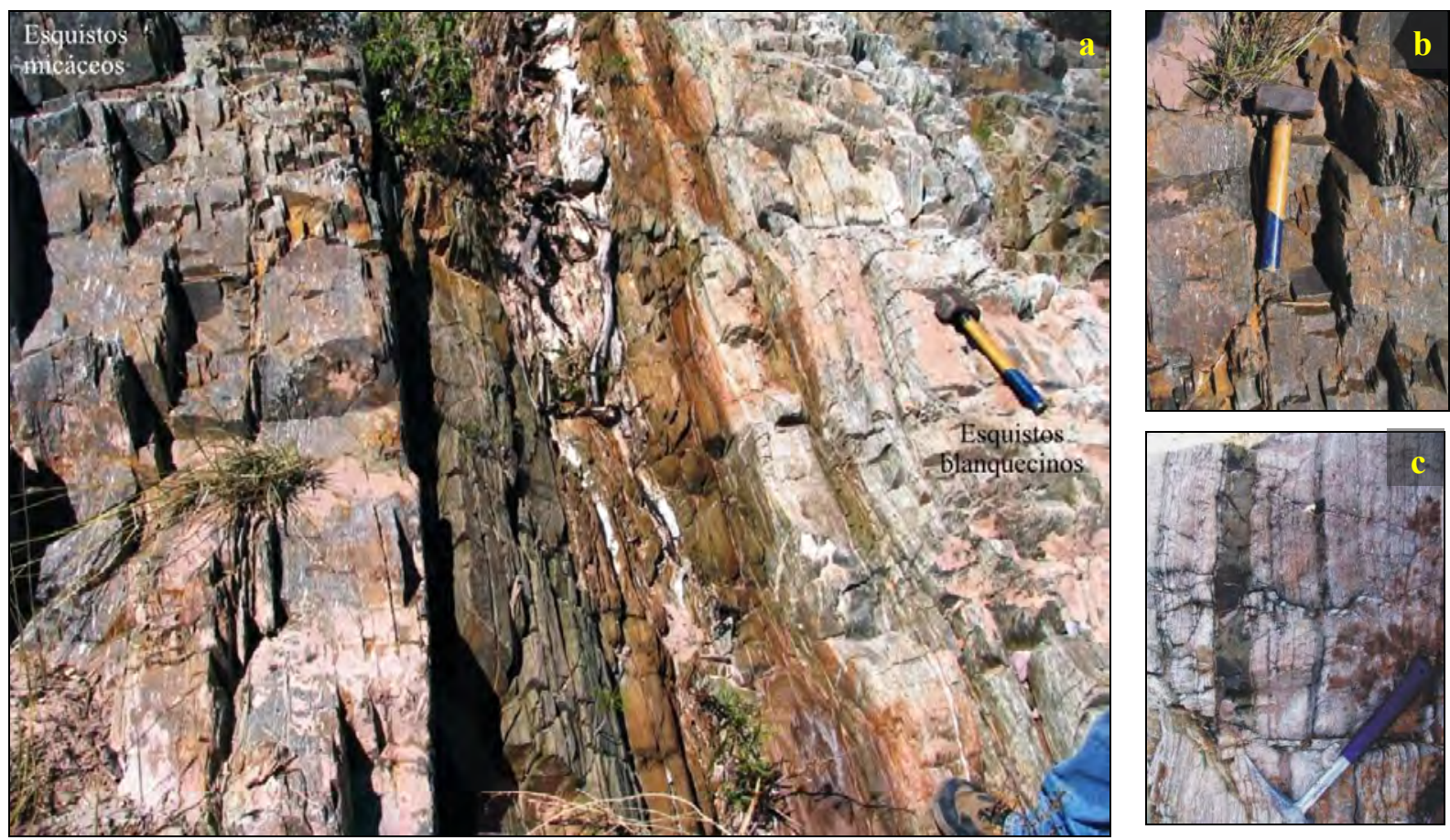

Figura 3.2.8: a)- Transición entre los esquistos micáceos y cuarzo-muscovíticos que aparecen en el tramo inferior y boca de la quebrada del Bonete dentro de la faja de cizalla; b)- detalle de los esquistos biotíticos con ojos estirados de cuarzo; c)detalle de los esquistos blanquecinos intruidos por filones de basaltos negros sin deformar que aprovecharon la foliación. 
Relaciones de campo.

La deformación dentro de la zona de cizalla permitió en algunos casos la mezcla de los distintos esquistos, sedimentitas clásticas, mármoles, metabasitas y venas e intrusiones cuarzosas o cuarzo-feldespáticas (ver más adelante "otros esquistos"). Las lentes graníticas intercaladas entre los esquistos del tramo inferior del Bonete están foliadas coherentemente con los esquistos de la caja por lo que su intrusión debió ser pre- a sin-cinemática, al menos respecto a la última reactivación de la faja de deformación (capítulo 3.2.6).

A lo largo del tramo inferior de la quebrada del Bonete es posible observar como las volcanitas de la Formación Chuscho cubren en discordancia angular a las metamorfitas de la Formación Río Bonete. Sin embargo, dentro de la faja de deformación aparecen metabasitas pertenecientes a ambas unidades. Así es que, sobre la quebrada, la faja de deformación está involucrando en parte a las rocas básicas del Chuscho, que quedan allí intercaladas como grandes escamas o lentes de rocas volcánicas y metavolcanitas básicas entre los esquistos de distintos orígenes. Esto es similar a lo que se observó en los afloramientos de Los Llantenes, hacia el contacto entre la Formación Río Bonete y la Formación Quebrada Seca, donde lavas almohadilladas afectadas por la deformación dúctil quedaron incluidas entre los esquistos verdes (ver antes).

Las filitas y esquistos verdes asociados a las metabasitas y mármoles del tramo medio del río Bonete y río Ciénaga Grande inferior presentan una deformación más penetrativa. Allí además se han obtenido edades $\mathrm{U}-\mathrm{Pb}$ en circones precámbricas, indicando que provendrían de un protolito distinto más antiguo (sección 3.2.7: b- Geología isotópica y edad).

En la desembocadura del río Ciénaga Grande en la quebrada del Bonete, los afloramientos de la Formación Río Bonete y faja de deformación de Jagüé, son truncados en ambas quebradas por una faja con rumbo noreste - sudoeste de los paraconglomerados castaños de la Formación Cerro Tres Cóndores (Carbonífero Inferior). Estos conglomerados además poseen clastos de las unidades previas, y proporcionan un límite temporal superior para la reactivación de la faja de deformación, previa a la apertura de la cuenca carbonífera.

\section{b. Petrografía}

A continuación se describen las características petrográficas principales que comparten y permiten distinguir los distintos tipos de esquistos y los mármoles. Las descripciones individuales se pueden consultar en el Anexo A4b: Cuadro II. 
Esquistos calcáreos y mármoles (Láminas 1 y 2):

Están compuestas principalmente por calcita, pero presentan impurezas como material opaco muy fino diseminado, variable contenido material micáceo y cuarzo de grano fino y recristalizado. Los opacos son en general grafito, y en menor cantidad pirita. La dolomitización se asocia a un mayor grado de silicificación y oxidación. Están afectadas por una deformación frágil - dúctil importante impuesta a un mosaico de calcita impura. Se observan microestructuras brechosas y miloníticas relacionadas con la laminación, conformando esquistos calcáreos miloníticos y brechas calcáreas. Presentan planos de disolución por presión que se observan como concentración de opacos en planos irregulares o estilolíticos, así como microplanos de cizalla, en los que tienden a concentrarse los granos de cuarzo, material opaco y micáceo. Estos planos son los que le dan el aspecto laminado a los mármoles en los afloramientos. En ellos pueden aparecer también granos extraños removilizados como micas (muscovita/biotita) flexuradas, feldespatos (plagioclasa y ortosa) y clorita, esta última producto de alteración de las micas.

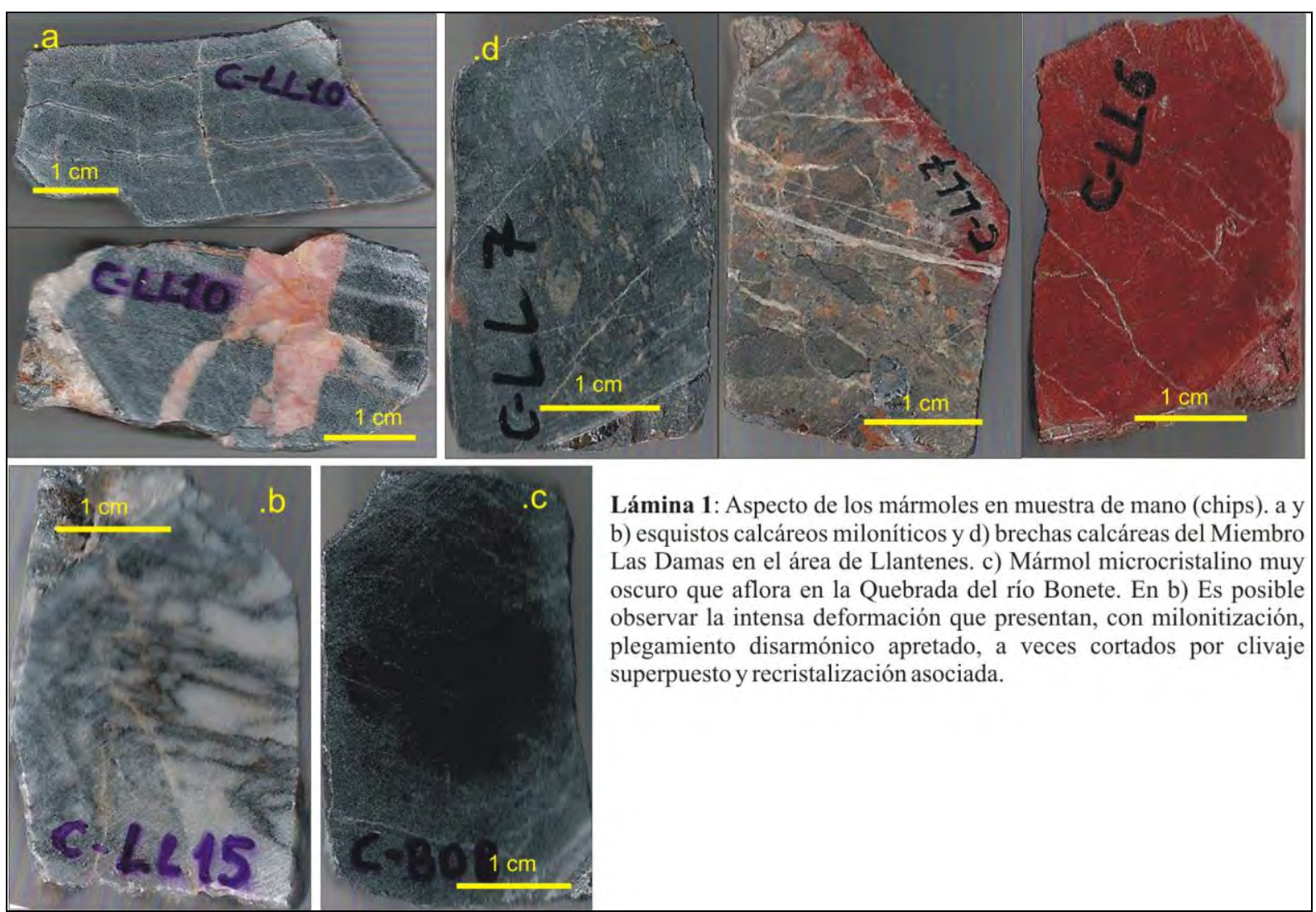



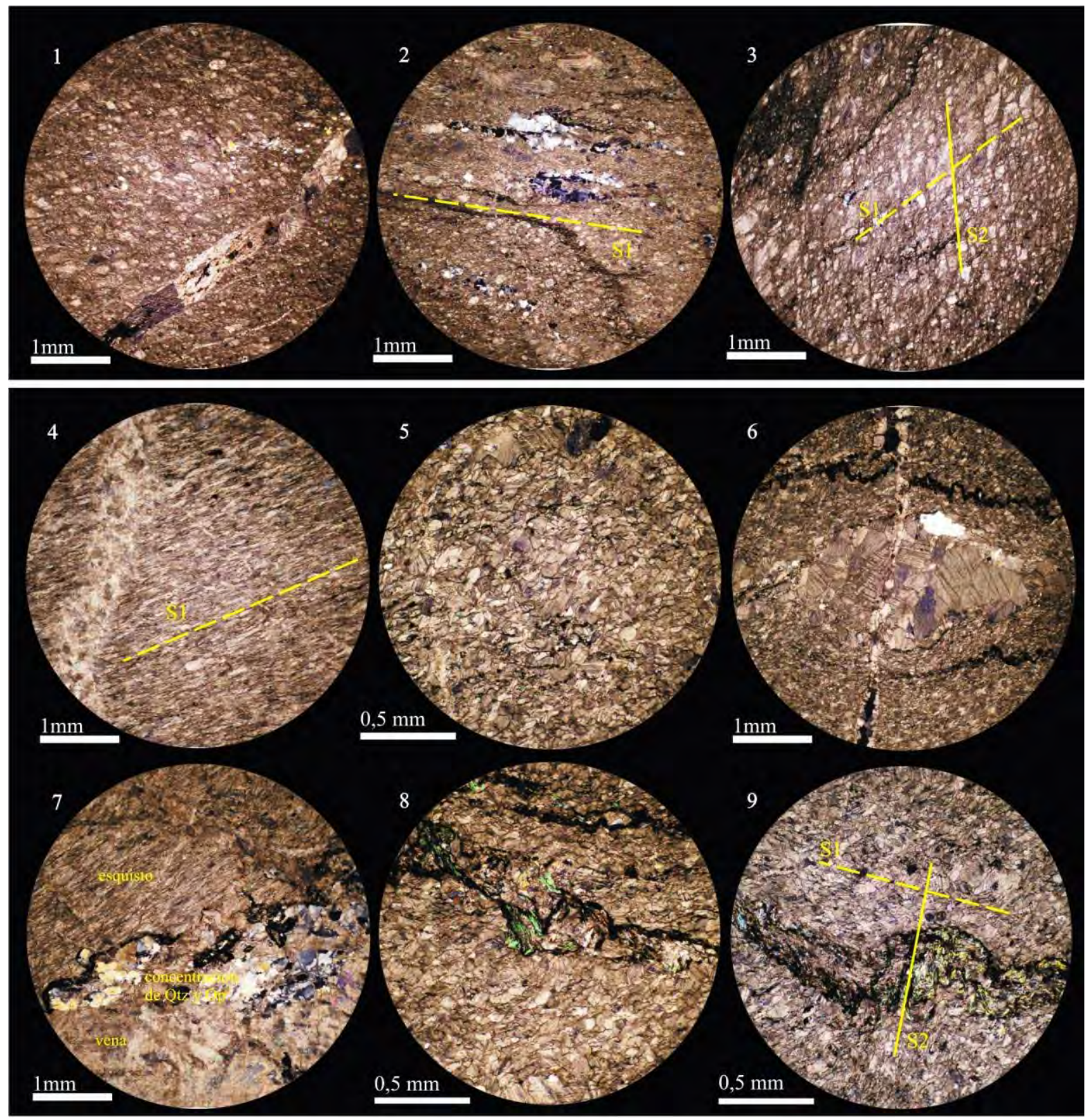

Lámina 2: Microfotografías de los cortes delgados correspondientes a las muestras calcáreas C-LL15(fotos 1 a 3 ) y C-LL10 (fotos 4 a 9). Todas las microfotografias tomadas con polarizador. Los mármoles son de grano fino y presentan variable grado de recristalización y orientación de la fábrica (clivaje continuo o foliación milonítica). Son impuros ya que presentan material cuarzoso, opaco y micáceo distribuido. Las concentraciones de cuarzo en la foto 2 corresponderían a nódulos de pedernal observados en los mármoles, recristalizados y deformados. Las concentraciones de material opaco corresponden a los planos de esquistosidad y superficies estilolíticas de las rocas en muestra de mano y son las que le otorgan el aspecto laminado. Luego son disturbados por una segunda foliación que la corta con alto ángulo; esto se observa especialmente en las fotos 3,8 y 9 en los que se han concentrado y recristalizado también las micas (Ms). Pueden estar secundariamente rellenos por calcita de grano mas grueso, y a veces por una primera etapa cuarzosa. Venillas delgadas de calcita cortan la esquistosidad y la foliación milonítica/clivaje. En la foto 9 se observa la deformación del mármol y superficies estilolíticas alrededor de un porfíroclásto calcáreo con cristales recristalizados de mayor tamaño. Todo esto atravesado por una venilla calcárea casi perpendicilarmente. Aumento: 4x (1 - 4,6 $7) ; 10 \times(5,8-9)$.

Los escasos fragmentos calcáreos mas preservados de la deformación, ya sea como fragmentos en las zonas de brecha o como lentes porfiroclásticas en las zonas milonitizadas, difieren en composición de la calcita que rellena fracturas. Esto se observa claramente en los cortes que han sido teñidos con alizarina. Los fragmentos y lentes porfiroclásticas están compuestos por calcita rica en hierro (colores azulados), relacionada con un proceso de dolomitización, mientras que la calcita esparítica que precipitó rellenando las fracturas es magnesiana (colores rosados), de grano más grueso y no presenta 
impurezas. Solo algunas excepciones muestran venas de calcita rica en hierro que atraviesan la foliación milonítica. (ej. C-BO17). Las maclas dentro de los cristales de calcita rica en hierro comúnmente están curvadas o con pliegues tipo kink, pero no en la calcita magnesiana secundaria (post-deformación). En algunos casos aparece primero cuarzo policristalino tapizando los huecos y fracturas y luego la calcita. Se observaron además evidencias de reemplazo pseudomórfico de dolomita por cristales de cuarzo que preservan formas romboidales y rectangulares de la dolomita, evinenciando un proceso de silicificación.

Esquistos cuarzo-muscovíticos blanquecinos (Láminas 3 y 4):

Son milonitas félsicas de granulometrías más gruesas, en cuya composición hay un predominio de cuarzo o cuarzo y muscovita, y variable proporción de feldespatos. El feldespato potásico generalmente es ortosa, aunque algunas muestras contienen microclino. La participación o no de la roca de caja sedimentaria condiciona la aparición de biotita. Pueden aparecer minerales de composiciones extrañas o removilizados, como epidoto granular disperso en el corte, titanita, calcita en parches, alterando a la plagioclasa o rellenando clivaje de fractura, entre otros.

La foliación milonítica es continua aunque en algunos sectores pueden aparecer dominios con mayor concentración de mica (muscovita) que pasan transicionalmente a dominios menos micáceos. Está marcada principalmente por la deformación y orientación de los filosilicatos y estiramiento del cuarzo, y generalmente se observa un grado variable de morterización asociado. El cuarzo puede llegar a estar bastante acintado, y con distinto grado de poligonalización según la muestra (ej. más poligonal en E-BO40 y E-BO50). Los feldespatos forman 'ojos', mientras que la mica blanca se encuentra flexurada y como peces de mica.

Algunas muestras (e.g. E-BO49) son una mezcla, con una base recristalizada de cuarzo y feldespato, muscovita y biotita orientadas según la foliación, gran cantidad dispersa de epidoto calcita - (titanita), y abundante apatita. La escasa biotita puede provenir tanto del granito como de sus enclaves, que luego fueron deformados en conjunto y transformados en esquistos cuarzo-muscovíticos y esquistos con clorita y epidoto (sección 3.2.6).

Esquistos micáceos (Lámina 5):

Se caracterizan por granulometrías más homogéneas y un predominio de biotita y cuarzo. La biotita es el único filosilicato presente o es muy dominante, y registra coloraciones castaño rojizas en lámina delgada. En las cercanías del Granito Potrerillos es originada por metamorfismo de contacto y se orienta formando clivaje. Crece a expensas de filosilicatos previos (principalmente muscovita o sericita, biotita), limitando el crecimiento del cuarzo. Cuando se preserva la laminación heterolítica primaria (pelita-limolita-vaque), ésta controla la mayor o menor concentración de biotita en distintos dominios de clivaje. El paso entre sectores más y menos micáceos es transicional. La muscovita puede 


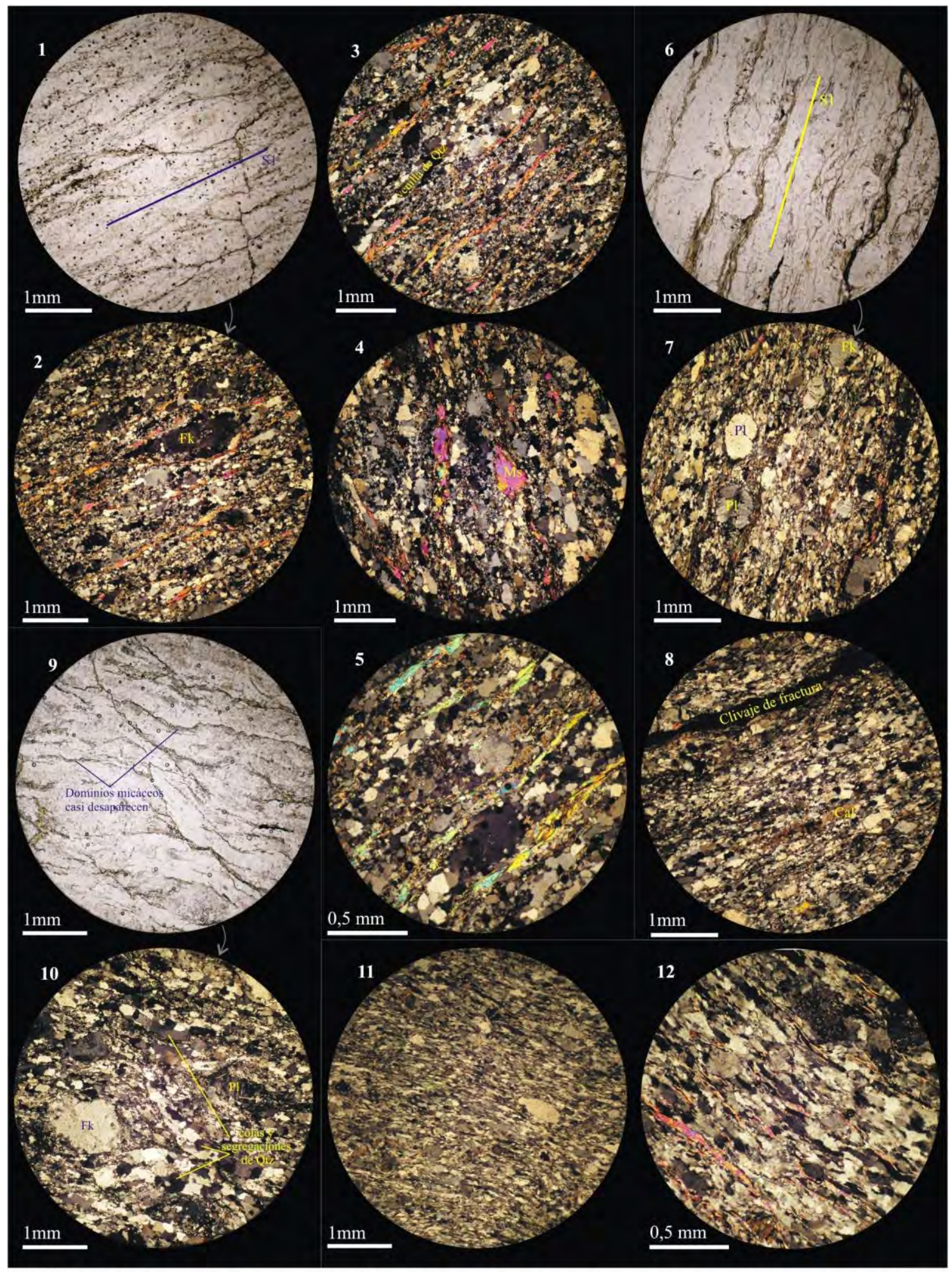

Lámina 3: Microfotografias de cortes petrográficos de los esquistos blanquecinos, en los que se observan su composición y microestructura general. 1-3 y 5: E-BO32; 4: E-BO31; 6-8: E-BO19; 9-10: E-BO28; 11-12: E-BO2. Las variaciones principales que se observan se refieren a un mayor o menor presencia de los dominios micáceos y a su composición (predominio de Bt o Ms). Además la intensidad de la deformación suele asociarse a una disminución del tamaño de grano por la milonitización y a un mayor grado de recristalización de los componentes, principalmente el Qtz. E-BO31 y E-BO32 son los ejemplos típicos de éstos esquistos, con predominio de Ms (e.g. ver 'peces' de mica en foto 4). E-BO19 presenta mayor cantidad de Bt, que parcialmente se retrograda a Ms o se altera a Chl formando interestratificados Chl-Bt. E-BO28 tiene una composición predominantemente cuarzo-feldespática, los dominios micáceos casi no existen. E-BO2 es un ejemplo que presenta una deformación mucho mas intensa con mayor remobilización de Ep y Cal. En la fig 8 se ve un ejemplo del clivaje de fractura que se genera cuando los dominios micáceos están mas desarrollados. Aumento: 4x (1-4, 6-11); 10x $(5,12)$. 


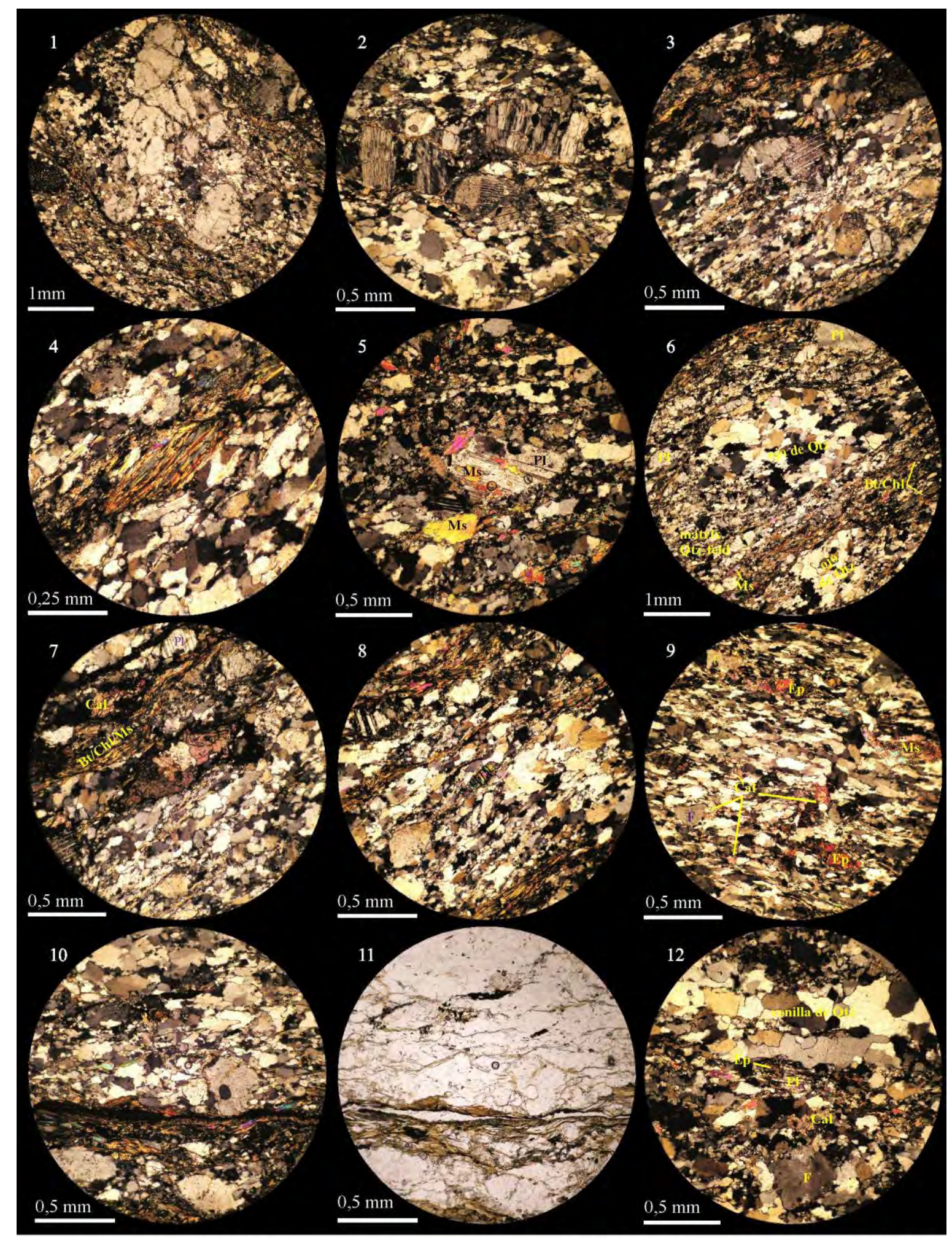

Lámina 4: Microfotografías que muestran diversos detalles de los esquistos blanquecinos. Fotos 1-4, 6-8, 10-11: E-BO19; 5 y 12: E-BO31; 9: E-BO2. 1 a 3: deformación que presentan los porfiroclastos de feldespato potásico y plagioclasa. 4: interestratificado de $\mathrm{Bt}$ y Chl por alteración de la Bt en los dominios micáceos. 5: Muscovita alterando a una plagioclasa; formación de fishes de Ms; venilla de calcita. 6: ojos de cuarzo con subgranos recristalizados y orientados, en una matrix de grano fino cuarzo-feldespático-micácea que se deforma a su alrededor. 7: porfiroclasto de calcita ahusado y orientado siguiendo la foliación milonítica. concentración de la $\mathrm{Cal}$ en los dominios de clivaje. 8: Cristal de epidoto removilizado y orientado siguiendo la foliación milonítica; se generaron fracturas perpendiculares al estiramiento. 9: Mosaico orientado de Qtz recristalizado y Ms neoformada, con abundante Cal dispersa cerca de una venilla rellena de Qtz y Cal; se observan peces de Ms y ojos de Ep. 10-11: clivaje de fractura asociado a los dominios micáceos. En éstos es posible observar la transformación de Bt en Ms + Op por desferrización y su alteración a Chl. Allí se concentra ademas la Cal y Ep (Ep y Czo). 12: venilla de Qtz recristalizada en un esquisto cuarzo-feldespático. Se observa también la alteración epidótica en un porfiroclasto deformado de Pl.Aumentos: $4 \mathrm{x}(1$ y 6$) ; 10 \mathrm{x}(2,3,5$ y $7-12) ; 20 \mathrm{x}(4)$. 
estar asociada a los cristales de biotita o quedar como relictos flexurados y/o desflecados. La clorita, cuando está presente, es aparentemente producto de alteración de la biotita, con quien comúnmente forma interestratificados biotita-clorita. Además se observan granos dispersos de apatita y circón de origen detrítico que persisten como porfiroclastos. El cuarzo llega a formar mosaicos recristalizados, con granos subedrales a poligonales. La temperatura no llegó a transformar completamente las asociaciones (ej. E-BO19), aunque en algunas muestras fue suficiente como para que los feldespatos comiencen a recristalizar.

Es común observar lentes o venillas de composiciones graníticas (cuarzo, ortosa, plagioclasa y a veces hornblenda) inyectadas entre los planos de clivaje de estos esquistos. En los casos en que las sedimentitas (roca de caja) es parcialmente asimilada por el granito o en aquellos en que los esquistos micáceos están inyectados, la biotita es de mayor tamaño y se presenta con texturas decusadas o formando nidos, concentrándose en los contactos con las inyecciones.

Esquistos verdes (Láminas 6 y 7):

Presentan una foliación milonítica fuerte y lineación mineral, que llega a ser muy fina y apretada (e.g. E-CG1, CH13), generándose planos oscuros por disolución por presión. El color verde de las rocas se debe a la abundancia de epidoto, clorita o/y actinolita-tremolita. Esta última solo presente en rocas de protolitos básicos. El epidoto que suele asociarse a la presencia de calcita es muy abundante, llegando a formar bandas y/u 'ojos' en los afloramientos. La clorita es habitual y generalmente tiene colores oscuros, pleocroismo marcado y color de interferencia marrón anómalo (clorita rica en hierro) o violeta. Puede originarse por retrogradación de biotita, o alteración de muscovita $u$ otros minerales. Se han podido distinguir 5 asociaciones minerales:

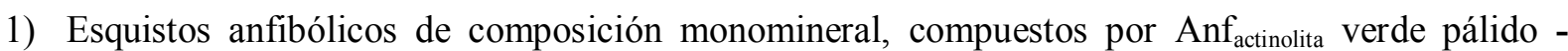
(E.g.: E-BO12).

2) Esquistos compuestos por $\mathrm{Anf}_{(\mathrm{Act} / \mathrm{Hbl})}+\mathrm{Pl}+\mathrm{Ep} \pm \mathrm{Chl} \pm \mathrm{Qtz}-(\mathrm{Ej} .: \mathrm{E}-\mathrm{BO} 22, \mathrm{E}-\mathrm{BO} 5-\mathrm{F}, \mathrm{E}-\mathrm{BO}-\mathrm{F})$.

3) Esquistos compuestos por Chl $+\mathrm{Ep}+\mathrm{Trem} \pm(\mathrm{Qtz})$, en los que, a diferencia de los anteriores, no aparece Pl, y tampoco micas, y tienen mayor cantidad de Qtz - (Ej.: CH13, E-CG1, E-BO56or, E-BOFE, BO44x, MQ6).

4) Esquistos compuestos por $\mathrm{Chl}(/ \mathrm{Bt} / \mathrm{Ms})+\mathrm{Ep} \pm \mathrm{Qtz}-(\mathrm{Ej} .:$ E-BO52, E-BO7, BO-D11x).

5) Bandas cuarzosas intercaladas en otras asociaciones (asoc. 3 o 4 en gral.), compuestas por Qtz + Ep - (ej. E-BO56or, E-BO-FE, E-CG1, etc.)

Las asociaciones 1, 2 y 3 tendrían su origen en protolitos básicos de distinta composición y variable grado de hidratación y metamorfismo. La asociación 4 se habría formado a partir de protolitos sedimentarios, entre ellos la roca de caja del granito (Formación Del Salto), con o sin inyecciones de éste. En algunos cortes se observan lentes relícticas o venillas cuarzosas compuestas de Qtz-Ep-Chl o Qtz-Ep (asociación 5), intercaladas entre lentes o dominios compuestos por Ep-Chl-Trem-Qtz 


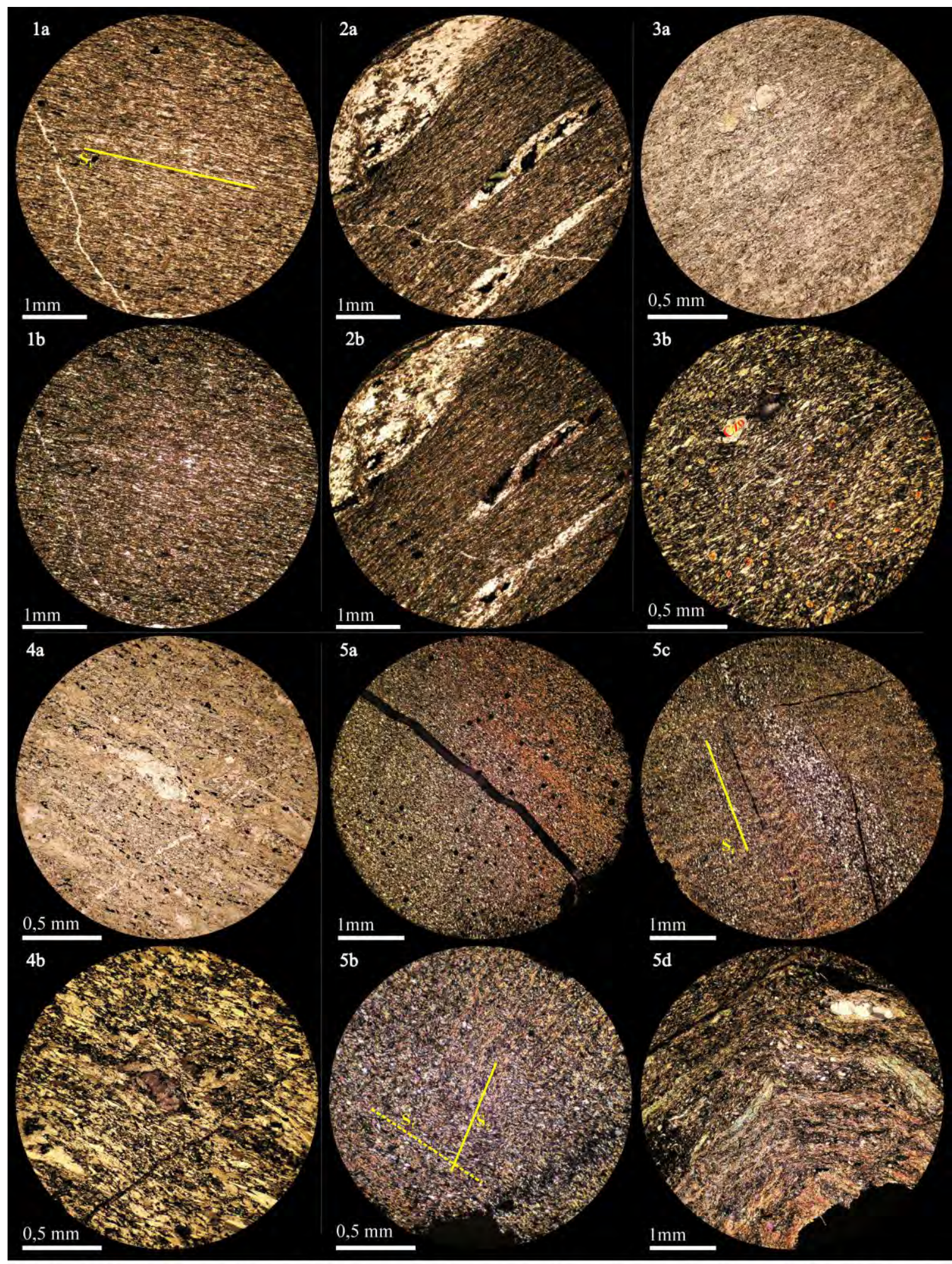

Lámina 5: Microfotografías de cortes delgados característicos mostrando aspectos generales de las variedades de esquistos verdes. En general son filitas o esquistos de granulometrías finas, con mucha Chl y/o Ep, en facies de esquistos verdes. Fotos lab y 2a-b: filita cuarzo-epidótica con Qtz-Ep-Chl y Op (e.g. E-CG1). Se observan diferenciados cuarzosos, que pueden poseer $\mathrm{Cal}$, en los que se han desarrollado porfiroclastos opacos euedrales que al deformarse desarrollaron colas de Chl rica en hierro. Fotos 3a-b: filita con predominio de Chl y Ep (e.g. E-BO22; ver también lámina 6 detalle 6: a (zona de esquisto). - Fotos 4a-b: esquisto anfibólico/actinolítico (e.g. E-BO12). Es un ejemplo de las metabasitas anfibolitizadas y retrogradadas que se encuentran intercaladas entre los esquistos en el tramo medio del río Bonete. - Fotos $5 \mathrm{a}-\mathrm{d}$ : aspectos de las filitas y esquistos de la zona de Los Llantenes (a: LL16b, b: LL16a, c: LL11b, d: LL11c). Las imágenes 5a-c muestran la laminación producida por la mayor o menor presencia de filosilicatos, la crenulación (S2) fina de la foliación S1, y el desarrollo de clivaje de fractura. La foto $5 \mathrm{~d}$ es un ejemplo de un esquisto muy deformado y en el que han recristalizado el cuarzo y las micas (Ms). - En las láminas 6 y $7 \mathrm{se}$ pueden observar detalles de estas rocas. Aumentos: 4 x (1-4,9, 11 y 12);10x $(5-8,10)$ 
(asociación 3). La asociación Qtz-Ep se habría originado por diferenciación metamórfica, o a partir de inyecciones o intercalaciones cuarzosas.

Es común la presencia de minerales opacos, generalmente agrupados en las superficies de clivaje, con brillo metálico y formas euedrales cúbicas. Entre estos abunda la magnetita y titanomagnetita, y en algunas muestras se pudo constatar también pirita. En el corte delgado de la muestra E-CG1 son abundantes y quedan como porfiroclastos rotados con colas de clorita pleocroica con kink-bands. La gran cantidad de magnetita hallada en muchas de estas muestras se asocia a la descomposición de mafitos (ej. biotita, anfíboles, olivinas y piroxenos).

La identificación de minerales pesados no magnéticos en la muestra E-BO5 (Chl/Bt-Ep-Qtz) con EDAX reveló que entre los minerales accesorios el mas abundante es la apatita y luego el circón. Salvo los circones, todos los demás granos analizados son anhedrales; raramente alguna apatita presenta un prisma imperfecto. Además se determinó un sulfato de bario con impurezas de hierro (baritina posiblemente) pero tendría un origen secundario. Estos minerales se ven opacos y de colores anaranjados, los circones son transparentes y rosados, con alto relieve, mientras que la apatita es incolora y transparente.

Otros litotipos de esquistos:

Es común que los esquistos presenten composiciones transicionales entre protolitos de composiciones distintas. Generalmente son mezclas originadas por la fuerte milonitización, más comunes cerca de los contactos entre las distintas litologías. Se pueden observar indicios de esto tanto en los afloramientos como en los cortes (ver detalles en Anexos A4b: Cuadro II).

Algunos esquistos muestran una intercalación de sectores con composiciones distintas, en que dominios micáceos biotíticos se intercalan entre sectores cuarzo-feldespáticos en los que quedan porfiroclastos de mayor tamaño de ortosa o plagioclasa rodeados por un mosaico deformado de cuarzo mas fino recristalizado. Esta variación composicional pudo existir en la roca sin deformar (por ejemplo un enclave inyectado), o pudo originarse posteriormente por intercalación durante la deformación por cizalla (mezcla de origen tectónico). Pueden aparecer también lentes de calcita (porfiroclastos deformados), indicando que la deformación es posterior a la formación de los mármoles.

A modo de ejemplo, se pueden citar los casos de las muestras MQ6, E-BO1or, E-BO11, EBO56or, E-BO-FE, entre otras. Estas muestras presentan estructuras esquistosas miloníticas y su mineralogía original ha sido reemplazada casi completamente. Los filosilicatos y los mafitos han sido sustituidos totalmente por clorita, opacos y óxidos de hierro, mientras que la gran abundancia de epidoto se debe a la presencia del calcio (por movilización de la calcita) en el ambiente. Además presentan abundantes minerales opacos, variables proporciones de calcita y cuarzo, y algunos granos de plagioclasa.

Las muestras E-BO1 y E-BO11 (Figura 3.2.9) son un ejemplo en que se hallan composiciones intermedias entre esquistos biotíticos y cuarzo-feldespáticos, con formación de epidoto a partir de los 


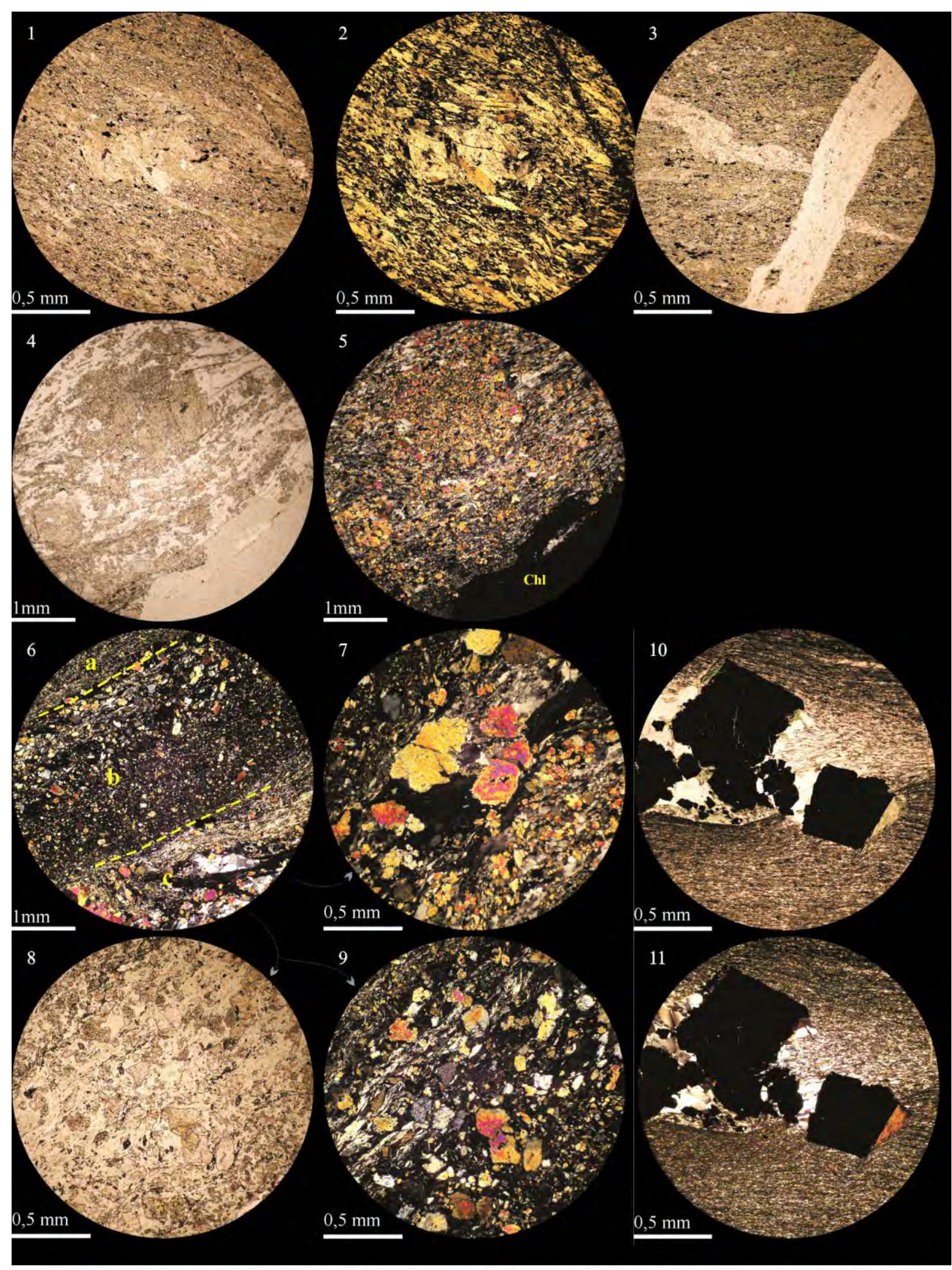

Lamina 6: Microfotografias de cortes delgados que muestran detalles de las variedades de esquistos verdes. Fotos 1-3: EBO12; 4-9: E-BO22; 10-11: E-CG1. Imágenes 1, 3, 4, 8 y10 tomadas sin polarizador. 1-2: ojo de Cpx anfibolitizado en una matrix foliada de anfíbol y $\mathrm{Chl}$, con muy poco Qtz. 3: vena de Qtz deformada cortando la foliacion de la anfibolita y a una venilla segregada en los planos de foliación. 4-5: ojos de Ep granular en un dominio mas cuarzoso y cerca del contacto con un sector cloritizado de los esquistos epidóticos. 6-9: Zona de contacto transicional (b: 8-9) entre los esquistos verdes epidóticos (a) y un dominio de segregación cuarzosa (c) en el que el Ep aumenta de tamaño y se asocia a Chl. 10-11: porfiroclastos euedrales y rotados concentrados en un dominio cuarzoso de un esquisto epidótico, en cuyas colas ha crecido Chl rica en Fe y Qtz. Aumentos: $4 x(4-6) ; 10 x(1-3$ y $7-11)$. 

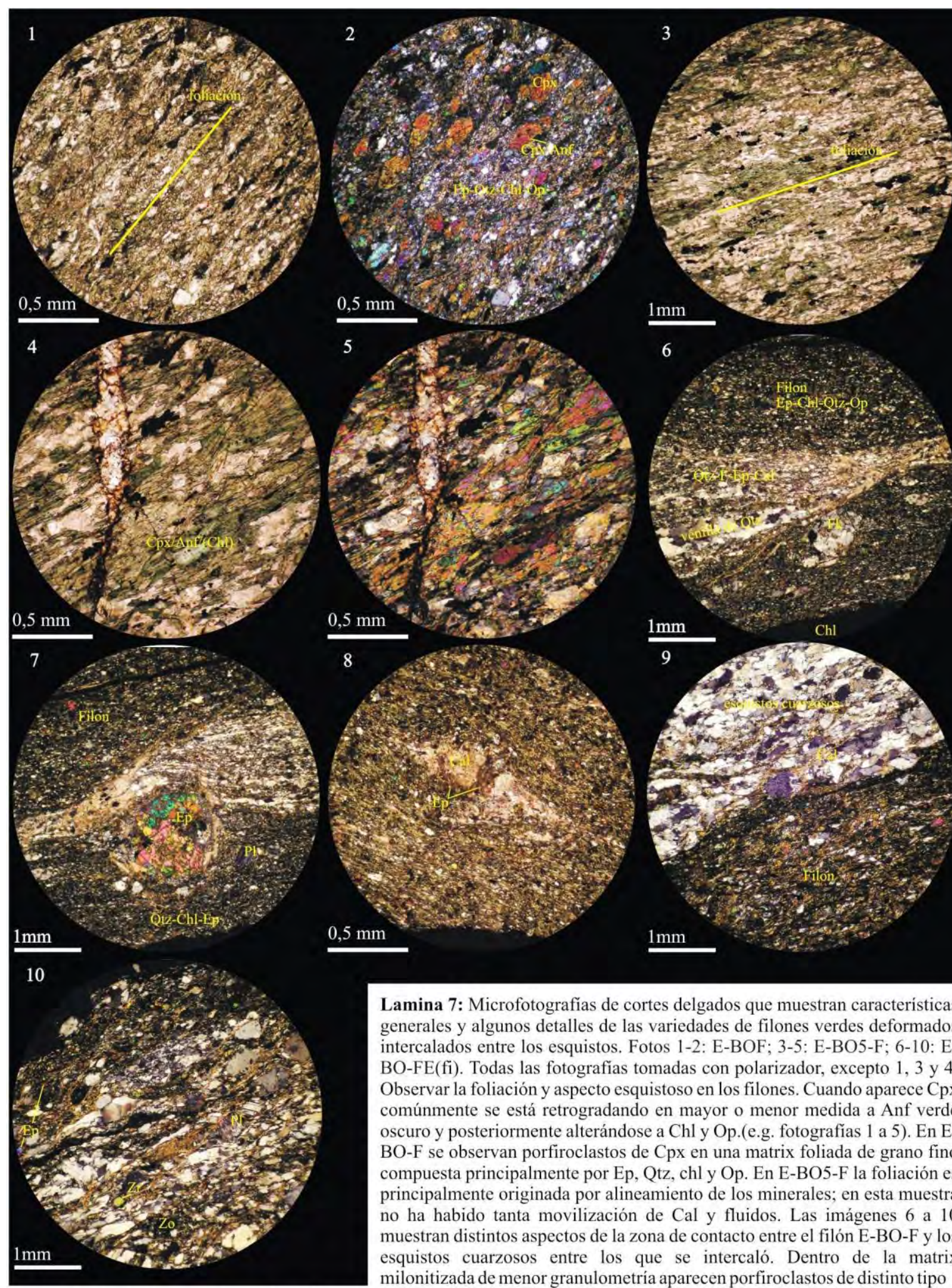

Lamina 7: Microfotografias de cortes delgados que muestran características generales y algunos detalles de las variedades de filones verdes deformados intercalados entre los esquistos. Fotos 1-2: E-BOF; 3-5: E-BO5-F; 6-10: E$\mathrm{BO}-\mathrm{FE}(\mathrm{fi})$. Todas las fotografias tomadas con polarizador, excepto 1,3 y 4 . Observar la foliación y aspecto esquistoso en los filones. Cuando aparece $\mathrm{Cpx}$ comúnmente se está retrogradando en mayor o menor medida a Anf verde oscuro y posteriormente alterándose a Chl y Op.(e.g. fotografias 1 a 5). En EBO-F se observan porfiroclastos de $\mathrm{Cpx}$ en una matrix foliada de grano fino compuesta principalmente por Ep, Qtz, chl y Op. En E-BO5-F la foliación es principalmente originada por alineamiento de los minerales; en esta muestra no ha habido tanta movilización de Cal y fluidos. Las imágenes 6 a 10 muestran distintos aspectos de la zona de contacto entre el filón E-BO-F y los esquistos cuarzosos entre los que se intercaló. Dentro de la matrix milonitizada de menor granulometría aparecen porfiroclastos de distinto tipo

(6: Fk; 7: ojo de Ep con colas en las rellenas con Qtz y Cal; lente de Cal con una corona de Ep posiblemente delimitando el contorno del porfiroclasto antes de la deformación). 9: el contacto neto entre el filón y los esquistos cuarzosos es aquí una delgada zona mas oscura y de grano muy fino; notar la mayor presencia de Cal cerca de esta zona. 10: zona de contacto transicional y heterogéneo, en la que se observan porfiroclastos de Pl, lentes de Qtz, Cal en los planos de foliación y abundante Ep (Zo y EP); aparece un pequeño cristal roto de Zr. Aumentos: 4x (3, 6-7, 9-10);10x (1-2,4-5 y 8$)$ 
carbonatos, y presencia de mafitos alterados $\left(\mathrm{Cpx}_{\text {incoloro }} / \mathrm{Anf}_{\text {verde o verde azulado }}\right)$. Entre los esquistos verdes, en la muestra MQ6 se observa la intercalación de lentes de calcita y la mayor concentración de clorita en superficies de cizalla (Figura 3.2.9a-b). En el caso de la muestra E-BO56 la roca calcárea original
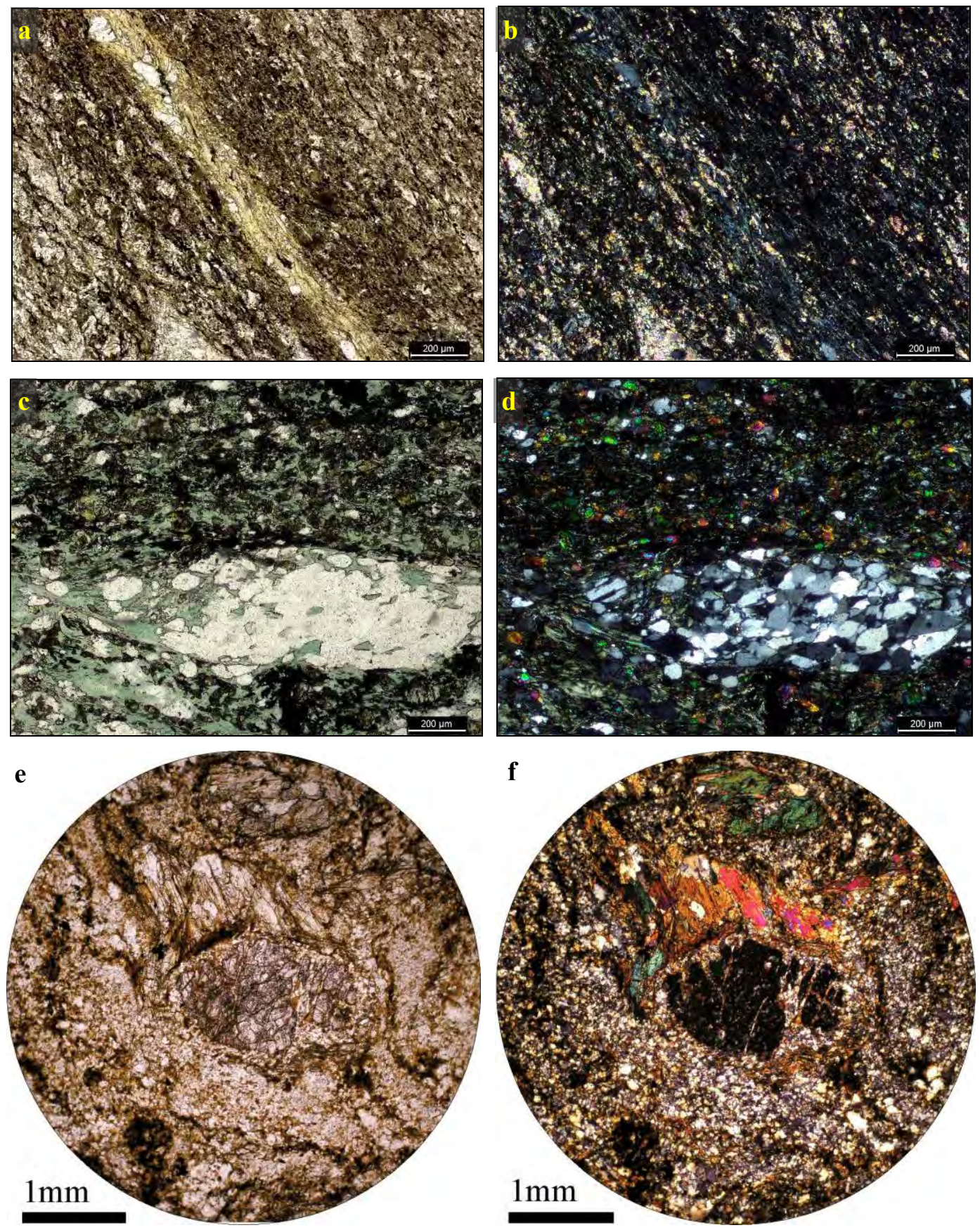

Figura 3.2.9: Microfotografías de las muestras de esquistos 'transicionales', en los que se observan las características generales de la foliación milonítica y composición (Chl - Ep - Op \pm Qtz $\pm \mathrm{Cal}$ ). a-b)- muestra MQ6: de color verdoso, originado por intercalación de una metapelita entre estratos calcáreos; c-d)- muestra E-BO56or: esquisto verdoso con abundante Ep y Chl intercalado entre metabasitas; presenta abundante calcita distribuida entre los componentes pero ésta no es visible sino que se reconoce por su reacción al $\mathrm{HCl}$; se observa una lente cuarzosa recristalizada con Chl y P 1. e-f)muestra E-BO1or (C): esquisto milonítico de protolito mixto; se observa un porfirocristal de granate rotado por la deformacion incrustándose en uno de clinopiroxeno parcialmente alterado rodeado de una matrix de grano fino cuarzofeldespática con concentraciones de biotita. 
ha tomado coloraciones verdosas debido a que la removilización y reemplazo ha llegado al punto en que no se observa la presencia directa de calcita sino toda una matrix deformada compuesta principalmente por clorita, epidoto, opacos y cuarzo. Sin embargo la muestra de mano reacciona inmediatamente con $\mathrm{HCl}$ (Figura 3.2.9c-d).

Solo en un sector de los afloramientos se llegó a formar granate. Uno de los pocos ejemplos se observa en los dominios micáceos del esquisto milonítico E- BO1or, Figura 3.2.9e-f), y presentan la asociación granate rojo, biotita y cuarzo. Luego fueron afectados por la deformación y quedaron como porfiroclastos rotados en los esquistos miloníticos. También aparecen en esta muestra 'ojos' y lentes de composición granítica. Otro rasgo característico de esta muestra es la presencia de grandes porfiroclastos de cristales incoloros con dos direcciones de clivaje (Cpx?) y de cristales verde-azulados de anfíbol (hornblenda transformada parcialmente en actinolita); es posible observar en algunos la transformación de uno en otro.

[Nota: el análisis de los resultados de geoquímica y análisis isotópicos se realizará luego de la descripción de las demás unidades, en la sección 3.2.7, ya que las conclusiones se han sacado básicamente por comparación con las litologías sin deformar].

3.2.3- FORMACIÓN DEL SALTO (emend.). ('Lutitas Del Salto' de Aceñolaza y Bernasconi, 1969a) + Formación Chuscho de Fauqué y Villar, 2003 + afloramientos del Miembro Cerro Cóndor del norte del Granito Potrerillos; Formación Chuscho, Martina y Astini, 2009).

\section{Introducción}

Esta unidad reune a las rocas metasedimentarias que afloran sobre las quebradas del Chuscho y del Salto y al norte del Granito Potrerillos, y también abarca a las rocas básicas de la Formación Chuscho, contenida en la parte inferior de las metasedimentitas. La relación entre ambas se observa sobre la Quebrada del Chuscho (Anexos A1: L2, M2).

Las metasedimentitas se caracterizan por preservar su identidad sedimentaria, particularmente por una estratificación marcada, alternando capas de granulometrías finas (metapelitas, metalimolitas) con capas de metavaques de grano mediano y muy raramente grueso. Estos rasgos permiten distinguirlas de las otras unidades de la región, especialmente de los esquistos. Además presentan una estructura caracterizada por plegamientos y fallamientos constantes, pero la deformación y el metamorfismo son menores que en la Formación Río Bonete. Por otro lado, no se asocian a rocas calcáreas ni a esquistos más que a través de fallas y discordancias erosivas y angulares, especialmente 
en el tramo inferior y boca del río Bonete. La presencia de una fauna compuesta por graptolites y bivalvos en lutitas negras del área del cerro Chuscho permitió asignarlas al Ordovícico.

Como ya se comentó en el capítulo de Antecedentes (sección 1.3), las metasedimentitas fosilíferas fueron denominadas informalmente como Lutitas del Salto por Aceñolaza y Bernasconi (1969a) quienes las consideraron equivalentes menos metamorfizados del Miembro Esquistos Cerro Cóndor de la Formación Río Bonete. Más recientemente Martina y Astini (2009) consideraron a las sedimentitas y a las lavas almohadilladas asociadas dentro de la misma unidad, a la que denominan Formación Chuscho, ya que representarían un mismo ambiente de depositación. Esta designación no equivale a la de Formación Chuscho, redefinida y caracterizada previamente por Fauqué y Villar (2003), quienes reúnen en esta unidad sólo a las rocas básicas del área del cerro Chuscho y posiblemente a las de la zona de Las Casitas, manteniendo a las sedimentitas dentro de la Formación Río Bonete según la definición de Aceñolaza et al. (1971). En el área de la quebrada del Chuscho las metasedimentitas efectivamente están intercaladas con las lavas almohadilladas (más autobrechas volcánicas y diques de diabasa). Para no llevar a confusiones se prefiere respetar los antecedentes previos y referir a las rocas básicas como Formación Chuscho (sección 3.2.4) siguiendo a Fauqué y Villar (2003) y Toselli y Durand (1996) y a las metasedimentitas (entre las que se intercalan estas lavas) como Rocas Metasedimentarias Estratificadas (sección 3.2.3.1). La Formación Del Salto entonces comprende a las Rocas Metasedimentarias Estratificadas que agrupa tanto a las Lutitas del Salto (Aceñolaza y Bernasconi, 1969a) y afloramientos sedimentarios al norte del Granito Potrerillos mapeados anteriormente dentro del Miembro Cerro Cóndor, así como a las rocas básicas (Formación Chuscho) relacionadas con ellas (Frigerio, 2011). De éste modo la Formación Del Salto sería en parte equivalente a la Formación Chuscho definida por Martina y Astini (2009). En este sentido cabe señalar que el uso de Formación Chuscho fue tradicionalmente referido a rocas básicas desde el comienzo, y que en el Cerro Chuscho, del que se toma este nombre, no aparecen rocas sedimentarias, habiéndose mencionado que posiblemente este sector sería el centro eruptivo de las rocas básicas (Fauqué y Villar, 2003; Aceñolaza y Bernasconi 1969b; Anexos A1: M1 y M2). Además, las rocas sedimentarias predominan respecto de las lavas y la presencia de estas últimas sólo se ha observado en los alrededores de la Quebrada del Chuscho (por estar mas cercanos al centro eruptivo).

Donde mejor se aprecia la relación que existe entre ambos miembros de la Formación del Salto (rocas básicas y metasedimentitas), es especialmente en el tramo medio a inferior de la quebrada del Chuscho (Anexos A1: L2, M2). Por este motivo y por ser el sector de más fácil acceso es que se propone este sitio como Area Tipo para la unidad. Para las lavas se mantiene como localidad el cerro Chuscho.

Por la complejidad estructural de la región y la escala de trabajo no ha sido posible realizar perfiles estratigráficos columnares de detalle, ni definir base y techo de la unidad. Sin embargo, la polaridad de las lavas almohadilladas en la boca de la quebrada del Chuscho indica una base hacia el oeste y techo hacia el este, al menos para los afloramientos de ese sector (Anexos A1: P3). A continuación se describirán principalmente las rocas metasedimentarias (sección 3.2.3.1), mientras que la unidad volcánica será descripta en detalle en el capítulo siguiente (sección 3.2.4) junto a otras volcanitas presentes. 


\subsubsection{1- ROCAS METASEDIMENTARIAS ESTRATIFICADAS.}

(Lutitas del Salto de Aceñolaza y Bernasconi, 1969a , más afloramientos estratificados al norte del Granito Potrerillos)

\section{a. Afloramientos.}

Son dos los afloramientos principales de las metasedimentitas, uno a cada lado de la faja de cizalla que pasa por el río Bonete: los que se encuentran al oeste, en una franja sobre las quebradas del Chuscho, del Salto y de los Árboles, y los que se encuentran hacia las nacientes y tramo superior de la quebrada de Potrerillos, donde constituyen la roca de caja del Granito Potrerillos (Anexos A1: M1 y P1; Figura 3.3.3). Además, en el tramo inferior y alrededores de la boca del río Bonete, existen pequeños afloramientos saltuarios en contacto siempre tectónico con las demás unidades. Es probable que estos contactos no se hallen expuestos claramente.

Como ya se mencionó, los afloramientos de metasedimentitas de esta unidad se caracterizan por preservar rasgos netamente sedimentarios, una estructura de plegamientos dislocados por pequeñas fallas o corrimientos, un grado metamórfico muy bajo, y la ausencia de mármoles y esquistos intercalados. La estratificación está bien marcada por la intercalación de estratos tabulares y continuos de metapelitas, metalimolitas y metavaques; este rasgo permite identificarlas y diferenciarlas de las demas unidades. Los bancos más espesos de lutitas puras son mas abundantes en los afloramientos fosilíferos de la zona de junta de las quebradas del Chuscho y del Salto, mientras que las facies con laminación heterolítica son especialmente comunes en los afloramientos de la quebrada de Potrerillos (Anexos A1: M1, M2 y M4). Sobre la quebrada del Chuscho están intercaladas con lavas almohadilladas, autobrechas volcánicas, filones y diques básicos ordovícicos de la Formación Chuscho (Fauqué y Villar, 2003; sección 3.2.4), sin embargo esto no se ha observado en los afloramientos de la quebrada de Potrerillos (esto sugiere que probablemente los afloramientos de la quebrada de Potrerillos corresponden a sectores alejados del centro eruptivo de las rocas básicas). A continuación se describen ambos afloramientos.

\section{Metasedimentitas del área del Chuscho.}

Presentan coloraciones castañas y amarillentas en superficie debido a oxidación (Figura 3.3.1), y son portadoras de la fauna de graptolitos y bivalvos que permite asignarles una edad ordovícica superior (ver más adelante). En este sector están cortadas por diques verdosos de diabasas de grano fino, ya sean intercaladas o en contacto tectónico con lavas almohadilladas, de la Formación Chuscho. Son pelitas y lutitas grises y negras que alternan con vaques verdosos o grises de grano fino a mediano. Las lutitas se hacen especialmente abundantes en una franja delgada que abarca los afloramientos fosilíferos más occidentales. En general las capas están inclinadas con ángulo alto, aunque es muy variable debido al plegamiento. Los vaques son masivos o presentan una tenue foliación, mientras que las pelitas presentan clivaje pizarreño bien marcado. Se hallan en contacto tectónico o en discordancia angular (no concordancia) 
sobre los esquistos y mármoles miloníticos de la Formación Río Bonete. Son afectados también por la faja de cizalla (Anexos A1: M1, M2).

Hacia la boca de la quebrada del Chuscho se hacen más abundantes los microplegamientos y kink-bands en las metapelitas que llegan a formar filitas. Esto es coherente con el hecho de que se encuentran más cerca de la faja de deformación principal. Los vaques pueden llegar a confundirse con diques verdes de diabasa de espesores, granulometrías y colores similares que atraviesan a las metasedimentitas y son dislocados junto con ellas. Aguas arriba de la quebrada del Chuscho y del Salto aparecen respectivamente basaltos porfíricos masivos (feno-andesitas, e.g. muestra $\mathrm{CH} 2$ ) y basaltos almohadillados (e.g. muestra CH3) en contacto con las sedimentitas ordovícicas, mientras que hacia la boca de la quebrada del Chuscho aparecen lavas almohadilladas (ej. CH15) asociadas a autobrechas volcánicas intercaladas con las metasedimentitas estratificadas. Por encima de las sedimentitas y rocas básicas aparece en forma saltuaria y en discordancia angular un conglomerado con coloraciones rojizas o violáceas que forma parte de las unidades del Paleozoico Superior (sección 3.2.8).

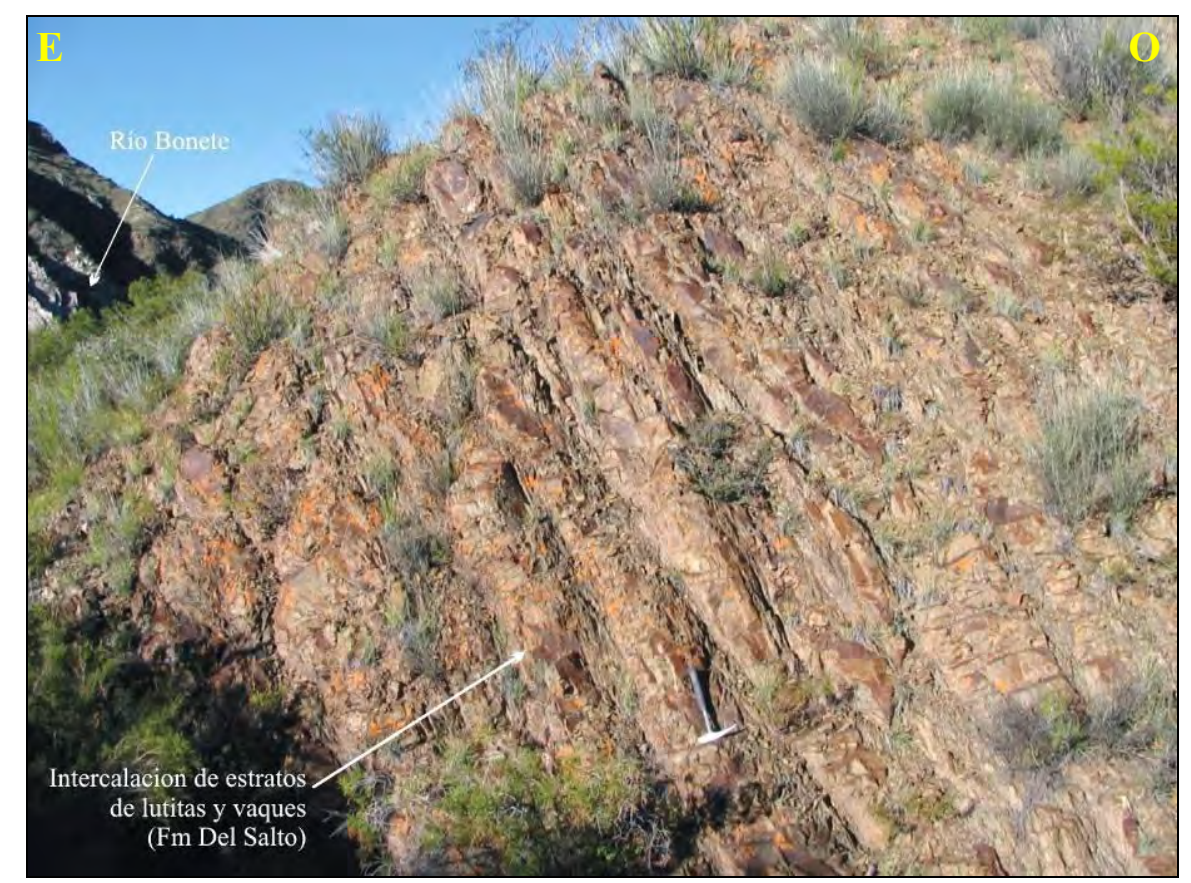

Figura 3.3.1: Aspecto típico de los afloramientos de las sedimentitas estratificadas fosilíferas de la Formación del Salto sobre la quebrada del Chuscho. Vista hacia el sur.

Afloramientos del norte del Granito Potrerillos.

Las rocas presentan una estratificación bien definida y una estructura de plegamientos y fallamientos similares a la de las metasedimentitas del área del Chuscho, lo que dificulta su análisis en continuidad areal, y determinación de espesor, evolución de facies, etc. (Figura 3.3.2). Los estratos están compuestos por una alternancia de pelitas, limolitas y vaques que frecuentemente tienen laminación heterolítica. Presentan tonalidades oscuras y abundante materia orgánica. En algunos sectores se han observado 


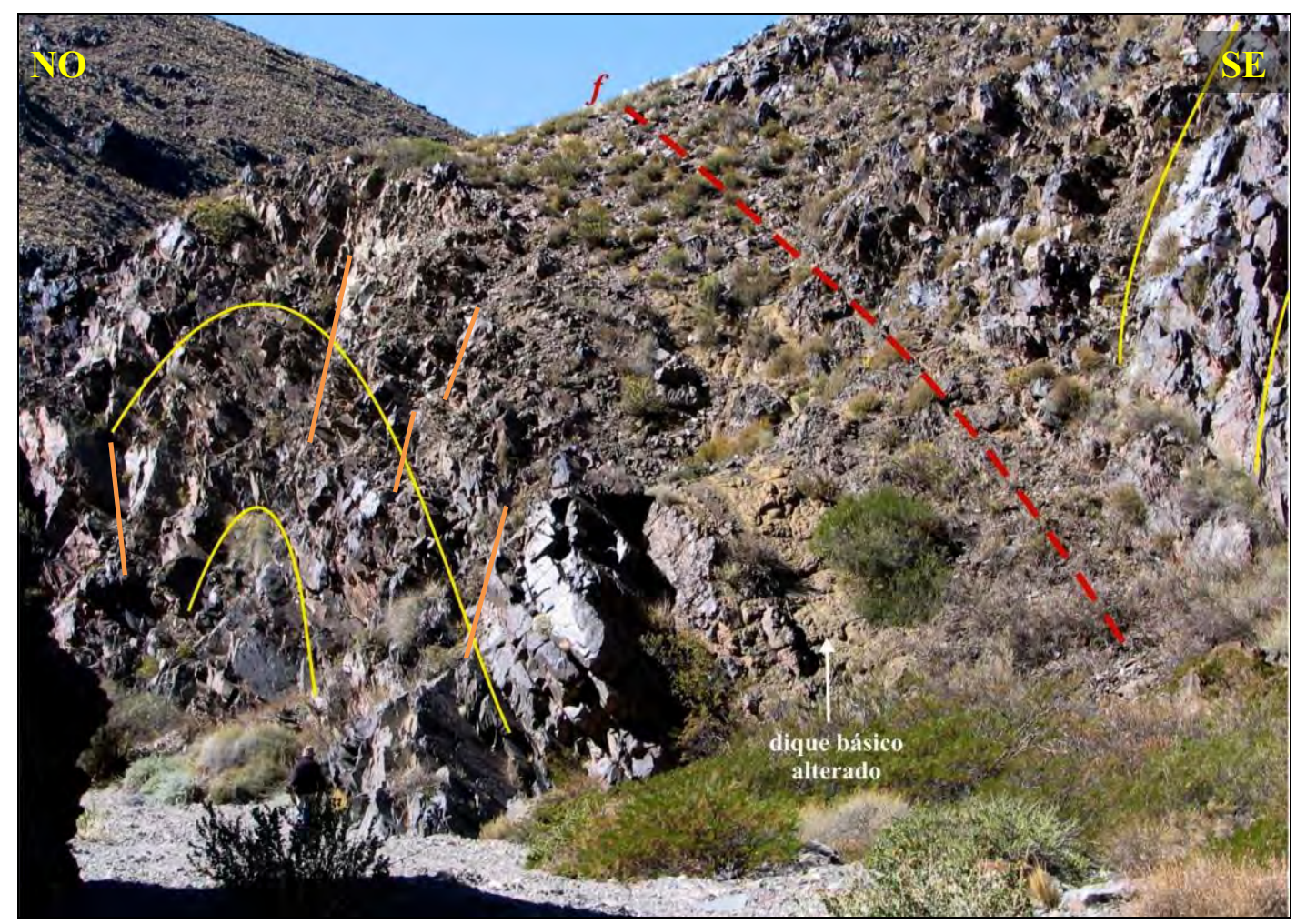

Figura 3.3.2: Aspecto típico de los afloramientos de las sedimentitas estratificadas de la Formación del Salto sobre la quebrada de Potrerillos. Se observan las superficies lustrosas y ennegrecidas por 'barníz del desierto', la estratificación afectada por corrimientos y plegamientos mas o menos apretados de plano axial subvertical, y el aspecto verdoso y opaco de los diques básicos que las cortan cuando estan alterados en superficie.

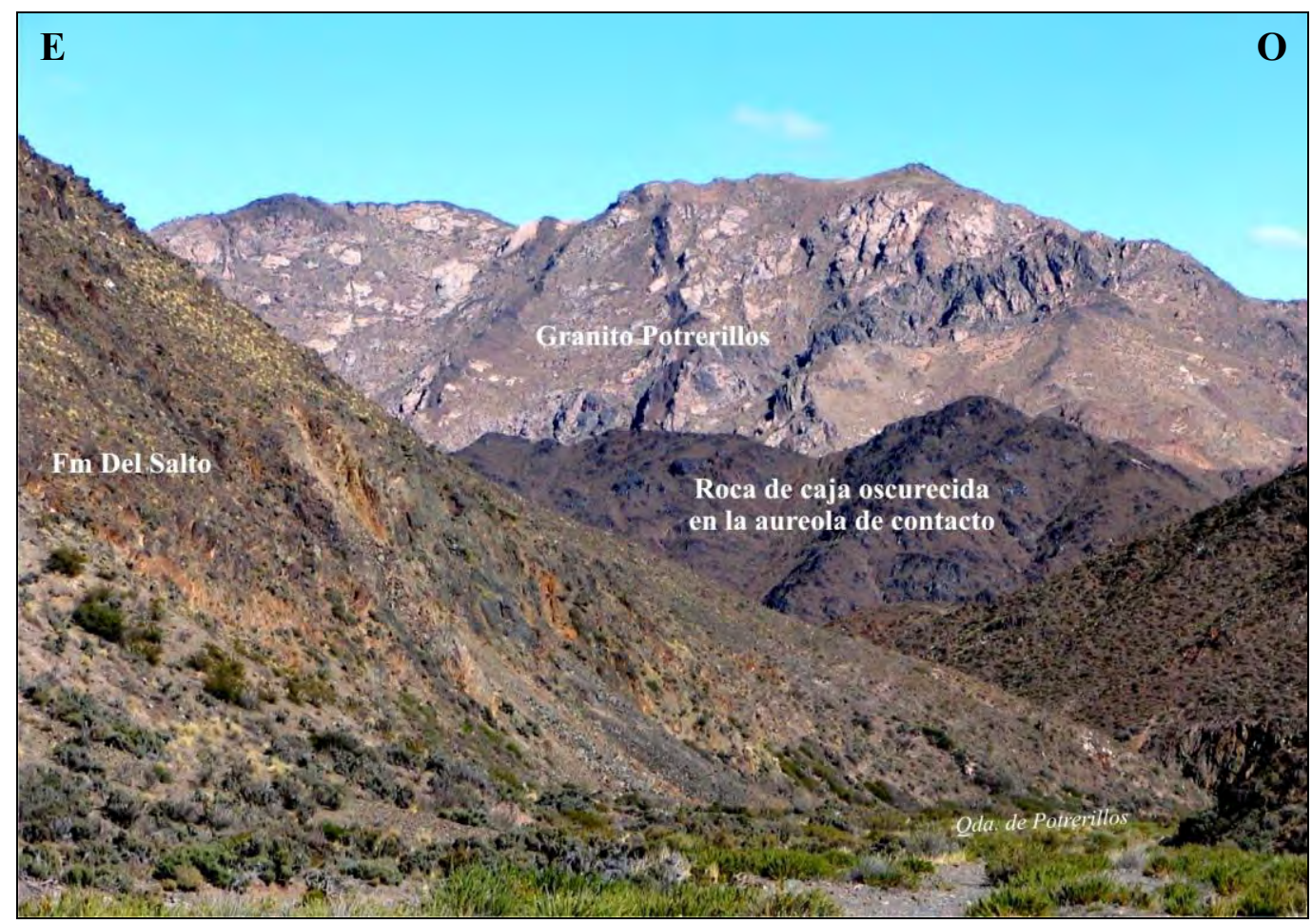

Figura 3.3.3: Afloramientos de la Formación Del Salto en el punto más septentrional alcanzado sobre la quebrada de Potrerillos. Vista hacia el sur en la que se observa la variación de aspecto de las metasedimentitas, especialmente el color, lejos y dentro de la aureola de contacto con el granito que las intruye. 
secuencias estratodecrecientes claras (Figura 3.3.4a), y ondulitas simétricas en las superficies estratales. Aun no se han hallado fósiles en este sector.

Las coloraciones oscuras y algo brillosas de los afloramientos en superficie se deben a que están cubiertas por 'barniz del desierto' que enmascara sus características, especialmente hacia el sur, donde son intruidas por el Granito Potrerillos generando una aureola de contacto (Figura 3.3.3). Por efecto de la temperatura, las metasedimentitas toman coloraciones más oscuras, con formación de motas en las facies más finas. Estas motas generalmente sin orientación preferencial, tienen morfologías redondeadas y a veces prismáticas, con diámetros promedio de entre 3 y $4 \mathrm{~mm}$. Las facies heterolíticas de los estratos cercanos al granito se diferencian por la ausencia o presencia de motas o de fisilidad, según sean de granulometrías más gruesas o finas respectivamente (Figuras 3.3.4b,c). Tanto el Granito Potrerillos, como su aureola y roca de caja fueron desplazadas por fallas de distintas magnitudes; una de las más notorias en
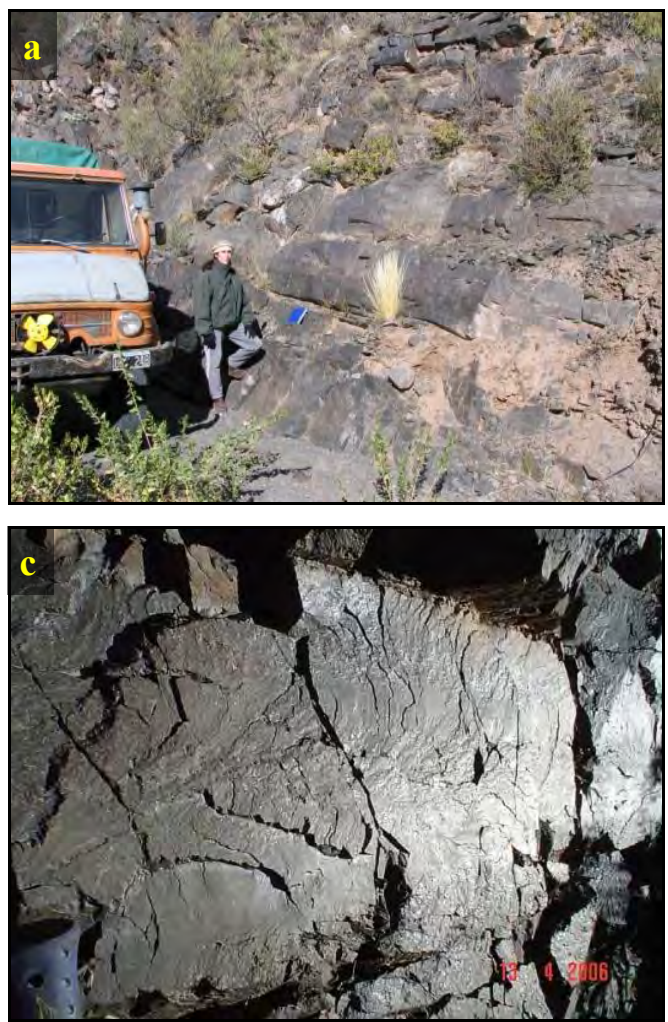

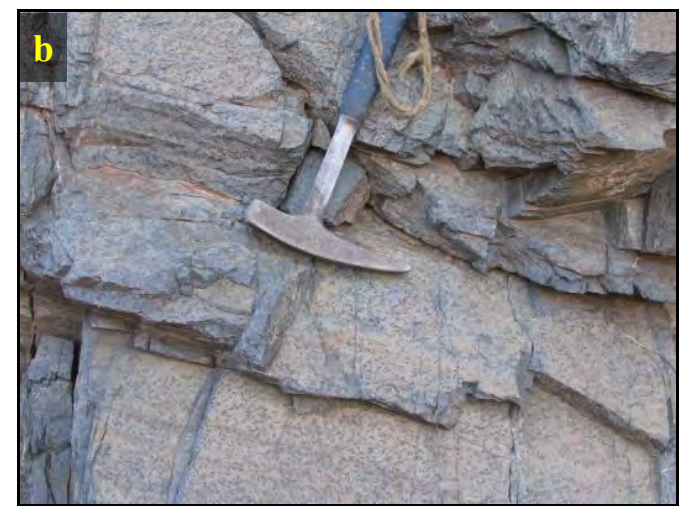

Figura 3.3.4: a)- arreglo estratodecreciente de la estratificacion en los afloramientos de la Formación del Salto en la quebrada de Potrerillos. b)motas en la superficie de las metasedimentitas de la aureola de contacto. c)- estrato oscurecido por barnices del desierto en el que las variaciones granulométricas internas quedan evidenciadas a contraluz por la presencia de motas en las láminas mas pelíticas y ausencia en las mas arenosas.

las imágenes es una falla sinestral con rumbo NNE-SSO que se corta contra la faja de deformación que pasa por la quebrada del Río Bonete en el extremo NO del granito (Anexos A1: M1). Las quebradas son angostas y abruptas en las cercanías del pluton debido a que la erosión esta controlada por la aureola de contacto. En las paredes casi verticales se observan alineamientos de lentes escalonadas de cuarzo lechoso, demarcando superficies de corrimientos superpuestas, con ángulos variables hasta subhorizontales.

Debido al plegamiento de las sedimentitas se ha desarrollado una foliacion de plano axial subvertical que puede llegar a confundir la inter pretación de los planos de estratificación (Figura 3.3.2). Sobre la quebrada de Potrerillos se ha

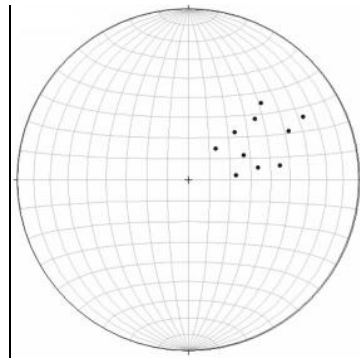

Figura 3.3.5: estereograma en el que se representa las actitudes de la foliación de plano axial medidas en los afloramientos de la quebrada de Potrerillos. 
medido un rumbo dominante de $134^{\circ}$, pero que varía entre $131^{\circ}-174^{\circ}$, y una inclinación variable entre $20^{\circ}$ y $66^{\circ}$ al E y NE (Figura 3.3.5). Estos planos son aprovechados por diversos diques básicos (sección 3.2.4).

\section{b. Petrografía.}

Estratos de metaareniscas, en su gran mayoría vaques finos, se intercalan con metapelitas y metalimolitas con abundante materia orgánica parcialmente grafitizada. Predominan las rocas de granulometrías finas, inmaduras tanto textural como composicionalmente, y comúnmente presentan una delgada laminación heterolítica, especialmente frecuente en los afloramientos del norte del granito, con gradaciones granulométricas entre pelitas y vaques medianos. Son comunes las microestructuras cataclásticas y miloníticas asociadas con el plegamiento, y presentan un grado variable de recristalización, mayor al acercarse al granito. En la aureola de contacto se observa neocrecimiento de biotita, recristalización de la matriz y formacion de motas en las pelitas.

A partir del estudio petrografico y de rayos X (Anexo A5) se comprueba que las metapelitas tienen composición micácea casi exclusivamente compuesta por Ill ( $\pm \mathrm{Chl})$, en algunos casos con delgadas láminas cuarzo-micáceas de mayor granulometría intercaladas. Los filosilicatos pueden llegar a estar fuertemente orientados por desarrollo de un clivaje pizarreño y en los sectores más pelíticos comúnmente pueden observarse crenulaciones y microplegamientos.

Las metalimolitas tienen aspecto equigranular, y composiciones cuarzosas, con variable proporcion de feldespatos y/o micas. Estan compuestas principalemente por cuarzo $(\mathrm{Qm})$, feldespato $(\mathrm{Pl}>\mathrm{Fk})$, Il1/Ms y opacos. Puede aparecer clorita secundaria relacionada con las micas de la matriz, o junto a opacos cuando son resultado de la descomposición de un mafito, generalmente biotita o líticos volcánicos alterados. Cuando la deformación es mayor el cuarzo se estira y la mica se orienta generando una foliación continua (clivaje), y puede presentarse mayor o menor efectos de cataclasis. En los dominios más pelíticos algunas muestras han desarrollado clivaje de fractura.

Las psamitas son de grano fino a mediano y tienen abundante matriz, constituyendo vaques de composiciones líticas y arcósicas (Figura 3.3.6). Lo más común es que muestren una gradación granulométrica interna, desde medianas hasta muy finas (Tabla 3.3.1), y una delgada laminación heterolítica. En general el máximo tamaño de grano es de arena mediana, cerca del límite inferior; excepcionelmente en sus fracciones mas gruesas llegan a acercarse (muestras LS1-7, LS1-9) o superar (muestras LS1-2, LS1-10) el límite de las areniscas gruesas. Son pocas las psamitas con granulometría adecuada (mediana) y porcentaje de matriz inferiores al 15\% que pudieron clasificarse por su composición modal con la aplicación del método de conteo de puntos de Gazzi - Dickinson (Ingersoll et al., 1984). La matriz está compuesta por cuarzo de grano fino, las arcillas se han transformado principalmente illita o illita + clorita y materia orgánica, y presenta variable grado de recristalización. En general gran parte de la matriz es pseudomatriz y, aunque muchas veces es evidente, no siempre es posible la delimitación e identificación de los clastos alterados y/o deformados que la componen. Entre los clastos del esqueleto hay un predomi- 
nio de cuarzo, plagioclasa y líticos (principalmente metamórficos y volcánicos básicos alterados). El grado de redondeamiento de los clastos va desde subredondeados hasta angulosos. El cuarzo es el componente principal y aparece como granos monocristalinos $(\mathrm{Qm})$ con extinción ondulosa o, mas abundante, como granos policristalinos (Qp) con subgranos poligonales o irregulares. Los feldespatos no superan el $50 \%$ de los clastos en la mayoría de las muestras. Entre ellos predominan ampliamente las plagioclasas, que se distinguen principalmente por las maclas y/o el tipo de alteración que presentan. En aquellos casos en que no ha sido posible la identificación de los feldespatos o se sospecha la presencia de feldespatos potásicos abundantes se han teñido los cortes con cobaltinitrito de sodio (ver metodología en capítulo 2). Los fragmentos líticos fueron caracterizados como líticos sedimentarios (Ls), metamórficos (Lm), volcánicos (Lv) y plutónicos (Lp); si no es posible su individualizacion fueron contabilizados como parte de la matriz (pseudomatriz). Los líticos volcánicos generalmente se encuentran alterados a Chl y $\mathrm{Op}( \pm \mathrm{Pl} \pm$ Qtz), adquiriendo un comportamiento mucho más dúctil. Los líticos metamórficos son de grano fino en general, están foliados y compuestos habitualmente por cuarzo policristalino y micas, aunque pueden presentar variable proporcion de minerales opacos. Aquellos clastos formados por cuarzo y feldespatos, raramente asociados con micas, pero que no presentan foliación, se contabilizaron como líticos plutónicos; sin embargo su preservación está condicionada por la granulometría.

Quebrada de Potrerillos: Los vaques tienen entre 32\% y $46 \%$ de matriz recristalizada (ortomatriz) que está compuesta por cuarzo, mica blanca, agregados terrosos de material opaco (materia orgánica, grafito, magnetita?) y puede haber clorita. Por otro lado en algunas muestras se ha observado la presencia de una pseudomatriz, asociada a la alteración y deformación de líticos, especialmente líticos volcánicos alterados $\left(\mathrm{Lv}_{\text {alt }}=\mathrm{Chl}+\mathrm{Op}\right)$. El esqueleto está formado por $\mathrm{Qtz}_{(\mathrm{Qp}>\mathrm{Qm})}, \mathrm{Pl}, \mathrm{Fk}$ y $\mathrm{L}_{(\mathrm{Lm}>(\mathrm{Ls}+\mathrm{Lp}))}$. El cuarzo presenta extinción ondulosa y recristalización, siendo el cuarzo policristalino el más abundante. Entre los feldespatos predomina la plagioclasa, aunque en porcentajes variables, y pueden estar alterados por calcita en forma de parches o desde los bordes, o también a sericita. Los feldespatos potásicos son anedrales. Los líticos metamórficos están foliados y compuestos por Qp + Ms o Qtz + Op, donde la mica o los opacos son los que se orientan; los líticos plutónicos son escasos y están compuestos por Qp + Fk o Qp + Pl. La muscovita detrítica tambien es escasa y de mayor tamaño que las micas de la matriz. Suele ser tabular o estar flexurada, y a veces se orienta según el clivaje. Como accesorios aparecen magnetita y circones euedrales a redondeados. En pocas muestras aparece calcita rellenando venillas y oquedades drusoides microscópicas. En líneas generales se puede resumir que en estos afloramientos hay un ligero predominio de las facies mas finas y heterolíticas respecto a las rocas del sector del Chuscho, los vaques son de composiciones ligeramente mas líticas, el cuarzo policristalino mas abundante que el monocristalino, la Ms detritica es mas escasa y los líticos predominantes son los metamórficos.

Area del Chuscho: los vaques son de composiciones similares aunque algo mas cuarzosas que los de la quebrada de Potrerillos (Figura 3.3.6), con variable proporción de granos de muscovita detrítica. 
a- Quebrada del Chuscho:
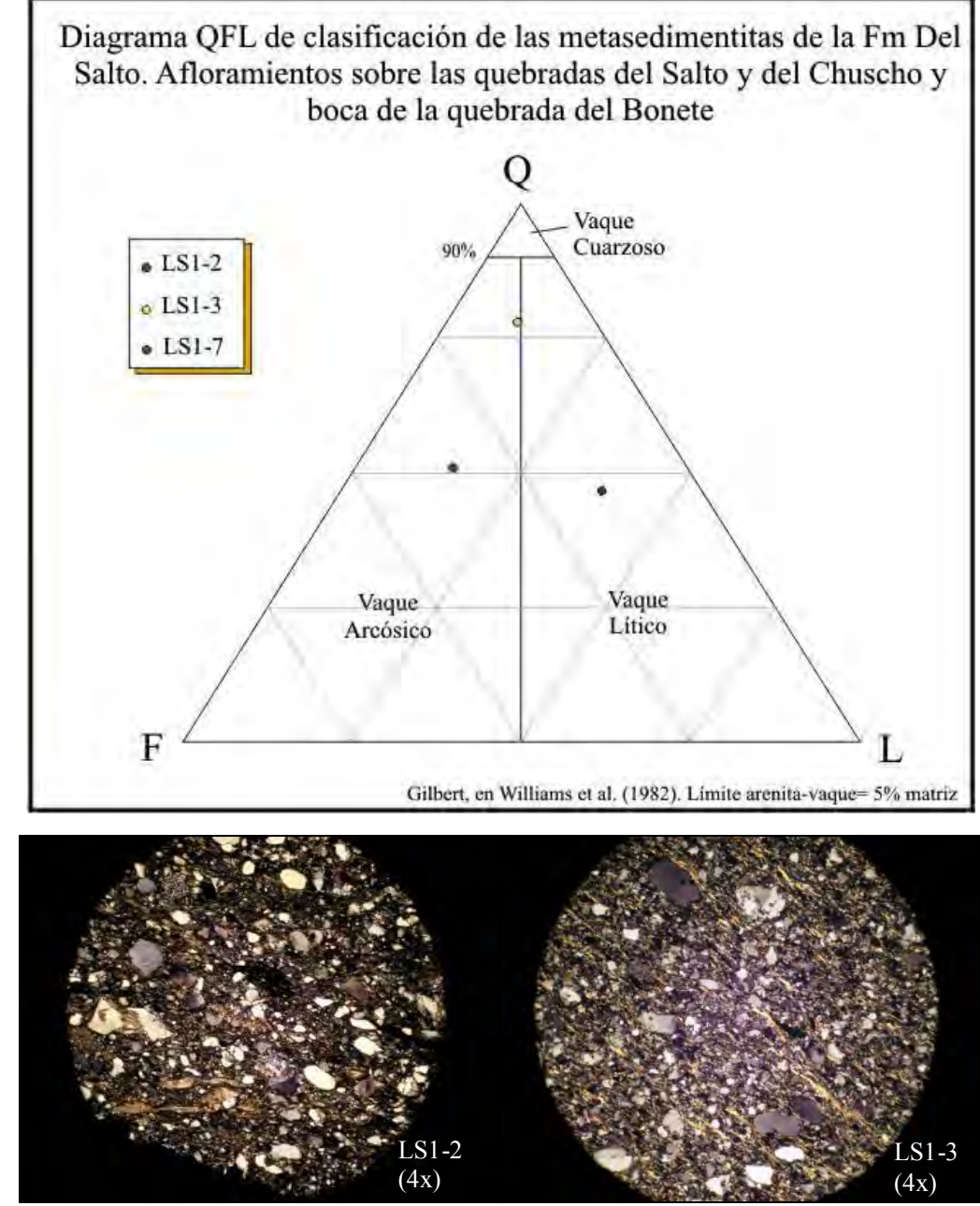
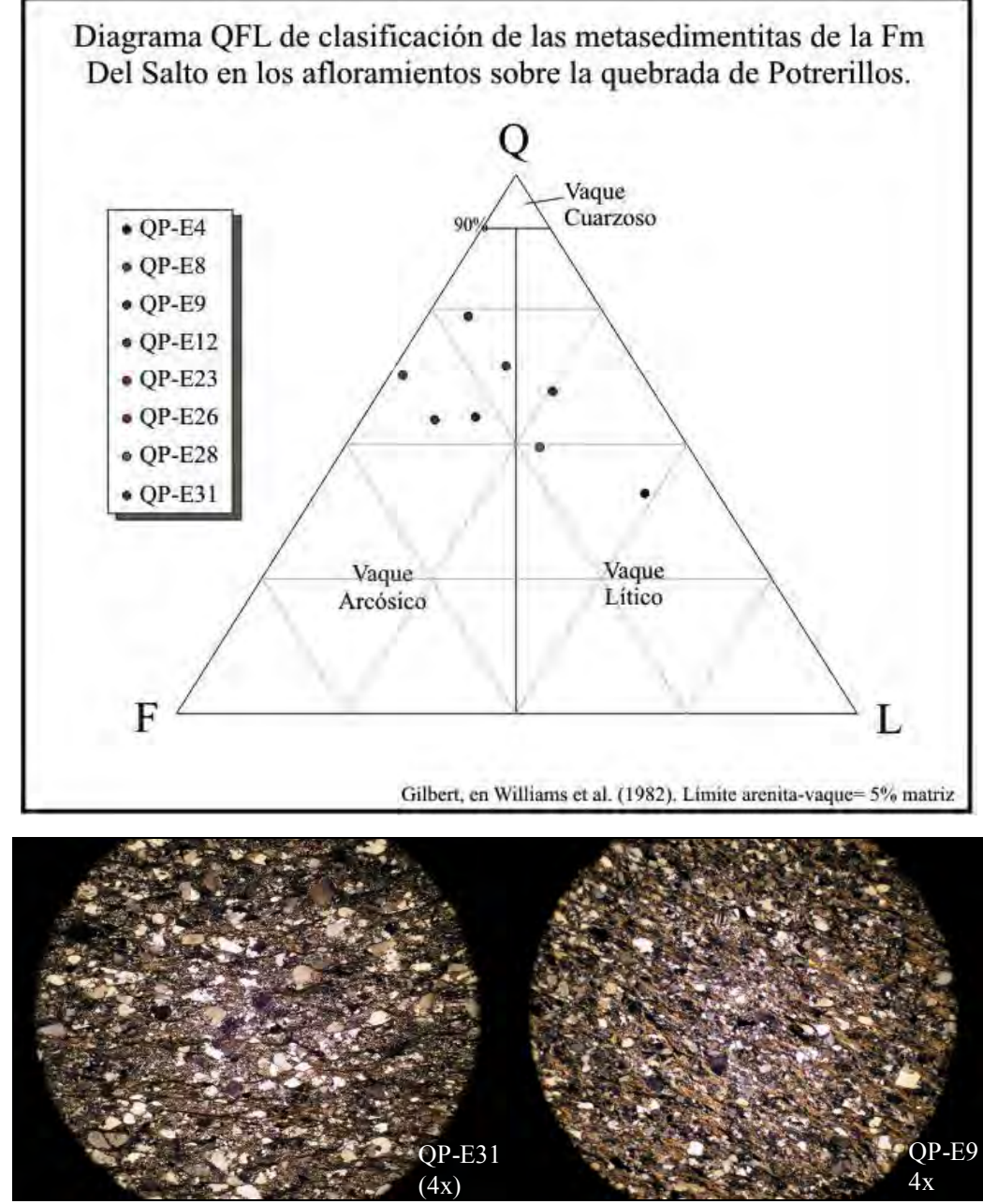

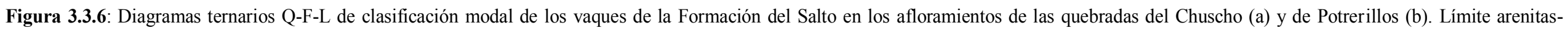
vaques: $5 \%$ de matriz (Gilbert, 1982). 
Hay una proporción algo mayor de capas de granulometrías mas gruesas. La textura primaria es matrizsostén, pero se desdibuja cuando la deformación y/o recristalización son más intensas. La matriz suele ser un agregado de grano fino de Qtz e Ill, que generalmente está recristalizado (ortomatriz) y puede estar deformada $u$ orientada. La presencia de materia orgánica se manifiesta en los cortes delgados con aspecto de manchas castañas u opacas terrosas distribuidas. En la matriz suelen encontrarse también agregados dispersos y de grano muy fino de epidoto granular. Los granos y porfiroclastos son generalmente angulosos, hasta subredondeados, y compuestos por $\mathrm{Qtz}_{(\mathrm{Qm}>\mathrm{Qp})}, \mathrm{F}_{(\mathrm{Pl} \pm \mathrm{Fk}(\mathrm{Or}))}+\mathrm{Ms}+\mathrm{L}_{(\mathrm{Lm}>\mathrm{Lp})}$, siendo lo mas abundante el Qm con extinción ondulosa, y luego los feldespatos; por último y en bastante menor proporción aparecen las micas (Ms) flexuradas y orientadas óptica y espacialmente marcando la foliación. Los líticos presentes son líticos cuarzo-feldespáticos (plutónicos?), metasedimentarios de grano fino ya sea cuarzosos (chert) o filíticos con Ill orientada; y líticos metamórficos cuarzosos compuestos por cuarzo policristalino recristalizado y foliados, con subgranos de variado tamaño (algunos de ellos podrían ser trozos de venas de Qtz deformadas). La composición y la presencia de líticos cuarzo-feldespáticos parecen indicar que una buena parte de los detritos provienen de una fuente granítica. En el caso de la muestra MQ-S es especialmente rica en $\mathrm{Pl}$ y Ep+Chl, siendo el aporte mas probable a partir de rocas básicas. Cuando la deformación es mayor la textura llega a ser cataclástica o milonítica, con recristalización de la matriz especialmente. Se generan colas pequeñas, se produce el estiramiento y/u orientación de clastos y de la Ill/Ms en la matriz. Las colas se componen de Qtz + Ill o Ill/Chl. Se observan lentes de Qp o micáceas, peces de mica (Ms), porfiroclastos ahusados y con colas pequeñas de Qtz - Chl - Ill, etc. Se han observado 'paquetes' de Chl creciendo dentro de granos de cuarzo o en las colas de los porfiroclastos.

Los granos de epidoto en estas muestras en parte procedería del aporte detrítico de la Formación Río Bonete y rocas básicas, y en parte probablemente es producto secundario de las sedimentitas en presencia de la importante presencia de rocas calcáreas del Miembro Mármol Las Damas en ese sector; en ambos casos la Formación Río Bonete ya estaría expuesta, aportando granos de epidoto o carbonatos.

\section{Deformación y relacion con el Granito Potrerillos:}

Debido al plegamiento regional es común observar que las capas desarrollaron un clivaje de plano axial y una foliación penetrativa que perturba la estratificación y laminación heterolítica primaria, principalmente a las láminas pelíticas. Esto se observa claramente en las rocas de la quebrada de Potrerillos (Figura 3.3.2). En las metapelitas se desarrolló clivaje pizarreño y de crenulación, mientras que vaques y limolitas suelen presentar texturas cataclásticas o miloníticas en los que se desarrollan dominios de clivaje oscuros vinculados a disolución, que se anastomosan alrededor de feldespatos y lentes de cuarzo elongadas y rodeadas de matriz fina recristalizada. Puede observarse que entre los granos de cuarzo elongados aparecen 'barbas' paralelas a la foliación compuestas por mica y clorita (e.g. Vernon, 2004, pág. 395). Otras microestructuras deformacionales observadas en los vaques son punzamientos $\mathrm{y}$, más raramente, 
Tabla 3.3.1: Litología y características texturales de las psamitas y limolitas de la Formación Del Salto. Granulometría vaques: $\mathrm{vf}=$ muy fino, $\mathrm{f}=$ fino, $\mathrm{m}=$ mediano, $\mathrm{c}=$ grueso; $\mathrm{U}=$ superior, $\mathrm{L}=$ inferior. Redondez: $\mathrm{R}=$ redondeado, $\mathrm{SR}=$ subredondeado, $\mathrm{BR}=$ bien redondeado, $\mathrm{A}=$ anguloso, $\mathrm{SA}=$ subanguloso. $\mathrm{mtz}=$ matriz.

\begin{tabular}{|c|c|c|c|c|c|c|}
\hline & \multirow[t]{2}{*}{ Muestra } & \multirow[t]{2}{*}{ Litología } & \multicolumn{2}{|c|}{ Granulometría } & \multirow[t]{2}{*}{ Redondez } & \multirow[t]{2}{*}{ Observaciones } \\
\hline & & & máx. & $\min$. & & \\
\hline \multirow{22}{*}{ 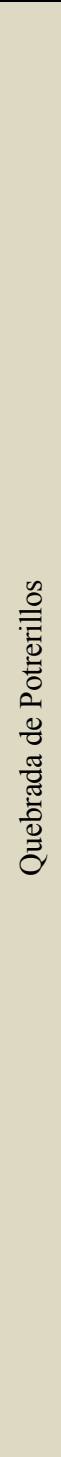 } & QP-E4 & vaque lítico & $\mathrm{mU}$ & $<$ vfL (pelita) & $\mathrm{R}-\mathrm{A}$ & Gradación granulométrica \\
\hline & QP-E5 & vaque & $(\mathrm{cL})-\mathrm{m}$ & $<$ vfL (pelita) & recrist & Milonit. abund. lentes de Qp recrist, $\mathrm{Pl}, \mathrm{F}$. \\
\hline & QP-E6 & vaque (heterolítico) & $\mathrm{fL} ; \mathrm{fU}$ & $<$ vfL (pelita) & SA - A & Motas (manchas) en las láminas pelíticas \\
\hline & QP-E8 & vaque arcósico & $\mathrm{mL}$ & $<$ vfL (pelita) & deformados & Foliado. Q-F, mtz pelítica y ortomatriz. \\
\hline & QP-E9 & $\begin{array}{l}\text { vaque arcósico. } \\
\text { (pizarra) }\end{array}$ & $\mathrm{fU}-\mathrm{mL}$ & $<$ vfL (pelita) & A-SR & Qtz-F. Gradación granulométrica. \\
\hline & QP-E12 & vaque arcósico & $\mathrm{mL}$ & $<$ vfL (pelita) & deformados & Qtz-F, foliado (lutita/pizarra) \\
\hline & QP-E13 & lutita & vfL & $<$ vfL (pelita) & recrist & Moteada. \\
\hline & QP-E15 & lutita & $<$ vfL & - & $\begin{array}{l}\text { recrist (Bt- } \\
\text { Q) }\end{array}$ & Moteada. \\
\hline & QP-E16 & $\begin{array}{l}\text { limo a arena muy } \\
\text { fina limosa }\end{array}$ & vfU-(fU) & $<$ vfL (pelita) & SR - A & Limo a arena muy fina limosa. \\
\hline & QP-E19 & vaque & mL-fU & $<$ vfL (pelita) & recrist & $\begin{array}{l}\text { Bt, ex-mafito(Chl-Op deform), abundante } \\
\text { Op. }\end{array}$ \\
\hline & QP-E20 & vaque fino a pizarra & $\mathrm{fL}$ & vfL & $(\mathrm{SA}-\mathrm{SR})$ & \\
\hline & QP-E21 & vaque/limolita & $\mathrm{fL}$ & vfL & muy recrist & Muy recristalizada (ortomatriz). Foliada. \\
\hline & QP-E22 & vaque $\mathrm{Q}-\mathrm{F}$ & $\mathrm{fL}$ & $<$ vfL (pelita) & SR - A & Gradación granulométrica. \\
\hline & QP-E23 & vaque arcósico & $\mathrm{fU}-(\mathrm{mL})$ & vfU-vfL & SR - A & Milonítico, poca mtz pelítica. \\
\hline & QP-E24 & pizarra & (fU)-fL & $<$ vfL (pelita) & SR - A & Milonítico. \\
\hline & QP-E25 & vaque (heterolítico) & $\mathrm{fU}$ & $<$ vfL (pelita) & SR - A & Láminas limolíticas alternan con pelíticas \\
\hline & QP-E26 & vaque arcósico & vfL & $<$ vfL (pelita) & $\mathrm{R}-\mathrm{A}$ & \\
\hline & QP-E27 & vaque (heterolítico) & $\mathrm{fU}$ & $<$ vfL (pelita) & SR - A & $\begin{array}{l}\text { Mucha mtz pelítica, sector mas grueso con } \\
\text { menor } \% \mathrm{mtz}\end{array}$ \\
\hline & QP-E28 & vaque lítico & $\mathrm{fU}-\mathrm{mL}$ & $<$ vfL (pelita) & SR - A & \\
\hline & QP-E31 & vaque lítico & $\mathrm{mL}$ & vfU & $\mathrm{R}-\mathrm{A}$ & Mtz pelítica, menor milonitización. \\
\hline & QP-E10 & pizarra & $\mathrm{fL}$ & $<$ vfL (pelita) & - & Recristalización. \\
\hline & QP-E11 & vaque & $\mathrm{fU}$ & $<$ vfL (pelita) & & \\
\hline \multirow{11}{*}{ 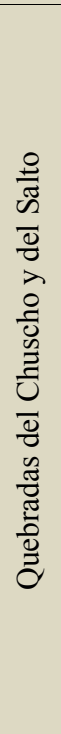 } & LS1-2 & vaque lítico & ve(U-L) & $\mathrm{mL}-<\mathrm{vfL}$ & $\mathrm{BR}$ - SA & $\begin{array}{l}\text { Text. cataclástica, colas (Chl-Ill-Qtz), } \\
\text { punzamientos }\end{array}$ \\
\hline & LS1-3 & vaque & $\mathrm{cL}$ & $<$ vfL (pelita) & SR - A & \\
\hline & LS1-7 & vaque arcósico (Q-F) & $\begin{array}{l}\mathrm{mU}(\mathrm{vcL}- \\
\mathrm{cU})\end{array}$ & $\operatorname{vf}(\mathrm{L}-\mathrm{U})$ & $\mathrm{R}-\mathrm{A}$ & $\begin{array}{l}\text { (Teñida alizarina). Alto \% Lp. Gradacion } \\
\text { granulométrica }\end{array}$ \\
\hline & LS1-9 & (meta-)vaque & $\mathrm{mU}-\mathrm{c}(\mathrm{L}-\mathrm{U})$ & $\operatorname{vf}(\mathrm{L}-\mathrm{U})$ & $\mathrm{R}-\mathrm{A}$ & Gradación granulométrica. \\
\hline & LS1-10 & vaque $\mathrm{Q}-\mathrm{F}$ & $\mathrm{cU}$ & vfL & SR - A & Alto $\% \mathrm{mtz}$. \\
\hline & LS1-20 & vaque fino & fL-(U) & $<$ vfL (pelita) & SR - A & Gradac. granulométrica, venas de Cal \\
\hline & LS1-21 & limolita & vfL-(U) & $<$ vfL (pelita) & - & Recristalización. \\
\hline & $\mathrm{CH} 10$ & vaque & $\mathrm{mL}$ & $<$ vfL (pelita) & SR - SA & \\
\hline & $\mathrm{CH} 11$ & vaque & $\mathrm{mL}$ & $<$ vfL (pelita) & SR - SA & Gradación granulométrica. \\
\hline & $\mathrm{CH} 12$ & vaque & vcL-mU & $\mathrm{f}(\mathrm{U}-\mathrm{L})$ & SR - A & Mtz recristalizada (ortomatriz) \\
\hline & MQ-S & vaque arcósico & $\mathrm{mL}$ & $\mathrm{fU}$ & - & $\begin{array}{l}\text { Milonita, laminación heterolítica. Mucha } \\
\text { Pl. Mtz Ep-Chl }\end{array}$ \\
\hline
\end{tabular}


microplegamientos. En algunos cortes delgados es posible observar que los clastos han sufrido un fracturamiento frágil sin mucho desplazamiento de las partes y comúnmente re-selladas por recristalización, como estructuras en dominó (ej.: LS1-7) y fracturas sin desplazamiento rellenas principalmente de calcita. Luego las fracturas fueron levemente desplazadas por la foliación milonítica en los planos de mayor deformación por cizalla y disolución por presión.

Las relaciones de corte entre las microestructuras observadas permite distinguir una secuencia de deformaciones sucesivas (e.g.: LS1-2). En primer lugar una deformación frágil durante la cual se generan las microfracturas que son rellenas por calcita, y que luego sufrieron recristalización. Posteriormente ocurrió el plegamiento regional caracterizado por el desarrollo de microestructuras de deformación frágildúctil como la cataclasis/milonitización y aparición de la foliación penetrativa típica, oblicua respecto de las fracturas, desplazándolas, con recristalización de cuarzo asociada. En algunas muestras se ha observado además la presencia de microplanos de cizalla que desplazan los dominios con foliación o generaron fracturas con poco desplazamiento que luego pueden o no ser rellenas con calcita.

Como es de esperar, los afloramientos del norte del Granito Potrerillos presentan rasgos asociados al efecto térmico de la intrusión. Dentro de la aureola de contacto se produjo la recristalización de la matrix cuarzo-micácea de las sedimentitas, con crecimiento de biotita (orientada y de colores rojizos), y desarrollo de motas subredondeadas. Las motas se desarrollan en las facies mas finas y forman concentraciones orientadas de clorita y sericita. Corresponden a porfiroblastos retrogradados (probablemente cordierita (?) por la composición) y se observa que crecieron a expensas de la biotita de la matrix, ya que ésta disminuye su concentración cerca de las motas, hasta casi desaparecer. Estan orientadas junto con la matrix que se deforma a su alrededor y muestran el desarrollo de colas incipientes. Se encuentran levemente rotadas y cortadas por el clivaje de plano axial que también corta a la laminación heterolítica primaria. Todo indica que las motas son pre- a sin- deformacionales. Esto es una evidencia, junto con la deformación que presenta el granito, que su intrusión es previa o ligeramente sincrónica con una etapa de deformación regional (Frigerio, 2008a, sección 3.2.7). En los bloques parcialmente asimilados por el granito la Bt es de mayor tamaño y aparece decusada o formando nidos, y asociada a inyecciones de venas cuarzosas o cuarzofeldespáticas (sección 3.2.2: esquistos micáceos). La asociación mineral primaria de los vaques $\left(\mathrm{Qtz}+\mathrm{Fk}+\mathrm{Pl}+\mathrm{Op}_{(\mathrm{MO})} \pm \mathrm{Ms}_{(\text {detrítica) }} \pm \mathrm{Ill} /\right.$ arcilla) no habría sido modificada en gran medida, siendo los cambios más importantes la transformación de la materia orgánica en grafito y oxidos de hierro, la recristalización del cuarzo y los filosilicatos de la matriz generando nuevos como Ill/Ms, Bt, y alteraciones posteriores como formación de clorita y sericita.

\section{Diagénesis y metamorfismo de muy bajo grado.}

Se considera que una roca es metamórfica cuando está totalmente recristalizada (Winkler, 1979; Turner, 1981), si bien, antes de alcanzar este estado, la roca pasa por estadios de presión-temperatura que se conocen con el nombre de metamorfismo de muy bajo grado. En estas condiciones de metamorfismo, sólo las rocas pelíticas y las rocas volcánicas ácidas son susceptibles de modificar su mineralogía. Por el 
contrario, en las psamitas y rocas plutónicas ácidas la mineralogía del protolito permanece prácticamente inalterada (Holdaway, 1971, pág. 379: sección 25.1: Asoc. Minerales en facies de grado muy bajo). 'Las condiciones de diagénesis [para las rocas sedimentarias] son equivalentes a la facies zeolita [definida para metabasitas], y la anquizona coincide con la facies prehnita-pumpellyita. La epizona se sitúa dentro de la facies de esquistos verdes' (Merriman y Roberts, 1985, en Holdaway, 1971). Los cambios diagenéticos que ocurren en fangos y lutitas entre los $20^{\circ} \mathrm{C}$ y cerca de $200{ }^{\circ} \mathrm{C}$ están bien documentados, asi como las características de la facies de esquistos verdes (FEV), el comienzo del 'verdadero' metamorfismo (Frey y Robinson 1999, cap. 1, y citas allí). Sin embargo, se conoce menos de las reacciones que ocurren durante el metamorfismo de muy bajo grado, aproximadamente entre los $200{ }^{\circ} \mathrm{C}$ y $\operatorname{los} 400{ }^{\circ} \mathrm{C}$ (Kübler, 1967, 1968; Kisch, 1968, 1974, 1980a, b; Frey, 1970, 1974, 1978; Frey and Niggli, 1971; Weber, 1976; Frey et al., 1980; y otras referencias allí). En Frey y Robinson (1999) se describe en detalle los cambios que ocurren durante la diagénesis tardía, metamorfismo de muy bajo grado y metamorfismo de grado bajo. Las condiciones metamorficas de grado bajo se hallan directamente controladas por el aumento de temperatura ligado al enterramiento (Coombs et al., 1959; Robinson y Bevins 1986), y corresponden al estadío posterior al de diagénesis.

Los datos de petrografía permitieron acotar la temperatura a la que fueron sometidas estas rocas entre los 400 y $500^{\circ} \mathrm{C}$. Teniendo en cuenta la respuesta de los minerales a la deformación la temperatura debió ser superior a los $300^{\circ} \mathrm{C}$ ya que el cuarzo se comporta dúctilmente, inferior a los $500^{\circ} \mathrm{C}$ porque los feldespatos se desgranan, y superior a los $400{ }^{\circ} \mathrm{C}$ allí donde aparece $\mathrm{Bt}$ (Llano et al., 1988). Por otro lado, los resultados de cristalinidad de la illita (Kübler, 1967) obtenidos para las metasedimentitas del área del Chuscho, efectuados a partir del análisis de rayos $\mathrm{X}$ en roca total en condiciones normales, dieron valores de IK entre 0,13 y 0,24. Estos datos indican que las rocas han sobrepasado los límites de la

Tabla 3.3.2: Valores del índice de Kübler (KI) obtenido para las muestras metasedimentarias de la Formación del Salto en el área del Chuscho.

\begin{tabular}{|c|c|c|c|c|}
\hline Muestra & KI & Zona diagenética correspondiente & Roca asociada & Unidad \\
\hline LS2 & 0,16 & Epizona & Metapelita & \\
LS2-3 & 0,16 & Epizona & Metapelita & \\
LS2-4 & 0,13 & Epizona & Metapelita & Rocas Sedimenta- \\
LS2-5 & 0,21 & Epizona & Metapelita & rias Estratificadas \\
LS1-2 & 0,15 & Epizona & Metavaque & (Fm Del Salto) \\
LS1-3 & 0,17 & Epizona & Metavaque & \\
LS1-9 & 0,13 & Epizona & Metavaque & \\
LS1-10 & 0,20 & Epizona & Metavaque & \\
\hline
\end{tabular}

diagénesis (hasta alrededor de $\operatorname{los} 200{ }^{\circ} \mathrm{C}, \mathrm{IK}<3,0$ ), asociándose a anquimetamorfismo (entre 200 y 400 ${ }^{\circ} \mathrm{C}$ aproximadamente) y epizona $(\mathrm{KI}<1,5$; Tabla 3.3.2) por efecto conjunto del metamorfismo regional y de contacto. Esto acotaría el máximo grado metamórfico dentro de la zona de Chl de la facies de esquistos verdes (FEV). Entre las micas blancas, a temperaturas mayores a $200-250^{\circ} \mathrm{C}$ la fase estable es phengita y la illita es metaestable; no obstante, la illita puede persistir durante la epizona, sin formar nuevas fases (Weaver, 1984). Para mayor información sobre metamorfismo de bajo grado se puede consultar a Frey y 
Robinson (1999), Kübler, B. (1967, 1984), Holdaway (1971), Weaver, (1984), Yardley (1989), Kisch (1991).

\section{c. Registro fosilífero.}

Como se ha resumido previamente, las referencias sobre el contenido fosilífero de esta unidad son escasas (Aceñolaza y Bernasconi, 1969; Aceñolaza, 1970; Aceñolaza et al., 1971; Ortega et al., 1991; Zimmermann y Van Staden, 2002; Frigerio et al., 2005. Sección 1.3), debido a las condiciones de metamorfismo y oxidación desfavorables para la preservación de los restos y a la dificultad para acceder a los afloramientos mas alejados.

El material fosilífero (esencialmente graptolitos) hallado durante el desarrollo de este trabajo corresponde a los afloramientos de una franja de pelitas que se encuentran en el extremo en el que inicia la serranía divisoria entre las quebradas del Chuscho y del Salto, en las coordenadas $28^{\circ} 30^{\prime} 49,8^{\prime \prime} \mathrm{S}$ y $68^{\circ}$ $31^{\prime} 46,4^{\prime \prime}$ O, y en la margen norte de la quebrada del Salto a los $28^{\circ} 30^{\prime} 41,8^{\prime \prime}$ S y $68^{\circ} 31^{\prime} 46,6^{\prime \prime}$ O (Figura 3.3.7).

En cuanto a la preservación de las colonias de graptolitos, estas se encuentran deformadas, en algunos casos, reemplazadas por óxidos minerales, que le confieren una coloración rojiza dando un fuerte contraste con la roca portadora, o bien se preservan como una película carbonosa o en relieve. En la mayoría de los casos el peridermo ha sido destruido.

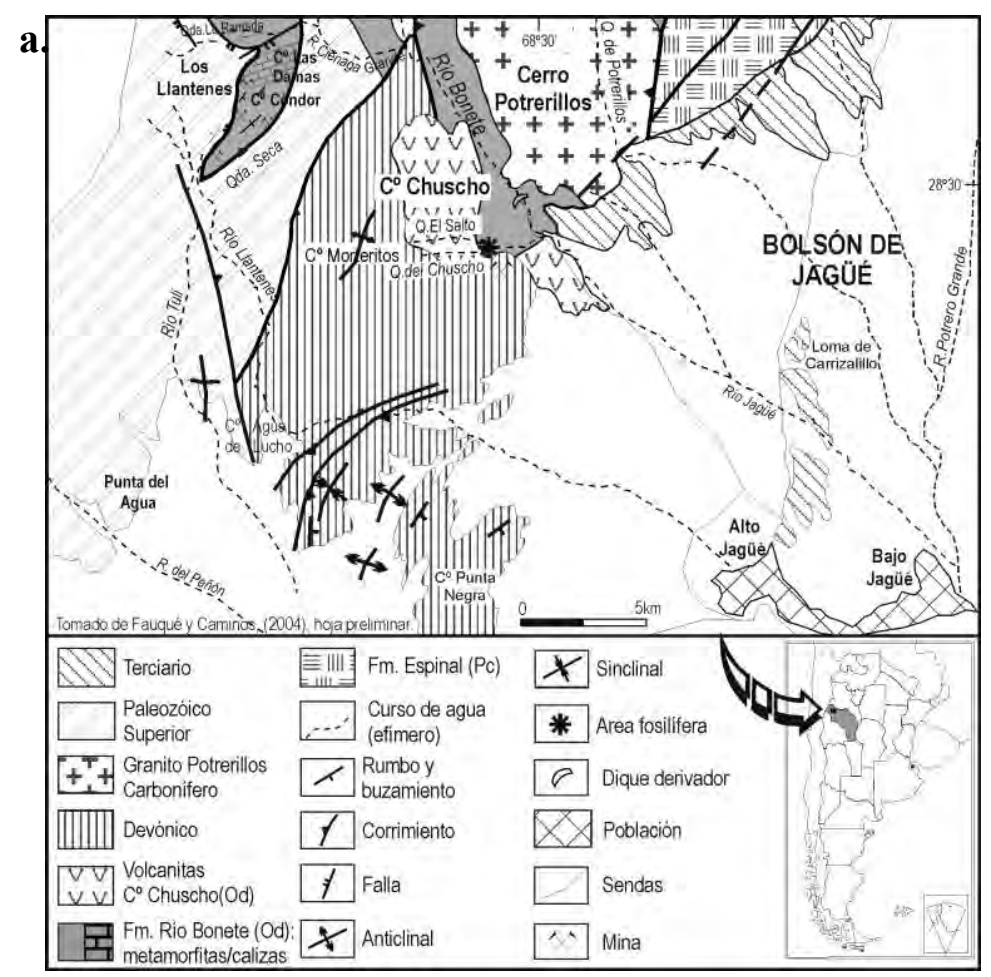

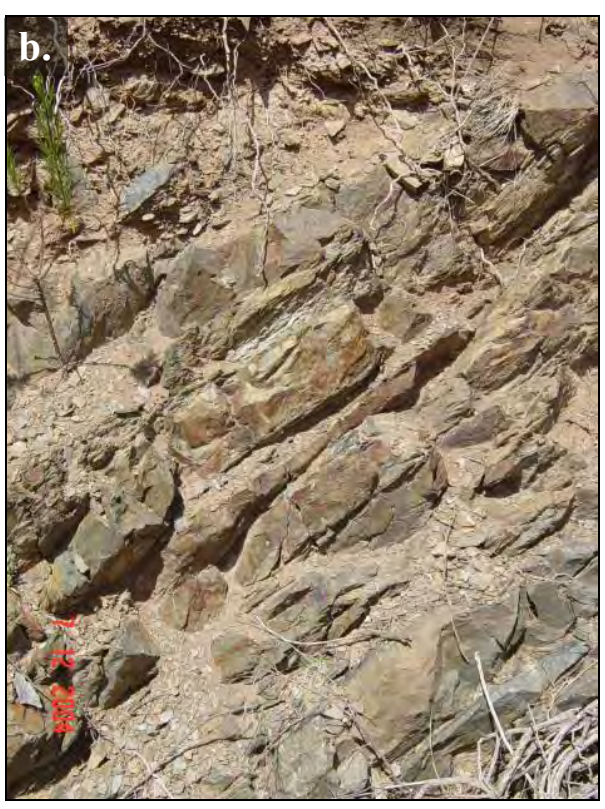

Figura 3.3.7: a- Ubicación de las pelitas fosilíferas; b- aspecto de los afloramientos.

El material colectado es numeroso, y consiste en impresiones de rabdosomas cuya morfología no se ha preservado excepto en las cuatro formas que se esquematizan en la Figura 3.3.8. Se trata de ejemplares imperfectamente conservados, incompletos, truncados distalmente y parcialmente destruidos en su extremo proximal. Uno de los ejemplares está roto y desplazado por efecto de microcizalla. 
El marcado tectonismo de la zona no permitió preservar los detalles del desarrollo proximal de los rabdosomas ni los detalles internos de las colonias, solo se han conservado, por tramos, las tecas parcialmente deformadas.

La longitud de los rabdosomas varía entre 6,5 y $14 \mathrm{~mm}$, el ancho inicial de la colonia se desconoce, siendo de 1,1-1,4 mm en su tramo medio, el cual aparentemente se mantiene. En ninguno de los ejemplares es posible reconocer las características de las tecas basales. No hay rasgos de la sícula ni del septo medio. El número de tecas en $10 \mathrm{~mm}$ se estima entre 14 a 18, no puede medirse su traslapamiento. Las tecas se caracterizan por presentar una ligera curvatura sigmoidal de su pared ventral, similares a tecas gliptográptidas. Las márgenes aperturales son rectas o ligeramente cóncavas.

Dada la ausencia de los rasgos de la extremidad proximal y estructuras internas de los rabdosomas, no se han podido asimilar las formas a los patrones astogénicos definidos por Mitchell (1987) como tampoco seguir las líneas evolutivas de los graptolitos diplográptidos propuestos por Mitchell et al. (1995). Por ende, la asignación taxonómica precisa del material es incierta, y solo se pueden describir como 'graptolitos biseriados' (colonias con dos hileras de tecas).

En base a la asociación de graptolites descripta por Aceñolaza y Bernasconi (1969), Aceñolaza (1970) y Aceñolaza et al. (1971), y asumiendo que estas sedimentitas eran equivalentes poco metamorfizados del Miembro Cerro Cóndor ('Lutitas del Salto'de Aceñolaza y Bernasconi, 1969a), estos autores asignaron a la Formación Río Bonete al Llandeiliano (Darriwiliano). Sin embargo Ortega et al. (1991) redefinen taxonómicamente esta fauna, y consideran que la edad de los niveles portadores es caradociana (Ordovícico Superior).

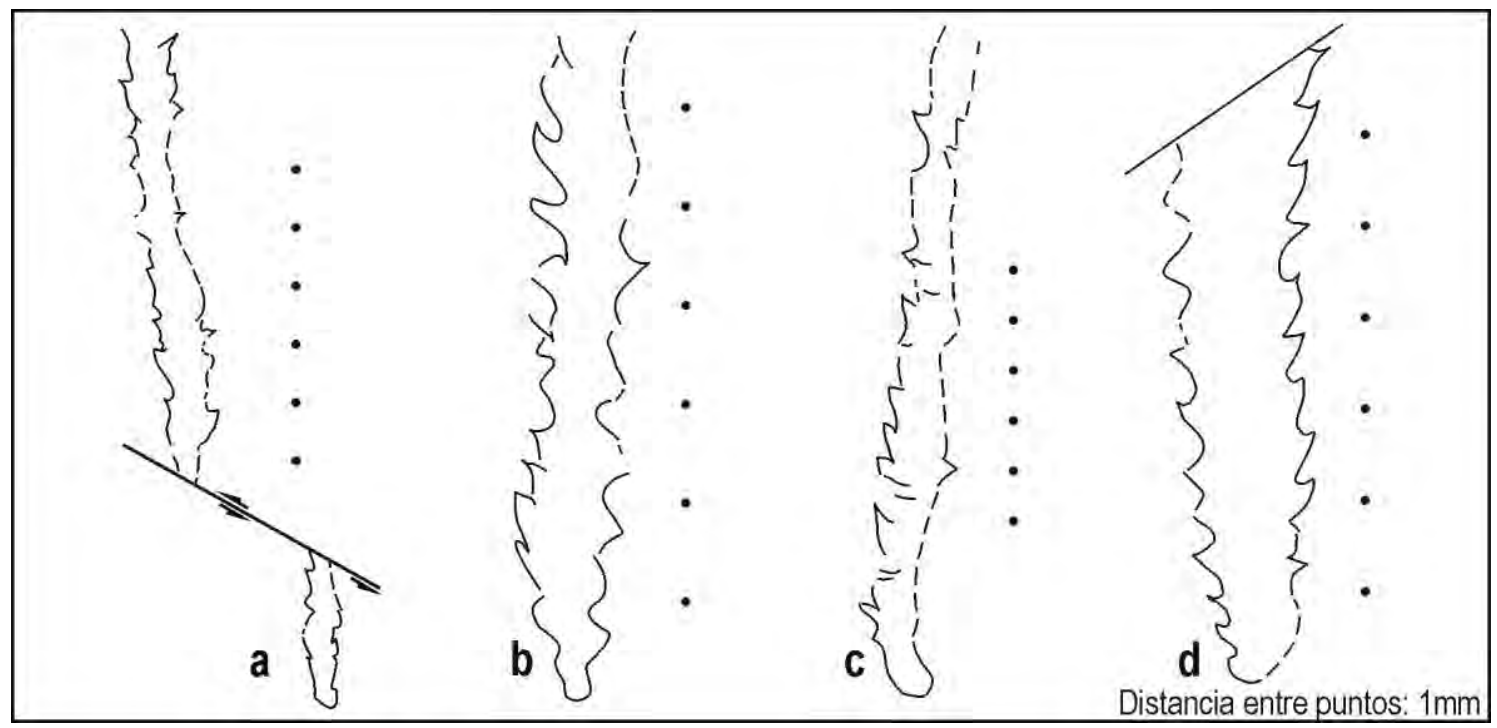

Figura 3.3.8: Interpretación del material fosilífero significativo recogido en la quebrada del Chuscho (Frigerio et al., 2005) a-d: Graptolitos biseriados. a, MLP. 18415, b, MLP. 18416, c, MLP. 18417, d, MLP. 18418. Repositorio del Departamento Científico de Paleozoología de Invertebrados del Museo de Ciencias Naturales de La Plata.

Las características sedimentarias de los afloramientos, su granulometría esencialmente pelítica en este sector, el tipo de material fósil y su preservación permiten interpretar que se han depositado en un ambiente marino abierto, con baja energía como los fangos de los fondos oceánicos. Según lo expresado por Aceñolaza (1970), "Las faunas marinas que portan estas rocas indican que el mar se 
abría hacia el oeste de la Sierra de Famatina (también con fósiles marinos en unidades equivalentes) para esta época".

\section{d. Geoquímica.}

Elementos mayoritarios:

La composición geoquímica de 21 muestras de pelitas, vaques y vaques heterolíticos de la Formación del Salto se presentan los Anexos (A6a: Tabla 3). Las pelitas presentan mayores contenidos de $\mathrm{Al}_{2} \mathrm{O}_{3}, \mathrm{MgO}$ y $\mathrm{K}_{2} \mathrm{O}$ que las psamitas, y menores valores en promedio de $\mathrm{SiO}_{2}$ y $\mathrm{Na}_{2} \mathrm{O}$. Las psamitas del área del Chuscho son las que presentan mayor enriquecimiento en $\mathrm{Na}_{2} \mathrm{O}$, lo que probablemente esté expresando mayor grado de albitización de feldespatos. Los contenidos de $\mathrm{MnO}, \mathrm{TiO}_{2}$ y $\mathrm{P}_{2} \mathrm{O}_{5}$ son variables. Los contenidos de hierro $\left(\mathrm{Fe}_{2} \mathrm{O}_{3}\right.$ total) y $\mathrm{CaO}$ también son variables y en algunas muestras estan controlados por el grado de alteración superficial y presencia de calcita ya sea como cemento y/o como alteración de granos. El contenido de volátiles es mayor en pelitas que en psamitas y en estas últimas está influenciado por el contenido de matriz (representado por valores de 2 a 4,8\% de LOI para pelitas y 1,5 a 3,8\% para vaques y vaques heterolíticos).

A modo comparativo se han ploteado muestras de pelitas y areniscas de los distintos afloramientos de las sedimentitas en los gráficos geoquímicos de clasificación de rocas sedimentarias propuestos por Herron (1988) y el de areniscas propuesta por Pettijohn et al. (1972, 1987. Figura 3.3.9, Tabla 3.3.3). En ambos diagramas la mayoría de las muestras se clasificarían como pelitas, vaques y arenitas líticas. Esto coincide con lo observado por petrografía. Las muestras son No Calcáreas, a excepción de la muestras QP-E10 ( $\mathrm{CaO}=5,27 \%$; Herron, 1988). La muestra LS1-7 es la que registra mayo-
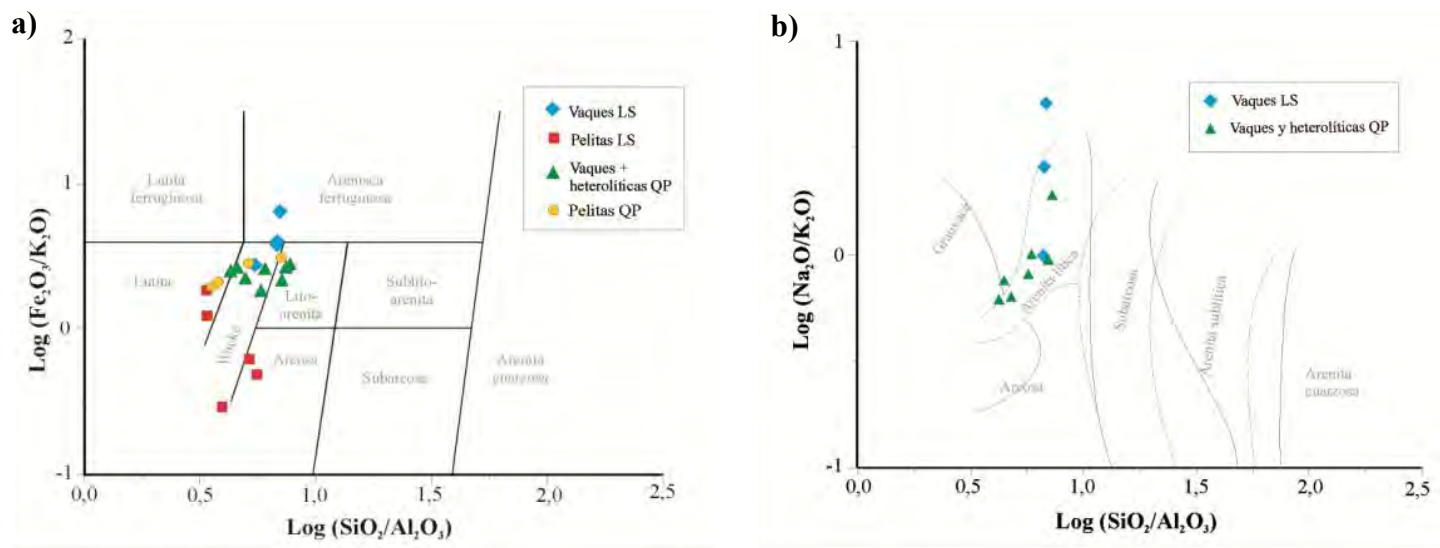

Figura 3.3.9: Clasificación geoquímica de las sedimentitas de la Formación del Salto en distintos afloramientos. a) Herron (1988); b)- Pettijohn et al. (1972, 1987).

res evidencias de haber sufrido movilización de los elementos por lo cual habrá que tener mayor precaución al trabajar con los resultados obtenidos. Tiene mayor contenido de Fe lo que la coloca en el campo de las arenitas férricas, pero este hierro es producto de la alteración superficial de la muestra, por lo que se agruparía con los vaques. También posee mayor contenido de Na que las demás mues- 
tras, separándose un poco del campo de las grauvacas en la clasificación de Pettijohn et al., (1972, 1987.).

Tabla 3.3.3: Datos para la clacificación geoquímica de las muestras sedimentarias de la Formación del Salto de Herron (1988), y de areniscas de Pettijohn et al. (1972, 1987).

\begin{tabular}{|c|c|c|c|c|c|c|c|}
\hline \multirow{3}{*}{$\begin{array}{l}\text { Muestra } \\
\text { LS2 }\end{array}$} & \multirow{3}{*}{$\begin{array}{c}\log \mathrm{SiO}_{2} / \mathrm{Al}_{2} \mathrm{O}_{3} \\
0.523\end{array}$} & \multirow{3}{*}{$\begin{array}{c}\log \mathrm{Fe}_{2} \mathrm{O}_{3} / \mathrm{K}_{2} \mathrm{O} \\
0.087\end{array}$} & \multirow{3}{*}{$\frac{\log \mathrm{Na}_{2} \mathrm{O} / \mathrm{K}_{2} \mathrm{O}}{-}$} & \multirow{3}{*}{$\begin{array}{c}\mathrm{CaO} \\
\% \\
0.24\end{array}$} & \multicolumn{3}{|c|}{ Clasificación } \\
\hline & & & & & \multirow{2}{*}{$\begin{array}{c}\begin{array}{c}\text { Pettijohn et al. (1972, } \\
\text { 1987) }\end{array} \\
-\end{array}$} & \multicolumn{2}{|c|}{ Herron $(1988)^{1}$} \\
\hline & & & & & & pelita & $N C$ \\
\hline LS2-2 & 0.591 & -0.542 & - & 0.21 & - & $\begin{array}{l}\text { vaque (fuera de } \\
\text { campo) }\end{array}$ & $N C$ \\
\hline LS2-3 & 0.521 & 0.263 & - & 0.71 & - & pelita & $N C$ \\
\hline LS2-5 & 0.710 & -0.212 & - & 0.17 & - & $\operatorname{arcosa}$ & $N C$ \\
\hline LS2-F & 0.737 & -0.314 & - & 0.09 & - & $\operatorname{arcosa}$ & $N C$ \\
\hline LS1-3 & 0.731 & 0.434 & 0.077 & 0.34 & $\begin{array}{c}\text { gravuaca /arenita } \\
\text { lítica }\end{array}$ & vaque & $N C$ \\
\hline LS1-7 & 0.841 & 0.804 & 0.713 & 1.42 & $\begin{array}{l}\text { gravuaca (fuera } \\
\text { de campo) }\end{array}$ & arenita-Fe & $N C$ \\
\hline LS1-10 & 0.829 & 0.574 & 0.413 & 2.01 & arenita lítica & vaque & $N C$ \\
\hline $\mathrm{CH} 10$ & 0.825 & 0.597 & -0.008 & 1.45 & arenita lítica & vaque & $N C$ \\
\hline QP-E5 & 0.885 & 0.441 & 0.101 & 1.11 & arenita lítica & litoarenita & $N C$ \\
\hline QP-E6 ${ }^{(*)}$ & 0.757 & 0.265 & -0.090 & 1.08 & arenita lítica & vaque & $N C$ \\
\hline QP-E7 & 0.546 & 0.281 & - & 0.33 & - & pelita & $N C$ \\
\hline QP-E8g & 0.573 & 0.322 & - & 0.39 & - & pelita & $N C$ \\
\hline QP-E9 & 0.849 & 0.331 & -0.024 & 0.90 & arenita lítica & litoarenita & $N C$ \\
\hline QP-E10 & 0.865 & 0.427 & 0.282 & 5.27 & arenita lítica & litoarenita & $C$ \\
\hline QP-E10g & 0.845 & 0.484 & - & 1.47 & - & litoarenita-vq & $N C$ \\
\hline QP-E11 & 0.653 & 0.420 & -0.116 & 0.86 & $\begin{array}{c}\text { gravuaca /arenita } \\
\text { lítica }\end{array}$ & vaque & $N C$ \\
\hline QP-E11g & 0.702 & 0.446 & - & 0.88 & - & vaque & $N C$ \\
\hline QP-E24 & 0.774 & 0.415 & 0.004 & 1.16 & arenita lítica & vaque & $N C$ \\
\hline QP-E25 & 0.692 & 0.344 & -0.198 & 0.63 & arenita lítica & vaque & $N C$ \\
\hline QP-E27 & 0.627 & 0.402 & -0.211 & 2.91 & $\begin{array}{c}\text { gravuaca /arenita } \\
\text { lítica }\end{array}$ & pelita & $N C$ \\
\hline
\end{tabular}

${ }^{1}$ Según el \% de Ca luego Herron (1988) separa las areniscas en calcáreas $(\mathrm{Ca}=4-5 \%$. C), no calcáreas $(\mathrm{Ca}<4 \%$. $N C)$ y carbonáticas $\left(\mathrm{Ca}<15 \%\right.$. Carb). ${ }^{(*)}$ Los resultados de la muestra QP-E6 son poco confiables ya que presenta moteado metamórfico marcado.
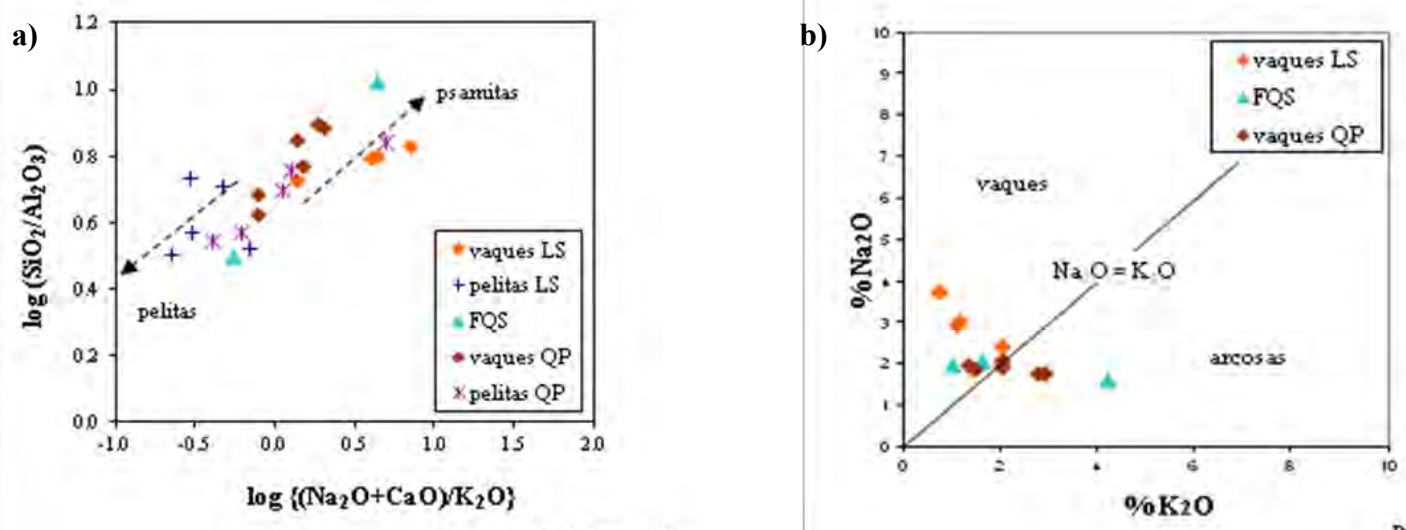

GanosalucLonew (197)

Potogolos 01963$)$

Figura 3.3.10: a)- Diagrama de discriminación geoquímica de pelitas y vaques de Garrels y McKenzie (1971). b)- Diagrama de discriminación geoquímica de vaques y arenitas feldespáticas (arcosas) en base a la relación $\mathrm{Na}_{2} \mathrm{O} / \mathrm{K}_{2} \mathrm{O}$ de Pettijohn (1963). 
Otros diagramas que usan las relaciónes de elementos mayoritarios para discriminar muestras sedimentarias son los de Garrels y McKenzie (1971) y Pettijohn (1963). El primero permite discriminar entre pelitas y psamitas (Figura 3.3.10a), mientras que el segundo fue propuesto para discriminar entre vaques y arcosas (arenitas feldespáticas. Figura 3.3.10b).

\section{Sobre el grado de alteracion de las muestras.}

Dado que las muestras recolectadas han sido afectadas por procesos secundarios de alteración, diagénesis y metamorfismo en distintos grados es conveniente observar estos efectos para determinar qué resguardo hay que tener en las interpretaciones geoquímicas.

Conociendo el comportamiento de los elementos durante los procesos sedimentarios y diagenéticos es posible caracterizar los efectos de la alteración, la meteorizacion y el reciclaje durante el transporte de los sedimentos. Para ello se utiliza comúnmente el índice de alteración química (CIA, capítulo 2.2.4) y algunas relaciones elementales como $\mathrm{Th} / \mathrm{U}, \mathrm{Th} / \mathrm{Sc}, \mathrm{Zr} / \mathrm{Sc}$ y $\mathrm{K} / \mathrm{Cs}$, que permiten hacer interpretaciones respecto a la influencia de estos procesos y a su vez demostrar la validez de los resultados obtenidos. Ciertos elementos son particularmente útiles en este sentido, especialmente los más inmóviles. Entre los efectos de la meteorización se ha observado que los cationes grandes (LILE: $\mathrm{Cs}, \mathrm{Rb}$ y $\mathrm{Ba}$ ) son retenidos en el perfil de meteorización mientras que los cationes mas pequeños ( $\mathrm{Na}$, $\mathrm{Ca}$ y $\mathrm{Sr}$ ) son más fácilmente lixiviados. Además de los controles que pueden ejercer los procesos sedimentarios y diagenéticos en la geoquímica de la roca, puede haber un control mineralógico en la concentración de algunos elementos que se ven influenciados por la composición de la roca. Algunos controles reconocidos son, por ejemplo, el de los feldespatos y titanita sobre $\mathrm{Ba}, \mathrm{Be}, \mathrm{Na}, \mathrm{Rb}$ y Cs; el de los minerales ferromagnesianos sobre Ta, Fe, Co, Sc y Cr (cromita); el del circón sobre el Hf y Zr; el de la titanita sobre las REE y Th; biotita y titanita suelen controlar el contenido de $\mathrm{TiO}_{2}$, la apatita el $\mathrm{P}_{2} \mathrm{O}_{5}$, etc. En rocas filosilicatadas con cierto contenido de carbonatos el $\mathrm{Mn}, \mathrm{Pb}$ y $\mathrm{Sr}$ son principalmente retenidos en el componente carbonático, por lo que valores anómalos para estos elementos pueden indicar su presencia.

Los valores de CIA (Tabla 3.3.4) para las sedimentitas del área del Chuscho (LS) son de 73,64 para las pelitas y 65,47 para los vaques (promedio pelitas + vaques $=68,53$ ). En los afloramientos del norte del Granito Potrerillos (QP) los valores de CIA dan 71,72 para pelitas y 67,80 para vaques (promedio pelitas + vaques $=69,11)$. Teniendo en cuenta ambos afloramientos $(\mathrm{LS}+\mathrm{QP})$ los valores de CIA obtenidos para pelitas y vaques son de 72,68 y 66,74 respectivamente (promedio total $=68,84)$. Estos valores se encuentran dentro de lo esperado para estas

Tabla 3.3.4: Valores de CIA promedio para las rocas sedimentarias estratificadas (LS + $\mathrm{QP})$, en las quebradas del Chuscho (LS) y de Potrerillos (QP).

\begin{tabular}{|l|c|c|c|}
\hline & Fm Del Salto (LS + QP) & Qda. del Chuscho (LS) & Qda. de Potrerillos (QP) \\
\hline Pelitas & 72,68 & 73,64 & 71,72 \\
\hline Vaques & 66,74 & 65,47 & 67,80 \\
\hline
\end{tabular}


litologías, indicando que no han sufrido una alteración severa. Las muestras con $\mathrm{CaO}>2 \%$ tienen influencia de carbonatos y no se puede calcular el CIA (Middleton, 1960; Merodio, 2005). Este es el caso para la muestra LS1-7, que presenta entonces valores anormalmente bajos para lo esperado en estas rocas. Es probable que el valor de CIA de la muestra QP-E10g también esté afectada por el contenido de $\mathrm{CaO}$.

En el diagrama combinado CIA versus A-CN-K (Nesbitt y Young, 1982, 1984; Fedo et al., 1995; Bahlburg, 2009. Figura 3.3.11) se genera un trend con cierta desviación hacia el vértice K, lo que evidencia un enriquecimiento en potasio, principalmente asociado a las pelitas. Este efecto puede ser producido ya sea a una composición inicial enriquecida en potasio respecto de la corteza continental superior (UCC) o debido al metasomatismo potásico asociado a transformaciones de caolinita en illita y de illita en feldespato potásico durante la diagénesis (Nesbitt y Young, 1989; Fedo et al., 1995). Así, estos procesos disminuyen los valores de CIA por efectos de la diágenesis (Bahlburgh, 2009).

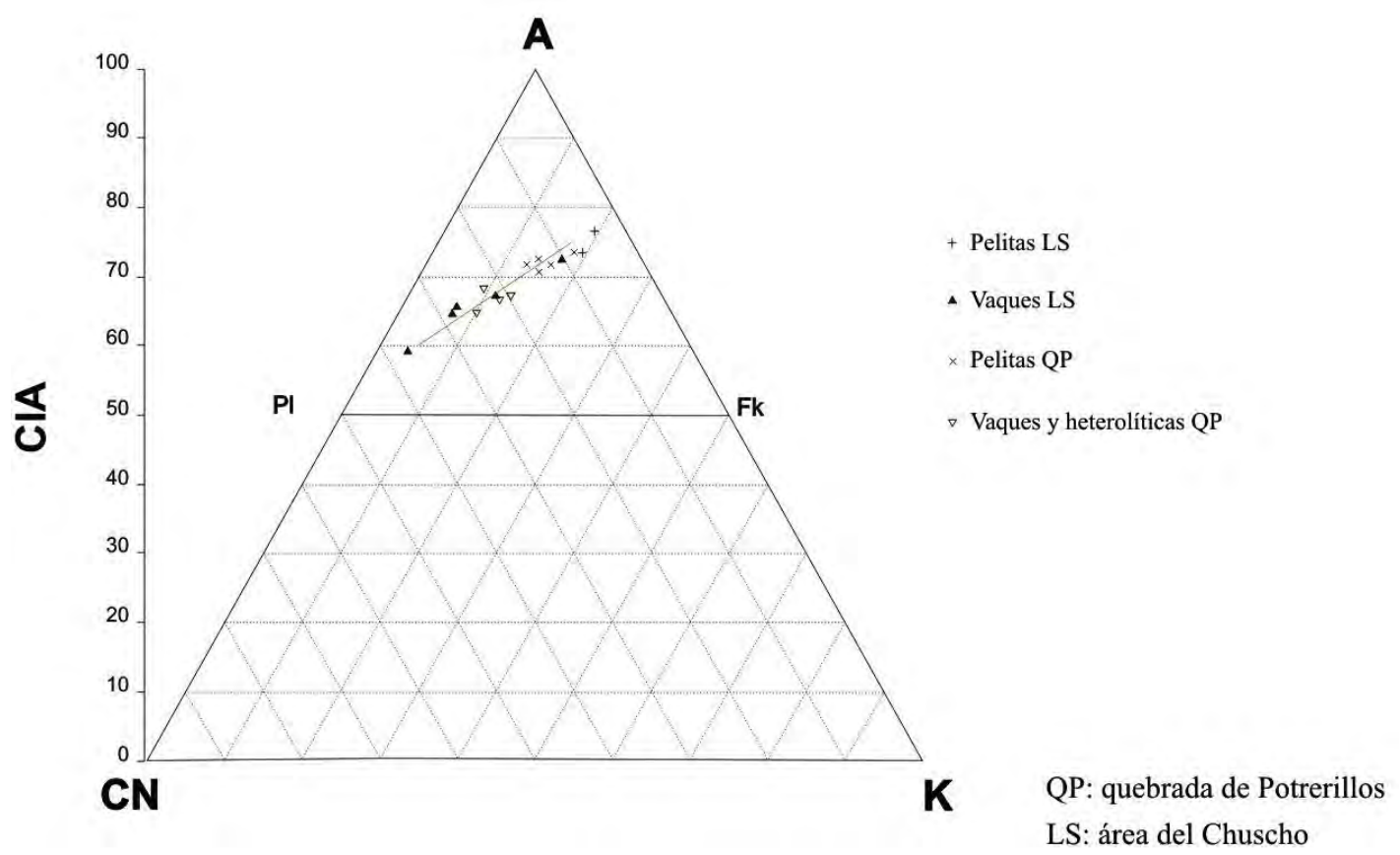

Figura 3.3.11: Comparación del CIA con el diagrama ternario A-CN-K (Nesbitt y Young, 1982, 1984; Fedo et al., 1995; Bahlburg, 2009). Se observa un trend de las sedimentitas hacia el extremo potásico, especialmente a las pelitas. En este caso estaría relacionado con un proceso de metasomatismo potásico durante las transformaciones diagenéticas.

La relación $\mathrm{K}_{2} \mathrm{O} / \mathrm{Na}_{2} \mathrm{O}$ también puede dar una idea del grado de evolución de las sedimentitas. Suele ser inferior a 1 en rocas inmaduras (menos evolucionadas y alteradas) y mayor a 1 en ambientes más maduros y evolucionados en los que hay más alteración (Middleton, 1960; Merodio, 2005). Como es de esperar entonces, en las lutitas se observa que presentan valores más altos que las psamitas de esta relación, debido a la mayor proporción de filosilicatos que concentran el $\mathrm{K}^{+}$. Las excepciones son las muestras LS1-7 y QP-E10g que presentan valores muy inferiores que el resto de las muestras indicando una mayor lixiviación de este catión y en el caso de los vaques probablemente este relacionado además con una mayor concentración de plagioclasas sódicas. 
El diagrama K/Cs vs. CIA (Bertolino et al. 2004, 2007) permite observar el grado de meteorización de las muestras, basándose en que al aumentar el grado de meteorización de las sedimentitas la relación $\mathrm{K} / \mathrm{Cs}$ disminuye por efecto de la lixiviación del $\mathrm{K}^{+}$durante este proceso. Las muestaras mo-

Tabla 3.3.5: Cálculo de la relación $\mathrm{K}_{2} \mathrm{O} / \mathrm{Na}_{2} \mathrm{O}$ para las muestras metasedimentarias de la Formación del Salto.

\begin{tabular}{|l|c|c|c|c|c|}
\hline Muestra & Litología & $\begin{array}{c}\mathrm{CaO} \\
\%\end{array}$ & $\begin{array}{c}\mathrm{Na}_{2} \mathrm{O} \\
\%\end{array}$ & $\begin{array}{c}\mathrm{K}_{2} \mathrm{O} \\
\%\end{array}$ & $\mathbf{K}_{\mathbf{2}} \mathbf{O} / \mathbf{N a}_{2} \mathbf{O}$ \\
\hline \multicolumn{1}{|l|}{ vaques y HL: } & & & \\
LS1-3 & vaque & 0.34 & 2.46 & 2.06 & $\mathbf{0 . 8 4}$ \\
LS1-7 & vaque & 1.31 & 3.76 & 0.72 & $\mathbf{0 . 1 9}$ \\
LS1-9 & vaque & 1.53 & 3.05 & 1.16 & $\mathbf{0 . 3 8}$ \\
LS1-10 & vaque & 2.01 & 2.94 & 1.13 & $\mathbf{0 . 3 8}$ \\
CH10 & vaque & 1.45 & 1.61 & 1.64 & $\mathbf{1 . 0 1}$ \\
QP-E5 & vaque HL & 1.11 & 1.899 & 1.504 & $\mathbf{0 . 7 9}$ \\
QP-E9 & vaque & 0.9 & 1.92 & 2.03 & $\mathbf{1 . 0 6}$ \\
QP-E11 & vaque & 0.86 & 2 & 2.614 & $\mathbf{1 . 3 1}$ \\
QP-E24 & vaque HL & 1.04 & 2.07 & 2.05 & $\mathbf{0 . 9 9}$ \\
QP-E25 & vaque HL & 0.42 & 1.77 & 2.79 & $\mathbf{1 . 5 8}$ \\
QP-E27 & vaque HL & 0.5 & 1.79 & 2.91 & $\mathbf{1 . 6 3}$ \\
QP-E 28 & vaque & 0.47 & 2 & 1.34 & $\mathbf{0 . 6 7}$ \\
Lutitas: & \multicolumn{3}{|c|}{} & & \\
LS 2 & lutita & 0.27 & 0.73 & 4.42 & $\mathbf{6 . 0 5}$ \\
LS 2-2 & lutita & 0.24 & 1.13 & 4.5 & $\mathbf{3 . 9 8}$ \\
LS2-3 & lutita & 0.713 & 2.022 & 3.985 & $\mathbf{1 . 9 7}$ \\
LS2-5 & lutita & 0.173 & 1.503 & 3.62 & $\mathbf{2 . 4 1}$ \\
LS2-F & lutita (arcosa) & 0.09 & 0.92 & 3.48 & $\mathbf{3 . 7 8}$ \\
QP-E6 & lutita & 1.082 & 1.939 & 2.386 & $\mathbf{1 . 2 3}$ \\
QP-E7 & lutita & 0.33 & 1.3 & 4.06 & $\mathbf{3 . 1 2}$ \\
QP-E8g & lutita & 0.39 & 1.79 & 3.5 & $\mathbf{1 . 9 6}$ \\
QP-E10g & pelita & 5.19 & 2.08 & 1.47 & $\mathbf{0 . 7 1}$ \\
QP-E11g & pelita & 0.76 & 1.82 & 2.29 & $\mathbf{1 . 2 6}$ \\
\hline
\end{tabular}

derada a fuertemente meteorizadas generalmente presentan valores de $\mathrm{K} / \mathrm{Cs}<2500$, pero estos valores no se obtuvieron para ninguna muestra. Teniendo en cuenta esto último, el valor de CIA anormalmente bajo que presenta la muestra LS1-7 se relacionaría con el elevado contenido de $\mathrm{CaO}$ que presenta y no con un elevado grado de meteorización por lixiviación de $\mathrm{K}^{+}$. Además, LS1-7 presenta valores de K/Cs muy superiores al promedio de la corteza continental superior. En la Figura 3.3.12 (Tabla 3.3.6) se observan valores normales para las muestras; los vaques plotean cercanos a los valores de la corteza continental superior (UCC) mientras que las pelitas, como es de esperar, se desvían ligeramente hacia la curva patrón del PAAS (Post Archean Australian Shales).

Los diagramas $\mathrm{Th} / \mathrm{U}$ versus $\mathrm{Th}$ y $\mathrm{Th} / \mathrm{Sc}$ versus $\mathrm{Zr} / \mathrm{Sc}$ (McLennan et al., 1993) son comúnmente utilizados para evaluar cuánto han sido afectadas las rocas por los procesos sedimentarios exógenos de meteorización (por oxidación del U) y reciclaje por adición de circón. El grado de reciclaje de los sedimentos puede estimarse utilizando el gráfico $\mathrm{Th} / \mathrm{Sc}$ versus $\mathrm{Zr} / \mathrm{Sc}$ (McLennan et al., 1993. Figura 3.3.13a). En este gráfico la relación $\mathrm{Th} / \mathrm{Sc}$ refleja el grado de enriquecimiento de Th respecto al Sc (mas compatible), común en las rocas de la corteza superior. La relación $\mathrm{Zr} / \mathrm{Sc}$ permite observar un mayor contenido de $\mathrm{Zr}$ por concentración diferencial de circón en los sedimentos a medida que es 
mayor el reciclaje. En los vaques se observa un trend poco manifiesto asociado a la concentración de circón (aumento de la relación $\mathrm{Zr} / \mathrm{Sc}$ ) por reciclaje de los sedimentos; pero en general se puede estimar que el reciclaje no fue importante en las muestras, en especial para las rocas ubicadas al norte del granito, y se agrupan cerca del valor de $\mathrm{Th} / \mathrm{Sc}$ promedio para la corteza continental superior (UCC, $\mathrm{Th} / \mathrm{Sc} \approx 1,0)$.

Tabla 3.3.6 (derecha): Cálculos correspondientes al gráfico de la Figura 3.3.12 (Bertolino et al., 2004, 2007).

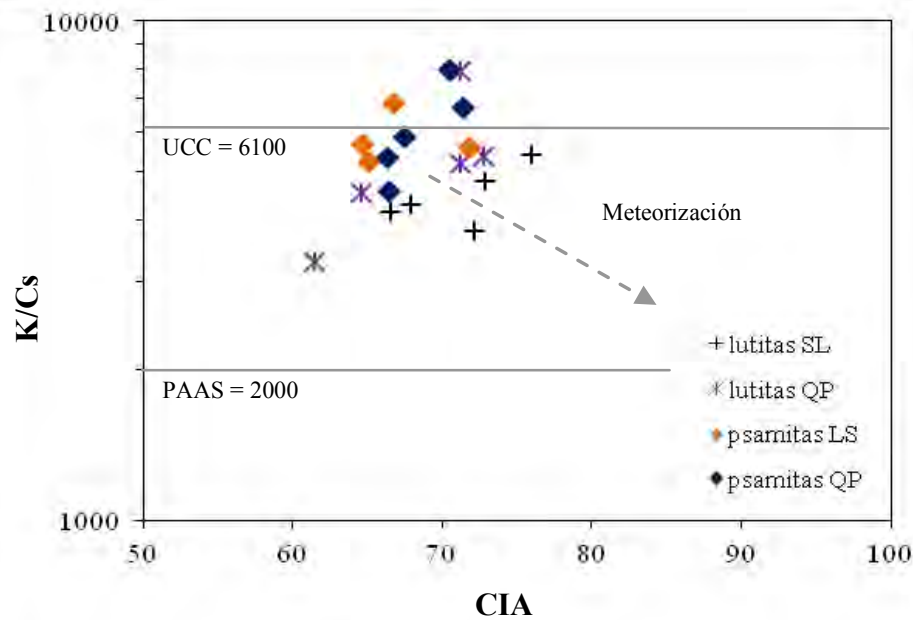

Figura 3.3.12: Diagrama K/Cs versus CIA (Bertolino et al,. 2004, 2007). La muestra LS1-7 cae fuera del campo graficado.

\begin{tabular}{|c|c|c|c|}
\hline \multicolumn{2}{|c|}{ Muestra } & $\mathbf{K} / \mathbf{C s}$ & CIA \\
\hline \multirow{10}{*}{ 㲵 } & LS 2 & $5.395,7$ & 75,93 \\
\hline & LS 2-2 & $4.789,0$ & 72,86 \\
\hline & LS2-F & $3.801,0$ & 72,11 \\
\hline & LS2-3 & $4.134,9$ & 66,58 \\
\hline & LS2-5 & $4.292,8$ & 67,94 \\
\hline & QP-E7 & $5.349,5$ & 72,73 \\
\hline & QP-E8g & $5.188,1$ & 71,25 \\
\hline & QP-E10g & 4.515 & 64,62 \\
\hline & QP-E & $7.920,5$ & 71,18 \\
\hline & QP-E6 & 3.30 & 61,50 \\
\hline \multirow{9}{*}{ 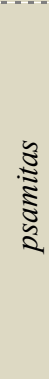 } & LS1-3 & 6.84 & 66,73 \\
\hline & LS1-7 & $14.941,8$ & 58,96 \\
\hline & LS1-9 & $5.664,2$ & 64,73 \\
\hline & LS1-10 & $5.211,2$ & 65,10 \\
\hline & QP-E9 & $4.554,3$ & 66,47 \\
\hline & QP-E24 & $5.317,8$ & 66,35 \\
\hline & QP-E25 & $7.986,1$ & 70,44 \\
\hline & QP-E27 & $6.710,0$ & 71,45 \\
\hline & QP-E28 & $5.854,4$ & 67,49 \\
\hline
\end{tabular}

El grado de meteorización que sufrieron los metasedimentos puede estimarse comparando con el valor promedio de la corteza continental superior (UCC, McLennan et al., 1993; Tabla 3.3.7; Anexos A6c: Tabla 1), usando las relaciones $\mathrm{Th} / \mathrm{U}(\mathrm{Th} / \mathrm{U}>\mathrm{UCC}=3,8), \mathrm{Rb} / \mathrm{Sr}(\mathrm{Rb} / \mathrm{Sr}>\mathrm{UCC}=5)$ y $\mathrm{K} / \mathrm{Rb}(\mathrm{K} / \mathrm{Rb}<\mathrm{UCC} \approx 250)$. Durante la meteorización, los cationes grandes (LILE: Cs, $\mathrm{Rb}$ y $\mathrm{Ba}$ ) son retenidos mientras que los cationes más pequeños $(\mathrm{Na}, \mathrm{Ca}$ y $\mathrm{Sr}$ ) son más fácilmente lixiviados. Los valores promedio de $\mathrm{Th} / \mathrm{U}$ para las metasedimentitas estratificadas se agrupan entre los valores $\mathrm{Th} / \mathrm{U}$ de UCC y PAAS, lo que es coherente con las observaciones de campo y petrológicas en cuanto a que los afloramientos del norte del granito no han sufrido meteorización importante mientras que en el área del Chuscho han sido mas afectadas (coloraciones castañas y amarillentas de los afloramientos.
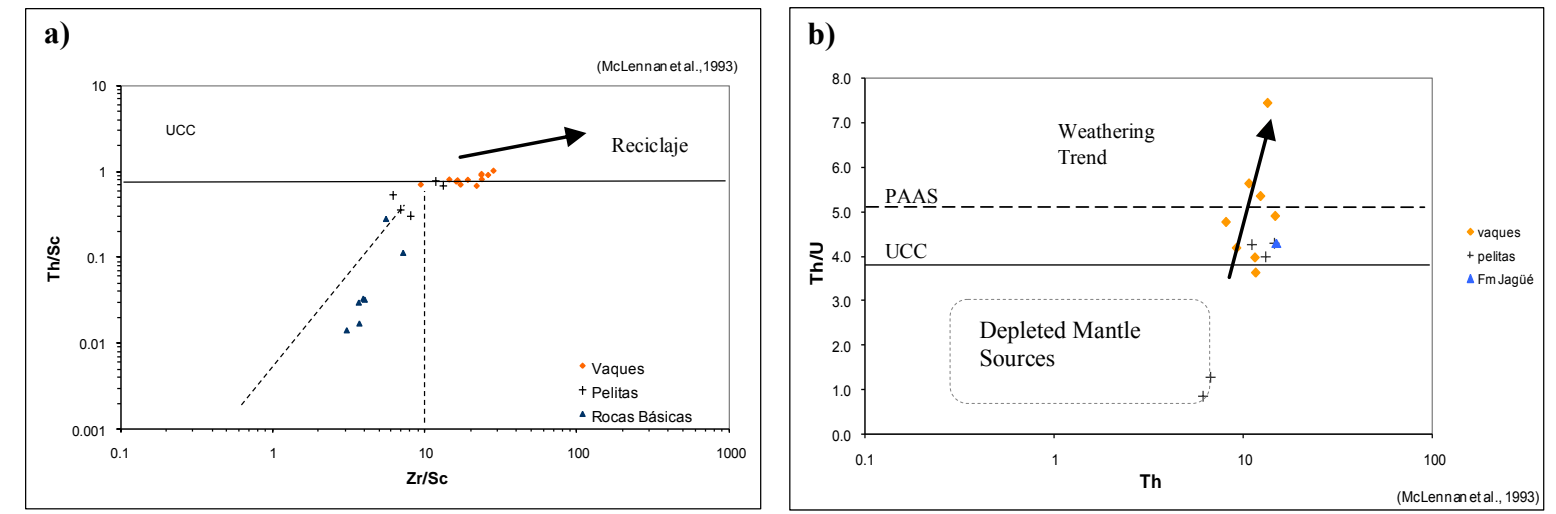

Figura 3.3.13: Diagramas para comprobar el grado de meteorización y reciclaje de las muestras sedimentarias (McLennan et al., 1993). a)- Th/Sc vs. Zr/Sc; b)- Th/U vs. Th. 
En las sedimetitas del área del Chuscho se observa que hubo movilización del U por cambio en su estado de oxidación (Figura 3.3.13b). Se observa tanto un enriquecimiento como un empobrecimiento de $U$ pero parece estar asociado a la granulometría: las lutitas muestran un enriquecimiento en $U$ mientras que en los vaques hay un empobrecimiento. En los diagramas multielementales (Figura 3.3.16a) puede verse, en la lutita LS2-F especialmente, un pico positivo de U, y eso coincide con que es una muestra en la que la oxidación es evidente.

\begin{tabular}{|c|c|c|c|}
\hline & LS & QP & $\begin{array}{c}\text { UCC } \\
\text { (McLennan } \text { et al., 1993) }\end{array}$ \\
\hline $\mathbf{T h} / \mathbf{U}$ & 4,5 & 3,91 & 3,8 \\
\hline $\mathbf{T h} / \mathbf{S c}$ & 0,65 & 0,8 & $\approx 1,0$ \\
\hline $\mathbf{E u} / \mathbf{E u} \mathbf{u}^{*}$ & 0,63 & 0,12 & $\approx 0,60-0,70$ \\
\hline $\mathbf{\varepsilon}_{\mathbf{N d}}{ }^{\mathbf{t}}$ & $-3,45$ & $-4,98$ & -10 \\
\hline $\mathbf{R b} / \mathbf{S r}$ & 1,9 & 1,44 & $\approx 0,32$ \\
\hline $\mathbf{K} / \mathbf{R b}$ & 194 & 195 & $\approx 250$ \\
\hline
\end{tabular}

Tabla 3.3.7: Valores promedio de relaciones elementales de las muestras metasedimentarias de la zona del Chuscho (LS) y quebrada de Potrerillos (QP) y comparación con los valores de la Corteza Superior (UCC; McLennan et al., 1993).

\section{Tierras raras.}

En los diagramas de tierras raras normalizados al condrito C1 (Taylor y McLennan, 1985. Figura 3.3.14a, b) se observan anomalías positivas de cerio en todas las muestras metasedimentarias. Este efecto suele observarse cuando hay un cambio del estado de oxidación del $\mathrm{Ce}^{+3} \mathrm{a} \mathrm{Ce}^{+4}$ en ambiente oxidante. En general, en todas las muestras se genera una anomalía negativa de Eu, indicando un fraccionamiento de este elemento en la fuente del sedimento. El pequeño pico positivo en el Tm probablemente es producto de la normalización usada.
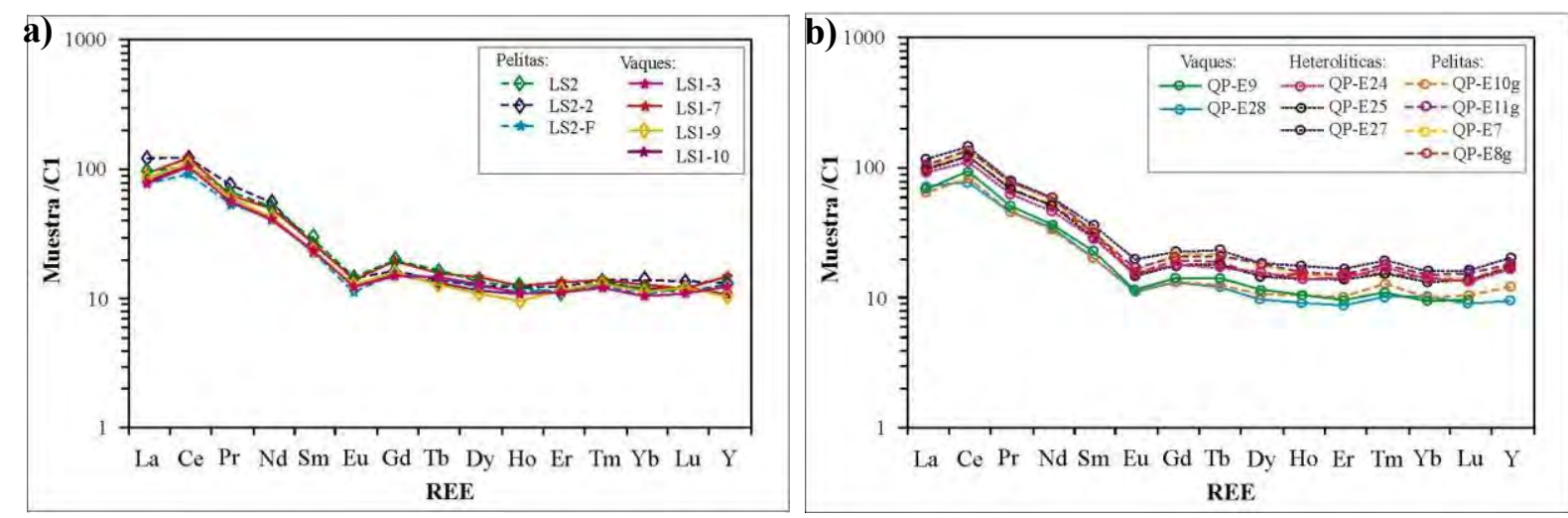

Figura 3.3.14: Diagramas de tierras raras normalizados al condrito C1 (Taylor y McLennan, 1985). a)- área del Chuscho, b)área de Potrerillos.

Al comparar las tierras raras con los patrones sedimentarios como la corteza continental superior (UCC) y la lutita australiana post-arqueana (PAAS, Taylor and McLennan, 1985; Figuras 3.3.15a y b respectivamente), tanto en pelitas como vaques se observa que las metasedimentitas del área del Chuscho y de Potrerillos presentan concentraciones similares a estos patrones (curvas subhorizontales). En algunos casos se ha observado pequeños picos positivos en el $\mathrm{Tm}$ y el Tb que se infiere efecto de la normalización y/o efectos intrínsecos relacionados con las variaciones de las tierras raras. 


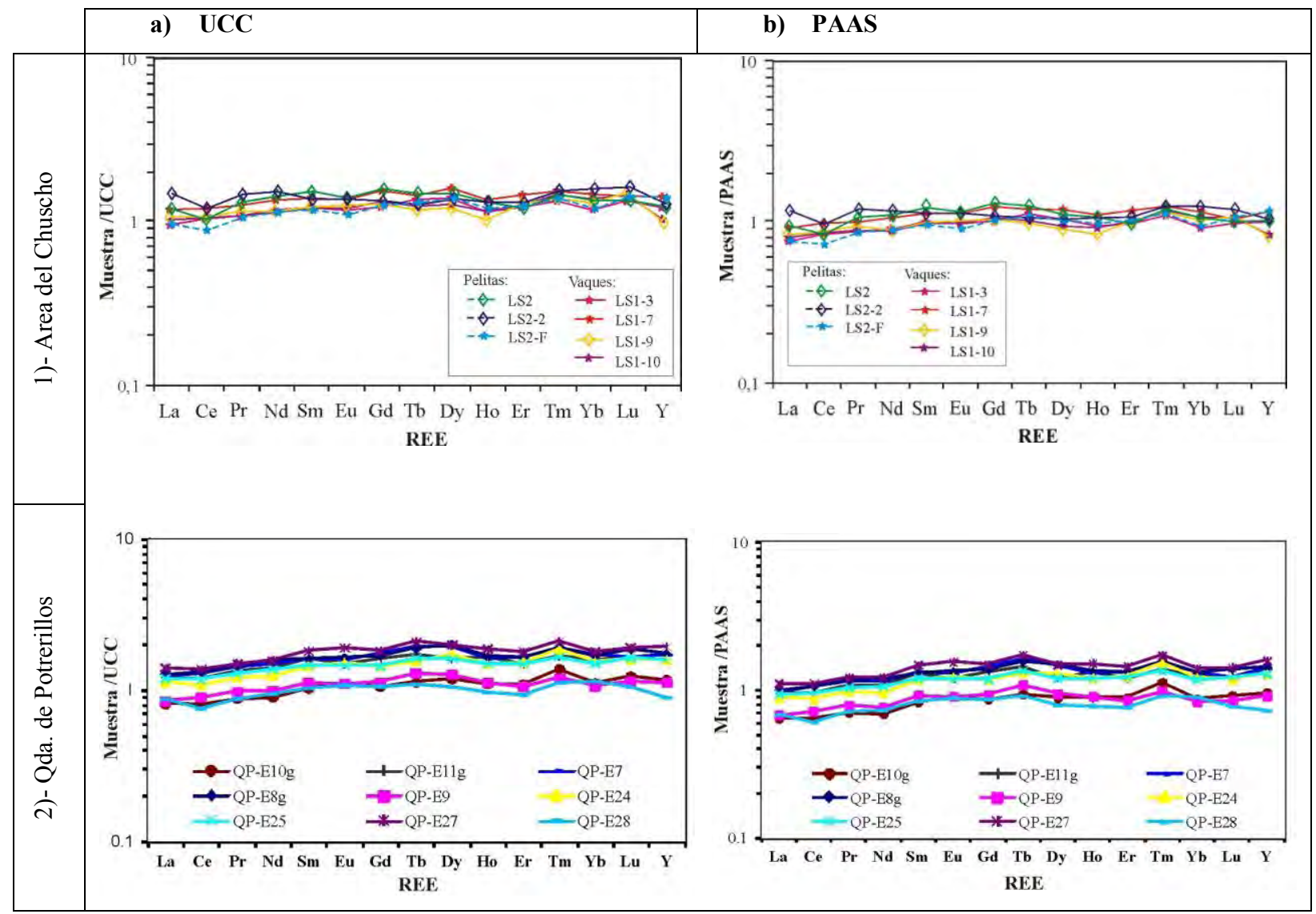

Figura 3.3.15: Diagramas de tierras raras normalizados a la corteza continental superior (UCC, columna a) y lutita postarqueana (PAAS, columna b). Valores de referencia tomados de Taylor and McLennan, (1985). Fila 1)- vaques (arriba) y pelitas (abajo) del área del Chuscho. Fila 2)- sedimentitas del área de Potrerillos (mayoritariamente heterolíticas).
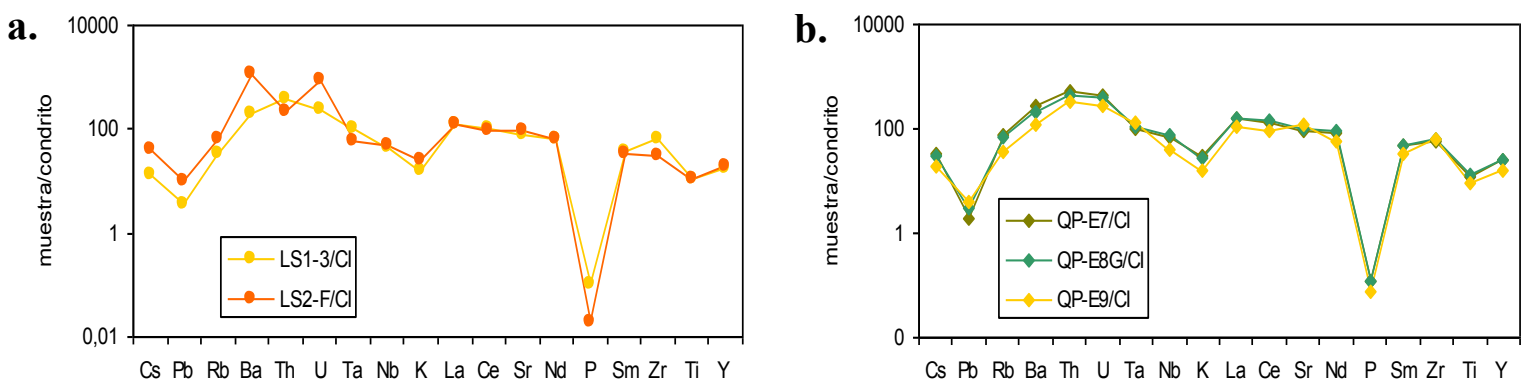

Figura 3.3.16: Diagramas multielementales normalizados al condrito $C 1$ (Sun \& McDonough, 1989) en los afloramientos del Chuscho (a) y de Potrerillos (b).

En los diagramas multielementales normalizados al condrito C1 (Sun \& McDonough, 1989, Figura 3.3.16) se observa un pico negativo importante en el $\mathrm{P}$ y picos menores en el $\mathrm{K} \mathrm{y} \mathrm{Pb}$, rasgos comúnmente observados para rocas sedimentarias. La pelita fosilífera LS2-F del área del Chuscho muestra enriquecimiento en Ba y U. El Ba puede estar asociado con un enriquecimiento diagenético (metasomatismo a partir del agua de mar?) mientras que el enriquecimiento en $U$ en pelitas es común en muestras alteradas. En los diagramas multielementales normalizados a la corteza continental superior (UCC, Taylor y McLennan, 1981; Figura 3.3.17) se observa un comportamiento similar para las sedimentitas de ambos afloramien tos. Como es de esperar, las muestras de granulometrías más gruesas (ej. QP-E9) 
muestran menores concentraciones de tierras raras, Sc y V en relacion a las lutitas y concentraciones algo mayor de Zr.

Como observación general podemos expresar que las muestras LS1-7 y QP-E10g presentan análisis atípicos en relación al promedio de las muestras y a las litologías consideradas, pero esto se relacionaría más que nada con la influencia de carbonatos (y albitización) que a los procesos de meteorización. La muestra LS2-F esta afectada por el intemperismo.

a.

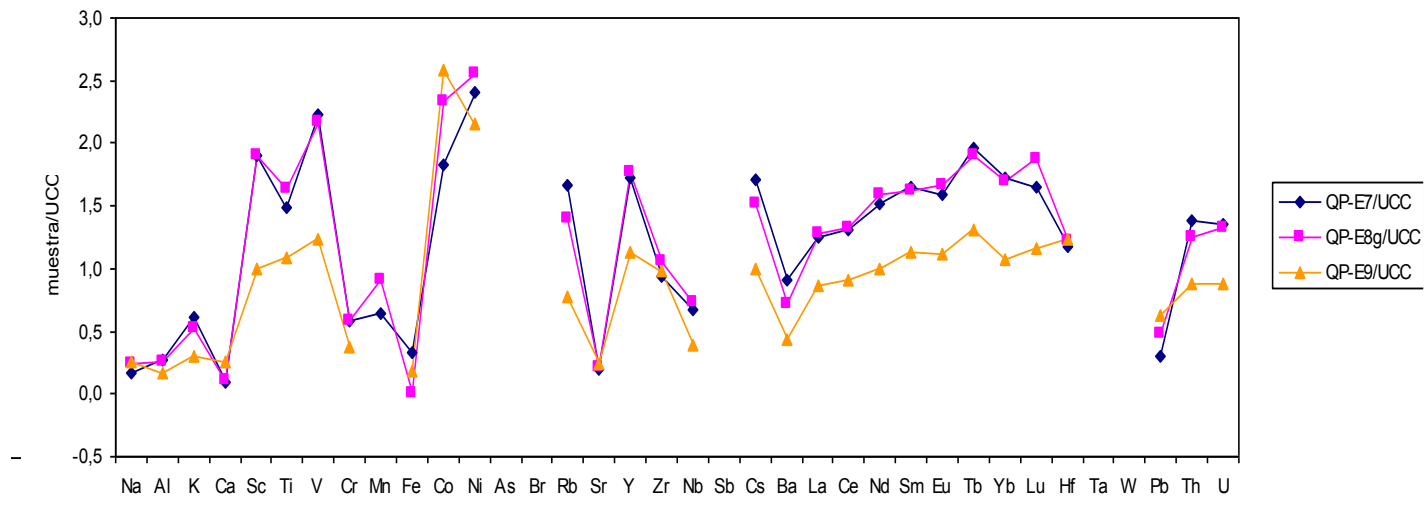

b.

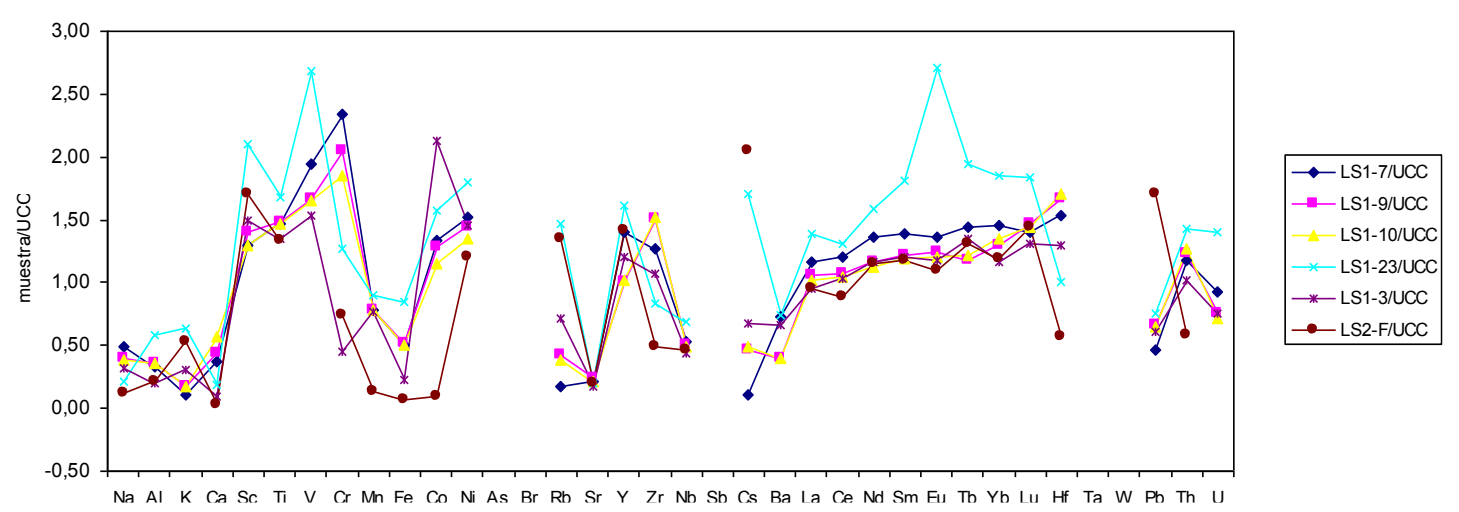

Figura 3.3.17: Diagramas multielementales normalizados a la corteza continental superior (UCC, Taylor y McLennan, 1981) en los afloramientos de Potrerillos (a) y del Chuscho (b).

\section{e. Geología isotópica.}

Isótopos de $U$ y $\mathrm{Pb}$

Se obtuvieron dos edades U-Pb por LA-ICP-MS en circones detríticos de las muestras LS1-3 y QP-E9 como representantes, respectivamente, de los afloramientos de metasedimentitas portadoras de fósiles ordovícicos que afloran sobre la quebrada del Chuscho y al conjunto metasedimentario bien estratificado que conforma la roca de caja del Granito Potrerillos. Los datos de edad U-Pb de circones detríticos son especialmente útiles en las unidades silicoclásticas que no poseen fósiles y/o han sufrido metamorfismo y deformación, ya que permiten establecer una edad máxima de sedimentación y edad promedio de la o las fuente/s de los sedimentos. En los afloramientos de la quebrada de Potrerillos no se han 
hallado fósiles que determinen su edad, por lo que en un principio se relacionaron aquí con los del área del Chuscho por la composición, estratificación marcada, estructura y grado metamórfico. Los resultados U-Pb obtenidos permitieron comparar también desde el punto de vista de su edad ambos afloramientos, y por otro lado permitió ajustar la edad de las metasedimentitas obtenida por fósiles en la zona del Chuscho. Para la interpretación de los resultados es preciso tener en cuenta las características texturales de los granos de circón ya que al ser detríticos pueden tener variados orígenes.

Caracterización de los circones:

Las características morfológicas de los circones detríticos (color, tamaño, forma, hábito y elongación; presencia de caracteres internos como núcleos heredados, fracturas, inclusiones, etc.) permiten diferenciar distintos grupos de cristales y conformar poblaciones que pueden ser propias de la roca de la cual provienen (Mange y Maurer, 1992; Naipauer, 2007). Uno de los parámetros más importante a tener en cuenta es la forma (idiomorfa a redondeados) y elongación (relación largo/ancho) de los cristales que se vinculan con la naturaleza de la roca de la cual proviene. El grado de redondeamiento que presenten los cristales esta relacionado directamente con el grado de transporte que sufrieran los sedimentos, y por consiguiente permiten sugerir cuán alejados se encuentran de la zona fuente. En rocas ígneas el promedio de la elongación medida en los cristales es comúnmente de 2 a 3 (prismas cortos), pero en muchos casos, especialmente en rocas volcánicas, se encuentran cristales con valores mucho más elevados (5 o más) correspondientes a formas prismáticas largas a aciculares. Valores cercanos o menores a 2 es típico de circones con formas subredondeadas y redondeadas provenientes de rocas recicladas y de varios ciclos sedimentarios (Mange y Maurer, 1992). En la Figura 18a, b se puede observar el aspecto de los granos de circones detríticos separados de las muestras de metasedimentitas estratificadas. En general son de coloraciones rosadas hasta transparentes y violáceas, y pueden mostrar distinto porcentaje de inclusiones
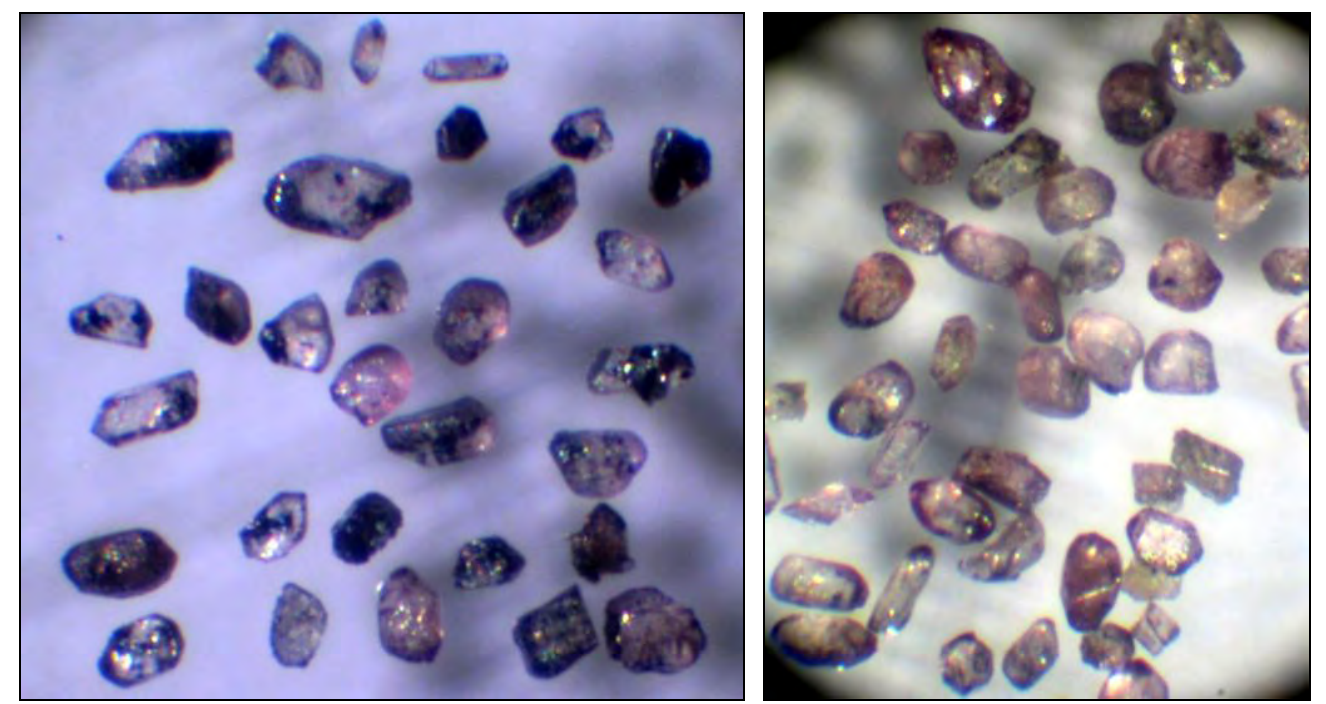

Figura 3.3.18: Fotografía bajo lupa binocular de poblaciones de circones detríticos. a)- muestra QP-E4, fracción 140; b)- muestra QP-E5, fracción 100. Aumento: 10x. 


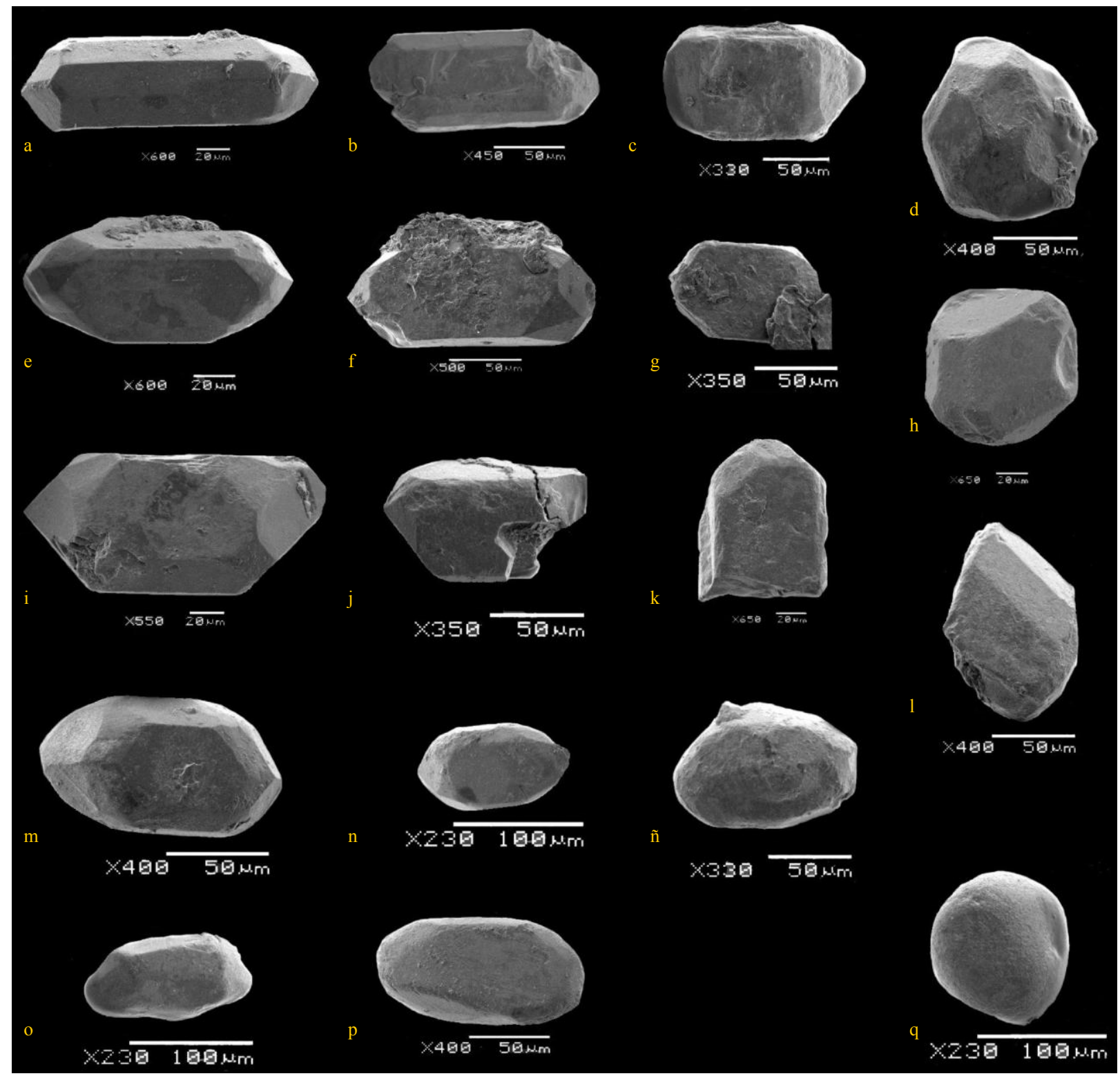

Figura 3.3.19: Microfotografías de granos de circón tomadas con microscopio electrónico de barrido (SEM) de la muestra QPE9, representando a las metasedimentitas que afloran sobre la quebrada de Potrerillos. El grado de redondeamiento de los granos es menor que el de los afloramientos del área del Chuscho, comúnmente sub- a euedrales, aunque llegan a estar bien redondeados.

oscuras. Presentan morfologías variables, de redondeados a euhedrales, y la población principal de cristales generalmente consta de cristales elongados con relación largo:ancho $=2: 1$ que tienen el prisma $\{100\}$ bien desarrollado (Figura 3.3.20a, e; Figura 3.3.19i). Sin embargo, pueden hallarse cristales mas aciculares con relaciones $1: a \geq 3: 1$ (ej. Figura 3.3.19a) y cristales con tendencias equidimensionales y multifacetados (ej. Figura 3.3.19ñ). Los granos parecen haber sufrido poco transporte, pero hay algunos cristales que llegan a presentarse bien redondeados (ej. Figura 3.3.19q, Figura 3.3.20g). El grado de redondeamiento parece ser algo mayor en los afloramientos del área del Chuscho. 


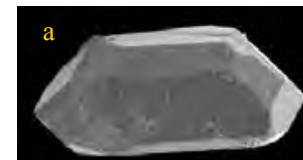

$x 850 \quad \overrightarrow{20 \mu m}$

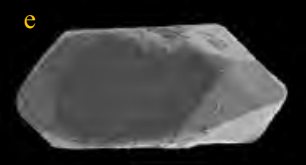

$\times 220100 \mu \mathrm{m}$

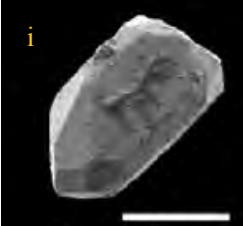

$\times 250100 \mu m$

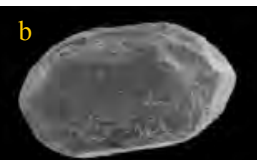

$\times 37050 \mu \mathrm{m}$

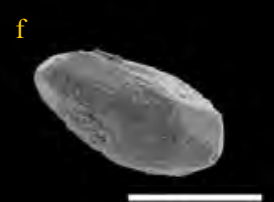

x190 100 $\mu \mathrm{m}$

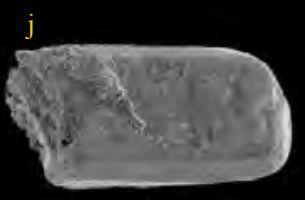

$\times 55020 \mu \mathrm{m}$

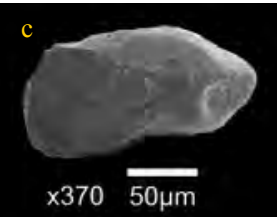

g
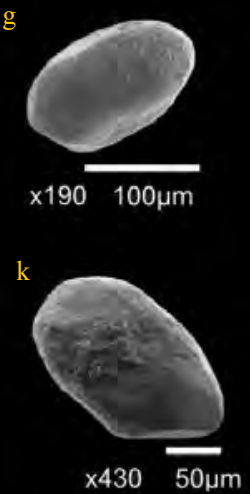

$\tilde{\mathbf{n}}$

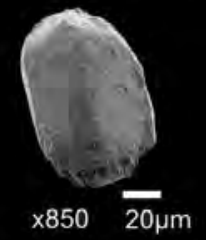

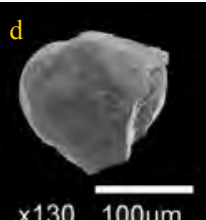

x130 100um

$\mathrm{h}$

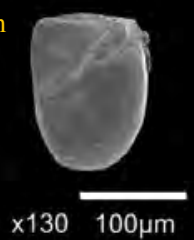

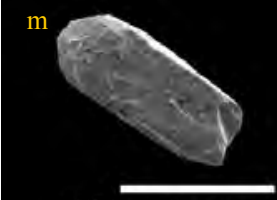

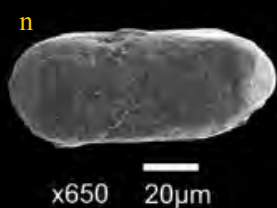

$\times 250100 \mu m$

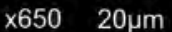

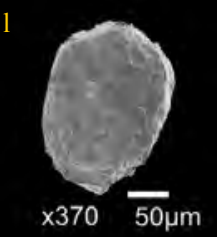

Figura 3.3.20: Microfotografías de granos de circón tomadas con microscopio electrónico de barrido (SEM) de la muestra LS1 3, representando a las metasedimentitas que afloran sobre las quebradas del Chuscho y del Salto. El grado de redondeamiento de los granos es variable, desde subredondeados hasta euedrales.

Edad U-Pb en circón:

Para la muestra LS1-3 $(n=10)$ se obtuvo una edad máxima para la sedimentación de $443 \pm 13$ $\mathrm{Ma}$, con MSWD =0,052, lo que corresponde a la sedimentación principal en el Ordovícico Superior alto y límite con el Silúrico. También preserva modas de un aporte sedimentario Mesoproterozoico y otro menor dentro del Paleoproterozoico. Los resultados de la muestra QP-E9 $(n=16)$ son comparables con los de la muestra LS1-3, y arrojan dos modas: un grupo de edades más jóvenes de 440 \pm 6,8 Ma, con MSWD $=0,00045$ que estaría marcando la edad máxima de sedimentación en el Ordovícico Superior,
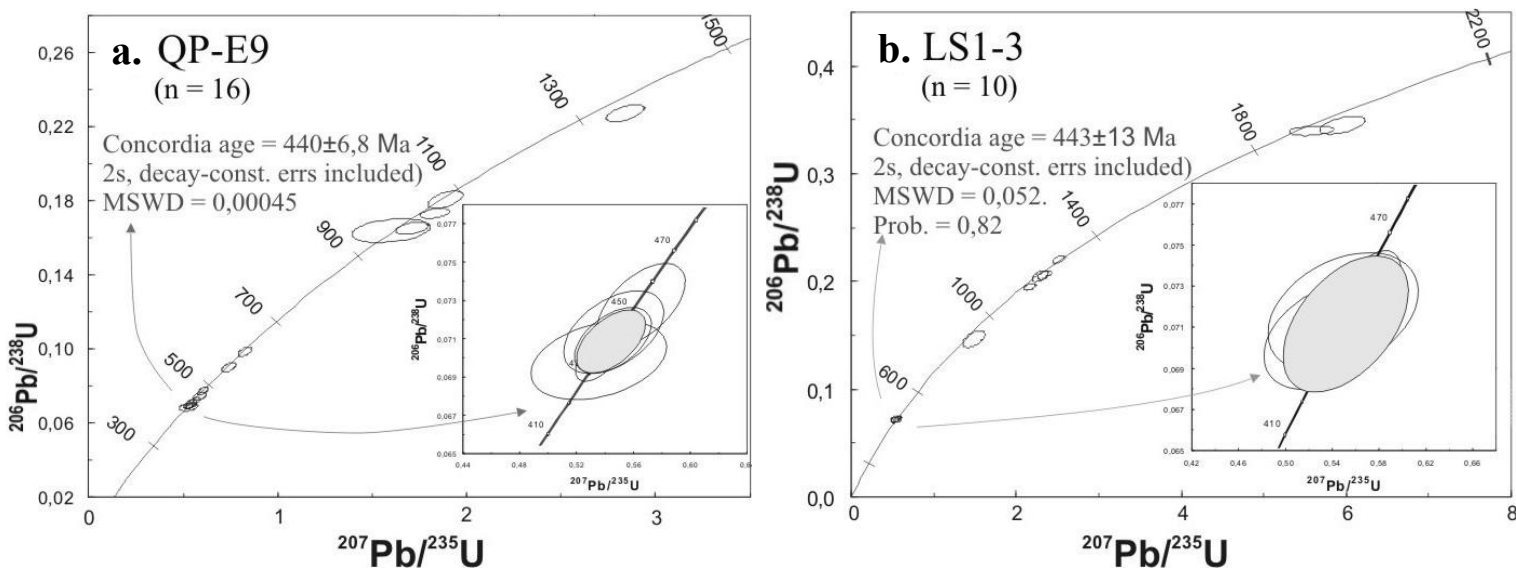

Figura 3.3.21: Diagramas de concordia obtenidos a partir de los resultados de dataciones por el método U-Pb ICP-MS-LA en circones extraidos de las metasedimentitas de la Formación Del Salto en las quebradas de Potrerillos (a) y Chuscho (b). 
cerca del límite Ordovícico - Silúrico, y un grupo de edades mesoproterozoicas (entre 1.000 y 1.100 Ma), similar al hallado en la muestra LS1-3. (Frigerio, 2008; Frigerio et al., 2009; Figura 3.3.21). En la Figura 3.3.22 se muestran algunas imágenes SEM de las superficies pulidas sobre las que se dataron los circones de la muestra QP-E9, en la que se puede apreciar la textura interna de los granos y la ubicación aproximada del punto de incidencia del láser.

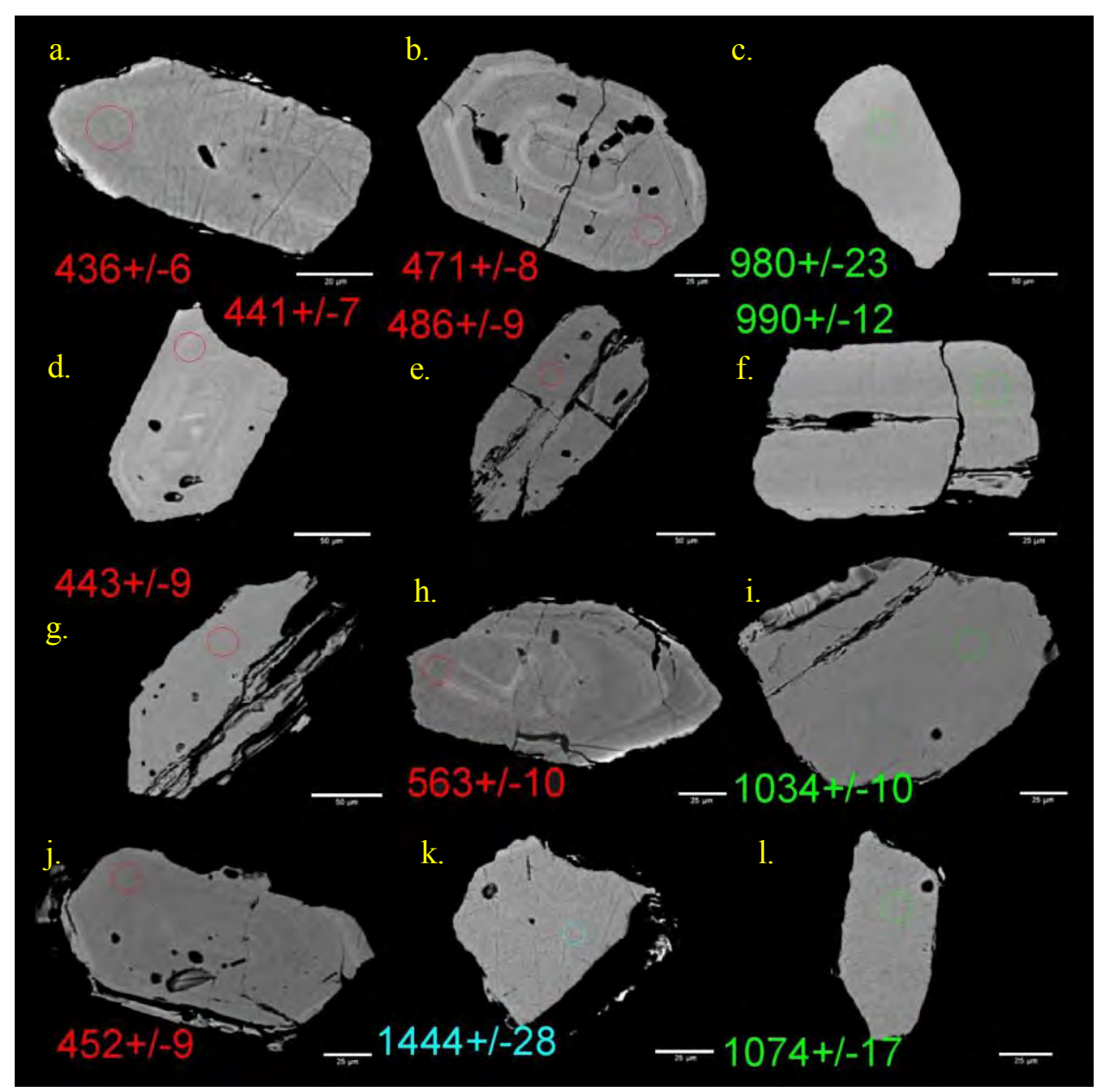

Figura 3.3.22: Imágenes tomadas con microscopio electrónico de las superficies pulidas de los cristales de circon datados por ICP-MS-LA de la muestra QP-E9, y ubicación aproximada del lugar de medición. Los colores estan relacionados a las edades. La escala gráfica corresponde a $25 \mu \mathrm{m}$ excepto para los granos a $(20 \mu \mathrm{m})$ y los c, d, e y g $(50 \mu \mathrm{m})$.

\section{Isótopos de Sm y Nd}

Para la caracterización isotópica por $\mathrm{Sm}-\mathrm{Nd}$ de las sedimentitas estratificadas se analizaron tres muestras del área del Chuscho y tres de la quebrada de Potrerillos, preferencialmente pelitas, con el objetivo de comparar ambos afloramientos (Anexos A6b: Tabla 5). Las edades modelo se calcularon sobre la base de De Paolo (1981; Figura 3.3.23), tomando como edad de referencia la edad obtenida por U-Pb en circones detríticos $(t=440$ y $443 \mathrm{Ma})$. Una edad modelo es una estimación del momento en que la muestra se separó de su fuente mantélica. Para rocas ígneas y meta-ígneas es una buena estimación de la edad de formación de la corteza. Los isótopos de Nd son los más útiles y en los que las edades modelo tienen mas sentido. Siempre hay que especificar el reservorio de referencia (CHUR o DM) y en el caso del 
manto deprimido también debe especificarse el modelo de evolución del manto deprimido utilizado. En el caso de las rocas sedimentarias las edades modelo de $\mathrm{Nd}$ representan una estimación de la edad mínima de residencia crustal o una edad de residencia crustal promedio de las rocas fuentes (capítulo 2).

Las muestras de la quebrada de Potrerillos son muy homogéneas y presentan valores $\varepsilon_{\mathrm{Nd}(\mathrm{t}=0)}$ levemente menos negativos y edades modelo algo mas jóvenes que las muestras del área del Chuscho. Pero en líneas generales se observa una buena coherencia entre ambos grupos de muestras, con valores de $\varepsilon_{\mathrm{Nd}(0)}$ entre $-7,3$ y $-9,2$ y edades $\mathrm{T}_{\mathrm{DM}}$ entre 1,28 y 1,61 Ga. Estos datos estarían indicando una fuente mantélica evolucionada extraida en tiempos esencialmente mesoproterozoicos. Los valores podrían compararse con los obtenidos para algunos esquistos (sección 3.2.7).

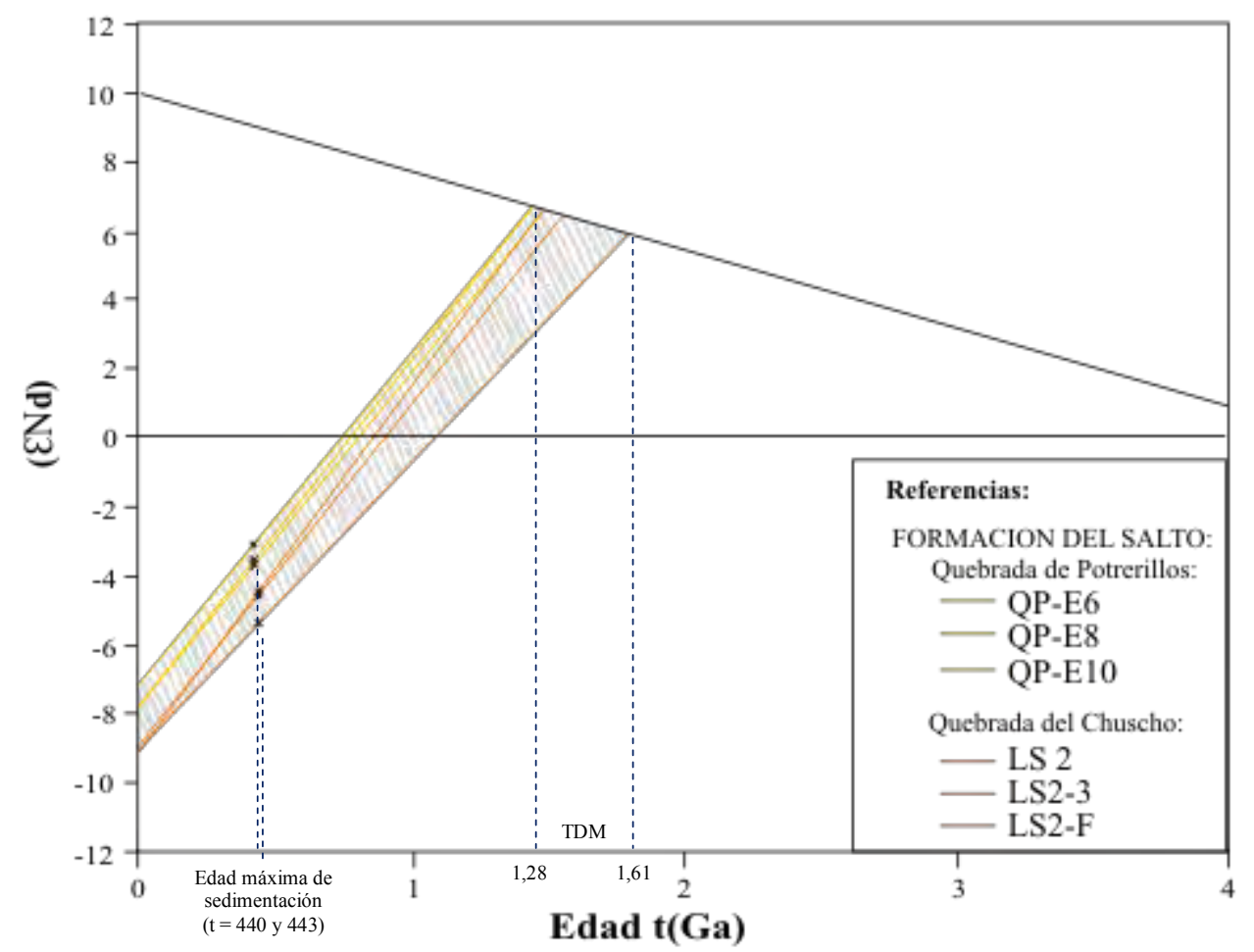

Figura 3.3.23: Edades modelo obtenidas en las muestras de ambos afloramientos de metasedimentitas estratificadas de la Formación del Salto. Calculos basados en el modelo de De Paolo (1981) para las edades máximas de sedimentación obtenidas por $\mathrm{U}-\mathrm{Pb}: \mathrm{t}=440 \mathrm{Ma}$ (quebrada de Potrerillos) y $\mathrm{t}=443 \mathrm{Ma}$ (quebrada del Chuscho).

\section{f. Análisis de la procedencia y ambiente tectónico.}

Los estudios de procedencia de las rocas sedimentarias intentan descifrar la composición y evolución geológica de sus áreas fuente, así como caracterizar el ambiente tectónico de la cuenca de depositación mediante la evaluación de indicadores, que reflejan la composición original de las áreas y rocas fuente. Este tipo de estudios involucran la evaluación en conjunto de resultados de diferentes estudios para llegar a una interpretación global del orígen del sedimento y/o sus probables fuentes de aporte. Estos estudios deben considerar en conjunto tanto datos de la petrografía como de geoquímica e isótopos, sin perder de vista el contexto geológico de campo y tectónico. Los datos obtenidos pueden idealmente ser usados para relacionar la composición y evolución de las regiones fuente con el ambiente tectónico de las 
cuencas de depositación en estudio, y evaluar el rol potencial de terrenos exóticos en el desarrollo de un bloque crustal particular.

Entre los estudios petrográficos comúnmente utilizados para análisis de procedencia se encuantran los conteos modales graficados en los triángulos Qt-F-L y Qm-F-Lt (Dickinson y Suczek, 1979; Basu et al., 1975; Dickinson et al., 1983; Dickinson, 1985; capítulo 2). Sin embargo, esta metodología no se ha podido emplear ya que fué desarrollado para muestras de psamitas con menos del $15 \%$ de matriz (arenitas) y granulometrías medianas, y lamentablemente ninguna muestra cumple con ambas premisas (Anexos A4 : Tabla 6). La inmadurez composicional y textural de los vaques (especialmente gran proporción de granos líticos y feldespatos, abundante matriz y morfología angulosa de los granos) indican poco transporte y reciclaje de los sedimentos.

La geoquímica de elementos mayoritarios es una herramienta importante para estudios de procedencia de rocas sedimentarias con mucha matriz, pero hay que testear que no haya sido afectada por diagénesis, metamorfismo u otra alteración (Manassero et al., 1991). Los valores de CIA obtenidos son normales para el tipo de muestras analizadas; las muestras QP-E6, QP-E10g, LS1-23 y LS1-7 fueron en alguna medida afectadas por procesos diagenéticos, alteración y metamorfismo (QP-E6), debiéndose tener en cuenta o descartarse para las interpretaciones. Debido a la abundancia de carbonatos en la región se evitó el uso de diagramas que utilicen $\mathrm{Ca}$ o $\mathrm{CaO}$ para evitar su influencia. Los elementos más utilizados para testear la procedencia de los sedimentos son aquellos más insolubles e inmóbiles en superficie, ya que al estar menos afectados por los procesos sedimentarios y diagenéticos tienden a conservar las características de la roca original. Especialmente útiles son elementos traza como Th, La, U, Hf, Zr, Ti, Sc, Co, Ta, y REE. Valores anómalos de Co y W, y de Ti, Nb y Ta pueden ser producidos por contaminación durante la molienda en muestras molidas en molinos de widia, por ello la mayoría de las muestras fue procesada por otros medios.

En algunos casos los minerales pesados pueden influenciar en gran medida la geoquímica y las interpretaciones respecto de la procedencia. Estos minerale suelen sobrivivir a los procesos sedimentarios post-depositacionales, por lo que su estudio puede contribuir a los análisis de procedencia de los sedimentos y evaluación de los procesos sedimentarios. Sin embargo, procesos como disolución postdepositacional y la edad geológica de la roca pueden influir en su estabilidad y preservación en el registro geológico. La edad geológica es un factor de control dominante en la complejidad de las suites de minerales pesados, ya que el orden de persistencia de los minerales (Pettijohn, 1941) depende de la edad de la roca y de la estabilidad química de los minerales pesados más comunes (Mange y Maurer 1992). Los procesos de disolución post-depositacionales pueden sesgar las interpretaciones mediante la eliminación de minerales inestables informativos, dejando un residuo de los ultraestables circón, turmalina, rutilo y, a veces, apatita (Mange y Maurer 1992). La abundancia de algunos elementos son controlados mineralógicamente por los minerales pesados, como por ejemplo el $\mathrm{Zr}$ que se concentra en los granos de circón, que además es un mineral pesado comun en los sedimentos. La relación $\mathrm{Gd}_{\mathrm{N}} / \mathrm{Yb}_{\mathrm{N}}$ se utiliza para rastrear las tierras raras pesadas (HREE) y el factor $\mathrm{La}_{N} / \mathrm{Sm}_{\mathrm{N}}$ las tierras raras livianas (LREE) y generalmente se puede asociar esto a controles mineralógicos por concentracion de determinados minerales pe- 
sados. Valores de $\mathrm{Gd}_{\mathrm{N}} / \mathrm{Yb}_{\mathrm{N}}>2$ indican un empobrecimiento en HREE (McLennan y Taylor, 1991). En el caso de las rocas estudiadas la variabilidad de la población de minerales pesados es pobre y se reduce a granos de circón y biotita dominantes, más raramente apatita (aporte de una fuente granítica?) y magnetita. La presencia de epidoto en algunas muestras probablemente sea un aporte de los esquistos verdes. Los escasos granos de apatita son transparentes y de morfologías muy irregulares, predominando los granos redondeados o subredondeados. No se han observado claras evidencias de una influencia importantes de procesos de disolución afectando a la población de minerales pesados, a pesar de la antigüedad de las rocas. La inmadurez textural y las granulometrías finas de los sedimentos apuntan a un ambiente de depositación de baja energía, pudiendo esto contribuir a la baja proporción de minerales pesados por concentración en zonas más proximales a las fuentes de aporte. Esto se refleja también en un predominio de circones poco redondeados, especialmente en las muestras de los afloramienros del área de Potrerillos (apartado e; Figuras 3.3.18 a 3.3.20). El único control mineralógico que se observa es el ejercida por la presencia de circón en la concentración de Zr especialmente en los vaques mas que en pelitas, como es

a)

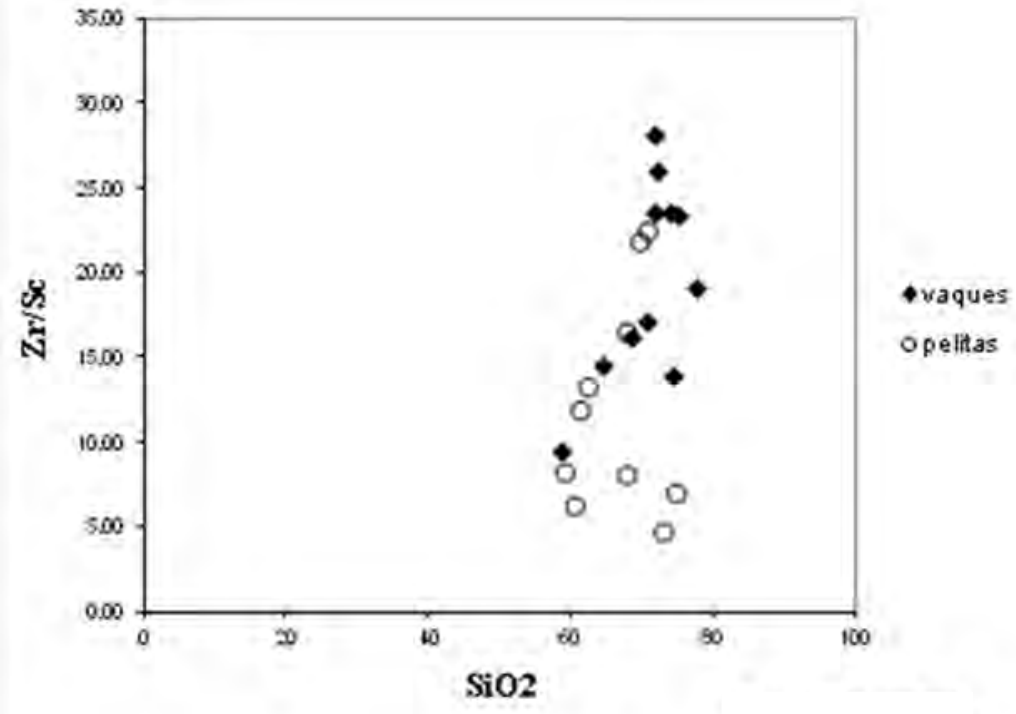

b)

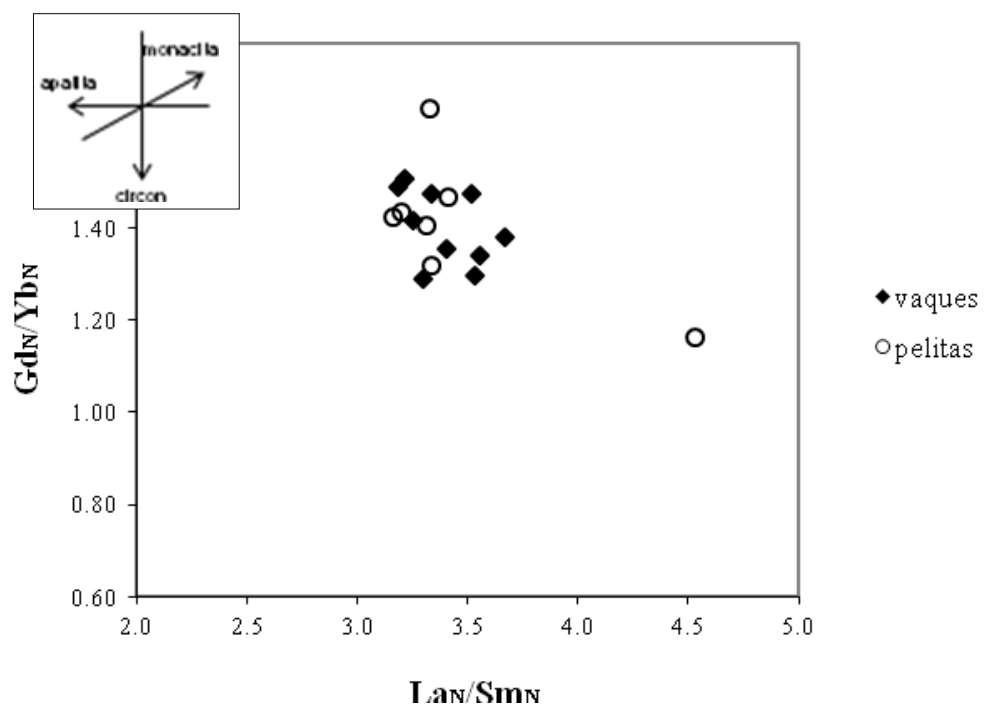


Figura 3.3.24: Diagramas bivariantes que permiten evaluar el control mineralógico ejercido por concentracion de minerales pesados durante el reciclaje de los sedimentos (Taylor y McLennan, 1985). a)- $\mathrm{Zr} / \mathrm{Sc}$ versus $\mathrm{SiO}_{2} ;$ b) $-\mathrm{Gd}_{\mathrm{N}} / \mathrm{Yb}_{\mathrm{N}}$ versus $\mathrm{La}_{\mathrm{N}} / \mathrm{Sm}_{\mathrm{N}}$. de esperar (Figura 3.3.24a, b). El mayor grado de redondeamiento en los afloramientos del área del Chuscho podría estar relacionada a una mayor energía en los agentes sedimentarios hacia el oeste, o a un ambiente más proximal.

Tabla 3.3.8: Datos correspondientes a la figura 23a, b.

\begin{tabular}{|l|cc|ccc|}
\hline & $\mathbf{~}_{\mathbf{0 S i O}}$ & $\mathbf{Z r} / \mathbf{S c}$ & $\mathbf{L a}_{\mathbf{N}} / \mathbf{Y b}_{\mathbf{N}}$ & $\mathbf{G d}_{\mathbf{N}} / \mathbf{Y} \mathbf{b}_{\mathbf{N}}$ & $\mathbf{L a}_{\mathbf{N}} / \mathbf{S m}_{\mathbf{N}}$ \\
\hline Psamitas & & & & & \\
LS1-3 & 70.87 & 17.18 & 7.52 & 1.47 & 3.33 \\
LS1-9 & 73.91 & 23.52 & 7.39 & 1.47 & 3.52 \\
LS1-10 & 72.09 & 25.95 & 7.57 & 1.38 & 3.67 \\
QP-E9 & 71.90 & 28.11 & 6.89 & 1.34 & 3.56 \\
QP-E24 & 75.11 & 23.46 & 7.36 & 1.49 & 3.18 \\
QP-E25 & 71.99 & 23.60 & 6.72 & 1.29 & 3.30 \\
QP-E27 & 68.60 & 16.13 & 7.35 & 1.35 & 3.41 \\
QP-E28 & 64.71 & 14.52 & 7.20 & 1.42 & 3.25 \\
& 77.91 & 19.15 & 6.97 & 1.30 & 3.53 \\
Pelitas & & & & & \\
LS 2 & 60.54 & 6.22 & 8.17 & 1.66 & 3.33 \\
LS 2-2 & 67.96 & 8.09 & 8.57 & 1.16 & 4.53 \\
LS2-F & 74.74 & 6.96 & 7.37 & 1.47 & 3.41 \\
LS2-3 & 59.237 & 8.25 & 8.16 & - & 3.10 \\
LS2-5 & 72.984 & 4.69 & 8.00 & - & 3.33 \\
QP-E7 & 61.41 & 11.85 & 6.69 & 1.43 & 3.20 \\
QP-E8g & 62.48 & 13.27 & 6.94 & 1.40 & 3.31 \\
QP-E10g & 69.73 & 21.85 & 6.70 & 1.32 & 3.34 \\
QP-E11g & 68.02 & 16.43 & 7.01 & 1.42 & 3.16 \\
QP-E6 & 70.814 & 22.48 & 6.76 & - & 3.23 \\
\hline
\end{tabular}

El Cr es un buen trazador de rocas ultramáficas o máficas ricas en cromita en la fuente. El diagrama $\mathrm{Cr} / \mathrm{V}$ versus $\mathrm{Y} / \mathrm{Ni}$ (McLennan et al., 2003) se utiliza para testear la presencia de un componente ofiolítico en la fuente de aporte detrítico. En la Figura 3.3.25 no se observa la presencia de este componente en el área fuente. Los mayores valores de $\mathrm{Cr} / \mathrm{V}$ e Y/Ni corresponden a las muestras QP-E5, QP-E6 y QP-E11.

Las tierras raras son indicadoras de procedencia bien establecidos pero puede haber una cierta movilización de los elementos durante la meteorización extrema. En muestras con mucho cuarzo puede haber poca concentración de REE por dilución. Las anomalías de Eu (positivas o negativas) se relacionan con procesos de diferenciación magmática y cristalización fraccionada, ya que se concentra en las plagioclasas, mientras que las anomalías positivas de Ce se asocian a la alteración en ambientes oxidantes. Por los resultados obtenidos la fuente de los sedimentos muestra gran fraccionamiento respecto a la corteza continental superior (UCC; Taylor y McLennan, 1981; Frigerio 2008a.)

Relaciones elementales tales como La/Sc, Th/Sc, Th/Co, $\mathrm{La} / \mathrm{Co}, \mathrm{Ba} / \mathrm{Sc} \mathrm{Ba} / \mathrm{Co}, \mathrm{Eu} / \mathrm{Sm}, \mathrm{y} \mathrm{La} / \mathrm{Lu}$ suelen ser útiles en las interpretaciones respecto de la procedencia y la composición de la fuente de los sedimentos. Los elementos más compatibles como V, Ni y Sc se concentran en rocas ultramáficas, mientras que los incompatibles como el Th en rocas félsicas. Los valores de $\mathrm{Th} / \mathrm{Sc}$ y $\mathrm{Zr} / \mathrm{Sc}$ se relacionan con 
la heterogeneidad composicional de la roca madre, por medio de la comparación de elementos incompatibles (Th, Zr) concentrados comúnmente en las rocas félsicas, con elementos compatibles ( $\mathrm{Sc}$ ) relacionadas con fuentes poco diferenciadas. Los valores de $\mathrm{Th} / \mathrm{Sc}$ inferiores a 1 observados en las metasedimentitas se asocian a arcos volcánicos jóvenes sin diferenciar (YUA en McLenann et al., 1993, 1995). Estos terrenos estan formados por rocas volcánicas o plutónicas derivadas de un arco volcánico jóven derivado del manto. Presentan composiciones variables y muestran además signaturas geoquímicas de elementos mayoritarios poco evolucionadas (e.g. bajos valores de Si/Al y CIA) y bajas abundancias de LILE (McLenann et al., 1993,1995).

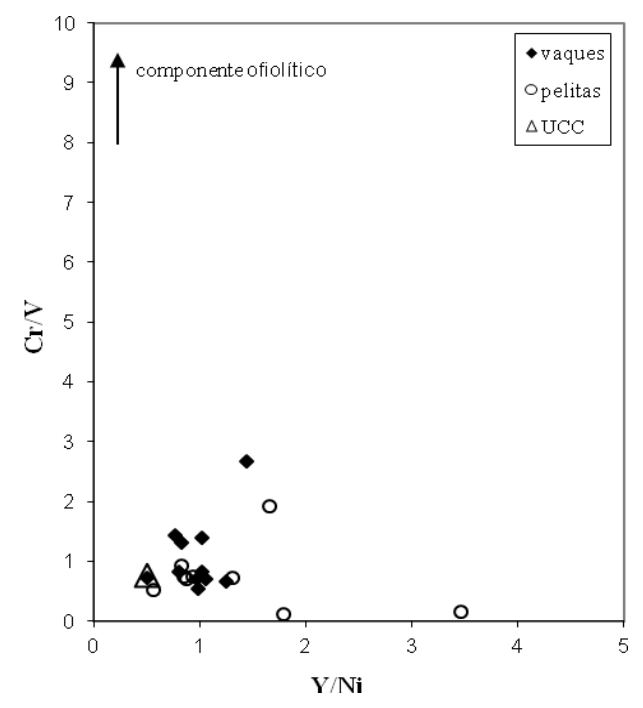

Figura 3.3.25: Diagrama Cr/V vs. Y/Ni (McLennan et al., 2003) que permite testear la presencia de un componente ofiolítico.

Los procesos de tectónica de placas otorgan una signatura geoquímica distintiva a los sedimentos, ya que diferentes ambientes tectónicos poseen características distintivas de procedencia y por otro lado, están caracterizados por procesos sedimentarios distintivos (Rollinson, 1993). Existen diagramas de discriminación tectónica que intentan distinguir entre ambientes tectónicos de procedencia de rocas detríticas y magmáticas. Como regla general se debe caracterizar la composición y establecer la procedencia de los sedimentos antes de proceder a la interpretación de los ambientes tectónicos de generación y depositación (Manassero, 1989). En general, las cuencas sedimentarias pueden asignarse a algunos de los siguientes ambientes tectónicos (Bathia y Crook, 1986, en Rollinson, 1993):

- arco de isla oceánico: cuencas de antearco o retroarco, adyacentes a arcos volcánicos desarrollados en corteza oceánica o corteza continental delgada.

- arco de isla continental: cuencas de intra-arco, antearco o retroarco, adyacentes a arcos volcánicos desarrollados en corteza continental gruesa o margenes continentales delgados.

- margen continental activo: cuencas tipo andinas desarrolladas sobre o adyacentes a márgenes continentales gruesos. Las cuencas de desplazamiento de rumbo (strike-slip) también se desarrollan en estos ambientes.

- margen continental pasivo: cuencas desarrollados en corteza continental gruesa en los bordes 'de arrastre' (trailing-edges) de los continentes que se separan. 
- ambientes colisionales: cuencas desarrolladas en corteza continental gruesa.

- ambientes de rift: cuencas intercratónicas desarrolladas en corteza continental gruesa.

En los diagramas de Rosser y Korsch (1986; Figura 3.3.26a, b), quienes utilizan elementos mayoritarios, se observa una vinculación de las sedimentitas con márgenes pasivos. Estos diagramas fueron confeccionados para pelitas sin embargo, debido al alto contenido de matriz de algunas muestras de vaques y sedimentitas heterolíticas se han ploteado también a modo comparativo. Observar que en la quebrada de Potrerillos -QP- pelitas y areniscas no se distinguen porque hay más facies heterolíticas. En el área del Chuscho -LS- se distinguen mejor.

A diferencia de los anteriores, en los diagramas de discriminación basados en elementos traza como Ti/Zr versus La/Sc, La-Th-Sc y Th-Sc-Zr/10 (Bathia y Crook, 1986; Figuras 3.3.27 y 3.3.28) los vaques y lutitas plotean en el campo de arco de isla continental (AIC) excepto la muestra LS2-F (márgenes continentales activos, MCA), pero esta muestra es la que posee la geoquímica mas disturbada.
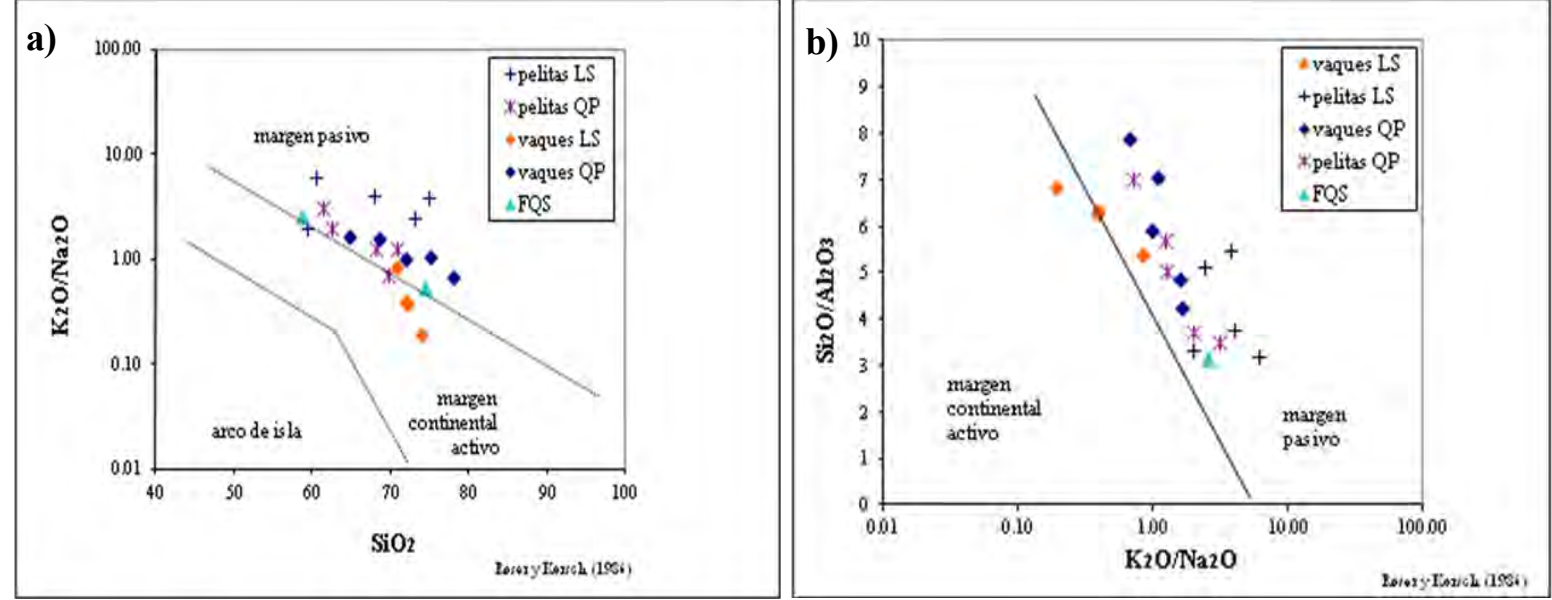

Figura 3.3.26a, b: Diagramas de discriminación tectónica de pelitas de Rosser y Korsch (1986) basados en elementos mayoritarios para las metasedimetnitas estratificadas. Muestras tomadas sobre la quebrada de Potrerillos (QP) y área del Chuscho (LS).

En el diagrama $\mathrm{Ti} / \mathrm{Zr}$ - La/Sc se observa que los vaques tienen cierta tendencia hacia el campo de márgen continental activo. Este trend es similar al que siguen las turbiditas de mar profundo actuales derivadas de y depositadas en márgenes de arco continental de McLennan et al. (1990, campo CA; Manassero et al., 2009). Aparentemente tienen que ver con un control litológico por la concentración de $\mathrm{Zr}$ en las psamitas respecto a las pelitas (Figura 3.3.24 a,b). Este control litológico asociado a la granulometría se observa mas claramente en las muestras del área del Chuscho que en las de Potrerillos, mayormente heterolíticas o con mayor contenido de matriz, por lo que las lutitas se separan de los vaques (ej. tienen mayor relación Ti/Zr, Figura 3.3.28).Respecto al uso de isótopos, los más importantes en estudios de procedencia son los isótopos de $\mathrm{Nd}$ y $\mathrm{Pb}$. Como puede observarse de los resultados de $\mathrm{U}-\mathrm{Pb}$, las edades máximas de sedimentación obtenidas para las muestras de ambos afloramientos fueron similares. Sin embargo, y aunque se necesitaría datar una población mayor de granos, algunas diferencias pueden observarse desde el punto de vista estadístico respecto a las edades de las rocas que contribuyeron al sedimento (Figura 3.3.29). Aparte de la moda más joven en el límite Ordovícico-Silúrico (30\%; apartado e-Edad U-Pb), el aporte principal de las sedimentitas de LS1-3 es de una fuente mesoproterozoica (50\%) 
y escaso aporte paleoproterozoico (20\%). En la muestra QP-E9 la moda principal coincide con la edad máxima de sedimentación en el límite Ordovícico - Silúrico (36\%), y además tuvo otras fuentes de
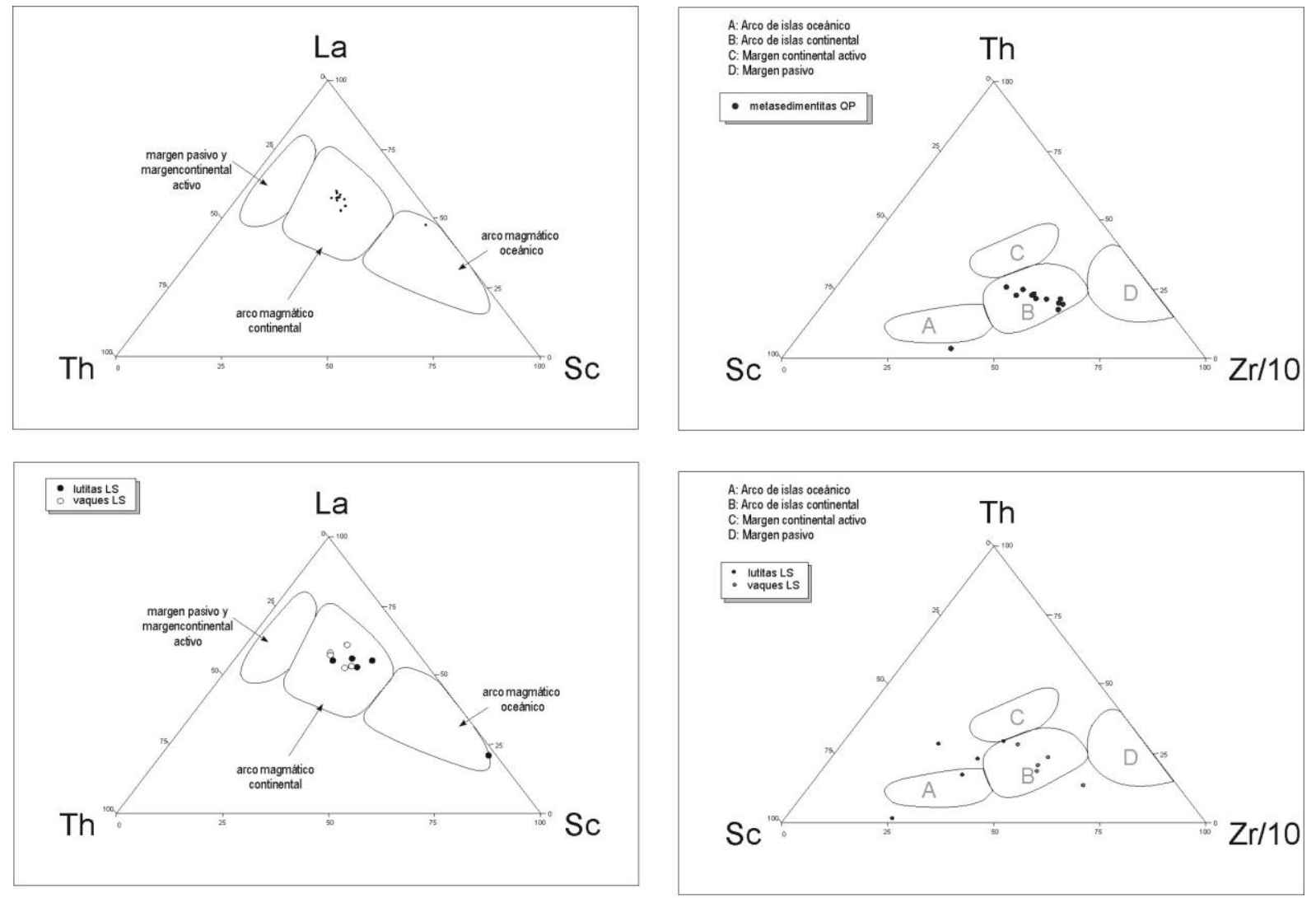

Figura 3.3.27: Diagramas ternarios de procedencia La-Th-Sc y Th-Sc-Zr/10 (Bathia y Crook, 1986) para las metasedimentitas de ambos afloramientos de la Formación Del Salto: a-b) Qda de Potrerillos; c-d) Area del Chuscho.

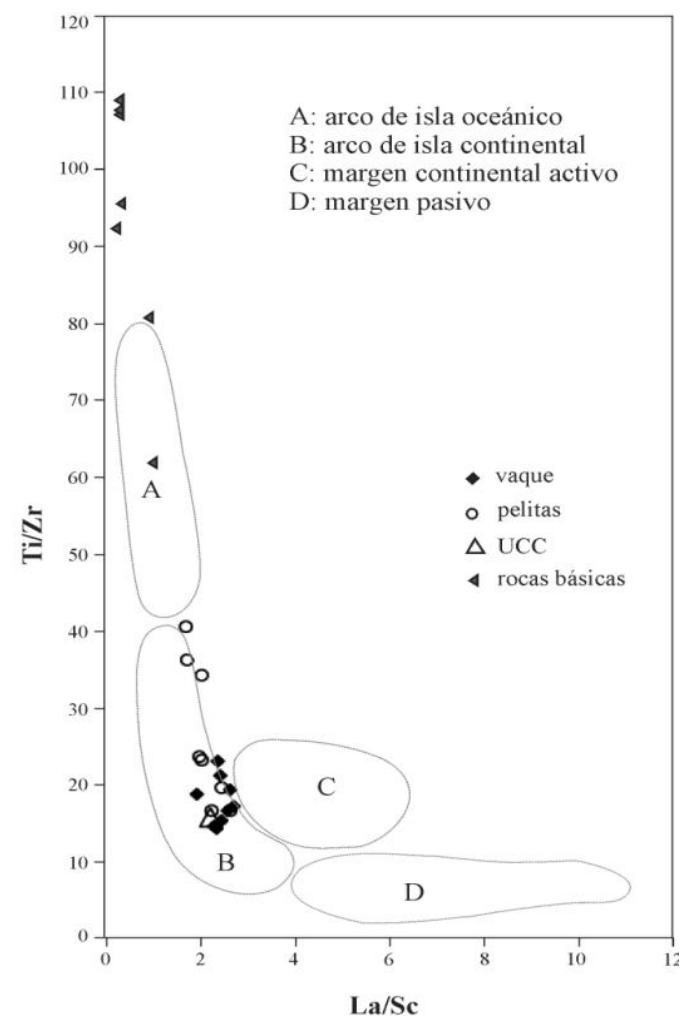

Figura 3.3.28: Diagrama de disctiminación tectónica de Bhatia y Crook (1986). A: arco de isla oceánico; B: arco de isla continental; C: margen continental activo; D: margen pasivo. 
aporte más variadas con edades del Mesoproterozoico (21\%), Neoproterozoico (29\% - Pampeano?) y un poco de material del Ordovícico Inferior (14\%).

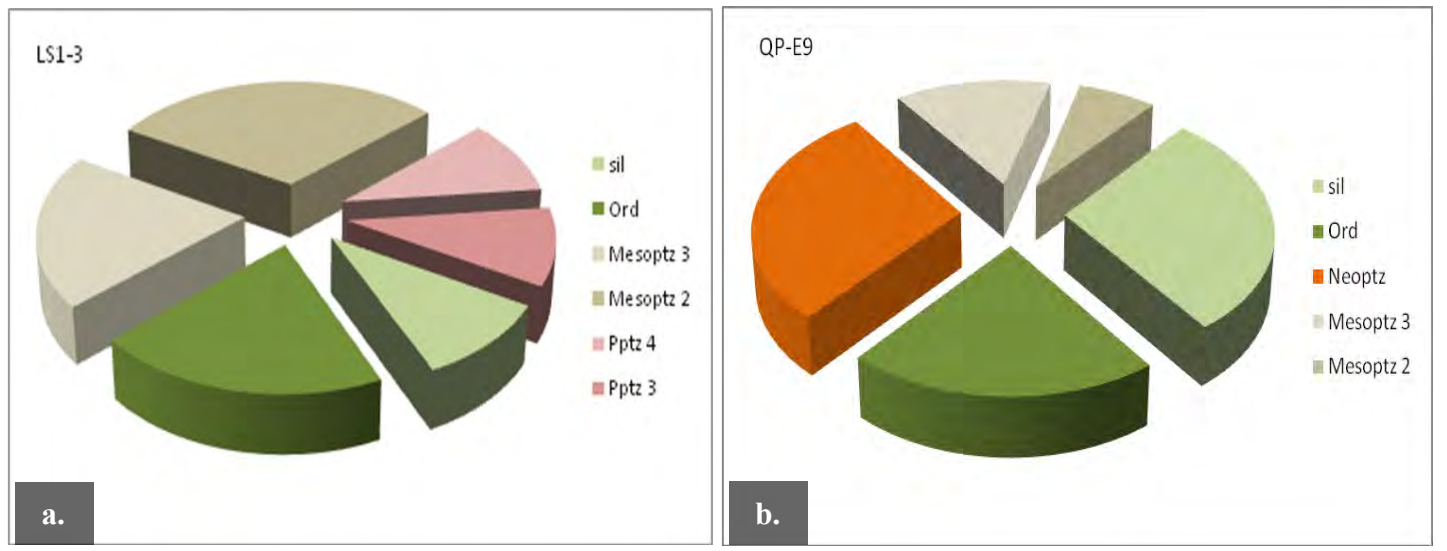

Figura 3.3.29: diagramas de torta en el que se representan los resultados de edades $\mathrm{U}-\mathrm{Pb}$ en circones detríticos obtenidos para las muestras de la Formación del Salto en los afloramientos del área del Chuscho (a) y de Potrerillos (b).

Los isótopos de $\mathrm{Nd}$ permiten hacer distinciones entre el material sedimentario que entra a una cuenca desde otros terrenos de variable composición crustal e historia geológica, mediante los parámetros $\varepsilon_{\mathrm{Nd}}(\mathrm{t})$, edades modelo $\mathrm{Sm} / \mathrm{Nd}\left(\mathrm{T}_{\mathrm{DM}}\right), f_{\mathrm{Sm} / \mathrm{Nd}}$, (desviación fraccional de una muestra de $\mathrm{Sm} / \mathrm{Nd}$ respecto a la referencia condrítica -CHUR), y diagramas de procedencia. Los valores de referencia usados para las determinaciones se detallan en los Anexos A6c. En el diagrama $f^{\mathrm{Sm} / \mathrm{Nd}}$ vesus $\varepsilon_{\mathrm{Nd}}(\mathrm{t})$ las pelitas de ambos

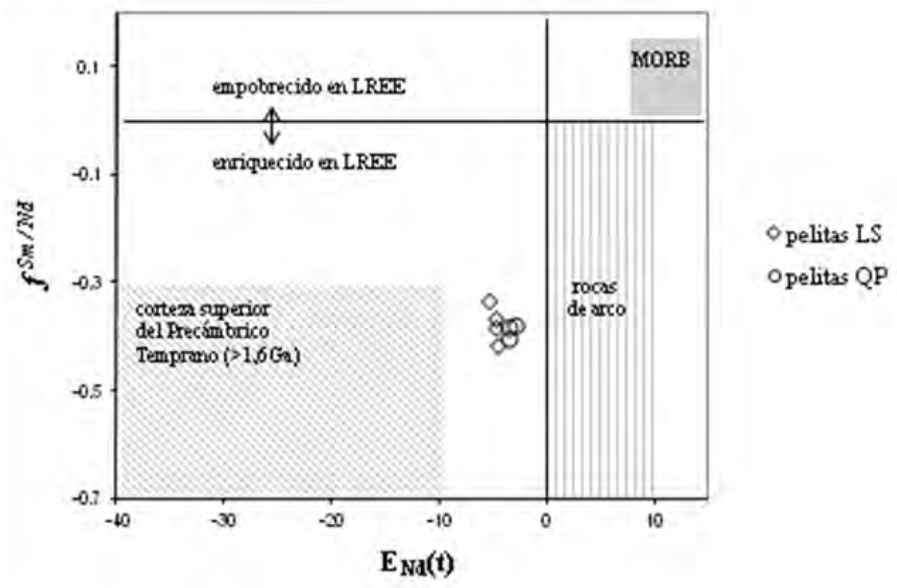

Figura 3.3.29: Diagrama $f^{\mathrm{Sm} / \mathrm{Nd}}$ vesus $\varepsilon_{\mathrm{Nd}}(\mathrm{t})$ para las sedimentitas pelíticas de la Formación del Salto en sus dos afloramientos. afloramientos se agrupan juntas en un campo intermedio entre las rocas de arco y las rocas de corteza superior antigua.

En el diagrama $\varepsilon_{\mathrm{Nd}}(\mathrm{t})$ vesus la relación $\mathrm{Th} / \mathrm{Sc}$ (Figura 3.3.31) se observa que las muestras pelíticas se agrupan cerca del trend típico de diferenciación de la corteza superior. El desplazamiento hacia la derecha de la curva de referencia probablemente se vincula con el mayor contenido de Th que generalmente se observa en las pelitas. 


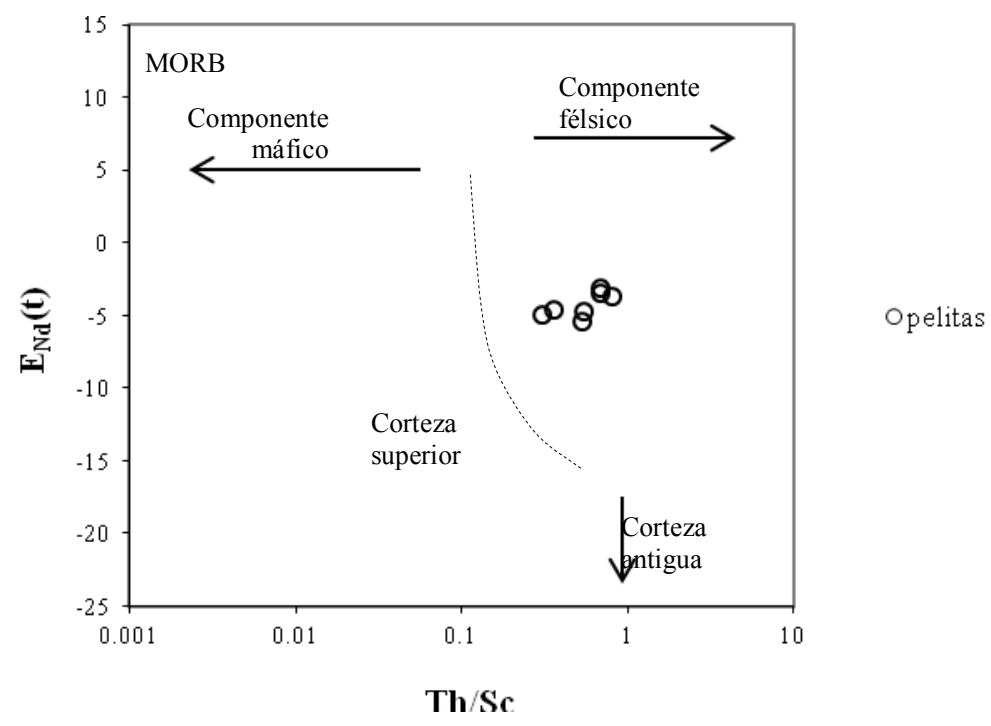

Figura 3.3.31: Diagrama $\varepsilon_{\mathrm{Nd}}(\mathrm{t})$ vesus la relación $\mathrm{Th} / \mathrm{Sc}$ para las sedimentitas pelíticas de la Formación del Salto.

En general, los resultados obtenidos sugieren un transporte relativamente corto del material detrítico hacia la cuenca, con poco efecto del intemperismo, habiéndose depositado en un ambiente con alta tasa de sedimentación y rápido enterramiento, como ocurre en márgenes continentales activos y sistemas de arco continental (Bhatia y Crook, 1986; McLennan et al., 1990 y 1993). La presencia de rocas relacionadas a un arco a lo largo del margen occidental de Gondwana durante el Ordovícico hace pensar en un ambiente tectónico de este tipo. Este arco podría estar en rocas ordovícicas de Famatina y/o la Puna. No se descarta que el aporte detrítico haya derivado de terrenos que se encontraban tectónicamente activos durante la depositación (Frigerio 2008a).

Tabla 3.3.9: Datos correspondientes a los gráficos de las Figuras 3.3.30 y 3.3.31.

\begin{tabular}{|l|c|ccc|c|}
\hline $\begin{array}{l}\text { Muestra } \\
\text { (pelitas) }\end{array}$ & $\begin{array}{c}\text { Edad } \\
\text { Ma }\end{array}$ & $\boldsymbol{f}^{\text {Sm/Nd }}$ & $\begin{array}{c}\mathbf{E}_{\text {Nd }}(\mathbf{0}) \\
\text { actual }\end{array}$ & $\begin{array}{c}\boldsymbol{\varepsilon}_{\text {Nd }}(\mathbf{t}) \\
\text { inicial }\end{array}$ & Th/Sc \\
\hline LS2 & 443 & $\mathbf{- 0 . 3 3}$ & -9.2 & $\mathbf{- 5 . 5}$ & $\mathbf{0 . 5 3}$ \\
LS 2 & 443 & $\mathbf{- 0 . 3 7}$ & -9.0 & $\mathbf{- 4 . 9}$ & $\mathbf{0 . 3 0}$ \\
LS2-3 & 443 & $\mathbf{- 0 . 3 8}$ & -9.0 & $\mathbf{- 4 . 8}$ & $\mathbf{0 . 5 5}$ \\
LS2-F & 443 & $\mathbf{- 0 . 4 1}$ & -9.2 & $\mathbf{- 4 . 6}$ & $\mathbf{0 . 3 6}$ \\
QP-E6 & 440 & $\mathbf{- 0 . 3 8}$ & -7.9 & $\mathbf{- 3 . 7}$ & $\mathbf{0 . 8 1}$ \\
QP-E8g & 440 & $\mathbf{- 0 . 4 0}$ & -8.0 & $\mathbf{- 3 . 5}$ & $\mathbf{0 . 6 9}$ \\
QP-E10g & 440 & $\mathbf{- 0 . 3 8}$ & -7.3 & $\mathbf{- 3 . 1}$ & $\mathbf{0 . 6 9}$ \\
\hline
\end{tabular}

Por otro lado, las edades $\mathrm{U} / \mathrm{Pb}$ de los circones detríticos indican que también habría un aporte del basamento meso-proterozoico de Cuyania (Sierras Pampeanas Occidentales). Esto implicaría que estos afloramientos de Precordillera recibieron sedimentos tanto del basamento de Sierras Pampeanas Occidentales como del arco ordovícico de Famatina o/y Puna. Asimismo, estos afloramientos podrían corresponder a otras provincias geológicas aledañas (Sierras Pampeanas Occidentales, Famatina, Puna), lo que podría coincidir quizás con el límite de Cuyania que plantearon Martino y Astini (1998). 
3.2.4- ROCAS BASICAS (Formación Chuscho de Toselli y Durand, 1996; Fauqué y Villar, 2003; parte de la Andesita Cerro Chuscho, Aceñolaza et al., 1971. Variedad de diques).

\section{Introducción: Magmatismo.}

El magmatismo de la Precordillera de Jagüé está representado por plutones aislados a los que tradicionalmente se asocia con el Carbonífero-Pérmico de la Cordillera Frontal (e.g. Llambías, 1999) y por rocas volcánicas y subvolcánicas básicas a intermedias de diferentes edades (Anexos A1: M1). Entre los granitoides se hará hincapié en el plutón denominado Granito Potrerillos o Formación Potrerillos (sección 3.2.6), ya que sobre la quebrada de Potrerillos intruye a las metasedimentitas estratificadas de la Formación del Salto.

Las rocas básicas están representadas por una variedad de litotipos: basaltos, diabasas y fenoandesitas, que se presentan como lavas almohadilladas, autobrechas volcánicas, diques, filones y lavas masivas. Se han podido identificar grupos de rocas básicas caracterizados por sus texturas y morfologías, y distinto grado de deformación, metamorfismo y alteración. Tradicionalmente, las rocas básicas se consideraron dentro de un único ciclo magmático carbonífero (Aceñolaza y Bernasconi, 1969b; Aceñolaza et al., 1971) pero a raíz de los resultados obtenidos del mapeo y análisis se han reconocido al menos tres ciclos magmáticos: uno Ordovícico atribuído a la Formación Chuscho (Toselli y Durand, 1996; Fauqué y Villar, 2003), otro Carbonífero y más extendido representado por la Formación Punta del Agua (Aceñolaza, 1971; González y Bossi, 1986; Remesal et al., 2004) y un último representado por diques más jóvenes de edad incierta (Triásico?, ver discusión más adelante). Además existen filones deformados y afectados por metamorfismo intercalados entre los esquistos de la Formación Río Bonete y faja de deformación de Jagüé, probablemente relacionados al magmatismo ordovícico.

Entre las rocas básicas se haran aquí aportes principalmente para la Formación Chuscho ya que se asocian a las unidades metasedimentarias y metamórficas directamente relacionadas con los objetivos de esta tesis (Rocas metasedimentarias estratificadas de la Formación Del Salto y Formación Río Bonete). En los capítulos siguientes se describen por separado y en el orden estratigráfico las rocas básicas asociadas a las metasedimentitas estratificadas de la Formación del Salto (sección 3.2.4.1) y los granitoides que componen el Granito Potrerillos (sección 3.2.6). Antes se mencionarán las características generales de las variedades de diques presentes (sección 3.2.4.2) ya que al no estar vinculados todos a un mismo evento magmático constituyen una problemática particular en el mapeo y análisis de datos.

\subsubsection{1- Distribución de los afloramientos.}

En toda el área mapeada es constante la aparición de rocas ígneas básicas, tanto en las quebradas de Potrerillos, Chuscho y Bonete como en el sector de Los Llantenes. La mayor parte son diques que cortan a las distintas unidades estratigráficas. Por las características petrológicas que presentan y las 
relaciones de corte observadas queda claro que no se originaron durante el mismo evento magmático. Los afloramientos observados se distribuyen de la siguiente manera:

- En la quebrada del Río Bonete y cerro Chuscho se concentran principalmente las rocas básicas asignadas a la Formación Chuscho, conformada por la asociación de lavas almohadilladas con autobrechas volcánicas, y diques de diabasa (Toselli y Durand, 1996; Fauqué y Villar, 2003. Anexos A1: M2 y P3). Además aparecen diques y filones negros afaníticos, fenoandesitas y metabasitas.

- En la quebrada de Potrerillos las rocas básicas se restringen casi exclusivamente a diques subverticales, negros, con textura afanítica a microporfírica. Cerca del Granito se hallaron algunos diques anchos y de grano grueso, también subverticales. Son raros los diques porfíricos gruesos, con abundantes fenocristales de plagioclasas que le otorgan coloración gris clara.

- En el área de Los Llantenes se observaron diques porfíricos violáceos (fenoandesitas) y basaltos afaníticos negros que cortan a los esquistos, metabasitas y mármoles de la Formación Río Bonete al norte de la Dorsal de la Orilla, mientras que al sur de esta dorsal aparecen lavas almohadilladas que fueron citadas y mapeadas por Cravero et al. (1984. Anexos A1: M6a-b y L1).

\section{Asociaciones de rocas básicas}

Se ha podido agrupar a la mayor parte de las rocas básicas según su asociación a distintos eventos magmáticos:

Grupo 1: Diques verdes y filones de diabasa, cuya expresión superficial serían las lavas almohadilladas y autobrechas volcánicas intercaladas entre la sedimentitas estratificadas de la Formacion del Salto (Ordovícico; sección 3.2.3). El conjunto de cuerpos se agrupan en la Formación Chuscho.

Grupo 2: Diques básicos de grano grueso (gabroides). Se vinculan a la Formación Potrerillos (Devónico Superior-Carbonífero Inferior, sección 3.2.6).

Grupo 3: Diques negros afaníticos. De edad incierta, probablemente vinculados a la Formación Punta del Agua (Remesal et al., 2004).

Grupo 4: Diques porfíricos (feno-andesitas). Son escasos y de ubicación temporal incierta. Por la coloración de la pasta, se reconocieron dos tipos: los más comunes tienen pastas violáceas y texturas claramente porfíricas, mientras que muy escasos se observaron con pasta gris clara y texturas seriadas.

\section{Caracterización de los Diques}

Como se mencionó, las unidades que afloran en la región están cortadas por diques básicos, mayormente subverticales o con alto ángulo de inclinación y con una variedad de texturas. Antes de 
describir la Formación Chuscho a continuación se describen brevemente las variedades de diques con el fin de caracterizarlos y exponer los criterios que se tuvieron en cuenta para poder diferenciarlos.

a)- Filones y diques verdes de diabasas. Son abundantes en el área del Chuscho y tramo inferior del río Bonete. Generalmente presentan colores verdosos en fractura fresca y con tonos ocres o amarillentos por alteración superficial. Por su aspecto (granulometría, espesor, colores verdosos) pueden ser difíciles de reconocer e incluso pasados por alto en los afloramientos deformados, especialmente los de granulometrías más finas que se confunden con los estratos de metavaques de la Formación del Salto. Intercalados entre los esquistos y aprovechando sus planos de debilidad, se encuentran delgados filones de diabasas concordantes a pseudoconcordantes con la foliación, especialmente en el área de la Boca del río Bonete. Los diques no cortan al Granito Potrerillos ni se observaron en su roca de caja, pero en la quebrada del Bonete sí son abundantes cortando a las sedimentitas ordovícicas del área del cerro Chuscho y a la asociación de mármoles y esquistos verdes de la Formación Río Bonete. Diques y filones se encuentran desplazados por pequeñas fallas junto con las metasedimentitas y suelen presentar bajo grado de metamorfismo (metabasitas) y rasgos de deformación tales como micro-brechamientos y cierta orientación de la fábrica (sección 3.2.3.2, b)- petrografía). Sobre la quebrada del Bonete están parcialmente transformados en anfibolitas de grano fino y esquistos verde-azulados actinolíticotremoliticos y por la deformación adquieren foliación y alineación de mafitos. La expresión superficial de estos intrusivos serían las fenoandesitas, lavas almohadilladas y autobrechas volcánicas intercaladas entre las metasedimentitas estratificadas de la Formación del Salto, considerándose entonces relacionados con el mismo magmatismo básico de la Formación Chuscho y que se describirán en la seccion siguiente (sección 3.2.4.2).

b)- Diques básicos de grano grueso. Cerca del Granito Potrerillos, tanto en la quebrada de Potrerillos como en la del río Bonete, aparecen diques de granulometría mediana a gruesa (gabroides), subverticales, con texturas granudas y seriadas y espesores importantes (10-15 metros). No cortan al Granito pero si a su roca de caja, y se relacionan a él como facies periféricas (apófisis o diques). Corresponden a dioritas y gabros (TAS: Cox et al., 1979; e.g. QP-G8, BO-G12, QP18) y están compuestos por plagioclasa, anfíbol y/o clinopiroxeno, con abundante titanita y la presencia de nidos de biotita (e.g.: muestras QP-G8, BO-G12, QP18). En la quebrada del Bonete la deformación y metamorfismo más intensos los transforma en anfibolitas con actinolita, epidoto y plagioclasa (e.g. BOD10), en forma similar a lo que ocurre con el resto de las rocas básicas.

c)- Diques negros. Los diques más abundantes son basaltos afaníticos que típicamente se encuentran sin deformar. Se han hallado en todos los afloramientos, principalmente como diques subverticales de poco espesor (entre 10 y $25 \mathrm{~cm}$ en promedio, aunque variable entre algunos centímetros y hasta poco más de $1 \mathrm{~m}$ ) y como filones. Cuando están frescos son de color negro y en adelante se referirán como "diques negros", pero en la quebrada de Potrerillos, donde los afloramientos están cubiertos por 'barniz del desierto', solo se distinguen facilmente de los metasedimentos cuando están alterados u oxidados en superficie tomando coloraciones verdosas u ocres, de otro modo pueden pasarse fácilmente por alto, más aún allí donde por la deformación de las sedimentitas los estratos y diaclasas 
toman orientaciones similares a los diques. Presentan textura afanítica dominante, aunque pueden ser microporfíricos y registrar pequeños fenocristales de P1 traslúcida y acicular y mafitos negros con augita dominante (e.g. muestra BO26). Comúnmente tienen concentraciones de pequeñas vesículas paralelas a las paredes del dique. Como se mencionó, no están deformados sino que rellenan fracturas previas como diaclasas y planos de cizalla; entre los esquistos cuarzo-muscovíticos blanquecinos y esquistos verdes y verde-azulados pueden encontrarse frecuentemente inyecciones de estos basaltos concordantes con la foliación (filones). La orientación predominante de estos diques varía entre oeste-este y sudoeste-noreste, en coincidencia con la orientación de la franja de conglomerados que atraviesa la quebrada del Bonete por su tramo medio y con las estructuras compresivas (plegamientos suaves de gran escala) que afectan al Paleozoico Superior. Son claramente más jóvenes ya que cortan todas las unidades previas mapeadas: diques verdes, sedimentitas ordovícicas, variedades de esquistos y mármoles, e incluso al Granito Potrerillos. Por esto se asume que al menos corresponden a un magmatismo posterior al del Granito Potrerillos (límite Devónico Superior hasta el inicio del Carbonífero Inferior, capítulo 3.2.6) y previo a los depósitos sedimentarios carboníferos. Cortan también la foliación milonítica de la faja de deformación y también aprovechan los planos de cizalla generados para alojarse, lo que permite argumentar que también son posteriores a la última reactivación de la faja de deformación de Jagüé. Sin embargo, durante el mapeo no se observó que cortaran a los para-conglomerados castaños carboníferos (Grupo Paganzo en sentido amplio; sección 3.2.8). Probablemente se relacionen con las rocas básicas de la Formación Punta del Agua aunque no se descarta otra posibilidad (capítulo 3.1: diques negros).

d)- Diques porfíricos. Se han hallado algunos diques porfíricos a seriados que se caracterizan por presentar gran abundancia de cristales de plagioclasa de entre 5 y $7 \mathrm{~mm}$ promedio y pastas violáceas. Se encuentran desplazados por fallas, habiéndose observado principalmente en el área de Los Llantenes y en menor medida sobre la quebrada del río Bonete. Cortan a las Formaciones Río Bonete, Chuscho, Del Salto y Quebrada Seca, pero no se observaron cortando al granito. De ubicación estratigráfica incierta, estos diques podrían relacionarse con el magmatismo carbonífero de la Formación Punta del Agua (equivalentes a las 'andesitas porfiricas' de Remesal et al., 2004).

Además de éstos diques violáceos, al norte de la quebrada de Potrerillos se han reconocido algunos diques porfíricos similares pero con escasa pasta de color gris claro, vesiculados y que poseen abundantes fenocristales de P1 en una pasta afanítica, microporfírica o seriada (e.g. QP17, QP-D3, QPD30). Son poco frecuentes y su ubicación estratigráfica es incierta; podrían relacionarse al mismo magmatismo o no. Ambos están deformados por fallamiento.

\subsubsection{2- La Formación Chuscho}

La "Formación Chuscho" (Toselli y Durand, 1996; Fauqué y Villar, 2003) está formada por lavas almohadilladas, autobrechas volcánicas, diques y filones de diabasas intercaladas entre las sedimentitas fosilíferas de la Formación Del Salto y deformadas junto con ellas. Se trata de volcanitas intermedias a básicas que se vinculan al magmatismo del cerro Chuscho. Forman intrusivos sub-volcánicos masivos y 

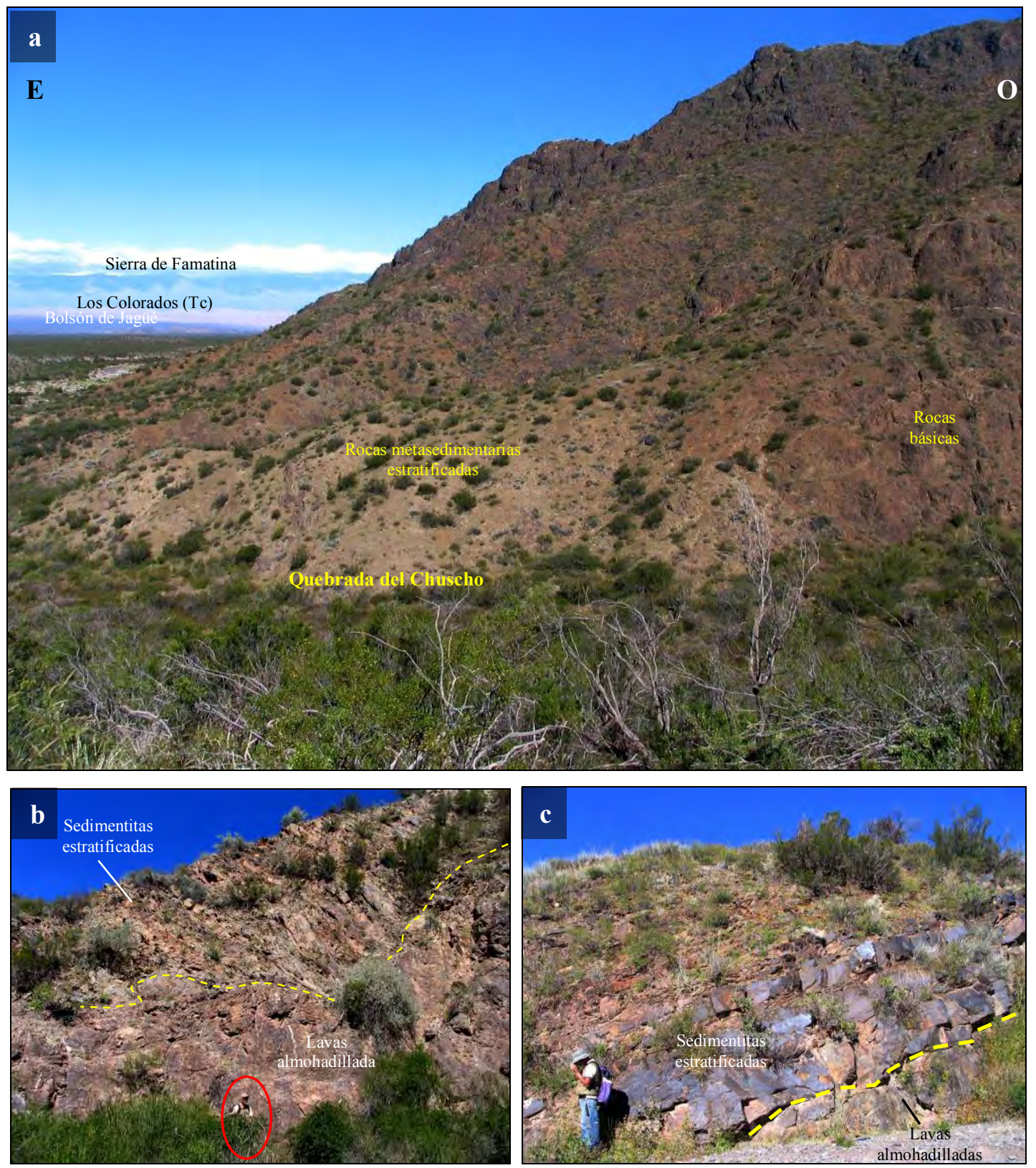

Figura 3.4.1: Afloramientos de la Formación Del Salto en la desembocadura de la quebrada del Chuscho. a)- vista panorámica hacia el sureste (Boca del Bonete) del pié del cerro Chuscho en el que se pueden observar las rocas básicas oscuras y ocres por alteracion superficial. b y c)- contacto neto entre las metasedimentitas estratificadas (arriba) y las lavas almohadilladas (abajo) en el márgen sur de la quebrada del Chuscho.

diques (ver antes: “diques verdes"), así como coladas y capas de lavas almohadilladas intercaladas con autobrechas volcánicas. Los diques no cortan al granito pero si a las sedimentitas fosilíferas y a la asociación de mármoles y esquistos verdes de la Formación Río Bonete. Los filones de diabasa son concordantes a pseudoconcordantes con la foliación de los esquistos verdes y verde-azulados de la Formación Río Bonete aprovechando estos planos de debilidad para alojarse. Diques y filones de diabasa están cortados por fallas y deformados por cataclasis. Las autobrechas volcánicas están intercaladas con las lavas almohadilladas y sedimentitas en el área del Chuscho y Boca del río Bonete principalmente. Estas rocas afloran especialmente en el área del Chuscho (donde se encontraría el centro eruptivo) y 
tramo inferior del río Bonete. Las texturas pueden ser porfíricas, afaníticas o seriadas e incluyen principalmente basaltos porfíricos (feno-andesitas), con facies de basaltos afaníticos y diabasas.

\section{a- Afloramientos}

Las lavas almohadilladas afloran en los alrededores de la Boca del Bonete y quebrada del Chuscho (ej: muestras $\mathrm{CH} 3, \mathrm{CH} 15)$ y un afloramiento muy alterado superficialmente y afectado por metamorfismo en el tramo medio del río Bonete (muestra BO27). Este afloramiento parece corresponder a una escama de rocas básicas que quedó incluido dentro de la faja de deformación. En el tramo inferior de la quebrada del Chuscho afloran mantos de lavas almohadilladas intercalados con secuencias de sedimentitas estratificadas ordovícicas (Figura 3.4.1). Aunque los afloramientos se encuentran deformados, en este sector el contacto no parece ser tectónico ya que no se observa arrastre de las capas ni claras estructuras de falla. Además, la sucesión de sedimentitas cubiertas por lavas almohadilladas y luego presencia de autobrechas volcánicas observadas hacia la desembocadura de la quebrada del Chuscho es compatible con un origen primario para dicha secuencia. En el área del Chuscho y Boca del río Bonete las autobrechas volcánicas están asociadas con lavas almohadilladas e intercaladas con sedimentitas estratificadas (Anexos 1: perfil P3). Zolezzi y Guerrero (1981) consideran que el autobrechamiento se debe a una primera etapa de cristalización violenta del magma pobre en volátiles, sedimentitas ordovícicas y esquistos y calizas de la Formación Río Bonete (ver antes: “diques verdes”); o c): como lavas masivas, afaníticas o porfíricas.

A lo largo de la quebrada del Bonete es posible observar cómo las volcanitas cubren en discordancia angular a las metamorfitas de la Formación Río Bonete (esquistos verdes y calcáreos, capítulo 3.2.2).

\section{b- Petrografía}

Las lavas almohadilladas presentan texturas variables: afaníticas y porfíricas en las composiciones basálticas y andesíticas, y seriadas en las diabasas. En los afloramientos es común encontrar estrellas blancas generalmente de cuatro puntas constituidas principalmente por cuarzo lechoso (Figura 3.4.5a) que se originan por relleno del espacio que dejan las almohadillas, corroborando un origen tardío para esos segregados. Las auto-brechas se observan como clastos volcánicos angulosos e irregulares inmersos en una matriz volcánica de igual composición; son afaníticas o mayormente porfíricos.

Los diques y filones de diabasa son de coloraciones verdosas a grises y presentan texturas microgranudas o seriadas. Están cortados por fallas y deformados por cataclasis y en algunos sectores llega a observarse cierta orientación de la fábrica (e.g. muestra BO24). Los cuerpos masivos corresponden a basaltos y feno-andesitas, comúnmente con fenocristales de plagioclasa y anfíbol y de tonos oscuros, que forman masas gruesas y tabulares (coladas?) mejor representadas especialmnente al pié del cerro 


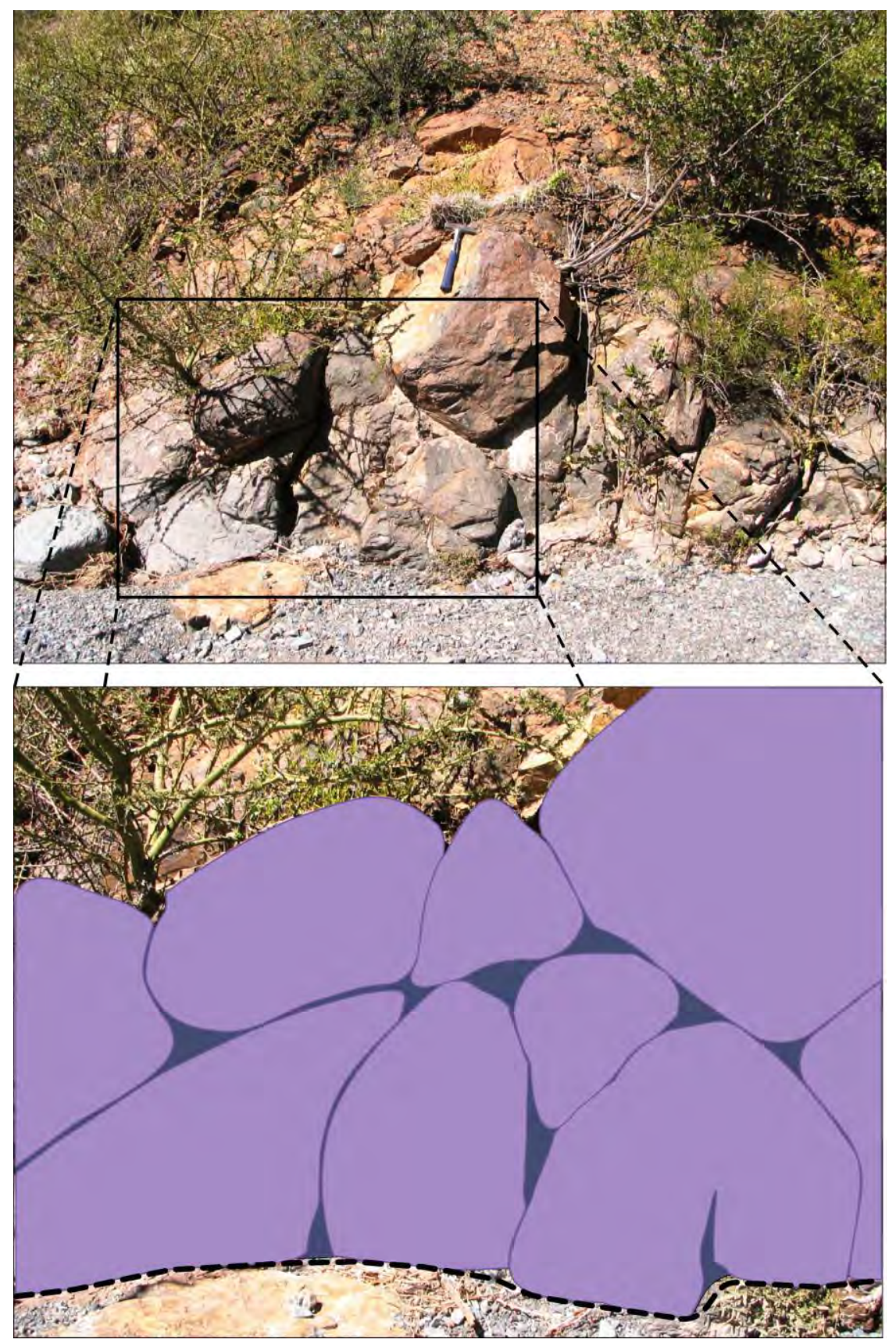

Figura 3.4.2: Afloramientos de las lavas almohadilladas en la quebrada del Chuscho e interpretación ampliada de la parte inferior.
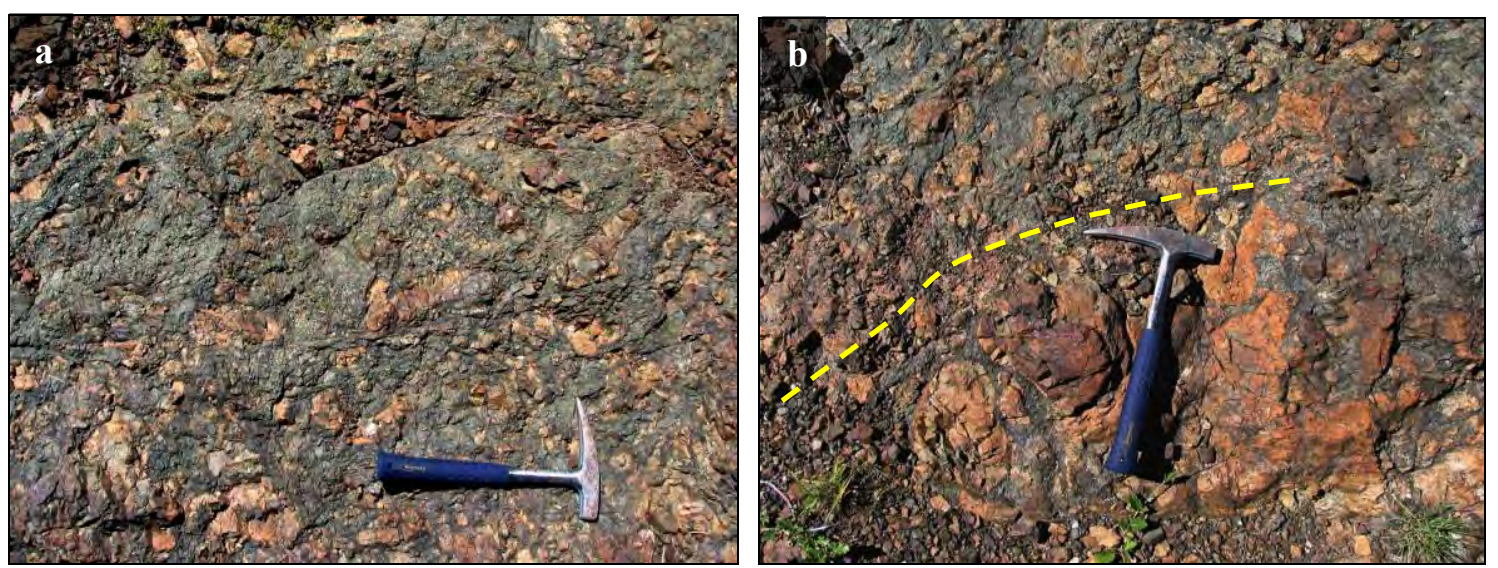

Figura 3.4. 3: a)- Aspecto de las autobrechas volcánicas intercaladas entre las lavas almohadilladas en la quebrada del Chuscho; b)- transición entre las lavas almohadilladas (abajo) y las autobrechas volcánicas (arriba). 
Chuscho y hacia la Boca del Bonete. En algunas muestras se ha observado olivina reemplazada pseudomórficamente por minerales secundarios (serpentina y clorita principalmente).

Las lavas de la Formación Chuscho se encuentran parcialmente espilitizadas. El proceso de espilitización ocurre como consecuencia de la interacción del agua de mar con las rocas volcánicas (basaltos) durante las erupciones submarinas. Es un proceso pneumatolítico-hidrotermal que implica un conjunto de importantes cambios químicos-mineralógicos, tales como la serpentinización y cloritización de olivinos y piroxenos, albitización de plagioclasas, anfibolitización, ceolitización, generación de carbonatos, etc. (ej.: López-Ruiz, 1970).

Sobre la base de lo observado en la petrografía, el conjunto de las rocas básicas se ha podido agrupar de la siguiente manera (Cuadro 3.4.1):

Cuadro 3.4.1: Grupos de rocas básicas definidos en base a sus caracteristicas petrográficas.

\begin{tabular}{|c|c|c|c|}
\hline & & & etrográficas generales \\
\hline & 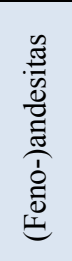 & & $\begin{array}{l}\text { - Texturas Porfíricas } \\
\text { - con fenocristales de Pl. La Pl es muy abundante. } \\
\text { - Alteración hidrotermal sericítica importante y homogénea en las Pl; mafitos cloritizados. } \\
\text { Compuestas por fenocristales de } \mathbf{P I}+\mathbf{A n f} / \mathbf{P x}+\mathbf{B t} \text { 'sandwich' (con exoluciones de titanita entre las hojas de Bt } \\
\text { y a veces alteración a Chl). Aparece } \mathbf{Q t z} .\end{array}$ \\
\hline & & & $\begin{array}{l}\text { - Texturas Porfiricas y Glomeruloporfiricas } \\
\text { - con fenocristales de: Augita(Cpx), Pl y mafito alterado a Srp (ex-Ol) o Chl (aparentemente ex-Opx). } \\
\text { La asociación principal consta de porfirocristales de Ti-Aug + } \mathbf{O l}+\mathbf{P l} \text {, en una base fina de } \mathbf{P I}+\mathbf{A n f} / \mathbf{P x} \text { castaño } \\
\text { (Ti-Aug?) + } \mathbf{O p} \pm \mathbf{T} \mathbf{t n} \text {. }\end{array}$ \\
\hline & & & $\begin{array}{l}\text { - Texturas porfiricas de grano más grueso. } \\
\text { - Entramado de Pl y Augita (Cpx) con algo de Chl intersticial } \\
\text { - Alteracion sericítica en Pl } \\
\text { - Op abundantes (Ilm, ¿y mgt?) }\end{array}$ \\
\hline$\nabla$ & 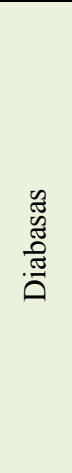 & & $\begin{array}{l}\text { - Metabasitas. } \\
\text { - Texturas relícticas seriadas, de grano mediano) } \\
\text { - Uralitización del Cpx (Augita) a anfiboles fibrosos del grupo de la Tremolita-Actinolita, (y a veces a Chl). } \\
\text { Transformacion de la Pl en Saussurita (mezcla de Zo y otros minerales del grupo del Ep, Ab, Chl, Actinol, Ory } \\
\text { otros minerales). } \\
\text { Asociacion relictica o inferida: Ti-Aug + Ol + Pl + Op } \pm \text { vidrio } \pm \text { Ttn } \\
\text { La asocicion primaria ha sido modificada en grado variable por minerales secundarios. La Ol es reemplazada por } \\
\text { Srp, Chl y Tlc, el Cpx (Ti-Aug) por Act-Trem, las Pl alteradas a Src, Cal y saussurita, y el vidrio } \\
\text { principalmente por Chl. }\end{array}$ \\
\hline in & 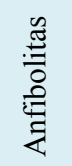 & & $\begin{array}{l}\text { - Metabasita (Anfibolita) } \\
\text { - El mineral predominante es Anf pleocroico de color verde azulado-amarillento, de grano medio a grueso, } \\
\text { transformándose en Trem-Act y Chl. Aparece también Pl sercitizada. }\end{array}$ \\
\hline & 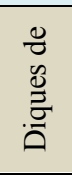 & 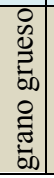 & $\begin{array}{l}\text { - Textura Granuda } \\
\text { - Pl alterada a Src+ Fe-Hbl marrón-rojiza con coronas de Bt y alteracion a Chl verde. Aparentemente esta Hbl } \\
\text { es formada parcialmente a partir de Augita, de la cual se ven algunos relictos). }\end{array}$ \\
\hline
\end{tabular}



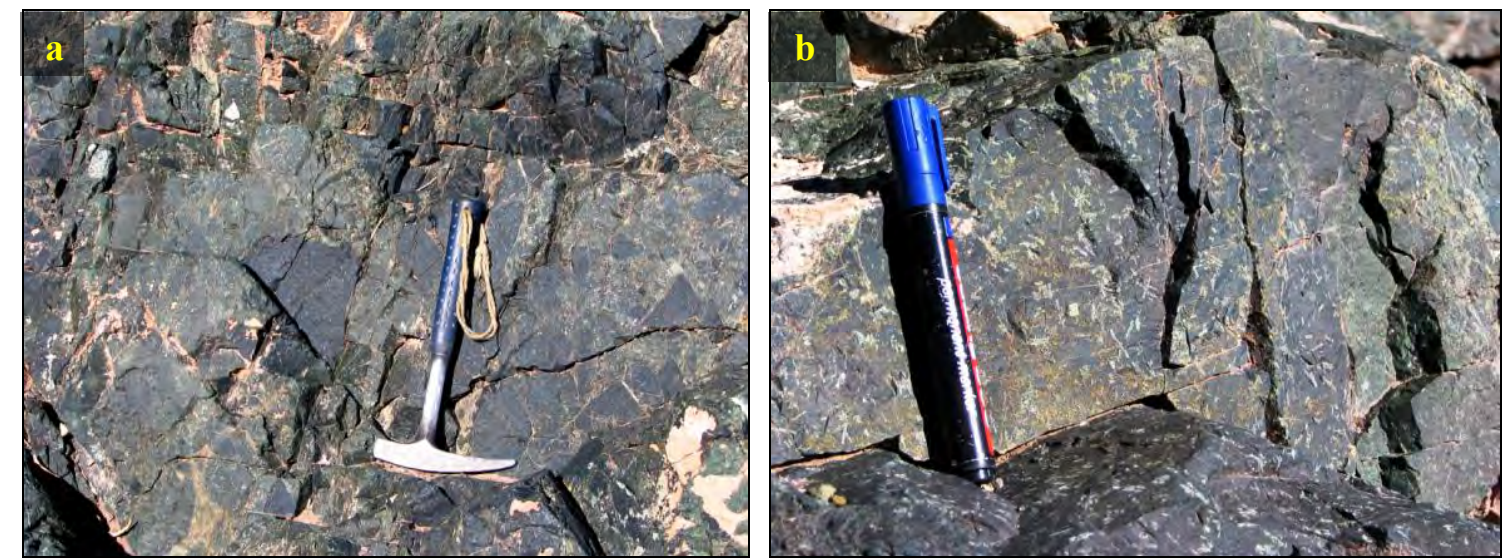

Figura 3.4.4: a)- detalle de textura brechosa en volcanitas basicas de la Fm Chuscho en la quebrada del Bonete; b)- detalle de la textura porfírica observada en ciertos afloramientos de las rocas básicas (feno-andesitas). Los fenocristales en este caso son tablillas delgadas de plagioclasa.

\section{Deformacion y metamorfismo:}

Los afloramientos están afectados por deformación principalmente frágil asociada con fallas que cortan tanto a las rocas básicas como a las sedimentitas ordovícicas (ej. diques y mantos de lavas almohadilladas desplazados). En varias muestras se han observado microvenillas rellenas por calcita. Allí donde la deformación frágil-dúctil (milonitización y cataclasis) y el metamorfismo afectan a estas litologías con mayor intensidad en la faja de deformación que pasa por la quebrada del Bonete, llegan a quedar intercaladas como escamas o integrados a las metamorfitas de la faja de cizalla como bloques de metabasitas y esquistos verdes miloníticos con variable intensidad de deformación, entre las demás litologías de la faja de cizalla (secciones 3.2.2. y 3.2.7).
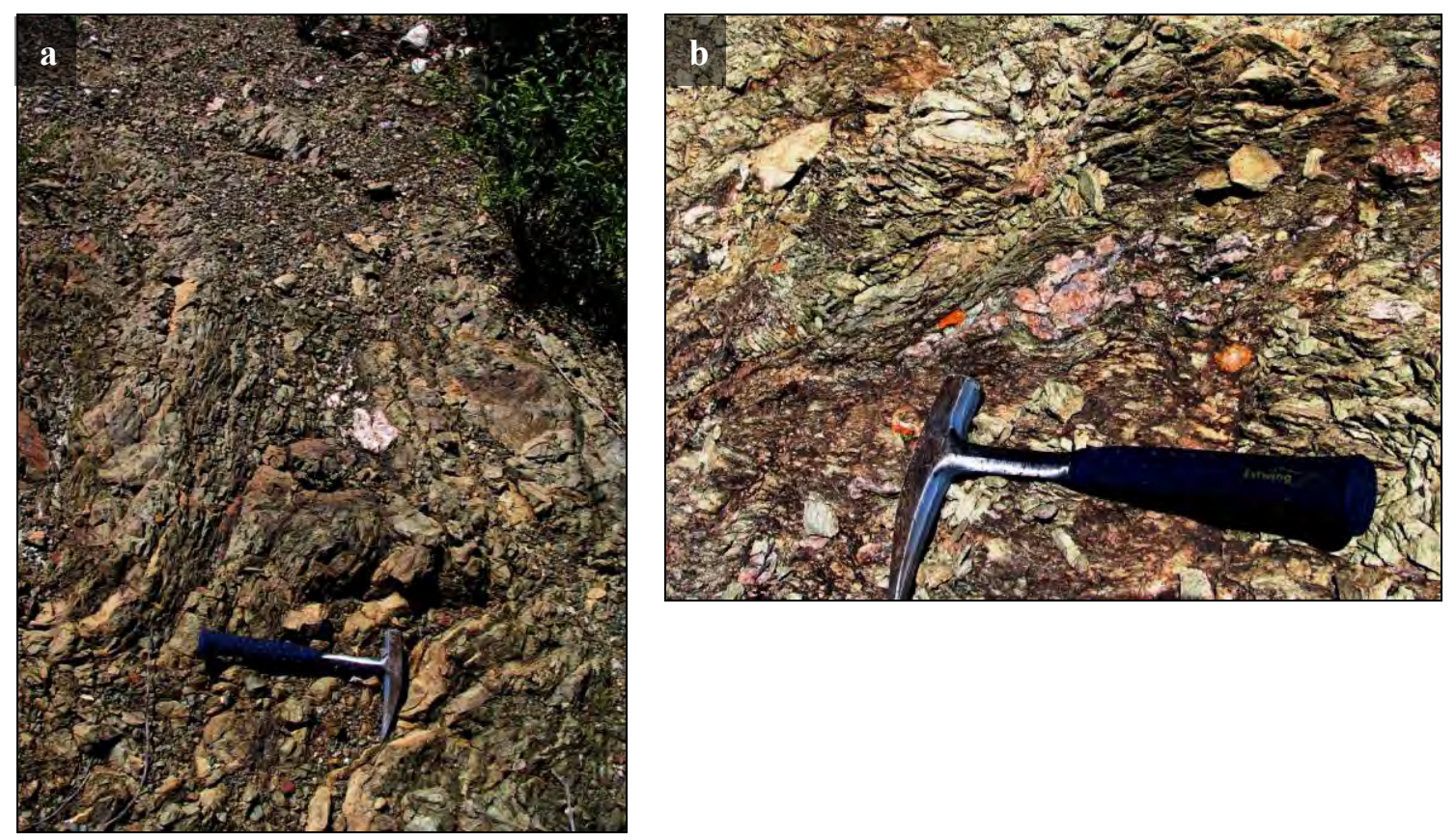

Figura 3.4.5: Deformación en las rocas básicas de la Formación Chuscho en la quebrada homónima y alrededores de la Cueva del Miquilo, y presencia de cuarzo lechoso aprovechando espacios entre almohadillas deformadas (estrellas de cuarzo) y 
fracturas. En zonas de fuerte deformación se generó una foliación marcada y plegamientos. El cuarzo también está deformado (foto b) indicando un evento de deformación posterior.

Las lavas son afectadas por metamorfismo de grado variable constituyendo metabasitas. El metamorfismo se asocia al grado de deformación en gran medida. La mayor parte de las rocas básicas son metabasitas en facies de esquistos verdes (zona de clorita). En los sectores más afectadas por la deformación el metamorfismo progrado va desde facies esquistos verdes hasta facies de anfibolitas epidóticas, con aparición de actinolita, epidoto y clorita, así como la neo-generación de anfíboles (e.g.: BO-D0, BO27). En los sectores menos deformados se observa un metamorfismo de muy bajo grado en facies prehnita - pumpelleyta (ej.: muestras $\mathrm{CH} 1, \mathrm{CH} 2$ ). Localmente pueden aparecer hialoclastitas formadas por metamorfismo dinámico en zonas de falla, pero son en general de poco espesor y pueden pasarse fácilmente por alto en los afloramientos. Las transformaciones principales observadas son la uralitización de los piroxenos y anfíboles, la alteración de las plagioclasas a sericita o saussurita y transformaciones pseudomórficas originadas por la hidratación. Debido a este último proceso se han observado coronas de minerales hidratados, especialmente de anfíboles en clinopiroxenos o menos frecuentemente biotita sobre anfíbol. Los anfíboles a su vez suelen estar parcialmente alterados a clorita. Cuando hay biotita se altera a clorita, titanita y opacos. Los minerales secundarios más comunes son epidoto, clinozoicita/zoicita y clorita.

La uralitización de la $\mathrm{Hbl}$ tipicamente se desarrolla a temperaturas metamórficas en facies de esquistos verdes. Por otro lado, los procesos de cloritización de biotita u hornblenda, sericitización y saussuritización de plagioclasas cálcicas y caolinización del feldespato potásico principalmente, son alteraciones típicamente deutéricas o hidrotermales (facies de esquistos verdes o sub-esquistos verdes. En las metabasitas típicas la alteración hidrotermal y metamorfismo ocurren a bajas temperaturas $\left(\leq 400^{\circ} \mathrm{C}\right)$, correspondiendo a facies de zeolitas (laumont.) y prehnita-pumpelleyta. En esta última son comunes la titanita y la actinolita. La asociación de calcita, epidoto, cuarzo y clorita es muy abundante en la facies de esquistos verdes (a partir de los $400^{\circ} \mathrm{C}$ ) y es lo que predomina entre las rocas encontradas en la región (esquistos verdes de protolito básico). Las muestras BO-D10, CH16, CH14 por ejemplo corresponden a rocas básicas anfibolitizadas, alteradas (en orden creciente de alteración) y afectadas por la deformación. Otras muestras llegan a generar una foliación fuerte quedando incorporadas entre los esquistos verdes de la faja de cizalla (e.g.: muestras $\mathrm{CH} 12$ y $\mathrm{CH} 13$, Anexos A4-2).

La muestra BO27 corresponde a una roca anfibolitizada (almohadilla completa). En la muestra de mano se observa la textura seriada, y fenocristales de anfíbol, biotita y plagioclasa, con poca pasta afanítica. Hacia los bordes de la almohadilla aparece una zona que toma colores castaños por oxidación superficial y los anfíboles y micas adquieren mayores dimensiones (hasta 1-2 cm), en respuesta al metamorfismo. Hacia el interior se encuentra fresca, de colores verdosos, y es de granulometría más fina. 


\section{c- Geoquímica.}

Se analizan a continuación los resultados de geoquímica obtenidos para siete muestras de rocas básicas recolectadas en la zona de estudio y que se han seleccionado como representativas de distintas facies de la Formación Chuscho. Los resultados de los análisis se presentan en la los Anexos A6a: Tabla 4. Las muestras $\mathrm{CH} 1, \mathrm{CH} 2, \mathrm{CH} 3$ y MQ-I2 corresponden a los afloramientos principales de la Formación Chuscho sobre la quebrada homónima y adyacencias de la Cueva del Miquilo. CH3 forma parte de un cuerpo de lavas almohadilladas mientras que MQ-I2 proviene de un cuerpo masivo, probablemente una colada. Las muestras BO13, BO-I y BO27 fueron recolectadas sobre la quebrada del Bonete y pueden mostrar mayores variaciones en los resultados debido a procesos secundarios de alteración (BO13) y metamorfismo (BO27). La muestra $\mathrm{BO} 27$ corresponde a una lava almohadillada anfibolitizada en la faja de cizalla, y la muestra BO13 es un dique de diabasa (/basalto olivínico) de tonalidades verdosas que presenta cierto grado de alteración.

También se anexan los resultados parciales obtenidos por fluorescencia de rayos X (FRX) de muestras de varios "diques verdes" (diabasas; BO24; LSI-1, LSI-2, LS1, LS1-4, LS1-8) y "diques negros" (basaltos afaníticos; BO14, BO26, MQ-I). Al tratarse de resultados parciales y debido a que el cierre de las concentraciones obtenido difiere bastante del $100 \%$ se trabajará principalmente con los análisis completos, en especial con respecto a los elementos mayoritarios.

\section{Elementos mayoritarios.}

Los valores de CIA obtenidos en las muestras seleccionadas varían entre 35,06 y 42,45, con un valor promedio de 43,37, dentro del rango normal para los basaltos frescos (CIA = 30 - 45; Nesbitt y Young, 1982). En el diagrama A-CN-K vs. CIA (Fedo et al., 1995) se observa que las muestras BO13 y BO27 se desvían de este rango (CIA: 62,83 y 48,58) observándose un grado variable de movilización de los elementos mayoritarios (Figura 3.4.1a). La muestra BO13 es la más alterada, con un valor de CIA muy elevado y coincide con un alto LOI (9.8). Ambas muestras (BO13 y BO27) son las más enriquecidas en $\mathrm{K}_{2} \mathrm{O}(>0.60 \%)$. En relación al resto de las muestras, la $\mathrm{BO} 27$ se encuentra enriquecida en $\mathrm{SiO}_{2}$ y en $\mathrm{MgO}$, y presenta bajos valores de $\mathrm{Al}_{2} \mathrm{O}_{3}$ y $\mathrm{CaO}$ (Anexos A6a: Tabla 4). Al contrario, la muestra $\mathrm{BO} 13$ presenta el menor valor de $\mathrm{SiO}_{2}$ y $\mathrm{MgO}$. No se observa una clara relación entre el porcentaje de $\mathrm{SiO}_{2}$ y los demás óxidos mayoritarios, exceptuando el $\mathrm{TiO}_{2}$ y quizás el $\mathrm{MgO}$ y el CaO.

En el diagrama TAS todas las muestras se clasifican geoquímicamente como basaltos y picrobasaltos (Figura 3.4.1b; Tabla 3.4.1). La alteración sericítica de las muestras puede relacionarse con el enriquecimiento en potasio observado en aquellas más alteradas, desviando su clasificación hacia los términos de Tefrita $(\mathrm{Ol}<10 \%)$ y Basanita $(\mathrm{Ol}>10 \%)$. La signatura geoquímica de las muestras es mixta, ya que se ubican tanto en el campo de la serie subalcalina (tholeiitica) como alcalina (Figura 3.4.1b; Tabla 3.4.1). La tendencia alcalina de las muestras, especialmente de los diques, coincide con los datos de la petrografía, indicada especialmente por la presencia de augita titanífera y olivina. La composición 
química normativa de las rocas volcánicas se puede consultar en los Anexos (A6a: Tabla 7). Se diferencian las muestras MQ-I2, BO13 y BO27, en las que aparece cuarzo e hiperstena normativos (“Tholeiítas"), de las muestras BO-I, $\mathrm{CH} 2$ y CH3, con olivino e hiperstena normativos ("Tholeiítas Olivínicas"). Sin embargo estas tendencias parecen estar afectadas por procesos secundarios y en su mayoría se trataría de tholeiítas olivínicas. Los basaltos se agrupan en dos tipos principales: alcalinos y tholeiíticos; estos últimos se dividen a su vez en tholeiítas olivínicas, tholeítas y tholeiítas cuarzosas. Los basaltos alcalinos tienen en sus pastas piroxeno de tipo titano-augita (Ti-aug) y típicamente presentan fenocristales de olivina (Ol), Ti-aug, plagioclasa (Pl), y óxidos de hierro (Fe-ox.). Suelen tener nefelina (Ne) moderada en su pasta y Ne normativa (CIPW). Para un mismo contenido de $\mathrm{SiO}_{2}$ los basaltos alcalinos tienen más $\mathrm{K}_{2} \mathrm{O}$ y $\mathrm{Na}_{2} \mathrm{O}$ que los tholeíticos. Los basaltos alcalinos se encuentran en las islas oceánicas y en la corteza continental en regiones afectadas por procesos de rifting y levantamiento. Algunas muestras en las que se observa claramente esta tendencia por la petrografía son la MQ.I2 (con O1 y Ti-Aug)y el dique E-BO23 (con Ti-Aug en rosetas, Nef y O1?). Los basaltos tholeííticos petrográficamente tienen en sus pastas pigeonita (un piroxeno pobre en $\mathrm{Ca}$ ). Las tholeítas se encuentran en los fondos oceánicos y sobre la corteza continental estable, donde suelen formar grandes mesetas.
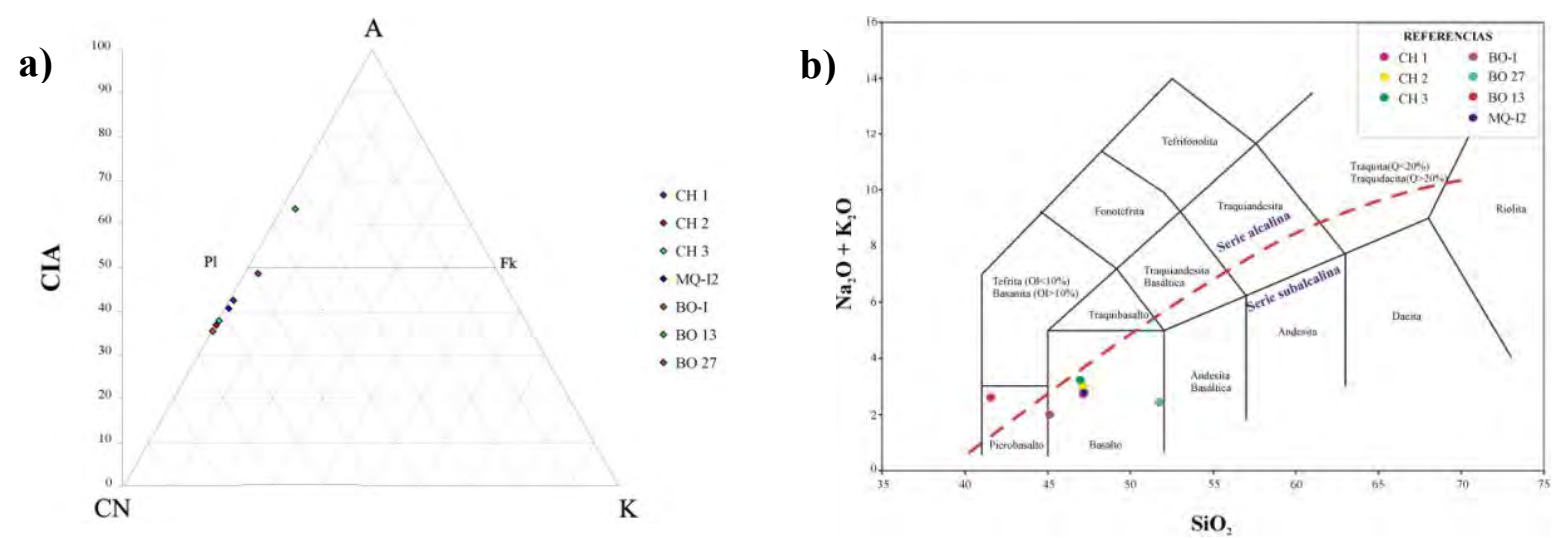

Figura 3.4.1: a)- ubicación de las rocas básicas en el diagrama A-CN-K vs. CIA (Fedo et al., 1995), que permite observar el grado de alteración de las muestras. b)- diagrama de clasificación TAS (Total Alcali Silica, Le Maitre, 1984) para las rocas ígneas volcánicas. La línea cortada divide el campo alcalino del subalcalino conforme a Irvine y Baragar (1971).

Tabla 3.4.1: Clasificación geoquímica de las rocas básicas de la Formación Chuscho y diques.

\begin{tabular}{|l|l|l|l|}
\hline \multirow{2}{*}{ Area de muestreo } & \multirow{2}{*}{ Muestra } & \multicolumn{2}{|c|}{ Diagrama (TAS) } \\
\cline { 3 - 4 } \multicolumn{2}{|l|}{} & Clasificación geoquímica & Serie magmática \\
\hline \multirow{2}{*}{ Qm Chuscho del Chuscho } & CH1 & Basalto & Subalcalina \\
\cline { 2 - 4 } & CH2 & Basalto & Subalcalina \\
\cline { 2 - 4 } & CH3 & Basalto & Subalcalina \\
\hline Cueva del Miquilo & MQ-12 & Basalto & Subalcalina \\
\hline Boca del Bonete & BO-I & Basalto (-picrobas) & Subalcalina \\
\hline \multirow{2}{*}{ Qda. del Bonete } & BO13 & Picrobasalto & Subalcalina \\
\cline { 2 - 4 } & BO27 & Basalto & \\
\hline
\end{tabular}


Elementos minoritarios y traza.

En el diagrama $\mathrm{Th} / \mathrm{Sc}$ versus $\mathrm{Zr} / \mathrm{Sc}$ (McLennan et al., 1993; Figura 3.4.2a) se observa que las rocas básicas siguen una orientación composicional subparalela a la teórica, reflejando un mayor contenido relativo de $\mathrm{Zr}$ que las rocas básicas promedio.

En los diagramas de tierras raras (REE) normalizados al condrito C1 (Taylor y McLennan, 1985) y manto primitivo (MP, Mc Donough et al., 1991; Figura 3.4.2b) se observa un leve y constante enriquecimiento hacia las LREE. No se observa anomalía negativa ni positiva de Eu, indicando que no hubo fraccionamiento de los feldespatos. La anomalía positiva de Ce presente en todas las muestras al normalizar al condrito $\mathrm{C} 1$ suele vincularse a oxidación $\left(\mathrm{Ce}^{+3} \rightarrow \mathrm{Ce}^{+4}\right)$ o al método analítico; en este caso probablemente se vincule a esto último ya que no se observa al normalizar al MP. Las tierras raras se consideran entre los elementos más inmóviles durante el metamorfismo de bajo grado, meteorización y alteración hidrotermal, sin embargo, las muestras $\mathrm{BO} 27$ y $\mathrm{BO} 13$ se encuentran más fuertemente enriquecidas en LREE (La-Eu) respecto a las demás muestras; BO27 registra además un empobrecimiento relativo de las tierras raras intermedias (MREE).

El uso de los diagramas multielementales es particularmente útil para basaltos (Rollinson, 1993) y permiten medir las desviaciones respecto a una composición primitiva. Se normalizaron los datos para comparar con el condrito C1 (Sun y McDonough, 1989) y con los MORB promedio (N-MORB, Pearce, 1983. Figura 3.4.2c). Los últimos son más apropiados para basaltos evolucionados, andesitas y rocas crustales. En general se observa una mayor movilización de los elementos incompatibles (LIL) mientras que los más compatibles (HFS) no han sido mayormente afectados. Las concentraciones de los elementos LIL ( $\mathrm{Cs}, \mathrm{Rb}, \mathrm{K}, \mathrm{Ba}, \mathrm{Sr}, \mathrm{Eu})$ puede ser función del comportamiento de la fase fluida mientras que la concentración de los HFS (Y, Hf, Zr, Ti, Nb, Ta) es controlada por la química de la fuente y los procesos cristal/ fundido que han tenido lugar durante la evolución de la roca (Rollinson, 1993, p.148). Entre los elementos menos móviles pueden existir controles mineralógicos. En este sentido, el $\mathrm{Zr}$ es controlado por el circón, el P por la apatita, el Sr por la plagioclasa, el Ti, el $\mathrm{Nb}$ y el Ta por la ilmenita, rutilo o esfena. La alta concentración de Ti observada en las muestras es coherente con la presencia de abundante ilmenita, Ti-Aug y titanita en las muestras (ver petrografía; Anexos A4-2: Cuadro V). Las menores variaciones elementales se observan en el diagrama normalizado al condrito C1 (Figura 3.4.2c). En este diagrama se destacan picos negativos de $\mathrm{K}, \mathrm{P}$ y $\mathrm{Pb}$, comúnmente generados en las rocas corticales. Además, el Ba se encuentra enriquecido en la mayoría de las muestras, con excepción de la BO-I. Esta muestra presenta también los menores valores de Sr y K, y por otro lado se encuentra mejor preservada la petrografía (podría corresponder a alguno de los magmatismos más modernos?). Las muestras más alteradas (BO27 y BO13) presentan anomalías de Th, U, Ce, La, y Nd. Los picos negativos de $\mathrm{K}, \mathrm{P}$ y $\mathrm{Pb}$ son rasgos comúnmente encontrados en rocas corticales. La contaminación de los magmas puede ser rastreada por la presencia de una anomalía negativa de $\mathrm{Nb}$ y por una mayor concentración de los elementos LIL (Rollinson, 1993, p.148). Sin embargo no se observa ninguno de estos rasgos y la 
variación heterogénea de los elementos LIL observada en las muestras hace pensar más en procesos de alteración.

\section{d- Geocronología.}

\section{Isótopos de $\mathbf{U}$ y $\mathbf{P b}$.}

Edad de la Formación Chuscho.

Fauqué y Villar (2003) son quienes redefinen a esta unidad anteriormente considerada carbonífera (Aceñolaza et al. 1971; González y Bossi, 1986; Toselli y Durand, 1996) y la reubican estratigráficamente dentro del Ordovícico en base a la datación U-Pb de un circón primario en 454Ma, reflejando una edad de cristalización ordovícica para las lavas almohadilladas que afloran en el cerro Chuscho. Esto está en concordancia con las observaciones hechas por Kay et al. (1984) en lavas espilitizadas del área de la boca del Bonete. Por otro lado estos autores indican la presencia de xenocristales mesoproterozoicos de $1036 \mathrm{Ma}$, que provendrían del basamento (Formación Espinal).

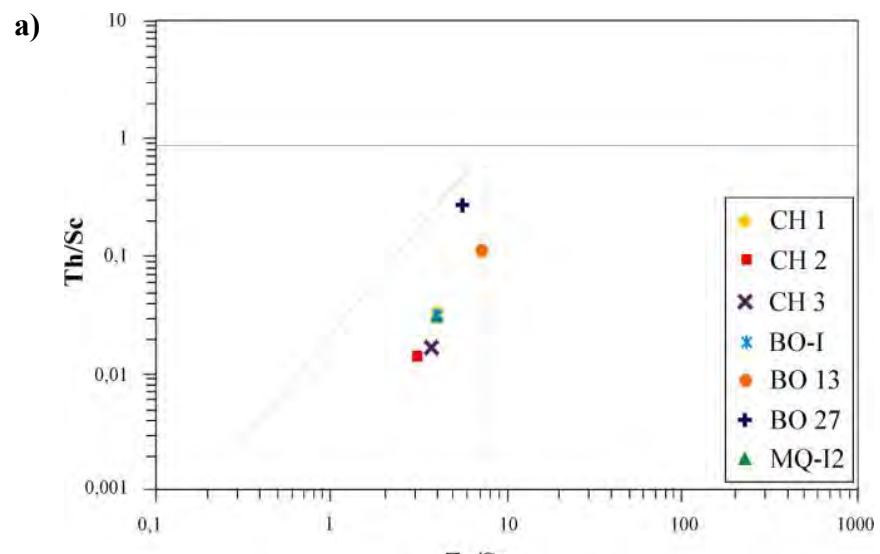

b)
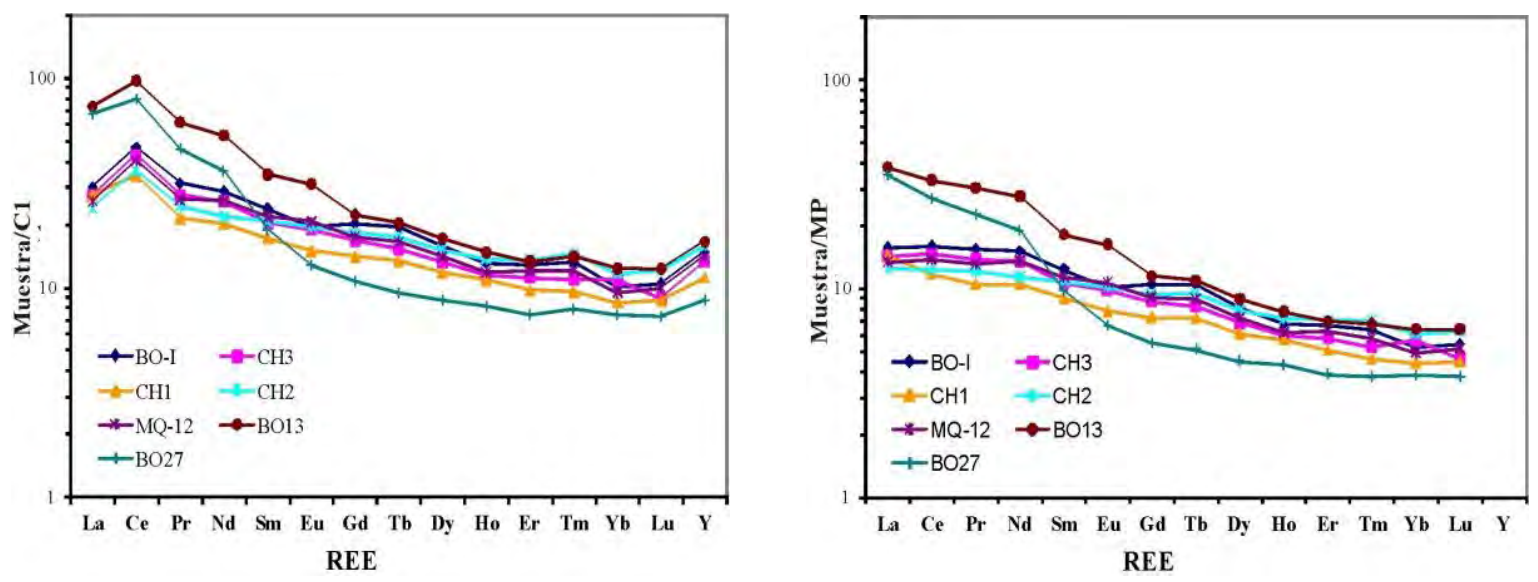

c) 

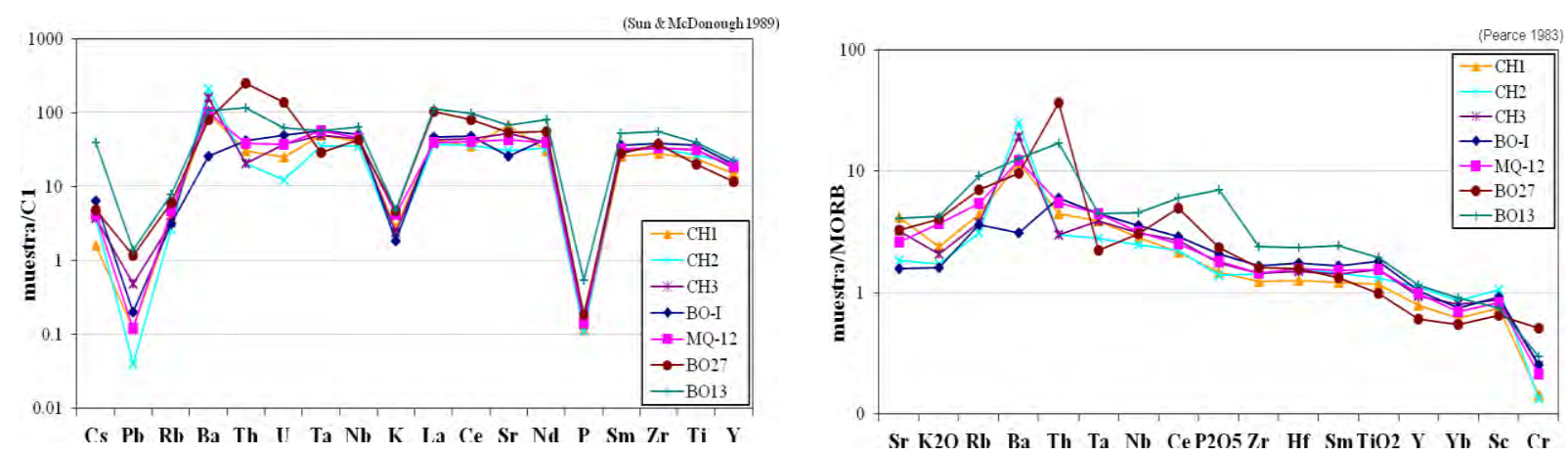

Figura 3.4.2: a)- Diagrama $\mathrm{Th} / \mathrm{Sc}$ versus $\mathrm{Zr} / \mathrm{Sc}$ (McLennan et al., 1993) en el que se observa la variación composicional de las rocas básicas. b)- Diagramas de tierras raras normalizado al condrito C1 (Taylor y McLennan, 1985) y manto primitivo (PM, Mc Donough et al., 1991) de las muestras representativas de las rocas básicas de la Formación Chuscho. c)- Diagramas multielementales de las rocas básicas normalizados al condrito C1 (Sun and McDonough, 1989) y a MORB (Pearce, 1983; Sc y Cr de Pearce, 1982).

Aunque no ha sido posible obtener una edad que represente a esta unidad, las observaciones de campo realizadas durante el mapeo confirman este esquema para al menos los afloramientos de la zona del cerro Chuscho, ya que se ha encontrado a las lavas almohadilladas y autobrechas volcánicas intercaladas entre las sedimentitas de la Formación del Salto y a los diques de diabasa en estrecha asociación con ellas, acotando su edad en las cercanías del límite Ordovícico-Silúrico (máxima edad de sedimentación de las sedimentitas: $443 \pm 13$ Ma en el área del Chuscho y $440.3 \pm 6.8$ Ma en la quebrada de Potrerillos; sección 3.2.3.1).

Por otro lado, las evidencias indican que el magmatismo es previo a la intrusión del Granito y al menos posterior al primer evento que generó foliación en la Formación Río Bonete. Como la deformación es claramente polifásica o policíclica probablemente fueron deformados junto con alguna de estas fases posteriores.

\section{Edad de la muestra BO27}

Se procesó la muestra BO27 (Anexos A1: M2) para la concentración de circones con bromoformo y luego los minerales pesados fueron identificados bajo lupa binocular y EDAX (CINDECA, La Plata) y separados manualmente. Es conocido que las rocas básicas en general suelen presentar escasa concentración de circones. El mineral más abundante es la apatita, que puede tener distintas coloraciones, desde incoloras y transparentes (dominantes) hasta negras y opacas, algunas con tonalidades más grises azuladaS o verdosas. Los circones encontrados se presentan como cristales transparentes y prismáticos, euhedrales a subhedrales, algunos con coloraciones más amarillentas pero en su mayor parte incoloros; los cristales más cortos probablemente hayan completado su desarrollado durante el metamorfismo (Figura 3.4.3). Junto con la población de minerales pesados se identificaron escasos cristales rojizos, traslúcidos u opacos, que probablemente correspondan a titanita. El mineral máfico que se observa más abundante se ha confirmado como hornblenda. 
Cristales alargados a aciculares, euedrales y fracturados(relac. ancho:largo $=1: 3,5$ a 1:4 aprox.)

1 prisma bien desarrollado (100) 2 bipirámides $(221,301)$

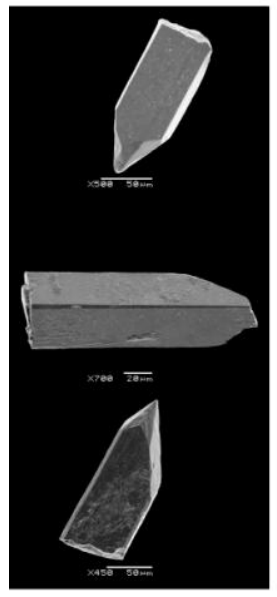

2 prismas desarrollados $(100,110)$ 3 bipirámides $(211,301,101)$

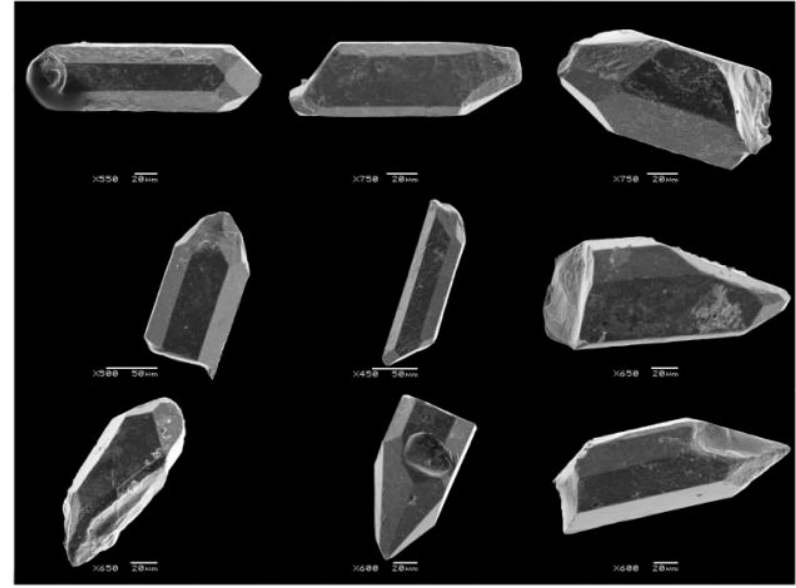

Cristales cortos euedrales y fracturados (relac. largo:ancho $=1: 2$ aprox.)

2 prismas desarrollados $(100,110)$ 3 bipirámides $(211,301,101)$

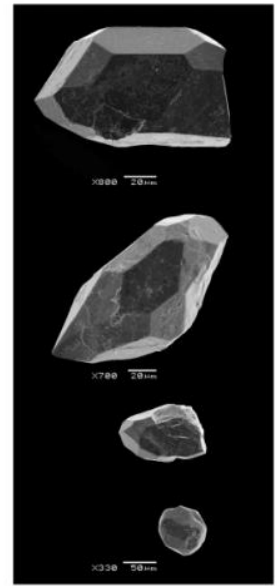

Figura 3.4.3: Microfotografías tomadas con microscopio electrónico de barrido (Museo de La Plata) en las que se observa la morfología y características texturales de una población de cristales de circón separados de la muestra BO27.

Se obtuvo una edad ${ }^{207} \mathrm{~Pb} /{ }^{206} \mathrm{~Pb}$ en circones de $385 \pm 1,5 \mathrm{Ma}(\mathrm{n}=23$; MSWD $=0,40$; con un nivel de confianza de 95\%; Figura 3.4.4), correspondiente a una lava almohadillada anfibolitizada que aflora en el tramo medio del río Bonete ( $28^{\circ} 29^{\prime}$ 19,7” latitud $\mathrm{S}-68^{\circ} 31^{\prime} 28,1^{\prime}$ ' longitud O). La muestra fue analizada por LA-MC-ICP-MS en el Laboratorio de Geología Isotópica de la Universidade Federal do Rio Grande do Sul (Porto Alegre, Brasil). Es probable que la edad que se obtuvo esté reflejando un pico de deformación en la faja de cizalla y no la cristalización de las lavas en virtud de que se encuentra ubicada dentro de la faja de deformación de Jagüé y ha sido afectada por metamorfismo llegando a facies de anfibolitas.

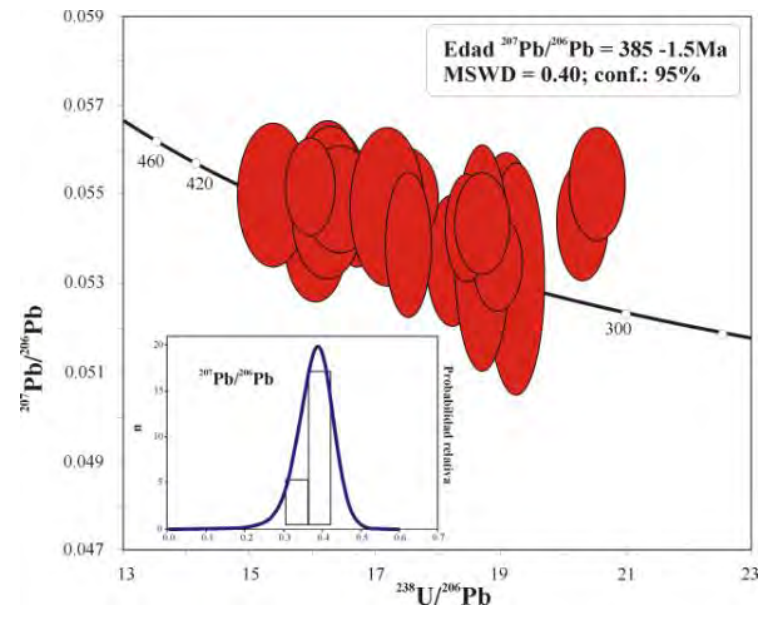

Figura 3.4.4: Diagrama concordia (Tera-Wasserburg, 1972) de edades $\mathrm{U} / \mathrm{Pb}$ obtenidas en las muestras de circones de la muestra $\mathrm{BO} 27$ por ICP-MS-LA $(\mathrm{n}=23)$.

\section{Isótopos de Sm y Nd}

Se efectuaron análisis isotópicos de Sm-Nd en tres muestras representativas de la Formación Chuscho. Se eligieron las menos disturbadas en su composición geoquímica. Se obtuvieron valores positivos de $\varepsilon_{\mathrm{Nd}}(\mathrm{t}=0)$ para un basalto porfírico $(\mathrm{CH} 2)$, un basalto almohadillado $(\mathrm{CH} 3)$ y un basalto masivo (MQ-I2), denotando un origen juvenil, con edades modelo $\mathrm{T}_{\mathrm{DM}}$ de 324, 332 у 323 Ma 
respectivamente (Tabla 3.4.2), usando el valor $t=454$ Ma obtenido por U-Pb TIMS para un circón primario por Fauqué y Villar (2003). Estos datos representan la edad de extracción del magma a partir de un manto deprimido, y fueron calculadas según el modelo de De Paolo (1981).

Tabla 3.4.2: Resultados de los análisis de isótopos de $\mathrm{Sm}-\mathrm{Nd}$ de tres muestras de basaltos de la zona del Chuscho. Edades modelo $\mathrm{T}_{\mathrm{DM}}$ calculadas según el modelo de De Paolo (1981). Muestras CH2 y CH3 recogidas en las quebradas del Chuscho y del Salto; MQ-I2 en el área de la Cueva del Miquilo. CH2: andesita; CH3: pillow-lava basáltica; MQ-I2: basalto porfírico masivo (¿colada?).

\begin{tabular}{lcccccccccccc}
\hline Muest. & $\begin{array}{c}\mathrm{Sm} \\
\mathrm{ppm}\end{array}$ & $\begin{array}{c}\mathrm{Nd} \\
\mathrm{ppm}\end{array}$ & $\begin{array}{c}{ }^{147} \mathrm{Sm} /{ }^{144} \mathrm{Nd} \\
\text { actual }\end{array}$ & $\begin{array}{c}{ }^{143} \mathrm{Nd} /{ }^{144} \mathrm{Nd} \\
\text { actual }\end{array}$ & $\mathrm{e}^{\lambda \mathrm{t}}$ & $f^{\mathrm{Sm} / \mathrm{Nd}}$ & $\begin{array}{c}\varepsilon_{\mathrm{Nd}}(0) \\
\text { actual }\end{array}$ & $\begin{array}{c}\varepsilon_{\mathrm{Nd}}(\mathrm{t}) \\
\text { inicial }\end{array}$ & $\begin{array}{c}{ }^{143} \mathrm{Nd} /{ }^{144} \mathrm{Nd} \\
\text { inicial }\end{array}$ & $\begin{array}{c}\mathrm{t} \\
\mathrm{Ma}\end{array}$ & $\begin{array}{c}\mathrm{T}_{\mathrm{DM}} \\
\mathrm{Ma}\end{array}$ \\
\hline CH 2 & 4,24 & 14,49 & 0,17589 & 0,51298 & 0,003 & $-0,11$ & 6,7 & 7,9 & 0,512458 & 454 & 324 \\
CH3 & 4,37 & 15,93 & 0,16510 & 0,51296 & 0,003 & $-0,16$ & 6,2 & 8,0 & 0,512464 & 454 & 332 \\
MQ-I 2 & 4,60 & 16,80 & 0,16498 & 0,51296 & 0,003 & $-0,16$ & 6,2 & 8,1 & 0,512468 & 454 & 323 \\
\hline
\end{tabular}

\section{e- Ambiente tectónico.}

Existe una variada cantidad de diagramas geoquímicos que se utilizan para distinguir entre tipos de basaltos y sus ambientes tectónicos. Los diagramas responden a variaciones en la intensidad de procesos de cristalizacion fraccionada y fusión parcial, o reflejan variaciones en la composición de la fuente del magma. Estos últimos utilizan elementos incompatibles y se usan principalmente para diferenciar entre basaltos de dorsales oceánicas (tipo MORB) y de arco volcánico. Los resultados que se observan en los gráficos confeccionados (Figuras 3.4.5 a 3.4.8) pueden mostrar cierta ambigüedad, especialmente en las muestras más alteradas y en los diagramas que utilizan elementos mayoritarios o trazas más móviles. En este sentido, es de esperar que las muestras BO13 y BO27 sean las que presentan mayor variación. Los resultados se sintetizan en la Tabla 3.4.3.

Los diagramas que se consideran más confiables son los de Bathia y Crook (1986), Shervais, 1982, Ti/Y - Nb/Y de Pearce (1982), Floyd y Winchester (1975). El resto de los diagramas muestran resultados poco definidos o erróneos. Teniendo esto en cuenta, en general las muestras presentan afinidad con basaltos tholeiíticos, con cierta tendencia alcalina. Las muestras $\mathrm{CH} 1$ y $\mathrm{CH} 2$, asi como las $\mathrm{CH} 3$ y MQ-I2 son muy similares entre si. Las muestras BO13 y BO27 se desvían constantemente hacia composiciones más alcalinas y esto se infiere que responde en gran medida a procesos secundarios de alteración. La mayoría se vincula con ambientes de isla oceánica. Las muestras $\mathrm{CH} 2$ es la que presenta mayor afinidad con losbasaltos tipo MORB y en menor medida la $\mathrm{CH} 1$.

Los diagramas de Bathia y Crook (1986; Figura 3.4.5a) relacionan a las muestras a ambientes de arco de isla oceánica, mientras que en el diagrama de Shervais (1982; Figura 3.4.6c) la dispersión de los puntos es mayor, pero se distribuyen mayoritariamente dentro del campo de los basaltos de isla oceánicos y basaltos alcalinos, excepto las muestras $\mathrm{CH} 1$ y $\mathrm{CH} 2$ que caen dentro del campo de los basaltos tipo MORB y basaltos de retroarco (este último se superpone con el de los basaltos de inundación continental). En los diagramas de Pearce (y otros) que usan Zr y Ti se observa el efecto de las altas concentraciones de estos elementos y que las muestras se ubican en los campos de basaltos de intraplaca y 
arco volcánico continental (ej: Pearce y Cann, 1973; Pearce y Gale, 1977; Pearce 1982, 1983; Figuras 3.4.5 y 3.4.6) marcando cierta tendencia alcalina en los diagramas que usan estos elementos. En el diagrama de Wood (1980; Figura 3.4.8d) las muestras se ubican en los campos de MORB y tholeiítas de intraplaca, excepto las muestras $\mathrm{BO} 13$ y $\mathrm{BO} 27$ que se desvían hacia el campo de arcos volcánicos por enriquecimiento en Th durante su alteración.

Los diagramas de Floyd y Winchester (1975) y Winchester y Floyd (1976) usan los elementos HFS y se aplican a rocas volcánicas alteradas. Winchester y Floyd (1976) reportan que la relación Y/Nb permanece constante durante el metamorfismo y la alteración, excepto en los márgenes de las lavas almohadilladas alteradas y metadoleritas (Rollinson, 1993, p.191). Esto último debe ser considerado en las muestras estudiadas y sería la razón por la cual los resultados dieron ambiguos (basaltos alcalinos y tholeiíticos). Permiten discriminar entre series magmaticas, aunque no permiten discriminar entre ambientes tectónicos, excepto en el diagrama $\mathrm{TiO}_{2}$ vs. Y/Nb (Winchester y Floyd, 1976; Rollinson, 1993, pp.190-191). En este diagrama la mayoría de las muestras se comparan con basaltos tholeííticos continentales. La BO27 se superpone con el campo de los baaltos tipo MORB.

Winchester y Floyd (1976) hallaron que la relación $\mathrm{Zr} / \mathrm{P}_{2} \mathrm{O}_{5}$ puede modificarse con la alteración progresiva debido a la movilización del $\mathrm{P}$, por lo que este diagrama debe usarse con cuidado en rocas fuertemente alteradas. Morrison (1987) halló que los diagramas $\mathrm{P}_{2} \mathrm{O}_{5}-\mathrm{Zr}, \mathrm{TiO}_{2}-\mathrm{Zr} / \mathrm{P}_{2} \mathrm{O}_{5}$ y Nb/Y-Zr/ $\mathrm{P}_{2} \mathrm{O}_{5}$ de Winchester y Floyd (1975) no permiten discriminar entre basaltos con hipersteno normativo y basaltos con nefelina normativa metamorfizados en facies de zeolita y esquistos verdes ya que plotean como basaltos tholeiíticos cuando probablemente sean transicionales entre tholeiíticos y alcalinos; esto indica que sirven mejor para basaltos frescos, más que para rocas antiguas más susceptibles a la alteración y metamorfismo como las muestras analizadas. Sin embargo, Smith y Smith (1976) hallaron que el diagrama $\mathrm{Nb} / \mathrm{Y}-\mathrm{Zr} / \mathrm{P}_{2} \mathrm{O}_{5}$ discrimina con éxito los basaltos metamorfizados en facies de prehnitapumpelleyta. (ver discusión en Rollinson, 1993, p.193).

Tabla 3.4.3: Síntesis de los resultados obtenidos de los distintos diagramas de discriminación de basaltos graficados para las muestras estudiadas. Nivel de confianza: $\mathrm{x}=$ bajo; $\mathrm{xx}=$ medio; $\mathrm{xxx}=$ alto.

\begin{tabular}{|c|c|c|c|c|}
\hline & diagrama & autores & Ambiente tectónico & $\begin{array}{l}\text { Nivel de } \\
\text { confianza }\end{array}$ \\
\hline 1 & Th-Sc-La y Th-Sc-Zr/10 & Bathia y Crook, 1986 & Arco de isla oceánico & $\mathrm{xxx}$ \\
\hline 2 & $\mathrm{Zr} / \mathrm{Y}$ vs. $\mathrm{Zr}$ & Pearce, 1983 & Arco continental & - \\
\hline 3 & $\mathrm{Zr} / \mathrm{Y}$ vs. Tl/Y & Pearce and Gale, 1977 & Basaltos de intraplaca (CH2: margen de placa) & - \\
\hline 4 & $\mathrm{Ti} / \mathrm{Y}$ vs. Nb/Y & Pearce, 1982 & Tholeítas de intraplaca & $\mathrm{xx}$ \\
\hline 5 & Ti vs. $\mathrm{Zr}$ & Pearce y Cann, 1973 & MORB & $x$ \\
\hline 6 & Ti vs. $\mathrm{Zr}$ & Pearce, 1982 & -varios- & $\mathrm{x}$ \\
\hline 7 & $\mathrm{~V}-\mathrm{Ti} / 1000$ & Shervais, 1982 & $\begin{array}{l}\text { MORB y basaltos de retroarco (CH1, CH2). OIB y } \\
\text { basaltos alcalinos (BO13, BO27); la mayoria cae } \\
\text { cerca de la la línea de transición entre ambos } \\
\text { campos. }\end{array}$ & $\mathrm{xx}$ \\
\hline 8 & $\mathrm{TiO}_{2}$ vs. $\mathrm{Y} / \mathrm{Nb}$ & $\begin{array}{c}\text { Floyd y Winchester, } \\
1975 \\
\end{array}$ & Basaltos tholeiíticos continentales & \\
\hline 9 & $\begin{array}{c}\mathrm{Nb} / \mathrm{Y} \text { vs. } \mathrm{Zr} /\left(\mathrm{P}_{2} \mathrm{O}_{5} \mathrm{X}\right. \\
10.000)\end{array}$ & $\begin{array}{l}\text { Floyd y Winchester, } \\
1975\end{array}$ & Basaltos tholeiíticos (oceánicos; BO13 transic.) & \\
\hline 10 & $\begin{array}{c}\mathrm{TiO}_{2} \text { vs. } \\
\mathrm{Zr} /\left(\mathrm{P}_{2} \mathrm{O}_{5} \times 10.000\right) \\
\end{array}$ & $\begin{array}{c}\text { Winchester y Floyd, } \\
1976 \\
\end{array}$ & Basaltos tholeiíticos (BO13 y BO-I: alcalinos) & $\mathrm{x}$ \\
\hline 11 & $\mathrm{P}_{2} \mathrm{O}_{5}$ versus $\mathrm{Zr}$ & $\begin{array}{l}\text { Winchester y Floyd, } \\
1976\end{array}$ & Basaltos alcalinos ( $\mathrm{CH} 2$ tholeiítico) & $\mathrm{x}$ \\
\hline
\end{tabular}




\begin{tabular}{|c|c|c|c|}
\hline 12 & $\mathrm{Nb} / \mathrm{Yb}$ vs. $\mathrm{La} / \mathrm{Nb}$ & Remesal et al, 2004 & $\mathrm{Nb} / \mathrm{La}>1.0$ \\
\hline 13 & $\mathrm{Yh} / \mathrm{Yb}$ vs. $\mathrm{Ta} / \mathrm{Yb}$ & Pearce, 1983 & Margenes continentales activos \\
\hline 14 & $\mathrm{Zr} / \mathrm{Y}$ vs. $\mathrm{Zr}$ & Pearce and Norry 1979 & Basaltos de islas oceánicas \\
\hline 15 & $\mathrm{Hf} / 3-\mathrm{Th}-\mathrm{Ta}$ & Wood, 1980 & $\begin{array}{c}\text { N-MORB (CH2); E-MORB (CH1, CH3, MQ-I2, } \\
\text { BO-I); arcos volcánicos (BO13 y BO27) }\end{array}$ \\
\hline
\end{tabular}

El diagrama Hf/3 - Th - Ta (Wood, 1980; Figura 3.4.8d) permite reconocer distintos tipos de MORB, y es particularmente efectivo para identificar basaltos de arco volcánico. Se aplica mejor en rocas poco alteradas porque el Th puede movilizarse.

De acuerdo a lo observado en los diagramas de tierras raras (Figura 3.4.2b) es probable que haya habido cierta movilización de las REE y de los elementos traza más móviles. Los basaltos tipo OIB suelen presentar estas características y estar enriquecidos en $\mathrm{Ba}$ y $\mathrm{Nb}$ respecto a los MORB, aunque los resultados difieren de las curvas típicas propuestos por Pearce (1983) para basaltos alcalinos tipo OIB normalizados a $\mathrm{C} 1 \mathrm{y}$ MORB. Por otro lado, el enriquecimiento en LREE es propio de los E-MORB, (Villar, 2003). El mayor contenido de $\mathrm{Ba}$ en las muestras $\mathrm{CH} 2$ y $\mathrm{CH} 3$ probablemente esté vinculado a metasomatismo por interacción con el agua de mar al extruirse el magma y generar los depósitos de lavas almohadilladas. 


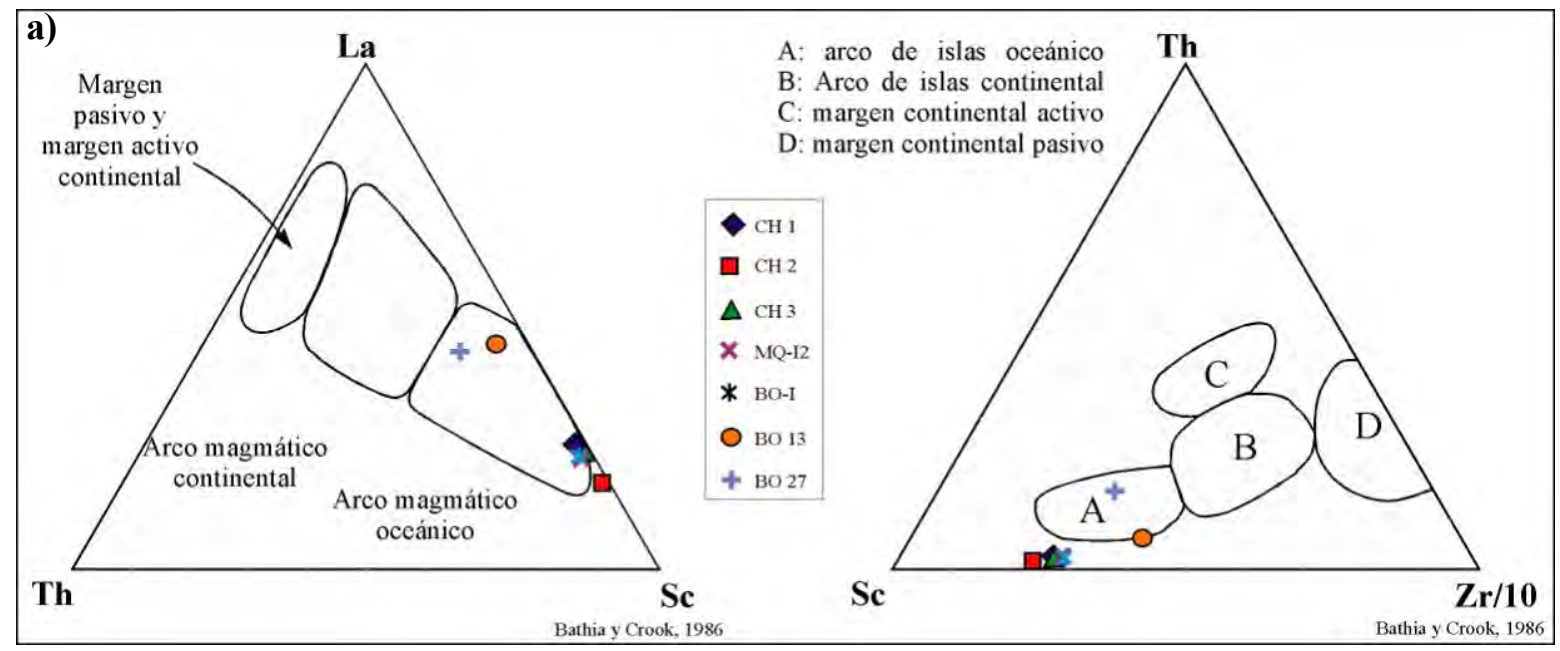

b)
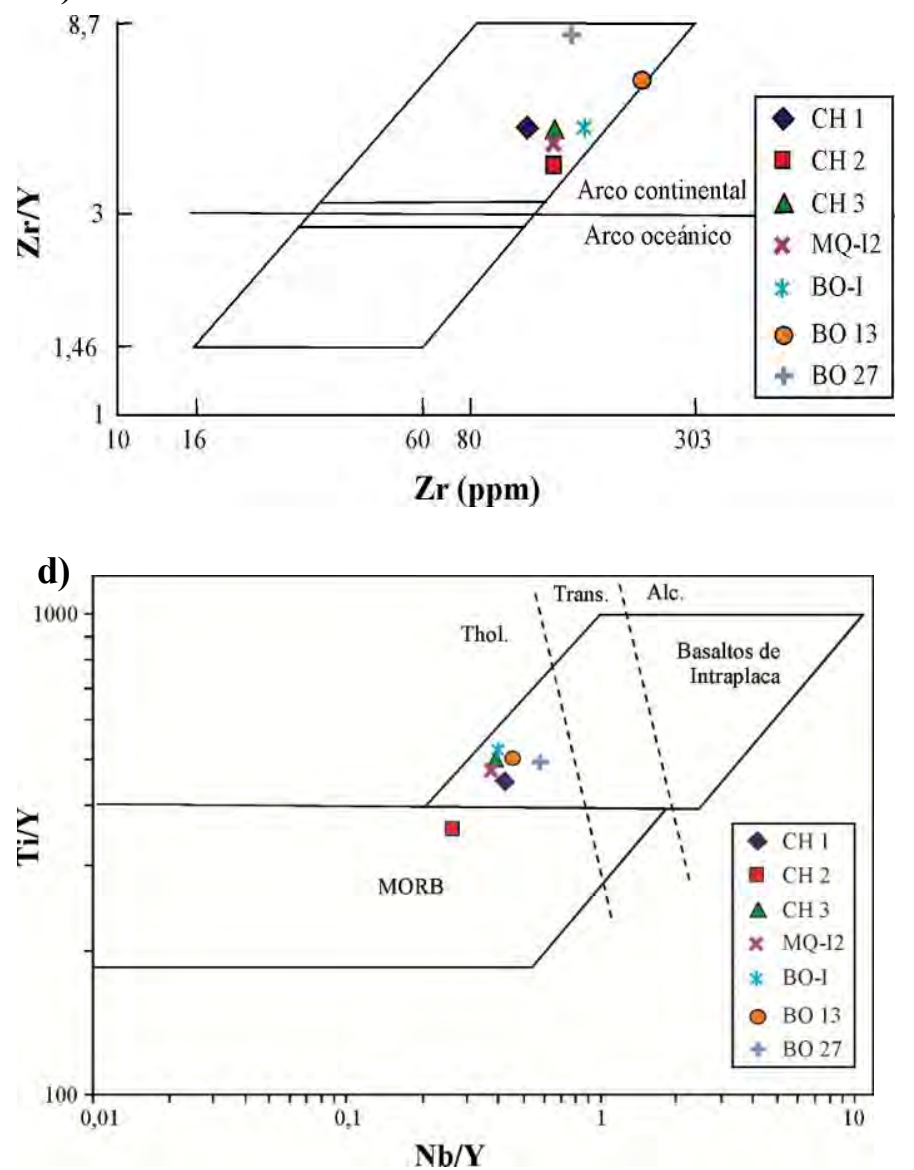

c)

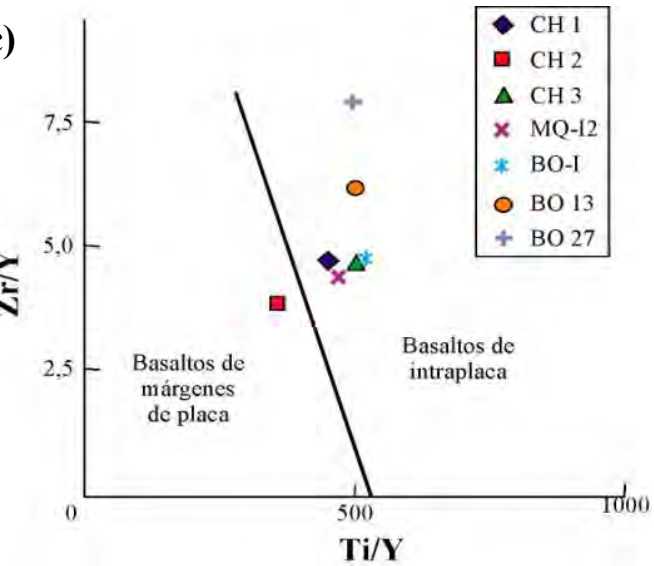

Figura 3.4.5: Diagramas de discriminación tectónica de basaltos. a)- diagramas Th-Sc-La y Th-Sc-Zr/10 (Bathia y Crook, 1986). Cada ambiente tectónico se representa en un campo composicional distinto. A: Arco de isla oceánico; B: Arco de isla continental; C: margen continental activo; D: margen pasivo. b)- diagrama Zr/Y vs. Zr (Pearce, 1983); c)- diagrama Zr/Y vs. Tl/Y (Pearce and Gale, 1977); d)- diagrama Ti/Y vs. Nb/Y (Pearce, 1982). Este diagrama separa con éxito los basaltos de intraplaca de los MORB y los basaltos de arco volcánico (estos últimos se traslapan bastante). Las altas relaciones $\mathrm{Ti} / \mathrm{Y}$ y $\mathrm{Nb} / \mathrm{Y}$ de los basaltos de intraplaca estarían reflejando una fuente en un manto enriquecido en relación a las fuentes de los MORB y basaltos de arco. 

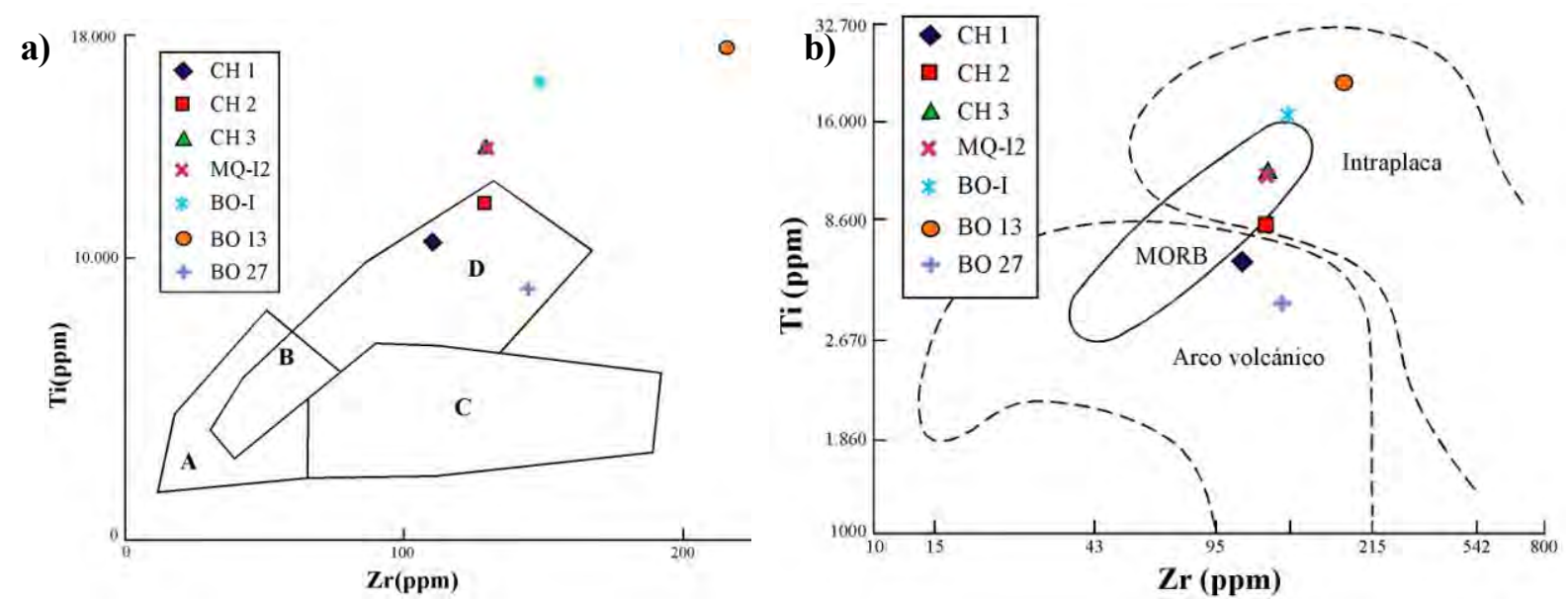

c)

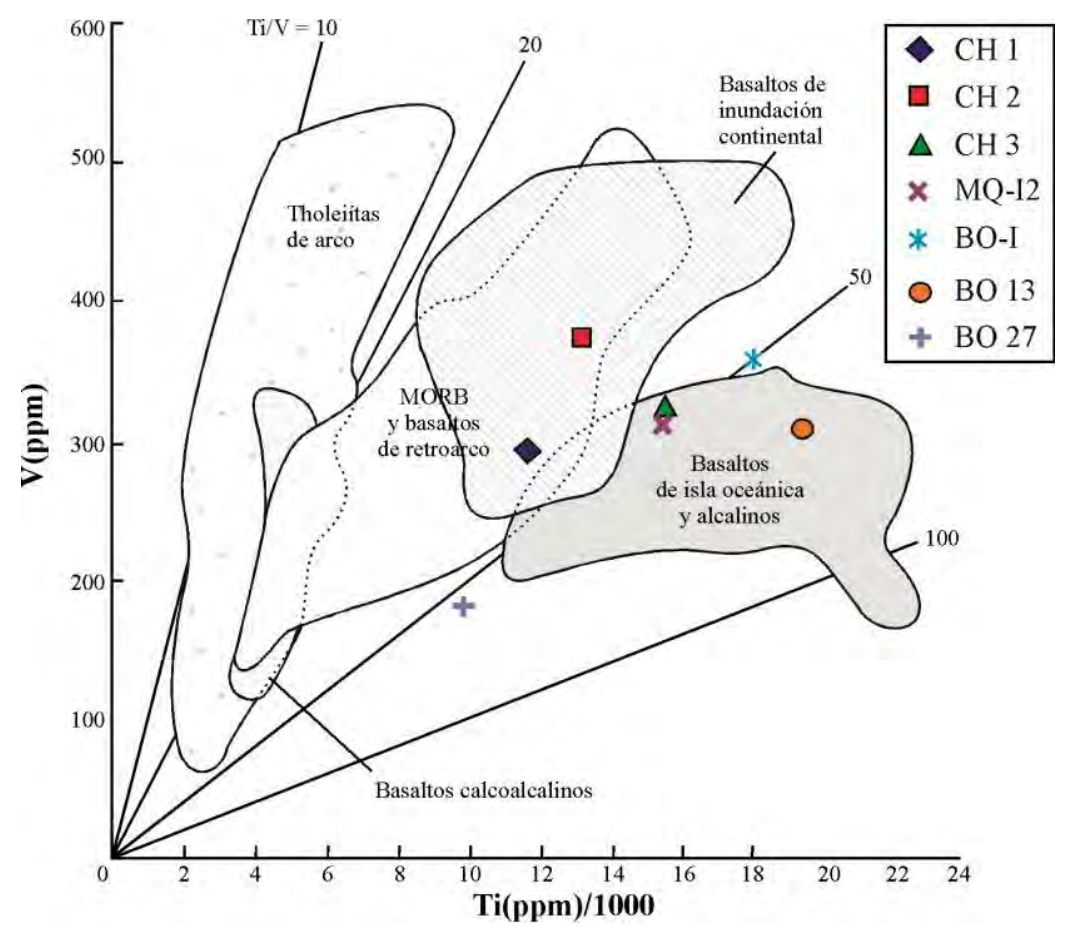

Figura 3.4.6: Diagramas de discriminación tectónica de basaltos. a)- Ti vs. Zr, (Pearce y Cann, 1973), A: tholeiítas de arcos de isla; B: MORB, basaltos calcoalcalinos y toleítas de arcos de isla; C: basaltos calcoalcalinos; D: MORB); b)- Ti vs. Zr (Pearce, 1982); c)- V-Ti/1000 (Shervais, 1982). Este diagrama permite distinguir tholeiitas de arco, MORB y basaltos alcalinos y se basa en que el Ti y el V son inmóviles durante la alteración hidrotermal y durante metamorfismo medio a alto, por lo que es útil para las muestras del Chuscho. 
a)

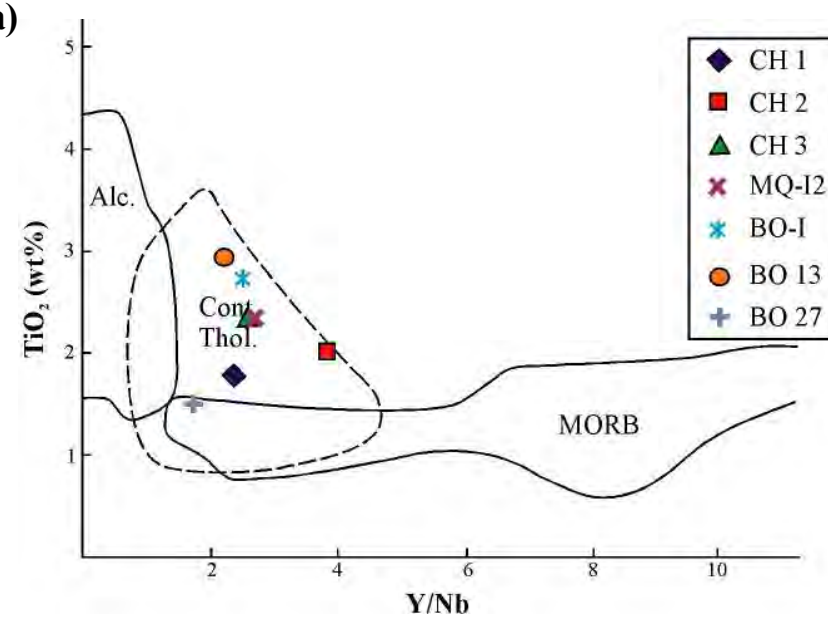

b)

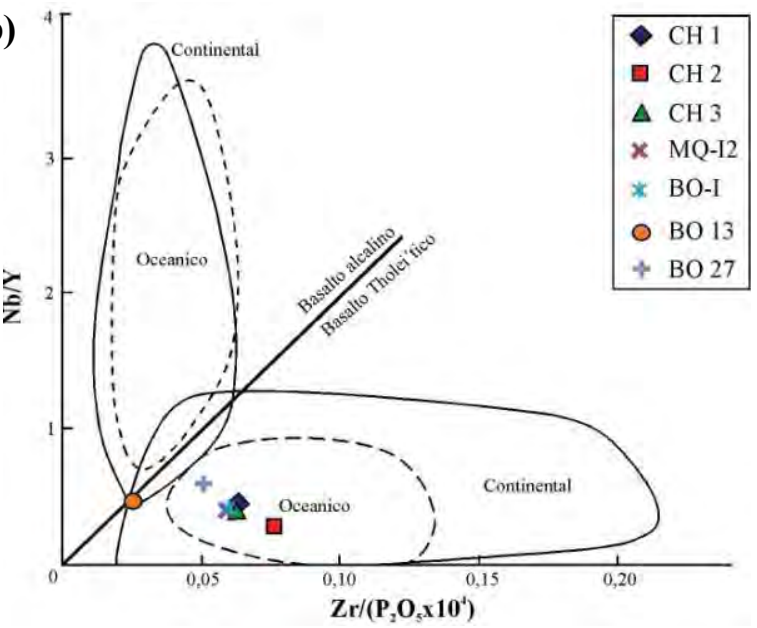

c)

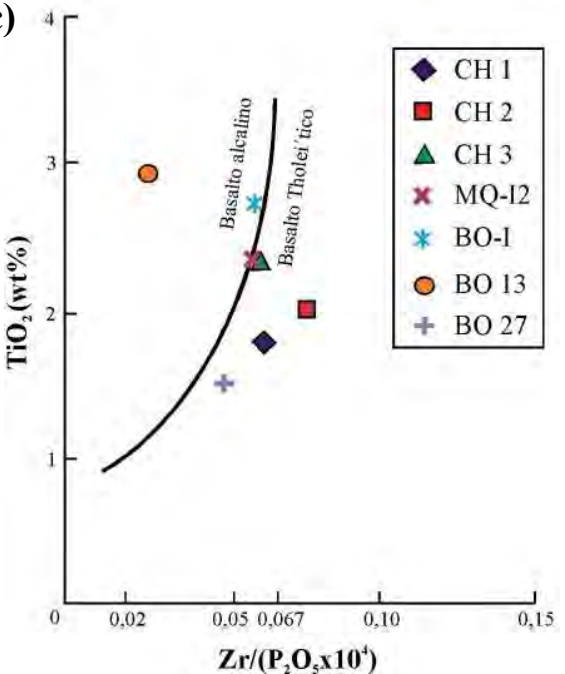

d)

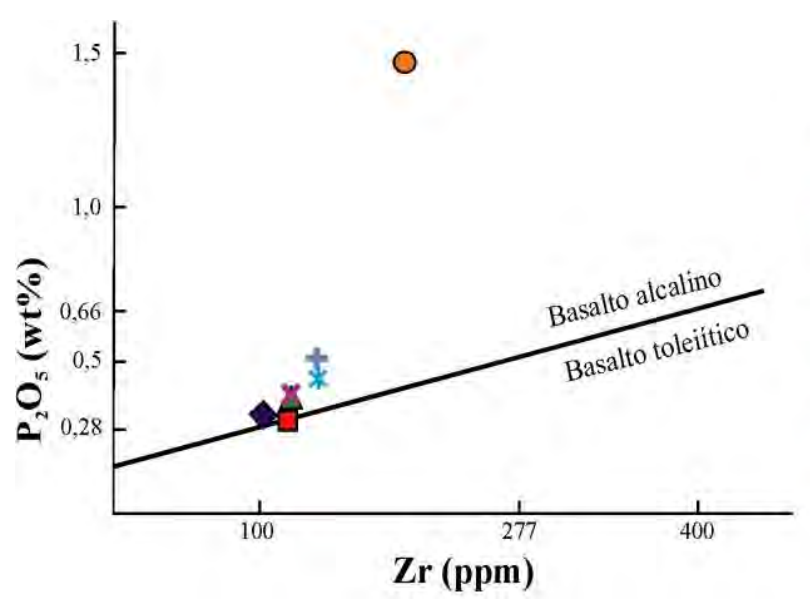

$\mathrm{CH} 1$

- $\mathrm{CH} 2$

$\triangle \mathrm{CH} 3$

* MQ-12

* BO-I

○ BO 13

+ BO 27

Figura 3.4.7: diagramas de discriminación de basaltos. a y b)- $\mathrm{TiO}_{2}-\mathrm{Y} / \mathrm{Nb}$ y Nb/Y $-\mathrm{Zr} /\left(\mathrm{P}_{2} \mathrm{O}_{5} \times 10.000\right)$ (Floyd y Winchester (1975). c y d)- $\mathrm{TiO}_{2}-\mathrm{Zr} /\left(\mathrm{P}_{2} \mathrm{O}_{5} \times 10.000\right)$ y $\mathrm{P}_{2} \mathrm{O}_{5}-\mathrm{Zr}$ (Winchester y Floyd, 1976).

Teniendo en cuenta la estratigrafia y que las lavas almohadilladas (y diques de diabasas) se asocian e intercalan con sedimentitas portadoras de fósiles marinos (graptolitos y bivalvos) lo más probable es que se trate de lavas formadas en ambientes de dorsales oceánicas (MORB) o arco de islas oceánicos (OIB). La tendencia levemente alcalina de las muestras se presenta comúnmente en este último ambiente. La albitización observada en los feldespatos es un proceso frecuente en las rocas básicas oceánicas por metasomatismo de sodio.

Al comparar las muestras del área del Chuscho con los valores de composiciones promedio de rocas básicas de distintos ambientes tectónicos (Robinson y Malpas, 2008), se observa una mayor afinidad con rocas tipo $E-M O R B$, tholeiítas de arco, y $\underline{O I B}$.

Tomando toda la información en conjunto se concluye para las rocas básicas de la Formación Chuscho que son basaltos tholeiíticos con tendencia alcalina. Para determinar el ambiente tectónico de formación los resultados son ambiguos, pero en base a todas las evidencias lo más probable es que se relacionen a un ambiente de arco de islas oceánicas. Por otro lado, se plantea la posibilidad de que 
estén registrando una evolución entre un ambiente de retroarco continental con basaltos de inundación (ruptura) y posterior formación de un arco de isla oceánico (subducción)?, entonces ambas signaturas tendrían significado.

Tabla 3.4.4: Composiciones promedio de las rocas basálticas de fondo oceánico comunes. (Fuente: Robinson P.T, y Malpas J., GSA TODAY, Nov-2008). MORB: basalto de dorsales centro oceánicas normales (N-MORB) y enriquecidos (E-MORB); OIB: basalto de islas oceánicas; Alk-Oliv: basalto alcalino-olivínico; Arc Thol: basalto tholeiítico de arco.

\begin{tabular}{lrrrrrr}
\hline & N-MORB & E-MORB & OIB & Alk-Oliv & Arc Thol & Boninite \\
\hline $\mathrm{SiO} 2$ & 50,4 & 51,2 & 49,2 & 47,6 & 51,7 & 53,6 \\
$\mathrm{TiO} 2$ & 1,36 & 1,69 & 2,57 & 3,23 & 1,36 & 0,26 \\
$\mathrm{Al2O} 3$ & 15,2 & 16 & 12,8 & 15,7 & 16,57 & 13,5 \\
$\mathrm{FeOt}$ & 9,31 & 8,46 & 11,4 & 13,4 & 8,4 & 8,6 \\
$\mathrm{MnO}$ & 0,18 & 0,16 & 0,17 & 0,19 & 0,16 & 0,15 \\
$\mathrm{MgO}$ & 9 & 6,9 & 10 & 5,6 & 6,6 & 10,2 \\
$\mathrm{CaO}$ & 11,4 & 11,5 & 10,8 & 7,9 & 10,8 & 12,2 \\
$\mathrm{Na} 2 \mathrm{O}$ & 2,3 & 2,7 & 2,1 & 4 & 3 & 0,92 \\
$\mathrm{~K} 2 \mathrm{O}$ & 0,09 & 0,4 & 0,5 & 1,5 & 0,34 & 0,41 \\
$\mathrm{P} 2 \mathrm{O} 5$ & 0,14 & 0,15 & 0,25 & 0,35 & 0,18 & 0,04 \\
\hline Total & 99,38 & 99,16 & 99,79 & 99,47 & 99,11 & 99,88 \\
\hline
\end{tabular}

Tabla 3.4.5: Composición comparativa de elementos mayoritarios en las rocas básicas del área del Chuscho. $\left(^{*}\right)$ : $\mathrm{FeO}$ total calculado a partir de $\mathrm{Fe}_{2} \mathrm{O}_{3}$ total.

\begin{tabular}{lrrrrrrr}
\hline & BO13 & BO-I & MQ-I2 & CH1 & CH2 & CH3 & \multicolumn{1}{c}{ BO27 } \\
\hline \% elem & $\begin{array}{c}\text { Diabasa } \\
\text { (diq.verde) }\end{array}$ & Basalto & $\begin{array}{c}\text { Basalto } \\
\text { porfírico }\end{array}$ & Basalto & $\begin{array}{c}\text { Basalto } \\
\text { porfírico }\end{array}$ & $\begin{array}{c}\text { Basalto } \\
\text { (pillow) }\end{array}$ & $\begin{array}{c}\text { Anfibolit } \\
\text { a (pillow) }\end{array}$ \\
\hline $\mathrm{SiO}_{2}$ & 41,42 & 45,03 & 47,28 & 47,24 & 47,22 & 46,99 & 51,72 \\
$\mathrm{TiO}_{2}$ & 2,92 & 2,71 & 2,33 & 1,76 & 1,99 & 2,34 & 1,49 \\
$\mathrm{Al}_{2} \mathrm{O}_{3}$ & 12,93 & 11,48 & 16,48 & 16,42 & 14,55 & 13,97 & 9,88 \\
$\mathrm{FeO}_{\mathrm{t}}$ * & 11,66 & 14,90 & 10,46 & 10,01 & 12,00 & 11,82 & 11,63 \\
$\mathrm{MnO}$ & 0,21 & 0,22 & 0,17 & 0,17 & 0,2 & 0,19 & 0,22 \\
$\mathrm{MgO}$ & 4,9 & 9,07 & 5,47 & 5,63 & 6,28 & 6,6 & 12,99 \\
$\mathrm{CaO}$ & 11,27 & 10,12 & 11,37 & 11,1 & 11,29 & 10,62 & 4,83 \\
$\mathrm{Na}{ }_{2} \mathrm{O}$ & 2,04 & 1,72 & 2,13 & 2,04 & 2,65 & 2,97 & 1,9 \\
$\mathrm{~K}_{2} \mathrm{O}$ & 0,64 & 0,24 & 0,55 & 0,36 & 0,26 & 0,31 & 0,61 \\
$\mathrm{P}_{2} \mathrm{O}_{5}$ & 0,844 & 0,25 & 0,219 & 0,176 & 0,169 & 0,21 & 0,283 \\
\hline Total & 91,01 & 100 & 99,72 & 99,8 & 98,38 & 99,8 & 97,49 \\
\hline & & & & & & & \\
\hline
\end{tabular}

Las muestras de la Formación Chuscho presentan afinidad principalmente con ambientes de arcos de islas oceánicos y MORB, a diferencia de las lavas de la Formación Punta del Agua, típicamente calcoalcalinas de arco relacionado a subducción. Las rocas básicas de esta unidad involucra andesitas orogénicas de arco volcánico emplazadas en ambiente continental, con edades que irían desde el Carbonífero Superior hasta el Pérmico Inferior (Fauqué y Villar, 2003; Remesal et al., 2004). Al comparar los resultados con los obtenidos por Remesal et al., (2004) para la Fm Punta del Agua, se observa que aquellas rocas son esencialmente intermedias aunque abarcan un amplio rango de composiciones (desde andesitas básicas hasta riolitas). Los patrones de REE muestran un mayor enriquecimiento en LREE y MREE, y una anomalía negativa de Eu puede estar presente. En los gráficos de la Figura 3.4 .8 se comparan los resultados con los obtenidos por Remesal et al. (2004) para la Formación Punta del Agua, observándose diferencias en todos ellos. La muestra $\mathrm{CH} 2$ es la que presenta más afinidad tholeiítica y los basaltos tipo N-MORB sin embargo no se acerca a las muestras de la Fm Punta del Agua. La muestra BO13, y en menor proporción la BO27, son las más alcalinas y con mayor 
afinidad con ambientes tipo OIB; sin embargo los resultados para ambas muestras es probable que estén reflejando procesos secundarios de alteración y metamorfismo.
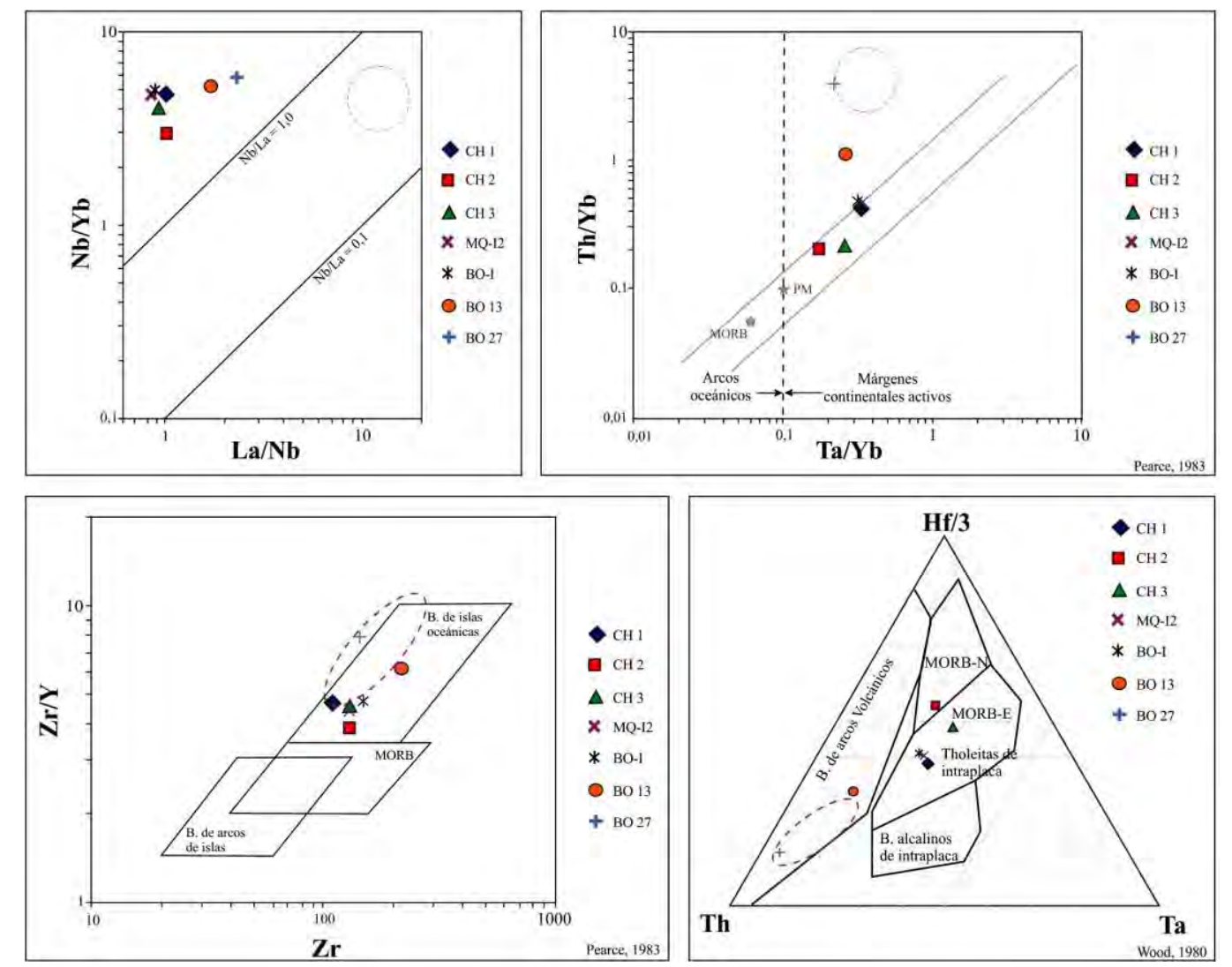

Figura 3.4.8: a)- diagrama $\mathrm{Nb} / \mathrm{Yb}$ vs. $\mathrm{La} / \mathrm{Nb}$ (Remesal et al., 2004). b)- diagrama $\mathrm{Th} / \mathrm{Yb}$ vs. $\mathrm{Ta} / \mathrm{Yb}$ (Pearce, 1983). $\mathrm{PM}=$ manto primordial; $\mathrm{MORB}=$ basaltos de dorsales cento-oceánicas. El círculo con línea de trazos corresponde a la ubicación general de los valores de la Formación Punta del Agua (Remesal et al., 2004). c)- diagrama Zr/Y vs. Zr (Pearce and Norry 1979). d)Diagrama Hf/3 - Th - Ta (Wood, 1980).

Los resultados son compatibles con las propuestas realizadas por Kay et al. (1984) y Fauqué y Villar (2003) quienes integran las lavas almohadilladas espilitizadas de la Formación Chuscho al complejo ofiolítico famatiniano del oeste de la Precordillera (Haller y Ramos, 1984), asociada a la apertura de un rift oceánico de cuenca marginal formado durante la acreción de Chilenia en el CambroOrdovícico y posterior colisión en el Devónico-Carbonífero. Las características de este rift parecen cambiar a lo largo del mismo, desde N-MORB en la Cordillera Frontal hasta E-MORB en la Precordillera de San Juan y La Rioja.

\section{Conclusiones estratigráficas sobre el magmatismo básico.}

Por las relaciones de campo que se observaron entre las unidades así como por sus edades es posible vincular a las rocas básicas con tres eventos magmáticos: 
Tabla 3.4.6: Síntesis de las características de las rocas magmáticas de la región estudiada.

\begin{tabular}{|c|c|c|c|}
\hline & $1^{\circ}$ magmatismo & $2^{\circ}$ magmatismo & $3^{\circ}$ magmatismo \\
\hline $\begin{array}{l}\text { T्ञ } \\
\text { III }\end{array}$ & Od & $\mathbf{C b}$ & Tr? \\
\hline 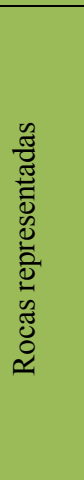 & $\begin{array}{l}\text { Fm Chuscho (y Las Casitas): } \\
\text { - Lavas almohadilladas, } \\
\text { autobrechas, diabasas (diques } \\
\text { verdes); lavas masivas. } \\
\text { - Deformados junto con las } \\
\text { sedimentitas ordovícicas. } \\
\text { - Metamorfizados en FEV } \\
\text { (uralitiza-ción de Px y } \\
\text { Saussuritización de Pl). }\end{array}$ & 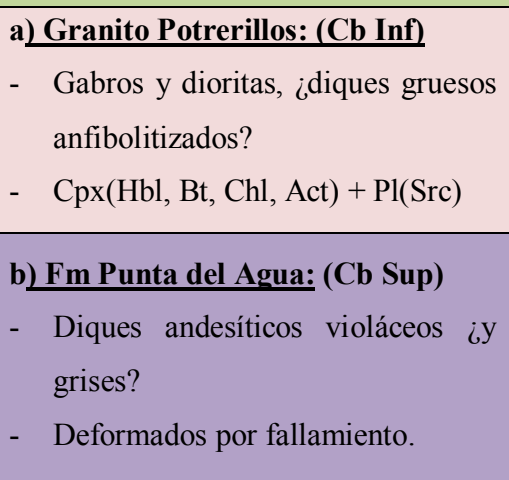 & $\begin{array}{l}\text { "Diques negros": } \\
\text { - } \\
\text { Basaltos alcalinos [con } \mathrm{Pl}(\mathrm{Src})+ \\
\mathrm{Ol}(\mathrm{Chl}, \mathrm{Srp}, \mathrm{Tlc})+\mathrm{Ti}-\mathrm{Aug}] \\
\text { - } \quad \text { Mucho Ti (Ti.Aug, Ttn, Ilm). } \\
\text { - } \quad \text { Sin deformar; cortan todas las } \\
\text { unidades hasta el Cb Inferior y } \\
\text { faja de cizalla. }\end{array}$ \\
\hline 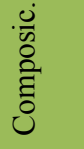 & $\begin{array}{c}\text { Tholeiítico (con tendencia } \\
\text { alcalina) }\end{array}$ & Calcoalcalino & (más alcalino) \\
\hline है 总 & Arco de isla oceánico? & Arco volcánico (subducción) & rift? \\
\hline
\end{tabular}

Aunque se interpreta aquí que corresponderían a intrusivos ordovícicos, que aprovecharon la foliación de la Formación Río Bonete y que han sido deformados en conjunto con estos en la faja de cizalla, dada la baja población de datos de edad en un área tan compleja no puede descartarse que algunos cuerpos se relacionen con un magmatismo más antiguo. Para poder confirmar y acotar con mejor precisión los distintos cuerpos y eventos magmáticos es necesario obtener una mayor cantidad de datos de edad y geoquímicos, así como un mapeo de detalle para ajustar las relaciones de corte de los distintos diques.

\section{Relación con la mineralización}

No se ha podido hacer un estudio detallado y sistemático de la mineralización, sin embargo se plantean algunas observaciones.

En el mapa Anexos A1: M6b (basado en Cravero et al., 1984) se ve claramente que las labores mineras de la región están asociadas a vetas (diques básicos) que se ubican cerca de los contactos entre la Formación Río Bonete y las lavas almohadilladas deformadas. La mineralización de la zona se asocia a estas vetas, que estarían asociadas al magmatismo básico carbonífero de la Formación Punta del Agua. Estos autores consideran tres etapas de mineralización:

- Primera etapa. Sulfuros y óxidos de $\mathrm{Cu}$ y Fe: representada por calcopirita - bornita - tetraedrita. Como minerales secundarios covelina - calcosina - neodigenita. Además hematita, limonitas, malaquita y azurita como minerales de oxidación.

- Segunda etapa. Seleniuros: representada por tiemmanita $(\mathrm{HgSe})$ - umanguita $\left(\mathrm{Cu}_{3} \mathrm{Se}_{2}\right)$ klockmannita (CuSe) - clausthalita ( $\mathrm{PbSe})$ - eucarita ( $\mathrm{AgCuSe})$. 
- Tercera etapa. Representada por calcita - siderita - calcosina.

Ademas aparecen minerales secundarios derivados de los seleniuros como calcomenita $\left(\mathrm{CuSeO}_{3}+\mathrm{H}_{2} \mathrm{O}\right)$ y schmiederita $\left((\mathrm{PbCu})_{2}(\mathrm{OH})_{2} \mathrm{SeO}_{4}\right)$.

\subsection{5- FORMACIÓN QUEBRADA SECA (Cravero et al., 1984) Y FORMACIÓN JAGÜEL} (González y Bossi, 1986; equivalentes a Formación Punilla, Furque, 1956. Dv-Cb Inf.; Formación Jagüé, Maisonave, 1979)

\section{Introducción}

La Formación Quebrada Seca ha sido definida por primera vez por Cravero et al. (1984) en el área de Los Llantenes, a lo largo de la quebrada Seca, afluente de la quebrada de Llantenes y límite oriental de la Dorsal de la Orilla, a los $28^{\circ} 27^{\prime}$ - $28^{\circ} 33^{\prime}$ latitud sur y $68^{\circ} 40^{\prime}$ longitud oeste (Anexos A1: M6a-b). Dado que su objetivo principal era el estudio de las manifestaciones cupro-seleníferas del Distrito Minero Los Llantenes, no se detuvieron especialmente en estudiar la estratigrafía. En los afloramientos que aparecen sobre la quebrada Seca dicha unidad consiste en pelitas concrecionales en las que se halló una asociación fosilífera de plantas e invertebrados (braquiópodos, bivalvos, corales, ver más adelante: d-Fósiles) que sitúan a esta unidad en el período Devónico - Carbonífero Inferior, siendo entonces temporalmente equivalente a la Formación Jagüel (González y Bossi, 1986) y Formación Agua de Lucho (González y Bossi, 1987) que aflora al sur y suroeste del Cerro Chuscho, y regionalmente a la Formación Punilla (Furque, 1956). En la hoja geologica 14c (Cerros Cuminchango, Maisonave, 1979) // 2969-II (Tinogasta; Fauqué y Caminos, 2004) ha sido mapeada como Formación Jagüé.

Además de estos afloramientos, se han hallado rocas similares en el tramo medio de la quebrada del Chuscho, antes de que se una aguas arriba con la quebrada del Salto. Aparecen en un bloque tectónico intercalado entre las sedimentitas estratificadas ordovícicas, y que si no se esta atento pueden pasarse por alto como parte de ellas. En este sector las rocas corresponderían a la Formación Jagüel (Anexos A1:M1).

\section{a- Afloramientos}

A lo largo de la quebrada Seca afloran metapelitas y lutitas grises y verdosas (e.g. LL2), con algunas intercalaciones de estratos amarillentos de limolitas y areniscas finas a medianas. Dentro de las metapelitas son muy frecuentes los niveles de concreciones limo - arenosas muy finas, subredondeadas, de colores oscuros o negros, y de tamaños muy variables, desde $4-5 \mathrm{~cm}$ hasta alrededor de $30 \mathrm{~cm}$ (Figura 3.5.1; ej: muestra LL2-Fpi). Las concreciones le dan un aspecto conglomerádico a las pelitas, suelen tener una línea a modo de carena en el sector medio originada por la deformación durante la compactación diagenética, y parecen hacerse cada vez más abundantes hacia el techo de la unidad (somerización?). 
Aparecen estratos tabulares de areniscas amarillentas intercalados, más comúnmente hacia la base, afectados por pliegues apretados y presentan estructuras sedimentarias supraestratales (ondulitas de interferencia, calcos de flujo) e infraestratales (calcos de carga). Las sedimentitas están cortadas por diques de fenoandesitas porfíricas con pasta violácea que han sido deformados y dislocados. Estos diques podrían relacionarse con el magmatismo de la Formación Punta del Agua (González y Bossi, 1986, sección 3.2.4).
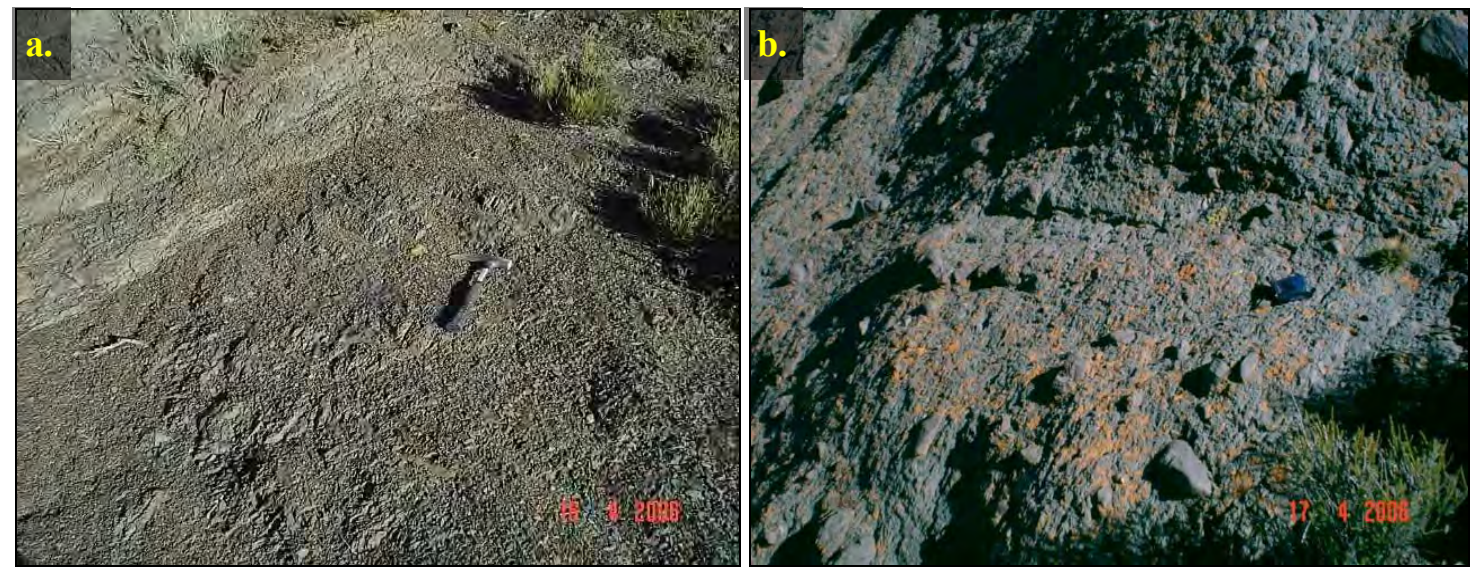

Figura 3.5.1a-b: Aspecto típico de los afloramientos de la Formacion Quebrada Seca sobre la quebrada homónima. Se observa la presencia de abundantes concreciones sedimentarias y clastos más gruesos distribuidos entre las metasedimentitas deformadas (b).

En el filo de la Dorsal de la Orilla, cruzando por su extremo norte, puede observarse la base de la unidad en discordancia angular sobre las metamorfitas de la Formación Río Bonete. Y hacia el este, en la margen oriental de la quebrada Seca, son cubiertas discordantemente por los conglomerados con los que se inicia la secuencia carbonífera en este sector (Formación Cerro Tres Cóndores, capítulo 3.2.7).

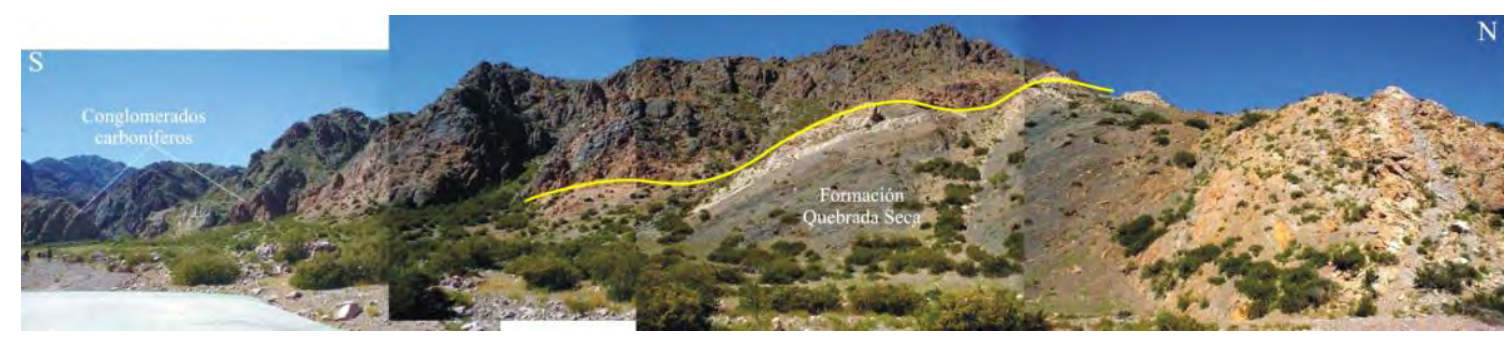

Figura 3.5.2: Vista del sector sur del bloque de Los Llantenes - Dorsal de la Orilla, donde comienzan los afloramientos de las metapelitas de la Formación Quebrada Seca del flanco oriental del sinclinal de conglomerados castaños carboníferos. La cresta más elevada que se observa de fondo corresponde a los afloramientos de lavas almohadilladas descriptos para este sector; se llegan a distinguir a lo lejos algunas estructuras almohadilladas pero en esta imagen no se precia la relación de contacto con las demás unidades. Fotografía tomada desde la Quebrada Seca hacia su margen occidental.

Sobre la margen sur de la quebrada del Chuscho, en un pequeño bloque limitado por fallas entre los afloramientos ordovícicos estratificados de la Formación del Salto, aparece una secuencia con características similares a los afloramientos de la quebrada Seca. Las capas de los 
afloramientos son verticales o con una pequeña inclinación hacia el oeste-noroeste. De base a techo dentro del bloque aparece primero una sucesión de estratos tabulares verde-amarillentos y granocrecientes, desde areniscas medianas en la base (LS1-23) hasta sabulitas en el techo de cada capa; luego la suceden 2 - $3 \mathrm{~m}$ de areniscas masivas grises sin una morfología particular (LS1-5) y afectadas por diaclasamiento. Por encima aparece un canal de paraconglomerado de unos 2 - $3 \mathrm{~m}$ de espesor con morfología lenticular asimétrica y base erosiva sobre las areniscas masivas. Este cuerpo está asociado con canales arenosos satélites de pequeño tamaño (hasta 1 $2 \mathrm{~m}$ de ancho por $10-30 \mathrm{~cm}$ de alto, e.g. LS1-6), masivos y de colores amarillentos. Estos cuerpos de origen fluvial se encuentran sumergidos dentro una matrix metapelítica deformada con abundantes concreciones sedimentarias, similar a lo que se observa en la quebrada Seca en Los Llantenes. En los anexos (Anexos A1: P4 I y II) se presenta el perfil esquemático de estos afloramientos y la columna estratigráfica correspondiente a este pequeño bloque de afloramiento de la Formación Jagüel sobre el margen sur de la quebrada del Chuscho.

La deformación que afecta a la Formación Quebrada Seca - Jagüel es distinta de la milonitización intensa de esquistos y mármoles de la Formación Río Bonete y metabasitas y metasedimentitas de la Formacion Del Salto. Presentan un metamorfismo de bajo grado que se observa principalmente en las metapelitas (lutitas y pizarras) que llegan a obtener un brillo sedoso y tonalidades verdosas (filitas). En la quebrada Seca están afectadas por plegamientos cerrados (evidentes cuando aparecen capas arenosas) y metamorfismo de muy bajo grado. En el área del Chuscho la deformación predominante en las metapelitas se manifiesta por la formación de pliegues tipo kink y kink-bands en áreas localizadas, generalmente cerca de zonas de falla.

\section{b. Petrografía.}

Para la caracterización y clasificación de estas muestras se procedió con las mismas metodologías empleadas para las sedimentitas de la Formación del Salto. En la Tabla 3.5.1 se sintetizan algunas características texturales observadas. La mayor parte de las muestras de psamitas corresponden a vaques con abundante pseudomatriz. Las muestras LS1-5 y LS1-11 puedieron clasificarse usando el diagrama ternario Q-F-L (Gilbert, 1982) como vaque arcósico (casi lítico) y vaque lítico respectivamente (Figura 3.5.3).

En el bloque de afloramientos que se encuentra sobre la quebrada del Chuscho, las capas tabulares granocrecientes con que inicia la secuencia presentan una buena selección textural pero una mala selección composicional. Son de composición lítica mayormente (e.g.: LS1-23). Hay gran cantidad de líticos deformados, especialmente volcánicos alterados a clorita, minerales opacos y óxidos de hierro, líticos sedimentarios y metamórficos foliados, que pueden formar pseudomatriz, otorgando a la matriz un aspecto de 'parches' en los cortes delgados. El 
canal principal de paraconglomerado es polimíctico y con mala selección textural, con clastos líticos redondeados a sub-angulosos de metamorfitas de bajo grado (esquistos, filitas) y psamitas. En el afloramiento no se observaron clastos calcáreos ni de granitoides pero sí cristaloclastos de feldespato potásico y cuarzo.

Tabla 3.5.1: Litología y características texturales de las muestras sedimentarias de las Formaciones Jagüel y Quebrada Seca (Dv-Cb Inf).

\begin{tabular}{|c|c|c|c|c|c|c|}
\hline & \multirow[t]{2}{*}{ Muestra } & \multirow[t]{2}{*}{ Litología } & \multicolumn{2}{|c|}{ Granulometría } & \multirow[t]{2}{*}{ Redondez } & \multirow[t]{2}{*}{ Observaciones } \\
\hline & & & máx. & $\min$ & & \\
\hline \multirow{6}{*}{ 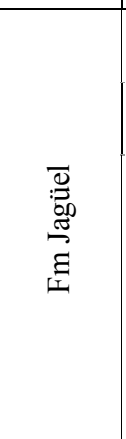 } & LS-20 & metavaque & $\begin{array}{l}\mathrm{m}(\mathrm{U}-\mathrm{L})- \\
\mathrm{fU}\end{array}$ & $\begin{array}{l}<\mathrm{vfL} \text { (matrix } \\
\text { recrist) }\end{array}$ & $\begin{array}{l}\text { Deform. } \\
\text { (milonita) }\end{array}$ & $\begin{array}{l}\text { Matriz pelítica invadida por Cal; } \\
\text { clastos de Q-F-Ms }\end{array}$ \\
\hline & LS-21 & metavaque & mU-cL & $<$ vfL (pelita) & $\mathrm{SR}-\mathrm{A}$ & $\begin{array}{l}\text { Idem CH10. Foliada, c/gradac. } \\
\text { granulom }\end{array}$ \\
\hline & LS1-5 & $\begin{array}{l}\text { vaque arcósico } \\
\text { (Q-F) }\end{array}$ & $\mathrm{c}(\mathrm{L}-\mathrm{U})$ & vf(L-U) & $\mathrm{R}-\mathrm{A}$ & Gradación granulom. \\
\hline & LS1-6 & arenisca lítica & $\mathrm{mU}$ & $\mathrm{fL}$ & $\mathrm{SR}-\mathrm{A}$ & $\begin{array}{l}\text { (Teñida c/alizarina). Grano- } \\
\text { sostén, con orto- y pseudomatriz }\end{array}$ \\
\hline & LS1-11 & vaque lítico & $\mathrm{m}(\mathrm{L})$ & vf(L-U) & SR - A & $\begin{array}{l}\text { Grano a matriz-sostén, orto y } \\
\text { pseudomtz. }\end{array}$ \\
\hline & LS1-23 & arenisca lítica & mU-cL & vfL & $\mathrm{SR}-\mathrm{A}$ & Clasto-sostén, pseudomtriz \\
\hline \multirow{7}{*}{ 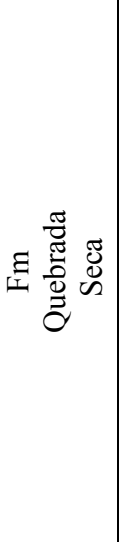 } & LL1 & vaque & $(\mathrm{cL})-\mathrm{mL}$ & $<$ vfL (pelita) & $\mathrm{SR}-\mathrm{A}$ & Cemento férrico \\
\hline & LL2 & pelitas/filitas & - & - & - & $\begin{array}{l}\text { Fosiliferas y con abundantes } \\
\text { concresiones. }\end{array}$ \\
\hline & LL2-Fpi & lutita & vfU & $<$ vfL (pelita) & A & Concresión sedim en LL2. \\
\hline & LL11b & lutita & - & - & - & \\
\hline & LL11c & lutita & - & - & - & \\
\hline & LL18 & vaque & $\mathrm{mL}$ & $\mathrm{fU}$ & $\mathrm{SR}-\mathrm{A}$ & $\begin{array}{l}\text { Capa arenosa intercalada entre las } \\
\text { pelitas LL19 }\end{array}$ \\
\hline & LL19 & lutita & - & - & - & $\begin{array}{l}\text { Con intercalacion blanquecina } \\
\text { (LL19obs) de material } \\
\text { inconsolidado (piroclastico?) }\end{array}$ \\
\hline
\end{tabular}

Los canales arenosos están compuestos por areniscas verdosas, líticas y arcósicas (e.g.: LS1-6). La matriz pelítica se encuentra en baja proporción y está compuesta principalmente por cuarzo e illita recristalizados y de grano fino, y la materia orgánica que se preserva como agregados opacos o castaños terrosos y dispersos. La Illita suele formar pequeñas colas en los clastos. Los líticos son de variadas composiciones: líticos con foliación metamórfica compuestos por cuarzo y filosilicatos ( \pm opacos); líticos volcánicos alterados compuestos por cloritas y opacos, muchas veces teñidos con óxidos de hierro; líticos sedimentarios pelíticos y arenosos. Los clastos líticos más dúctiles se encuentran deformados por los clastos más resistentes y en casos extremos se presentan como pseudomatriz. Los clastos cuarzosos son angulosos, suelen presentar extinción ondulosa y comúnmente bordes irregulares. Se han observado algunos granos con engolfamientos indicando un probable origen volcánico en las áreas de procedencia. Los feldespatos son principalmente de plagioclasas, pero también puede haber feldespato potásico. También aparecen granos de cuarzo policristalino/chert con subgranos muy finos, que pueden o 


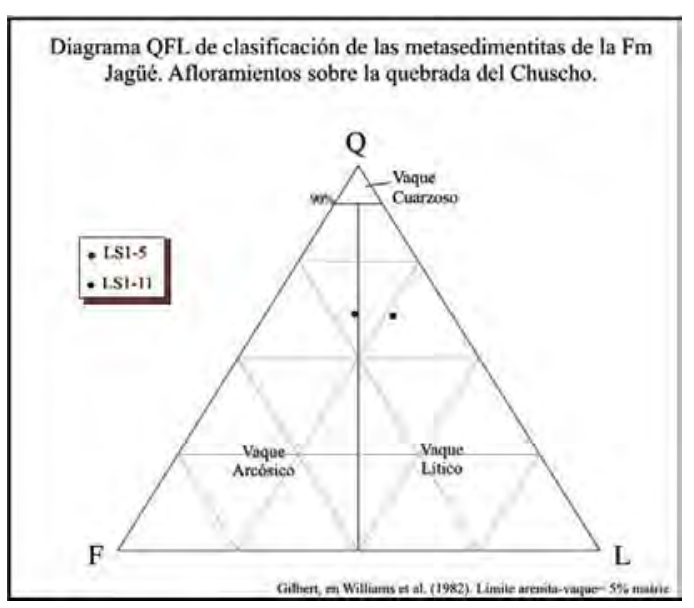

Figura 3.5.3: Diagrama ternario Q-F-L de clasificación modal de los vaques de la Formación Quebrada Seca en el bloque que aflora en el tramo medio de la quebrada del Chuscho. Límite arenitas-vaques: 5\% de matriz (Gilbert, 1982).

no presentar impurezas de otros minerales (opacos, clorita, illita, etc.). También hay un aporte de granos calcáreos y mas raramente de micas detríticas de mayor tamaño (muscovita).

En el área de Los Llantenes dentro de la Formación Quebrada Seca predominan las pelitas concrecionales (LL2 y LL2pi) similares a las que engloban a los canales arenosos y conglomerádicos en el área del Chuscho. La muestra LL18 corresponde a un banco potente de areniscas intercalado entre las pelitas de la Formación Quebrada Seca (LL19); tiene características similares a la muestra LS1-23 pero no se observan variaciones granulométricas internas. No se hallaron cuerpos conglomerádicos en este área.

Los vaques tienen clastos calcáreos, rocas básicas y pelitas. Son bastante maduros texturalmente aunque no composicionalmente. Tienen empaquetamiento apretado y textura clasto-sostén, aunque la abundante cantidad de líticos alterados o deformados da la apariencia de una textura matriz-soportada donde la matriz es pseudomatriz. Los clastos son angulosos hasta subredondeados. Esto sumado a la gran abundancia de líticos preservados, indican que no hubo mucho transporte. Los líticos son principalmente metasedimentarios cuarzo-micáceos (pizarras, vaques y heterolíticos; Lm) con mayor o menor proporción de opacos. Se observan líticos plutónicos (Lp) compuestos principalmente de cuarzo + plagioclasa \pm muscovita, así como abundantes líticos volcánicos alterados (Lv alt) de composiciones intermedias a básicas compuestos de clorita \pm actinolita \pm plagioclasa + óxidos de hierro de colores castaños y verdosos; algunos han preservado texturas volcánicas relícticas microporfíricas o seriadas. Además de los líticos, lo que más abunda es el cuarzo monocristalino (Qm) con extinción ondulosa. También se encuentra cuarzo policristalino de origen metamórfico de grano fino, con subgranos recristalizados y orientados (Lm cuarzoso), y en menor medida granos de cuarzo policristalino de origen sedimentario (chert, de grano muy fino; Qp). Los feldespatos aparecen en variable proporción según la muestra, principalmente es plagioclasa (Pl). Otros detritos presentes son las micas blancas detríticas (muscovita), y clastos de calizas. Se han observado clastos verdosos de minerales máficos resistentes (hornblenda?). 
En cuanto a la deformación las facies arenosas no muestran microestructuras de deformación importante. Se observan granos fracturados, cuarzos con extinción ondulosa, y micas y líticos algo flexurados o deformados in situ por la compactación. En las pelitas se observa orientación de fábrica y formación de clivaje. En los afloramientos se observa que han sido transformadas en pizarras y filitas con tonalidades grises y verdosas, con formacion de kink-bands localizados. El índice de cristalinidad de la illita (KI) determinado en dos de las muestras de esta unidad sobre la quebrada del Chuscho son coherentes con un grado de epizona, con valores de 0,24 para la muestra LS1-6 y 0,20 para LS1-11. Estos valores son bastante similares a los que se obtuvieron para la Formación del Salto en el mismo sector (Tabla 3.5.2), indicando que han llegado a Epizona (facies de Esquistos Verdes). Esto es coherente con la composición de los argilominerales observados ya que en la evolución diagenética de los filosilicatos la asociación de Ill + Chl se alcanza al final de la serie, ya habiendo superado el límite del metamorfismo de muy bajo y bajo grado.

Tabla 3.5.2: Valores del índice de Kübler (KI) obtenido para las muestras metasedimentarias de la Formación Jagüel en el área del Chuscho.

\begin{tabular}{|c|c|c|c|c|}
\hline Muestra & KI & Zona diagenética correspondiente & Roca asociada & Unidad \\
\hline LS1-6 & 0,24 & Epizona & Pizarra & Fm Quebrada Seca \\
LS1-11 & 0,20 & Epizona & Pizarra & Fm Quebrada Seca \\
\hline
\end{tabular}

\section{c. Geoquímica}

No se han realizado análisis geoquímicos en las muestras del área de Los Llantenes, pero si en tres muestras de la quebrada del Chuscho: LS1-23, LS1-5 y LS1-6. Los valores de CIA son variables en estas pocas muestras debido aparentemente a que su comportamiento esta afectado por la composición (lítica y arcósica subordinada) de las muestras y a alteración. Las muestras LS1-5 y LS1-6 se descartaron ya que la sumatoria de los calculos en la primera supera el $100 \%$, mientras que la muestra LS1-6 presenta un valor muy bajo $(43,87)$ que se solapa con los valores típicos de rocas básicas; esto estaría relacionado más que nada con la influencia de carbonatos (y albitización) que a los procesos de meteorización. Por ello, la clasificación de las muestras se realizó esencialmente en base a la petrografía.

La muestra LS1-23 presenta un comportamiento particular debido a su composicion muy feldespática y lítica. Es una arenisca lítica gruesa, sin embargo geoquímicamente se asemeja a las pelitas (ej. LS2-3, CIA=71,8). Esto puede deberse a que presenta una mayor cantidad de matriz sumado a la composición de los líticos. Presenta bajas concentraciones de $\mathrm{SiO}_{2}(58,64 \%)$ y altos contenidos de $\mathrm{Al}_{2} \mathrm{O}_{3}(18,6 \%)$. En los diagramas de tierras raras normalizados al condrito C1 (Taylor y McLennan, 1985) no presenta anomalía de Eu mientras que en los diagramas normalizados a la corteza superior (UCC) y al PAAS (Taylor y McLennan, 1985) esta es positiva, lo que estaría indicando un fuerte control litológico en su 
comportamiento geoquímico, especialmente por la abundancia de plagioclasas relacionado probablemente con un mayor aporte volcánico (Figura 3.5.3a-c).
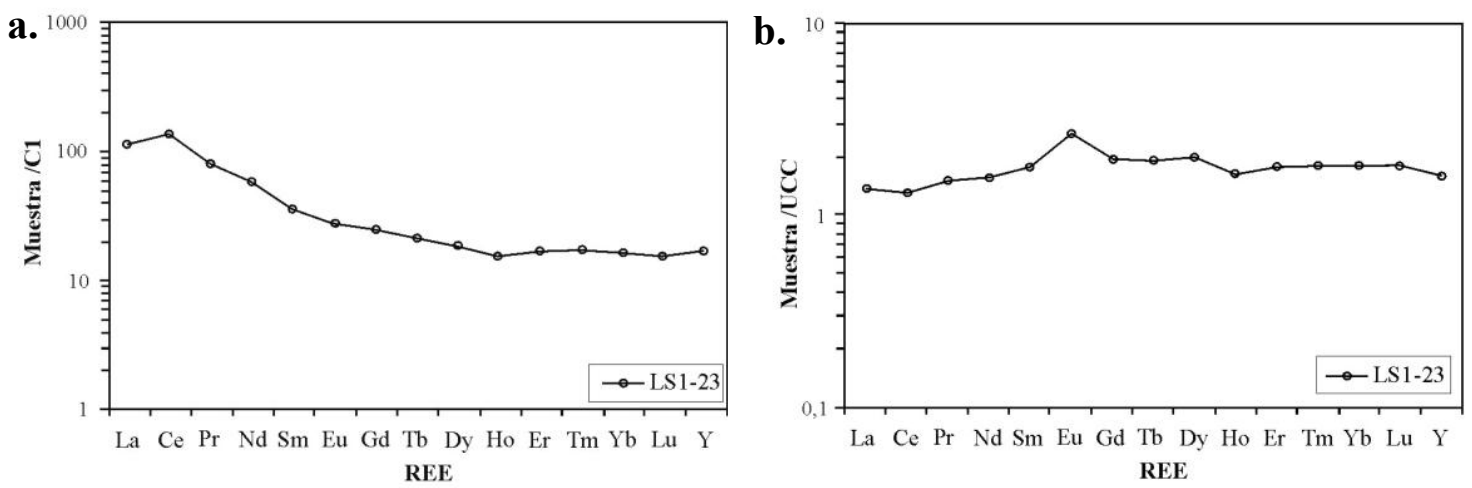

Figura 3.5.3: Diagramas de tierras raras de la muestra LS1-23 normalizados al condrito C1 (a), a la corteza continental superior (UCC, b) y a la pelita postarqueana promedio (PAAS, c). (Taylor y McLennan, 1985).

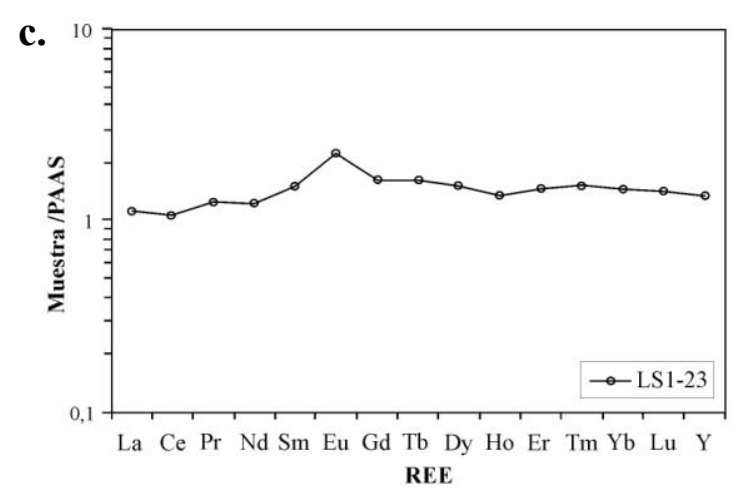

\section{d. Fósiles}

Cravero et al. (1984) describen la unidad como una sucesión grano-decreciente a la que interpretaron como los componentes sedimentarios del Miembro Cerro Cóndor de la Formación Río Bonete (considerada ordovícica, Aceñolaza y Bernasconi, 1969a; Aceñolaza et al., 1971), considerando solo a las rocas metamórficas dentro del Miembro Cerro Cóndor y reuniendo a las rocas sedimentarias bajo lo que los autores definen como Formación Quebrada Seca. En su esquema estratigráfico ubican a la Formación Río Bonete, dentro del Cámbrico Superior y a la Formación Quebrada Seca dentro del Ordovícico, debido a que consideran a ésta última como equivalente a las lutitas y sedimentitas del área del cerro Chuscho - río Bonete en las que se hallaron fósiles ordovícicos (graptolitos y bivalvos de las Lutitas del Salto, Aceñolaza y Bernasconi, 1969; Aceñolaza, 1970; Aceñolaza et al, 1971).

Sin embargo, en las metapelitas de la Formación Quebrada Seca se han hallado las primeras briznas y restos vegetales, y una fauna de invertebrados marinos bentónicos, principalmente braquiópodos, y otros restos de invertebrados indeterminados, cuya preservación lamentablemente no es buena debido a la oxidación y a la fuerte deformación de las pizarras y filitas que contienen el material (Figura 3.5.4a-g). La presencia de estos fósiles en el área en que 

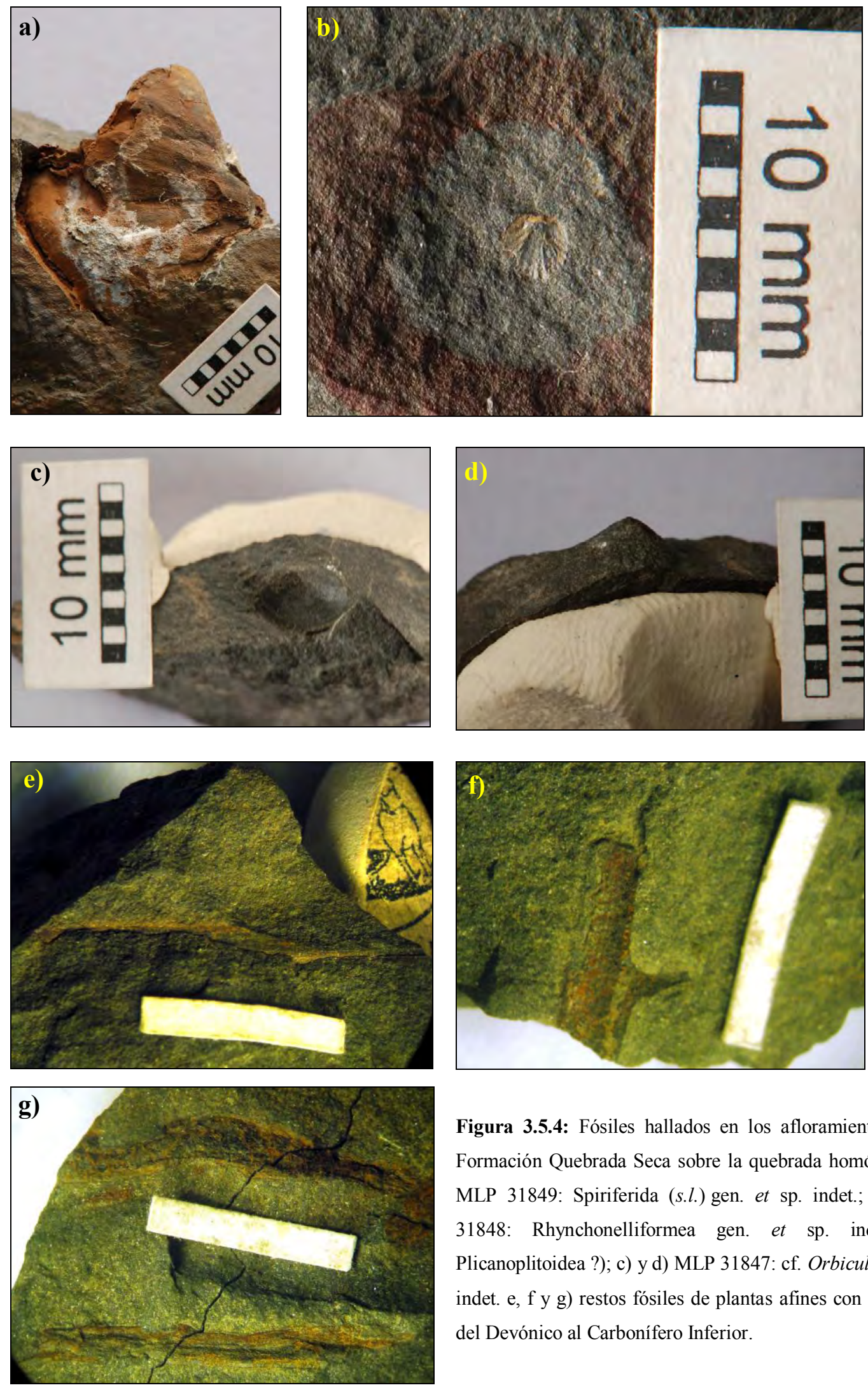

Figura 3.5.4: Fósiles hallados en los afloramientos de la Formación Quebrada Seca sobre la quebrada homónima: a) MLP 31849: Spiriferida (s.l.) gen. et sp. indet.; b) MLP 31848: Rhynchonelliformea gen. et sp. indet. (cf. Plicanoplitoidea ?); c) y d) MLP 31847: cf. Orbiculoidea sp. indet. e, f y g) restos fósiles de plantas afines con las floras del Devónico al Carbonífero Inferior. 
fuera definida, reubica estratigráficamente a la Formación Quebrada Seca entre el Devónico y el Carbonífero Inferior. La flora está compuesta por briznas y restos vegetales del Devónico Superior hasta Carbonífero Inferior, no siendo posible una determinación mas precisa. La fauna de invertebrados que ha sido posible determinar está compuesta por los braquiópodos cf. Orbiculoidea sp. indet. (Repositorio del Museo de La Plata MLP 31847), Rhynchonelliformea gén. et sp. indet. (cf. Plicanoplitoidea?; MLP 31848), y Spiriferida (s.l.) gén. et sp. indet. (MLP 31849. Figura 3.5.4). Las conchillas comúnmente están alteradas, corroídas o disueltas, mientras que la deformación hace que la roca se desarme y sea casi imposible obtener lajas de tamaño suficiente como para que el material se preserve. A pesar de ello, la asociación hallada permite reubicar estratigráficamente estos afloramientos entre el Devónico hasta posiblemente Sil? por un braquiópodo Spiriferida (s.l.; gen. et sp. indet.) y el Carbonífero Inferior.

\section{Ambiente de depositación}

La asociación fosilífera hallada en las metapelitas de la quebrada Seca hace pensar que se depositaron en un ambiente de plataforma marina de baja energía y cercana a la costa, de donde provienen los restos vegetales; o bien, que los restos de vegetales e invertebrados fueron arrastrados por alguna corriente turbidítica (o similar) hacia mayores profundidades.

Las capas iniciales estratocrecientes de la columna estratigráfica preservada en el área del Chuscho pudieron haberse generado en una ambiente de playa, con alta energía, mientras que la secuencia posterior, de menor y baja energía, podría interpretarse como una inundación de la plataforma, en la que se desarrolla un sistema fluvio - deltáico. Otra opción es que las capas estratocrecientes representen depósitos de desbordamiento de los mismos ambientes de abanicos subácueos. Esta última opción parece la más probable (ver esquema de interpretación en los Anexos A1: P4 II). La asociación de facies se asemeja a las que pueden encontrarse en abanicos aluviales relacionados con crecidas en manto ${ }^{(1)}$. Los ambientes de abanicos aluviales se forman en frentes montañosos y los procesos dominantes en el transporte y acumulación son: flujos gravitacionales, crecidas en manto y flujos fluidos.

1- Los flujos gravitacionales ocurren en zonas más proximales, por lluvias excepcionales en ambientes áridos, tienen bases netas, y se componen de brechas y conglomerados matrizsosten.

2- ${ }^{(1)}$ : crecidas en manto. Son flujos no canalizados de corta duración que ocurren en condiciones de alto régimen; tienen distribución variable y poca profundidad $(<50 \mathrm{~cm})$. Son abanicos pequeños a medianos, comunes en zonas aridas formados por areniscas y areniscas conglomerádicas con capa plana de alto régimen. Facies asociadas a flujos no confinados; estratos delgados ligados a crecidas individuales. 
3- flujos fluidos. Se da en regimenes con lluvias más estables, en pendientes estables; diseño de canales distributarios; retrabajan los depositos previamente descriptos. Se generan cambios granulométricos importantes por ejemplo.

\section{Correlación}

Por su edad y características, la Formación Quebrada Seca (Cravero et al., 1984) es muy similar a las Formaciones Jagüel y Agua de Lucho descriptas por González y Bossi $(1986,1987)$ hacia el sur del Cerro Chuscho. Por su litología, edad y ubicación de los afloramientos en el contexto regional podría ser equivalente a la Formación Punilla (Furque, 1956, 1972). También a la Formación Malimán (Tournasiano; Scalabrini Ortiz, 1973) dentro del Grupo Angualasto (Scalabrini Ortiz, 1973).

Por otra parte, aunque previamente fue mapeada dentro de la Formación Guandacol (Aceñolaza et al., 1971, Maisonave, 1979), recientemente se ha mencionado que la Formación Cerro Tres Cóndores (González y Bossi, 1987) podría ser equivalente a la Formación Cortaderas (Carbonífero Inferior alto), unidad superior del Grupo Angualasto (Scalabrini Ortiz 1973; Martina y Astini, 2009). Considerando este último caso, en este sector de la Precordillera el Grupo Angualasto estaría integrada por la Formación Quebrada Seca y equivalentes (miembro inferior de grano fino) y por los conglomerados de la Formación Cortaderas (Cuadro 3.5.1).

Cuadro 3.5.1: Cuadro esquemático comparativo en el que se observan las correlaciones estratigráficas sugeridas para las Formaciones Quebrada Seca y Jagüel/Agua de Lucho (Dv-Cb Inf.)

\begin{tabular}{|c|c|c|c|}
\hline $\begin{array}{c}\text { Precordillera de } \\
\text { San Juan y La Rioja }\end{array}$ & Precordillera de Jagüé & \multicolumn{2}{|c|}{$\begin{array}{l}\text { Precordillera de San Juan } \\
\text { (Río Blanco) }\end{array}$} \\
\hline Fm Guandacol & $\begin{array}{l}\text { Fm Cerro Tres Cóndores } \\
\text { (Cb Inf.) }\end{array}$ & $\begin{array}{c}\text { Fm Cortaderas } \\
\text { (Cb Inf. - Viseano) }\end{array}$ & ब্ \\
\hline $\begin{array}{c}\text { Fm Punilla } \\
\text { (Dv - Cb Inf.) }\end{array}$ & $\begin{array}{l}\text { Fms Jagüel/ Agua de Lucho y } \\
\text { Quebrada Seca (Dv-Cb Inf.) }\end{array}$ & $\begin{array}{c}\text { Fm Malimán } \\
\text { (Cb Inf. - Tournasiano) }\end{array}$ & $\begin{array}{l}\overrightarrow{\mathrm{N}} \\
\overrightarrow{0} \\
\underset{\vec{\omega}}{\omega}\end{array}$ \\
\hline
\end{tabular}

\section{e. Correlación estratigráfica}

\section{Síntesis:}

La Formación Quebrada Seca está conformada por metapelitas concrecionales con restos de plantas e invertebrados que engloban canales arenosos y gravosos, y presentan algunas capas arenosas con estructuras sedimentarias superficiales hacia la base de la unidad. Son cubiertas en discordancia angular por los conglomerados de la Formación Guandacol (Los Llantenes). Los invertebrados así 
como los restos vegetales hallados contribuyen al conocimiento y estratigrafía de esta unidad. Estos indicarían que los sedimentos se habrían depositado en un ambiente fluvio-deltaico o marino cercano a la costa y en general con baja energía. La presencia de estos fósiles en el área en que fuera definida, reubican a la Formación Quebrada Seca entre el Devónico y el Carbonífero Inferior. La deformación no ha permitido una buena preservacion del material por lo que no ha sido posible acotar mejor su edad. Sobre la Quebrada del Chuscho aparece un bloque de características similares que correspondería a la unidad mapeada como Formación Jagüel o Jagüé en ese sector, unidad a la cual sería equivalente.

Evidencias petrográficas que contribuyen a la estratigrafía:

La presencia de clastos metapelíticos heterolíticos (e.g. LS1-23) y otros similares a las rocas sedimentarias estratificadas de la Formación del Salto, sugierien que estos sedimentos son posteriores y erosionaron a las metasedimentitas ordovícicas. También hay líticos volcánicos alterados (diabasas o basaltos por su textura), así como abundante cuarzo y líticos plutónicos, por lo que se habrían erosionado también las rocas básicas y rocas graníticas. El aporte de material de la Formación Río Bonete queda en evidencia por la presencia de clastos calcáreos y de líticos metamórficos esquistos de grano fino similares a los de esa unidad, compuestos por cuarzo recristalizado y micas orientadas.

Cravero et al. (1984) describieron la secuencia hasta entonces ordovícica de la Formación Río Bonete en Los Llantenes compuesta por esquistos y calizas, separando de esta unidad a sedimentos marinos de granometría variable que asignan a la Formación Quebrada Seca. Estos autores mencionaron además, que las sedimentitas están parcialmente cubiertas por efusivas básicas (lavas almohadilladas) y cortadas por sus diques asociados (Figura 2. Cravero et al. 1984, en Fauque y Villar, 2003)

En base a las observaciones de campo, el cuerpo de paraconglomerado que aparece en la quebrada del Chuscho es distinto al conglomerado rojo carbonífero (sección 3.2.8). Representa un canal aislado de paraconglomerado con tonalidades gris-verdosas a castañas. No se observan clastos de calizas ni de esquistos sino que la mayor parte son sedimentarios y algunos de volcánitas básicas; tampoco aparecen clastos graníticos (aunque si cristales de feldespato potásico), por lo que este no afloraba aun o se encontraba fuera del área de aporte fluvial. Los clastos son redondeados y gradan su granulometría hasta ser parte de la matriz. Martina y Astini (2009, p. 326) consideran los conglomerados de la quebrada del Chuscho dentro de lo que denominan Formación Chuscho (equiv. a Formación Del Salto), y consideran que fueron originados por el material que provino de la exhumación y erosión de la faja de deformación de Jagüé, a la que vinculan con el emplazamiento del terreno Precordillera contra el margen occidental de Gondwana" durante la orogenia Oclóyica (Ordovícico Medio). Sin embargo estos conglomerados corresponden a un canal fluvial que se 
encuentra dentro de un bloque pequeño de la Formación Jagüel ( $\mathrm{Dv}$ - Cb Inf., equivalente a la Formación Quebrada Seca en el área de Los Llantenes) intercalado tectónicamente entre las metasedimentitas estratificadas y lavas almohadilladas ordovícicas.

Estratigrafía del Carbonifero en la región (Cuadro 3.5.2):

En la Precordillera riojana, ubicada al oeste de Jagüé, afloran dos secuencias sedimentarias carboníferas, una eocarbonífera y otra neocarbonífera, Se diferencian por su litología, contenido fosilífero, paleoambientes de sedimentación y estilo tectónico, y están separadas por una fuerte discordancia angular asociada a diastrofismo. Estas secuencias evidencian interrupciones en la sedimentación y deformación, a la que están asociados períodos de intrusión o extrusión de rocas magmáticas (Fauqué y Limarino, 1991).

Los primeros registros del Carbónico Inferior en la zona de la Precordillera riojana corresponden a los trabajos de González y Bossi (1986) al O de Jagüé, Fauqué et al. (1989) en el río de la Troya, Fauqué y Limarino (1991) en el área de Agua de Carlos (también llamada Agua de Cándido), y Aceñolaza (1971) describió el volcanismo eocarbónico.

Las unidades Devónico-Carbonífero Inferiores es lo que Borrello (1955) denominó 'Jagüeliano', y fueron denominadas como Formación Guandacol por Aceñolaza et al. (1971) y Formación Jagüel por González y Bossi (1986) al oeste de la localidad de Jagüé, en la desembocadura del río del Peñón; luego separadas como Formaciones Jagüel, Agua de Lucho y Cerro Tres Cóndores por González y Bossi (1987). Se indica además que esta sucesión sería correlacionable con la Formación Punilla, descripta en el sector septentrional de la mencionada sierra (Caminos et al. 1993) y más al sur con las Formaciones Malimán y Cortaderas (Limarino y Césari 1992). Presenta abundantes fósiles de la Fauna de Protocanites (Fauqué et al., 1989) y de la Flora de Lepidodendropsis (González y Bossi, 1986, 1987; Fauqué et al. 1989). Durante la depositación de esta secuencia hubo una importante actividad magmática, propia de una región orogénica, muy bien registrada en la Precordillera riojana, representada por pequeños plutones aislados de composiciones intermedias y rocas filonianas andesíticas y básicas y stocks de composición diorítico-tonalítica emplazadas en las sedimentitas (Fauqué y Villar, 2003).

El Carbónico Medio a Superior está representado en la región por las sedimentitas epiclásticas gris-blanquecinas de la Formación Río del Peñón (Borrello 1955, González y Bossi, 1986) y por las rocas básicas de la Formación Punta del Agua (Aceñolaza et al 1971; González y Bossi, 1986) que se intercalan en la parte inferior de la secuencia sedimentaria. Otros nombres equivalentes usados para estas rocas son Formación Tupe (Aceñolaza et al., 1971), Formacion Quebrada Larga (Scalabrini Ortiz, 1972) y Formación Volcán (Aceñolaza, 1971).

En la zona de Agua de Carlos es posible observar una fuerte discordancia angular que marca el contacto entre ambas secuencias, asociado a la Fase Diastrófica Río Blanco propuesta por Fauqué y 
Limarino (1991), causante de la deformación por plegamiento y asociada a magmatismo. Los depositos del Carbonífero inferior tienen plegamientos de longitud de onda baja a moderada mientras que los del Carbonífero Medio a Superior solo poseen plieguesde longitud de onda alta (sinclinal de Rincón Blanco).

Cuadro 3.5.2: Estratigrafía comparativa para el Paleozoico Superior de la Precordillera de Jagüé y alrededores.

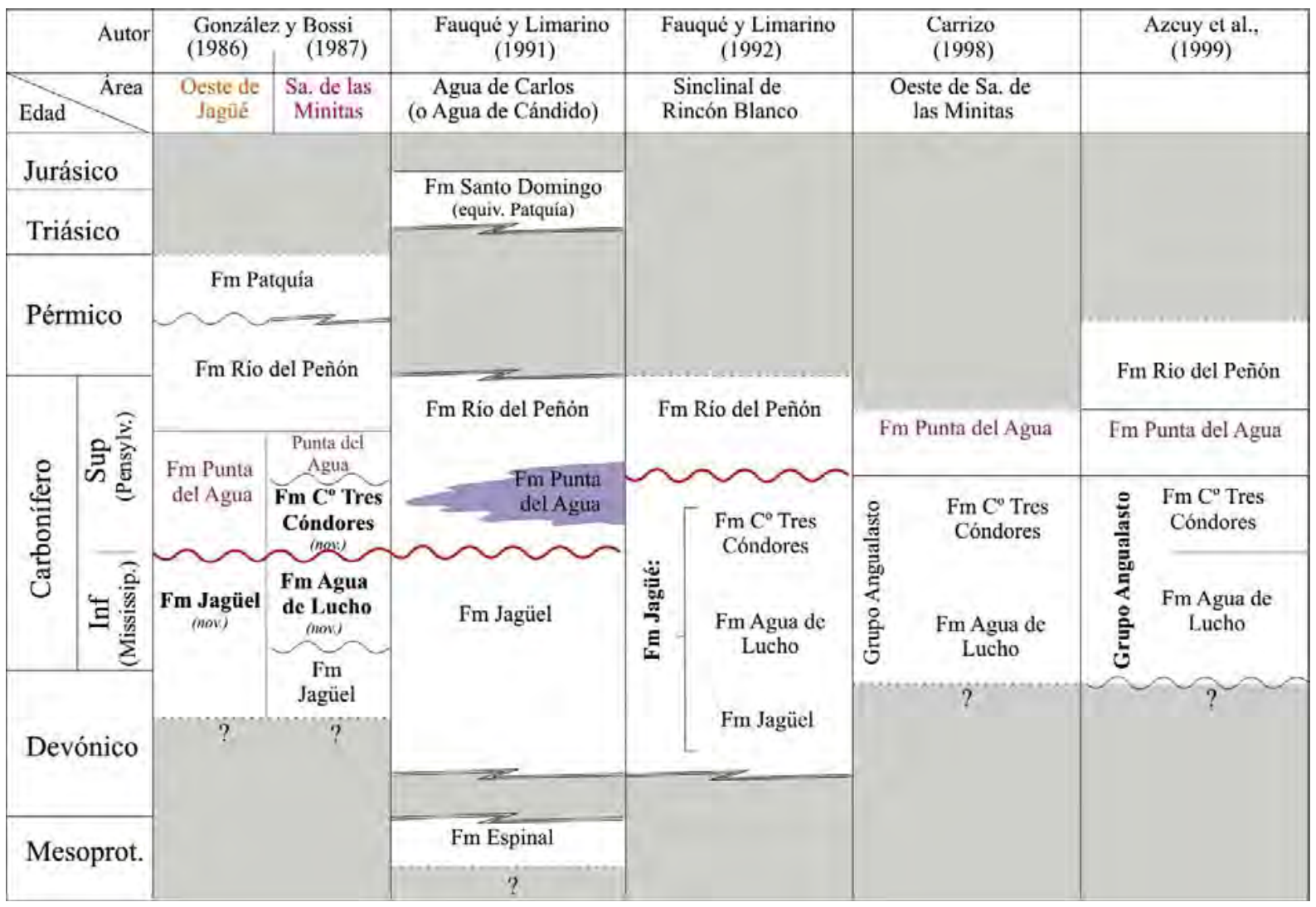

3.2.6- GRANITO POTRERILlOS (Aceñolaza y Bernasconi, 1969b) o FORMACIÓN POTRERILLOS (Maisonave, 1979).

\section{Introducción}

El Granito Potrerillos (Aceñolaza y Bernasconi, 1969b) está expuesto a los $68^{\circ} 30^{\prime} \mathrm{O}$ y $28^{\circ}$ 27'S, en la denominada Precordillera de Jagüé, en el extremo norte de la Precordillera s.s. (Frigerio et al., 2010, Figura 3.6.1). Aflora en un bloque limitado por fallas regionales con rumbos meridionales que lo exponen en contacto hacia el este con los asomos más occidentales del basamento metamórfico mesoproterozoico de las Sierras Pampeanas Occidentales (Formación Espinal) y hacia el oeste con el Paleozoico Inferior y Superior del ámbito nor-precordillerano. Al sudoeste está afectado por la 'faja 
de deformación de Jagüé' expuesta a lo largo de la quebrada del río Bonete, mientras que al sudeste se encuentra cubierto por los abanicos cenozoicos que circundan el Bolsón de Jagüé. Entre los estudios previos que aportan información sobre este granitoide en su contexto regional, se pueden mencionar a Aceñolaza y Bernasconi (1969b), Aceñolaza et al. (1971), Caminos (1972), Maisonave (1979) y más recientemente a Caminos y Fauqué (2004).

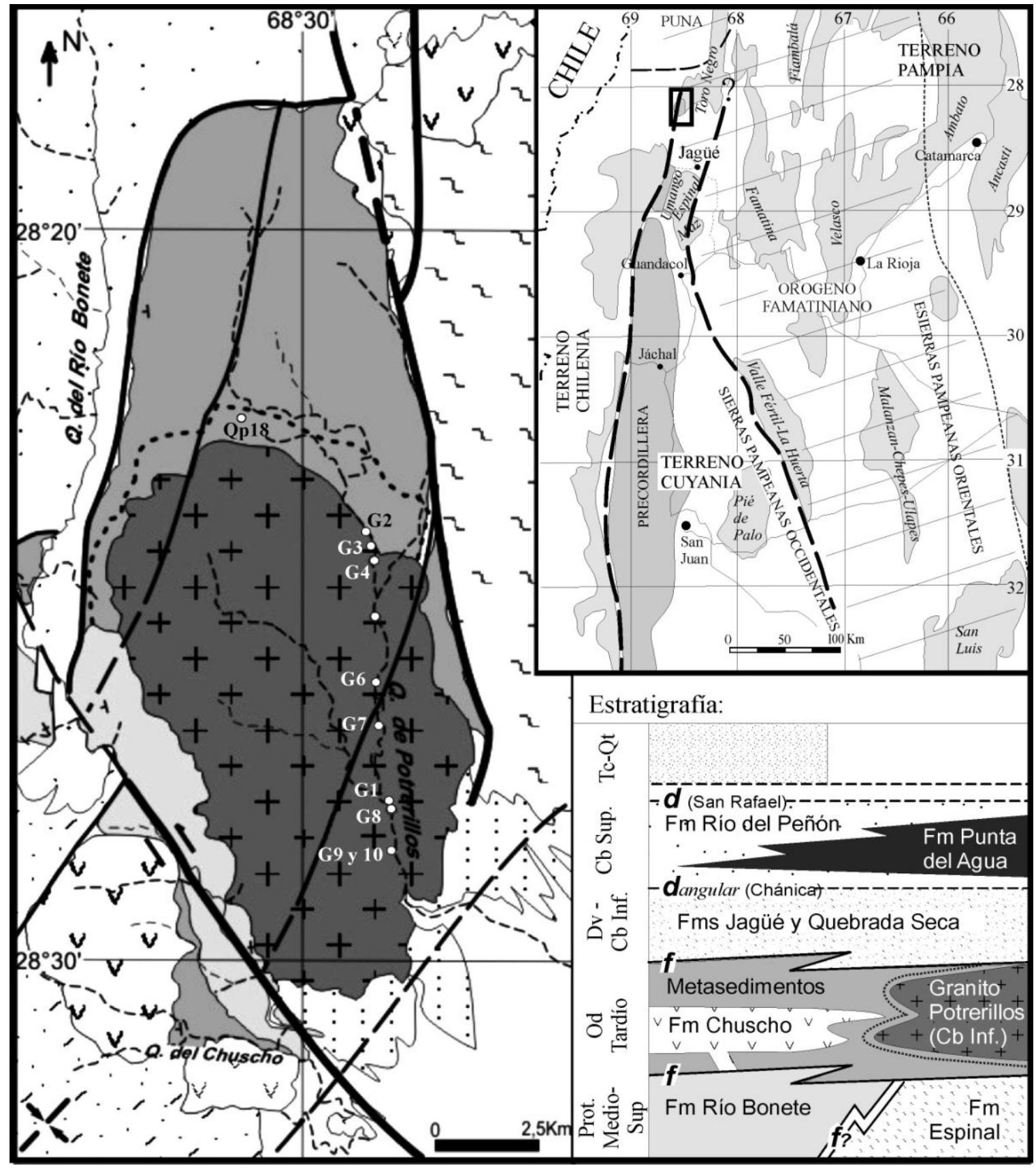

Figura 3.6.1: Ubicación regional de la zona de estudio, bosquejo geológico, columna estratigráfica y posicionamiento de las muestras analizadas.

Las rocas de caja del plutón Potrerillos son las metasedimentitas ordovícicas (a silúricas) de la Formación del Salto (Frigerio, 2008a, b; Martina y Astini, 2009), que fueron parcialmente asimiladas por el magma. En las imágenes satelitales es posible observar cómo el granito, las rocas de caja y la 
aureola de contacto generada, son desplazadas posteriormente por fallas. En su extremo sudoeste el cuerpo granítico también está intruyendo a los esquistos de la 'faja de deformación de Jagüé', siendo a su vez afectado por una tectónica posterior de reactivación de la mencionada faja de cizalla. El mapeo más detallado del cuerpo intrusivo en el contexto geológico de la zona, la producción de análisis petrográficos, geoquímicos y geocronológicos, resultará importante para constreñir la historia tectónica del extremo norte de la Precordillera.

En general, las rocas plutónicas de la Precordillera de Jagüé se consideraron como pertenecientes al 'arco magmático gondwánico' típico de la Cordillera Frontal, incluyendo al Granito Potrerillos (e.g. Llambías y Caminos, 1987; Llambías, 1999). Este arco tiene distribución norte-sur, composiciones intermedias dominantes y características típicamente calco-alcalinas (Llambías, 1999). Sin embargo, recientemente se discutió la posibilidad que pudieran corresponder a ciclos magmáticos distintos (Frigerio et al., 2010).

La petrografía, características geoquímicas y ambiente tectónico de formación del granito ya fueron sintetizados en Frigerio (2008a)

\section{a- Afloramientos}

Se trata de un plutón de forma elipsoidal en superficie, con aproximadamente $13 \mathrm{~km}$ de largo en sentido N-S y $6 \mathrm{~km}$ de ancho. Los afloramientos principales se encuentran en su área tipo, sobre la quebrada de Potrerillos y sus afluentes Esta quebrada atraviesa de norte a sur al plutón por su lado oriental cortando las distintas facies que lo componen (Anexos A1: M4 y M5). También hay algunos asomos menores ascendiendo por el margen oriental de la quebrada del río Bonete, especialmente en sus tramos inferior y medio (Figura 3.6.1).

En las quebradas de Potrerillos y río Bonete pueden encontrarse diques subverticales cortando a las metasedimentitas de caja y metamorfitas de la faja de cizalla, que son interpretados como apófisis externas del plutón. Estos diques tienen rumbos $\mathrm{NE}$ a $\mathrm{E}$ y en la quebrada del río Bonete predominan NO.

También afloran otras dos variedades de diques subverticales, unos de tipo lamprofírico de tonos verdosos, con cristales de $\mathrm{Hbl}$ en pasta alterada que constituyen parte de estas apófisis externas del plutón que han sido más afectadas por la alteración, y otros negros y afaníticos de composición basáltica que cortan tanto a los diques previamente descriptos (en la quebrada del Bonete) como al cuerpo principal del plutón y a sus enclaves sedimentarios.

Las muestras para su estudio en laboratorio se tomaron a lo largo de la quebrada de Potrerillos y en el extremo suroeste ascendiendo por la desembocadura de la quebrada del Bonete (Figura 3.6.1, Tabla 3.6.1). 
Tabla 3.6.1: Coordenadas de ubicación y clasificación modal de las muestras ploteadas en la Figura 3.6.8. En la columna derecha se ha ploteado además el índice de color M’ de cada una.

\begin{tabular}{|c|c|c|c|c|}
\hline MUESTRA & LATITUD & LONGITUD & $\begin{array}{c}\text { Clasificación modal } \\
(Q A P F, \text { Le Maitre, } \\
\text { 1989) }\end{array}$ & Índice de Color $\left(M^{\prime}\right)$ \\
\hline \multicolumn{5}{|c|}{ Quebrada de Potrerillos: } \\
\hline G1 & $28^{\circ} 27^{\prime} 32.20^{\prime \prime} \mathrm{S}$ & $68^{\circ} 28^{\prime} 47.50^{\prime \prime} \mathrm{W}$ & Anortosita & leucocrática \\
\hline G2 & $28^{\circ} 23^{\prime} 51.40^{\prime \prime} \mathrm{S}$ & $68^{\circ} 29^{\prime} 13.50^{\prime \prime} \mathrm{W}$ & (Monzo -)granito & holo-leucocrática \\
\hline G3 & $28^{\circ} 24^{\prime} 4.00^{\prime \prime} \mathrm{S}$ & $68^{\circ} 29^{\prime} 9.20^{\prime \prime} \mathrm{W}$ & - & - \\
\hline G4 & $28^{\circ} 24^{\prime} 5.00^{\prime \prime} \mathrm{S}$ & $68^{\circ} 29^{\prime} 8.20^{\prime \prime} \mathrm{W}$ & (Monzo-)granito & holo-leucocrática \\
\hline G5 & $28^{\circ} 25^{\prime} 1.70^{\prime \prime} \mathrm{S}$ & $68^{\circ} 29^{\prime} 5.00^{\prime \prime} \mathrm{W}$ & Tonalita & \\
\hline G6 & $28^{\circ} 26^{\prime} 6.20^{\prime \prime} \mathrm{S}$ & $68^{\circ} 29^{\prime} 2.50^{\prime \prime} \mathrm{W}$ & Granodiorita & holo-leucocrática \\
\hline G7 & $28^{\circ} 26^{\prime} 35.70^{\prime \prime} \mathrm{S}$ & $68^{\circ} 28^{\prime} 59.70^{\prime \prime} \mathrm{W}$ & Tonalita - granodiorita & leucocrática \\
\hline G8 & $28^{\circ} 27^{\prime} 35.50^{\prime \prime} \mathrm{S}$ & $68^{\circ} 28^{\prime} 50.60^{\prime \prime} \mathrm{W}$ & Gabro hornbléndico & leucocrática(meso--) \\
\hline G9 & $28^{\circ} 28^{\prime} 22.60^{\prime \prime} \mathrm{S}$ & $68^{\circ} 28^{\prime} 44.40^{\prime \prime} \mathrm{W}$ & (Monzo -)granito & holo-leucocrática \\
\hline G10 & $28^{\circ} 28^{\prime} 22.60^{\prime \prime} \mathrm{S}$ & $68^{\circ} 28^{\prime} 44.40^{\prime \prime} \mathrm{W}$ & Anortosita & leucocrática \\
\hline G10 enclave & “ & “ & Anortosita & mesocrática \\
\hline \multicolumn{5}{|c|}{ Quebrada del Bonete: } \\
\hline G11 & $28^{\circ} 28^{\prime} 57.20^{\prime \prime} \mathrm{S}$ & $68^{\circ} 31^{\prime} 26.00^{\prime \prime} \mathrm{W}$ & - & - \\
\hline G12 & $28^{\circ} 28^{\prime} 59.80^{\prime \prime} \mathrm{S}$ & $68^{\circ} 31^{\prime} 23.50^{\prime \prime} \mathrm{W}$ & Gabro hornbléndico & mesocrática \\
\hline BO9-I & $28^{\circ} 27^{\prime} 32.60^{\prime \prime} \mathrm{S}$ & $68^{\circ} 32^{\prime} 51.80^{\prime} \mathrm{W}$ & Gabro hornbléndico & mesocrática \\
\hline
\end{tabular}

\section{b- Petrografía.}

El cuerpo principal del plutón está compuesto por una variedad de facies entre las que dominan monzonitas y granodioritas, existiendo además granitos, granitos alcalinos, tonalitas, dioritas, sienodioritas y gabros, con texturas porfiroides a granudas (Figuras 3.6.2 y 3.6.7).
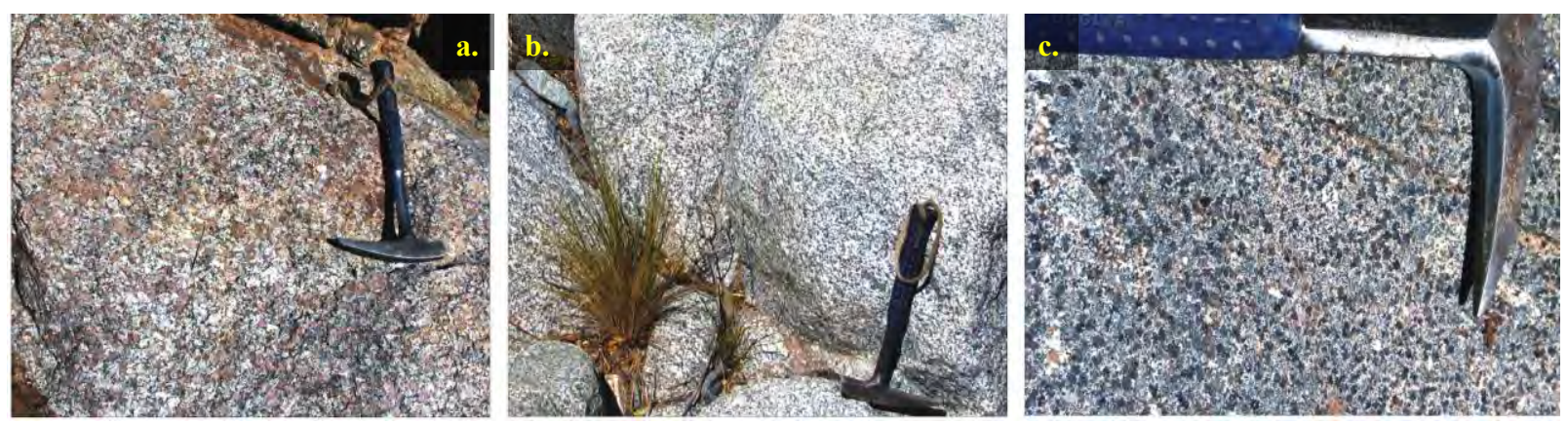

Figura 3.6.2: Algunas de las variedades litológicas y texturales que componen el Granito Potrerillos. a) granito rosado porfiroide a granudo; b) granito gris (monzonita); c) dique gabroide anfibolitizado.

En general se trata rocas ricas en biotita y plagioclasa. Las asociaciones minerales presentes en las distintas facies son: $\mathrm{Pl}+\mathrm{Kfs}+\mathrm{Qtz}+\mathrm{Bt} \pm \mathrm{Hbl} \pm \mathrm{Ttn} \pm \mathrm{Zrn} \pm \mathrm{Ap}+\mathrm{Op}$ en los granitos, granodioritas 
y monzonitas; $\mathrm{Pl}+\mathrm{Kfs}+\mathrm{Qtz} \pm(\mathrm{Bt})+(\mathrm{Ms})$ en las aplitas; $\mathrm{y} \mathrm{Pl}+\mathrm{Hbl} \pm \mathrm{Bt} \pm \mathrm{Qtz} \pm(\mathrm{Cpx})+\mathrm{Ap}+\mathrm{Op} \pm$ $\operatorname{Ttn} \pm$ Zrn (abreviaciones minerales según Kretz, 1983) en las dioritas y gabros. El feldespato alcalino es ortosa o antipertita, de colores rosados y grises; más raramente aparece microclino. En algunas muestras se ha observado la formación de mirmequitas localmente abundantes. El circón, la apatita y los minerales opacos se asocian principalmente a la biotita, aunque en las facies más básicas la apatita forma fases separadas y en cristales muy elongados. La titanita es euhedral a subhedral y llega a ser abundante en las facies intermedias a básicas. Se han observado crecimientos secundarios en cristales de circón y apatita, lo que se relacionaría a distintas etapas de crecimiento, que pueden estar asociadas al magmatismo y/o al crecimiento luego de la asimilación de la roca de caja. Los circones son rosados, desde euhedrales a redondeados, revelando que hay una población magmática y otra heredada de las rocas sedimentarias, lo cual estaría de acuerdo con las observaciones de campo. En una muestra de monzogranito (G2) se observaron cristales euhedrales a subhedrales de allanita (Figura 3.6.3).

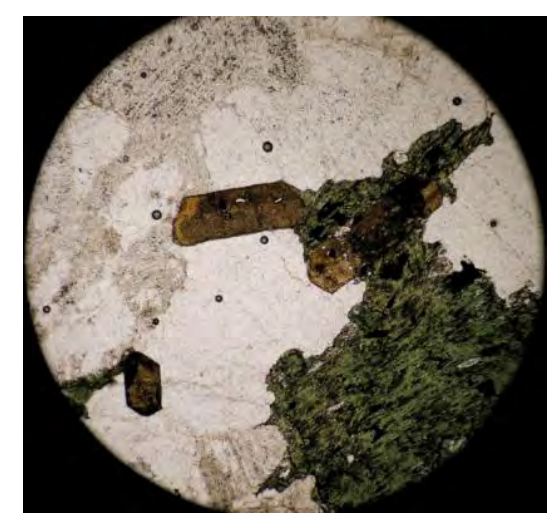

Figura 3.6.3: cristales euhedrales a subhedrales de allanita castaño-anaranjados en un monzogranito (G2). Fotomicrografía $4 \mathrm{x}, \mathrm{N} / /$.

La presencia de miarolas rellenas, lentes pegmatíticas marginales y abundantes enclaves de la roca de caja sedimentaria sugieren un emplazamiento en profundidades someras (Figura 3.6.4). Estos enclaves típicamente presentan un borde muy rico en biotita de mayor granulometría y están formados por plagioclasa + biotita eu- a subhedrales, cuyo origen estaría en la asimilación parcial de trozos de la roca de caja. Pueden tener tamaños muy diversos, desde pequeños enclaves de algunos centímetros hasta grandes bloques parcialmente asimilados e inyectados con aspecto gnéisico (Figura 3.6.5).

En algunos sectores del granito se observaron diferenciados félsicos de pequeñas dimensiones (decímetros) con texturas granudas compuestos por fenocristales de feldespato potásico de hasta $2 \mathrm{~cm}$ con hornblenda en su interior, rodeados de una base microgranuda muy rica en biotita, que podrían ser producto de la fusión y asimilación de bloques de la roca de caja sedimentaria.

Las facies más ácidas las conforman filones sin-magmáticos aplíticos, tabulares y subhorizontales cuya presencia permite inferir que el cuerpo ha sido emplazado en una corteza rígida, ya enfriada, asimilando bloques de la roca de caja.

Hacia el margen septentrional del plutón se hallaron pequeñas lentes pegmatíticas de $4-5 \mathrm{~m}$ de largo por 1 - $2 \mathrm{~m}$ de ancho.

Por otro lado, especialmente en las facies monzoníticas se han observado abundantes enclaves máficos con los bordes irregulares por asimilación parcial (Figura 3.6.6) que permiten identificar la ocurrencia de un proceso de mezcla de magmas (mingling) de distintas composiciones. Estos enclaves 
están compuestos por anfíbol y plagioclasa, y generalmente son de menor tamaño que los enclaves de la roca de caja.
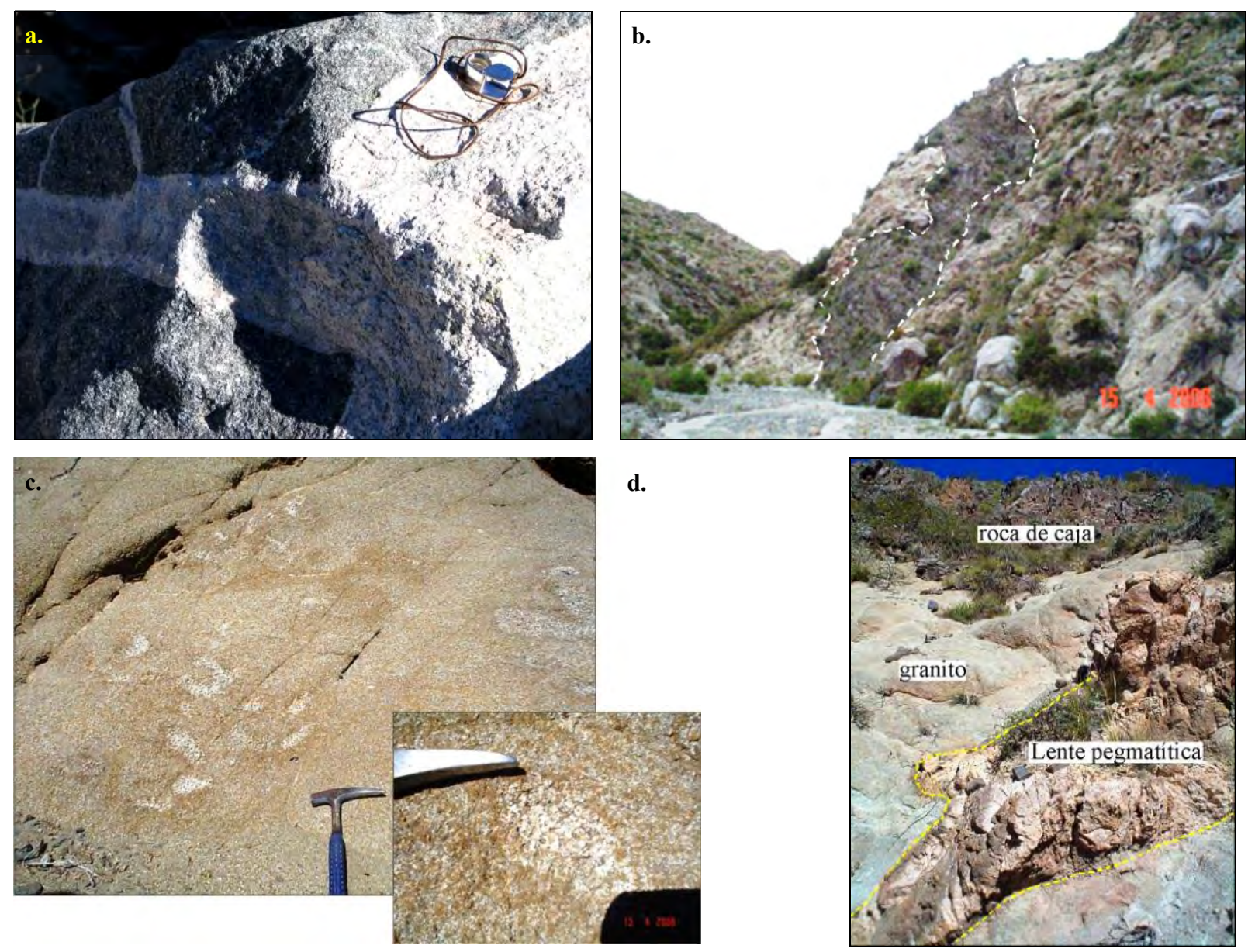

Figura 3.6.4: a) Diques y venillas félsicas cortan una facies máfica del granito, b) enclave de la roca de caja dentro del granito en la margen septentrional de los afloramientos, c) miarolas rellenas en un granito rosado, d) lente pegmatítica de unos $2 \mathrm{~m}$ de largo en un sector periférico del granito, cerca del contacto con la roca de caja sedimentaria.

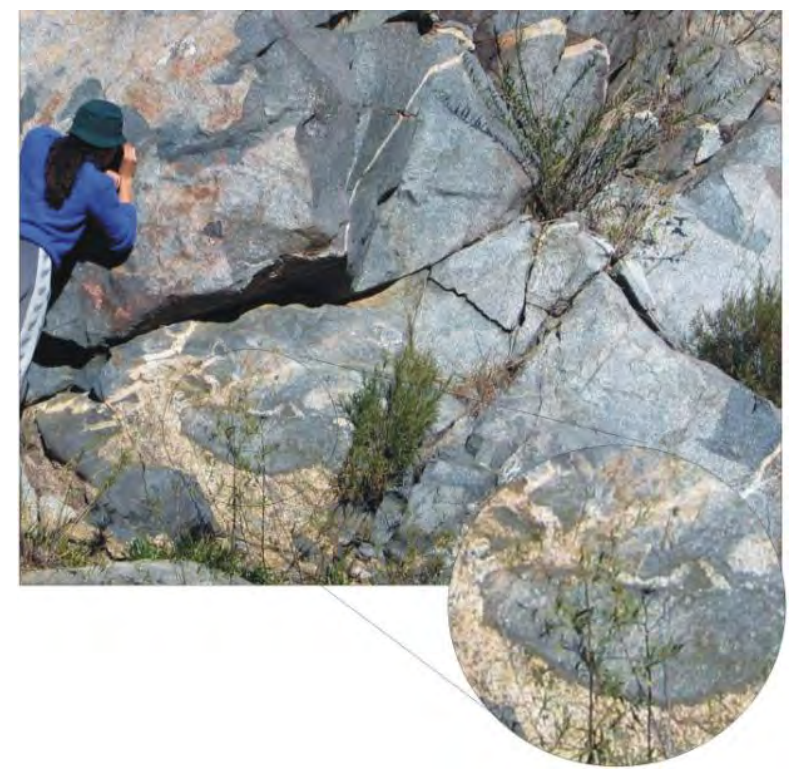

Figura 3.6.5: Aspecto heterogéneo de los afloramientos en un sector de mezcla incompleta de fundidos. Se observan diferenciados félsicos y máficos dentro del granito dominante (gris), asi como enclaves de la roca de caja sedimentaria. En el detalle se observa el borde de un enclave en contacto con un diferenciado félsico del granito oscurecido por la concentración de biotita. Inyecciones aplíticas félsicas cortan estas estructuras. 

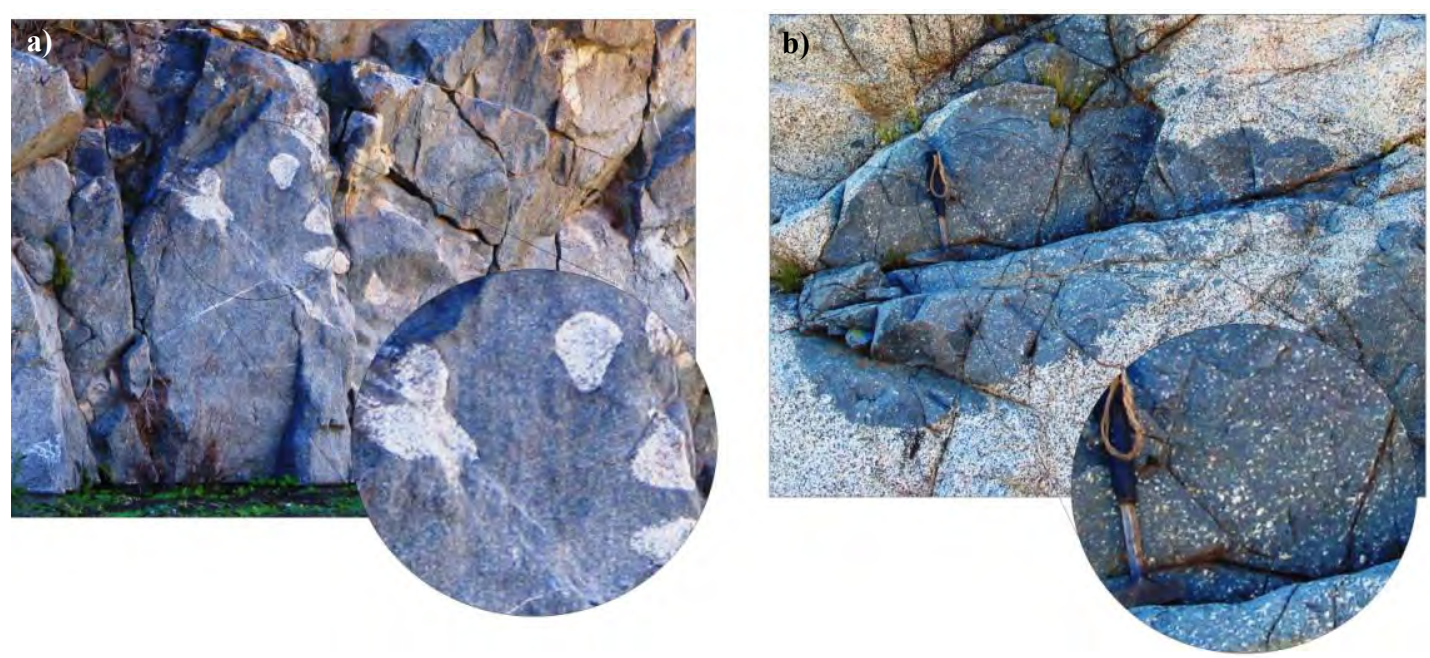

Figura 3.6.6: a) Miarolas rellenas y complejos de venillas félsicas en una facies mafica del granito con textura medianamente gruesa (detalle). b) Enclave microgranular máfico con bordes irregulares compuesto por plagioclasa y anfíbol principalmente; detalle de la textura.

Los diques máficos periféricos, están compuestos por dioritas y gabros. En la quebrada de Potrerillos registran texturas granudas a seriadas y es común que presenten concentraciones de biotita por retrogradación de los mafitos. En los asomos de la quebrada del Bonete los diques pueden presentarse más alterados y/o anfibolitizados y con granulometrías más gruesas, con textura seriada o de tipo lamprofírica (fenocristales de hornblenda en pasta verdosa alterada). Un cuerpo de anfibolita de grano grueso hallado en esta quebrada podría corresponder a estos diques afectados por el metamorfismo, y cortados por diques oscuros afaníticos más jóvenes.

En la Figura 3.6.7 se puede observar el aspecto de las diferentes facies del granito en muestra de mano.

Al norte del granito se ha observado la aureola de contacto generada en las sedimentitas de la Formación del Salto, asignada al Ordovícico (hasta Silúrico), que es evidente en las facies de grano más fino (pelitas y limolitas) por un intenso moteado, recristalización de la matriz cuarzo-feldespáticamicácea y tonalidades oscuras de las rocas.

Tanto el plutón como su roca de caja han sido afectados por deformación y metamorfismo regional de grado medio a bajo (facies de esquistos verdes-zonas de clorita y biotita dominantes-, hasta un pico metamórfico en facies de anfibolitas epidóticas). En los afloramientos se observan zonas de cizalla, algunas con superficies cloritizadas. Al microscopio se registran texturas miloníticas, deformación intracristalina y recristalización de los minerales de menor temperatura del granito. En algunas muestras se observó la presencia de cuarzo generado a bajas temperaturas, el reemplazo del clinopiroxeno por hornblenda verde y de biotita por una asociación de clorita + opacos.

Algunas muestras de los granitoides (G1, G2, G4 a G10, G12, BO9-I y un enclave microgranular en G10, Tabla 3.6.1) fueron clasificadas modalmente. Para ello se realizó el conteo de puntos una vez teñidos los feldespatos con cobaltinitrito de sodio. Las rocas son muy ricas en Pl por lo que sólo los términos más potásicos muestran la tinción. La muestra G10 posee enclaves microgranu- 


\section{CUERPO DEL PLUTON:}
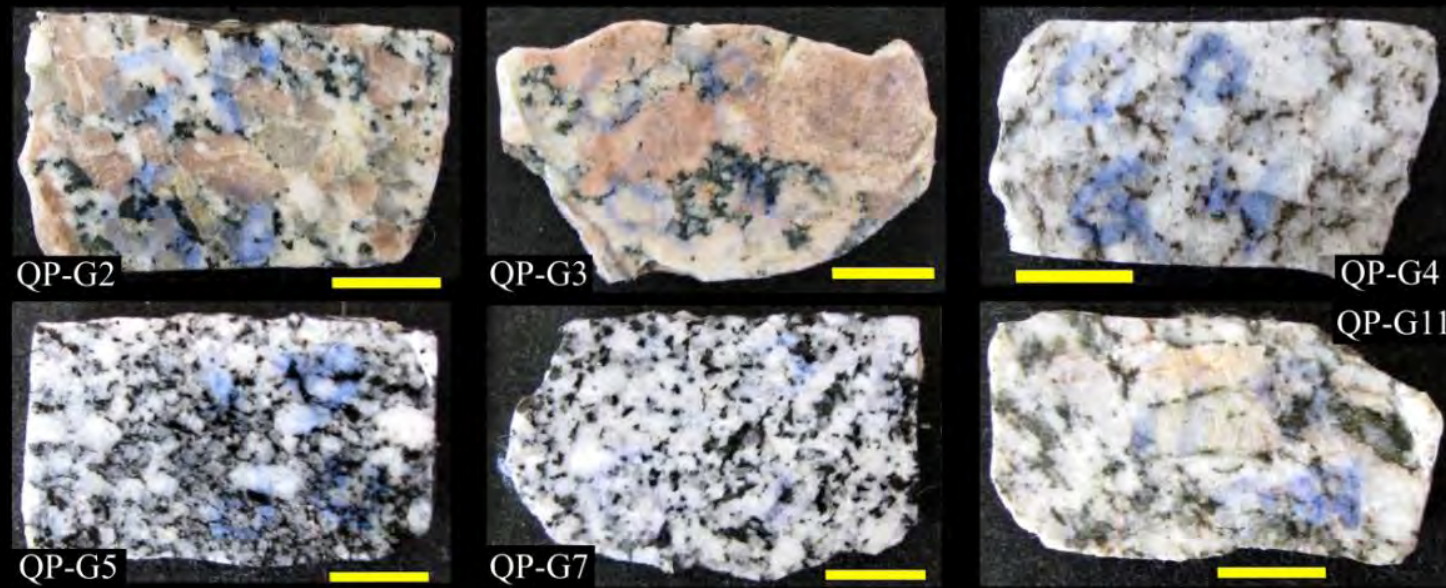

Aspecto de las distintas facies que componen el cuerpo del granito. Arriba : granitos, granodioritas y monzonitas. Izquierda: facies mas alcalinas $y$ enclave microgranular máfico en G10. Abajo:
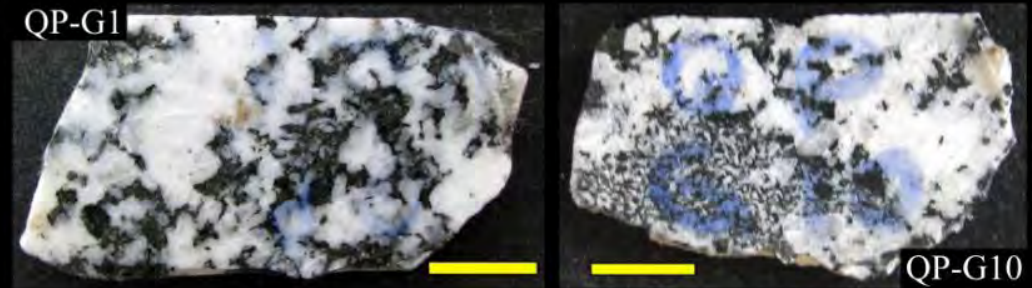
facies mas básicas.
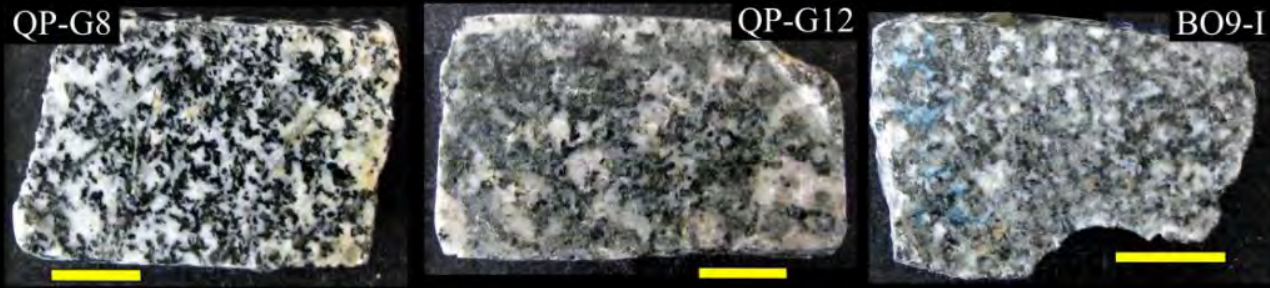

\section{FILONES FELSICOS:}
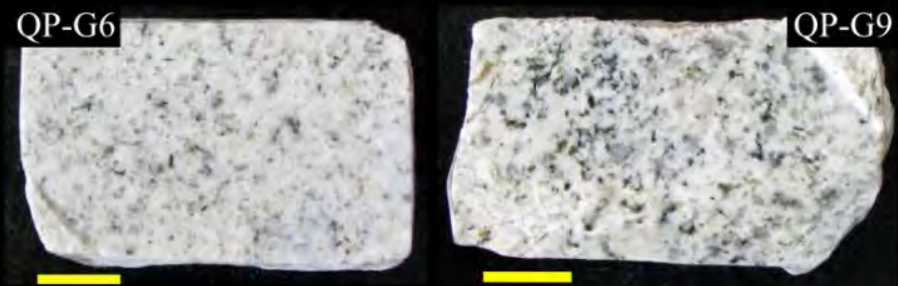

Filones félsicos aplíticos. son discordantes y rellenan los espacios y fracturas que se generan al contraerse el magma durante el enfriamiento.

\section{FILONES BASICOS:}

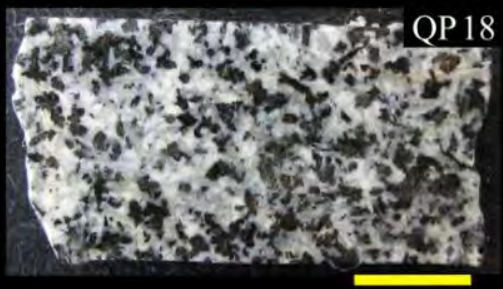

Diques de diabasa microgranudos, no vinculados al cuerpo del plutón. Cortan a la roca de caja (Formación Río Bonete), son subverticales y poseen un espesor de 1 o $2 \mathrm{~m}$ hasta más de $10 \mathrm{~m}$.

Figura 3.6.7: Aspecto de las diversas facies del Granito Potrerillos. Escala gráfica $=1 \mathrm{~cm}$.

-lares máficos muy comunes. En ella se ha realizado un conteo diferenciado para los enclaves más ricos en Bt y de menor granulometría, y la roca que los contiene. Las rocas básicas, que se ubican en 
los campos de las dioritas, gabros, anortositas y dioritas, gabros, anortositas cuarzosas, han sido ploteadas en el diagramas Pl-Px-Hbl de discriminación de rocas gabroides (Le Maitre, 1989), en el que es posible observar claramente la diferencia entre rocas de tendencia anortosítica (G1, G10 y G10 enclave) que forman facies dentro del plutón principal y rocas gábricas con Pl y Hbl que pertenecen a apófisis y filones máficos periféricos asociados al plutón. Los resultados de estos análisis se exponen en la Figura 3.6.8 (a, b) y Tabla 3.6.1.

a)

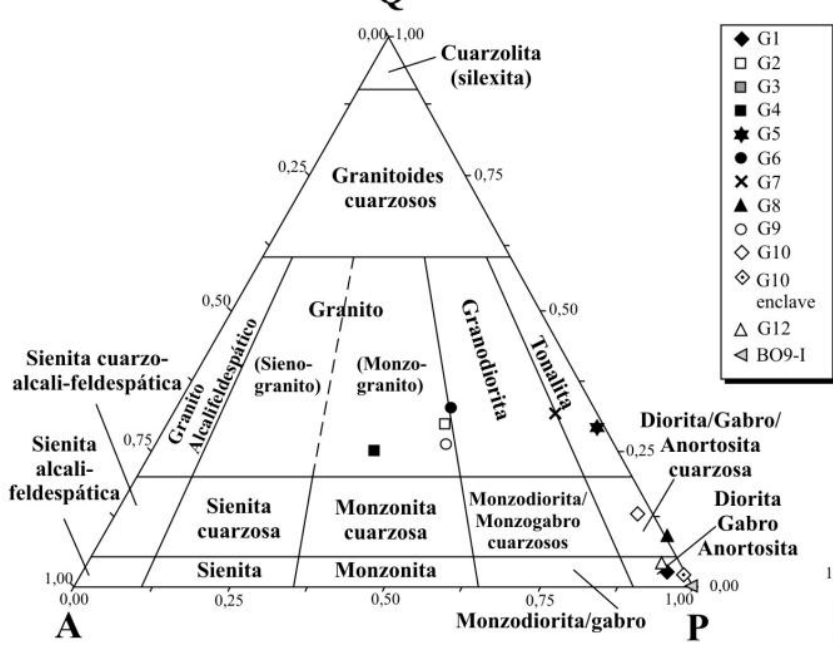

b)

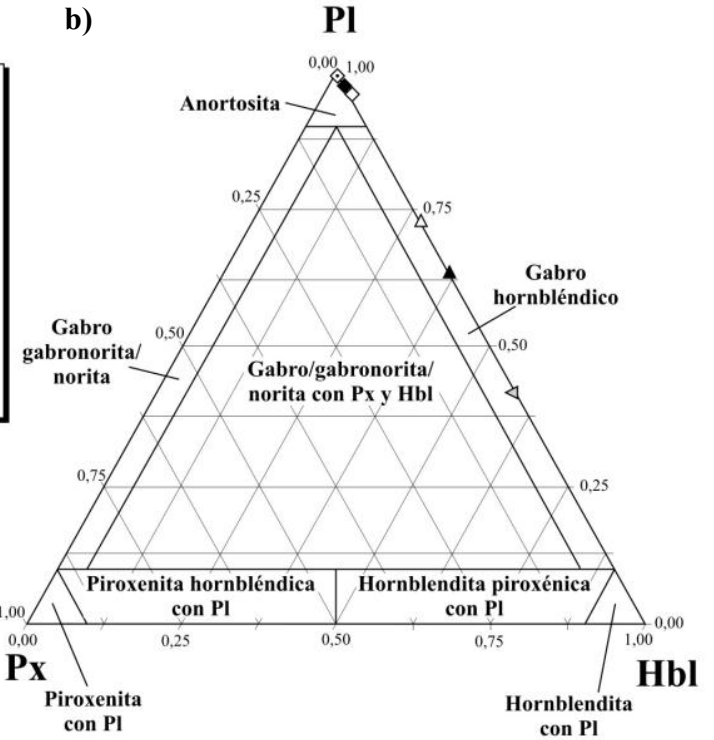

Figura 3.6.8: a) Clasificación modal de los tipos litológicos que conforman el Granito Potrerillos según el diagrama QAPF de Le Maitre et al. (1989). b) Clasificación de las facies mas básicas en el triángulo Pl - Px - Hbl para diferenciación de gabroides (Le Maitre, 1989).

\section{c- Geoquímica}

Elementos Mayoritarios

Las composiciones químicas (y normativas) de las muestras pueden observarse en las Anexos (A6: Tablas 5 y 6). La clasificación geoquímica sobre la base de los elementos mayoritarios se observa en la Figura 3.6.9 (Cox et al., 1979). Allí se aprecia el amplio rango de composiciones que abarca el cuerpo del plutón. El contenido de volátiles (LOI) oscila entre 0 y 2,3\%, mientras que el índice de alteración química (CIA, Nesbitt y Young, 1982) varía entre 54 y 63, con un promedio de 60,40. Teniendo en cuenta que los valores de CIA promedio para granitos y granodioritas se encuentran entre 45 y 55 \% (Nesbitt y Young, 1982), los valores obtenidos estarían indicando que ha habido cierta alteración o movilización de los elementos mayoritarios. Esto puede observarse en la ligera desviación de las muestras ploteadas respecto al eje A-CN en la Figura 3.6.10a. 
De acuerdo con los datos obtenidos se trata de un granitoide tipo I y de afinidad calcoalcalina, y generalmente rico en potasio (Figura 3.6.10b-e). Las muestras G1 y G10 se ubican dentro del campo alcalino. La abundancia de titanita (o Ti en general) en las muestras es una característica común entre los granitoides tipo $\mathrm{S}$, a diferencia de los granitoides tipo I en los que suele predominar la magnetita. Éstos no son rasgos excluyentes y hay variaciones entre ambos (Krauskopf y Byrd, 1995). En el caso del Granito Potrerillos, sus características lo asemejan con los granitoides de tipo I, sin embargo es evidente el aporte de rocas sedimentarias parcialmente asimiladas. En general las muestras se ubican dentro del campo peraluminoso, lo que es coherente con la gran abundancia de biotita observada en la mayoría de ellas, sin embargo pueden registrarse algunas variaciones hacia el campo meta-aluminoso, especialmente en las muestras G11, las más básicas $(\mathrm{G} 8, \mathrm{G} 12)$ y las más alcalinas (G1, G10. Figura 3.6.10d). Es probable la mezcla de un magma alcalino con uno subalcalino, especialmente teniendo en cuenta que las muestras G1 y G10 corresponden a los afloramientos en cuyas inmediaciones se han observado enclaves microgranulares máficos y otras evidencias de mingling como zonas de mezcla incompleta con sectores de morfologías irregulares, que además muestran variaciones de composición, textura, coloración y aspecto general entre las facies involucradas.

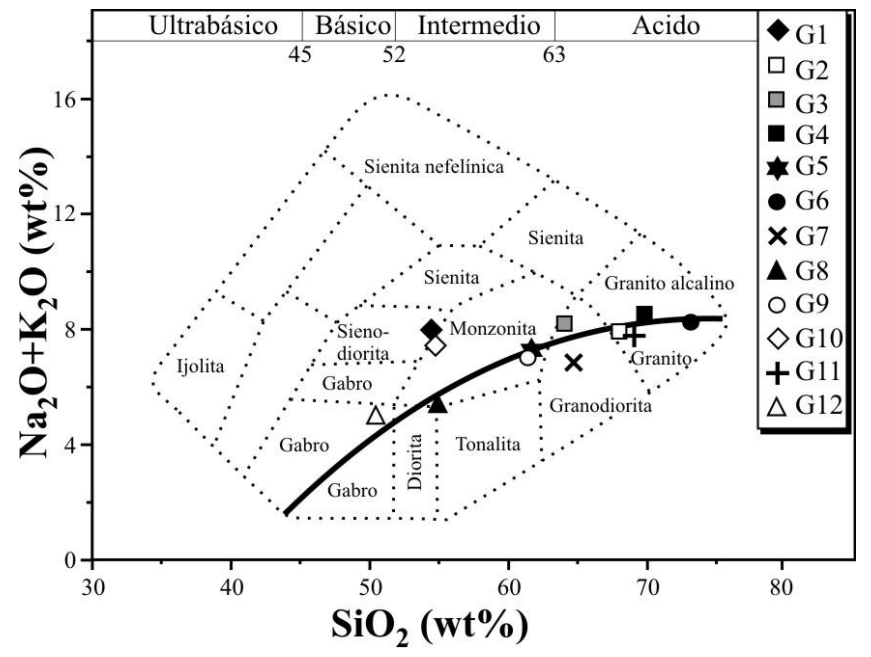

Figura 3.6.9: Ubicación de las muestras analizadas del Granito Potrerillos en el gráfico TAS (Cox et al., 1979).

\section{Elementos Minoritarios y Traza}

Los diagramas multielementales (spider diagrams) son comúnmente ordenados según un aumento del grado de incompatibilidad hacia la izquierda del mismo. En los diagramas multielementales normalizados al Condrito C1 (Sun y McDonough, 1989) y MORB (Pearce, 1983) se han ploteado 12 muestras del Granipo Potrerillos separándose las facies mas ácidas y las más básicas de las del cuerpo del plutón para poder observar mejor su comportamiento. Los patrones que se observan en general son comparables con los patrones típicos de la corteza continental.

Las muestras del Granito Potrerillos se han volcado en los diagramas multielementales normalizados al condrito C1 (Sun y McDonough, 1989) y al MORB (Pearce, 1983). Las facies más ácidas y las más básicas fueron separadas de las del cuerpo principal del plutón para observar mejor su comportamiento geoquímico. Los patrones que se observan en general son comparables con los típicos de la corteza continental. Los esquemas se asemejan a los obtenidos para magmas calco-alcalinos. En 
a)

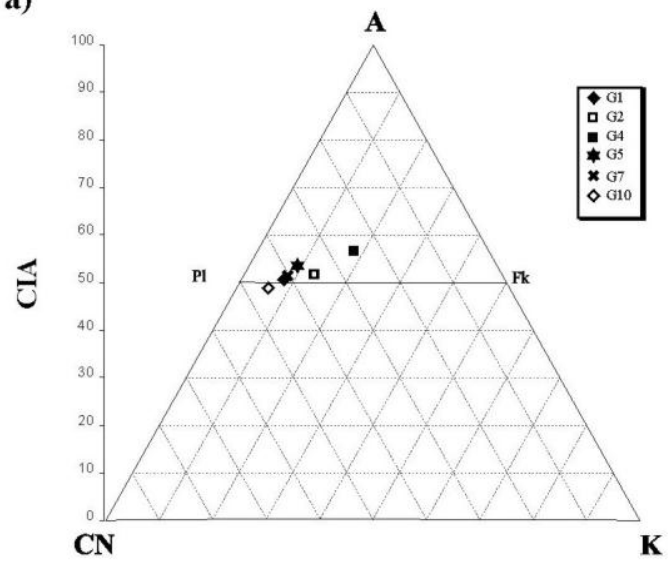

c)

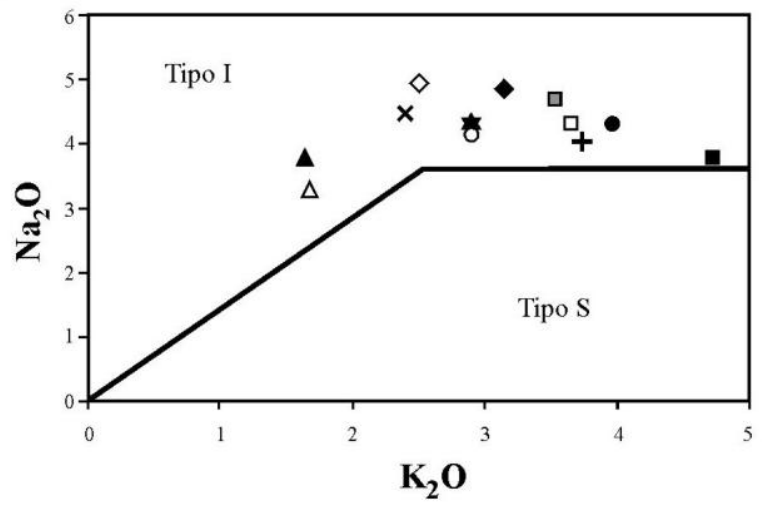

e)

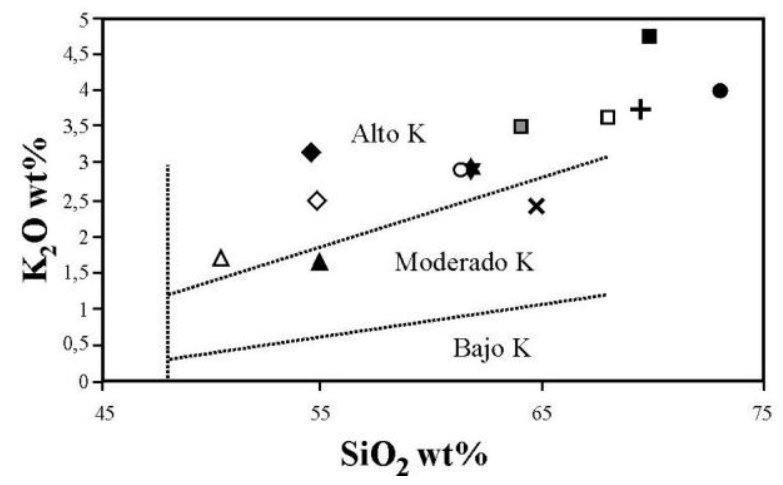

b)

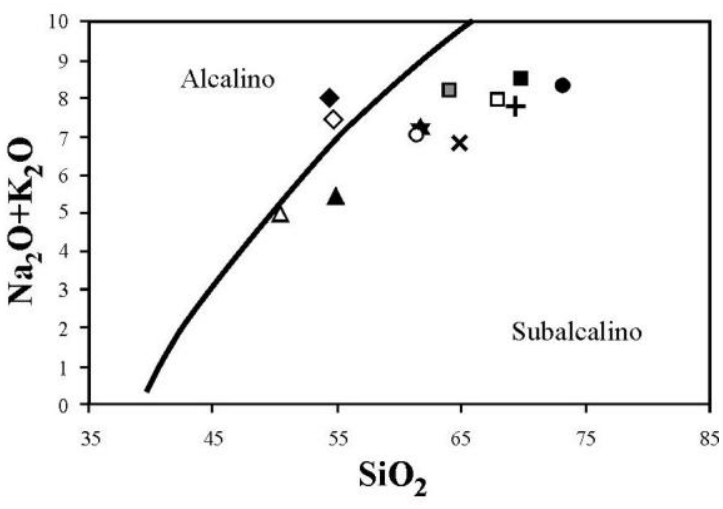

d)

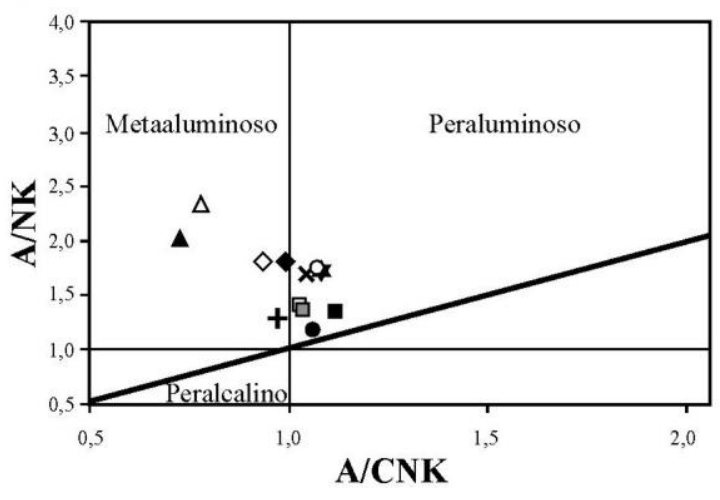

f)

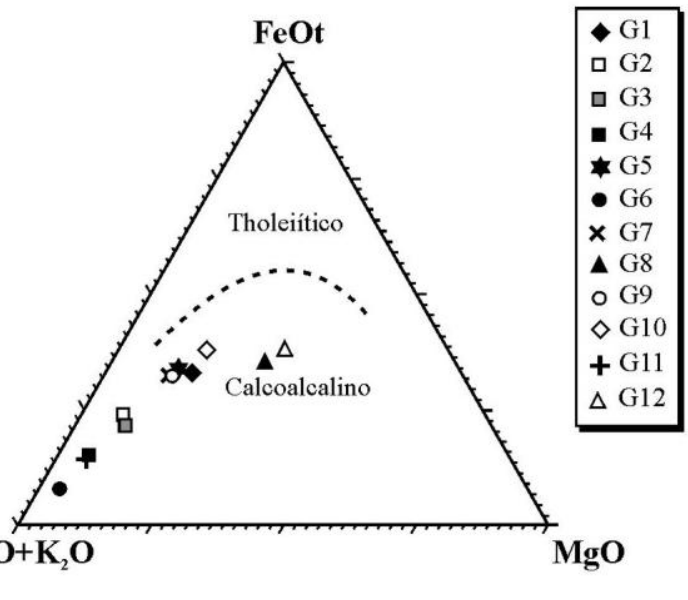

Figura 3.6.10: Diagramas de caracterización geoquímica del Granito Potrerillos. a) Diagrama A-CN-K vs. CIA (Fedo et al., 1995) en el que se observa la desviación del trend de puntos de las muestras respecto a la evolución teórica esperada para la evolución del magma (paralela al eje A-CN). b) Relación álcalis-sílice (Irvine y Baragar, 1971); c) Diagrama de álcalis de Chappel y White (1984); d) Índice de saturación de aluminio (Shand, 1927); e) relación $\mathrm{K}_{2} \mathrm{O} v s$. $\mathrm{SiO}_{2}$ (límites según Le Maitre et al., 1989); f) Diagrama AFM (Irvine y Baragar, 1971), en el que se observa la dispersión de puntos correspondientes a las muestras de las distintas facies del Granito Potrerillos siguiendo una serie de evolución calcoalcalina.

los diagramas normalizados a $\mathrm{C} 1$ son característicos los picos negativos de $\mathrm{Pb}$ y $\mathrm{P}$ y ligeramente en $\mathrm{K}$, así como picos de enriquecimiento en Ba y Th (Figura 3.6.11). Entre las facies máficas, los diques representados por la muestra G8 presentan además un ligero enriquecimiento en U (Figura 3.6.11c). Si 
bien para las aplitas se presentan análisis incompletos, se aprecia un mayor grado de diferenciación de la muestra G6 respecto de la G9 (Figura 3.6.11b). En los diagramas normalizados al MORB (Figura 3.6.12) se observa un enriquecimiento general en elementos incompatibles (hacia la izquierda del diagrama) así como picos negativos de $\mathrm{P}_{2} \mathrm{O}_{5}, \mathrm{TiO}_{2}, \mathrm{Ta}-\mathrm{Nb}$. En general las muestras G1 y G10 presentan un comportamiento similar y parecido al de G2 y G4, mientras que las muestras G3, G7, G11 y G5 se asemejan más entre sí. La muestra G5 tiene un comportamiento algo diferente, con picos negativos de $\mathrm{Zr}$ e $\mathrm{Y}$, alto $\mathrm{Yb}$ y Th y mayor contenido de $\mathrm{P}_{2} \mathrm{O}_{5}$ respecto al resto de las muestras.

A continuación se resumen las características de algunos elementos traza particularmente útiles como indicadores petrogenéticos analizándose sus comportamientos para el caso del Granito Potrerillos. El Ni, el Co y el Cr son elementos altamente compatibles. El Ni (y el Co) se concentran en las olivinas y el $\mathrm{Cr}$ en los espinelos y clinopiroxenos. Las muestras G8, G10 y G12 son las que presentan mayores valores de Ni y Co (Ni entre 25 y 38 ppm, Co $>30$ ppm). La muestra G8 es la única que registra valores algo más elevados de $\mathrm{Cr}$ (95,1 ppm).

El V y el Ti son elementos altamente fraccionados en los óxidos de Fe y Ti (ilmentita o titanomagnetita). Si se comportan en forma diferente, probablemente el Ti se encuentre fraccionado en una fase accesoria como titanita o rutilo. La correlación de estos elementos en las muestras analizadas es evidente y se asocia al tipo de roca. Las muestras G2, G4, G6 y G11 presentan los menores valores de V y Ti mientras que las muestras G1, G8, G10 y G12 presentan altos valores de ambos y coincide con la presencia de titanita (especialmente abundante en las muestras G8 y G12).
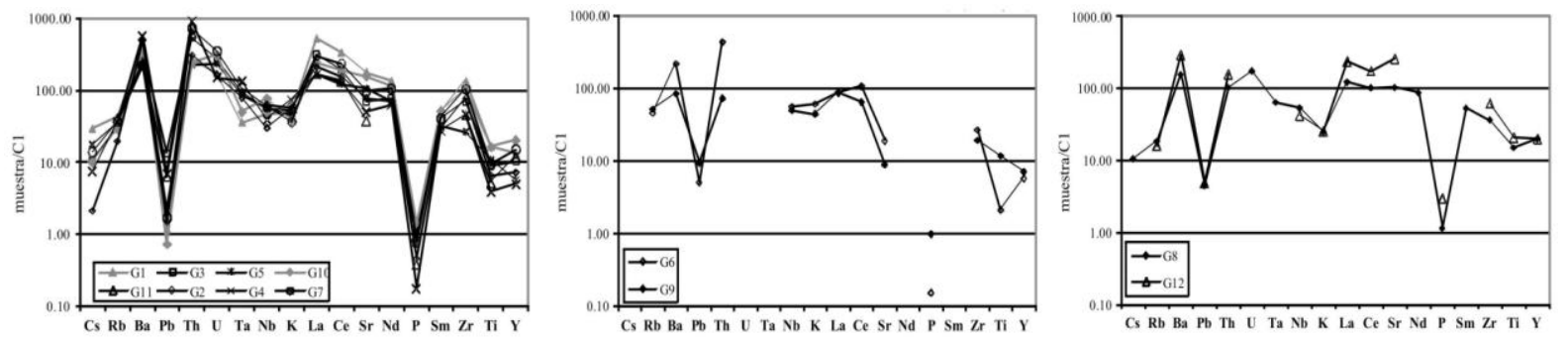

Figura 3.6.11: Diagramas multielementales normalizados al condrito C1 (Sun y McDonough, 1989) de doce muestras del Granito Potrerillos. a)- facies principales del cuerpo del plutón; b)- facies ácidas; c)- facies básicas.
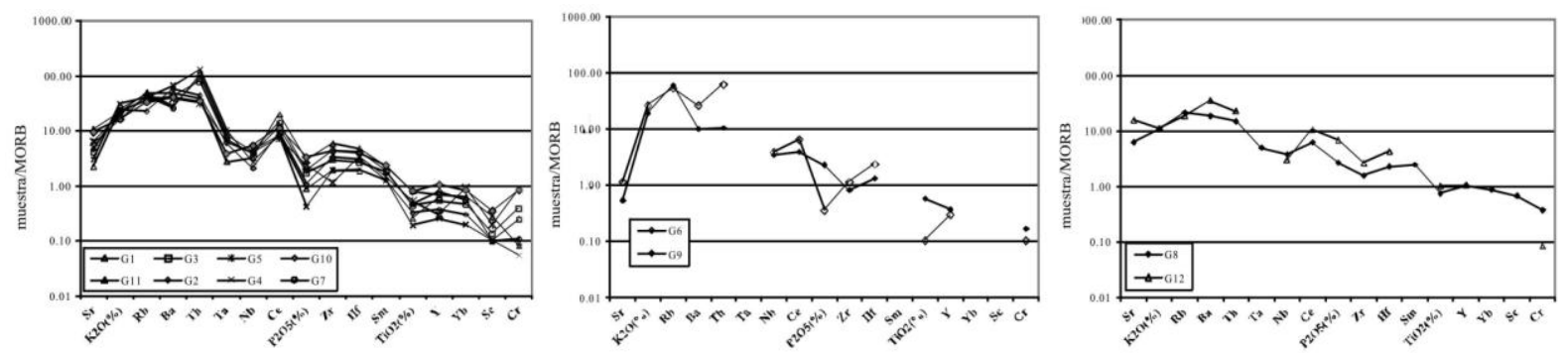

Figura 3.6.12: Diagramas multielementales normalizados a MORB (Pearce, 1983) de doce muestras del Granito Potrerillos. a)- facies principales del cuerpo del plutón; b)- facies ácidas; c)- facies básicas. Ordenamiento de los elementos según el aumento del grado de incompatibilidad hacia la izquierda.

Por su parte $\mathrm{Zr}$ y Hf son elementos muy incompatibles que no se sustituyen en las fases mayoritarias silicatadas (aunque pueden reemplazar al Ti en la titanita o rutilo). En este caso, las muestras G1 y G10 claramente presentan valores altos para ambos elementos, sin embargo la 
correlación no es tan clara para el resto de las muestras, siendo G4, G6, G9 y G11 quienes presentan valores más bajos. La variabilidad probablemente se relacione a la mayor o menor abundancia de fases minerales que fraccionan Hf y $\mathrm{Zr}$ (e.g. circón).

$\mathrm{El} \mathrm{Ba}$ y el $\mathrm{Rb}$ son elementos incompatibles que sustituyen al $\mathrm{K}$ en el feldespato potásico, micas u hornblenda. El Rb sustituye en proporción menor en la hornblenda que en el feldespato potásico y micas, por ello la relación $\mathrm{K} / \mathrm{Ba}$ permite distinguir entre estas fases. La mayor parte de las muestras del granito tienen valores relativamente altos de Ba y Rb (G1, G3, G4 y G5). La muestra G8 es la única que registra valores bajos de ambos elementos por lo que es muy probable el control mineralógico. Por ejemplo, en G2 se observa un alto contenido de Ba pero bajas concentraciones de $\mathrm{Rb}$, lo que estaría probablemente relacionado a la presencia de hornblenda. El caso opuesto se observa para las muestras G9 y G6 en la cual las altas concentraciones de Rb en relación al Ba se asociarían a la mayor concentración de feldespato potásico.

El Sr sustituye al $\mathrm{Ca}$ en las plagioclasas (pero no en los piroxenos), y en menor cantidad al $\mathrm{K}$ del feldespato potásico. A mayores presiones, donde la plagioclasa ya no es estable, se comporta como elemento incompatible. Por las características de campo ya expuestas, se asume un emplazamiento poco profundo del granito, por lo que se descartaría esta última opción. Las muestras G6, G9 y G11 presentan los valores más bajos de $\mathrm{Sr}$, porque son las muestras con menor contenido de plagioclasa y pocos mafitos en general. Las muestras G1 y G12 son especialmente ricas en Sr, sin embargo no es claro que esto se relacione solo a la presencia de plagioclasa ya que las muestras restantes también son ricas en este mineral, quizás podría deberse a la abundancia de minerales máficos cálcicos en dichas muestras (augita, hornblenda).

El Y comúnmente es incompatible y presenta un comportamiento similar al de las tierras raras pesadas (HREE). Es fuertemente particionado en el granate y anfíbol. La titanita y la apatita también concentran $\mathrm{Y}$, por lo tanto la presencia de estas fases minerales como accesorios podría tener un efecto significativo en la abundancia de este elemento. En el caso del granito Potrerillos no se observan particularidades respecto a las concentraciones de este elemento. Las muestras G8 y G12 presentan titanita, mientras que en el resto de las muestras, las únicas fases minerales accesorias importantes son el circón y la apatita. Por lo tanto, se puede expresar que la muestra G5 es una excepción ya que muestra valores bajos tanto de $\mathrm{Y}$ como de $\mathrm{Zr}$ y valores altos de $\mathrm{TiO}_{2}$ (o Ti) respecto al resto de las muestras analizadas.

Elementos de las tierras raras (REE).

En la Tabla 3.6.4 se resumen los valores normalizados al condrito C1 (Sun y McDonough, 1989) para 6 muestras del cuerpo principal del plutón. En el diagrama de tierras raras correspondiente (Figura 3.6.13) se observa un enriquecimiento de las tierras raras livianas (LREE) en relación a las pesadas (HREE), incluso afectando en parte a las tierras raras intermedias. Por otro lado, no se observa una anomalía negativa de Eu, o ésta es levemente positiva. Estas características son coherentes con los 
patrones de tierras raras que suelen formarse en los términos menos diferenciados de los magmas calcoalcalinos. También se advierte un leve enriquecimiento en las tierras raras pesadas (HREE) que podría estar relacionado a un control mineralógico. En este sentido, algunas fases (especialmente el granate) retienen las HREE con preferencia a las LREE, mientras que el ortopiroxeno y la hornblenda lo hacen en menor proporción. La esfena y la plagioclasa (ambas presentes en el Granito Potrerillos) por el contrario retienen con preferencia las LREE.

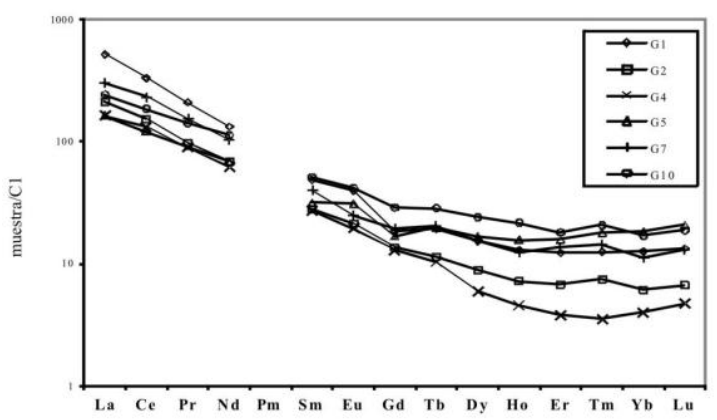

Figura 3.6.13: Diagramas de tierras raras normalizados al C1 promedio (Sun y McDonough, 1989) de seis muestras de distintas fases del Granito Potrerillos.

\begin{tabular}{|c|c|c|c|c|c|c|c|}
\hline & Avg.C1 & G1 & G2 & G4 & G5 & G7 & G10 \\
\hline La & 0.237 & 521.1 & 213.08 & 164.56 & 164.6 & 302.53 & 244.30 \\
\hline $\mathrm{Ce}$ & 0.612 & 334.5 & 154.08 & 132.03 & 121.9 & 233.82 & 186.11 \\
\hline Pr & 0.095 & 210.7 & 98.32 & 90.11 & 92.1 & 153.37 & 142.21 \\
\hline Nd & 0.467 & 133.8 & 69.16 & 62.31 & 69.2 & 104.71 & 113.70 \\
\hline \multicolumn{8}{|l|}{ Pm } \\
\hline Sm & 0.153 & 48.5 & 28.10 & 27.45 & 31.7 & 40.52 & 51.50 \\
\hline Eu & 0.058 & 39.8 & 21.38 & 19.66 & 31.0 & 24.83 & 42.07 \\
\hline Gd & 0.2055 & 18.4 & 13.67 & 12.94 & 16.8 & 19.66 & 29.00 \\
\hline Tb & 0.0374 & 19.3 & 11.50 & 10.43 & 19.8 & 20.59 & 28.61 \\
\hline Dy & 0.254 & 15.4 & 8.90 & 5.94 & 16.9 & 15.59 & 24.13 \\
\hline Но & 0.0566 & 13.1 & 7.24 & 4.59 & 15.7 & 12.54 & 21.73 \\
\hline $\mathbf{E r}$ & 0.1655 & 12.3 & 6.77 & 3.81 & 15.9 & 13.60 & 18.13 \\
\hline Tm & 0.0255 & 12.5 & 7.45 & 3.53 & 18.0 & 14.51 & 20.78 \\
\hline $\mathbf{Y b}$ & 0.17 & 12.6 & 6.12 & 4.00 & 18.4 & 11.12 & 17.00 \\
\hline Lu & 0.0254 & 13.4 & 6.69 & 4.72 & 20.9 & 12.99 & 18.90 \\
\hline $\mathbf{Y}$ & 1.57 & 13.4 & 7.26 & 4.97 & 5.7 & 15.03 & 20.25 \\
\hline $\mathbf{L} \mathbf{a}_{\mathbf{N}} / \mathbf{Y} \mathbf{b}_{\mathbf{N}}$ & & 41.20 & 34.83 & 41.14 & 8.97 & 27.21 & 14.37 \\
\hline $\mathbf{L a}_{N} / \mathbf{S m}_{\mathbf{N}}$ & & 10.74 & 7.58 & 5.99 & 5.19 & 7.47 & 4.74 \\
\hline $\mathbf{G} \mathbf{d}_{\mathbf{N}} / \mathbf{Y} \mathbf{b}_{\mathbf{N}}$ & & 1.45 & 2.24 & 3.24 & 0.92 & 1.77 & 1.71 \\
\hline $\mathbf{E u}$ * & & 29.87 & 19.60 & 18.85 & 23.10 & 28.23 & 38.65 \\
\hline $\mathbf{E u} / \mathbf{E u} *$ & & 1.33 & 1.09 & 1.04 & 1.34 & 0.88 & 1.09 \\
\hline
\end{tabular}

Tabla 3.6.4: Composición de tierras raras de las muestras del Granito Potrerillos. Valores en ppm. " $\mathrm{X}_{\mathrm{N}}$ ": valores normalizados al condrito C1 (Sun \& McDonough, 1989).

Las muestras G1 y G5 presentan leve anomalía positiva de Eu mientras que G2, G4, G7 y G10 no registran anomalía de Eu pero presentan un pico positivo en el Tm, excepto G4. Por lo general se asume que una anomalía negativa de Eu en los diagramas de tierras raras se debe a un proceso de 
fraccionamiento de la plagioclasa en el magma permitiendo que el $\mathrm{Eu}^{+3}$ cambie su estado de oxidación a $\mathrm{Eu}^{+2}$, diferenciándose así del comportamiento de las demás tierras raras. Esto le permite entrar preferentemente en la estructura de la plagioclasa, que al fraccionarse en las primeras etapas de diferenciación del magma deja un líquido empobrecido en Eu. En las rocas generadas a partir de este magma pobre en plagioclasa se genera una anomalía negativa de Eu. La ausencia de anomalía de Eu o
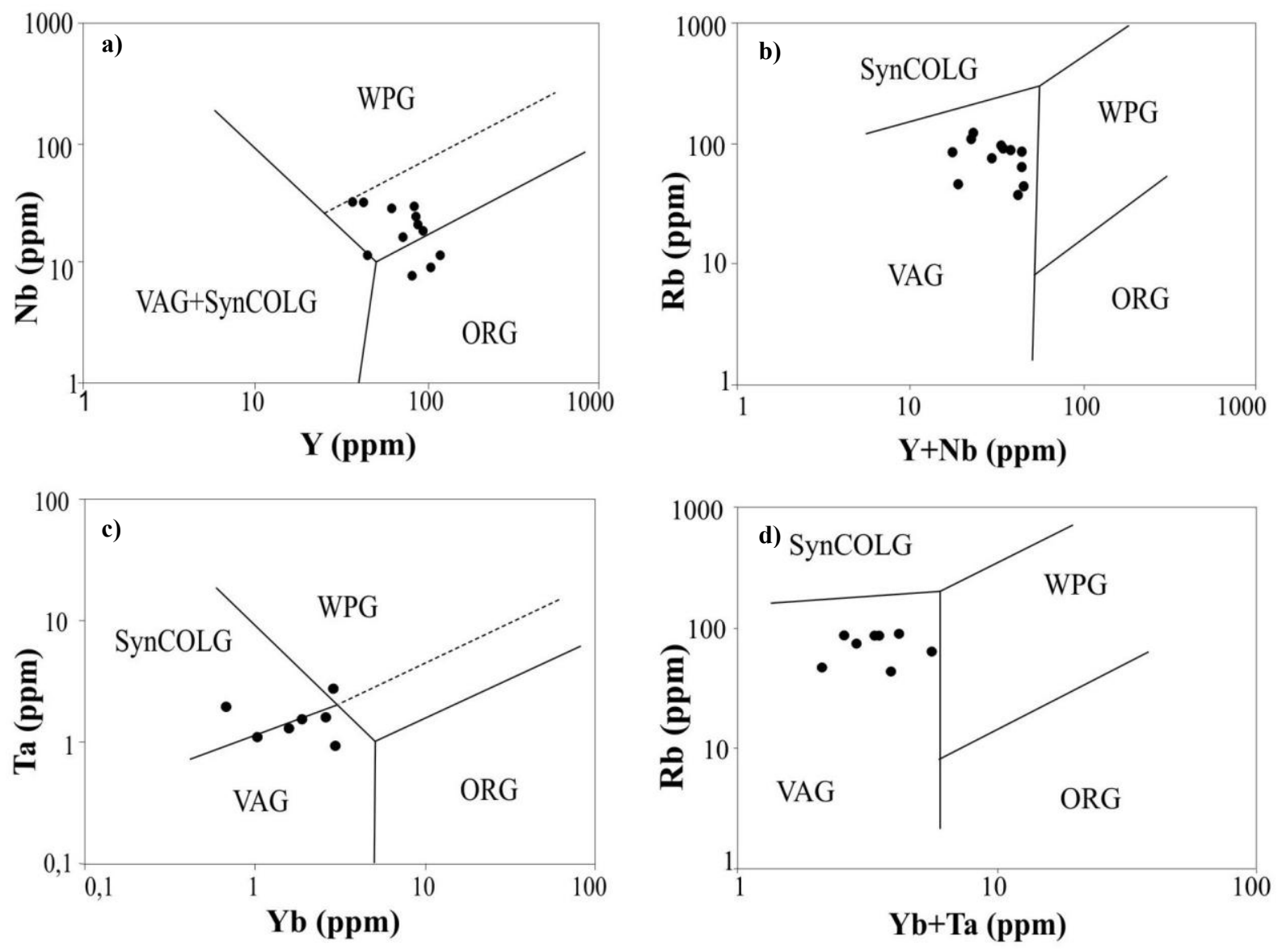

e)

$\mathbf{R b} / \mathbf{1 0}$

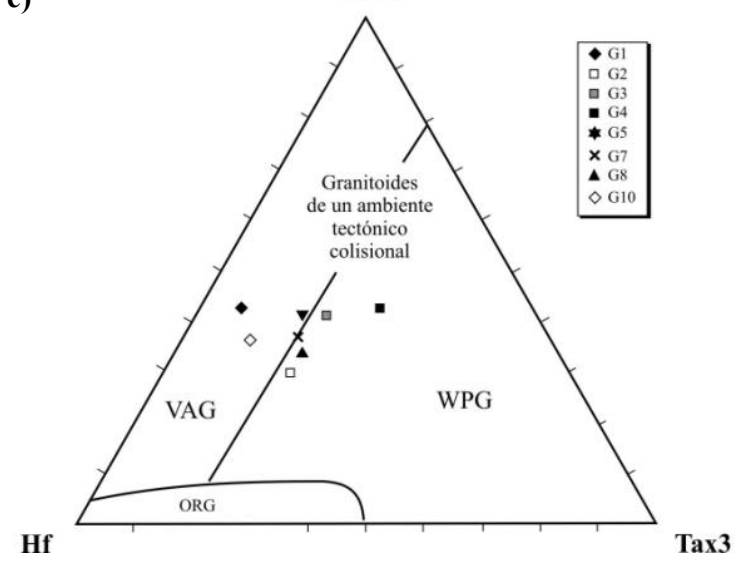

Figura 3.6.14: a), b), c) y d): Diagramas de discriminacion tectónica del Granito Potrerillos que lo vinculan a un ambiente de arco volcánico. (Pearce et al., 1984). ORG: granitoides de dorsales oceánicas (normales, anormales, dorsales de cuencas de retroarco y antearco); WPG: granitoides de intraplaca (complejos anulares, corteza atenuada e islas oceánicas); VAG: granitoides de arco volcánico (arcos oceánicos tholeíticos, calcoalcalinos, y arcos de margen continental); COLG: granitoides colisionales (sintectónicos y postectónicos en colisión continental; sintectónicos en colisión arco-continente). e) Diagrama Rb/10 - Hf - Ta*3 (Harris et al., 1986): para discriminación de granitoides de fondo oceánico, arco volcánico e intraplaca; los granitoides colisionales caen en el límite entre estos dos últimos 
leve anomalía positiva observada se atribuye a que no ha habido fraccionamiento de la plagioclasa, que es abundante especialmente en las muestras de composición intermedia a básica.

\section{d. Implicaciones sobre el ambiente tectónico}

Los diagramas geoquímicos de discriminación tectónica vinculan al magmatismo a un ambiente de arco relacionado a márgenes continentales activos (Pearce et al., 1984; Harris et al., 1986, Figura 3.6.14). La abundancia de minerales hidratados, especialmente biotita, es común en granitoides formados en este tipo de ambiente tectónico. Los granitoides postorogénicos no pueden distinguirse de granitoides de arco volcánico (VAG) y sin-colisionales (Syn-COLG) en los diagramas de Pearce (1984). Debido a la relación que existe entre la intrusión y la deformación como motas (cordierita?, andalusita?) cortadas por clivaje y rotadas, el Granito Potrerillos sería pre-colisional a levemente sincolisional. Los diagramas de Harris et al. (1986) probablemente estén más influenciados por la movilidad del $\mathrm{Rb}$ teniendo en cuenta los valores de CIA obtenidos y las características de los afloramientos, pero se observa un resultado coherente con los obtenidos en los diagramas de Pearce et al. (1984).

Con el incremento de la madurez del arco, los granitoides VAG se enriquecen en $\mathrm{Rb}, \mathrm{Th}, \mathrm{U}$, $\mathrm{Ta}, \mathrm{Nb}$, Hf e Y, mientras que se empobrecen en Ba, Sr, P, Zr y Ti. (Rollinson, 1993). Brown et al. (1984) proponen los diagramas $\mathrm{Rb} / \mathrm{Zr}$ vs. $\mathrm{Nb}$ o $\mathrm{Rb} / \mathrm{Zr}$ vs. $\mathrm{Y}$, en los que con una mayor madurez del arco se observa una correlación positiva entre estos pares de valores. Sin embargo, no se observa una correlación clara entre los valores obtenidos para las muestras del Granito Potrerillos. Las muestras con mayores valores de $\mathrm{Rb} / \mathrm{Zr}$ corresponden a los diferenciados félsicos más tardíos (Figura 3.6.15).

a)

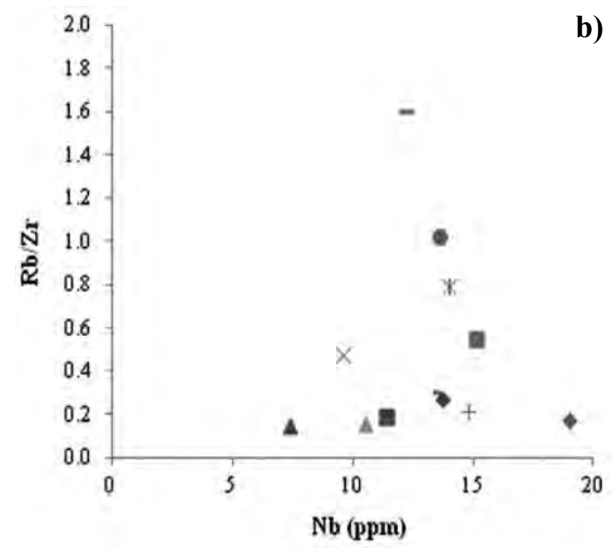

b)

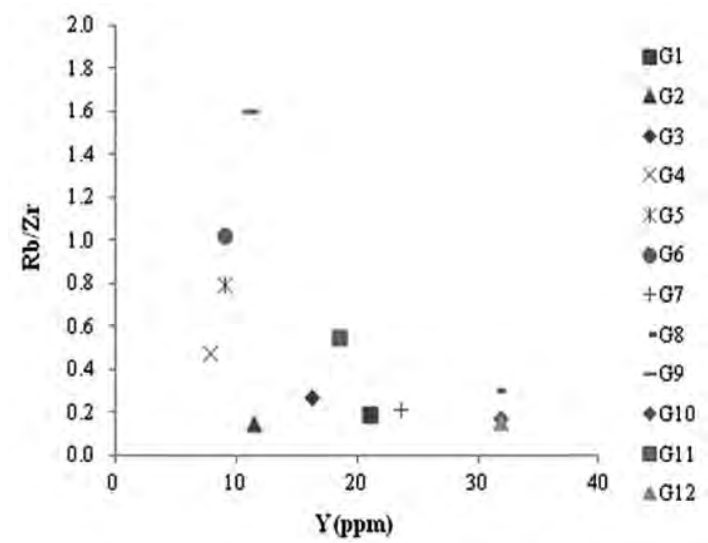

Figura 3.6.15: Diagramas de correlación $\mathrm{Rb} / \mathrm{Zr} v s . \mathrm{Nb}$ (a) y $\mathrm{Rb} / \mathrm{Zr}$ vs. $\mathrm{Y}$ (b) propuestos por Brown et al. (1984).

\section{e- Geología isotópica y edad.}

La edad del magmatismo que originó este cuerpo granítico fue estimada como silúrica con dudas (Aceñolaza y Bernasconi, 1969b; Aceñolaza et al., 1971). Algunas dataciones obtenidas posteriormente por el método K-Ar en biotita y anfíbol en cuerpos graníticos de la región permitieron 
referir tentativamente su edad al Carbonífero Tardío (313 Ma, Caminos 1972; Llambías y Caminos, 1987). Considerando la deformación sobreimpuesta en el área, estas edades podrían estar reflejando eventos metamórficos posteriores a la cristalización. La deformación que se ha observado en el granito no es un rasgo común para los granitoides carboníferos (Caminos, 1972; Llambías y Caminos, 1987); esto sugiere una edad más antigua para el Granito Potrerillos, aunque evidentemente más joven que la edad de la roca de caja (Ordovícico Tardío a Silúrico Temprano; ca. 440 Ma, Frigerio 2008b; Frigerio et al., 2009) y que la 'faja de deformación de Jagüé' (pre-Carbonífero Inferior-Medio con varias reactivaciones). En la Tabla 3.6.5 se resumen los antecedentes de datos geocronológicos.

\section{Isocrona $\mathbf{R b} / \mathbf{S r}_{\mathrm{RT}}$}

Para acotar la edad del Granito Potrerillos se realizó una datación por $\mathrm{Rb} / \mathrm{Sr}$ en roca total analizando 7 muestras de las distintas facies del granito. Las muestras analizadas G2, G4, G7 y G10 pertenecen al cuerpo principal del granito, G6 y G9 son filones aplíticos póstumos y G8 es un dique diorítico asociado y periférico al granito. El procesamiento de laboratorio fue realizado en el Centro de Investigaciones Geológicas (CIG, La Plata) y la espectrometría de masas en la Universidad de Sao Paulo, Brasil. Para el cálculo de la edad se utilizó el programa Isoplot, ex-modelo 3 de Ludwig (2001, Tabla 3.6.6). Como se observa en la Figura 3.6.16, se obtuvo una edad de $338 \pm 33$ Ma, con relación ${ }^{87} \mathrm{Sr}^{86}{ }^{36} r_{\mathrm{i}}=0,70449 \pm 0.00085$ y MSWD $=349$. Por el error calculado puede considerarse que

Tabla 3.6.5: Síntesis de los antecedentes de edad para el Granito Potrerillos y otros granitoides carboníferos de la región (modificado de Maisonave, 1979 y Llambías, 1999). Se han resaltado en gris los cuerpos que tradicionalmente se consideraron vinculados.

\begin{tabular}{|c|c|c|c|c|c|}
\hline Localidad & Edad & Método & & Ubicación & Fuente \\
\hline $\mathrm{C}^{\mathrm{o}}$ Veladero & $311 \pm 15$ & $\mathrm{Rb} / \mathrm{Sr}$ & $\begin{array}{l}\mathrm{Cb} \text { sup bajo- } \\
\text { medio }\end{array}$ & $\begin{array}{l}29^{\circ} 10^{\prime}-69^{\circ} 45^{\prime} \\
\text { (Sas. Pampeanas) LRja }\end{array}$ & Cingolani et al., 1993 \\
\hline $\begin{array}{l}\mathrm{C}^{\circ} \text { de las Tunas } \\
\text { (Granito) }\end{array}$ & $330 \pm 10$ & $\mathrm{~K} / \mathrm{Ar}_{(\mathrm{Bt})}$ & $\begin{array}{l}\mathrm{Cb} \text { inf medio } \\
\text { (viseano) }\end{array}$ & $\begin{array}{l}28^{\circ} 20^{\prime}-68^{\circ} 45^{\prime} \\
\text { (Precord.) LRja }\end{array}$ & $\begin{array}{l}\text { Caminos, } 1972(324 \pm 5,8) \text {, } \\
\text { actualizada por Llambías y } \\
\text { Caminos, } 1987\end{array}$ \\
\hline $\begin{array}{l}\text { Qda Potrerillos } \\
\text { (Granodiorita) }\end{array}$ & $313 \pm 17$ & $\mathrm{~K} / \mathrm{Ar}_{(\mathrm{Bt})}$ & $\mathrm{Cb}$ sup bajo & $\begin{array}{l}28^{\circ} 30^{\prime}-68^{\circ} 30^{\prime} \\
\text { (Precord-SPamp) LRja }\end{array}$ & $\begin{array}{l}\text { Caminos, } 1972(306,5 \pm 17) \text {, } \\
\text { actualizada por Llambías y } \\
\text { Caminos, } 1987\end{array}$ \\
\hline Tabaquito & $326-329$ & $\mathrm{Rb} / \mathrm{Sr}$ & $\mathrm{Cb}$ inf alto & $\begin{array}{l}29^{\circ} 05^{\prime}-69^{\circ} 10^{\prime} \\
\text { (CFront) SJ norte }\end{array}$ & Sato et al. 1990 \\
\hline $\mathrm{C}^{\mathrm{o}}$ Pta Blanca & $337 \pm 15$ & $\mathrm{~K} / \mathrm{Ar}$ & $\mathrm{Cb}$ inf medio & $\begin{array}{l}33^{\circ} 35^{\prime}-69^{\circ} 30^{\prime} \\
\text { (CFront) Mza }\end{array}$ & Caminos et al. 1979 \\
\hline $\mathrm{C}^{\circ}$ Carrizallito & $341 \pm 17$ & $\mathrm{~K} / \mathrm{Ar}$ & $\begin{array}{l}\text { Cb inf medio } \\
\text { (viseano) }\end{array}$ & $\begin{array}{l}34^{\circ} 40^{\prime}-69^{\circ} 30^{\prime} \\
\text { (CFront) Mza }\end{array}$ & Desanti y Caminos, 1967 \\
\hline $\begin{array}{l}\mathrm{C}^{\circ} \text { Come Caballos } \\
\text { (Granitos y } \\
\text { pórfidos graníticos) }\end{array}$ & $\begin{array}{l}224 \pm 12 \\
233 \pm 12\end{array}$ & $\mathrm{~K} / \mathrm{Ar}_{(\mathrm{Bt})}$ & $\begin{array}{l}\text { Tr medio- } \\
\text { sup }\end{array}$ & Límite con Chile & Caminos, 1972 \\
\hline $\begin{array}{l}\text { Sa. de Punilla } \\
\text { (Monzodiorita) }\end{array}$ & $\begin{array}{l}320+/-20 \\
325+/-9 \\
\end{array}$ & $\begin{array}{l}\mathrm{K} / \mathrm{Ar}_{(\mathrm{Anf})} \\
\mathrm{K} / \mathrm{Ar}_{(\mathrm{Bt})}\end{array}$ & $\mathrm{Cb}$ inf alto & & Mc Bride et al., 1976 \\
\hline
\end{tabular}

$\left.{ }^{*}\right)$ : Abreviaturas utilizadas: Precord: Precordillera, CFront: Cordillera Frontal, Spamp: Sierras Pampeanas; LRja: La Rioja, SJ: San Juan, Mza: Mendoza

constituye una isocrona de referencia o discutida más adelante. La baja relación inicial de errorcrona, por lo que esta datación será ${ }^{87} \mathrm{Sr} /{ }^{86} \mathrm{Sr}$ es muy cercana al valor promedio de 0,704 
estimado para rocas mantélicas a partir de xenolitos, por lo cual se puede inferir que el magma que originó este cuerpo se formó por diferenciación o fusión parcial de material mantélico (o material cortical recientemente separado del manto).

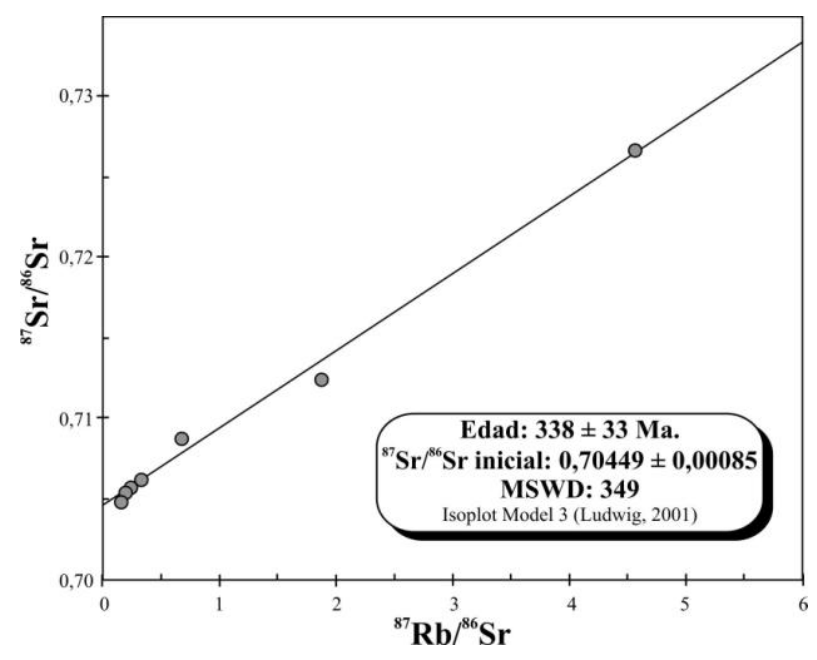

Figura 3.6.16: a) Diagrama de isocrona (errorcrona) $\mathrm{Rb} / \mathrm{Sr}$ obtenido para el Granito Potrerillos ( $n=7)$.

Tabla 3.6.6: Análisis Análisis isotópicos Rb-Sr en roca total de 7 muestras del Granito Potrerillos. La preparación química y el concentrado de $\mathrm{Sr}$ fueron realizados en el laboratorio de Rb-Sr del Centro de Investigaciones Geológicas, contenidos de $\mathrm{Rb}$ y $\mathrm{Sr}$ determinados por FRX en IG-USP (Brasil).

\begin{tabular}{|ccccccc|}
\hline $\mathbf{N}^{\mathbf{0}}$ Muestra & $\mathbf{R b}(\mathbf{p p m})$ & $\begin{array}{c}\mathbf{S r} \\
(\mathbf{p p m})\end{array}$ & ${ }^{\mathbf{8 7}} \mathbf{R b} /{ }^{\mathbf{6}} \mathbf{S r}$ & Error & ${ }^{\mathbf{8 7}} \mathbf{S r}{ }^{86} \mathbf{S r}$ & Error \\
\hline $\mathbf{G 2}$ & 47,2 & 581,8 & 0,235 & 0,005 & 0,705706 & 0,000019 \\
\hline $\mathbf{G 7}$ & 80,3 & 705,7 & 0,329 & 0,007 & 0,706220 & 0,000014 \\
\hline $\mathbf{G 1 0}$ & 70,6 & 1079,7 & 0,189 & 0,004 & 0,705328 & 0,000012 \\
\hline $\mathbf{G 9}$ & 100,8 & 64,3 & 4,547 & 0,091 & 0,726695 & 0,000011 \\
\hline $\mathbf{G 8}$ & 47,2 & 875,0 & 0,156 & 0,003 & 0,704827 & 0,000011 \\
\hline $\mathbf{G 4}$ & 89,9 & 384,4 & 0,677 & 0,014 & 0,708789 & 0,000019 \\
\hline
\end{tabular}

\section{Isótopos de U-Pb.}

En virtud que el diagrama isocrónico obtenido por $\mathrm{Rb} / \mathrm{Sr}$ en roca total presentó un error elevado, se encararon dataciones por U-Pb en circones con el fin de obtener una edad mas precisa del Granito Potrerillos. Las tres muestras seleccionadas para ser datadas forman parte de los afloramientos más homogéneos y con ausencia de enclaves. Corresponden a un granito alcalino (G4) y un monzogranito (G5) que fueron analizados in situ por LA-MC-ICP-MS en el Laboratorio de Geología Isotópica de la Universidade Federal do Rio Grande do Sul (Porto Alegre, Brasil), y a una monzonita (sienodiorita, G1) analizada por ID-TIMS en el Centro de Pesquisas Geocronológicas de la Universidade de Sao Paulo (Brasil). Los resultados se presentan en los Anexos A6b: Tabla 2 y 3. 
Tipología de circones: (Atlas de texturas -Corfu et al., 2003-, Imágenes MEB-BSE).

Los circones obtenidos son rosados a violáceos, prismáticos y euhedrales a subhedrales. Tienen longitudes variables y comúnmente presentan crecimientos secundarios. Las imágenes tomadas con microscopio electrónico (MEB-BSE) permitieron identificar una zonación magmática oscilatoria en varios circones y la presencia de núcleos en algunos de ellos. La zonación oscilatoria es generalmente débil y puede incluso no ser visible, pero en otros casos es posible distinguirla bien en la zona central o en la más externa de los cristales, dejando una zona intermedia más homogénea. Pocos núcleos presentan una zonación desdibujada o en parches.

\section{Relación $T h / U$.}

Esta relación puede usarse para discriminar entre granos de circones magmáticos y metamórficos en las rocas sedimentarias, como una herramienta para los estudios de procedencia (Hartmann y Santos, 2004). Las relaciones Th/U de los spots (LA-ICP-MS, Anexos A6b: Tabla 3) de los cristales analizados se encuentran entre 0,33 y 0,88 para G5, con un promedio de 0,53 , y para G4 varía entre 0,34 y 1,55, con un promedio de 0,74 . Se observó que la relación $\mathrm{Th} / \mathrm{U}$ de los núcleos es siempre mayor que la de los bordes externos. Las características texturales observadas en la zonación son típicas de circones ígneos, aún para los núcleos, que también poseen valores de $\mathrm{Th} / \mathrm{U}$ que los vinculan a un origen magmático (Th/U = 0,2 a 1,5; Hartmann y Santos, 2004). En el circón A-I-07 (Anexos A6b: Tabla 3) de la muestra G4 se ha observado una alta concentración de Th $(>1,5)$.

\section{Edades $U-P b$.}

Los resultados obtenidos por ID-TIMS de la muestra G1 y por LA-MC-ICP-MS para las muestras G4 y G5 se muestran en los Anexos (A6b: Tabla 2 y 3) y se grafinan en la Figura 3.6.17. Para la muestra QP-G1 ( $\mathrm{n}=3$ ) dieron una edad principal ${ }^{206} \mathrm{~Pb} /{ }^{238} \mathrm{U}$ de $350,8 \pm 7,1 \mathrm{Ma}(\mathrm{MSWD}=6,4$, con un nivel de confidencia de 0,95). Para la muestra G4 $(\mathrm{n}=16)$, dos grupos de edades ${ }^{206} \mathrm{~Pb} /{ }^{238} \mathrm{U}$ : una edad más joven y predominante de 355,8 $\pm 3,1 \mathrm{Ma}$ (MSWD $=0,047$, con un nivel de confidencia de 0,83 ), y una edad más antigua de 374,9 \pm 9,3 Ma (MSWD =0,0067, con un nivel de confidencia de 93\%). Esta última generalmente corresponde a los núcleos con altos valores de $\mathrm{Th} / \mathrm{U}$ observados en algunos granos. La muestra G5 $(\mathrm{n}=20)$ arrojó una edad concordia de 345,8 \pm 2,6 Ma (MSWD = 0,014, con un nivel de confidencia de 0,90). La edad más antigua obtenida para la muestra G4 (374,9 \pm 9,3 Ma) indica la edad de cristalización inicial del magma en el Devónico Superior, mientras que las edades más jóvenes que presentan la mayoría de los cristales y bordes externos recristalizados $(345,8 \pm 2,6$ Ma, 355,8 \pm 3,1 Ma y 350,8 \pm 7,1 Ma) están relacionadas al magmatismo principal del Carbonífero Temprano (Tournasiano) o cerca del límite Devónico-Carbonífero. 
a)

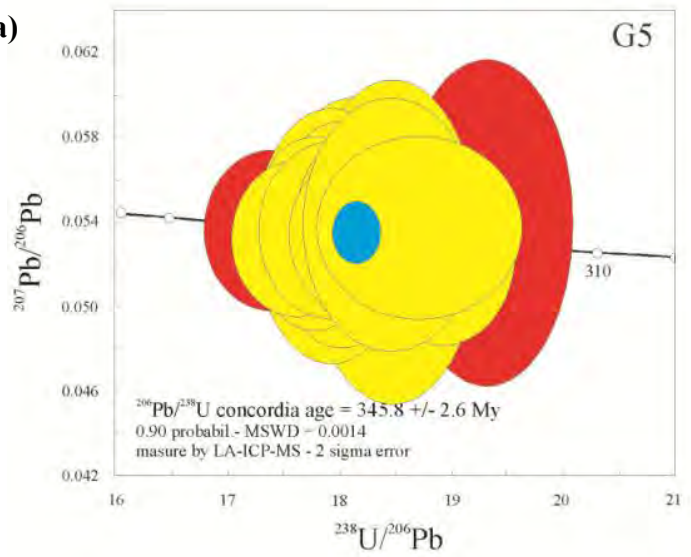

c)

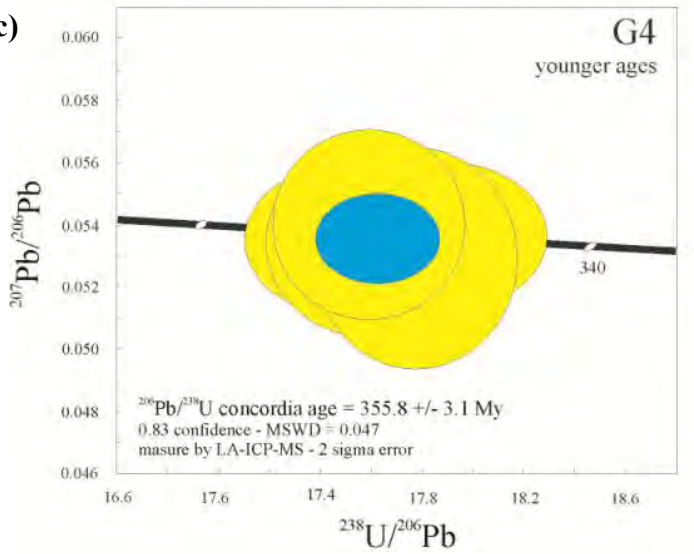

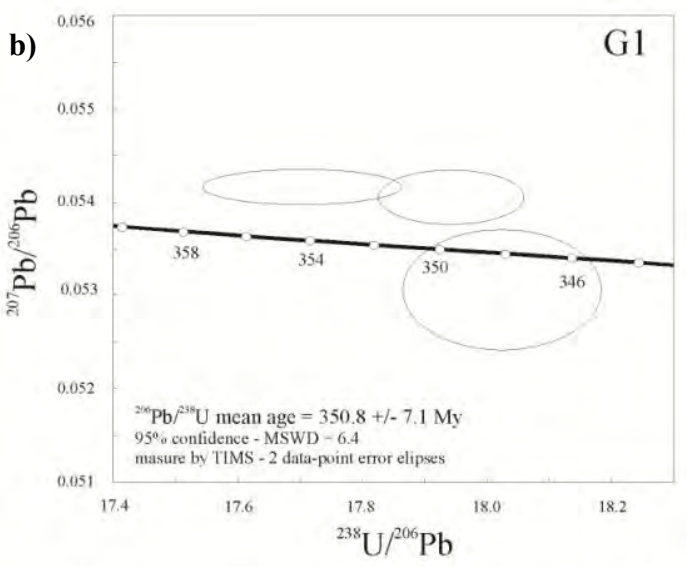

d)

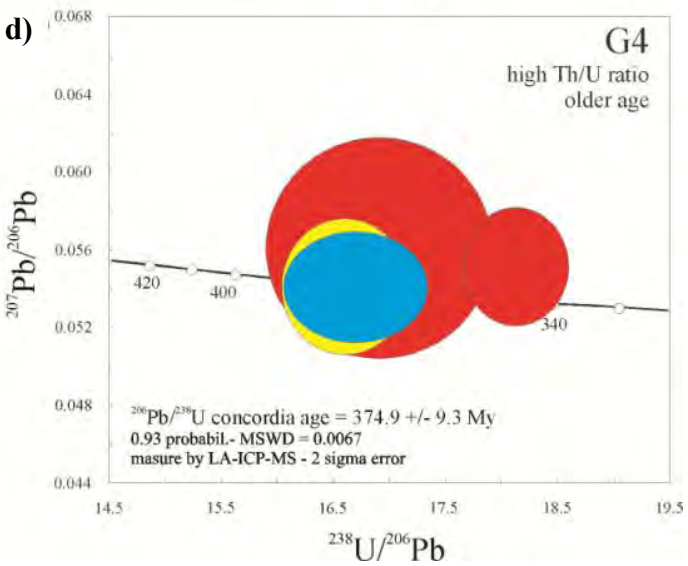

Figura 3.6.17: Diagramas concordia (Tera-Wasserburg, 1972) de edades U/Pb obtenidas en las muestras de circones del Granito Potrerillos. a), c), d): por ICP-MS-LA y b): por TIMS. Edades obtenidas para muestras de cristales de a) G5 (n=20); b) G1 $(\mathrm{n}=3)$; c) y d)- G4, anillo externo y núcleo, respectivamente $(\mathrm{n}=16)$.

G4

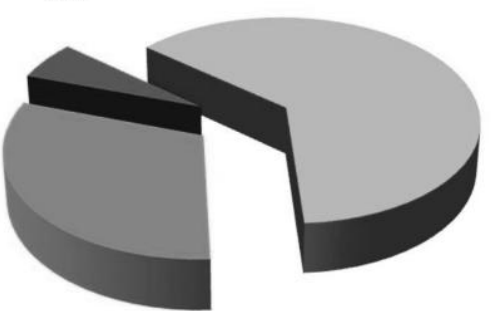

G5

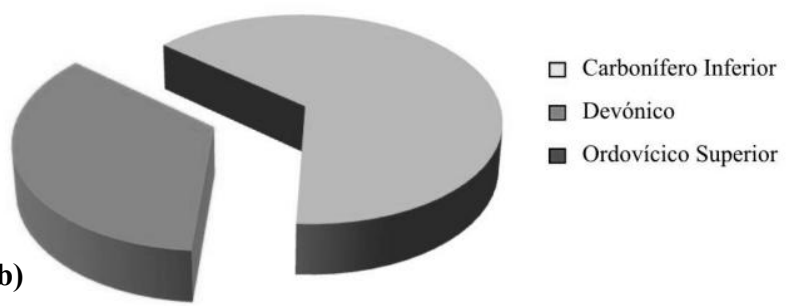

Figura 3.6.18: Distribución de edades ${ }^{206} \mathrm{~Pb} /{ }^{238} \mathrm{U}$ en circón obtenidas por ICP-MS-LA para las muestras del Granito Potrerillos. a)- G4; b)- G5.

Morfología de circones.

Los circones de la muestra G4 son euhedrales, aunque suelen estar quebrados o fracturados. Pueden presentar algunas aristas algo redondeadas o caras con irregularidades leves o engolfamientos, debido probablemente a un proceso de reabsorción magmática. Algunos de los cristales poseen núcleos relícticos (xenocristales) en los que el proceso de reabsorción es más evidente. En las 
imágenes MEB-BSE se observa una zonación magmática oscilatoria muy tenue y gradual, e incluso algunos cristales casi homogéneos, indicando que la composición del magma no ha variado mucho durante el crecimiento de los cristales. Aparecen algunos pocos anillos más brillantes en la zona media y luego uno o dos hacia los bordes de los cristales, y sólo en algunos cristales se observan áreas más brillantes y difusas en los núcleos. La zonación magmática es más conspicua en los xenocristales. Estos núcleos son redondeados o anedrales y la superficie limitante suele cortar la zonación magmática interna de los xenocristales. En algunos casos no es clara la existencia de un núcleo relíctico. En otros, los núcleos o anillos medios bien marcados presentan fracturas radiales hacia los bordes y algunas fracturas concéntricas paralelas a este anillo; estos sectores se expanden por causa de la mayor concentración de $\mathrm{Pb}$ radiactivo generando las fracturas. Se observan inclusiones hexagonales (Ap?), redondeadas o elongadas. Algunas de ellas son grandes en comparación con el tamaño del cristal y suelen estar distribuidas al azar y otras veces se alinean en concordancia con la zonación magmática interna.

La edad ${ }^{206} \mathrm{~Pb} /{ }^{238} \mathrm{U}$ de los núcleos y cristales formados durante la primera etapa de crecimiento varía entre 377 y 364 Ma (Devónico Superior), mientras que la edad de los anillos externos de los circones con núcleos varía entre 358 y $346 \mathrm{Ma}$ (Carbonífero Inferior bajo).

El circón A-I-15 (Anexos A6b: Tabla 3) es un caso particular ya que tiene una edad casi igual en el núcleo (357 Ma) y en el borde (358 Ma) en el sistema ${ }^{206} \mathrm{~Pb} /{ }^{238} \mathrm{U}$, y lo mismo ocurre en el sistema ${ }^{207} \mathrm{~Pb} /{ }^{235} \mathrm{U}$. Esto puede significar que ha habido pérdida de $\mathrm{Pb}$ en el núcleo generando un rejuvenecimiento, o que el núcleo se formó durante la misma etapa de crecimiento magmático que el borde, indicando que no se trata de un xenocristal. Por otro lado, las edades ${ }^{207} \mathrm{~Pb} /{ }^{206} \mathrm{~Pb}$ coinciden con los demás valores de 371 y 349 Ma para núcleo y borde respectivamente.

En la muestra G5 los cristales son euhedrales a subhedrales, suelen tener aristas redondeadas y alguna cara con irregularidades (reabsorción). La presencia de inclusiones es abundante, y en algunos cristales se concentran y alinean siguiendo la zonación magmática. La mayoría de los granos tienen zonación magmática tenue y con anillos anchos/separados. En otros no es evidente una zonación o presentan áreas con zonaciones difusas. Algunos cristales han crecido a partir de un núcleo más acicular y luego se ensancharon. Los núcleos continúan hacia los bordes casi sin superficies de separación claras, por ello es difícil apreciar la presencia de xenocristales internos.

Las edades ${ }^{206} \mathrm{~Pb} /{ }^{238} \mathrm{U}$ de esta muestra indican que los circones se formaron durante el Carbonífero Inferior, aunque son algo más jóvenes que las de la muestra G4 (entre 325 a 356 Ma). Dos cristales revelaron núcleos con edades del Devónico Medio y Superior (389 y $371 \mathrm{Ma}$ ) y un cristal registró una edad ordovícica superior (459 Ma). Este último cristal habría sido incorporado de la roca de caja sedimentaria, aunque en la imagen BSE no se observan características texturales que apoyen esta interpretación.

El circón C-III-33 (Anexos A6b: Tabla 3) tiene una edad más joven en el núcleo (346 Ma, Carbonífero Inferior) que en el borde (360 Ma, Devónico Superior) en el sistema ${ }^{206} \mathrm{~Pb} /{ }^{238} \mathrm{U}$, por lo que no es conveniente considerar este dato. Es probable que se haya producido una pérdida de $\mathrm{Pb}$ en el 
núcleo y quizás también en los bordes. El cristal C-III-09 (Anexos A6b: Tabla 3) tiene un núcleo con edad ordovícica superior $\left({ }^{206} \mathrm{~Pb} /{ }^{238} \mathrm{U}=459 \pm 8 \mathrm{Ma}\right)$ y un borde con edad carbonífera inferior $\left({ }^{206} \mathrm{~Pb} /{ }^{238} \mathrm{U}=356 \pm 5 \mathrm{Ma}\right)$. Este sería un cristal asimilado desde la roca de caja ordovícica, aunque la edad de ésta es algo más joven (440,3 \pm 6,8, límite Ordovícico-Silúrico, Frigerio, 2008b).

Interpretación de los datos $U-P b$.

Las edades del Carbonífero Superior obtenidas previamente por el método K/Ar en biotita y Carbonífero Inferior obtenidas por $\mathrm{Rb} / \mathrm{Sr}_{(\mathrm{RT})}$ podrían haber sido rejuvenecidas por un evento posterior aunque cercano a la intrusión del granito. Entre el 63 y $65 \%$ de las edades concordia $\mathrm{U} / \mathrm{Pb}_{\mathrm{Zr}}$ se ubican dentro del Carbonífero Inferior bajo (Tournasiano; G5: 345,8 \pm 2,6 Ma; G4: 355,8 \pm 3,1 Ma y 374,9 \pm 9,3 Ma), y la edad más antigua en la muestra G5 es del Devónico Superior. Las edades de cristalización de G5 caen dentro del Carbonífero Inferior, aunque alcanzan edades más jóvenes que G4. Sobre la base de la relación $\mathrm{Th} / \mathrm{U}$ toda la población de circones datados tendrían un origen magmático $(\mathrm{Th} / \mathrm{U}=0,2$ a 1,5$)$. Los estudios isotópicos realizados sugieren que habría un proceso de mezcla de dos magmas, uno más básico y otro más ácido. La mezcla no fue completamente miscible, con evidencias de mingling en los afloramientos: e.g. 'gotas' y complejos de venas félsicas en los sectores más máficos, enclaves microgranulares máficos en las granodioritas y rocas más félsicas con predominio de magma félsico. Dado que se trata de un plutón bastante superficial, probablemente no hubo suficiente tiempo para que se homogeneíce la mezcla de ambos magmas antes de enfriarse. Teniendo en cuenta las evidencias de campo (y geoquímicas) de que el plutón ha sufrido un proceso de mingling, y asociando esto a las edades obtenidas en núcleos y bordes de los circones, puede interpretarse que la población de circones del plutón consta de cristales nuevos (formados en el magma híbrido) y cristales previos al proceso de mezcla. Lo más probable es que estos últimos hayan sobrevivido a un proceso de disolución/reabsorción asociado al evento de hibridización por mingling, luego del cual continuaron su crecimiento durante el enfriamiento del nuevo sistema. En los casos en que existen núcleos de xenocristales, éstos presentan características ígneas y arrojan edades muy cercanas a los sobrecrecimientos externos. Según lo que se observa en las imágenes MEB, los xenocristales crecieron en un sistema de composición más variable en el tiempo respecto a los bordes, cuyas evidencias son: zonación oscilatoria más conspicua y núcleos más brillantes con BSE, que indicarían una mayor concentración y variación del contenido de elementos traza (Hf, P, Y, REE, U y Th). A pesar de las evidencias de asimilación de bloques de la roca de caja que se observan en el campo, los circones analizados no habrían sido aportados por la roca de caja sino en su mayoría formados in situ dentro del magma. Así, el proceso de asimilación parcial de la roca de caja habría sido poco significativo ya sea porque no habría tenido tiempo o temperatura suficiente, quedando como esquistos inyectados y bloques angulosos concentrados localmente dentro del granito. Se interpreta que el magma básico se mezcló con el magma ácido en el Devónico Superior, promoviendo la reabsorción magmática (disolución por sub-saturación del fundido y aumento de temperatura) de los 
cristales de circón. Aquellos cristales que sobrevivieron quedaron como xenocristales en el fundido. Luego continuó el enfriamiento y crecimiento de los cristales en el nuevo sistema magmático híbrido hasta el Carbonífero Inferior.

\section{Isótopos de Sm y Nd}

Una edad modelo "manto deprimido" $\left(\mathrm{T}_{\mathrm{DM}}\right)$ es una estimación del momento en el cual la roca se separó de su fuente mantélica. Para rocas ígneas y meta-ígneas es una buena estimación de la "edad de formación cortical". En el caso de los granitoides derivados del manto, la edad modelo registra la edad de fraccionamiento del precursor basáltico del granitoide, y se asume que está muy cerca de la edad de cristalización del mismo. Para los granitoides que derivan de la fusión parcial de corteza continental antigua, las edades modelo indican la edad de la fuente cortical que los originó; esto es posible ya que los procesos de fraccionamiento intra-corticales no disturban el sistema Sm-Nd. Sin embargo, es común que los granitoides sean resultado de una mezcla de fuentes cortical y mantélica; en este caso la edad modelo da un resultado intermedio.

Tabla 3.6.9: Tabla de resultados isotópicos de Sm-Nd para tres muestras del Granito Potrerillos y cálculo de las edades modelo correspondientes según el modelo de De Paolo et al. (1981).

\begin{tabular}{|l|cc|cc|ccccc|}
\hline Muestra & $\begin{array}{c}\text { Sm } \\
(\mathrm{ppm})\end{array}$ & $\begin{array}{c}\mathbf{N d} \\
(\mathrm{ppm})\end{array}$ & ${ }^{147} \mathbf{S m} /{ }^{144} \mathbf{N d}$ & ${ }^{143} \mathbf{N d} /{ }^{144} \mathbf{N d}$ & $\begin{array}{c}\text { error } \\
(\mathrm{ppm})\end{array}$ & $\mathbf{E N d}_{(\mathbf{0})}$ & $\mathbf{E N d}_{(\mathbf{t})}$ & $\begin{array}{c}\mathbf{t} \\
(\mathrm{Ma})\end{array}$ & $\mathbf{T D M}$ \\
\hline G1 & 9.10 & 68.80 & 0.07995 & 0.51264 & 18 & 0.04 & $\mathbf{5 . 2 5}$ & 350 & $\mathbf{4 6 9}$ \\
G10 & 6.07 & 36.99 & 0.09919 & 0.51257 & 15 & $\mathbf{- 1 . 3 3}$ & $\mathbf{3 . 0 3}$ & 350 & $\mathbf{6 3 0}$ \\
G4 & 4.05 & 26.73 & 0.09164 & 0.51267 & 19 & 0.62 & $\mathbf{5 . 3 2}$ & 356 & $\mathbf{4 7 5}$ \\
\hline
\end{tabular}

Tabla 3.6.10: Tabla de resultados isotópicos de Sm-Nd para tres muestras del Granito Potrerillos y cálculo de las edades modelo correspondientes según el modelo de De Paolo et al. (1991).

\begin{tabular}{|l|cc|cc|ccccc|}
\hline Muestra & $\begin{array}{c}\text { Sm } \\
(\mathrm{ppm})\end{array}$ & $\begin{array}{c}\mathbf{N d} \\
(\mathrm{ppm})\end{array}$ & ${ }^{147} \mathbf{S m} /{ }^{144} \mathbf{N d}$ & ${ }^{143} \mathbf{N d} /{ }^{144} \mathbf{N d}$ & $\begin{array}{c}\text { error } \\
(\mathrm{ppm})\end{array}$ & $\mathbf{E N d}_{(\mathbf{0})}$ & $\mathbf{\varepsilon N d}_{(\mathrm{cc})}$ & $\begin{array}{c}\text { t } \\
(\mathrm{Ma})\end{array}$ & $\mathbf{T D M}$ \\
\hline G1 & 9.10 & 68.80 & 0.07995 & 0.51264 & 18 & 0.04 & $\mathbf{5 . 3 0}$ & 350 & $\mathbf{6 3 0}$ \\
G4 & 4.05 & 26.73 & 0.09164 & 0.51267 & 19 & 0.62 & $\mathbf{5 . 4 0}$ & 356 & $\mathbf{6 2 0}$ \\
G10 & 6.07 & 36.99 & 0.09919 & 0.51257 & 15 & -1.33 & $\mathbf{3 . 0 0}$ & 350 & $\mathbf{8 5 0}$ \\
\hline
\end{tabular}
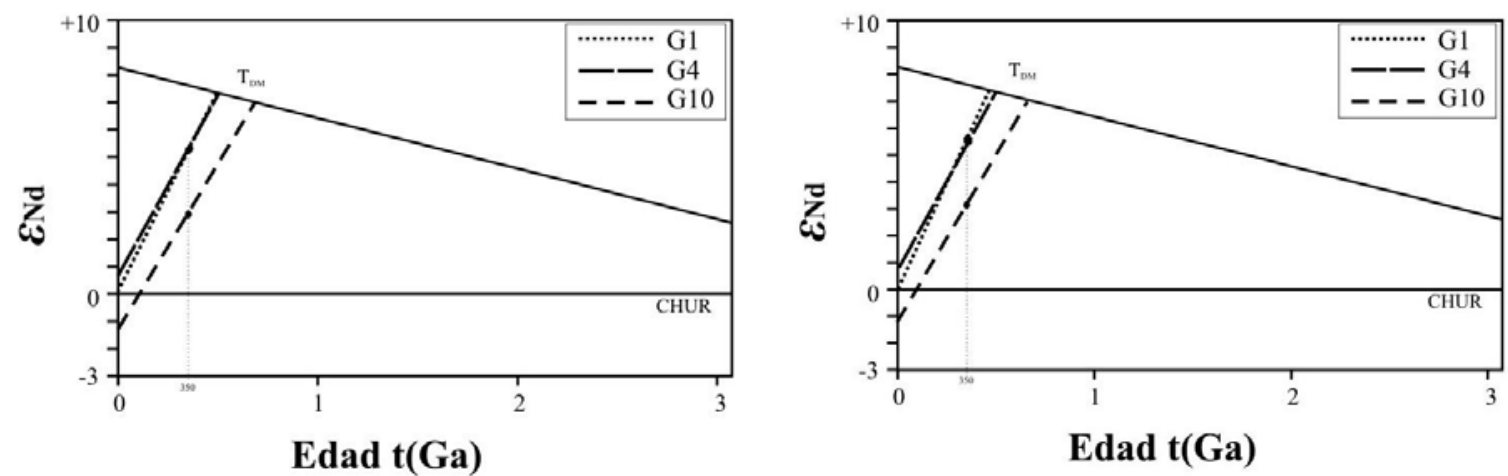

Figura 19: Gráfico $\varepsilon N d$ versus edad (t), en el que se muestran las edades modelo obtenidas para las muestras analizadas del Granito Potrerillos. a) según modelo de De Paolo (1981); b) según modelo de De Paolo (1991). 
Para el Granito Potrerillos se obtuvieron edades $\mathrm{T}_{\mathrm{DM}}$ más antiguas (G1: 630Ma, G4: 620Ma, G10: 850Ma) usando el modelo propuesto por De Paolo et al. (1991), en el que se consideran dos etapas de diferenciación magmática, que el modelo de De Paolo (1981, G1: 469 Ma, G4: 475 Ma, G10: $630 \mathrm{Ma}$ ) en el que se considera una sola etapa de diferenciación. Los valores de $\varepsilon N d$ positivos a ligeramente negativos de las muestras del Granito Potrerillos (Figura 3.6.19, Tablas 3.6.9 y 3.6.10) estarían indicando una fuente mantélica/magma poco contaminado durante su ascenso y emplazamiento en la corteza. Esto podría deberse a una corteza delgada o a un ascenso rápido del magma, de manera que el sistema no se haya llegado a contaminar significativamente. Acorde con los valores positivos o poco negativos de $\varepsilon N d$ se prefirió usar el modelo de De Paolo (1981), considerando que el magma no debió haberse diferenciado demasiado como sería de esperar en el modelo de dos etapas.

\section{f- Consideraciones finales.}

El Granito Potrerillos es un plutón compuesto por una variedad de facies composicionales entre las que dominan las monzonitas y granodioritas. Son rocas ricas en biotita y plagioclasa, y como minerales accesorios presentan apatita y circón. En dioritas y gabros llega a ser importante la titanita. Hay evidencias de asimilación de la roca de caja, representadas por enclaves esquistosos ricos en biotita. Las características observadas principalmente en los afloramientos (enclaves máficos, zonas heterogéneas de inmiscibilidad), han permitido identificar un proceso de mingling entre dos magmas de distinta composición. La presencia de filones sin-magmáticos aplíticos indica un comportamiento rígido de la roca de caja durante el enfriamiento. Los crecimientos secundarios observados en cristales de circón y apatita pueden relacionarse a distintas etapas de crecimiento durante el magmatismo y/o al crecimiento luego de la asimilación de bloques de la roca de caja. La presencia de miarolas rellenas, lentes pegmatíticas marginales y los abundantes enclaves de la roca de caja sedimentaria sugieren un emplazamiento en profundidades someras.

El Granito está deformado y ha sido afectado por metamorfismo regional de medio a bajo grado junto a la roca de caja sedimentaria, en la cual además generó una aureola de contacto caracterizada por el moteado de las facies finas y crecimiento de biotita.

En cuanto a su ambiente tectónico de emplazamiento, los datos obtenidos sugieren que se trata de un plutón de arco relacionado a subducción de composición principalmente monzonítica emplazado a bajas profundidades. Las edades ${ }^{206} \mathrm{~Pb} /{ }^{238} \mathrm{U}$ ubican el pulso magmático principal en el Carbonífero Temprano (Tournasiano), cerca del límite Devónico-Carbonífero, mejorando la edad previa de enfriamiento $\mathrm{K} / \mathrm{Ar}_{(\mathrm{Bt})}$. La edad más antigua Devónico Superior obtenida en la muestra G4 corresponde a núcleos de circones ígneos que pudieron haberse formado en un pulso magmatico previo posteriormente invadido por el evento magmático principal del Carbonífero. Los núcleos discordantes parecen haber sido cristales magmáticos tempranos reabsorbidos antes de ser incorporados al pulso principal o durante el proceso de mingling. 
El Granito Potrerillos se ubica en un área compleja con respecto a la evolución y marco geotectónico regional (Figura 3.6.1), intruyendo a metasedimentitas ordovícicas de la Precordillera riojana y siendo tradicionalmente considerado dentro del arco magmático gondwánico de Cordillera Frontal. Las características petrológicas y geoquímicas del Granito Potrerillos son consistentes con un ambiente tectónico de arco volcánico, relacionado a procesos de subducción en un margen continental activo. Esta característica también se observa en los metasedimentos de la roca de caja, la cual posee una edad máxima de sedimentacion ordovícica (a silúrica). Las características geoquímicas de los metasedimentos de la roca de caja (Frigerio, 2008b) coinciden con las del plutón para un ambiente de arco magmático continental, aunque no necesariamente del mismo ciclo.

Por su edad K-Ar fue tradicionalmente considerado como parte del arco magmático Gondwánico (e.g. Llambías et al., 1999). Sin embargo, considerando las relaciones estratigráficas y estructurales observadas, la actividad magmática principal ocurrió antes de las fases tectónicas Río Blanco y San Rafael, las cuales pudieron haber reseteado el sistema K/Ar. Las edades U/Pb obtenidas relacionarían al plutón a la fase tectónica Chánica, pero considerando las características observadas en los afloramientos (discordantes respecto a la roca de caja sedimentaria y de morfología subcircular especialmente), y su signatura geoquímica intermedia con composiciones principalmente monzoníticas-granodioríticas, puede ser considerado dentro de los granitoides tardío a post-tectónicos de la orogenia Famatiniana descriptos en la Sierra de San Luis (e.g. González et al., 2006). La evidencia de un proceso de mingling y la ausencia o escasa presencia de allanita podrían vincular al Granito Potrerillos con el arco Carbonífero según las consideraciones hechas por Dahlquist (2001). Este autor discute respecto de la relación entre la presencia de epidota magmática en granitoides y la fuente como otro punto de vista para entender de mejor manera el ambiente geotectónico. Según este autor, "la abundancia de epidota magmática es una característica distintiva de los granitoides del Ordovícico Inferior, en oposición a los granitoides andinos del Carbonifero (e.g., el Complejo Santo Domingo,7 kbar), donde la epidota magmática es escasa y la presencia de epidota secundaria es común.” (...) Se observa que "la presencia de epidota magmática en granitoides puede ser relacionado con diferencias en la fuente, ya que los granitoides del Orógeno Famatiniano fueron esencialmente derivados por fusión de una litósfera continental antigua con probable contribución parcial del manto litosférico subcontinental, y los granitoides andinos carboniferos son, esencialmente, el resultado de una mezcla de magmas derivados de la corteza y el manto". La diferencia de edades con los cuerpos plutónicos cercanos es pequeña, sin embargo, mientras que los granitoides del cerro de Las Tunas, sierra del Peñón y cerro Comecaballos pertenecen a los inicios del ciclo magmático gondwánico, de acuerdo con los resultados obtenidos hasta el momento para el Granito Potrerillos y las distintas observaciones de campo y de la geología regional, se lo considera aquí dentro de los estadíos finales del ciclo Famatiniano (fase Chánica) como se expresa anteriormente (Frigerio et al., 2010). 


\subsection{7- LA FAJA DE DEFORMACIÓN DE JAGÜÉ (Segunda Parte: esquistos miloníticos).}

\section{a. Geoquímica}

Considerando la milonitización que presentan los esquistos, especialmente sobre la quebrada del Bonete, es de esperar una gran movilización de los elementos, aun de los más inmóviles. Sin embargo los diagramas de tierras raras muestran algunas tendencias, que sólo se toman a modo indicativo cuando suman coherentemente a otras observaciones petrográficas, en especial en cuanto a la composición y origen de los esquistos. Pero de ninguna manera deben tomarse como definitorias.Así, se tomaron como ejemplos característicos de las variedades de esquistos a las muestras E-BO19 y E-BO32 entre los esquistos cuarzosos, E-BO4(2) y E-BO5 entre los micáceos, y a las muestras E-CG1 y E-BO12 entre los esquistos verdes clorítico - epidóticos y clorítico actinolíticos respectivamente. Los análisis geoquímicos de las muestras pueden consultarse en los Anexos (A6a: Tabla 3.7.2).

Los esquistos cuarzosos presentan los mayores valores de $\mathrm{SiO}_{2}$ (entre 70 y $80 \%$ ), $\mathrm{Pb}$ y Mo, y los menores contenidos de $\mathrm{Fe}_{2} \mathrm{O}_{3}(\mathrm{t}), \mathrm{MgO}(<1 \%), \mathrm{TiO}_{2} \mathrm{y}_{2} \mathrm{O}_{5}$. Además presentan bajos valores de $\mathrm{Co}$, $\mathrm{V}, \mathrm{Sc}, \mathrm{Ni}, \mathrm{Cu}$ y Ta, elementos que generalmente se concentran en rocas básicas. La muestra E-BO32 es la que se muestra más enriquecida en elementos incompatibles y tierras raras. Presenta altas concentraciones de $\mathrm{K}_{2} \mathrm{O}, \mathrm{Rb}, \mathrm{Ba}, \mathrm{Cs}, \mathrm{Be}, \mathrm{Sn}, \mathrm{Th}, \mathrm{U}, \mathrm{Y}$ y la mayoría de las REE; esto está asociado principalmente a la abundante cantidad de feldespatos y muscovita en esta muestra. Por el contrario, E-BO19 es la más cuarzosa y esto se refleja en los mayores contenidos de $\mathrm{SiO}_{2}$ y las menores concentraciones de REE y otros elementos, especialmente incompatibles (habría un efecto de dilución por cuarzo, al menos en parte).

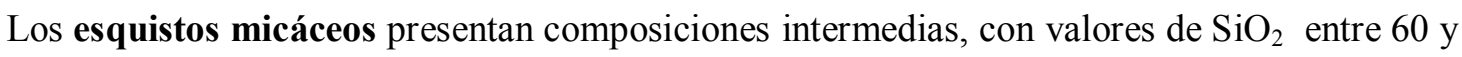
$65 \%, \mathrm{Fe}_{2} \mathrm{O}_{3}(\mathrm{t})$ entre 4 y $5 \%, \mathrm{MgO}$ entre 1 y $2 \%, \mathrm{~K}_{2} \mathrm{O}$ de 2,36 y $3,03 \%, \mathrm{TiO}_{2}$ entre 0,6 y $0,7 \%$, y $\mathrm{P}_{2} \mathrm{O}_{5}$ entre 0,1 y $0,2 \%$. Además presentan altas concentraciones de $\mathrm{Cs}$, Hf y Rb los mayores valores de $\mathrm{Ba}(>500 \mathrm{ppm}), \mathrm{y} \mathrm{Zr}$ ( $>350 \mathrm{ppm})$. Como es de esperar, las pizarras y pizarras moteadas son las que presentan mayores valores de $\mathrm{Al}_{2} \mathrm{O}_{3}$ (entre 18 y $20 \%$ ), y su concentración parece aumentar proporcionalmente al contenido de muscovita y clorita.

Entre los esquistos verdes E-CG1 y E-BO12 hay una gran variación en la concentración de varios elementos, sin embargo ambas manifiestan similitudes con las rocas básicas. En este sentido Vaquer (Melgarejo (ed.), 1997, p.343) indican que "En general las metabasitas se distinguen de las metapelitas por tener $\mathrm{CaO}$ como componente importante y concentraciones bajas o muy bajas de $\mathrm{K}_{2} \mathrm{O}$, con mayor presencia de $\mathrm{FeO}$ y menor $\mathrm{SiO}_{2}$. Esto implica que no hay minerales potásicos esenciales en porcentajes importantes y que las fases cálcicas son muy significativas en contraposición a las metapelitas. Con relación a las rocas ultramáficas las metabasitas son mas ricas en $\mathrm{CaO}, \mathrm{Al}_{2} \mathrm{O}_{3}$ y $\mathrm{Na}_{2} \mathrm{O}$ y mas pobres en $\mathrm{MgO}$, siendo el $\mathrm{FeO}$ un componente esencial a diferencia de las primeras". Lo primero que resalta en los esquistos verdes es el contenido muy bajo de $\mathrm{SiO}_{2}$ de alrededor del $45 \%$. 
Presentan las mayores concentraciones de $\mathrm{Fe}_{2} \mathrm{O}_{3}\left(\mathrm{t}\right.$ ) (entre 12 y 14\%) y $\mathrm{TiO}_{2}$ (entre 2 y 3\%). Los contenidos de $\mathrm{MgO}$ son inferiores a $1 \%$ en esquistos cuarzosos y llegan hasta alrededor de 1,5\% en los micáceos, a diferencia de los valores de $\mathrm{MgO}>3 \%$ que presentan los esquistos verdes. El contenido de $\mathrm{CaO}$ de los esquistos verdes es variable pero toma valores entre 5 y $13 \%$, bastante superiores a la concentración de este óxido en los esquistos micáceos y cuarzosos, en los que generalmente no supera el 1\%. En E-BO12 es evidente su relación con el mayor contenido de anfíboles cálcicos. El $\mathrm{MnO}$ toma los valores de 0,16 y $0,19 \%$, triplicando los valores inferiores o iguales a $0,05 \%$ de los demás esquistos. $\mathrm{El}_{2} \mathrm{O}$ toma valores de $0,33 \%$ para E-BO12 y 1,03\% para ECG1. También presentan bajas concentraciones de elementos incompatibles como $\mathrm{Rb}$, Th y $\mathrm{Pb}, \mathrm{y}$ altas de $\mathrm{V}, \mathrm{Sc}, \mathrm{Ni}$, indicadores de composiciones básicas. E-BO12 tiene bajos valores de las tierras raras livianas La, Ce y Pr. La muestra E-CG1 presenta alto contenido de volátiles por la abundancia de clorita $(\mathrm{LOI}=3,2 \%), \mathrm{Na}_{2} \mathrm{O}(4,72 \%), \mathrm{Nb}(43,2 \mathrm{ppm})$ y algunas tierras raras intermedias a pesadas $(\mathrm{Sm}$ - $\mathrm{Ho}, \mathrm{Yb})$.

En los diagramas de tierras raras normalizados a la corteza continental superior (UCC, Taylor y McLennan, 1981; Figura 3.7.1a) y otros patrones sedimentarios como el PAAS (McLennan 1989; Figura 3.7.1b) también se ponen de manifiesto las diferencias entre los distintos esquistos. Los esquistos micáceos E-BO4 y E-BO5 siguen una tendencia subparalela a la UCC, con $\mathrm{REE}_{\text {muestra }}>$ $\mathrm{REE}_{\mathrm{UCC}}$ entre las tierras raras medias y pesadas, y menor concentración de tierras raras livianas. Los esquistos cuarzosos E-BO19 y E-BO32 son las que presentan mayores diferencias, especialmente entre $\mathrm{Nd}$ y Eu, y una tendencia general positiva hacia las HREE. Los esquistos verdes E-BO12 y ECG1 muestran picos positivos de Eu y menor concentración de algunas tierras raras pesadas, en especial $\mathrm{Yb}$ y Lu, y en las livianas. En todas las muestras el $\mathrm{Y}$ esta enriquecido respecto a los valores de la corteza superior promedio ( $\mathrm{Y}_{\mathrm{UCC}}=22$ ppm, Taylor y McLennan, 1985; McLennan et al., 2006), y presentan valores mas parecidos o superiores a los de la lutita australiana post-arqueana promedio $\left(\mathrm{Y}_{\mathrm{PAAS}}=27\right.$ ppm, Taylor y McLennan, 1985). Una excepción es E-BO19, que presenta un valor muy bajo $(\mathrm{Y}=16 \mathrm{ppm})$.

a

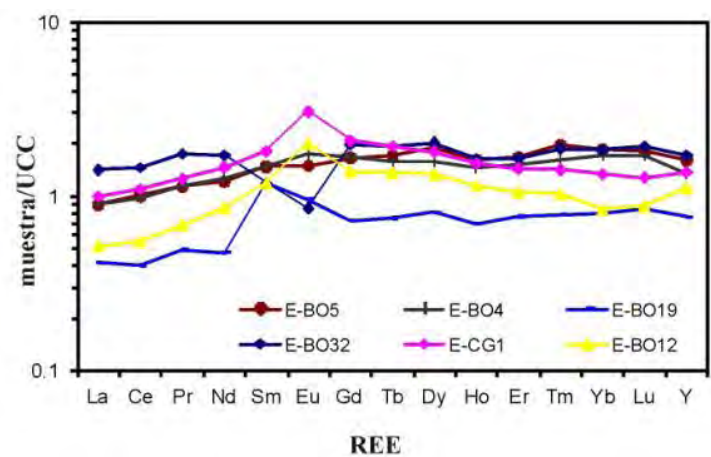

b

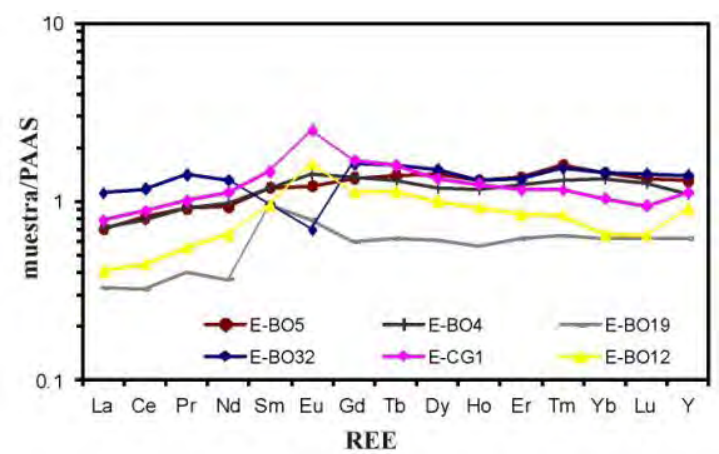

Figura 3.7.1: Diagramas de tierras raras normalizados a: a) la corteza continental superior (UCC, Taylor y McLennan, 1981); b) Post-Arquean Australian Shale (PAAS, McLennan, 1989).

En los diagramas de tierras raras normalizados al condrito C1 (Taylor y McLennan, 1985; Figura 2) se observa la diferencia de comportamientos que presentan las distintas muestras de 
esquistos. Todos están enriquecidos en LREE en relación a HREE y presentan pendientes negativas hacia las HREE.Las muestras ECG1 y E-BO12 presentan comportamientos similares entre si, con una pendiente negativa mas o menos constante, sin anomalías de Eu y con menores concentraciones de $\mathrm{Yb}$ y $\mathrm{Lu}$ y mayores de Y. Las muestras E-BO4 y E-BO5 también son muy similares, con una pendiente negativa entre el La y Dy, anomalía negativa de Eu moderada, y un patrón subhorizontal

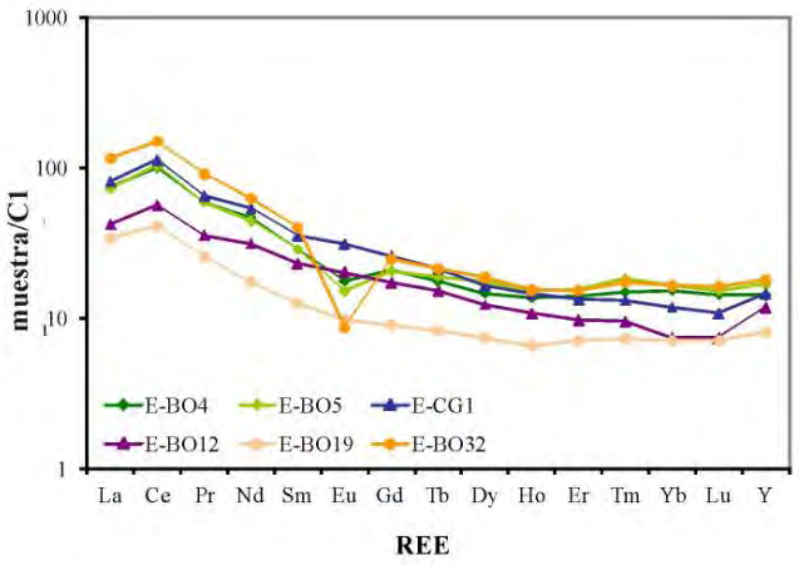

Figura 3.7.2: Diagramas de tierras raras normalizados al condrito C1 (Taylor y McLennan, 1985).

entre Ho e Y. La muestra E-BO32 presenta un patrón similar pero en cambio presenta anomalía negativa de Eu pronunciada y mayor enriquecimiento en LREE. Por otro lado, la muestra E-BO19 es la que menos concentración de REE presenta, sinanomalía de Eu pero con un claro enriquecimiento de LREE y un patrón que se horizontaliza hacia las HREE.

En líneas generales, al comparar con los patrones de tierras raras obtenidos para las rocas de las unidades aledañas (sedimentitas, granitoides, rocas básicas; ver secciones anteriores) se observa que E-CG1 y E-BO12 siguen el comportamiento de las rocas básicas; E-BO19 tiene un tendencia parecida al del Granito Potrerillos; y E-BO32, E-BO4 y E-BO5 siguen los patrones de las rocas corticales, en especial E-BO32.

Solo para observar su comportamiento con fines comparativos se han ploteado muestras de esquistos en algunos diagramas utilizados para análisis de procedencia de sedimentos (Figura 3.7.3).

\section{b. Geologia isotópica y edad}

\section{Rocas calcáreas}

Teniendo en cuenta que las rocas calcáreas son tradicionalmente correlacionadas con la Formación San Juan, de la Precordillera, uno de los objetivos proyectados en el plan de tesis es el de intentar obtener una edad mas precisa para estas rocas.

Se planteó realizar análisis bioestratigráficos, pero no se han preservado macrofósiles en los afloramientos. Los carbonatos biogénicos son secretados directamente del agua marina por los organismos y son resistentes a la alteración diagenética. Desafortunadamente, debido a su escaso contenido de $\mathrm{Rb}$ no pueden ser fechados convencionalmente por el sistema $\mathrm{Rb}$-Sr, pero puede usarse como una herramienta indirecta de fechado una curva calibrada de la evolución de las relaciones isotópicas de ${ }^{87} \mathrm{Sr} /{ }^{86} \mathrm{Sr}$ del agua marina. Este método no puede competir en precisión con el fechado bioestratigráfico, pero es muy útil en perfiles de carbonatos sin fósiles. Así, otra posibilidad planteada fue la de realizar análisis de las relaciones isotópicas de ${ }^{87} \mathrm{Sr} /{ }^{86} \mathrm{Sr}$ para comparar con las curvas 
(a)

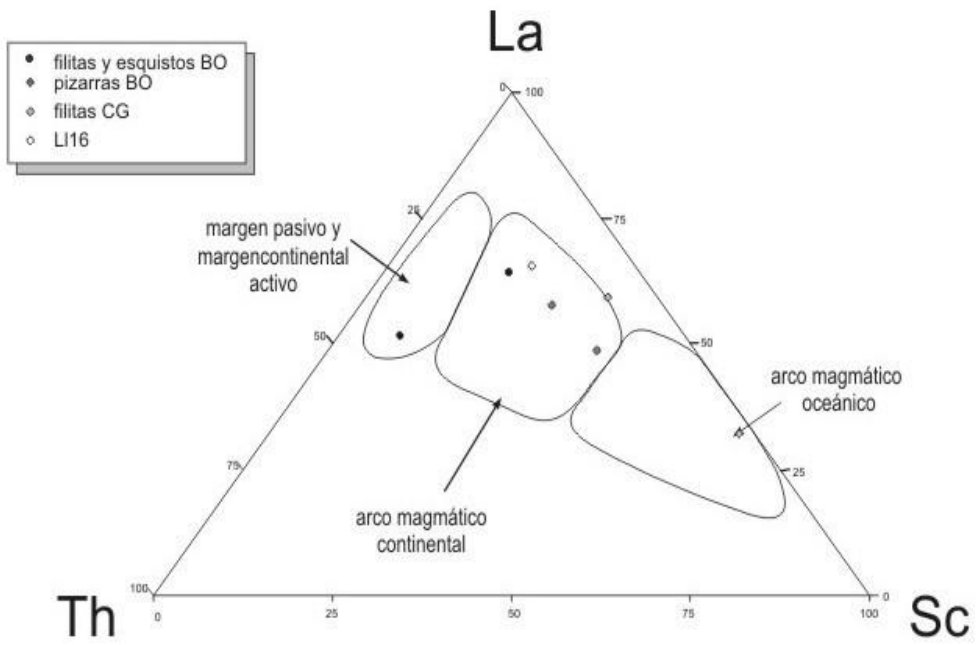

(b) A: Arco de islas oceánico

C: Margen continental activo

Th

D: Margen pasivo

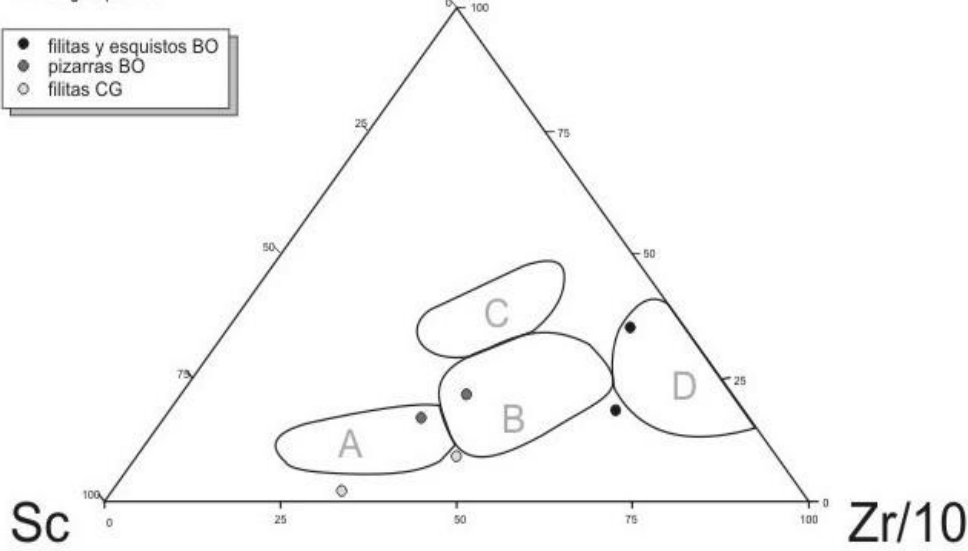

(c)

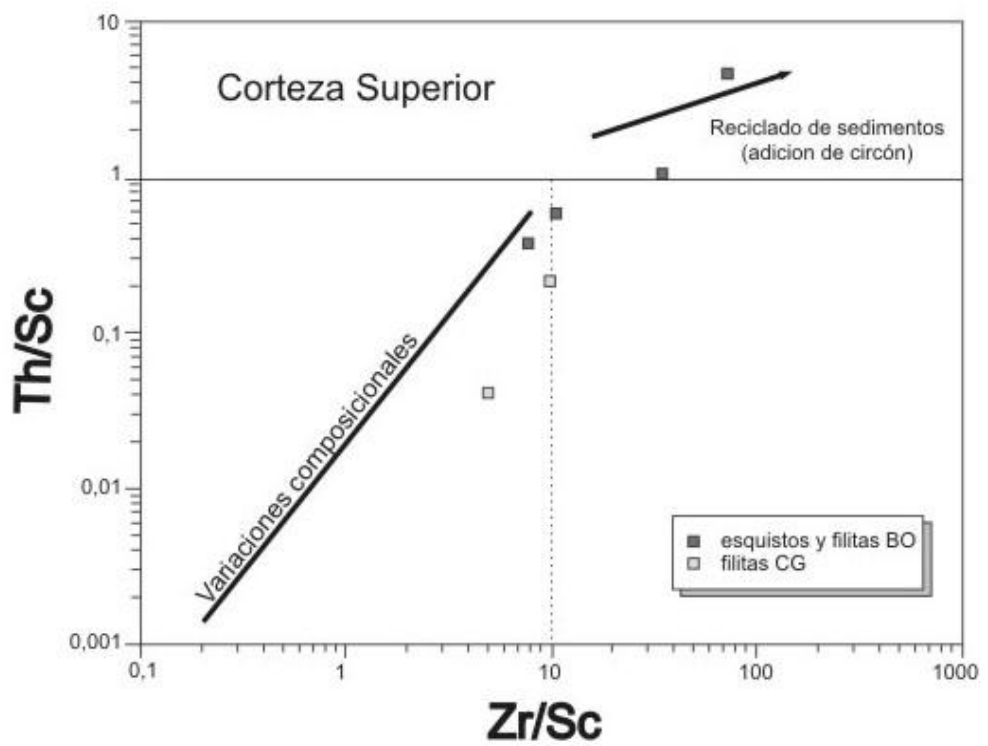

Figura 3.7.3: Ubicación de las muestras de esquistos en los triángulos $\mathrm{La}-\mathrm{Th}-\mathrm{Sc}$ (a) y $\mathrm{Th}-\mathrm{Sc}-\mathrm{Zr} / 10$ (b) de Bathia y Crook (1986) y en el diagrama $\mathrm{Th} / \mathrm{Sc}$ vs. $\mathrm{Zr} / \mathrm{Sc}$ (c) modificado de McLennan et al. (1993) propuestos para análisis de procedencia de rocas sedimentarias. 
patrones del agua de mar, y obtener informaciones detalladas de la composición y de la historia diagenética mediante mediciones de tierras raras y de isótopos estables. Sin embargo, la escala de la deformación de las 'calizas' (esquistos calcáreos y mármoles) no permite realizar un perfil de muestreo confiable.

Por otro lado se procesaron muestras para buscar material microfosilífero, con especial énfasis en hallar conodontes, ya que éstos por su composición son más resistentes a la temperatura y deformación. Se eligieron las muestras menos deformadas y más oscuras (y entonces con mayor posibilidad de preservación de la materia orgánica). Originalmente se procesaron cinco muestras recogidas sobre la quebrada del Bonete (ver metodología en capítulo 2). Estas fueron C-BO8 (500 g), C-BO15 (500 g), C-BO16 (350 g), C-BO17 (400 g) y C-BO18 (400 g). Luego se analizó más material de C-BO17 (300 g), C-BO18 (300 g) y C-BO8 (300 g) y se agregaron otras dos del área de los Llantenes C-LL7 (300 g), C-LL10 (300 g). Lamentablemente no se obtuvieron resultados positivos confiables en ningun caso. En la muestra C-BO8 se halló un "fragmento de algo orgánico tipo conchilla" y un resto que podría ser un "trozo de cúspide de conodonte ordovícico", con coloración muy blanca, lo que en el índice CAi significa que fue sometida a mucha temperatura (hasta 700$750^{\circ} \mathrm{C}$ ). Además en la muestra C-BO17 se encontró un resto orgánico mal preservado de morfología aproximadamente cónica y color negro, que podría ser comparable con los conodontes del Cámbrico Superior, sin embargo no se ha podido hallar más evidencia para mejorar y constatar este dato.

No se ha hallado más material que permita confirmar los restos hallados, por lo que es imposible por ahora dar una edad a las rocas calcáreas en base a fósiles (o isótopos estables). Martina y Astini (2009) consideran que los mármoles por la proporción de dolomita que presentan y por su bandeado composicional, al que consideran derivado de la estratofábrica primaria, 'se correlacionarían con las unidades cámbricas del Terreno Precordillera' (Formaciones Zonda y La Flecha), a diferencia de las calizas ordovícicas de la Precordillera y rocas calcáreas de las Sierras Pampeanas, netamente cálcicas. Se trata de calizas impuras, con nódulos de pedernal y abundante material detrítico silicoclástico especialmente micáceo y cuarzoso, característica que, junto a la dolomitización observada, en general no se observa en las calizas ordovícicas de la Precordillera. La presencia de abundantes nódulos de pedernal de colores castaño oscuros, especialmente en el área Los Llantenes (por ejemplo en C-LL7), es otro carácter que se ha observado en la plataforma cámbrica.

\section{Esquistos}

Isótopos de $U$ y $\mathrm{Pb}$

Se dataron circones detríticos de la muestra E-BO5 por el método U-Pb LA-ICP-MS. Se eligió esta muestra ya que representa a los esquistos característicos de la Formación Río Bonete (Miembro Cerro Cóndor) en su área tipo. 
Las características texturales de los granos indican que se trata de circones detríticos de origen ígneo en su gran mayoría. Se han tomado fotografías con microscopio electrónico de barrido y las imágenes tomadas con electrones retro-difundidos (BSE) permitieron observar y analizar las texturas internas de los granos pulidos. Los granos tienen morfologías prismáticas, subredondeadas o irregulares, y en ciertos casos han preservado caras imperfectas. La mayoría presenta bordes irregulares debido al retrabajo sedimentario o fracturas. Salvando algunas excepciones, los granos datados corresponden a fragmentos subedrales a anedrales, con zonación interna oscilatoria débil, que muchas veces puede estar parcialmente modificada. En algunos pocos granos se han observado zonaciones internas irregulares o en parches (ej. Zr-031-I-IX-11), y en algunos granos la zonación oscilatoria muestra sectores mas desdibujados o convoluciones, lo que podría estar reflejando una respuesta al metamorfismo en facies anfibolita (Corfu et al., 2003, pág. 481). En toda la población de granos fotografiados es común la presencia de inclusiones subredondeadas aisladas y de gran tamaño. Otros granos muestran inclusiones muy abundantes y pequeñas concentradas en los sectores con baja concentración de $U$, resultando una especie de textura 'esponjosa'. Esta última textura es probablemente de origen hidrotermal. $\mathrm{Y}$ en estos sectores también suelen aparecer microfases minerales con alta concentración de U (se observan blancas en BSE). Algunos cristales muestran muchas fracturas paralelas al alargamiento del cristal. En otros las fracturas internas siguen patrones concéntricos asociados al grado de metamictización (hay expansión) en los límites entre sectores de alta y baja concentración de $\mathrm{U}$ en la zonación oscilatoria. Otros factores que causan el fracturado de los circones son los esfuerzos externos durante la milonitización (Wayne and Sinha, 1988) o diagénesis (Medenbach, 1976). Cuando están sujetos a diagénesis progresiva u otras sobreimposiciones metamórficas, dichos sistemas de fracturas pueden estar cicatrizadas y solo observarse bajo determinadas circunstancias (Corfu et al., 2003).

Se obtuvo un rango continuo de edades $\mathrm{U} / \mathrm{Pb}_{\mathrm{Zr}}$ entre los 837 y $1.470 \mathrm{Ma}(\mathrm{n}=46)$, generándose una curva unimodal con un pico principal de $c a .1000$ Ma (Figura 3.7.4). Pueden agruparse en rangos de edad menores de $837 \pm 16 \mathrm{Ma}, 912 \pm 13$ a $1.061 \pm 21 \mathrm{Ma}$, y $1.094 \pm 12$ a $1.470 \pm 22 \mathrm{Ma}$. El único antecedente que existe es el presentado por Martina et al. (2005), quienes reportan una edad de 1.118 $\pm 17 \mathrm{Ma}$ por método U-Pb en circones de una milonita granítica incluida en la faja de deformación de Jagüé ('ortogneiss' de Martino y Astini, 1998).

La contribución predominante de circones es de un basamento mesoproterozoico (74\%), mientras que el $26 \%$ restante $(n=12)$ corresponde al Neoproterozoico, con una edad máxima de aporte de $837 \pm 16 \mathrm{Ma}$ (Figura 3.7.4). Es destacable la ausencia de edades mas jóvenes dentro de los ciclos Pampeano o Famatiniano. Esto ubica la fuente de aporte ígnea dentro del ciclo Grenvilliano, junto al basamento de Precordillera y Sierras Pampeanas Occidentales. Por otro lado, la ausencia de edades más jóvenes permite inferir que la fuente ordovícica que contribuyó a las metasedimentitas ordovícicas de la Formación Del Salto aun no existía o estaba fuera de las áreas de aporte de estos sedimentos (sección 3.2.3.1); las observaciones apuntan al primer caso. 

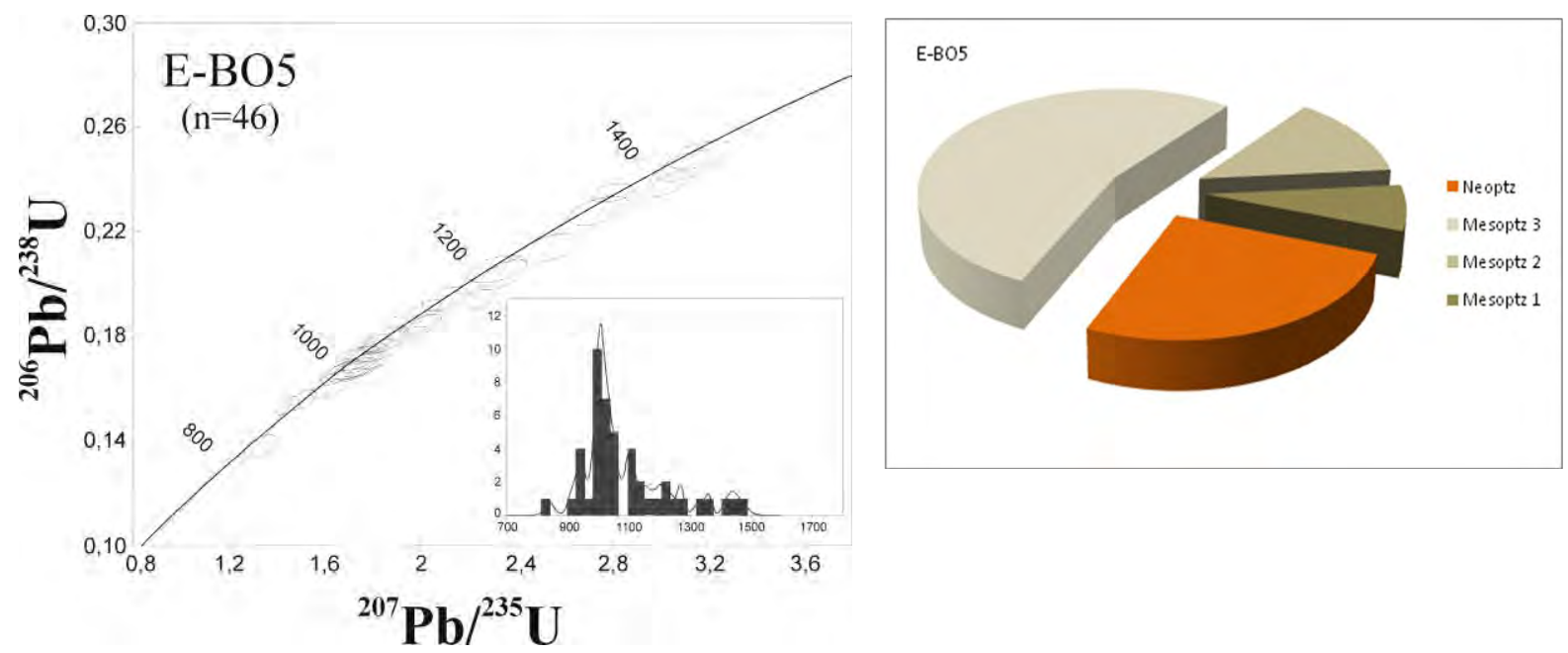

Figura 3.7.4: a)- Diagrama de concordia y curva acumulativa generados a partir de los resultados $\mathrm{U} / \mathrm{Pb}$ en circones de la muestra E-BO5 representativa de los Esquistos Cerro Cóndor en su Área Tipo. b)- diagrama de torta correspondiente.

En base a los datos de U-Pb y las texturas de los granos de circón es posible diferenciar claramente entre la muestra E-BO5 que representa a las rocas típicas definidas para la Fm Río Bonete s.s., de las dos muestras datadas de las rocas sedimentarias fosilíferas de la Formación Del Salto (sección 3.2.3.1).

Isótopos de Sm y Nd

Considerando que los isótopos de $\mathrm{Nd}$ son extremadamente inmóviles, se realizaron análisis de seis muestras de esquistos mapeadas dentro de la Formación Río Bonete. Se consideraron las muestras de grano fino E-BO6, E.BO20, E-BO29 (pizarras) y E-CG1 (filita) por ser en este tipo de muestras que se concentran mas las tierras raras. Además se analizó el esquisto anfibólico E-BO12 para comparar con las metabasitas.

Sin embargo, cuando se analiza un gráfico con las edades modelo (De Paolo, 1991) los resultados no han sido los deseados, ya que si se asume una edad de referencia de $c a .1000$ Ma como la que dio el pico principal de edades $\mathrm{U}-\mathrm{Pb}_{(\mathrm{Zr})}$ en E-BO5, las líneas de las pizarras cortan por encima de la curva del CHUR (lo mismo ocurrió considerando el modelo original de De Paolo, 1981). Este resultado no tiene significado ya que se parte de la base teórica de que las rocas se generaron y evolucionaron a partir del reservorio que representa esta curva. Así, se estima que el sistema Sm-Nd ha sido modificado por la deformación, alteración y/o metamorfismo y por lo tanto no se pueden usar estos datos. 


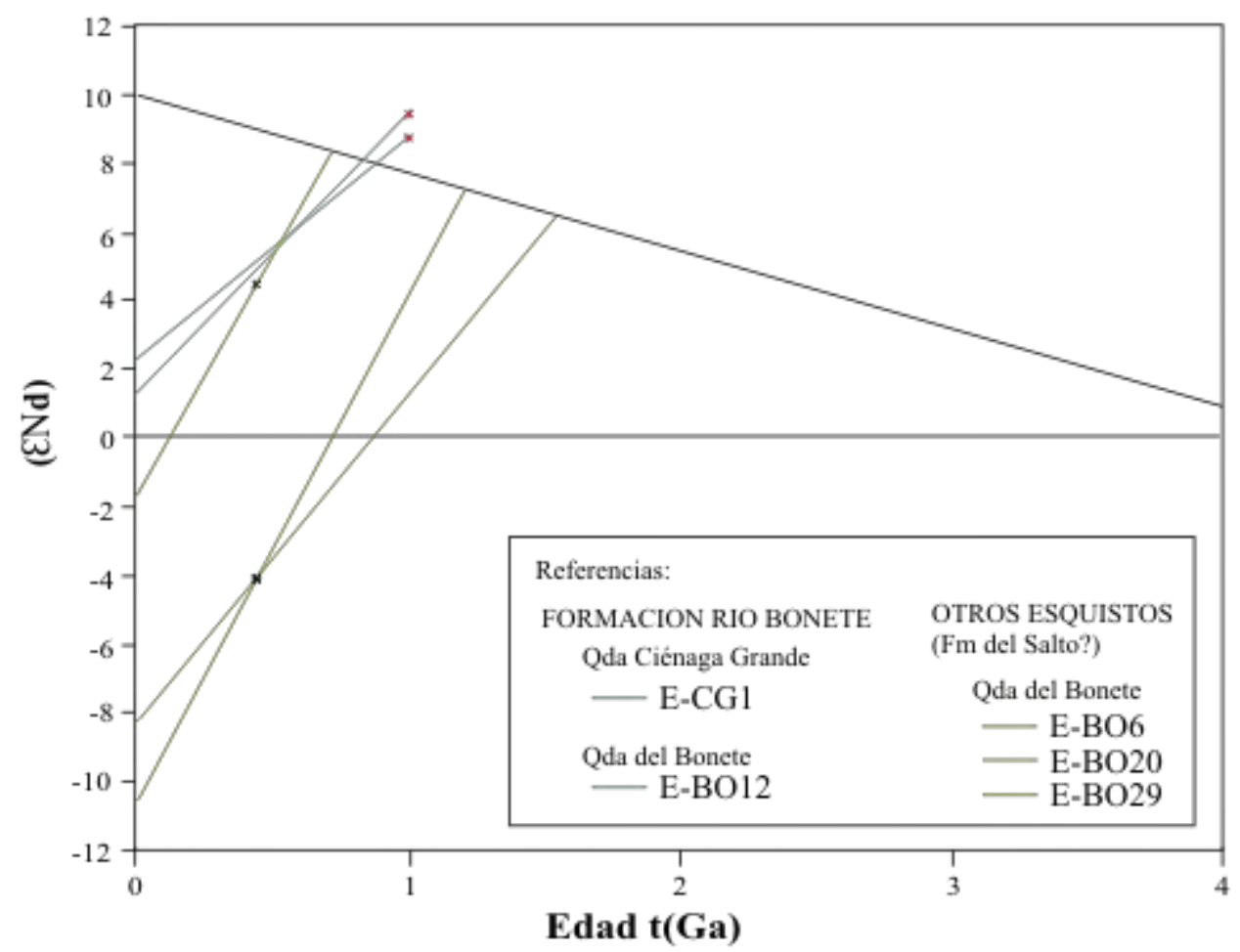

Figura 3.7.5: Edades modelo Sm-Nd obtenidas para cinco esquistos de los alrededores de la quebrada del Bonete, Formación Río Bonete y otros esquistos comparables con las sedimentitas de la Formación del Salto. Cálculos según modelo de De Paolo (1981).

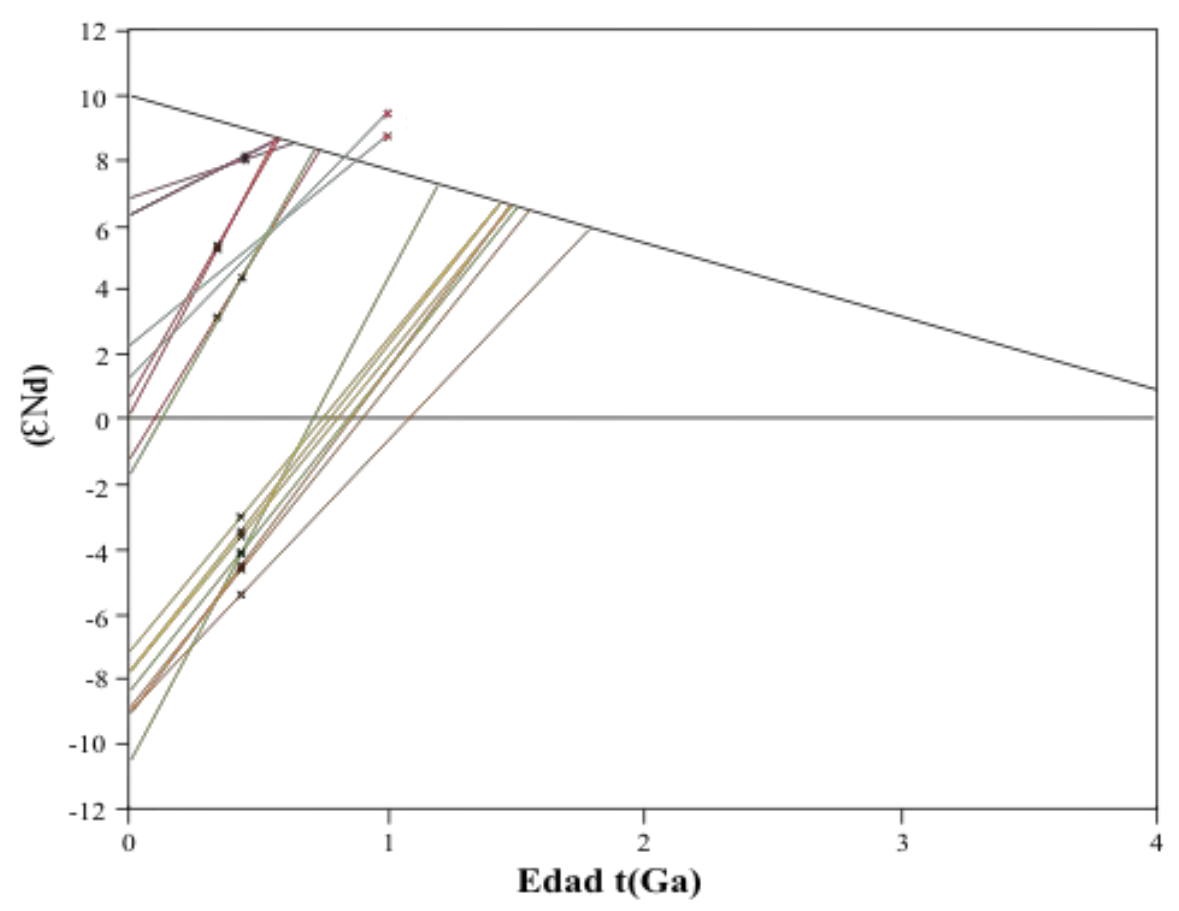

\section{Referencias:}

FORMACION RIO BONETE Qda de Potrerillos: QP-E6 QP-E8 QP-E10

Qda del Chuscho

LS 2

LS2-3

LS2-F

Qda del Bonete

- E-BO6

- E-BO20

- E-BO29

- E-BO12

- E-CG1

FORMACION POTRERILLOS

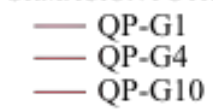

FORMACION CHUSCHO

$-\mathrm{CH} 2$

$-\mathrm{CH} 3$

- MQ-I2

Figura 3.7.6: Diagrama comparativo de las edades modelo de las distintas unidades de la Precordillera de Jagüé que han sido afectadas por la faja de cizalla. 
La muestra E-BO20 tiene muy poco $\mathrm{Sm}$ y $\mathrm{Nd}$ en relación al resto de las muestras, y da un valor de epsilon $\mathrm{Nd}_{(\mathrm{t})}$ muy elevado $(12,17)$. Por este motivo se descarta ya que se infiere que el sistema isotópico fué modificado por los procesos secundarios y/o metamórficos.

\section{c- Correlaciones.}

Principalmente en base a su edad, los esquistos participarían del basamento del Terreno Precordillera o Cuyania. Considerando la continuidad de las estructuras regionales, da la impresión de que la asociación de esquistos verdes y las rocas calcáreas serían la continuación hacia el norte de los afloramientos de la Sierra de Umango. Allí podrían correlacionarse por su edad, características litológicas y grado metamórfico, con los esquistos y calizas de la Sierra de Cacho y adyacencias (falda oriental de la Sierra de la Punilla, Sierras de Cacho, Tambillos, Umango, y falda occidental de la Sierra del Espinal), en el flanco occidental de esta sierra (Zolezzi y Guerrero, 1981). Estos autores describen para estos sectores la presencia de calizas, anfibolitas y esquistos similares a los de la Formación Río Bonete en el "Paleozoico Inferior o pre-Paleozoico?". Por otro lado, por lo descripto en trabajos de Varela y otros en la sierra de Umango los esquistos Cerro Cóndor podrían ser equivalentes al basamento precámbrico de bajo grado (en facies de esquistos verdes) que constituye la Formación Umango (Arigós, 1949; Varela et al., 2003).

Las rocas calcáreas han sido correlacionadas, en base a su litología, con la plataforma carbonática de la Precordillera, pero su edad es aun incierta. Tradicionalmente fueron correlacionadas con la Formación San Juan (Ordovócico), porque se asociaban a las sedimentitas con fósiles ordovícicos del área del Chuscho (Aceñolaza et al., 1971). Sin embargo, recientemente fueron correlacionadas con las Formaciones La Laja (Cámbrico) y La Flecha, del Cámbrico Superior, por Martina y Astini, (2009), quienes consideraron el mayor grado de dolomitización que presentan respecto a las calizas ordovícicas, y la presencia de ojos de cuarzo, comunes en estas unidades de la Precordillera Oriental. En este sentido, las abundantes concreciones de pedernal que se hallaron especialmente en las rocas calcáreas de los cerros Las Damas, así como el único resto de conodonte hallado en la muestra C-BO17 en el tramo medio del río Bonete, apuntan a una edad similar.

\section{d- Apuntes sobre metamorfismo y variedades de esquistos.}

El tipo y grado de metamorfismo que afecta a las unidades estudiadas en la Precordillera de Jagüé no es homogéneo, ya que hay eventos superpuestos al metamorfismo regional, como el metamorfismo de contacto asociado a la intrusión del Granito Potrerillos y el metamorfismo dinámico (aparentemente relacionado con un metamorfismo retrógrado) que afecta a las rocas dentro de las fajas de deformación que pasan por las quebradas del río Bonete y área de Los Llantenes. 


\section{Metamorfismo regional.}

Krauskopf y Byrd, (1995, p.428) relacionan las condiciones de temperatura y presión que caracterizan a las distintas facies del metamorfismo regional en base a las asociaciones minerales presentes (Tabla 3.7.1). Siguiendo a estos autores, las rocas de la región se encontrarían en facies de esquistos verdes característica del metamorfismo regional de baja temperatura $\left(350^{\circ}-550^{\circ} \mathrm{C}\right)$ y presiones intermedias a altas ( 3 - $10 \mathrm{Kbars;}$ indicado por la aparición de Chl), generando las asociaciones minerales $\mathrm{Qtz}-\mathrm{Ab}-\mathrm{Ms}-\mathrm{Bt}-\mathrm{Chl}$ en las metasedimentitas y $\mathrm{Ab}-\mathrm{Ep}-\mathrm{Act}-\mathrm{Chl}$ en las metabasitas.

Por otro lado, Winkler (1978) da como límite entre la facies de esquistos verdes y facies anfibolitas la aparición de $\mathrm{Hbl}$ a expensas de Chl y Ep. En la mayoría de las rocas tanto Chl como Ep son las fases minerales dominantes, por lo tanto no han sobrepasado condiciones de facies de esquistos verdes, excepto en las cercanías del granito y en algunos sectores puntuales sobre la quebrada del Bonete.

Tabla 1.7.1: Asociaciones minerales características desarrolladas en lutitas y rocas básicas en base a las cuales se definen las distintas facies metamórficas (Krauskopf y Byrd, 1995, p.428). Sh: del inglés 'shale' (pelita); Rbás: rocas ígneas básicas. FEV: facies de esquistos verdes; FAnf: facies de anfibolitas.

\begin{tabular}{|c|c|c|}
\hline Temperatura & $\begin{array}{c}\text { - Metamorfismo de Contacto - } \\
\text { Presión Baja } \\
\text { (<3 Kbars, }<10 \mathrm{Km} \text { prof.) }\end{array}$ & $\begin{array}{l}\text { - Metamorfismo Regional - } \\
\text { Presión intermedia a alta } \\
(3-10 \mathrm{~Kb}, 10-35 \mathrm{Km} \text { prof. })\end{array}$ \\
\hline $350-550^{\circ} \mathrm{C}$ & $\begin{array}{l}\text { F. Hornfels de Ab-Ep } \\
\text { Sh: } \quad \text { Qtz }-\mathrm{Ab}-\mathrm{Ms}-\underline{\mathrm{Bt}} \\
\text { Rbás: } \mathrm{Ab}-\mathrm{Ep}-\mathrm{Act}-\mathrm{Chl}\end{array}$ & $\begin{array}{lc} & \text { FEV } \\
\text { Sh: } & \mathrm{Qtz}-\mathrm{Ab}-\mathrm{Ms}-\mathrm{Bt}-\underline{\mathrm{Chl}} \\
\text { Rbás: } & \mathrm{Ab}-\mathrm{Ep}-\mathrm{Act}-\mathrm{Chl}\end{array}$ \\
\hline $\begin{array}{c}\mathbf{5 0 0}-\mathbf{7 0 0}^{\mathbf{0}} \mathbf{C} \\
(\text { desaparece la } \mathrm{Chl})\end{array}$ & $\begin{array}{lr} & \text { F. Hornfels de Hbl } \\
\text { Sh: } & \mathrm{Qtz}-\mathrm{Pl}-\underline{\mathrm{Fk}}-\mathrm{Ms}-\mathrm{Bt} \\
\text { Rbás: } & \mathrm{Pl}-\mathrm{Hbl}\end{array}$ & $\begin{array}{lc} & \text { F. Anf } \\
\text { Sh: } & \mathrm{Qtz}-\mathrm{Pl}-\mathrm{Ms}-\mathrm{Bt}-\underline{\mathrm{Alm}} \\
\text { Rbás: } \mathrm{Pl}-\mathrm{Hbl}\end{array}$ \\
\hline $\begin{array}{c}>\mathbf{7 0 0}^{\circ} \mathrm{C} \\
(\text { desaparece la Ms) }\end{array}$ & $\begin{array}{lr} & \text { F. Hornfels de Px } \\
\text { Sh: } & \text { Qtz }-\mathrm{Pl}-\mathrm{Fk}-\mathrm{Crd}-\text { And } \\
\text { Rbás: } & \mathrm{Pl}-\mathrm{Dp}-\mathrm{Hy}\end{array}$ & $\begin{array}{lr} & \text { F. Granulitas } \\
\text { Sh: } & \text { Qtz }-\mathrm{Pl}-\mathrm{Fk}-\mathrm{Grt}-\mathrm{Sil} \\
\text { Rbás: } \mathrm{Pl}-\mathrm{Dp}-\mathrm{Hy}-\mathrm{Grt}\end{array}$ \\
\hline
\end{tabular}

Otra evidencia petrográfica observada y que se relaciona con la temperatura es la diferencia de comportamiento entre el cuarzo y los feldespatos (principalmente plagioclasas). Mientras que la temperatura de fluxión del cuarzo es a $\operatorname{los} 300{ }^{\circ} \mathrm{C}$, la de los feldespatos comienza recién a los $500{ }^{\circ} \mathrm{C}$. En la mayoría de los cortes de las muestras deformadas el cuarzo se comporta dúctilmente y la plagioclasa se desgrana o forma porfiroclastos. Esto acota la temperatura entre los 300 y $500{ }^{\circ} \mathrm{C}$, posicionándonos también dentro de la facies de esquistos verdes (ver Holdaway, 1971). Sólo localmente este umbral es superado ya que los feldespatos también se encuentran deformados y/o presentan subgranos. Cerca del granito Potrerillos las sedimentitas han sufrido mayor temperatura, 
llegando a generar Alm (facies Anfibolita, $500^{\circ}-700^{\circ} \mathrm{C}$ ) a expensas de $\mathrm{Chl}$ y Bt, pero esto no es un rasgo comun (sección 3.2.2: Figura 3.7.9e-f).

Sin embargo, dentro de la faja de deformación se han hallado anfibolitas y lavas almohadilladas anfibolitizadas, que estarían dando evidencias de que al menos las metabasitas alcanzaron localmente la facies de anfibolitas. La aparición de Ttn parece relacionarse a metamorfismo retrógrado durante un evento metamórfico posterior en facies de esquistos verdes, probablemente durante la deformación frágil dúctil en la faja de cizalla en la que se generaron milonitas y texturas cataclásticas. (Características similares halló Durand (1998) en las anfibolitas de la Sierra de Socoscora, en la provincia de San Luis, quien atribuye este último evento retrógrado al Dv?, con dudas).

Calizas: las calizas dolomíticas mas o menos impuras son bastante abundantes en la naturaleza, y su composición puede ser representada dentro del sistema de cuatro componentes $\mathrm{CaO}$ $\mathrm{MgO}-\mathrm{SiO} 2-\mathrm{CO}_{2}$, junto con $\mathrm{H}_{2} \mathrm{O}$ si, como producto de las reacciones metamórficas con el agua presente en la roca se forman fases hidratadas (Margarejo, 2003, p. 361). Metz (1976) estableció que las reacciones estables necesarias para definir las asociaciones minerales dentro de este sistema en metamorfismo de grado bajo a medio eran 12 , de las cuales la siguiente se ha detectado en las rocas estudiadas:

$3 \mathrm{dol}+4 \mathrm{Qtz}+\mathrm{H} 2 \mathrm{O}=\mathrm{Tlc}+3 \mathrm{Cal}+3 \mathrm{CO} 2$ (si hay algún proceso previo que aumente la fracción molar de $\mathrm{CO}_{2}\left(\mathrm{X}_{\mathrm{CO} 2}\right)$ el Tle no se forma)

Las demás asociaciones (de mayor grado) no se han observado.

\section{Metamorfismo de contacto:}

La aureola de contacto del granito es esencialmente de bajo grado, habiéndose desarrollado a bajas presiones $(<3-5 \mathrm{~Kb})$ y temperaturas intermedias a bajas, en facies de Hornfels de $\mathrm{Ab}-\mathrm{Ep}$; esto es coherente con las texturas observadas en el granito Potrerillos, emplazado en niveles poco profundos (sección 3.2.6). En las metasedimentitas de la roca de caja se observa una fuerte neoformación de biotita, con la consecuente desaparición de la clorita y la mayor parte de la mica blanca. Se han generado motas compuestas por un agregado de Src/Ms y Chl, probablemente de Crd (o andalucita?). Estarían relacionadas a la reacción Chl - Ms - Qtz $\rightarrow \mathrm{Crd}$ (motas) $+\mathrm{Bt}+\mathrm{H}_{2} \mathrm{O}$. La temperatura dentro de la aureola de contacto puede acotarse por la petrografía. La aparición de Bt ocurre a partir de los $400^{\circ} \mathrm{C}$ a través de la reacción $\mathrm{Chl}+\mathrm{Fk} \rightarrow \mathrm{Bt}+\mathrm{Ms}+\mathrm{Qtz}+\mathrm{H} 2 \mathrm{O}$, y excepto cerca de los contactos con el granito no llegaría a $\operatorname{los} 550-700^{\circ} \mathrm{C}$, temperaturas a las que desaparece la Ms por la reacción $\mathrm{Ms}+\mathrm{Qtz} \rightarrow \mathrm{Fk}+\mathrm{Als}+\mathrm{H}_{2} \mathrm{O}$. 
Además se han hallado rocas gabroides y diabasas con asociación metamórfica de Pl $(\mathrm{Ab})+$ Act + Ep \pm Chl, lo que coincide tambien con este rango de condiciones P-T. (Los datos de microsonda de algunas muestras indican que las plagioclasas estan albitizadas).

\section{Metamorfismo dinámico.}

El efecto del metamorfismo dinámico es principalmente la deformación frágil-dúctil y formación de los esquistos miloníticos que caracterizan la zona del río Bonete y en los Llantenes. Estaría relacionado con un metamorfismo retrógrado en facies de esquistos verdes.

A continuación se describen aspectos generales para las rocas cataclásticas relacionándose a lo observado en las rocas estudiadas. Como referencias pueden tomarse lo explicado especialmente en Llano et al. (1988), Bonalumi (2003), y (Brogioni, 2000).

La presencia de una textura cataclástica en corte delgado es la prueba más positiva de este tipo de deformación. Las rocas cataclásticas son generalmente cuarzo-feldespáticas, pues las rocas básicas, bajo las mismas condiciones de $\mathrm{T}^{\mathrm{o}}$ - P- X, recristalizan fácilmente en un esquisto (Bonalumi, 2003), sin embargo en este sector la cataclasis se puede reconocer incluso en las rocas básicas. En las zonas de fallas principales, hay a menudo distintos tipos de rocas deformadas que gradan entre sí, y pueden registrarse también mas de un proceso cataclástico en una misma roca (rocas policlásticas). Este es el caso de algunas rocas dentro de la faja de deformación de Jagüé, que habría sido reactivada mas de una vez.

El principal neomineral generado en las rocas cataclásticas es la clorita que se forma a partir de los mafitos disponibles (biotita, granate, anfíboles, etc.). La sericita y epidoto formadas a partir de feldespatos son también muy comunes. Si las condiciones de $T^{o}-P-X$ son altas, puede aparecer neobiotita o neohornblenda; esto sólo se observa en los esquistos micáceos mas cercanos al granito Potrerillos (Bt). Pero hay que tener en cuenta que cloritización y/o sericitización son también procesos típicos en el metamorfismo retrógrado de esquistos y gneises. (Bonalumi, 2003).

Deformación progresiva de las fases más comunes (ver Bonalumi, 2003):

Como el cuarzo es el mineral más común y sensible a la deformación, será un buen indicador del grado de ésta. Pueden describirse tres etapas principales de deformación progresiva de éste mineral: 1) El primer efecto de la presión es la extinción ondulosa y formación de láminas de deslizamiento (láminas de Böhm). No hay granulación perigranular ni suturas. Se podría describir como estructura débilmente cataclástica. 2) Luego comienza la fracturación en pedazos grandes no elongados, con granulación perigranular o suturas (éstas son el resultado de la incorporación de los granos al fragmento más grande). 3) Por último se forman bandas de flujo, donde el cuarzo forma un 
agregado de lentículos. No quedan ya trozos grandes de cuarzo en la roca [en esta etapa estarían las rocas estudiadas].

En contraste con el cuarzo, los feldespatos son notablemente resistentes a la trituración y quedan generalmente como porfiroclastos en las tectonitas. La trituración del feldespato comienza de afuera hacia adentro del cristal, y se produce recién cuando el cuarzo ya está muy triturado. Lo primero que se muele son las esquinas del cristal y luego, por granulación, se vuelve ovalado, y a medida que va rolando, disminuye su tamaño.

El cuarzo comienza a recristalizar alrededor de $\operatorname{los} 270^{\circ} \mathrm{C}$ con forma poligonal a ameboidal, mientras que el feldespato no recristaliza hasta alcanzar la facies anfibolitas o superior (Llano et al., 1988). Las rocas estudiadas se encuentran en su mayoria dentro del rango de temperatura en que el cuarzo ya ha comenzado a recristalizar pero el feldespato aun se comporta en forma frágil.

Por su lado, las micas son fácilmente deformadas por la cataclasis, pero al mismo tiempo recristalizan y registran asi la deformación. La muscovita tiende a formar masas fusiformes torcidas, conocidas como 'pescados de mica', de 2 a $5 \mathrm{~mm}$. La biotita difícilmente soporta la cataclasis sin alterarse, se desferriza y el Fe eliminado, se concentra en "colas" oscuras de magnetita y hematita en los planos de flujo. Estos productos sirven para reconocer o confirmar la cataclasis. La biotita, por otra parte, puede, bajo ciertas condiciones de $T^{o}-P$, regenerarse (neobiotita). La magnetita (y la ilmenita) es muy abundante en esquistos verdes y metabasitas, lo que podría relacionarse entonces con pocesos de desferrización de los minerales primarios. Ademas es comun observar la transformacion de biotita a muscovita y/o clorita.

\subsection{8- CONGLOMERADOS DE JAGÜÉ (Paleozoico Superior)}

\section{Introducción:}

Se han hallado afloramientos de conglomerados relacionados tectónicamente o mediante discordancia angular con las unidades estudiadas y a la faja de cizalla. Los conglomerados se distinguen por sus características texturales y composicionales, y, aunque no se ahondará mucho en su descripción, se mencionan y describen brevemente ya que han permitido hacer algunas observaciones y definiciones importantes en cuanto al mapeo y relaciones de campo. La estratigrafía de las unidades del Paleozoico Superior de la región representa una problemática aparte que no se tratará en detalle en esta síntesis (concentrándose más que nada en lo observado). A continuación se hacen algunas aclaraciones sobre la nomenclatura que se tendrá en cuenta al referirse a ellas en este sector de la Precordillera, en especial a los conglomerados con los que se inicia la secuencia carbonífero - pérmica en este sector. 


\section{Formación Cerro Tres Cóndores (Conglomerados castaños)}

Los conglomerados castaños son los más extendidos. Corresponderían a la unidad denominada Formación Cerro Tres Cóndores por González y Bossi (1987). Por encima de la faja de cizalla del río Bonete aparecen en fuerte discordancia angular, espesas sucesiones de paraconglomerados polimícticos masivos. Es medianamente grueso, tiene mala selección textural, con clastos de variable tamaño y en general bastante redondeados y compuestos por líticos predominantemente sedimentarios, así como de esquistos calcáreos, metabasitas, esquistos, y cristaloclastos de cuarzo y ortosa. Presentan colores castaños hasta rojizos y amarillentos por oxidación superficial. En algunos sectores es posible observar una estratificación grosera y parecen tener un origen fluvial (Figura 3.8.1). Presentan afloramientos potentes tanto en la región norte del río Bonete como en el área de Los Llantenes. Afloran en una franja con rumbo noreste - sudoeste que cruza la quebrada del Bonete justo por desembocadura de la quebrada Ciénaga Grande (Anexos A1: M1, M3). Allí la discordancia se relaciona a fallas normales que cortan la faja de cizalla con rumbo SO - NE. Son similares a los que, en el área de Los Llantenes, conforman los flancos del anticlinal de la Dorsal de la Orilla. En este último sector es posible observar los grandes y suaves pliegues, típicos de las secuencias carboníferopérmicas de la región (Grupo Paganzo en sentido amplio), que inician con estos depósitos y apoyan en discordancia angular sobre las Formaciones Quebrada Seca y Río Bonete. (Figura 3.8.1; Anexos A1: M1, M6a-b).
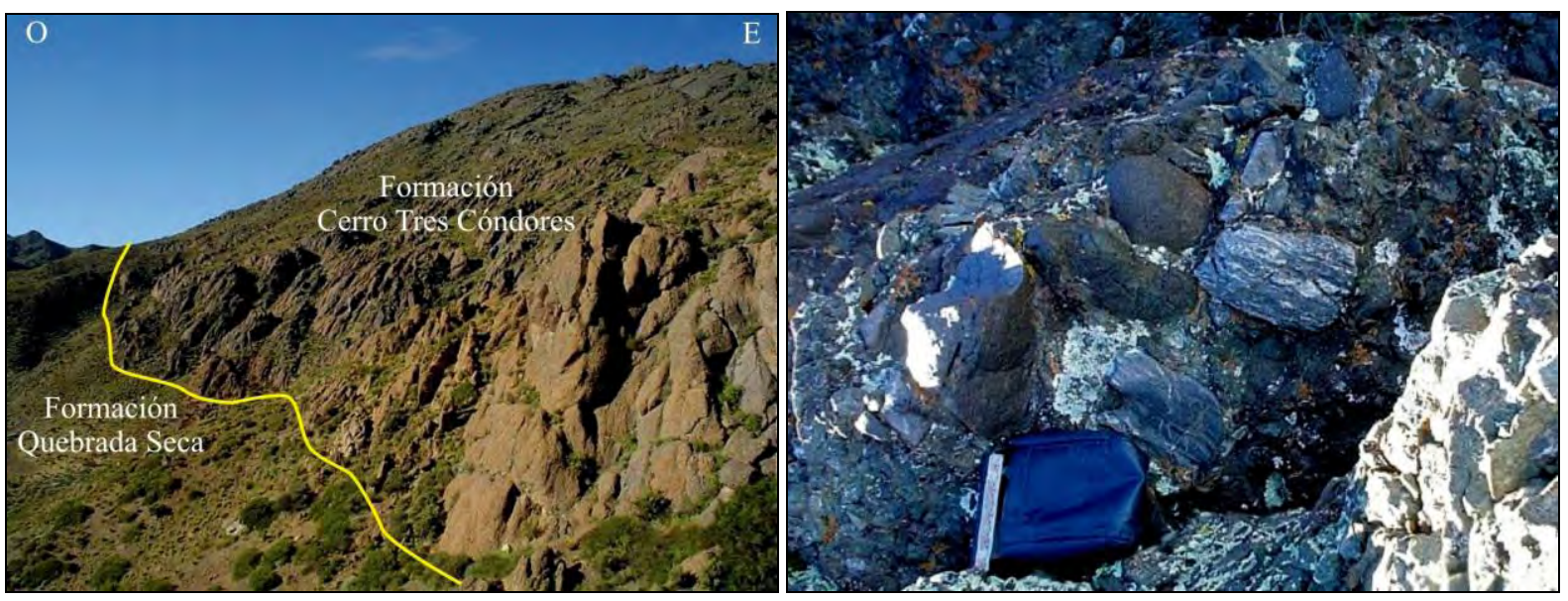

Figura 3.8.1: Izquierda: Afloramientos de los conglomerados castaños de la Formación Cerro Tres Cóndores González y Bossi (1987) sobre las metapelitas concrecionales y areniscas de la Formación Quebrada Seca. Vista del margen oriental de la quebrada Seca, donde los conglomerados corresponden al flanco oriental del anticlinal en cuyo núcleo se encuentran los afloramientos de la Dorsal de la Orilla. Derecha: Detalle de los conglomerados en el que se aprecia la presencia de clastos calcáreos y esquistos verdes de la Formación Río Bonete, así como de metabasitas.

Estos depósitos conglomerádicos han sido considerados generalmente equivalentes a la Formación Guandacol (Aceñolaza, 1971; Aceñolaza et al., 1971; Maisonave 1979; ver Gutierrez, P. R., 2008: Formación Guandacol: observaciones'), u homologados incluso a los afloramientos que posteriormente fueron definidos como Formación Jagüel (González y Bossi, 1986). Sin embargo esta última unidad porta fósiles algo más antiguos correspondiendo a la secuencia devónico - carbonífera 
inferior (Formaciones Quebrada Seca, Jagüel y Agua de Lucho; sección 3.2.5), y además se encuentra cubierta en discordancia angular por los conglomerados carboníferos. Dado que la ubicación estratigráfica de la Formación Guandacol no está clara aún a nivel regional, se prefiere tener en cuenta la estratigrafía local, en la cual los conglomerados castaños formarían parte de la Formación Cerro Tres Cóndores definida por González y Bossi (1987), que apoya en discordancia sobre la Formación Agua de Lucho. La Formación Cerro Tres Cóndores ha sido correlacionada con la Formación Cortaderas (Mississipiano Superior. Scalabrini Ortiz, 1973) que inicia con una sucesión de conglomerados que sobreyacen en discordancia erosiva a las lutitas y limolitas de la Formación Malimán (Tournaisiano; Scalabrini Ortiz, 1973); ambas unidades integran el Grupo Angualasto (Carbonífero Inferor - Limarino y Césari, 1992, Azcuy et al 2000), en el norte de la precordillera sanjuanina (ver también González y Díaz Saravia, 2007). En el Cuadro 3.8.1 se presenta una síntesis estratigrafica comparativa de los afloramientos del Paleozoico Superior de la región.

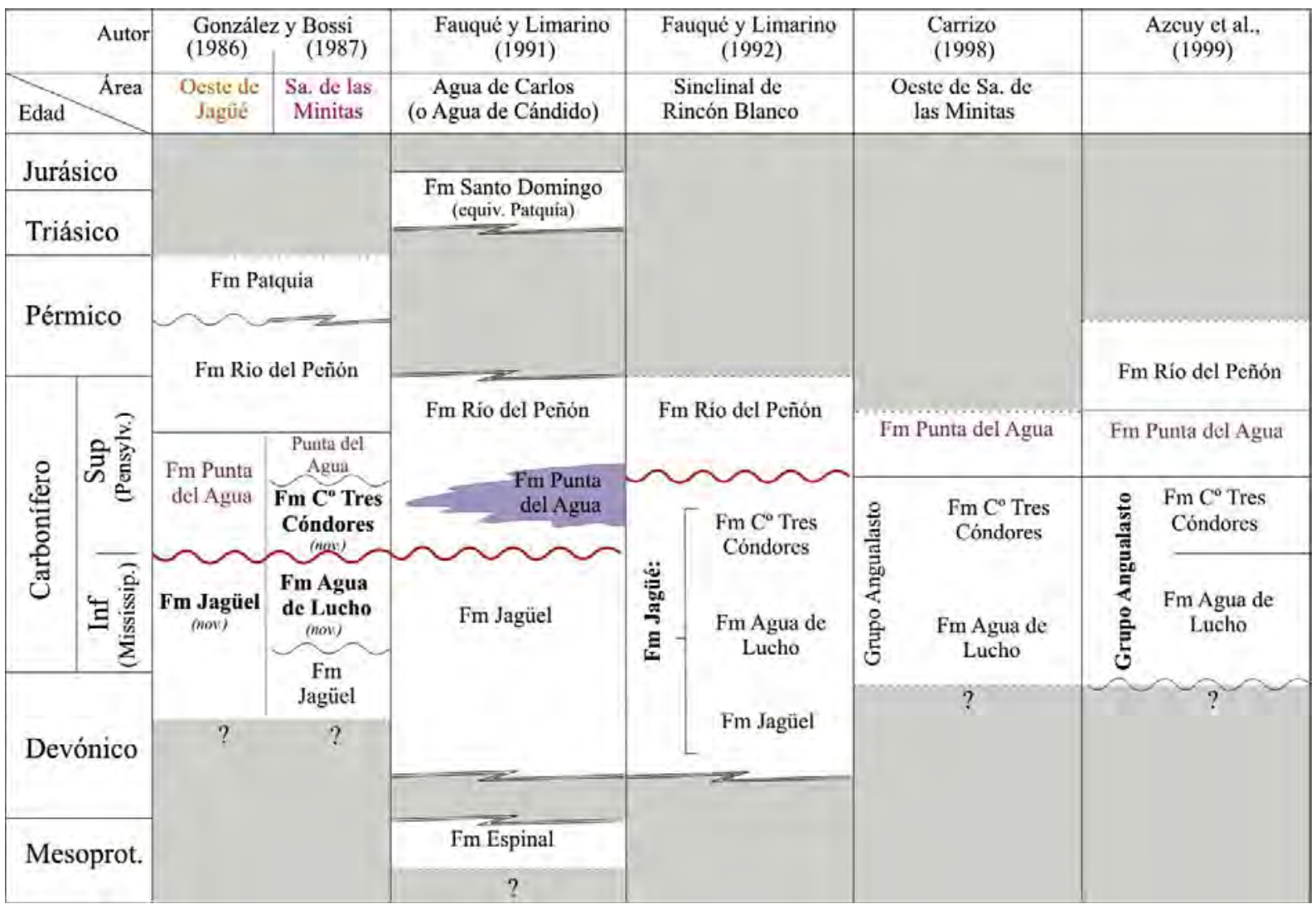

Cuadro 3.8.1: Distintas propuestas estratigráficas para las unidades del Paleozoico Superior de la region norte de la Precordillera (cuenca Uspallata - Calingasta - Iglesia).

Luego de los conglomerados castaños continúa la secuencia representada por las arcosas blanquecinas, sabulitas y pelitas, típicas de la Formación Río del Peñón (Carbonífero Superior Pérmico Inferior; González y Bossi, 1986, 1987), que contiene al límite Carbonífero - Pérmico (Fauqué y Limarino, 1991), y en cuya base se intercalan las volcanitas de la Formación Punta del Agua (González y Bossi, 1986). 


\section{Otros conglomerados.}

Además de estos conglomerados de distribución areal importante, se han hallado afloramientos pequeños y distribuidos saltuariamente de otros conglomerados, también en discordancia angular sobre la faja de cizalla y las Formaciones Río Bonete y Jagüé/Agua de Lucho. Son dos depósitos muy restringidos localmente, pero con características claramente distinguibles.

Primero aparece un conglomerado grueso polimíctico con clastos redondeados de granitoides, que apoya en discordancia angular sobre los esquistos verdes de la Formación Río Bonete y faja de cizalla. La característica sobresaliente de este conglomerado es que está compuesto predominantemente por clastos de líticos plutónicos de tonalidades claras que pueden llegar a tener grandes dimensiones (hasta unos $30-40 \mathrm{~cm}$ ). Los clastos en general se encuentran bastante redondeados (hasta angulosos) y muestran cierta imbricación. El tamaño, redondeamiento e imbricación de los clastos indica un buen retrabajo en un flujo direccionado, de alta energía. Sus características hacen pensar en facies fluviales, en zonas de alta pendiente o cercanas a un talud.
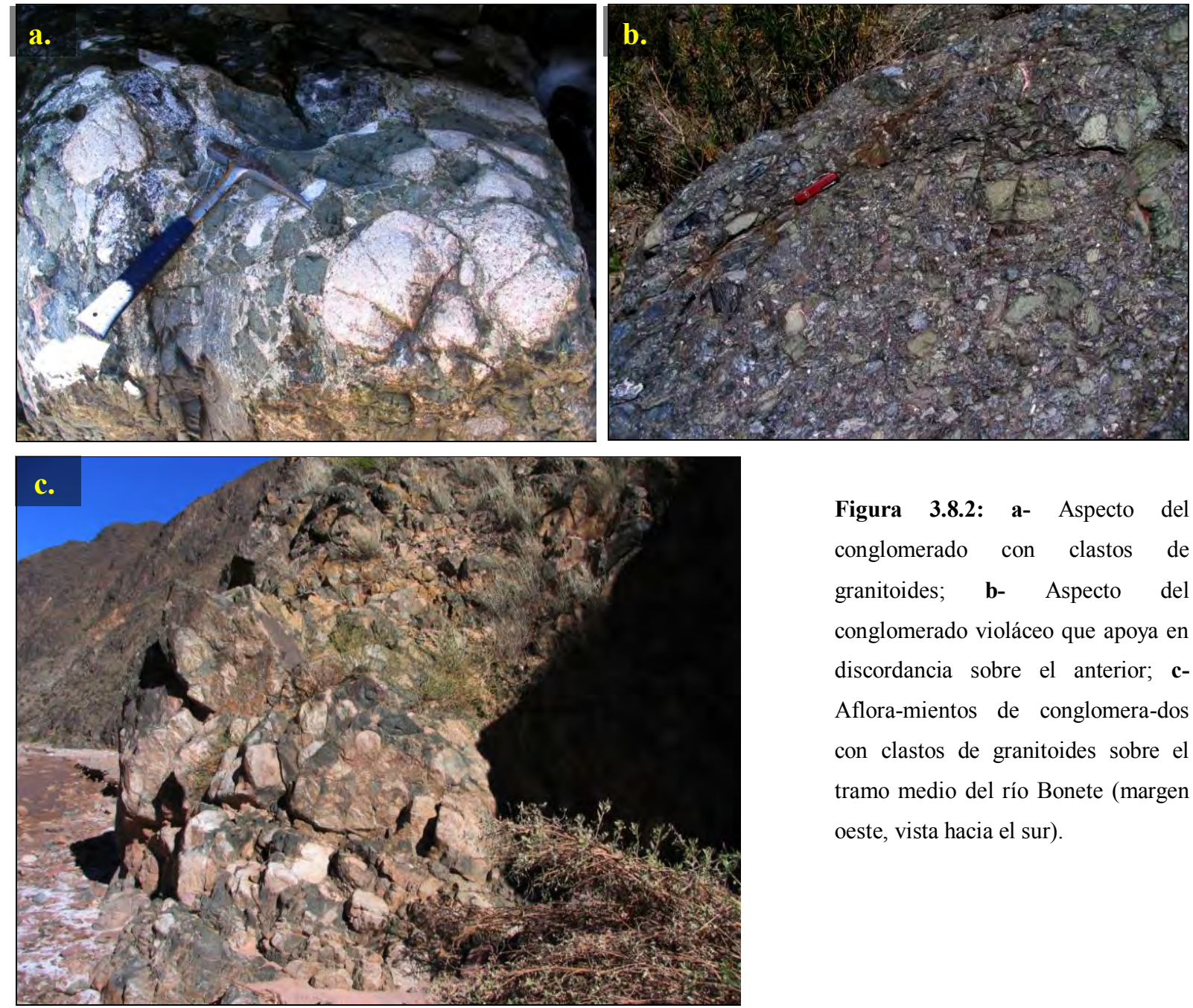

Figura 3.8.2: a- Aspecto del conglomerado con clastos de granitoides; b- Aspecto del conglomerado violáceo que apoya en discordancia sobre el anterior; cAflora-mientos de conglomera-dos con clastos de granitoides sobre el tramo medio del río Bonete (margen oeste, vista hacia el sur).

Lo cubre en discordancia un conglomerado fino, de aspecto brechoso, que presenta tonalidades violáceas a verdosas por la gran abundancia de clastos de volcanitas básicas 
(conglomerado 'violeta' o 'rojizo'). Lo componen también clastos de filitas, esquistos verdes, rocas calcáreas, cuarzo lechoso y granitoides (Figura 3.8.3). Los clastos volcánicos predominantes provendrían de la erosión de las volcanitas de la Formación Chuscho y/o Punta del Agua. En el filo sur de la quebrada del Chuscho y alrededores de la Cueva del Miquilo este conglomerado cubre en discordancia a las unidades ordovícicas y devónico - carboníferas inferiores.

Los conglomerados con clastos de granitoides y el violáceo aparecen asociados, ya que el segundo apoya sobre el primero en neta discordancia angular. Son de carácter muy localizado (generalmente no superan los 2 metros de espesor) y se presentan en franjas asociadas a escalones tectónicos entre los esquistos y mármoles de la Formación Río Bonete, las lavas de la Formación Chuscho, y las secuencias del Paleozoico Superior. Aparecen algunos asomos sobre el tramo medio de la quebrada del Bonete y forman una franja estrecha que cruza los cauces de los tributarios/afluentes por el margen occidental del río Bonete, antes de llegar a la quebrada Ciénaga Grande (e.g. Ciénaga
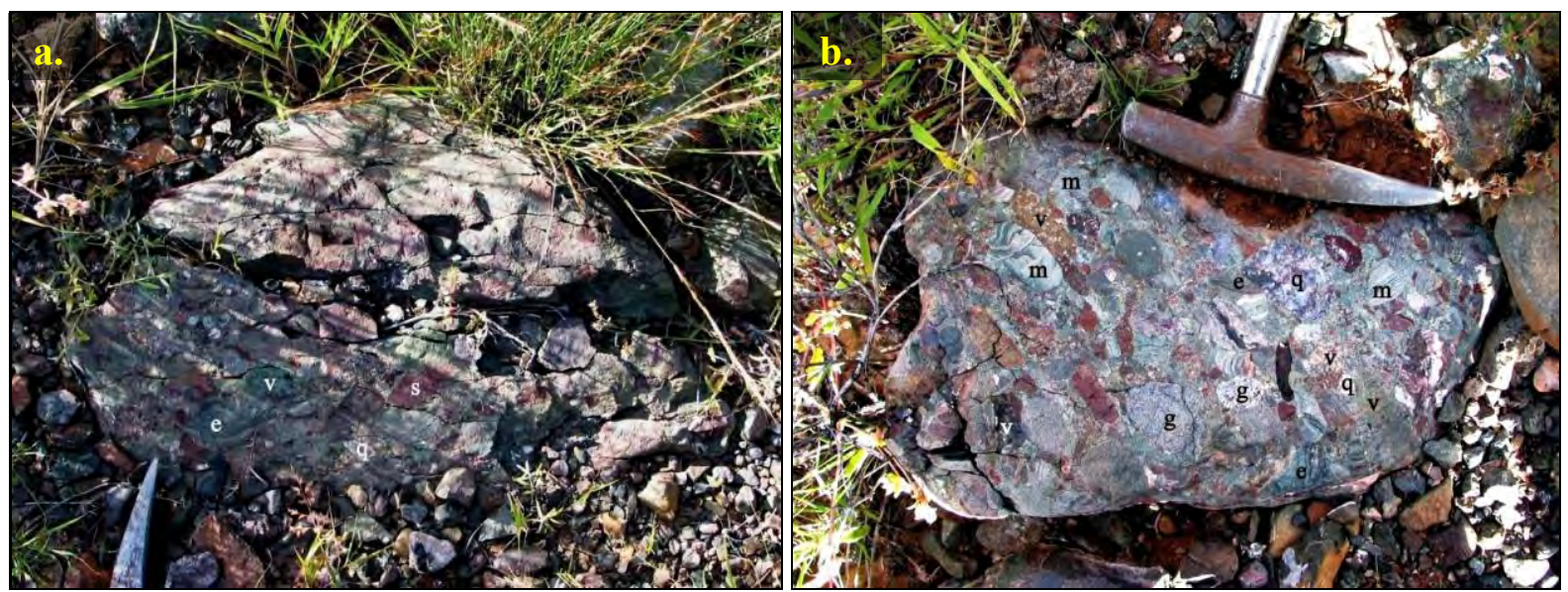

Figura 3.8.3: Detalles de los paraconglomerados brechosos violáceos/rojizos que apoyan en discordancia sobre las Formaciones del Salto y Jagüel y la faja de deformación de Jagüé, en la zona de desembocadura del río Chuscho en el márgen oeste del Bonete. Los clastos son desde angulosos a redondeados y líticos de variada composición: e = esquistos; $\mathrm{m}=$ mármoles y esquistos calcáreos; $\mathrm{v}=$ volcanitas (básicas y ácidas); $\mathrm{q}=$ cuarzo lechoso; $\mathrm{g}=$ plutonitas.

Grande y otras dos paralelas al sur de esta). Además, los conglomerados violáceos son los que, subiendo por los filos del área del Cerro Chuscho y alrededores, apoyan en discordancia sobre las rocas estratificadas de la Formación del Salto, esquistos y mármoles de la Formación Río Bonete, pelitas conglomerádicas de la Formación Jagüé y rocas básicas de la Formación Chuscho (Figura $3.8 .3)$

La edad de depositación de los conglomerados con clastos de granitoides y el violeta también quedaría acotada al Carbonífero Inferior ya que estarían recibiendo aporte del granito carbonífero y luego serían cubiertos por la Formación Cerro Tres Cóndores (Carbonífero Inferior). Sin embargo, esta última relación no se ha observado claramente, por lo que no se puede descartar una edad más jóven. En este sentido, Zolezzi y Guerrero (1981) hacen una descripción para los conglomerados de la Formación Ojo de Agua (Pérmico) en las adyacencias del cerro Cacho, entre las sierras de Umango y de la Punilla, en la que mencionan que se componen de una 'fracción fina' esencialmente compuesta 
por clastos volcánicos, ortocuarcitas, granitos y óxidos, y una 'fracción gruesa' con predominio de esquistos, granitoides, areniscas y riolitas; estas características son muy parecidas a las de los conglomerados que observados en las quebradas afluentes del tramo medio del río Bonete (conglomerado violeta y conglomerado con clastos de granitoides).

\section{Estructura del Paleozoico Superior y correlación regional.}

Los depósitos neopaleozoicos se encuentran deformados por amplios sinclinales y anticlinales con ejes de rumbos $\mathrm{NE}$ - SO a N - S. Estas secuencias apoyan en discordancia angular sobre las unidades previas, que comúnmente afloran en los núcleos de estos anticlinales (ej. afloramientos del área tipo de la Formación Río Bonete expuestos en la Dorsal de La Orilla en Los Llantenes; Anexos A1: M3, M6, P1). Luego la región ha sido afectada por las estructuras andinas y reactivando las estructuras previas y generando las regionales principales de rumbo $\mathrm{N}-\mathrm{S}$.

Estas secuencias corresponden localmente al relleno del depocentro de Río Blanco, que continúa mas al sur en los de la cuenca de Calingasta - Uspallata en la Precordillera (Grupo Angualasto: Formaciones Malimán y Cortaderas) y la cuenca de Paganzo en el ámbito de las Sierras Pampeanas Occidentales y Sistema de Famatina (Grupo Paganzo). Las cuencas Paganzo y Río Blanco constituyen dos áreas de acumulación durante el Paleozoico Superior separadas por el arco positivo, probablemente discontinuo, que representaba la Protoprecordillera.

En este contexto paleogeográfico, las sucesiones sedimentarias que rellenan las cuencas han sido agrupadas en tres secuencias aproximadamente isocronas y genéticamente relacionadas, separadas por superficies de discontinuidad que se vinculan a los distintos eventos tectónicos registrados en los alrededores (Limarino et al., 1999; Limarino et al., 2002, 2006).

Etapa sinorogénica: corresponde a los sedimentos depositados entre el Devónico Superior y fines del Carbonífero Inferior. Durante este intervalo se depositaron el Grupo Angualasto y la Formación Jagüel (González y Bossi, 1986) o Formaciones Jagüel y Agua de Lucho de González y Bossi (1987); según lo que se interpreta de la información antecedente, la Fm Cerro Tres Cóndores no aparecería en este sector. Esta etapa se encuentra limitada en la base por los movimientos de la Fase Chánica y en su techo por los de la fase Río Blanco.

- Etapa de Cuenca de Antepaís: caracterizado por el desarrollo de una importante cuenca de antepaís fracturado representado por la cuenca Paganzo, esta etapa se extiende desde el Carbonífero Medio al Carbonífero Superior.

Etapa de extensión: hacia fines del Carbonífero y principios del Pérmico tuvo lugar un importante cambio en el régimen tectónico del área y la instauración de un régimen extensional responsable del derrame de lavas basálticas alcalinas, de una menor tasa de subsidencia y de movimientos localizados en sectores de borde de cuenca que produjeron la ampliación de las áreas deporitacionales. 
La discordancia existente entre las Formaciones Quebrada Seca/Jagüel y más antiguas y los conglomerados (Formación Cerro Tres Cóndores, conglomerado violeta y conglomerado con clastos de granitoides) se habría generado por la Fase diastrófica Río Blanco (Fauqué y Limarino, 1991), que separa la secuencia devónica superior - carbonífera inferior de la secuencia carbonífera superior pérmica inferior. Se correlaciona regionalmente con los movimientos intracarboníferos (confirmados por Scalabrini Ortiz, 1973) o con la Fase Malimán (Aceñolaza y Toselli, 1981) definida en el sector de la Quebrada de la Cortadera. (Ver Limarino et al., 1988; Fauqué y Limarino, 1991; Fauqué, 1999; o ver discusión en González y Díaz Saravia, 2007).

En este esquema, y considerando la estructuración de las unidades y la correlación regional, la estratigrafía local sería la siguiente (ver también sección 3.2.5: Cuadro 3.5.2):

Secuencias Pérmicas: Formación Patquía y equivalentes.

Fase San Rafael-

(Extensión. Formación de basaltos alcalinos)

Secuencia Cb Sup - Pm Inf.: comienza con los conglomerados de la Formación Cerro Tres

Cóndores, a la que se correlaciona con la Formación Cortaderas, y luego es seguida por la Formación

$\underline{\text { Río del Peñón en la que se intercalan las volcanitas de la Formación Punta del Agua. }}$

Fase Río Blanco

(Movimientos Intracarboniferos. Discordancia erosiva/angular. Desarrollo de la cuenca de antepaís de Paganzo hacia el este)

Secuencia Dv - Cb Inf.: Estaría representada por la Formaciones Jagüel y Agua de Lucho, que se correlacionan con las Formaciones Malimán y Punilla. Presentan plegamientos apretados y una granulometría predominantemente fina, y son portadoras de fósiles marinos y restos vegetales.

Fase Chánica

(Compresiva y diacrónica. Discordancia angular. Cuenca de Uspallata-Iglesia)

Los conglomerado con clastos de granitoides y violáceo probablemente estén asociados a los movimientos diastróficos iniciales de la apertura de las cuencas carbonífero-pérmicas (?). 


\section{Capítulo 4: \\ DISCUSIÓN}

Introducción:

El objetivo original de esta tesis es el análisis de la Formación Río Bonete, estudiada y definida entre los años sesenta y setenta como una asociación de esquistos verdes (Miembro Cerro Cóndor) y calizas (Miembro Caliza Las Damas) en la denominada Precordillera de Jagüé (e.g. Aceñolaza et al., 1971). Las rocas fueron consideradas ordovícicas en base a material fosilífero hallado en sedimentitas denominadas informalmente como "Lutitas del Salto" (Aceñolaza y Bernasconi, 1969a), que fueron correlacionadas con los esquistos como "sectores menos metamorfoseados" y por homologación con las rocas que aparecen más al sur en la Precordillera.

Actualmente el acceso a los afloramientos ha mejorado aunque sigue siendo complejo, y por otro lado se ha ido modificando la composición de los procesos y las hipótesis geológicas. Así es que durante el mapeo y estudios de mayor detalle realizados, y con el análisis de los pocos trabajos más actuales que existen de la región, los resultados han llevado a redefinir la estratigrafía local para las rocas más antiguas. En este contexto, se halló que los afloramientos considerados dentro de la Formación Río Bonete originalmente descripta involucran a rocas de distinta edad, que han sido aquí redefinidas y agrupadas en las Formaciones Río Bonete, Del Salto (nom. nov.) y Quebrada Seca-Jagüel, considerándose por separado la Faja de deformación de Jagüé (Martino y Astini, 1998), que afecta e intercala a estas y otras unidades previas a los depósitos del Paleozoico Superior (Grupo Paganzo en sentido amplio) durante distintas reactivaciones.

Debido a la escasa información actualizada que existe de las unidades que afloran en el área se han descripto en menor detalle unidades que se hallaron en relación con las rocas de interés, haciéndose algunos aportes más a la geología regional.

\section{1 - CONSIDERACIONES SOBRE LA ESTRATIGRAFÍA.}

Tanto las rocas sedimentarias estratificadas de los alrededores de la quebrada de Potrerillos como los esquistos y mármoles de la Formación Río Bonete, afloran en bloques que constituyen los núcleos más antiguos de pliegues cuyos flancos son bien marcados por conglomerados carboníferos (ej: Los Llantenes, boca de la quebrada Ciénaga Grande, margen oeste de los afloramientos de la quebrada de Potrerillos).

Desde los primeros trabajos de Caminos, Aceñolaza, Toselli, Guerrero y algunos otros entre fines de la década de los sesenta y comienzo de los setenta, es muy escasa la información específica que existe de la región, dificultada por lejanía de centros urbanos, una topografía escarpada y difícil acceso a los afloramientos y falta de agua en gran parte de la región. Sin embargo en estos últimos años, con los nuevos enfoques de la geología han surgido nuevas investigaciones. La faja de cizalla que pasa por el río 
Bonete y con cinemática sinestral ha sido propuesta como el límite norte del Terreno Precordillera (Martino y Astini, 1998). Debido a esto, la Precordillera de Jagüé adquirió nueva importancia para los investigadores dentro del marco geotectónico regional, ya que su mejor conocimiento y entendimiento constituyen datos clave para comprender la evolución geológica de la zona, establecer las relaciones estratigráficas entre las unidades presentes y comprender la vinculación entre los terrenos y unidades que allí se ponen en contacto.

Recientemente Martina y Astini (2009) proponen una modificación interesante a la estratigrafía de la Precordillera de Jagüé. Postulan la denominación de Complejo Metamórfico Río Bonete para las "rocas con deformación dúctil", lo cual parece acertado, y de Formación Chuscho para las "metasedimentitas interdigitadas con vulcanitas básicas". Además sugieren "reemplazar el término Caliza Las Damas por el de Mármol Las Damas que refleja mejor su composición”. Este es un gran avance, sin embargo se hacen algunas consideraciones que surgen de este trabajo de tesis:

- Estos autores proponen la denominación de Formación Chuscho para el conjunto de rocas básicas y metasedimentitas ordovícicas. Para no llevar a confusiones aquí se prefiere y propone respetar los antecedentes previos y referir a las rocas básicas como Formación Chuscho (sección 3.2.4) siguiendo a Fauqué y Villar (2003) y Toselli y Durand (1996), y por el momento referirse a las metasedimentitas entre las que se intercalan estas lavas de manera informal como Rocas Metasedimentarias Estratificadas (sección 3.2.3.1) ya que la estratificación es un rasgo sobresaliente y que permite identificarlas en el campo. Cabe señalar que el uso de Formación Chuscho fue tradicionalmente referido a rocas básicas desde el comienzo, y que en el Cerro Chuscho, del que se toma este nombre, no aparecen rocas sedimentarias, habiéndose mencionado que posiblemente este sector sería el centro eruptivo de las rocas básicas (Fauqué y Villar, 2003; Aceñolaza y Bernasconi 1969b).

- En todo caso sería apropiado buscar otra denominación que englobe a ambas litologías (rocas básicas más metasedimentitas). Con esta idea y en un intento de clarificar la estratigrafía de estos afloramientos se propone la denominación de Formación Del Salto (nomen novus; sección 3.2.3) para las metasedimentitas estratificadas entre las que se intercalan rocas básicas en el área del Chuscho, respetando el antecedente de Aceñolaza y Bernasconi (1969a) más las metasedimentitas que constituyen la roca de caja del Granito Potrerillos, manteniendo las denominaciones antecedentes y evitar llevar a confusión. Otra posibilidad que se propone a tener en cuenta es considerar tanto a las rocas de la Formación Chuscho como a las metasedimentitas estratificadas entre las que se intercalan como dos Miembros dentro de la Formación Del Salto dado que su vinculación es evidente. Si este esquema es considerado la Formación del Salto quedaría conformada por el MiembroCerro Chuscho y el Miembro Rocas Metasedimentarias Estratificadas. La Formación Del Salto por ahora agrupa tanto a las Lutitas del Salto (Aceñolaza y Bernasconi, 1969a) y afloramientos sedimentarios al norte del Granito Potrerillos (mapeados anteriormente dentro del Miembro Cerro Cóndor de la Formación Río Bonete), como a las rocas básicas relacionadas con ellas (Frigerio, 2011). Además, 
sería en su mayor parte equivalente a la Formación Chuscho definida por Martina y Astini (2009) aunque se prefiere no usar esta terminología por las razones antes citadas.

- La denominación de Complejo Metamórfico Río Bonete (Martina y Astini, 2009) parece una terminología acertada. Si se considera dentro del Complejo Metamórfico Río Bonete a las "rocas con deformación dúctil" sería equivalente a las rocas reunidas en la Faja de deformación de Jagüé y reuniría litologías de diferente edad y origen. Sin embargo no serían denominaciones equivalentes debido a que estos autores no incluyeron a los metasedimentos de la Formación Chuscho y al Granito Protrerillos dentro del Complejo Metamórfico Río Bonete, excepto que las anfibolitas y metagranitos descriptos por ellos correspondan a estas unidades. Por otra parte, la interpretación de la edad de la deformación difiere de la interpretación que aquí se hace: la edad del Complejo Metamórfico Río Bonete (Martina y Astini, 2009) sería la edad de la deformación (oclóyica según interpretan estos autores), y la edad de sus miembros son edades estratigráficas (Neoproterozoico para el Miembro Esquistos Cerro Cóndor y Cámbrico para el Miembro Mármol Las Damas). Es muy probable que efectivamente se haya generado durante la orogenia oclóyica, y, por la edad U-Pb que se obtuvo en la muestra BO27 (lava almohadillada anfibolitizada) el pico metamórfico parece haber ocurrido durante la orogenia Chánica (Devónico), muy importante en la región. Más allá de cuál haya sido el evento que la generó por primera vez, la última reactivación de la faja de cizalla es más joven, probablemente Carbonífero Inferior. El Complejo Metamórfico Río Bonete tampoco sería equivalente a la Formación Río Bonete s.s. ya que este último incluye solamente a esquistos verdes (en parte metabasitas) asociados a mármoles.

Entonces, se propone la posibilidad de redefinir como "Complejo Metamórfico Río Bonete" a una unidad mapeable correspondiente a la mélange tectónica generada por la faja de deformación de Jagüé (Martino y Astini, 1998), e incluiría no sólo a las "rocas con deformación dúctil" (Martina y Astini, 2009), sino también a los bloques de lavas almohadilladas de la Formación Chuscho (Fauqué y Villar, 2003), algunas lentes graníticas relacionadas al Granito Potrerillos (Aceñolaza y Bernasconi, 1969b) y otras unidades que hayan quedado intercalados entre estas rocas (Formación del Salto, ¿Formación Jagüel?), restringiéndola arealmente y ampliando la variedad de litologías y edad de las unidades a las que afecta. Hay que tener en cuenta que la faja de cizalla no constituye una unidad litoestratigráfica).

- Se coincide en que es apropiado reemplazar la denominación de Caliza Las Damas ya que las rocas calcáreas han sido transformadas en mármoles y se encuentran fuertemente deformados por milonitización. Se propone reemplazar la terminología por el de Esquisto Calcáreo Las Damas, ya que refleja mejor su estructura laminada (por deformación) y porque 'mármol' a secas hace pensar en una roca recristalizada no deformada; sin embargo el término de Mármol Las Damas (Martina y Astini, 2009) también es válido y más conveniente que el original de Caliza Las Damas (Aceñolaza et al., 1971). 


\section{El "basamento": la Formación Espinal y la Formación Río Bonete s.s.}

La Formación Espinal aflora al este de los afloramientos de la Precordillera de Jagüé y constituye parte del basamento de medio a alto grado de las Sierras Pampeanas Occidentales. Su relación con las rocas estudiadas es tectónica a través de un lineamiento muy bien definido (Anexos 1: M1). Hasta el momento era considerado como el basamento de las rocas de la Precordillera de Jagüé ya que éstas se consideraba empezaban con la secuencia ordovícica de la Formación Río Bonete (e.g.: Aceñolaza et al., 1971). Sin embargo, en base a los resultados de edad obtenidos y relaciones de campo observadas, los esquistos verdes de la Formación Río Bonete (Formación Río Bonete s.s.) constituyen las rocas más antiguas en la Precordillera de Jagüé. El análisis de la información regional (Martina y Astini 2009; Varela et al., 2003, 2011; Rapela et al., 2010; Martina et al., 2012) permite distinguir dos basamentos en el sector estudiado: la Formación Espinal, constituida por rocas de medio a alto grado metamórfico y con edades meso a neoproterozoicas, y la Formación Río Bonete s.s., de bajo a medio grado (facies esquistos verdes) y edad probablemente neoproterozoica. El contacto entre ambos no se observa directamente. En este sentido, la faja de deformación de Jagüé podría ser la conexión entre ambos basamentos. El Granito Potrerillos se encuentra entre ambos, probablemente aprovechando la zona de debilidad para emplazarse. Las sedimentitas de la Formación del Salto se habrían depositado entre ambos. Observando las estructuras e información de estudios regionales (e.g.: Varela et al., 2003, 2011; Rapela et al., 2010) los afloramientos de la Formación Río Bonete aparentemente serían la continuación de las rocas que forman parte del basamento que aflora hacia el noroeste de la Sierra de Umango, que desde el sur hacia el norte se curva hacia el este. En la Precordillera de Jagüé constituye bloques rotados preservados en núcleos de pliegues anticlinales.

\section{Rocas calcáreas: Miembro Esquistos Calcáreos Las Damas.}

La ubicación estratigráfica de las rocas calcáreas es incierta debido a la intensa deformación y a que no se han hallado fósiles u otro rasgo concluyente que permita definir su edad hasta el momento. En base a la presencia común de nódulos de pedernal, porcentajes relativos de tipos cálcicos y dolomíticos y por el bandeado composicional (estimado primario) que presentan las rocas calcáreas Martina y Astini (2009) consideran que serían comparables con las unidades cámbricas de la plataforma precordillerana, representada por las Formaciones Zonda y La Flecha, y no con las calizas de la Formación San Juan (Tremadociano Superior- Arenigiano) y otros mármoles descriptos en la región próxima de Sierras Pampeanas (Galindo et al. 2004), ya que "a diferencia de los carbonatos mixtos del Cámbrico (Gómez y Astini 2006), las calizas ordovícicas de la Precordillera son netamente cálcicas y homogéneas, caracterizadas por una estratofábrica mediana a gruesa. A su vez, los mármoles descriptos por Galindo et al. (2004) en Sierras Pampeanas Occidentales son también cálcicos y presentan fracciones de minerales accesorios silicatados que denotan la existencia de proporciones menores clásticas en los carbonatos, diferenciándose de aquellos del río Bonete (Martina y Astini, 2009). En las calizas de Los Llantenes se 
encontraron abundantes nódulos de pedernal que apoyarían esta deducción. Los mármoles se encuentran íntimamente asociados con los esquistos verdes precámbricos y no con las sedimentitas ordovícicas por lo que su formación queda acotada en base y techoa ese lapso (Neoproterozoico-Ordovícico), como máximo.

\section{Miembro Esquistos Cerro Cóndor}

El Miembro Esquistos Cerro Cóndor de la Formación Río Bonete, tal y como fuera definido por Aceñolaza y Bernasconi (1969a) y Aceñolaza et al. (1971), agrupa a rocas con diferentes características tanto en los afloramientos como a nivel microscópico y de muestra de mano, incluyendo esquistos y rocas (meta-)sedimentarias. El área tipo de la Formación y sus Miembros fue establecida en afloramientos con distintas características de aquellos estratos en que se definió su edad. La de la Formación Río Bonete fue definida para las rocas que afloran en el tramo medio del Río Bonete, donde se da una alternancia de gruesos bancos de esquistos y filitas verdes y calizas, mientras que la sección tipo definida para cada Miembro (calizas y esquistos) se encuentra más al oeste, en los afloramientos del área de Los Llantenes (cerro las Damas y cerro Cóndor, respectivamente). En éstas áreas las rocas presentan colores y aspectos similares. La edad ordovícica de la Formación Río Bonete se asignó originalmente por extensión de la edad asignada por la fauna fósil hallada en las Lutitas del Salto (Aceñolaza y Bernasconi, 1969b; Frigerio et al., 2005) a toda la unidad, pero como vimos, en su conceptualización original esta unidad agrupaba a rocas de diferentes edades y orígenes, que han sido "unificadas" en cierto sentido por la deformación.

Finalmente, las rocas consideradas dentro de los "esquistos" presentan distintas características, que permiten distinguir al menos tres tipos, todos con estructuras foliadas, comúnmente miloníticas: 1)esquistos verdes cloríticos; 2)- esquistos grises y blanquecinos cuarzo-muscovíticos; 3)- esquistos biotíticos. A continuación se resumen sus rasgos sobresalientes.

a)- Esquistos verdes cloríticos: de coloración verde azulada, siempre están asociados a los bancos de calizas, en una franja que arranca en la Cueva del Miquilo en dirección NO y luego girando hacia el norte, entre las lavas de la Formación Chuscho y por detrás del filo de la margen oeste de la quebrada del Bonete, hasta reaparecer en el tramo medio de esta quebrada y la de Ciénaga Grande (área tipo, intercalación de bancos de calizas y esquistos verdes). Están compuestas por Chl + Qtz + Ep $( \pm$ Act $) \pm$ $\mathrm{Cal}+\mathrm{Op}$, casi todos componentes de origen secundario por alteración y deformación de la roca original. En corte delgado es posible observar una laminación milonítica continua asociada a la esquistosidad. Cerca de los contactos aparecen milonitas con láminas de calcita intercaladas con las de clorita-cuarzo generándose una foliación discontinua pero no estrictamente de origen metamórfico. La moda de las edades U-Pb en circones obtenida en la muestra E-BO5 es de $c a$. 1000Ma (Frigerio, 2011), por lo que el aporte principal podría asociarse con los basamentos del ciclo Grenvilliano existentes en la región. La edad máxima de aporte es de $837 \pm 16$ Ma (Neoproterozoico Inferior). No aparecen granos más jóvenes 
que permitan asociarla con el ciclo Famatiniano como sería de esperar considerando la definición original de la Formación Río Bonete como ordovícica. Estos esquistos provendrían de un protolito básico asociado a bancos de calizas, probablemente con algunas intercalaciones sedimentarias silicoclásticas. En la zona de Los Llantenes se han hecho observaciones que indicarían que es probable que en algunos sectores se hayan generado esquistos verdes por deformación de lavas almohadilladas y/o andesitas pero hacen falta una buena cantidad de datos de edad para poder mapearlas ya que quedarían intercaladas con los esquistos verdes precámbricos representados por la muestra E-BO5 en la sección tipo.

b)- Esquistos grises y blanquecinos cuarzo-muscovíticos: Estos afloran en el área de la boca y tramo inferior de la quebrada del río Bonete, donde aparecen como fuertes paredones. Tienen intercalaciones de algunos filones básicos verdosos alterados, pero no aparecen bancos de calizas. En el primer tramo de la quebrada del Bonete se ve una intercalación de 2 o 3 paquetes de éstos esquistos claros con los verdes más oscuros dando un aspecto bandeado, hacia el este de la franja de esquistos verdes y calizas. Suelen ser de granulometría más gruesa, y están compuestos por Qtz $+\mathrm{Ms} \pm \mathrm{Pl} \pm \mathrm{Kf}$. Es posible por el lugar en que se encuentran los afloramientos y por su composición (más 'granítica'), que estos esquistos estén relacionados a la deformación del Granito Potrerillos por la faja de cizalla que afecta a este sector con mayor intensidad.

c)- Esquistos biotíticos: Aparecen en una franja más bien restringida a los márgenes del Granito Potrerillos en el tramo inferior de la quebrada del Río Bonete. Esto se debe a que serían bloques o sectores de la roca de caja del plutón, que ha sido afectada en éste margen por la faja de cizalla, adquiriendo así su aspecto esquistoso. Están compuestos por Qtz $+\mathrm{Bt}+\mathrm{Pl}+\mathrm{Fk} \pm \mathrm{Ms} \pm \mathrm{Chl}$, siendo la clorita de origen retrógrado y la biotita generada por recristalización y metamorfismo de contacto cerca del plutón. Algunos de ellos parecen haber sido afectados por asimilación parcial por parte del granito antes de la deformación, y es posible observar texturas granoblásticas, recristalizadas e inyecciones graníticas entre las láminas micáceas.

\section{Origen de la intercalación esquistos-calizas:}

Otra cuestión que siempre suscitó dudas es cuál es el origen de la intercalación de mármoles y esquistos que otorga a los afloramientos su típico aspecto bandeado, especialmente en el área tipo de los esquistos. Se ha observado, tanto por el mapeo de campo como por imágenes, que esta alternancia responde principalmente a un plegamiento apretado de la asociación mármoles-esquistos. Sin embargo no se puede descartar que haya además una repetición de litologías asociada a dislocación.

Debido a la recristalización y deformación de las rocas calcáreas no ha sido posible concluir si hay más de un banco calcáreo ya que no se han hallado fósiles ni otra característica que permita distinguirlos y mapearlos en detalle.

\section{Formación Del Salto}




\section{Miembro Metasedimentitas Estratificadas}

Se trata de rocas sedimentarias bien estratificadas y de coloraciones ocres que afloran sobre la quebrada del Chuscho y sobre la quebrada de Potrerillos. En este último afloran solamente las rocas sedimentarias que constituyen la roca de caja del Granito Potrerillos. En el área del Chuscho se ven asociadas con rocas ígneas básicas que se agrupan dentro del Miembro Cerro Chuscho aquí propuesto. Un rasgo a destacar es que las rocas 'estratificadas' no se encuentran nunca vinculadas con calizas, filitas o esquistos, ni en el área del Chuscho ni en los afloramientos sedimentarios al norte del Granito Potrerillos. La polaridad de los depósitos es difícil de determinar debido a la deformación que afecta a todas las unidades. Actualmente el techo pareciera estar hacia el este. Si se considera la propuesta de que las sedimentitas reciben aporte de un arco continental y las rocas básicas tienen afinidades con ambientes de arco de isla, es muy probable. Sobre la quebrada de Potrerillos no se han hallado fósiles por lo que la correlación con las sedimentitas ordovícicas se hizo primero por similitudes lítológicas y estructurales con los otros afloramientos ordovícicos, aunque las rocas son más oscuras, presentan un menor grado metamórfico y no aparecen calizas (Frigerio, 2008a). La edad ordovícica de la unidad está documentada por una fauna fósil de graptolitos y bivalvos que afloran en las quebradas del Chuscho, del Salto y de los Árboles, en una franja de orientación aproximada N-S (Aceñolaza y Bernasconi, 1969b; Zimmermann y Van Staden, 2002; Frigerio et al., 2005). Los resultados isotópicos de U/Pb obtenidos sobre circones detríticos han permitido acotar las edades máximas de sedimentación cerca del límite Ordovícico-Silúrico (440 $\pm 6,8$ Ma y $443 \pm 13$ Ma), comparar las metasedimentitas de ambos afloramientos y separarlas de los esquistos verdes de la Formación Río Bonete s.s. (moda de $c a .1000 \mathrm{Ma}$ ). En las lavas almohadilladas intercaladas con las sedimentitas Fauqué y Villar (2003) obtuvieron una edad $\mathrm{U} / \mathrm{Pb}_{\mathrm{Zr}}$ de $454 \mathrm{Ma}$, muy similar a las obtenidas para las metasedimentitas $\mathrm{y}$, aunque este dato no es estadísticamente representativo, podría estar confirmando la interrelación que se observa en el campo entre ambas litologías (metasedimentitas estratificadas intercaladas con lavas almohadilladas y autobrechas volcánicas). La moda secundaria de edades U-Pb mesoproterozoicas entre 1 y 1,1 Ga estaría revelando una fuente de detritos comparables con el ciclo Grenviliano que indicarían que hubo un aporte del basamento de Cuyania (Sierras Pampeanas Occidentales); por otro lado, las signaturas geoquímicas indican un aporte de detritos de arco volcánico, que podrían vincularse con rocas magmáticas ordovícicas de Famatina al este o/y la Puna al norte. Esto implicaría entonces que estos afloramientos de Precordillera habrían recibido sedimentos tanto del basamento de Sierras Pampeanas Occidentales como del arco ordovícico de Famatina o/y Puna.

\section{Miembro Cerro Chuscho (rocas básicas)}

Corresponde a afloramientos de rocas básicas hasta ahora reunidas en la Formación Chuscho (Tosselli y Durand, 1996; Fauqué y Villar, 2003), inicialmente referidas como Andesita Cerro Chuscho (Aceñolaza et al., 1971). Está representada por lavas almohadilladas, diques de diabasas, feno-andesitas, 
brechas y autobrechas volcánicas, afectadas por variable grado de alteración y metamorfismo. Los procesos secundarios se intensifican hacia la faja de cizalla y han sido tenidos en cuenta a la hora de trabajar con los datos de geoquímica. Aunque en los afloramientos y muestras de mano muchas de las rocas básicas parecen andesitas (feno-andesitas) por su composición geoquímica se clasificaron todas como basaltos y picrobasaltos. Esto se aprecia también por la composición petrográfica en la que predominan plagioclasas y clinopiroxenos como porfirocristales y en las pastas, incluso pueden aparecer ortopiroxenos y olivinas generalmente alterados, sin presencia de cuarzo en la gran mayoría de los cortes petrográficos analizados. Entonces las feno-andesitas son en realidad basaltos porfíricos con fenocristales de plagioclasa y a veces piroxeno.

Se propone aquí considerar estas rocas como un Miembro dentro de la definida Formación Del Salto (nom. nov.) ya que en los afloramientos que existen sobre la quebrada del Chuscho se encuentran intercaladas con el Miembro Metasedimentitas Estratificadas.

Para la Formación Del Salto, en los diagramas de Bathia y Crook (1986) las metasedimentitas estratificadas plotean sin dudas en el campo de arco magmático continental y arco de islas continental indicando que estas serían sus áreas de aporte principal (sección 3.2.3.1), mientras que las rocas básicas de la Formación Chuscho que se asocian a ellas muestran una tendencia más definida hacia el campo de arco de islas oceánico; esta tendencia en las rocas básicas es confirmada en otros diagramas, así como en evidencias de la petrografía y observaciones de las relaciones de campo (sección 3.2.4).

Tomando toda la información en conjunto se concluye para las rocas básicas de la Formación Chuscho que son basaltos tholeiíticos con tendencia alcalina. Para el ambiente tectónico de formación los resultados son ambiguos, pero en base a todas las evidencias lo más probable es que se relacionen a un ambiente de arco de islas oceánicas. Por otro lado, se plantea la posibilidad de que estén registrando una evolución entre un ambiente de retroarco continental con basaltos de inundación (ruptura) y posterior formación de un arco de isla oceánico (subducción)?, entonces ambas signaturas tendrían significado.

El hecho de que no se observaron diques verdes de diabasas ni lavas almohadilladas en los afloramientos de la Formación del Salto que corresponden a la roca de caja del Granito, probablemente se deba a la ubicación más alejada del centro eruptivo de estos afloramientos (Cerro Chuscho); esto también sería coherente con la mayor presencia de litofacies finas y heterolíticas hacia el este y litofacies ligeramente más gruesas en las sedimentitas del área del Chuscho.

Respecto de otros cuerpos de rocas básicas de la zona

En la quebrada del río Bonete se encuentran diques granudos de anfibolitas mucho más deformados y afectados por metamorfismo en facies de esquistos verdes y anfibolitas. Estos conforman cuerpos de grano grueso compuestos por Act-Ep-Pl, aparentemente concordantes con la foliación de los esquistos sobre la quebrada del río Bonete. Por su textura es posible que estén relacionados al Granito Potrerillos (e.g. BO-D10), y en ese caso serían equivalentes a los diques granudos que se registran al 
norte del granito (e.g. QP18). Otra opción es que se trate de bloques o escamas de rocas básicas asociadas con la Formación Chuscho afectadas e incluidas por la faja de cizalla (e.g. BO27). Esta última opción solo se confirma para los afloramientos de lavas almohadilladas anfibolitizadas a los que corresponde la muestra $\mathrm{BO} 27$.

Respecto de la edad de los diques negros, ésta se desconoce, pero por las relaciones de corte (y las referencias que existen de magmatismos básicos en la región) se interpreta aquí que podría ser triásica, con dudas. Presentan composiciones más alcalinas. En este caso podría estar vinculado al magmatismo de intraplaca asociado a la apertura de las cuencas de rift desarrolladas en el oeste argentino durante esta época (ej. Cuencas de Ischigualasto - Villa Unión, Marayes, Cuyana y San Rafael; ver: Spalletti, 1999). Sin embargo, aunque en la etapa de post-rift se han generado mantos de basaltos, el magmatismo del Choiyoi en el Permo-Triásico es de composición intermedia a ácida. Por otro lado, aunque no se observó que cortara a las sedimentitas carboníferas, por los antecedentes de la región podrían vincularse con las coladas de basaltos intercaladas en la Formación Santo Domingo (Triásico Superior - Jurásico Inferior), que se encuentra relacionada al importante régimen extensional que dominó durante el Triásico (Charrier, 1979). De estas rocas existe una edad de 212 Ma, (Coughlin, 2000). No se vinculan con la Formación Punta del Agua (Carbonífero Superior) ya que ésta es de composición predominantemente andesítica. Tampoco con el magmatismo asociado a la Formación Veladero (Plio-Pleistoceno), de características más efusivas, composiciones dominantes diferentes y se relaciona más con la Puna Austral y norte de la Cordillera Frontal, al noroeste de la zona estudiada (Marcos et al., 1971; Fauqué y Villar 2003).

En el área de Los Llantenes Cravero et al. (1984) mencionan lavas almohadilladas que cubren parcialmente a la Formación Quebrada Seca y es cortada por diques asociados a ellas. Dado que la Formación Quebrada Seca tiene una edad Devónico-Carbonífero Inferior por los fósiles hallados, estos diques (y posiblemente las lavas almohadilladas del área de Los Llantenes si es que efectivamente se hallan vinculadas a los diques) se asociarían al magmatismo carbonífero representado en la zona por la Formación Punta del Agua (González y Bossi, 1986; Remesal et al., 2004). A diferencia de las rocas básicas del Miembro Cerro Chuscho, este magmatismo es calcoalcalino y se vincula con un arco volcánico.

Fauqué y Villar (2003) mencionan la posibilidad de que el cuerpo volcánico de Las Casitas (Anexos I: M1) corresponda al mismo magmatismo que el del Cerro Chuscho, sin embargo no hay nuevos datos sobre estas rocas desde que fueran mapeados por Aceñolaza et al. (1971), quienes lo consideraron dentro del magmatismo carbonífero (ver también Caminos, 1972; Maisonave 1979). Este intrusivo aflora en el extremo noreste de la zona de estudio, al S y SE del Cordón de La Escarcha, y se aloja aprovechando el contacto tectónico entre las secuencias carbonífero-pérmicas y la Formación Espinal (Anexos 1: M1). En las imágenes se observa la presencia de otro cuerpo de similares características que aprovechó para alojarse la falla que pone en contacto las metasedimentitas ordovícicas que afloran al norte del Granito Potrerillos y la Formación Espinal. Este afloramiento también está cubierto por las secuencias neopaleozoicas y pareciera estar en concordancia estratigráfica con el de Las Casitas, por lo que podrían estar vinculados (Anexos 1: M1). Es necesario llegar a dichos afloramientos 
para constatar las características de estos cuerpos y su relación con las metasedimentitas, y de este modo verificar la presencia o no de rocas equivalentes a las lavas de la Formación Chuscho asociadas a las sedimentitas también en ese sector.

\section{El Granito Potrerillos y su relación con otros cuerpos de la región.}

Es un plutón elíptico de emplazamiento somero que es atravesado por la Quebrada de Potrerillos. Allí intruye a las metasedimentitas de la Formación Del Salto generando una aureola de contacto y englobando colgajos y enclaves de éstas. Incluye una variedad de facies entre las que dominan monzonitas y granodioritas, existiendo además granitos, granitos alcalinos, tonalitas, dioritas, sienodioritas y gabros, con texturas porfiroides a granudas. Presenta diques sin-magmáticos aplíticos y anchos diques periféricos gabroides subverticales. De acuerdo a sus características geoquímicas es un granitoide tipo I, peraluminoso a metaaluminoso, de afinidad calcoalcalina con cierta tendencia alcalina en las facies más básicas y generalmente rico en potasio. Los diagramas geoquímicos de discriminación tectónica vinculan al magmatismo a un ambiente de arco volcánico relacionado a márgenes continentales activos. La ausencia de anomalía de Eu o leve anomalía positiva observada en los diagramas de tierras raras se atribuye a que no ha habido fraccionamiento de la plagioclasa, que es abundante especialmente en las muestras de composición intermedia a básica.

Por el único dato de edad que existía fue tradicionalmente considerado como parte del arco magmático Gondwánico (K-Ar en biotita de 313Ma; e.g. Llambías, 1999) junto a otros granitoides de la región (granitoides del cerro de Las Tunas, sierra del Peñón y cerro Comecaballos). Se presentan tres edades U-Pb en circones magmáticos de 350,8 \pm 7,1 Ma, 355,8 $\pm 3,1$ Ma y 374,9 \pm 9,3 Ma que modifican la edad existente permitiendo sacar nuevas conclusiones. Considerando las relaciones estratigráficas y estructurales observadas, la actividad magmática principal ocurrió antes de las fases tectónicas Río Blanco y San Rafael, las cuales pudieron haber reseteado el sistema K/Ar y Rb-Sr. La diferencia de edades con los cuerpos plutónicos cercanos es pequeña, sin embargo, las edades U/Pb obtenidas relacionarían al plutón a la fase tectónica Chánica (sincrónica), pero considerando las características observadas en los afloramientos (discordantes respecto a la roca de caja sedimentaria y de morfología subcircular especialmente), y su signatura geoquímica intermedia con composiciones principalmente monzoníticas-granodioríticas, puede ser considerado dentro de los granitoides tardío a post-tectónicos de la orogenia Famatiniana descriptos en la en la Sierra de San Luis (e.g. González et al., 2006. Frigerio et al., 2010; 2012).

Los datos Sm-Nd pueden ser muy buenos "rastreadores" de las cortezas en las cuales se originaron los magmas. Se obtuvieron edades Sm-Nd $\mathrm{T}_{\mathrm{DM}}$ de $469 \mathrm{Ma}, 475 \mathrm{Ma}$ y 630 Ma que vincularían al magmatismo con un origen por fusión de corteza neoproterozoica o pampeana. Acorde con los valores positivos a ligeramente negativos de $\varepsilon N d$ se prefirió usar el modelo de De Paolo (1981), y estarían indicando una fuente mantélica o un magma poco contaminado durante su ascenso y emplazamiento en la corteza. Esto podría deberse a una corteza delgada o a un ascenso rápido del magma, de manera que el 
sistema no se haya llegado a contaminar significativamente. En el otro extremo del Terreno Precordillera, en Mendoza, el Granito Cacheuta (Rossi, 1947) es un granitoide de arco de edad pérmica (aprox. 260 $\mathrm{Ma}$ ), con edades $\mathrm{T}_{\mathrm{DM}}$ de $c a$. 1100 Ma que vinculan el origen del magma que lo generó con una corteza mesoproterozoica juvenil, sugiriendo que el basamento de la región de la Precordillera mendocina posee las características generales de Cuyania analizadas por otros autores en las sierras de Umango y Pié de Palo, en los xenolitos de Ullúm, y en los bloques de San Rafael y Las Matras (Varela et al., 2011 y referencias allí; Cingolani et al., 2012). A diferencia del Granito Potrerillos, se vincula al magmatismo del ciclo Choiyoi y al ciclo gondwánico ampliamente extendido en la Cordillera Frontal (Cingolani et al., 2012).

\section{Otras unidades intercaladas entre los afloramientos estudiados:}

\section{Conglomerados del Paleozoico Superior:}

Además de los conglomerados castaños (Formación Cerro Tres Cóndores), entre los afloramientos de la Formación Río Bonete aparecen pequeños afloramientos saltuarios y de escaso espesor de conglomerados del Paleozoico Superior, uno con clastos de granitoides y otro violeta y brechoso con clastos volcánicos predominantes. Pero su vinculación con el resto de las unidades es incierta. Aparentemente no estarían asociados al evento compresivo con componente sinestral que produjo la faja de deformación de Jagüé ni a sus posibles reactivaciones, sino a escalones generados durante deformación extensional (¿estaría asociada al rift que abre las cuencas del Ciclo Gondwánico?). La orientación de las estructuras de estos conglomerados también es NE - SO.

Martina y Astini (2009) indican la presencia de conglomerados dentro de la Formación Chuscho, con clastos calcáreos y de esquistos que los llevan a interpretar que con posterioridad al pico de deformación se habría producido la exhumación de la faja de deformación, que actuó como área fuente de los conglomerados incluidos en la Formación Chuscho (equivalente aquí a Formación Del Salto). No queda claro si se están refiriendo a los conglomerados del canal que está en la quebrada del Chuscho en los que no se hallaron clastos de calizas ni esquistos (Formación Jagüé, relacionados a las sedimentitas ordovícicas por falla), o a los conglomerados que aparecen en la quebrada del río Bonete que sí presentan clastos calcáreos y de los esquistos (¿Formación Cerro Tres Cóndores o conglomerado violeta?, sección $3.2 .8)$.

\section{Sedimentitas devónico-carboníferas.}

La secuencia que aparece sobre la quebrada del Chuscho no ha sido descripta previamente ya que se pasaron por alto como parte de las Lutitas del Salto. Es un bloque tectónico muy pequeño en el que afloran conglomerados castaños, areniscas y pelitas concrecionales asociadas. Conforman una asociación de canales dentro de facies marinas proximales con idénticas características a los afloramientos de lo que 
fue mapeado como Formación Quebrada Seca por Cravero et al. (1984) en el área de Los Llantenes, unidad con la que aquí se correlacionan.

Se han hallado fósiles que reubican los afloramientos en el ciclo Devónico-Carbonífero Inferior, y es posible que llegue al Silúrico (braquiópodo). Esto permite correlacionarlo con la Formación Jagüel (González y Bossi, 1986) que aflora hacia el sur. Martina y Astini (2009) consideran que la Formación Quebrada Seca es parte de lo que Aceñolaza (1969) definió como Formación Guandacol en Los Llantenes. Las observaciones realizadas en cuanto a su granulometría, estructura y edad, permiten separar las lutitas concrecionales con bancos de arenas amarillentas replegados de la Formación Quebrada Seca de los conglomerados castaños afectados por amplios plegamientos abiertos (Formación Cerro Tres Cóndores). La Formación Jagüel porta fósiles algo más antiguos correspondiendo a la secuencia devónico - carbonífera inferior (Formaciones Quebrada Seca, Jagüel y Agua de Lucho; sección 3.2.5), y además se encuentra cubierta en discordancia angular por los conglomerados castaños carboníferos de la Formación Cerro Tres Cóndores (González y Bossi, 1987). En la definición original el conglomerado apoya en discordancia sobre la Formación Agua de Lucho, que probablemente sea equivalente también a la Formación Quebrada Seca. Por la estructura regional y la fauna lo más probable es que las Formaciones Jagüé y Quebrada Seca sean equivalentes a la Formación Punilla que aflora más al sur de la Precordillera.

\section{Mineralización}

La mineralización característica que se encuentra en la región no tendría vinculación con el magmatismo del Cerro Chuscho, sino que se relacionaría al magmatismo carbonífero-pérmico de la Formación Punta del Agua, alojándose en vetas de rocas básicas que se ubican cerca de los contactos entre la Formación Río Bonete y las lavas almohadilladas deformadas, así como en esquistos verdes mineralizados (ver mapa Anexos A1: M6b, basado en Cravero et al., 1984). No se ha podido avanzar más en su estudio.

\section{2 - DEFORMACIÓN:}

\section{La faja de cizalla}

La faja de cizalla que pasa por el río Bonete ha sido denominada como faja de deformación de Jagüé (Martino y Astini, 1998) y las rocas esquistosas generadas fueron originalmente incluidas dentro del Miembro Cerro Cóndor de la Formación Río Bonete. Esta estructura afecta a todas las unidades previos a los depósitos del Carbonífero Inferior que comienzan con los conglomerados de la Formación Cerro Tres Cóndores, equivalente del Grupo Paganzo. Este rasgo constituye un lineamiento y un lugar de debilidad en la corteza, lo que ha llevado a ser reactivada en distintas ocasiones durante los procesos geológicos que afectaron a la región (tiene una evolución policíclica). Presenta una cinemática compresiva sinestral dominante con una historia compleja de reactivaciones durante las orogenia 
famatiniana (Cámbrico tardío - Devónico tardío, Varela et al., 2011). Martina y Astini (2009) consideran que la deformación asociada a la faja de deformación de Jagüé sería oclóyica tentativamente y la responsable de la deformación del Complejo Metamórfico Río Bonete. En este sentido, la faja de deformación también podría ser más antigua, reactivada fuertemente por la orogenia Oclóyica y necesariamente la última deformación es posterior a la intrusión del Granito Potrerillos (Tournaisiano) al cual está afectando. La edad devónica de $385 \pm 1,5$ Ma que se obtuvo en las lavas almohadilladas anfibolitizadas en la quebrada del Bonete estaría relacionada al pico máximo de la deformación y metamorfismo en la faja de cizalla y no a la cristalización de las lavas, ya que la muestra datada corresponde a un bloque de rocas básicas incluido dentro de la faja de deformación siendo transformado en anfibolitas. Este habría ocurrido entonces durante la fase Chánica (Devónico, 400 - 360Ma, Varela et al., 2011), relacionada a la colisión de Chilenia. Aceñolaza y otros (2002) mencionan la presencia de milonitas entre el sistema de Famatina y Sierras Pampeanas con edades que permiten registrar un evento importante de acreción en el Devónico Temprano (Hökenreiner et al., 2001a, b). La faja milonítica TiPA (López y Toselli, 1993) está ubicada al borde del Famatina y tiene edades de deformación que abarcan el Devónico Inferior, entre 436 y 402 Ma (López et al 2000, Höckenreiner at al 2001, 2003). Esta y otras fajas miloníticas registradas en sus alrededores presentan orientaciones similares NNO-SSE (Bellos et al., 2010). Estos últimos autores hacen un análisis cinemático a partir del cual interpretan un movimiento de cizalla inverso, oblicuo compresivo desde el N-NO hacia el S-SE que sería también coherente con las observaciones en la faja de deformación de Jagüé.

\section{Características de la deformación y cronología de los eventos}

Las estructuras de deformación observadas en las unidades tienen origen en más de un evento. Cronológicamente se observó lo siguiente:

- La asociación de esquistos verdes + mármoles (Formación Río Bonete s.s.) está deformada dúctilmente por plegamientos apretados y foliación milonítica penetrativa, tanto en la quebrada del Bonete como en el área de Los Llantenes.

- Esta deformación es distinta y no afecta a las sedimentitas y rocas básicas de la Formación del Salto (límite Ordovícico-Silúrico) que se encuentran en relación de discordancia angular o mediante fallamiento con los esquistos y mármoles. Por otro lado las unidades Od-Sil están afectadas por plegamientos más abiertos dislocados por fallas, observándose una menor ductilidad en las estructuras y microestructuras.

- El Granito Potrerillos se intruyó en las metasedimentitas asimilando bloques de la roca de caja y luego ambos se encuentran afectados por la faja de deformación que pasa por el río Bonete. Evidencia de ello es la presencia de lentes graníticas deformadas entre esquistos verdes, esquistos blanquecinos y biotíticos. Durante esta deformación se generaron estructuras esencialmente compresivas y de cizalla sinestral, y afecta tanto a los esquistos y mármoles de la Formación Río Bonete s.s., como a las Metasedimentitas Estratificadas, 
Formación Chuscho y al Granito Potrerillos. Esto permite deducir que al menos su reactivación última debió ocurrir luego de la intrusión del Granito Potrerillos, probablemente durante la fase orogénica San Rafael que afecta a la región.

- Las unidades sedimentarias marinas proximales del Devónico-Carbonífero Inferior (Formaciones Quebrada Seca y Jagüé) están dislocadas por algunas fallas y afectados por algunos plegamientos pero presenta menor deformación. Su relación con las sedimentitas y rocas básicas de la Formación del Salto es tectónica en la quebrada del Chuscho, mientras que en el área de Los Llantenes apoya en discordancia angular sobre los esquistos y mármoles y parecen continuar el plegamiento a gran escala de los conglomerados carboníferos. Sin embargo no se ha podido observar una clara relación con la faja de deformación del río Bonete, ni con el Granito Potrerillos.

- Estratigráficamente siguen los pequeños afloramientos de conglomerados con clastos plutónicos y brecha con clastos volcánicos (Paleozoico Superior) que aparecen en algunas quebradas del margen oeste del río Bonete. Éstos, por el contrario, estarían asociadas a un evento extensivo posterior. Probablemente se asocien a la etapa de extensión de la Fase Orogénica San Rafael (FOSR) que comienza durante el Pérmico Inferior, y es posible además que la faja de deformación de Jagüé se haya generado (o reactivado) durante las etapas previas compresivas de la FOSR, afectando al granito pero no a los depósitos neopaleozoicos posteriores.

A diferencia de las rocas precámbricas foliadas, la deformación penetrativa afecta a la Formación del Salto y al Granito Potrerillos sólo cuando se observan sobre la quebrada del Bonete. Esto permite distinguir entre la estructuración precámbrica y la asociada con la faja de deformación de Jagüé.

Las deformaciones acaecidas durante la Fase Orogénica San Rafael generaron una intensa deformación penetrativa en las rocas paleozoicas, que desde la orogenia gondwánica participaron como un bloque rígido durante la orogenia andina, hasta que a fines del Mioceno se levantara la Cordillera Frontal. A partir del Pérmico medio se generó una extensión generalizada (atribuida a una disminución en la velocidad de convergencia (Ramos et al., 1996).

La vergencia de las estructuras medidas en las metasedimentitas de los afloramientos que se encuentran en la quebrada de Potrerillos es hacia el E y NE (sección 3.2.3.1, Figura 3.3.5). Si se asume que la estructuración más fuerte de esta zona se relaciona con la colisión de Cuyania con Gondwana, estos datos son coherentes con un modelo en el que la subducción (famatiniana) se haya producido en este sentido.

La polaridad de las lavas almohadilladas intercaladas entre las sedimentitas estratificadas de la Formación del Salto y Jagüé en la desembocadura y tramo inferior de la quebrada del Chuscho indicaría un techo de las secuencias hacia el este y base hacia el oeste, aunque los contactos son tectónicos con el resto de las unidades en ese sector (Anexos A1: P3). Sin embargo, esta disposición puede tener su origen en la basculación del bloque y plegamiento de las unidades dejando la estratificación con inclinación hacia el este. 
En el Cuadro 4.1 se sintetizan las características geológicas de las distintas unidades en cada sector de afloramiento.

\section{3 - LA PRECORDILLERA DE JAGÜÉ EN EL MARCO GEOLÓGICO REGIONAL. CORRELACIONES.}

La Precordillera de Jagüé constituye el extremo más septentrional de la Precordillera y forma el nexo entre las provincias geológicas aledañas de Cordillera Frontal, Sierras Pampeanas y Puna. Sus afloramientos son una cuña limitada por la Sierra del Peñón y afloramientos del Grupo Paganzo y Puna al oeste y norte, los primeros afloramientos de la Formación Espinal y Cordón de la Escarcha hacia el este y el valle del río del Peñón hacia el sur. En muchos mapeos regionales se la ubica dentro de las Sierras Pampeanas Occidentales, pudiendo corresponder a otras provincias geológicas aledañas (Cordillera Frontal, Famatina, Puna), sin embargo, la presencia de rocas sedimentarias con fósiles ordovícicos de características comparables a unidades de la Precordillera llevó a extender sus afloramientos hacia este sector. Esto correspondería quizás con el límite de Cuyania que plantearon Martino y Astini (1998) sobre el lineamiento del río Bonete. El basamento representado por la Formación Río Bonete s.s. tiene similitudes en edad, composición y estructura con el de Precordillera y Sierras Pampeanas Occidentales, por lo que es preferible hablar de terreno Precordillera o Cuyania que involucra a ambos.

Teniendo en cuenta el mapeo geológico, la estructura regional y los datos isotópicos producidos, resulta probable que el Miembro Esquistos Cerro Cóndor represente bloques del basamento de bajo grado que se extendería desde el noroeste de la Sierra de Umango, Sierra de Cacho y alrededores (e.g. Varela et al. 2003). Los esquistos calcáreos del Miembro Mármol Las Damas (cf. Martina y Astini, 2009) se asocian al Miembro Esquistos Cerro Cóndor por su distribución y deformación tanto en la región de Los Llantenes como en los ríos Bonete y Ciénaga Grande. Sin embargo, su edad no puede acotarse con certeza hasta el momento. Podrían ser parte del basamento, pero si efectivamente representaran la continuación de la plataforma carbonática del Paleozoico Inferior de la Precordillera, ésta debió desarrollarse sobre el basamento representado por el Miembro Esquistos Cerro Cóndor y luego deformados conjuntamente durante la orogenia Famatiniana. Regionalmente se han descripto rocas calcáreas comparables al menos en la sierra de Pié de Palo y sierra de Umango. En la sierra de Pié de Palo están representadas por las Formaciones El Desecho y Angacos dentro del Grupo Caucete (Proterozoico Superior - Cámbrico Inferior), y rocas calcáreas intercaladas entre metabasitas en el Complejo Pié de Palo (Mesoproterozoico). En este sentido, Naipauer et al. (2005) sugirieron una posible correlación entre parte de los carbonatos del Grupo Caucete con el Cámbrico de Precordillera en base de isótopos de Sr. En la sierra de Umango quedan representados por mármoles en la Formación Tambillos, donde también se encuentran asociados a esquistos verdes. La sucesión de esquistos y mármoles descriptos en de la sierra de Umango son más abundantes hacia el sector occidental. Los datos isotópicos de C y Sr sugieren una edad neoproterozóica 


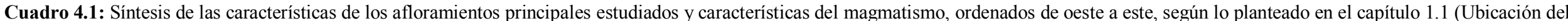
área de estudio). [1]- Formación Río Bonete (Prot. 1/2); [2] Formaciones Del Salto y Chuscho (Od Sup-Sil inf)); [3] Formaciones Quebrada Seca-Jagüé-Punilla (Dv sup-Cb inf); [4] Formación

Potrerillos; [5] Fm Guandacol (Cb); [6] Formación Punta del Agua (Cb); [7] Diques negros (Tr?); [FDJ] Faja de deformación de Jagüé

\begin{tabular}{|c|c|c|c|c|c|c|}
\hline \multicolumn{2}{|c|}{$\begin{array}{l}\text { Zona de } \\
\text { Afloramiento }\end{array}$} & Rocas sedimetarias y metamórficas & Rocas ígneas & Estructuras & Metamorfismo & Observaciones \\
\hline $\mathbf{a}$ & $\begin{array}{l}\text { Área de Los } \\
\text { Llantenes } \\
\text { (Qda de La } \\
\text { Damas) }\end{array}$ & $\begin{array}{l}\text { - Filitas y esquistos verdes de grano } \\
\text { fino. Mármoles con laminación } \\
\text { milonítica [1], meta-basitas talcosas } \\
\text { [1]. } \\
\text { - Lutitas concrecionales con estratos de } \\
\text { areniscas amarillentas intercalados [3] } \\
\text { - Paraconglomerados (castaño) [5] }\end{array}$ & $\begin{array}{l}\text { - pillow-lavas [2] (y esquistos } \\
\left.\left.\text { verde-azulados y talcosos [ } \begin{array}{lll}1 & 0 & 2\end{array}\right]\right) \\
\text { - Veta deformada corta a los } \\
\text { mármoles. } \\
\text { - Diques violáceos más jóvenes, } \\
\text { feno-andesíticos, con abundantes } \\
\text { fenocristales de Pl [6] } \\
\text { - Diques negros afaníticos [7] }\end{array}$ & $\begin{array}{l}\text { Fuerte foliación milonítica en esquistos } \\
\text { verdes, metabasitas y calizas. } \\
\text { Discordancia angular esquistos-calizas. } \\
\text { Kink-bands en esquistos. } \\
\text { Metabasitas con 'lentes' de andesitas y } \\
\text { cuarzo 'estrellado' (entre almohadillas). } \\
\text { Diques andesíticos subverticales } \\
\text { Plegamiento apretado de estratos de } \\
\text { areniscas amarillentas de [3] }\end{array}$ & Facies esquistos verdes & $\begin{array}{l}\text { mineralización de veta en } \\
\text { caliza (mina La Ramada) } \\
\text { **¿Contacto caliza- } \\
\text { esquisto es tectónico? }\end{array}$ \\
\hline $\mathbf{b}$ & $\begin{array}{l}\text { Quebradas } \\
\text { del Bonete } \\
\text { medio y } \\
\text { Ciénaga } \\
\text { Grande }\end{array}$ & $\begin{array}{l}\text { Intercalación de capas de mármoles } \\
\text { laminados con esquistos verdes [1]. } \\
\text { Esquistos biotíticos mas abundantes en } \\
\text { la margen oriental, con venas } \\
\text { sigmoidales de cuarzo asociadas }[4+2 \\
\text { en FDJ]. }\end{array}$ & \begin{tabular}{|l} 
Afloramientos localizados de lavas \\
almohadilladas $\quad$ [2] y rocas \\
plutónicas [4]. \\
$\begin{array}{lll}\text { Diques negros } & \text { subverticales [7] y } \\
\text { verdes [2] }\end{array}$
\end{tabular} & $\begin{array}{l}\text { Plegamiento muy apretado, y foliación } \\
\text { muy fuerte (laminación milonítica) en } \\
\text { mármoles y esquistos verdes. } \\
\text { Plegamientos tipo kink, lineación de } \\
\text { crenulación y composicional en } \\
\text { esquistos. Brechamiento de esquistos, } \\
\text { mármoles y rocas ígneas. } \\
\text { Diques negros cortan todo. }\end{array}$ & $\begin{array}{l}\text { Facies esquistos verdes baja } \\
\text { (Chl) hasta media (Bt), Act- } \\
\text { Tremolita en esquistos; llega } \\
\text { hasta facies de anfibolitas } \\
\text { epidóticas con epidoto muy } \\
\text { abundante. Se observó Pump. en } \\
\text { metabasitas. } \\
\begin{array}{l}\text { Recristalización en } \\
\text { calcáreas. }\end{array} \\
\end{array}$ & $\begin{array}{l}\text { Movimiento sinestral. } \\
\text { **La intercalación } \\
\text { litológica característica } \\
\text { de la Fm Río Bonete } \\
\text { responde al plegamiento } \\
\text { apretado de mármoles y } \\
\text { esquistos (no se observan } \\
\text { rasgos primarios). }\end{array}$ \\
\hline c & $\begin{array}{l}\text { Quebradas } \\
\text { del Salto y } \\
\text { Chuscho }\end{array}$ & $\begin{array}{l}\text { Metasedimentitas estratificadas: } \\
\text { metavaques, metalimolitas y pizarras } \\
\text { [2]. } \\
\text { Bloque intercalado tectónicamente: } \\
\text { filitas concresionales que engloban } \\
\text { canales arenosos y conglomerádicos, } \\
\text { sobre capas } \\
\text { granodecrecientes [3]. }\end{array}$ & $\begin{array}{l}\text { Diques verdes [2] y negros } \\
\text { afaníticos [7]. } \\
\text { Feno-andesitas [2?, 6?] en contacto } \\
\text { con lavas almohadilladas basálticas } \\
\text { (con cuarzo lechoso 'estrellado' } \\
\text { [2]); autobrechas y lavas } \\
\text { almohadilladas intercaladas entre } \\
\text { las metasedimentitas estratificadas. } \\
{[2] .}\end{array}$ & $\begin{array}{l}\text { Cataclasis, fallamiento y diaclasamiento. } \\
\text { Kink-bands en filitas. } \\
\text { Rocas ígneas apoyan en discordancia } \\
\text { angular sobre metasedimentitas, mientras } \\
\text { que son cortadas por los diques. }\end{array}$ & Anquimetamorfismo (Epizona). & $\begin{array}{l}\text { Coloraciones castañas y } \\
\text { amarillentas por } \\
\text { oxidación superficial. } \\
\text { No aparecen venas } \\
\text { sigmoidales de cuarzo } \\
\text { lechoso como en QP. }\end{array}$ \\
\hline $\begin{array}{l}\text { b } \\
1 \\
\text { c }\end{array}$ & $\begin{array}{l}\text { Miquilo y } \\
\text { Boca de } \\
\text { Bonete }\end{array}$ & $\begin{array}{l}\text { - Metamorfitas miloníticas [FDJ]: } \\
\text { Mármoles entre esquistos y filitas } \\
\text { verdes [1]. Esquistos blanquecinos } \\
\text { cuarzo-muscovíticos [4]. } \\
\text { - Metasedimentitas estratificadas [2]: } \\
\text { en contacto por falla con las } \\
\text { metamorfitas. }\end{array}$ & 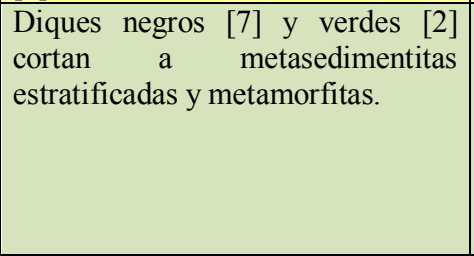 & $\begin{array}{l}\text { - Fuerte milonitización y cataclasis de } \\
\text { esquistos, filitas, y mármoles. Filitas con } \\
\text { pliegues tipo kink. } \\
\text { - Plegamiento abierto y fallamientos } \\
\text { menores de las metasedimentitas } \\
\text { estratificadas. } \\
\text { Diaclasamiento. }\end{array}$ & $\begin{array}{l}\text { - Facies esquistos verdes en } \\
\text { metamorfitas. } \\
\text { - Anquimetamorfismo en } \\
\text { metasedimentitas. }\end{array}$ & $\begin{array}{l}\text { Dolomitización de los } \\
\text { bordes de las capas } \\
\text { calcáreas, previa a la } \\
\text { milonitización. }\end{array}$ \\
\hline d & $\begin{array}{l}\text { Qda de } \\
\text { Potrerillos }\end{array}$ & $\begin{array}{l}\text { Metasedimentitas estratificadas negras } \\
{[2] \text { : metavaques, metalimolitas y }} \\
\text { pizarras. }\end{array}$ & $\begin{array}{l}\text { Intruidas por diques andesíticos [2] } \\
\text { y basálticos [7], y diques de } \\
\text { gabroides [4]. }\end{array}$ & $\begin{array}{l}\text { Plegamiento y fallamiento de la } \\
\text { estratificación (So) en metasedimentitas. } \\
\text { Abundantes venas sigmoidales de Qtz, en } \\
\text { echelon asociadas a corrimientos. } \\
\text { Clivaje de plano axial fuerte, } \\
\text { especialmente en metapelitas. }\end{array}$ & $\begin{array}{l}\text { Metapsamitas y metalimolitas } \\
\text { con lineación de crenulación y } \\
\text { bandeamiento composicional } \\
\text { (raro) Metamorfismo de } \\
\text { contacto (motas) en facies finas, } \\
\text { con crecimiento de Bt. }\end{array}$ & $\begin{array}{l}\text { No hay mármoles ni } \\
\text { esquistos. } \\
\text { Afloramientos } \\
\text { ennegrecidos por barnices } \\
\text { del desierto. }\end{array}$ \\
\hline
\end{tabular}


para la sedimentación de la sucesión siliciclástica-calcárea, en el intervalo 640-580 Ma (Varela et al., 2001). Según la interpretación de Varela et al. (2010) habría sido una sucesión de plataforma, cortada por filones capa y diques basálticos. Puede compararse con los resultados obtenidos en mármoles intercalados con metaclásticas del Grupo Caucete, en la Sierra Pie de Palo, San Juan (Sial et al., 2001; Varela et al., 2003).

Las diferencias que se observan en las modas de las edades U-Pb entre las muestras LS1-3 y QP-E9 representativas de los dos afloramientos principales de las metasedimentitas estratificadas de la Formación del Salto a ambos lados de la quebrada del río Bonete podrían tener relación con la ubicación geográfica de los depósitos en la cuenca en el marco geotectónico. Por ejemplo, las sedimentitas de la quebrada del Chuscho se encuentran al oeste de los afloramientos y de la faja de deformación de Jagüé, mostrando una mayor contribución de material mesoproterozoico (¿ciclo Grenvilliano?) y vínculo con las volcanitas del cerro Chuscho, mientras que las sedimentitas de la quebrada de Potrerillos son los afloramientos más orientales y se encuentran al este de la faja de deformación, en el límite con los afloramientos de las Sierras Pampeanas, que podrían ser los responsables del aporte vinculado al Neoproterozoico (¿ciclo Pampeano?). Las metasedimentitas intercaladas con lavas almohadilladas de la Formación Del Salto podrían correlacionarse con unidades equivalentes de la Precordillera occidental (ej: formaciones Yerba Loca, Alcaparrosa). A pesar de que la edad máxima de sedimentación de las metasedimentitas estratificadas es mas jóven (llegando al Silúrico temprano), las edades U-Pb obtenidas podrían ser comparables, especialmente con las de la Formación Alcaparrosa.

Los conglomerados castaños son los afloramientos de conglomerado más extendidos en la zona y tradicionalmente se mapean dentro de la Formación Guandacol (Aceñolaza, 1971; Aceñolaza et al., 1971; Maisonave 1979; ver Gutiérrez, P. R., 2008: Formación Guandacol: observaciones'), o son homologados a los afloramientos definidos como Formación Jagüel (González y Bossi, 1986). Formarían parte de la Formación Cerro Tres Cóndores definida por González y Bossi (1987) que apoya en discordancia sobre la Formación Agua de Lucho. Esta unidad ha sido correlacionada con la Formación Cortaderas (Mississippiano Superior; Scalabrini Ortiz, 1973) que inicia con una sucesión de conglomerados que sobreyacen en discordancia erosiva a las lutitas y limolitas de la Formación Malimán (Tournaisiano; Scalabrini Ortiz, 1973); ambas unidades integran el Grupo Angualasto (Carbonífero Inferior - Limarino y Césari, 1992, Azcuy et al., 2000), en el norte de la Precordillera sanjuanina (ver también González y Díaz Saravia, 2007). En el Cuadro 3.8.1 de la sección 3.2.8 se presenta una síntesis estratigráfica comparativa de los afloramientos del Paleozoico Superior de la región.

\section{4 - IMPLICANCIAS TECTONICAS.}

Tanto por las litologías presentes como por las estructuras regionales observadas, los afloramientos de la Precordillera de Jagüé parecen constituir los últimos afloramientos que continúan hacia el norte de las rocas y estructuras descriptas en la Sierra de Umango, particularmente en su 
sector occidental. Se presenta en este sector como bloques de un basamento fracturado y deformado que se preservan como núcleos de anticlinales cuyos flancos los constituyen las unidades del Paleozoico Superior. Sobre la base de lo observado se propone el siguiente esquema de eventos posibles para la región, considerando un contexto inicial en el que los distintos basamentos observados en el área (Formación Espinal y Formación Río Bonete s.s.) conforman dos bloques, uno autóctono de medio a alto grado y otro probablemente alóctono? en facies de esquistos verdes dominante y con aporte sedimentario principal de rocas grenvilianas.

Primero habría ocurrido el depósito de rocas básicas y sedimentarias, probablemente en un ambiente marino de plataforma, y posteriormente transformados en esquistos verdes que forman el basamento del bloque de bajo grado. Luego se habrían depositado las rocas carbonáticas (plataforma carbonática C?-Od?). Mientras en el bloque de medio a alto grado el protolito parece ser sedimentario e ígneo. Durante el ciclo Pampeano en esta corteza se debería estar formando el arco en consecuencia de la subducción del alóctono (arco pampeano, ¿Sierras de Maz, de la Huerta?).

Posteriormente, al ocurrir el choque del bloque alóctono con el autóctono durante el Ordovícico Superior se habría producido una deformación penetrativa asociada a fuerte replegamiento apretado e isoclinal de esquistos y calizas con metamorfismo asociado (deformación D1), con milonitización, formación de los de esquistos verdes precámbricos asociados a esquistos calcáreos de la Formación Río Bonete s.s., y la generación de fajas de cizalla como la Faja de deformación de Jagüé.

Posteriormente se habrían depositado los sedimentos turbidíticos y ocurrido la erupción de la lavas de la Formación del Salto. Esto implica la presencia nuevamente de un ambiente marino, ya sea por una nueva apertura de cuenca, o su desarrollo sobre el margen costero pero ahora al oeste del bloque. Los resultados obtenidos para las rocas básicas de la Formación Chuscho relacionadas con las sedimentitas indican un ambiente de arco de isla oceánico y podrían estar registrando la transición entre un ambiente de retroarco continental con basaltos de inundación (ruptura) y posterior formación de un arco de isla oceánico (subducción)?, entonces ambas signaturas tendrían significado.

Luego se habría reactivado la faja de cizalla con deformación de sedimentitas y lavas almohadilladas y metabasitas ordovícicas (deformación D2). Es probable que la edad de esta reactivación esté relacionada con la edad obtenida para la muestra BO27 sobre la quebrada del Bonete, que estaría indicando un pico metamórfico en facies anfibolitas durante el Devónico Medio. Este evento estaría ligado a la fase diastrófica Chánica o Precordilleránica, que se da de manera diacrónica en la Precordillera. Esta fase se relaciona a la acreción del Terreno Chilenia en el margen occidental del Gondwana occidental. Edades similares de deformación se han citado para otras regiones en la sierra de Umango por ejemplo (Varela et al., 2003).

El siguiente ciclo de depositación corresponde a las sedimentitas de las Formaciones Quebrada Seca y Jagüé, ya sea sobre bloques del basamento o de la Formación del Salto. La deformación que afecta a estas unidades es distinta de la milonitización intensa de las metabasitas y esquistos, e incluye plegamiento, fallamiento e intrusión de diques básicos (deformación D3). 
Luego de un período de erosión hubo una extensión regionalmente importante durante la apertura de las cuencas carbonífero-pérmicas y el depósito en fuerte discordancia de las unidades equivalentes a las Formaciones Guandacol y Patquía (e.g. Formación Cerro Tres Cóndores). Todas estas unidades se encuentran levemente deformadas por plegamientos suaves (deformación D4).

La intrusión de los diques negros alcalinos podrían vincularse al rift que abre las cuencas del Triásico (?), sin embargo no se ha podido ahondar en su estudio ni resolver su ubicación estratigráfica y se ubican en esta edad de modo provisorio.

Siguiendo la descripción de Varela et al., 2003 se observan varias similitudes entre la geología de la Precordillera de Jagüé y las rocas que aparecen en el sector occidental de la Sierra de Umango. Teniendo en cuenta la desviación de las estructuras regionales y la ubicación del sector de estudio inmediatamente al norte de esta sierra es de esperar una evolución similar y lo observado es coherente con el modelo planteado por estos autores. Según se expresa "en el basamento de la sierra de Umango se conservan núcleos del Proterozoico medio (Ciclo Grenville) que han sido el apoyo de sedimentos clástico-carbonáticos y el conjunto fue intruido por magmas básicos (plataforma calcárea y ruptura continental). Subducción seguida de colisión continente-continente (o acreción de microcontinentes), habrían regido la evolución cortical durante el Paleozoico Inferior (Ciclos Pampeano a Famatiniano). Estos núcleos pueden ser comparables con los núcleos en los que afloran los esquistos y mármoles de la Formación Río Bonete s.s.. Si este fuera el caso, las rocas calcáreas (más jóvenes) habrían quedado intercaladas entre los esquistos tectónicamente, y esto pudo haber ocurrido durante esta etapa de colisión continental/acreción de microcontinentes (ver antes: "origen de la intercalacion entre

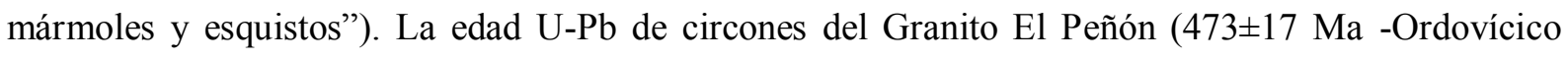
Inferior) puede relacionarse con una primera etapa de metamorfismo y magmatismo y en el Devónico se reiteraron esas condiciones. Por los resultados obtenidos la intrusión del Granito Potrerillos y el pico metamorfico en la faja de deformación de Jagüé podrían relacionarse con este segundo período de metamorfismo y magmatismo. El ambiente tectónico interpretado, relacionado a un evento colisional, está de acuerdo con la vergencia estructural dirigida al oeste, con importantes corrimientos ('nappes?', no se observan en la Precordillera de Jagüé), desde el interior del orógeno hacia el contiguo antepaís. Por la edad de los carbonatos de plataforma de la contigua Precordillera (Cámbrico Inferior, sin base expuesta, a Ordovícico Inferior) y el relleno clástico de las cuencas de antepaís de la misma Precordillera (Ordovícico Medio a Devónico) estos autores interpretan que limitan el lapso de ocurrencia del proceso colisional al Paleozoico Inferior-Medio. De acuerdo con las características descritas para la sierra de Umango, que pueden en parte también ser comprobadas en las sierras de Fiambalá, Espinal, Maz y Pie de Palo, las Sierras Pampeanas Occidentales se caracterizan por contener núcleos ígneo-metamórficos del Proterozoico medio, una cobertura metasedimentaria clástico-calcárea estrechamente relacionada con rocas ígneas básicas (Neoproterozoico?-Cámbrico Inferior), y por los importantes procesos de metamorfismo y deformación ocurridos en el Ordovícico y Devónico (Varela et al., 2003). 
En la denominada Precordillera de Jagüé se reúnen unidades correlacionables tanto con Sierras Pampeanas Occidentales como Precordillera por lo que sería conveniente hablar de Terreno Precordillera o Cuyania, ya que abarca a ambas provincias geológicas. 


\section{Capítulo 5:}

\section{CONCLUSIONES}

El Paleozoico Inferior de la Precordillera de Jagüé estaba representado por una única unidad, la Formación Río Bonete, sobre la base del hallazgo de una fauna fósil ordovícica. Los resultados obtenidos desde los distintos puntos de vista con que se encaró el estudio, han permitido reorganizar la estratigrafía de la región, redefiniendo esta unidad y aportando nuevos datos a otras unidades que allí afloran. A continuación se presentan las conclusiones generales a las que se ha llegado.

1) Lo que fuera definido por Aceñolaza et al., (1971) como Formación Río Bonete aflora en una zona muy compleja tectónicamente y reúne rocas de distinto origen y/o edad. Las edades obtenidas, las asociaciones y relaciones de campo, así como las características estructurales observadas con mayor detalle permiten redefinir la unidad y separarla en asociaciones de rocas de distinta edad y origen: la Formacion Río Bonete s.s. y la Formación del Salto (emend.).

2) La Formación Río Bonete s.s. quedaría integrada por el Miembro Esquistos Cerro Cóndor que comprende filitas y esquistos verdes, y el Miembro Mármol Las Damas (Martina y Astini, 2009) que comprende rocas calcáreas representadas por esquistos cálcareos, mármoles y brechas calcáreas, en forma similar a la definición original de Aceñolaza (1969). Ambas litologías se encuentran asociadas por su distribución y deformación tanto en la región de Los Llantenes como en los ríos Bonete y Ciénaga Grande. Quedan excluidas las metasedimentitas fosilíferas estratificadas con fósiles ordovícicos. Quedan excluídas también otras variedades de esquistos generados por la faja de deformación de Jagüé. Los esquistos blanquecinos cuarzo-muscovíticos y los esquistos micáceos corresponden a unidades más jóvenes que han quedado intercaladas junto con esquistos verdes y anfibolitas dentro de la faja de cizalla y muchas veces no es fácil separar las litologías.

3) La edad del Miembro Mármol Las Damas es muy difícil de establecer con certeza hasta el momento. Por las características observadas se estima que puede correlacionarse con la plataforma cámbrica de la Precordillera Sanjuanina como sugieren Martina y Astini (2009). Podrían ser parte del basamento, pero si efectivamente representaran la continuación de la plataforma carbonática del Paleozoico Inferior de la Precordillera, ésta debió desarrollarse sobre el basamento 'grenvilliano' representado por el Miembro Esquistos Cerro Cóndor y luego deformados conjuntamente.

4) El Miembro Esquistos Cerro Cóndor registró un único pico de edades U-Pb en circones $c a$. $1 \mathrm{Ga}$, demarcando una edad máxima de aporte para estas rocas en el Mesoproterozoico Superior, comparable con las de los basamentos asociados al 'ciclo Grenvilliano' de la Precordillera y Sierras Pampeanas Occidentales. Por estas edades y la edad cámbrica inferida para el Miembro Mármol Las Damas, la edad de los esquistos quedaría acotada al Neoproterozoico. Teniendo en cuenta el mapeo geológico, la estructura regional y los datos isotópicos producidos, resulta 
probable que el Miembro Esquistos Cerro Cóndor represente bloques del basamento que se extendería desde la Sierra de Umango y alrededores (e.g. Varela et al. 2003).

5) Las metasedimentitas estratificadas con fósiles ordovícicos corresponden a los afloramientos mapeados informalmente como 'Lutitas del Salto' por Aceñolaza y Bernasconi (1969), por lo que se sugiere la denominación de Formación Del Salto (emend.), respetando el antecedente citado e incluyendo además a las lavas almohadilladas que se intercalan entre ellas. Reúne a los afloramientos de los alrededores de la quebrada del Salto, Chuscho y Boca del Bonete así como los que se encuentran al norte del Granito Potrerillos. Se encuentran intercaladas con las rocas básicas tradicionalmente denominadas como Andesita Cerro Chuscho o Formación Chuscho. Ya que ambas litologías se encuentran asociadas, se propone que la Formación del Salto quede constituida por dos miembros informales: el Miembro Metasedimentitas Estratificadas, que incluya a las sedimentitas fosilíferas datadas en el límite Ordovícico Superior - Silúrico Inferior del área de la quebrada del Chuscho y quebrada de Potrerillos, y el Miembro Cerro Chuscho que quedaría representado por las rocas básicas relacionadas con ellas.

6) El Miembro Cerro Chuscho (Formación Chuscho de Toselli y Durand, 1996; Fauque y Villar, 2003) se restringe a las rocas básicas que constituyen el cerro homónimo y afloramientos aledaños, y su edad ordovícica se desprende del hecho de que se encuentran intercaladas entre las metasedimentitas estratificadas con fósiles de esta edad. Se diferencia así de las rocas básicas carboníferas de la Formación Punta del Agua y del magmatismo carbonífero al que tradicionalmente fuera asignado. Por la ubicación estratigráfica de los afloramientos de lavas almohadilladas del extremo sur de la Dorsal de la Orilla en Los Llantenes se consideraron también dentro de este ciclo magmático, pero es necesario corroborar esto con estudios específicos. Las rocas básicas de Las Casitas podrían integrar también esta unidad pero no se ha podido llegar a dichos afloramientos.

7) El Miembro Metasedimentitas Estratificadas esta compuesto por la intercalación de estratos tabulares y continuos de metapelitas, metalimolitas y metavaques. Se caracteriza por preservar rasgos netamente sedimentarios, un grado metamórfico muy bajo, una estructura de plegamientos dislocados por pequeñas fallas o corrimientos, y la ausencia de mármoles y esquistos intercalados. La estratificación es un rasgo sobresaliente y permite identificarlas y diferenciarlas de las demás unidades. Portan fósiles caradocianos y se registraron dos picos principales de edades $\mathrm{U}-\mathrm{Pb}$ en circones detríticos: el pico principal indica una edad máxima de sedimentación cerca del límite Ordovícico - Silúrico (440,3 $\pm 6,8$ Ma en los afloramientos de la quebrada de Potrerillos y $443 \pm$ $13 \mathrm{Ma}$ en los afloramientos fosilíferos), y una moda secundaria que indica aporte del basamento mesoproterozoico. Este último aporte es comparable con el pico obtenido para el Miembro Cerro Cóndor. Los datos de petrografía permitieron acotar la temperatura a la que fueron sometidas estas rocas entre los 400 y $500{ }^{\circ} \mathrm{C}$. Los resultados de cristalinidad de la illita (IK entre 0,13 y 0,24 ) acotaría el máximo grado metamórfico dentro de la zona de clorita de la facies de esquistos verdes. 
8) Por las relaciones de campo y sus edades es posible vincular a las rocas básicas con tres eventos magmáticos: uno ordovícico tholeí́tico (con tendencia alcalina), vinculado a un ambiente de arco de isla oceánico(?), otro carbonífero calcoalcalino de arco relacionado a subducción, y un último probablemente Triásico (?) y más alcalino que podría vincularse a un ambiente de rift(?). Al primero se vinculan las rocas básicas del Miembro Cerro Chuscho, al segundo las de la Formación Punta del Agua y el pico de formación del Granito Potrerillos, y el tercero estaría representado por los diques negros sin deformar que se observan en la región cortando a las demás unidades

9) Las metasedimentitas estratificadas tendrían aporte tanto desde el basamento Meso-proterozoico de Cuyania (Sierras Pampeanas Occidentales) como de un arco relacionado a margen continental activo. Existen rocas relacionadas a un arco a lo largo del margen occidental de Gondwana durante el Ordovícico, tanto en Famatina como en la Puna. Esto implicaría que estos afloramientos de Precordillera recibieron sedimentos tanto del basamento de Sierras Pampeanas Occidentales como del arco Ordovícico de Famatina o/y Puna. No se descarta que el aporte detrítico haya derivado de terrenos que se encontraban tectónicamente activos durante la depositación.

10) En el área de Los Llantenes se hallaron fósiles del Devónico - Carbonífero Inferior en las lutitas de la Formación Quebrada Seca (Cravero et al., 1984), unidad previamente definida dentro del Ordovícico. Estas rocas pasarían a ser entonces equivalentes a la Formación Jagüel (González y Bossi, 1986) y Formación Punilla (Furque, 1956). Sobre la quebrada del Chuscho se halló un pequeño bloque relacionado mediante fallas con las metasedimentitas de la Formación Del Salto que hasta el momento se ha pasado por alto en las descripciones y que correspondería a la Formación Jagüel que aflora inmediatamente al sur. En este bloque sobresale un cuerpo canaliforme de conglomerados desarrollado sobre facies arenosas finas y otros canales menores de arenitas medianas a gruesas englobados por pelitas concrecionales deformadas similares a las observadas para la Formación Quebrada Seca en Los Llantenes. Ambos afloramientos serían equivalentes.

11) El Granito Potrerillos es un plutón tipo I representado por una serie de facies de composición variable, desde peraluminosas a metaaluminosas, de afinidad calcoalcalina, con facies de cierta tendencia alcalina y generalmente rico en potasio. Presenta evidencias de mezcla de un magma basico y uno más ácido por mingling, asi como de asimilación parcial de la roca de caja sedimentaria (enclaves). Se obtuvieron tres edades U-Pb en circones para el Granito Potrerillos de $350,8 \pm 7,1 \mathrm{Ma}, 355,8 \pm 3,1$ Ma y 374,9 \pm 9,3 Ma. Estas edades (Frasniano-Tournaisiano), sus características petrográficas, geoquímicas, relaciones de campo y análisis de imágenes, llevan a interpretar que el plutón se habría formado durante los estadíos magmáticos tardío a posttectónicos respecto de la orogenia Famatiniana, diferenciándose de los granitoides del cerro de Las Tunas, sierra del Peñón y cerro Comecaballos que pertenecen a los inicios del ciclo magmático gondwánico típico de la Cordillera Frontal y con los que tradicionalmente se correlacionaba. Los diagramas geoquímicos de discriminación tectónica vinculan al magmatismo a un ambiente de arco relacionado a márgenes continentales activos. 
12) Se han hallado afloramientos de conglomerados relacionados tectónicamente o mediante discordancia angular con las unidades estudiadas y a la faja de cizalla. Los principales son los correspondientes a la Formación Cerro Tres Cóndores del Grupo Angualasto (Carbonífero Inferior) de amplia distribución en la región, pero en los alrededores del tramo medio del río Bonete se hallaron pequeños afloramientos de escaso espesor de otras unidades. Sobre la Formacion Río Bonete apoya un conglomerado grueso y con clastos redondeados de composición granítica dominante sobre el que se desarrolla otro conglomerado mas fino y de aspecto brechoso con tonalidades violáceas y aporte de volcanitas. Estos dos últimos de edad incierta pero se estima que corresponden también al Carbonífero Inferior. En el filo sur de la quebrada del Chuscho y alrededores de la Cueva del Miquilo este conglomerado cubre en discordancia a las unidades ordovícicas y devónico - carboníferas inferiores.

13) Las unidades de la región han sido afectadas por más de un evento de deformación, que han dejado rasgos estructurales característicos y se asocian a condiciones de metamorfismo. El primer evento registrado es el que deforma con grandes plegamientos isoclinales a la Formación Río Bonete s.s. luego del depósito de las rocas calcáreas. Este evento podría ser Famatiniano, y por la intensidad de la deformación es probable que este sea el evento al que se asocia el primer movimiento de la faja de deformación de Jagüé (?) y durante el cual se produjo la fracturación y rotación de los bloques de este basamento. Luego del depósito de las metasedimentitas ordovícicas ocurrió una nueva deformación compresiva que genera la estructura de plegamientos constantes y corrimientos menores (probablemente fase Río Blanco, movimientos Chánicos). Posteriormente a la intrusión del granito Potrerillos en el Carbonífero Inferior se han generado las estructuras extensionales asociadas a la apertura de las cuencas de rift neopaleozoicas con orientaciones generales SO - NE a cuyo relleno corresponden los conglomerados de la Formación Cerro Tres Cóndores. Por último, durante el ciclo Ándico se habrían reactivado algunas estructuras y se generan las estructuras regionales de rumbo N-S.

14) La faja de deformación de Jagüé es muy importante en el área y controla el curso del río Bonete en su tramo inferior a medio, así como la deformación de las unidades a las que afecta (Formación Río Bonete s.s., metasedimentitas y rocas básicas de la Formación Del Salto, Granito Potrerillos y, aunque no hay evidencias claras, probablemente también a la Formación Jagüé) generando distintas variedades de esquistos. La edad de la deformación es incierta aún, pero habría sido reactivada más de una vez. La última reactivación ocurrió con seguridad en el Carbonífero Inferior, ya que afecta al Granito Potrerillos (Tournaisiano) y es cortado por los depósitos de paraconglomerados de la Formación Cerro Tres Cóndores (Carbonífero Inferior). El pico metamórfico dado por la edad obtenida en una lava anfibolitizada sobre la quebrada del Bonete

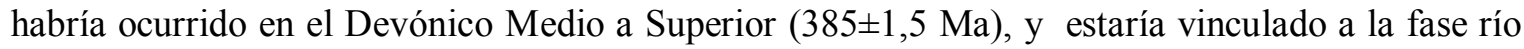
Blanco de la orogenia Chánica. En el bloque de Los Llantenes existe otra faja de cizalla que está afectando a las lavas almohadilladas y a los afloramientos de la Formación Río Bonete en ese 
sector, que por su ubicación posiblemente tenga el mismo origen que la faja de deformación de Jagüé, aunque no necesariamente la misma historia de reactivaciones.

15) El grado metamórfico dominante alcanzado en la región es el de facies de esquistos verdes, en zona de clorita (retrógrada, en los esquistos de la Formación Río Bonete principalmente, y algunas metabasitas) y biotita. En este último caso generalmente es retrógrado a partir de rocas que han alcanzado la facies de anfibolitas (pico máximo en facies anfibolitas epidóticas según las evidencias observadas por la petrografía). Sólo cerca de la Boca del Bonete se ha llegado a la zona de granate (esquistos con granate). En las rocas básicas se presenta una variedad de facies desde metabasitas en facies de prehnita-pumpelleyta (quebrada del Chuscho) hasta facies anfibolitas en el tramo medio del río Bonete, ya que se encuentra más cerca del contacto tectónico, sobre la faja de cizalla.

16) La evolución geológica de la Precordillera de Jagüé entre el Precámbrico y el Paleozoico Inferior a Medio es compleja y estaría vinculada a la descripta para el sector noroccidental de la sierra de Umango y la evolución de Cuyania.

17) Las labores mineras de la zona son pequeñas y están asociadas a vetas (diques básicos) que se ubican cerca de los contactos entre la Formación Río Bonete y las almohadillas deformadas. Todo parece indicar que la mineralización particular que hay en la región estaría asociada al magmatismo carbonífero de la Formación Punta del Agua y no al de la Formación Chuscho, mineralizando vetas principalmente y esquistos en menor medida. 


\section{AGRADECIMIENTOS}

Aprovecho este espacio para agradecer y recordar a todas las personas y entidades que colaboraron de una u otra manera para poder realizar esta tesis en sus distintas etapas.

En primer lugar agradezco a la Fundación YPF y Agencia Nacional de Promoción Científica y Técnica (ANPCyT) por las becas de posgrado que me otorgaron, así como a los proyectos PICT 07-10829, FCNyM-UNLP 11/447 y PIP-CONICET 0647 que brindaron fondos sin los cuales hubiera sido imposible encarar las campañas y los distintos estudios realizados.

En segundo lugar al Centro de Investigaciones Geológicas, y a la Universidad de Johannesburgo por brindarme un espacio para trabajar y la oportunidad de disponer de sus instalaciones.

Al SEGEMAR de San Juan, especialmente al Sr. Ricardo Castro, por su apoyo logístico invaluable para realizar las campañas. Al personal del SEGEMAR de La Rioja, por la colaboración bibliográfica, cartográfica y comentarios de la zona.

Concluir este doctorado es un objetivo que no se puede lograr sin el apoyo y creatividad de un grupo de personas, tanto colegas profesionales como amigos y familiares, que colaboraron y me apoyaron siempre firmemente. Quiero agradecer muy especialmente el apoyo constante e incondicional de mi director de tesis, Dr. Carlos Cingolani, quien me enseñó un nuevo principio: lo importante es avanzar. Gracias por este y muchos sabios consejos.

A mi co-director, Dr. Udo Zimmermann, con quien compartí muy interesantes discusiones, y a pesar de sus altos encargos internacionales, ha dedicado su tiempo para atender correcciones y comentarios de esta tesis.

A los Dres. Luis Fauqué (SEGEMAR, Buenos Aires) y Pablo Pazos (FCEN-UBA), con quienes tuve unas charlas muy constructivas sobre la geología de la región, rocas básicas y Paleozoico Superior.

A Marta Alfaro y los Dres. Jorge Manceñido y Eduardo Morel (Museo de Cs Naturales, FCNyM-UNLP) por su aporte y comentarios en los aspectos paleontológicos.

A Mario Campaña por su colaboración en los gráficos.

A la Dra. Susana Heredia de la Universidad Nacional de San Juan, por su entrenamiento en fósiles específicos, en la pasantía que tuve oportunidad de cumplir y su bondad al darme alojamiento. 
A Marisa Fernández, y muy especialmente a Nilda Menegatti quien fue un soporte invaluable en momentos difíciles. Conté con el apoyo de ambas en la Universidad Nacional del Sur prestándome materiales e instrumental de trabajo.

A todas las personas que a través de charlas, comentarios o sugerencias, y ayuda en los laboratorios y en el campo, han colaborado para llevar esta tesis adelante desde el punto de vista científico pero también en lo personal, en especial a Norberto Uriz y Jorge Maggi, Noelia Iannizzotto, Karina Pamoukaghlián, Eduardo Llambías, Marcelo Manassero, Ricardo Varela, Claudia Cavarozzi, Paulina Abre, Ana Sato, Pablo González, Paula Falaschi, Alfredo Benialgo, Pablo García, Jorge Wlasiuk.

A mis amigos y a mi familia, que están siempre presentes y apoyándome a pesar de la distancia en que nos encontrábamos. De manera especial me quiero referir a mis padres, Erich Frigerio e Irene De Paul, mis guías e inspiración de vida, a mi hermano Marcos, compañero de aventuras y sueños, a todos mis tíos y a la Oma que me dieron la fortaleza de familia.

A los miembros del jurado, Dres. Ricardo Varela y Marcelo Manassero, de la Universidad Nacional de La Plata, y al Dr. Florencio Aceñolaza, de la Universidad Nacional de Tucumán.

Agradezco a todos ya que hicieron posible que hoy estuviéramos reunidos, a todas las personas a quienes tengo presentes, pero por falta de espacio, no puedo contener en estos agradecimientos.

Y a quienes inician sus estudios, a los nuevos geólogos, sigan preguntándose ¿Por qué? Y contesten ¿Por qué no? 


\section{Capítulo 6: \\ BIBLIOGRAFÍA}

A

Abre, P., 2007. Provenance of Ordovician to Silurian clastic rocks of the Argentinean precordillera and its geotectonic implications. Phd Thesis, Johannesbourgh University.

Abre, P., Cingolani, C. A., Zimmermann, U., Cairncross, B., 2007. Detrital chromian spinels from Upper Ordovician deposits in the Precordillera Terrane, Argentina: A mafic crust input. Journal of South American Earth Sciences. Special Issue on Mafic Rocks.

Abre, P., Zimmermann, U., Cingolani, C., Cairncross, B., Chemale Jr., F. 2008. Detrital zircon datimg from Ordovician clastic units of the San Rafael Block, Precordillera Terrane, Western Argentina. VI SSAGI, Bariloche, Actas (CDRom version).

Abre, P., Zimmermann, U., Cingolani, C., Cairncross, B., Chemale Jr. F. 2006. Nd isotopes from Yerba Loca formation (upper Ordovician), Cuyania Terrane, Argentina. V SSAGI

Abbruzzi, J., Kay, S.M. y Bickbord, M. (1993). Implications for the nature of the Precordilleran Basement from Precambriam xenoliths in Miocene volcanic rocks, San Juan Province, Argentina. XII Congreso Geológico Argentino y II Congreso de Explotación de Hirdocarburos, Actas 3: 331-339.

Aceñolaza, F. y Castaño, O., 1968. Estudio preliminar de la región de Los Llantenes, Departamento de General Sarmiento. Informe inédito, Dirección Provincial de Minería de La Rioja.

Aceñolaza, F. G., 1969. Características Geológicas y Estratigráficas del sector Septentrional de la Precordillera Riojana zona de Los Llantenes, Cerro de Las Damas, Dto. Gral. Sarmiento. $4^{\circ}$ Jornadas Geológicas Argentinas, Actas 1: 1-13.

Aceñolaza, F. G., 1970. Fósiles ordovícicos del área del río Bonete, departamento de Jagüé, provincia de La Rioja. Acta Geológica Lilloana, 10 (15): 313-328, Tucumán.

Aceñolaza, F.G., 1971. Geología estratigráfica de la zona comprendida entre Punta del Agua y Rincón Blanco, departamento de Gral. Lamadrid, La Rioja. Acta Geológica Lilloana, 11 (7): 125-150, San Miguel de Tucumán.

Aceñolaza, F. G. y Bernasconi, A., 1969a. Acerca del primer hallazgo de una fauna ordovícica en el sector norte de la Precordillera Riojana. Revista de la Asociación Geológica Argentina, 24 (2): 79-84.

Aceñolaza, F.G. y Bernasconi, A., 1969b. Sobre la edad de las intrusivas que afloran en el sector norte de la Precordillera Riojana: área del Río Bonete. $4^{\circ}$ Jornadas Geológicas Argentinas, tomo 2: 61-67. Mendoza.

Aceñolaza, F. y Toselli, A., 1981. Geología el noroeste argentino. Publicación especial. Facultad de Ciencias Naturales, Universidad Nacional de Tucuman, 212 pags., Tucumán. 
Aceñolaza, F.G. y Toselli, A.J., 1988. El Sistema de Famatina, Argentina: su interpretación como orógeno de margen continental activo. V Congreso Geológico Chileno, Actas 1: 55-67. Antofagasta.

Aceñolaza, F.G. y Toselli, A.J., 2000. Argentine Precordillera. Allochthonous or authochthonous gondwanic?. Zentralblatt für Geologie und Paläontologie 7/8:743-756.

Aceñolaza, F. G., Toselli A. J. y Bernasconi A., 1971. La Precordillera de Jagüé, La Rioja, Argentina, su importancia geológica y estructural. Acta Geológica Lilloana 11 (14): 257-290, Tucumán, Argentina.

Aceñolaza, F.G. y Baldis B., 1986. The Ordovician System of South America. Carta de Correlación y Notas Explicativas. IUSG-UNESCO, IGCP.

Aceñolaza, F. G., Miller, H. y Toselli, A. J., 1996. Geología del sistema de Famatina. Münchner Geologische Hefte, 19 (Reihe A); München.

Adams, C.J.; Pankhurst, R.J.; Maas, R.; Millar, I.L.. $2005 \mathrm{Nd}$ and $\mathrm{Sr}$ isotopic signatures of metasedimentary rocks around the South Pacific margin and implications for their provenance. En: Vaughan, A.P.M.; Leat, P.T.; Pankhurst, R.J., (eds.), Terrane processes at the margins of Gondwana. Geological Society of London Special Publication 246: 113-141. London. - doi: 10.1144/GSL.SP.2005.246.01.04

Alonso, J.L., Gallastegui, J., García-Sansegundo, J., Farías, P., Rodríguez Fernándes, L.R., Ramos, V.A., 2008. Extensional tectonics and gravitational collapse in an Ordovician passive margin: The Western Argentina Precordillera. Gondwana Research 13: 204-225. - doi: 10.1016/j.gr.2007.05.014

Andersen, T. y Laajoki, K., 2003. Provenance characteristics of Mesoproterozoic metasedimentary rocks from Telemark, South Norway: a Nd-isotope mass balance model. Precambrian Research, Elsevier. - doi:10.1016/S0301-9268(03)00174-8

Anderson, J. L. and Smith, D. R., 1995. The effects of temperature and $\mathrm{f}\left(\mathrm{O}_{2}\right)$ on the Al-in-hornblende barometer. American Mineralogist, 80 (2): 549-559.

Angelelli, V., 1984. Yacimientos minerales de la República Argentina, Vol. II. Comision de Investigaciones Científicas, FCNyM - UNLP, Instituto de Geología Aplicada., pp. 493-498, 553-560. Buenos Aires.

Arigós, L. (1949): Descripción geológica de la hoja 14c - Cerros Cuminchango (provincias de La Rioja y Catamarca), Instituto Nacional de Geología y Minería, (Bs.As. inédito).

Arigós, L. E., 1956. Informe técnico de la Comisión Geológica № 5. Informe interno YPFB. (GXG 332).

Asmerom, Y. and Jacobsen, S. B., 1993. The Pb isotopic evolution of the Earth - Inferences fromriver water suspended loads. Earth and Planetary Science Letters 115 (1-4): 245.256.

Astini, R. A., Benedetto, J. L. y Vaccari, N. E., 1995. The early Paleozoic evolution of the Argentine Precordillera as a Laurentian rifted, drifted and collided terrane: a geodynamic model. Geological Society of America Bulletin, 107: 253-273. 
Astini, R., Ramos, V., Benedetto, J., Vaccari, E. y Cañas, F. (1996). La Precordillera: un terreno exótico a Gondwana 13. Congreso Geológico Argentino, Actas, 5, 293-324. Buenos Aires

Astini, R., 1996. Las fases diastróficas del Paleozoico Medio en la Precordillera del oeste argentino evidencias estratigráficas-. $13^{\circ}$ Congreso Geologico Argentino y $3^{\circ}$ Congreso de Exploración de Hidrocarburos. Actas 5: 509-526.

Astini, R.A., Brussa, E.D. y Mitchell, C.E. 2000. Revisión estratigráfica y consideraciones paleogeográficas de la tectofacies occidental de la Precordillera Argentina. Revista de la Asociación Geológica Argentina 55: 378-386.

Augustithis, S.S., 1990: Atlas of metamorphic-metasomatic textures and processes. Amsterdam, New York, Elsevier.

B

Bahlburg, H., 1998. The geochemistry and provenance of Ordovician turbidities in the Argentine Puna. En Pankhurst, R.J. \& Rapela, C.W. (eds.), The Proto-Andean Margin of Gondwana, Geological Society, London, Special Publications, 142: 127-142.

Bahlburg, H., 2009. A review of the Chemical Index of Alteration (CIA) and its aplication to the study of Neoptoterozoic gracial deposits and climate transitions. En: Arnaud E., Halverson G.P. and Shields G.A. (Eds.). The geological record of Neoproterozoic Glaciations. Geological Society of London, Memoir.

Bahlburg, H., Vervoort, J. D., Du Frane, S. A., Bock, B., 2009. Timing of crust formation and recycling in accretionary orogens: Insights learned from the western margin of South America. Earth-Science Reviews 97: 215 - 241.

Baldis, B., Peralta, S. y Villegas, R. (1989). Esquematizaciones sobre una posible transcurrencia del terreno Precordillera como fragmento continental procedente de áreas pampeano-bonaerenses. Serie Correlación Geológica, 5: 81-100.

Baldis, B. A., Beresi, M.S., Uliarte E.R. y Vaca, A., 1981. Causas estructurales del acuñamiento norte de la Precordillera. Acta Geológica Lilloana XV: 3, pp. 27-29.

Basu, A., Molinaroli, E., 1991. Reliability and application of detrital opaque Fe-Ti oxide minerals in provenance determination. En Morton, A. C., Todd, S.P. and Haughton, P.D.W. (Eds.) Developments in Sedimentary Provenance Studies, Geological Society Special Publication $\mathrm{N}^{\mathrm{o}}$ $57,55-65$.

Basu, Young, Suttner, James y Mack, 1975. Re-evaluation of the use of ondulatory extinction and policrystallinity in detrital quartz for provenance interpretation. Journal of Sedimentary Petrology 45, 873-882.

Batchelor, R. A. y Bowden, P., 1985. Petrogenetic interpretation of granitoid rock series using multicationic parameters. Chemical Geology 48: 43-55.

Bathia, M. R., 1983. Plate tectonics and geochemical composition of sandstones. Journal of Geology 91: 611-627. 
Bathia, M. R. y Crook, K. A. W., 1986. Trace elements characteristics of graywackes and tectonic setting discrimination of sedimentary basins. Contributions to Mineralogy and Petrology 92: 181-193.

Benn, D.I., 1994. Fabric shape and interpretation of sedimentary fabric data. Journal of Sedimentary Research, Actas 64: 910-915.

Bernett, M., Basset, K., 2005. Provenance analysis by single-quarz-grain SEM-CL/optical microscopy. Journal of Sedimentary Research, 75 (3): 492-500.

Bernett, M., Basset, K., 2004. Provenance of Mount Sommers quartz arenites: combined SEMCL/optical microscopy analysis. Geophysiscal Research Abstracts, 6: 1164. European Geosciences Union.

Bertolino, S.R.A., Zimmermann, U. \& Sattler, S.J., 2007. Mineralogy and geochemistry of bottom sediments from water reservoirs in the vicinity of Córdoba, Argentina: Environmental and health constraints. Applied Clay Science, 36, 206-220.

Bock, B., McLennan, S. M. and Hanson, G. N. 1994. Rare earth element redistribution and its effects on the neodymium isotope system in the Austin Glen Member of the Normanskill Formation,New York, USA. Geochim. Cosmochim. Acta 58, 5245-53.

Bock, B., Bahlburg, H., Wörner, G., Zimmermann, U., 2000. Tracing crustal evolution in the Sothern Central Andes from Late Precambrian to Permian with geochemical and $\mathrm{Nd}$ and $\mathrm{Pb}$ isotope data. The Journal of Geology, 108: 515-535.

Boggs, S., Kwon, Y. I., Goles, G. G., Rusk, B. G., Krinsley, D., and Seyedolali, A., 2002. Is quartz cathodoluminescence color a reliable provenance tool? A quantitative examination. Journal of Sedimentary Research, 72 (3): 408-415.

Bonalumi, A.A. (2003): Petrología metamórfica. Compendio didáctico de grado, Guía Prospectiva, Cátedra de Petrología Ígnea y Metamórfica, FCEFN-UNC. Capítulo XIII: Rocas cataclásticas.

Borrello, A., 1955. Los conglomerados del cerro Punta Negra al oeste de Jagüé. Revista de la Asociación Geológica Argentina, 10 (1): 46-53, Buenos Aires.

Brogioni, N., (2000): Apuntes de la cátedra de Petrología II (rocas metamórficas), 2000, Facultad de Ciencias Naturales y Museo, Universidad Nacional de La Plata.

Brown, G.C., Thorpe, R. S. and Webb, P.C., 1984. The geochemical characteristics of granitoids in contrasting arcs and comments on magma sources. Journal of the Geological Society 141(3): 413-426 - doi: 10.1144/gsjgs.141.3.0413.

Brown, M. y Rushmer, T., 2006. Evolution and differenciation of continental crust. Brown, M. y Rushmer, T. (Eds.), Cambridge University Press, Nueva York. 553 páginas.

Brod, A. (2004): Apuntes del curso "Uso e interpretación de las tierras raras en petrología ígnea, metamórfica y sedimentaria”, 6 al 10 de Septiembre, Facultad de Cs. Naturales, UNSa.

Bryon, D.N., Atherton, M.P. and Hunter, R.H., 1994. The description of the primary textures of "Cordilleran" granitic rocks. Contributions to Mineral Petrology 117: 66-75. 
Busby and Ingersoll, 1995. Tectonics of sedimentary basins. Blackwell, Oxford.

C

Camacho, A., y Ireland, T.R., 1997. U-Pb Geochronology: Final Report. Geoscientific mapping of the Sierras Pampeanas, Argentine-Australian Cooperative Project, Australian Geological Survey Organization. En Leanza, E. (Ed.): Geología Regional Argentina, Academia Nacional de Ciencias Córdoba; pp. 41-80.

Caminos, R., 1972. Perfil geológico de la Cordillera entre los $28^{\circ} 00^{\prime}$ y los $28^{\circ} 30^{\prime}$ de latitud sur, provincia de La Rioja, República Argentina. Revista de la Asociación Geológica Argentina, 27 (1): 71-83. Bs. As.

Caminos, R., 1979. Sierras Pampeanas Noroccidentales, Salta, Tucumán, Catamarca, La Rioja y San Juan. En J.C. Turner (Ed.) 2 Simposio de Geología Regional Argentina. Academia Nacional de Ciencias 1:225-291.

Caminos, R., (Ed.), 1999. Geología Argentina, SEGEMAR, Instituto de Geología y Recursos Minerales, Subsecretaría de Minería de la Nación. Anales N²9, Buenos Aires 796 pgs.

Caminos R. y Fauqué, L. E., 2004. Descripción geológica de la hoja 2969-II Tinogasta (Preliminar), Escala 1:250.000. SEGEMAR, Buenos Aires, 100: 1-85. Inédita.

Caminos, R., Fauqué, L., Cingolani, C., Varela, R. y Morel, E., 1993. Estratigrafía y estructura del Devónico-Carbonífero en el sector septentrional de la Sierra de la Punilla, Precordillera de La Rioja y San Juan. $12^{\circ}$ Congreso Geológico Argentino y $2^{\circ}$ Congreso de Exploración de Hidrocarburos, Actas 2: 31-41, Mendoza.

Carrizo, H. A. 1998. Estudio de floras eocarboníferas de Argentina y su comparación con las de otras regiones relacionadas. Tesis Doctoral Facultad de Ciencias Naturales, Universidad Nacional de Salta (inédito) 304 pp. Salta.

Castro de Machuca, B., Conte-Grand, A., Meissl, E., Pontoriero, S., Sumay, C., Morata, D., 2007. El magmatismo neopaleozoico en la Sierra de La Huerta, Sierras Pampeanas Occidentales, Provincia de San Juan: los porfidos Marayes Viejo y El Arriero. Revista de la Asociación Geológica Argentina 62(3): 447-459.

Castro de Machuca, B., Sumay, C., Meissl, E., Pontoriero, S. y Conte-Grand, A. 2000. Alteración hidrotermal y mineralización en el área del Cerro El Temblor, Sierra de La Huerta, Provincia de San Juan. En Schalamuk, I., Brodtkorb, M. y Etcheverry, R. (eds.): Mineralogía y Metalogenia, Instituto de Recursos Minerales, Publicación 6, 80-86, La Plata.

Cawood, P.A., Nemchin, A.A., Smith, M., Loewy, S., 2003. Source of the Dalradian Supergroup constrained by $\mathrm{U}-\mathrm{Pb}$ dating of detrital zircon and implications for the East Laurentian margin. Journal of the Geologycal Society, London, 160: 231-246.

Chappel, B. and White, A., 1984. I and S type granites in the Lachland Fold Belt, SE Australia”. Transactions of the Royal Society of Edimburg, Earth Sciences 83:1-26. 
Chernicoff, C.J. y G.I. Vujovich, 2004. Zonas de sutura grenvilianas identificadas en la porción septentrional del terreno Cuyania, República Argentina, a partir de datos geofísicos. $4^{\circ}$ Congreso Uruguayo de Geología, Actas (digital). Montevideo.

Cingolani, C. A., Uriz, N., Chemale Jr., F. y Varela, R., 2012. Las rocas monzoníticas del sector oriental del plutón de Cacheuta, Precordillera mendocina: características geoquímicas y edad U/Pb (LA-ICP-MS). Revista de la Asociacion Geológica Argentina 69 (2): 193 - 204.

Clarke, F.W., 1924. The data of Geochemistry, $5^{\text {th }}$ edition. United States Geological Survey, Bulletin 770., Washington.

Clemens, K. A., Miller, H., 1996. Sedimentología, proveniencia y posición geotectónica de las sedimentitas del Precámbrico y Paleozoico inferior del Sistema de Famatina. En: Aceñolaza, F.G., Miller, H. y Toselli, A., Geología del sistema de Famatina, Müncher Geologische Hefte A 19: 31-49. Munich.

Código Argentino de Estratigrafía. Comité Argentino de estratigrafía, Asoc. Geol. Argentina, Serie B, Didáctica y Complementaria, 20:1-64. Bs.As., 1992.

Corfu, F., Hanchar, J.M., Hoskin, P.W.O., Kinny, P., 2003. Atlas of zircon textures. Mineralogical Society of America. Reviews in Mineralogy and Geochemistry: 53 (1), pp. 469 - 500. - doi: $10.2113 / 0530469$.

Cox, R., and Lowe, D.R., 1996, Quantification of the effects of secondary matrix on the analysis of sandstone composition, and a petrographic-chemical technique for retrieving original framework grain modes of altered sandstones: Journal of Sedimentary Research, v. A66, p. 548-558.

Cox, K. G., Bell, J. D. and Pankhurst, R. J., 1979. The interpretation of igneous rocks. Hindman Unwin Ltd., George, Allen and Unwin, London. 450 páginas.

Cravero, O. V., Ríos Gómez, J. A., Prieri, A. E., 1984. Geología del distrito minero Los Llantenes, Precordillera de La Rioja. $9^{\circ}$ Congreso Geológico Argentino, Actas I: 142-153, Bariloche.

Cross, W., Iddings, J. P., Pirsson, L. V. and Washington, H. S. 1902. A quantitative chemicomineralogical classification and nomenclature of igneous rocks. Journal of Geology, 10, $555-690$.

Cuerda, A. J., 1948. Nota sobre un perfil geológico en la Alta Cordillera. Revista de la Asociación Geológica Argentina 3 (4): 258-260.

D

Dalla Salda, L., Cingolani, C. y Varela, R., 1992. El orógeno colisional paleozoico en la Argentina. Serie Correlación Geológica, San Miguel de Tucumán, 9: 165-178.

Dahlquist, J. A., 2001. Granitoides metaluminosos con epidota emplazados a baja presión en la Sierra de Chepes (Orógeno Famatiniano, Sierras Pampeanas, Argentina) y su relación con la fuente magmática. Abstract. 
Davis, J. S., Roeske, S. M., Mc Clelland, W. C., Snee, L. W., 2000. Closing the ocean between the Precordillera terrane and Chilenia: Early Devonian ophiolite emplacement and deformation in the SW Precordillera. En: Ramos, V.A. and Keppie, J.D. (Eds.). Laurentia-Gondwana connections before Pangea. Geological Society of America, Special Paper 336: 115-138.

De Celles, P. G., 1988. Lithologic provenance modeling applied to the Late Cretaceous synorogenic Echo Canyon Conglomerate, Utah: A case of multiple source areas: Geology, 16 (2): 10391043.

Decker, J., and Helmold, K.P., 1985. The Effect of Grain-Size on Detrital Modes - a Test of the GazziDickinson Point-Counting Method - Discussion. Journal of Sedimentary Petrology, 55 (4): 618-620.

Deer, W.A., Howie, R.A. and Zusmann, J., 1992. An introduction to rock-forming minerals. Longman, London, $696 \mathrm{pp}$.

De Paolo, D.J., 1981. Trace elements and isotope effects of combined wall rock assimilation and fractional cristalization. Earth and Planetary Sciences Letters 53: 189-202.

De Paolo, D.J., Linn, A.M., Schubert, G., 1991. The continental crustal age distribution: methods of determining mantle separation ages from $\mathrm{Sm}-\mathrm{Nd}$ isotopic data and application to the Southwestern United States. Journal of Geophysical Research, 96(82): 2071-2088.

De Paolo, D. J., Wasserburg, G. J., 1979. Petrogenetic mixing models and Nd-Sr isotopic patterns. Geochimica et Cosmochimica Acta, 43: 615-627.

Dickinson, W. R., 1970. Interpreting detrital modes of graywake and arkose. Journal of Sedimentary Petrology, 40 (2): 695-707.

Dickinson, W.R., 1988. Provenance and sediment dispersal in relation to paleotectonics and paleogeography of sedimentary basins. En: Kleinspehn, K. L. and Paola, C. (Eds.). New perspectives in basin analysis. Springer-Verlag, pp. 3-25.

Dickinson, W. R., Suczek, C. A., 1979. Plate tectonics and sandstone compositions. The American Association of Petroleum Geologists Bulletin, 63 (12): 2164-2182.

Durand, A.C., 1998. Geología y Petrología de la Sierra de Socoscora, Provincia de San Luis, República Argentina. Congreso Uruguayo de Geología, Actas II: 108-112.

$\mathbf{E}$

Ernst, W. G. and Liu, J., 1998. Experimental phase-equilibrium study of Al- and Ti-contents of calcic amphibole in MORB - A semiquantitative thermobarometer. American Mineralogist, 83 (2): 952-969.

$\mathbf{F}$

Fauqué, L. E. y Limarino, C. O., 1991. El carbonífero de Agua de Carlos (Precordillera de La Rioja), su importancia tectónica y paleoambiental. Revista de la Asociación Geológica Argentina, 46 (1-2): 103-114, Buenos Aires. 
Fauqué, L. E, Caminos, R., Limarino, C. y Carullo, M., 1991. Relaciones estratigráficas del magmatismo carbonífero en la Precordillera riojana, República Argentina. VI Congreso Geológico Chileno, Viña del Mar, Actas, pp. 552-556.

Fauqué (1999): Síntesis y principales problemas del Paleozoico Superior de la precordillera riojana. Conferencia. Ameghiniana 36 (4): 30R, Suplemento - Resúmenes.

Fauqué, L. E. y Caminos, R., 2004. Hoja Preliminar 2969-Tinogasta. SEGEMAR, Buenos Aires.

Fauqué, L. E. y Villar, L. M., 2003. Reinterpretación estratigráfica y petrología de la Formación Chuscho, Precordillera de La Rioja. Revista de la Asociación Geológica Argentina, 58 (2): 218-232.

Fedo, C. M., Nesbitt, H. W. and Young, G. M., 1995. Unraveling the effects of potassium metasomatism in sedimentary rocks and paleosols, with implications for paleoweathering conditions and provenance. Geology, 23 (10): 921-924.

Fedo, C. M., Sircombe, K. N. and Rainbird, R. H., 2003. Detrital zircon analysis of the sedimentary record. Hanchar, J. M. and Hoskin, P. W. O. (Eds): Zircon. Reviews in Mineralogy 53: 277303.

Finney, S.C. y Berry, W.N., 2010. The Ordovician System. Geological Society of America, 193 páginas.

Floyd, P.A., Leveridge, B.E., Franke, W., Shail, R. and Dörr, W., 1990. Provenance and depositional environment of Rhenohercynian synorogenic greywackes from the Giessen Nappe, Germany. Geologishe Rundshau, 79 (3): 611-626.

Floyd, P.A. and Winchester, J.A., 1975. Magma type and tectonic setting discrimination using immobile elements. Earth and Planetary Science Letters, 27: 211-218.

Floyd, P.A., Winchester, J.A., 1978. Identification and discrimination of altered and metamorphosed volcanic rocks using immobile elements. Chemical Geology, 21: 291-306.

Floyd, P.A. y Leveridge, B.E., 1987. Tectonic environment of the Devonian Grambscatho basin, south Cornwall: framework mode and geochemical evidence from turbiditic sandstones. Journal of the Geological Society, 144: 531-542.

Flood y Vernon, 1988. Microstructural evidence of order of cristalization in granitic rocks. Lithos 21: 237-245.

Förster, H. J., Tischendorf, G. and Trumbull, R. B., 1997. An evaluation of the Rb vs. $(\mathrm{Y}+\mathrm{Nb})$ discrimination diagram to infer tectonic setting of silicic igneous rocks. Lithos 40 (2): 261-293 (33). Elsevier. Abstract.

Frey, M. y Robinson, D. (Eds.), 1999). Low grade metamorphism. Blackwell Sience Ltd. Londres, 313 páginas.

Frigerio P.V., Uriz, N.J., Alfaro M.B., 2005. Un nuevo registro de Graptolithina en la Formación Río Bonete (Ordovícico), Precordillera de Jagüé, La Rioja. XVI Congreso Geológico Argentino, , La Plata. Actas, pp. 299-302. 
Frigerio, P.V., 2008a. El granito Potrerillos, noroeste de La Rioja: Un plutón relacionado a subducción en el extremo norte del Terreno Precordillera. XVII Congreso Geológico Argentino, Jujuy. Actas 3: 1014-1015.

Frigerio, P.V., 2008b. Caracterización de la Formación Río Bonete en el perfil de la Quebrada de Potrerillos, Precordillera de Jagüé, La Rioja: implicancias geotectónicas. XVII Congreso Geológico Argentino, Jujuy. Actas 3: 1012-1013.

Frigerio, P.V., Cingolani, C.A. and Chemale Jr, F., 2009. Edades U/Pb de circones detríticos de metasedimentitas Ordovícico-Silúricas de la Precordillera de Jagüé, La Rioja, Argentina. Simposio 45 anos de geocronologia no Brasil, Centro de Pesquisas Geocronológicas, Instituto de Geociencias, Universidad de Sao Paulo, Resumos Expandidos, pp. 245-247.

Frigerio, P.V., Cingolani, C.A., Chemale Jr, F. y Basei, M.A.S., 2010. U-Pb ages of the subduction related Potrerillos pluton, Northern Cuyania Terrane, La Rioja Province, Argentina. VII South American Simposium on Isotope Geology (SSAGI), Brasilia, pp. 162-165.

Frigerio P.V., 2011. La Formación Río Bonete en la Precordillera de Jagüé, extremo norte del Terreno Precordillera/Cuyania, La Rioja: nuevos datos isotópicos y aportes estratigráficos. XVIII Congreso Geológico Argentino, Neuquén, Argentina. Actas electronicas.

Frigerio, P.V., Cingolani, C.A. y Chemale Jr, F., 2012. El Granito Potrerillos de la Precordillera de Jagüé, La Rioja: caracterización petrológica, geoquímica y geocronológica. Instituto Superior de Correlación Geológica, Serie Correlación Geológica 28(2): 107-138. Tucumán.

Fry, N., 1984. Field description of metamorphic rocks. New York: Open University Press.

Furque, G., 1956. Nuevos depósitos devónicos y carbónicos en la Precordillera Sanjuanina. Revista de la Asociación Geológica Argentina, 11 (1): 46-71.

Furque, G. y Baldis, B., 1973. Nuevos enfoques estratigráficos en el Paleozoico del noroeste de la Precordillera. $5^{\circ}$ Congreso Geológico Argentino. Villa Carlos Paz. Córdoba. 1972, Actas 3: $241-251$.

Furque, G., 1972. Precordillera de La Rioja, San Juan y Mendoza. En: Leanza, A. (Ed.), Geología Regional Argentina, Academia Nacional de Ciencias (Córdoba), pp. 237-287.

Furque, G., 1972. Descripción geológica de la Hoja 16b, Cerro La Bolsa, provincias de La Rioja y San Juan. Carta Geológico-Económica de la República Argentina, Escala 1:200.000. Ministerio de Industria y Minería, Buenos Aires.

G

Gehrels, G. E., Dickison, W. R., Ross, G. M., Stewart, J. H., Howell, D. G., 1995. Detrital zircon reference for Cambrian to Triasic miogeoclinal strata of western North America. Geology, 23 (9): 831-834.

Gleason, J. D., Patchett, P. J., Dickinson, W. R. and Ruiz, J., 1995. Nd isotopic constraints on sediment sources of the Ouachita-Marathon fold belt. Geologycal Society of America Bulletin, 107, (10): 1192-1210. 
González, C., 1981. El Paleozoico Superior marino de la República Argentina. Bioestratigrafía y Paleoclimatología. Ameghiniana 18 (1): 51-65.

González, C. R. y Bossi, G. E., 1986. Los depósitos carbónicos al oeste de Jagüel, La Rioja. $4^{\circ}$ Congreso Argentino de Paleontología y Bioestratigrafía, Mendoza, Actas 1: 231-236.

González, C. R. y Bossi, G. E., 1987. Descubrimiento del Carbónico inferior marino al oeste de Jagüel, La Rioja. $4^{\circ}$ Congreso Latinoamericano de Paleontología, Santa Cruz de la Sierra, Actas 2: 713-724.

González, C. R. y Díaz Saravia, P., 2007. Faunas y paleoclimatología del Paleozoico Superior de Argentina, revisión crítica. Acta Geológica Lilloana 20 (1): 41-72.

Gonzalez, P. D., Sato, A. M., Llambías, E. J. y Basei, M. A., 2006. Deformación y edad de plutones y diques monzonítico graníticos post-orogénicos tempranos del oeste de la Sierra de San Luis. En: Temas de la Geología Argentina I, INSUGEO, Tucumán, Serie Correlación Geológica 21: $105-132$.

Green, T.H., 1995. Significance of $\mathrm{Nb} / \mathrm{Ta}$ as an indicator of geochemical processes in the crust-mantle system, Elsevier Science B.V. - doi:10.1016/0009-2541(94)00145-X (Abstract)

Guerrero, M., 1969. Distrito minero Los Llantenes. Informe inédito. Servicio Minero Nacional, Plan La Rioja.

Gutiérrez, P. R., 1988. Análisis paleoflorístico, bioestratigráfico y aspectos paleoambientales de la Formación Agua Colorada en el sector sudoriental de la sierra de Famatina, provincia de La Rioja, República Argentina. Unpublished PhD thesis. Facultad de Ciencias Exactas y Naturales, Universidad de Buenos Aires. Argentina. 850 pp.

Gutiérrez, P.R., 2008. Formación Guandacol. En: Gutiérrez, P.R. (Ed.): Léxico estratigráfico de la Argentina, Vol. VI: Carbonífero. Asociación Geológica Argentina, Serie "B” (didáctica y complementaria) N³0. Servicio Geologico Minero Argentino, Publicación №169. Buenos Aires.

H

Haller, M. A. and Ramos, V. A., 1984. Las ofiolitas famatinianas (Eopaleozoico) de las provincias de San Juan y Mendoza. $9^{\circ}$ Congreso Geológico Argentino (Bariloche), Actas 2: 66-83.

Hartman, L. A. y Santos, J. O. S., 2004. Predominance of high $\mathrm{Th} / \mathrm{U}$, magmatic zircon in Brazilian Shield sandstones. Geological Society of America Inc., Geology 32 (1): 73-76.

Harris, N. B. W., Pearce, J. A. and Tindle, A. G., 1986. Geochemical characteristics of collision-zone magmatism. En: Coward, M. P. and Reis A. C. (Eds.). Collision tectonics. Special Publication of the Geological Society 19: 67-81.

Helmold, K. P., 1985. Provenance of feldespathic sandstones - The effect of diagenesis on provenance interpretations: a review. En Zuffa, G.G. (Ed.) Provenance of Arenites, 139-163. D. Reidel Publishing Company. 
Henry, D. J. and Guidotti, C. V., 2002. Ti in biotite from metapelitic rocks: Temperature effects, crystallochemical controls and petrologic applications. American Mineralogist, 87: 375-382.

Henry, D. J., Guidotti, C. V. and Thomson, J. A., 2005. The Ti-saturation surface for low-to-medium pressure metapelitic biotite: Implications for Geothermometry and Ti-substitution Mechanisms. American Mineralogist, 90: 316-328.

Hernández-Bernal, M. S., Tolson, G. y Solís-Pichardo G., 2000. Geoquímica de elementos traza y su relación con la petrogénesis de rocas ígneas: modelado de sistemas isotópicos, Parte II. Unión Geofísica Mexicana, GEOS 20 (2): 107-118.

Hoskin, and Schaltegger, 2003. The composition of Zircon and igneous and metamorphic petrogenesis. Mineralogical Society of America, Reviews in Mineralogy and Geochemistry, 53 (1): $27-62$.

Hutchinson, Ch. S., 1973. Laboratory Handbook of petrographic techniques. John Wiley \& Sons. New York.

\section{I}

Ingersoll, R.V., 1990. Actualistic sandstone petrofacies: Discriminating modern and ancient source rocks. Geology, 18 (2): 733-736.

Ingersoll, R. V., Bullard, T. F., Ford, R. L., Grimm, J. P., Pickle, J. D. and Sares, S. W., 1984. The effect of grain size on detrital modes: a test of the Gazzi-Dickinson point-counting method. Journal of Sedimentary Petrology 54 (1): 103-116.

Ingersoll, R. V. and Suczek, C. A., 1979. Petrology and provenance of neogene sand from Nicobar and Bengal fans, DSDP sites 211 and 21. Journal of Sedimentary Petrology 49 (4): 1217-1228.

Irvine, T. N. and Baragar, W. R. A., 1971. A guide to the chemical classification of the common rocks. Canadian Journal of Earth Sciences 8: 523-548.

\section{$\mathbf{J}$}

Jochum, K. P. and Verma, S. P., 1996. Extreme enrichment of Sb, Tl and other trace elements in altered MORB, Chemical Geology 130 (3): 289-299. Elsevier.

Johnsson, M. J., 1993. The system controlling the composition of clastic sediments. In: Johnsson, M. J., and Basu, A. (Eds.), Processing controlling the composition of clastic sediments. Geological Society of America Special Paper 284 (2), p. 1-19.

Johnsson, M. J., Stallward, R. F., and Meade, R. H., 1988. First-cycle quartz arenites in the Orinoco River basin, Venezuela and Colombia. Journal of Geology 96 (2): 263-277.

\section{$\mathbf{K}$}

Kay, W. R. and Hubbard, N. J, 1978. Trace elements in ocean ridge basalts. Earth and Planetary Science Letters 38: 95-116. 
Kay, S. M., Ramos, V. A. and Kay, R., 1984. Elementos mayoritarios y trazas de las vulcanitas ordovícicas de la Precordillera Occidental: basaltos de rift oceánico temprano (?) próximos al margen continental. $9^{\circ}$ Congreso Geológico Argentino, San Carlos de Bariloche. Actas II: 4865.

Kempe, U., and Gotze, J., 2002. Cathodoluminescence (CL) behaviour and crystal chemistry of apatite from rare-metal deposits. Mineralogical Magazine 66 (1): 151-172.

Keller, M., 1999. Argentine Precordillera: Sedimentary and Plate Tectonic History of a Laurentian Crustal Fragment in South America, Special Paper 341. Geological Society of America, Inc., Estados Unidos. $131 \mathrm{pp}$.

Kinny, P. D., Strachan, R. A., Friend, C. R. L., Kocks, H., Rogers, G. and Paterson, B. A., 2003. U-Pb geochronology of deformed ductil deformation of the Moine Supergroup during the Caledonian orogeny. Journal of the Geological Socienty, London, 160: 259-269.

Kostov, I., 1973. Zircon morphology as a cristallogenetic indicador. Kristallogr. Technica, 8: 11-19.

Koukharsky, M., Tassinari, C., Brodtkorb, M. K., Leal, P., 2001. Basaltos del Neopaleozoico-Triásico temprano? En las sierras Norte de Córdoba y de Ambargastá, Sierras Pampeanas Orientales: Petrografía y edades K/Ar. Revista de la Asociación Geológica Argentina, 56 (3): 400-403.

Krauskopf, K. B. y Byrd, D. K., 1995. Introduction to geochemistry (Third edition). WCB/McGrawHill, Estados Unidos, 646 pp. (p.461, 413, 551, 428).

Kretz, R., 1983. Symbols for rock-forming minerals. American Mineralogist 78: 277-279.

Kübler, B., 1968. Evaluation quantitative du métamorphisme par la cristallinité de l'illite. État des progrès réalisés ces dernières années. Bulletin Centre de Recherches de Pau-SNPA, 2 (2): 385397.

Kübler, B., 1984. Les indicateurs des transformations physiques dans la diagenèse. Température et calorimétrie. En: Thermométrie et barométrie géologiques. M. Lagache (Ed.) 2: 486-596.

Kübler, B. y Jaboyedoff, M., 2000. Illite crystallinity. Compte Rendu Académie Sciences Paris, Sciences de la Terre et des planetes 331: 75-89.

$\mathbf{L}$

Lapworth, C.,1873. On an improved classification of the Rhabdopora. Geological Magazine, 10: 500504, 555-560. London.

Le Maitre, R.W., 2002. Igneous rocks, a classification and glossary of terms ( $2^{\text {nd }}$ Ed.). Cambridge University Press, $236 \mathrm{pp}$.

Le Maitre, R. W., Bateman, P., Dudek, A., Keller, J., Lameyre, J., Le Bas, M. J., Sabine, P. A., Schmid, R., Sorensen, H., Streckeisen, A., Woolley, A. R. and Zanettin, B., 1989. A Classification of Igneous Rocks and Glossary of Terms: Recommendations of the International Union of Geological Sciences Subcommission on the Systematics of Igneous Rocks. Blackwell Scientific, Oxford, 193 pp. 
Leake, B. E., 1964. The chemical distinction between Ortho and Para-amphibolites. Journal of Petrology: 5 (2): 238-254.

Lee, M. R., Thompson, P., Poeml, P., and Parsons, I., 2003. Peristeritic plagioclase in North Sea hydrocarbon reservoir rocks: Implications for diagenesis, provenance and stratigraphic correlation. American Mineralogist, 88 (5-6): 866-875.

Lev, S. M., McLennan, S. M. y Hanson G. N., 2000. Late diagenetic redistribution of uranium and disturbance of the U-Pb whole rock isotope system in black shale. Journal of Sedimentary Research, 70 (5): 1234-1245.

Limarino, C. O. y Cesari, S. N., 1992. Reubicación estratigráfica de la Formación Cortaderas y definición del Grupo Angualasto (Carbonífero inferior, Precordillera de San Juan). Revista de la Asociación Geológica Argentina, 47 (1): 61-72.

Limarino, Cesari, S. y Page R. (1988): Nuevas precisiones acerca de la edad de algunas fases diastróficas del Paleozoico Superior de argentina. RAGA 43 (4): 562 - 566.

Limarino C. O. , Fauqué L. y Net L. (1999): Análisis tectosedimentario de las cuencas Paganzo y Río Blanco, noroeste argentino. - Ameghiniana 43 (4) -Suplemento, resúmenes, pag 33R.

Linares, E. y González, R. R., 1990. Catálogo de dataciones radimétricas de la República Argentina 1957-1987. Asociagión Geológica Argentina, Publicacion especiale, Serie 'B' (didáctica y complementaria) $\mathrm{N}^{\mathrm{o}} 19,628$ páginas.

Llambías, E. J., 1999. Las rocas ígneas gondwánicas. En: Caminos, R. (Ed.): Geología Argentina, Instituto de Geología y Recursos Minerales, Buenos Aires. Anales 29 (14): 349-376.

Llambías, E. J. y Caminos, R., 1987. El magmatismo neopaleozoico de argentina. En: Archangelsky, S. (Ed.). El sistema carbonífero en la República Argentina. Academia Nacional Ciencias, Córdoba, 253-279.

Llambías, E. J. y Sato, A. M., 1995. El batolito de Colangüil: transición entre orogénesis y anorogénesis. Revista de la Asociación Geológica Argentina 50 (1-4): 111-131.

Llano, J. A., Castro de Machuca, B. y Uliarte, E. R., 1988. Atlas de microfábricas deformacionales, Universidad Nacional de San Juan, Facultad de Ciencias Exactas, Físicas y Naturales.

\section{M}

Mainar, P. O. y Piccoli, P. M., 1989. Tectonic discrimination of granitoids. Geological Society of America Bulletin, 101: 635-643.

Maisonave, H. M., 1979. Descripción Geológica de la Hoja 14c, Cerros Cuminchango. Provincias de La Rioja y Catamarca. Servicio Geológico Naciónal. Buenos Aires. Boletín No 162.

Margarejo, J.C., 2003. Atlas de asociaciones minerales en lámina delgada, Editions U.B., Barcelona, $447 \mathrm{pp}$

Mange M. A. y Maurer, F. W., 1992. Heavy minerals in colour. Enke-Verlag, Stuttgart, 147pp.

Martina, F., Astini, R. A., Becker T. P. y Thomas, W. A., 2005. Granitos grenvilianos milonitizados en la faja de deformación de Jagüé. XVI Congreso Geológico Argentino, Actas 4: 591-594. 
Martina, F., Astini, R. A., 2009. Geología de la región del río Bonete en el antepaís andino (27 30' LS): extremo norte del terreno de Precordillera. Revista de la Asociación Geológica Argentina, 64 (2): 312-328.

Martina, F., Astini, R. A., Ezpeleta, M., y Dávila, F., 2010. Ordenamiento estratigráfico y aspectos paleoambientales del Paleozoico Superior en la Precordillera Septentrional (oeste de Jagüé), La Rioja. Revista Geológica de Chile.

Martino, R. D. y Astini, R. A., 1998. La Faja de Deformación de Jagüé: Límite septentrional del Terreno Precordillera?. X Congreso Latinoamericano de Geología y VI Congreso Nacional de Geología Económica, Buenos Aires, Actas II: 433.

Maynard, J. B., 1984. Composition of plagioclase feldspar in modern deep-sea sands: relationship to tectonic setting. Sedimentology 31: 493-501.

Mc Bride, E. F., 1985. Diagenetic processes that affect provenance determinations in sandstone. En Zuffa, G. G. (Ed.). Provenance of arenites: 95-113, D. Reidel Publishing Company.

McBride, S., Caelles, J. C., Clark, A. and Farrar, E., 1976. Palaeozoic Radiometric age provinces in the Andean Basement, Latitudes $25^{\circ}-30^{\circ}$ S. Earth and Planetary Science Letters, 29: 373-383.

McCulloch, M. T. and Wasserburg, G. J. (1978). Sm-Nd and Rb-Sr chronology of continental crust formation. Science 200: 1003-1011.

McLennan, S. M., Bock, B., Compston, W., Hemming, S. R., McDaniel, D. K., 2001. Detrital zircon geochronology of Taconian and Acadian foreland sedimentary rocks in New England. Journal of Sedimentary Research, 71 (2): 305-317.

McLennan, S. M., Bock, B., Hemming, S.R., Hurowitz, J. A., Lev S. M. and McDaniel, D. K., 2003. The roles of provenance and sedimentary processes in the geochemistry of sedimentary rocks. En: Lentz D. R. (Ed.). Geochemistry of Sediments and Sedimentary Rocks: Evolution considerations to mineral deposit-forming environments. Geological Association of Canada.

McLennan, S. M., Taylor, S. R. and Hemming, S. R., 2006. Composition, differentiation, and evolution of continental crust: Constraints from sedimentary rocks and heat flow. En: Brown, M. and Rushmer, T. (Eds.). Evolution and Differentiation of the Continental Crust. Cambridge University. Press, pp. 92-134.

Mange M. A. y Maurer, F. W., 1992. Heavy minerals in colour. Enke-Verlag, Stuttgart, 147 pp.

McPhie, J., Doyle, M., and Allen, R., 1993. Volcanic Textures: a guide to the interpretation of textures in volcanic rocks. Centre for Ore Deposit and Exploration Studies, University of Tasmania.

McLennan, S. M., 1981. Trace element geochemistry of sedimentary rocks: Implications for the composition and evolution of the continental crust. Phd. Dissertation, The Australian National University, Camberra, 609 pp.

McLennan, S. M., 1989. Rare earth elements in sedimentary rocks: Influence of provenance and sedimentary processes. En: B. P. Lipin and G.A. McKay (Eds.), Capítulo 7, Geochemistry and Mineralogy of Rare Earth Elements, Mineralogical Society of America, Reviews of Mineralogy 21: 169-200. Washington, D.C. 
McLennan, S. M., Taylor, S. M., McCulloch, M. T. y Maynard, J. B., 1990. Geochemical and Nd-Sr isotopic composition of deep sea turbidites: Crustal evolution and plate tectonic association. Geochimica et Cosmochimica Acta, Vol. 54: 2015-2050.

McLennan, S. M., Taylor, S. M., 1991. Sedimentary rocks and crustal evolution: tectonic setting and secular trends. The Journal of Geology, 99 (1): 1-21.

McLennan, S. M., Hemming, S., McDaniel, D. K. and Hanson, G. N., 1993. Geochemical approaches to sedimentation, provenance and tectonics. En Johnson, M. J. y Basu, A., (Eds.). Processes controlling the composition of clastic sediments: Boulder, Colorado. Geological Society of America, Special Paper 284: 21-40.

McLennan, S. M., Hemming, S. R., Taylor, S. R. y Eriksson, K. A., 1995. Early Proterozoic crustal evolution: Geochemical and $\mathrm{Nd}-\mathrm{Pb}$ isotopic evidence from metasedimentary rocks, southwestern Northamerica. Geochimica et Cosmochimica Acta, 59 (6): 1153-1177.

McLennan, S. M., 2001. Relationships between the trace elements composition of sedimentary rocks and upper continental crust. Geochemistry, Geophisics, Geosystems, 2(4): 1021-45 doi:10.1029/2000GC000109

Merodio, J. C., 2005. Geoquímica de rocas sedimentarias. Curso de actualización. Asociación Argentina de Sedimentología, Facultad de Ciencias Naturales y Museo, Universidad Nacional de La Plata.

Merodio, J. C., 2008. Geoquímica de rocas sedimentarias. Curso de actualización. Asociación Argentina de Sedimentología, Facultad de Ciencias Exactas y Naturales, Universidad Nacional de Buenos Aires.

Middlemost, E. A. K., 1989. Iron oxidation ratios, norms and the classification of volcanic rocks. Chemical Geology, 77: 19-26.

Miller, C. F., Stoddard, E. F., Bradfish, L. J. and Dollase, W. A., 1983. Composition of plutonic muscovite: genetic implications. Canadian Mineralogist, Vol 19: 25-34.

Milliken, K. L. and Reed, R. M., 2002. Internal structure of deformation bands as revealed by cathodoluminescence imaging, Hickory Sandstone (Cambrian), central Texas. Gulf Coast Association of Geological Societies Transactions, 52 (2): 725-736.

Mitchell, C., 1987. Evolution and Phylogenetic classification of the Diplograptacea. Paleontology, 30 (2): 353-405.

Mitchell, C. E., Maletz, J. y Zhang, Y. D., 1995. Evolutionary origins of the Diplograptacea. En: Cooper, J. D., Droser, M. L. y Finney, S. C. (Eds.). Ordovician Odyssey. Short papers for the Seventh International Syposium on the Ordovician System, The Pacific section Society for Sedimentary Geology (SEPM), Book 77, Fullerton, California, pp.401-404.

Monteiro, P. C., Rolando A. P. y Macambira, M. J. B., 2003. Time constraint for the sedimentary sequence of the Serra do Inajá region (southern part of the carajas province), Amazonian craton, Brazil, based on detrital zircon dating. Abstract $3^{\text {rd }}$ Latinoamerican Congress of Sedimentology, 70. 
Moore, D. M. y Reynolds Jr., R. C., 1989. X-ray diffraction and the identification and analysis of Clay Minerals. Oxford University Press, Inc. New York. 332 pp.

Morton, A. C., and Hallsworth, C. R., 1999. Processes controlling the composition of heavy mineral assemblages in sandstones. Sedimentary Geology, 124 (1-4): 3-29.

Morton A. C., 1985. Heavy minerals in provenance studies. In: Zuffa G.G. (Ed.) Provenance of arenites: Reidel, Dordrecht 249-277.

Morton, A. C. and Hallsworth, C. R., 1999. Processes controlling the composition of heavy mineral assemblages in sandstones. Sedimentary Geology, 124 (1-4), 3-29.

$\mathbf{N}$

Naipauer, M., 2007. Análisis de la procedencia sedimentaria del Grupo Caucete (Sierras Pampeanas Occidentales) y su comparación con unidades cámbricas de Precordillera. Tesis doctoral, Universidad Nacional de La Plata.

Najman, Y., 2006. The detrital record of orogenesis: a review of approaches and techniques used in the Himalayan sedimentary basins. Earth-Science Reviews, 74: 1-72.

Nascimento, M. S., Góes, A. M., 2003. Provenance of the Ipixuna Formation (Upper Cretasceous), Northeastern Pará, Brazil. Abstract $3^{\text {rd }}$. Latinoamerican Congress of Sedimentology, 70.

Nesbitt I. W and Young G. M., 1982. Early Proterozoic climates and plate motions inferred from major element chemistry of lutites. Nature, Vol. 299: 715-717.

Nesbitt I. W y Young G. M., 1996. Petrogenesis of sediments in the absence of chemical weathering: effects of abrasion and sorting on bulk composition and mineralogy. Sedimentology 43: 341358.

Nesbitt, H.W., MacRae, N.D., Kronberg, B.I., 1990. Amazon deep-sea fan muds: light REE enriched products of extreme chemical weathering. Earth and Planetary Science Letters, 100: 118-123.

Nesbitt, Young, McLennan, Keays, 1996. Effects of chemical weathering \& sorting on the petrogenesis of siliciclastic sediments, with implications for provenance studies. Journal of Geology, 104: 525-542.

Nockolds, S. R., Knox, R. W. O’B. y Chinner, G. A., 1978. Petrology for students. Cambridge University Press, Gran Bretaña. 430 pp.

\section{$\mathbf{O}$}

Omil y Bobovnikov , 2000. Cambios mineralógicos en rocas deformadas de la Sierra de Guasayán, Santiago del Estero. Mineralogía y Metalogenia, INREMI, La Plata, Publicación 6, 497-500.

Ortega, G., Brussa, E. D. y Astini, R. A., 1991. Nuevos hallazgos de graptolitos en la Formación Yerba Loca y su implicancia estratigráfica, Precordillera de San Juan, Argentina. Ameghiniana, 28 (1-2): 163-178, Buenos Aires. 
$\mathbf{P}$

Paar, W. H., Sureda, R. J. y Brodtkorb, M. K., 1996. Mineralogía de los yacimientos de selenio en La Rioja, Argentina. Krutaita, tyrrellita y trogtalita de Los Llantenes. Revista de la Asociación Geológica Argentina, 51 (4): 304-312. Buenos Aires

Page, S., Litvak, V. D. y Limarino, C. O., 2002. Nueva edad en el basamento de la sierra de Los Llanos, La Rioja: Intrusividad pampeana en el arco famatiniano. Revista de la Asociación Geológica Argentina, 57 (3): 345-348.

Pankurst, R. J., Rapela, C. W., Saavedra, J., Baldo, E., Dahlquist, J., Pascua, I., Fanning, C. M., 1998. The Famatinian magmatic arc in the central Sierras Pampeanas: An Early to Mid-Ordovician continental arc on the Gondwana margin. En: Pankurst, R. J. and Rapela, C. W. (Eds.). The Proto-Andean margin of Gonwana. Geological Society, London, Special Publications, 142: 343-367.

Patchett, P. J., Ross, G. M., Gleason, J. D., 1999. Continental drainage in North America during the Phanerozoic from Nd isotopes. Science, 283: 671-673.

Patiño Douce, A., 1999. What do experiments tell us about the relative contributions of crust and mantle to the origin of granitic magmas? Understanding Granites: Integrating New and Classical Techniques. A. Castro, C. Fernandez and L. Vigneresse (Eds). Geological Society Special Publication, 168: 55-75.

Pearce, J. A., 1982. Trace element characteristics of lavas from destructive plate boundaries. Andesites Thorpe, R.S. (Ed.) John Wiley and Sons, 525-548.

Pearce, J. A., Harris, N. B. W. and Tindle, A. G., 1984. Trace element discrimination diagrams for the tectonic interpretations of granitic rocks. Journal of Petrology 25: 956-983.

Pearce, J. A. and Norry, M. J., 1979. Petrogenetic implications of $\mathrm{Ti}, \mathrm{Zr}, \mathrm{Y}$ and $\mathrm{Nb}$ variations in volcanic rocks. Contributions of Mineralogy Petrology. 69: 33-47.

PearceJ.A. and Gale, G.H., 1977 Identification of ore.deposition enviroment from trace element geochemistry of associated ingeneous host rocks. Geological society special publication 7:14-24.

Pearce, J. A., 1983. Role of sub-continental lithosphere in magma genesis at active continental margins. En Continental Basalts and Mantle Xenoliths. Hawkesworth, C.J. y Norry, J.M. (eds.), pp. 230-249. Shiva, Nantwich.

Pearce, J. A., 1983. Role of sub-continental lithosphere in magma genesis at active continental margins. En Continental Basalts and Mantle Xenoliths. Hawkesworth, C.J. y Norry, J.M. (eds.), pp. 230-249. Shiva, Nantwich.

Peel, E., Veroslavsky, G. y Fulfaro, V. J., 1998. Geoquímica de las pelitas de las formaciones Castellanos y Migues (Cretácico), Cuenca de Santa Lucía-Uruguay: Consideraciones paleoambientales. II Congreso Uruguayo de Geología, Actas 1: 151-157. 
Pe-Piper, G., 1988. Calcic amphiboles of mafic rocks of the Jeffers Brook plutonic Complex, Nova Scotia, Canada. American Mineralogist, 73 (2): 993-1006.

Peralta, S. y Finney, S.C. (2002). The Upper Ordovician Graptolite Faunas of the Cuyania Terrane: Their Bioestratigraphic and Paleogeographic significance in yhe Westwrn Margin of Gondwana. En Aspects of the Ordovician System in Argentina. F. G. Aceñolaza (Ed). INSUGEO, Serie Correlación Geológica 16: 41-70.

Pettijohn, F. J., 1941 persistence of heavy minerals and geology age. Journal of geology 79: 610-625. Pettijohn, F.J.; Potter, P.E. y Siever, R,. 1987, Sand and sandstone. Segunda edición, Springer-Verlag, New York, 617 págs.

Pettijohn, F. J., 1963. Chemical composition of Sandstones Excluding Carbonate and Volcanic Sands. Data of Geochemistry, $6^{\text {th }}$ Edition, Fleischer, M. (Ed.). Geological Survey Professional Paper 440-S. United States Government Printing Office, Washington, 1963.

Pichevin, L., Bertrand, P., Boussafir, M., Disnar, J. R., 2004. Organic Matter Accumulation and Preservation Controls in a Deep-Sea Modern Environment: an example from Namibian Slope sediments. Organic Geochemistry, 35, p.543-599.

Pitcher, W. 1985. Magmatism at a Plate edge. Ed. Wallas P. et al. Glasgow: Blackie.

Pober, E., Faupl, P., 1988. The chemistry of chromian spinels and its implications for the geodynamics evolution of the Eastern Alps. Geologishe Rundschau, 77 (3): 641-670.

Polanski, J., 1966. Edades de eruptivas suprapaleozoicas asociadas con el diastrofismo varíscico. Revista de la Asociación Geológica Argentina, 21 (1): 5-19.

Potter, P.E., Maynard J.B. y Depetris P.J., 2005. Mud \& Mudstones: Introduction and Overview. Springer-Verlag, Berlin Heidelberg, 298 pp.

Potter, P. E., Maynard, J. B., Depetris, P. J., 2005. Mud \& Mudstones. Introduction and Overview. Springer. Germany.

Press, S., 1986. Detrital spinels from alpinotype source rocks in middle devonian sediments of the Rhenish Massif. Geologishe Rundschau 75 (2): 333-340.

Pupin, J. P., 1980. 'Zircon and Granite Petrology'. Contribution to Mineral Petrology 73: 207-220.

$\mathbf{R}$

Ramaccióni, D. y Olsacher, J., 1962. Los Yacimientos de minerales de Mercurio y Selenio de Cuesta de Llantenes, provincia de La Rioja. $1^{\circ}$ Jornadas Geológicas Argentina, Buenos Aires, Anales 3: 295-305.

Ramos, V., 1979. Estratigrafía y estructura del Terciario en la Sierra de Los Colorados (Provincia de La Rioja), República Argentina. Revista de la Asociación Geológica Argentina, XXV (3): 359-382.

Ramos, V. A., 1970. Estratigrafía y estructura del Terciario en la Sierra de Los Colorados (Provincia de La Rioja), República Argentina. Revista de la Asociación Geológica Argentina 25 (3): 359382. 
Ramos, V. A., Jordan, T. E., Allmendinger, W. R., Kay, S. M., Cortés J. M., Palma , M. A., 1984. Chilenia un terreno alóctono en la evolución paleozoica de los Andes Centrales. $9^{\circ}$ Congreso Geológico Argentino, Bariloche. Actas 2: 84-106.

Ramos, V. A., Jordan, T. E., Allmendinger, R. W., Mpodozis, C., Kay, S. M., Cortés J. M. and Palma, M.A., 1986. Paleozoic terranes of central Argentine-Chilean Andes. Tectonics, 5 (6): 855-880.

Ramos, V.A., 1982. Descripción Geológica de la Hoja 20f, Chepes, provincia de La Rioja. Secretaría de Estado de Industria y Minería, Subsecretaría de Minería, Boletín 188: 52 pp.

Ramos, V. A., Vujovich, G., Kay, S. M. y Mc Donough, M. R., 1993. La orogénesis de Grenville en las Sierras Pampeanas Occidentales: La Sierra de Pie de Palo y su integración al Supercontinente Proterozoico. $12^{\circ}$ Congreso Geológico Argentino y $2^{\circ}$ Congreso de Exploración de Hidrocarburos, Actas 3: 343-357, Mendoza.

Ramos,VA., Vujovich,. G.I. y Dallmeyer, R.D. , 1996c. Los Klippes y ventanas tectónicas de la estructura preándica de la Sierra de Pie de Palo (San Juan): edad e implicaciones tectónicas. $13^{\circ}$ Congreso Geológico Argentino y $3^{\circ}$ Congreso Exploración de Hidrocarburos, Actas 5: 377-392.

Ramos, V.A.; Dallmeyer, R.D.; Vujovich, G. 1998. Time constraints on the Early Palaeozoic docking of the Precordillera, central Argentina. In The Proto-Andean Margin of Gondwana (Pankhurst, R.J.; Rapela, C.W.; editors). Geological Society, Special Publication, No. 142, p. 143-158. London.

Ramos, V. A., 1999. Los depósitos sinorogénicos terciarios de la región andina. En: Caminos, R.L. (Ed.): Geología Argentina, Anales 29: 651-682, Instituto de Geología y Recursos Minerales. Buenos Aires.

Ramos, V. A., Escayola, M., Mutti, D. I. and Vujovich, G. I., 2000. Proterozoic-early Paleozoic ophiolites of the Andean basement of southern South América. En: Dilek, Y., Moores, E. M., Elthon, D. y Nicolas, A. (Eds.). Ophiolites and Oceanic Crust. New insights from field studies and the Ocean Drilling Program: Boulder, Colorado. Geological Society of America Special Paper 349: 331-349.

Rapela, C., Pankhurst, R., Casquet, C., Bbaldo, E., Galindo, C., Fanning, C. and Dahlquist, J., 2010. The Western Sierras Pampeanas: Protracted Grenville-age history (1330-1030 Ma) of intraoceanic arcs, subduction-accretion at continental-edge and AMCG intraplate magmatism. Journal of South American Earth Sciences, 29: 105-127.

Rapela, Cw.., Pankhurst, R.J., Casquet, C, Baldo E.,Galindo, C., Fanning,C.M.,dahlquist, J.M. 2010. The Western Sierras Pampeanas: Protracted Grenville-age history (1330-1030 Ma) of intraoceanic arcs, subduction-accretion at continental-edge and AMCG intraplate magmatism. Journal of South American Earth Sciences, 29: 105-127.

Remesal, M., Fauqué L. A. y Limarino, C. O., 2004. Volcanismo calcoalcalino neopaleozoico en la precordillera de La Rioja. Petrología y caracterización litoestratigráfica de la Formación Punta 
del Agua (Carbonífero Superior-Pérmico Inferior). Revista de la Asociación Geológica Argentina 59 (3): 462-476.

Riddle, Ch., 1993. Analysis of geological materials. Chris Riddle (Ed). Marcel Decker Inc. New York. $463 \mathrm{pp}$.

Rollinson, H., 1993. Using geochemical data: evaluation, presentation, interpretation. Longman Scientific \& Technical. John Willey and Sons, New Cork U.S.A. 352p.

Roser, B.P. y Korsch, R.J., 1986. Determination of tectonic setting of sandstone-mudstone su• es using $\mathrm{SiO}_{2}$ content and $\mathrm{Na}_{2} \mathrm{O} / \mathrm{K}_{2} \mathrm{O}$ ratio. Journal of Geology 94: 635- 650 .

Roser, B.P. y Korsch, R.J., 1988. Provenance signaturas of sandstones-mudstone suites determined using discriminant function analysis of major element data. Chemical Geology 67, 119-139.

Rossi, 1947. El "stock" compuesto de Cacheuta (Prov. de Mendoza). Revista de la Asociación Geológica Argentina II (1): 13-40. Buenos Aires, 1967.

Rubin, J. N., Henry, C. D., Price, J. G., 1993. The mobility of zirconium and other "immobile" elements during hydrothermal alteration. Chemical Geology, 110: 29-47.

Rubiolo, D., Cisterna, C., Villeneuve, M., Hickson, C., 2002. Edad U/Pb del granito de las angosturas en la Sierra de Narvaez (Sistema de Famatina, Provincia de Catamarca). Actas del XV Congreso Geológico Argentino, El Calafate.

Rudnick R. L. and Gao S., 2003. Composition of the continental crust. En: R.L. Rudnick (Ed.): The Crust. Vol. 3 Treatise on Geochemistry. Holland H.D. and Turekian K.K. (eds.). ElsevierPergamon, Oxford.

$\mathbf{S}$

Santanna, L. G., Riccomini, C., Dantas, E., Fetter, A, Roig, H. L., 2003. Geology, mineralogy and provenance of detrital clay minerals of the continental rift of Southeastern Brazil. Abstract $3^{\text {rd }}$. Latinoamerican Congress of Sedimentology, 73.

Scalabrini Ortiz, J. 1973. El Carbónico en el sector sepentrional de la Precordillera sanjuanina. Revista de la Asociación Geológica Argentina27: 351-377.

Scalabrini Ortiz, J. y Arrondo, O. G., 1973. Contribución al conocimiento del Carbónico en los perfiles del Cerro Veladero y del Río del Peñón (Precordillera de La Rioja). Revista del Museo de La Plata, 8: 257-279.

Scasso, R. A. y Limarino, C. O., 1997. Petrología y diagénesis de rocas clásticas. Asociación Argentina de Sedimentología, Publicación especial Nº1, 259 pp.

Shand, S. J., 1927. The Eruptive Rock. John Wiley. New York. 360 pp.

Shervais, J.W., 1982. Ti-V plots and the petrogenesis of modern and ophiolitic lavas. Earth, Planetary Science Letters, 59: 101-118

Sibson R., H., 1979. Fault rocks and fault mechanisms. Journal of Geological Society of London, 133: 191-213.

Sørensen, H., 1974. The alkaline Rocks. Ed. John Wiley and Sons, London. 622 páginas. 
Spalletti, L.A.; Merodio, J.C. y Matheos, S.D., 1993. Composición, procedencia y marco tectónico de sedimentitas eojurásicas (Formación Nestares) del sudeste de la Cuenca Neuquina, Revista de la Asociación Geológica Argentina 47: 277-286.

Spalletti L., 1999. Cuencas triásicas del Oeste argentino: origen y evolución. Acta Geológica Hispánica 32 (1-2): 29-50.

Spear, F. S., and Pyle, J. M., 2002. Apatite, monazite, and xenotime in metamorphic rocks. In Kohn, M. J., Rakovan, J. and Hughes, J. M. (Eds). Phosphates: Geochemical, Geobiological, and Materials Importance. Reviews in Mineralogy and Geochemistry, 48 (2): 293-335.

Steiger, R. H. y Jager, E., 1977. Subcommission on geochronology: convention on the use of decay constants in geo- and cosmochronology. Earth and Planetary Science Letters, 36 (3): 359-362.

Stanley D. J., 1983. Parallel laminated deep-sea muds and coupled gravity flow hemipelagic settling in the Mediterranean. Smithsonian Contributions to Marine Science, 19: 1-19.

Sun, S. S. y McDonough, W. F., 1989. Chemical and isotopic systematics of ocean basalts: implications for mantle composition and processes. En Saunders, A. D. and Norry, M. J., (Eds). Magmatism in the Ocean Basins. Special Publication of the Geological Society of London, 42: 313-345.

Suttner, L. J., and Dutta, P. K., 1985. Alluvial sandstone composition and paleoclimate framework mineralogy: Journal of Sedimentary Petrology, 56 (2): 329-345.

Suttner, S. J., and Basu, A., 1985. The effect of grain size on detrital modes: A test of the GazziDickinson point-counting method. Journal of Sedimentary Petrology, 55: 616-617.

T

Taylor, S. R., McLennan, S. M., Armstrong, R. L., y Tarney, J., 1981. The Composition and Evolution of the Continental Crust: Rare Earth Element Evidence from Sedimentary Rocks [and Discussion] The Origin and Evolution of the Earth's Continental Crust. Philosophical Transactions of the Royal Society of London. Series A, Mathematical and Physical Sciences, 301 (1461): 381-399.

Taylor, S. R. and McLennan, S. M., 1985. The Continental Crust: Its Composition and Evolution. Blackwell Scientific Publications (Oxford), 312 pp.

Tera, F. and Wasserburg, G., 1972. U-Th-Pb systematics in three Apollo 14 basalts and the problem of initial $\mathrm{Pb}$ in lunar rocks. Earth and Planetary Science Letters, 14: 281-304.

Thomas, W.A. \& Astini, R.A., 1996.The Argentine Precordillera: a traveler from the Ouachita embayment of North American Laurentia. Science, 273: 752-757.

Thomas, W. \& Astini, R.A., 1999. Ordovician collision of the Argentine Precordillera with Gondwana, independent of Laurentia Taconic Orogeny. Forth International Symposium on Andean Geodynamics, 745-748. Goettingen.

Thornton, C. P. y Tuttle, O. F., 1960. Chemistry of igneous rocks. I. Differentiation index. American Journal of Sciences, 258: 664-684 
Thorpe, R.S., (Ed.), 1982. Andesites and related rocks. Wiley \& Sons, New York, p. 525-568

Toselli, A. J. y Durand, F. R., 1996. Vulcanismo del Ciclo Precordillerano. En: Aceñolaza, F. G., Miller, H. y Toselli, A. (Eds.): Geología del Sistema de Famatina. Münchner Geologische Hafte, 19 (Reihe A); pp. 293-295. Münich, Alemania.

Toselli, A. J. y Aceñolaza, F. G., 1971. La mineralización cuproselenífera con mercurio de la Precordillera de Jagüé, provincia de La Rioja. Consideraciones petrogenéticas y edad de mineralización. Simposio Nacional de Geología Económica, , San Juan, Actas 2: 367-378.

Trevena, A. S. and Nash, W. P., 1981. An electron microprobe study of detrital feldspar. Journal of Sedimentary Petrology, 51(2): 137-150.

Turner, J. C. M. y Verhoogen, J., 1975. Petrología ígnea y metamórfica. Ed. Omega, Barcelona, 726 páginas.

Turner, J.C.M. (1960): Faunas Graptolíticas de América del Sur. Asociación Geológica Argentina, 16 (1-2): 5-180.

Turner, J. C. M., 1960: Estratigrafía del tramo medio de la Sierra de Famatina y adyacencias (La Rioja). Acad. Nac. De Cs. Cba, Bol. XLII (Córdoba): 77-126.

Turner, J. C. M., 1962: Las Sierras Transpampeanas como unidad estructural. An. $1^{\text {a }}$ jornada Geol. Arg., II (Bs. As): 387-402.

Turner, J.C.M. (1964): Descripción geológica de la hoja 15c-Vinchina, Provincia de La Rioja. Boletín de la Dirección Nacional de Geología y Minería. Buenos Aires, 100:1-85.

V

Van Staden, A, Zimmermann, U., (2003): Tillites or ordinary conglomerates? Provenance studies on diamictites of the Neoproterozoic Puncoviscana in NW Argentina. $3^{\text {rd }}$ Latinoamerican Congress of Sedimentology, 74, Abstract.

Varela, R., López de Luchi, M., Cingolani, C., Dalla Salda, L., 1996. Geocronología de gneises y granitoides de la Sierra de Unamgo, La Rioja. Implicancias tectónicas. $13^{\circ}$ Congreso Geológico Argentino y $3^{\text {er }}$ Congreso de Exploración de Hidrocarburos, Actas III: 519-528. Buenos Aires.

Varela, R., Valencio, S., Ramos V.A., Sato, K., González, P., Panarello, H., Roverano, D., 2001. Isotopic Strontium, Carbon and Oxigen study on Neoproterozoic marbles from Sierra de Umango, Andean Foreland, Argentina. III Southamerican Simposium on Isotope Geology, pp. 450-453.

Varela, R., Basei, M.A.S., Sato A.M., Gonzalez, P.D., Siga Jr. O., Campos Neto, M.C., Cingolani C.A., 2003. Grenvillian basement and famatinian events of the Sierra de Umango (29 ${ }^{\circ}$ S): A review and new geocronological data. $4^{\circ}$ Southamerican Simposium on Isotope Geology, 304306.

Varela, R., Basei, M.A.S., Gonzalez, P.D., Sato A.M., Naipauer, M., Campos Neto, M., Cingolani, C., Meira, V. T., 2011. Acretion of Grenvillian terranes to the southwestern border of the Río de 
la Plata craton, western Argentina. Int. Journal of Sciences (Geologische Rundschau) 100: 243-272. Springer Verlag. DOI 10.1007/s00531-010-0614-2.

Vaughan, A.P.M., Leat, P.T. y Pankhurst, R.J. (eds.): Terrane Processes at the Margins of Gondwana. Geologinal Society of London, Special Publications. Londres. 328 páginas.

Villar, L.M., 1998. Los gabros de fondo oceánico de la ofiolita de la Cordillera Frontal de Mendoza. $10^{\circ}$ Congreso Latinoamericano de Geología y $6^{\circ}$ Congreso Nacional de Geología Económica. Actas II: 405-410. IGCP 376. Laurentia Gondwana Connections Before Pangea.

Villar, L.M. y Escayola, M. 1999. Las rocas máficas MORB asociadas a la faja ultramáfica del Cordón del Portillo. Cordillera Frontal de Mendoza. 14 Congreso Geológico Argentino. Actas II: 147-149.

Villar, L. M., 2003. Lavas Almohadilladas del Cerro Chuscho, Provinacia de La Rioja, como parte de la ofiolita de la Precordillera Occidental. Correlaciones petrológicas en Cuyania y Chilenia. $10^{\circ}$ Congreso Geológico Chileno, Universidad de Concepción, Chile.

Vujovich, G.I. y Porcher, C., 2008. El basamento greenvilliano del Terreno Cuyania: Características isotópicas. Actas XVII CGA, tomo I: 55-56, Jujuy.

Vujovich G.I., 1994. Geología del basamento ígneo-metamórfico de la loma de Las Chacras, Sierra de La Huerta, San Juan. RAGA 49(3-4): 321 - 336.

Vujovich, G.I. y Kay, S., 1996. Evidencias geoquímicas del orígen y ambiente geológico de las rocas metamórficas de composición máfica e intermedia de las Sierras Pampeanas Occidentales. XIII Congreso Geológico Argentino - III Congreso de Exploración Hidrocarburos. Actas V: 273-291.

Vujovich, G.I.; Porcher, C.C.; Chernicoff, C.J.; Fernandes, L.A.D.; Pérez, D.J., 2005. Extremo norte del basamento del Terreno Cuyania: nuevos aportes multidisciplinarios para su identificación. AGA, Serie D: Publicación Especial No 8: 15-38.

W

Weaver, Ch. E. (1984): Shale-Slate metamorphism in southern Appalachians. Developments in Petrology Series, vol. 10. Elsevier Science Publishers B.V., Amsterdam., 239 páginas.

Winchester, J.A y Floyd, P.A. (1977): Geochemical discrimination of different magma series and their differentiation products using immobile elements. Chemical Geology 20:325-343.

Winkler, H.G.F. (1978): Petrogénesis de rocas Metamórficas. H.Blume Ediciones. España.

Wood, D.A. (1980): The applications of Th-Hf-Ta diagram to problems of tectonomagmatic classification and to stablishing the nature of crustal contamination of Tertiary Basaltic Lavas of the British tertiary Volcanic province. Earth and Planetary Science Letters. 50: 11-30

\section{Y}

Yardley, B.W.D., (1989): An introduction to metamorphic petrology. Longman, Harlow. New York, 284 páginas. 
Yardley, B.W.D., McKenzie, W.D. and Guilford, C., 1990. Atlas of metamorphic rocks and their textures. London: Longman; New York: Wiley. 120 páginas.

Young, S.W. (1976): Petrographic textures of detrital polycrystalline quartz as an aid to interpreting crystalline source rocks. Journal of Sedimentary Petrology 46: 595-603.

\section{$\mathbf{Z}$}

Zack, T., Moraes, R., and Kronz, A. (2004a): Temperature dependence of $\mathrm{Zr}$ in rutile: empirical calibration of a rutile thermometer. Contributions to Mineralogy and Petrology, 148(4), 471488.

Zack, T., Von Eynatten, H., and Kronz, A. (2004b): Rutile geochemistry and its potential use in quantitative provenance studies. Sedimentary Geology, 171(1-4), 37-58.

Zenk, M. and Schulz, B. (2004) Zoned Ca-amphiboles and related P-T evolution in metabasites from the classical Barrovian metamorphic zones in Scotland. Mineralogical Magazine, 68, 769-786.

Zimmermann, U. (2005): Provenance studies of very low -to low-grade metasedimentary rocks of the Puncoviscana complex, northwest Argentina. En: Vaughan, A.P.M., Leat, P.T. y Pankhurst, R.J. (eds.): Terrane Processes at the Margins of Gondwana. Geologinal Society of London, Special Publications, 246, 381-416. Londres.

Zimmermann, U. y Van Staden, A. (2002). Río Bonete (La Rioja Province, Northwest Argentina): a typical Ordovician succesión?-Preliminary sedimentological and paleontological data. XV Congreso Geológico Argentino, Actas I: 792-796. El Calafate.

Zimmermann, U. y Bahlburg, H. (2003): Provenance analysis and tectonic setting of the Ordovician clastic deposits in the Southern Puna Basin, NOA. Sedimentology 50: 1079-1114.

Zolezzi R.E. y Guerrero M.A. (1981): Geología del Cerro Cacho y adyacencias, Departamento de General Lamadrid, Provincia de La Rioja. Acta Geológica Llilloana XV (3): 117 - 125. 